UNIVERSIDADE DE SÃO PAULO

FACULDADE DE FILOSOFIA, LETRAS E CIÊNCIAS HUMANAS

DEPARTAMENTO DE HISTÓRIA

PROGRAMA DE PÓS-GRADUAÇÃO EM HISTÓRIA SOCIAL

\title{
Poder local e palavra impressa: a dinâmica política em torno dos Conselhos Provinciais e da imprensa periódica em São Paulo, 1824-1834
}

\section{Carlos Eduardo França de Oliveira}

\author{
Dissertação apresentada ao Programa de Pós- \\ Graduação em História Social da Faculdade de \\ Filosofia, Letras e Ciências Humanas da \\ Universidade de São Paulo, para obtenção do \\ título de Mestre em História.
}

Orientadora: Prof ${ }^{a}$. Dr ${ }^{\mathrm{a}}$.Cecilia Helena de Salles Oliveira

São Paulo

2009 


\section{RESUMO}

O presente trabalho tem como objetivo analisar a criação de espaços de poder provincial em São Paulo mediante o estudo da atuação política do Conselho da Presidência (1824-1834) e do Conselho Geral (1828-34), os quais juntamente com a presidência da província constituíram a base do poder provincial durante o Primeiro Reinado e os anos iniciais do período regencial, até a extinção de ambos os Conselhos, em 1834.

A dissertação procura, concomitantemente, entrelaçar tal discussão com o debate político desenvolvido pela imprensa paulista do período, notadamente pelos periódicos $O$ Farol Paulistano (1827-1831) e O Observador Constitucional (1829-1832), que por sua vez representam os dois primeiros jornais impressos na província de São Paulo. Ao levar em consideração o papel fundamental que a imprensa desse período desempenhou como veículo de produção, discussão e disseminação de ideais e projetos políticos vinculados a grupos de interesses distintos, a análise dos periódicos selecionados possibilita aprofundar o entendimento não apenas da imprensa paulista e dos elementos envolvidos na sua implementação e manutenção, mas também da inserção da província de São Paulo no interior de um processo histórico mais amplo que foi o da construção das bases políticas do Império. Nesse sentido, o trabalho pretende problematizar o posicionamento político dos periódicos em questão, partindo da hipótese de que não constituíam conjunto homogêneo, aspecto esse que ajuda a compreender as nuanças políticas da Província de São Paulo no Primeiro Reinado e no período inicial da Regência. 
Palavras-chave: província de São Paulo; imprensa; história do Império; Conselhos Provinciais; história política. 


\section{ABSTRACT}

The aim of this dissertation is to analyze the creation of provincial political areas in São Paulo through the study of the political performance of the Provincial Councils (“Conselho da Presidência” and “Conselho Geral”), which along with the province’s presidency formed the local power structure between the First Reign (1822-1831) and the beginning of the Regency Period (1831-1834).

The dissertation purposes at the same time to link such analysis to the political discuss developed by the paulista press, mainly by $O$ Farol Paulistano (1827-1831) and $O$ Observador Constitucional (1829-1832), the first two printed newspapers in São Paulo. Taking into consideration the basic role that the press of that time represented as a vehicle of discussion and dissemination of distinct political projects, the analysis about the chosen periodicals enables a better understanding of the São Paulo’s press, the people involved in its implementation and maintenance, as well as the insertion of São Paulo in the political emperial bases construction in $19^{\text {th }}$ century. In this regard, the research intends to bring out the essential elements of the political conceptions of the two newspapers, starting from the hypothesis that they didn't compose a homogeneous group, aspect that helps to understand the political nuances in São Paulo in the First Reign and in the initial period of the Regency.

Keys-words: province of São Paulo; press; history of braziliam Empire; provincial councils; polical history. 


\section{AGRADECIMENTOS}

Aos poucos o historiador aprende a lidar, antes mesmo do que com as fontes, com a solidão do seu ofício. Livros e documentos tornam-se seus principais interlocutores, às vezes os únicos. Ainda assim sempre existem aqueles que o fazem seguir adiante. A esses ofereço meu reconhecimento.

Primeiramente, eu gostaria de agradecer à FAPESP pelo apoio financeiro concedido para a realização desta pesquisa.

À professora Cecilia Helena sou imensamente grato pela orientação que vem desde os tempos de Iniciação Científica e que se tornou parte constitutiva da minha formação acadêmica. Muito obrigado pela dedicação e por proporcionar um convívio intelectual tão rico durante esses anos.

A leitura cuidadosa e estimulante feita pela minha Banca de Qualificação foi de importância fundamental para o desdobramento da pesquisa. Agradeço à professora Laima Mesgravis pela generosidade intelectual, especialmente pelas indicações bibliográficas e pelas recomendações referentes à estruturação de um texto acadêmico. À professora Marisa Saenz Leme, pelas atentas observações feitas sobre os Conselhos Provinciais, as quais certamente auxiliaram no aprofundamento do tema.

Pelas reuniões mensais, palavras de incentivo e cumplicidade acadêmica sou grato aos orientandos da Prof ${ }^{a}$. Cecilia Helena. Todos contribuíram, cada um a sua maneira e até mesmo sem se dar conta, para o encaminhamento deste trabalho.

Aos meus pais ofereço meu reconhecimento pelo incentivo que me deram durante toda minha trajetória na Universidade de São Paulo. Sem eles este percurso teria sido muito mais árduo. 
Por fim agradeço à Heidi, minha esposa, pelo apoio incondicional e por compreender que o historiador funciona num tempo outro, de fruição lenta e paciente, mas que apesar disso depende dos que o cercam para ser feliz. 


\section{SUMÁRIO}

Introdução

p.10

Capítulo 1: Imprensa e política em São Paulo nos primeiros anos do Império p.23

1.1. Tipógrafos, redatores e leitores $\quad$ p.44

1.2. O surgimento da imprensa em São Paulo p.51

1.3. O Farol Paulistano e O Observador Constitucional p.59

Capítulo 2: A construção de um governo provincial: o funcionamento do Conselho da Presidência e do Conselho Geral da província de São Paulo

p.101

2.1. O Conselho da Presidência da província de São Paulo

p.111

2.2. Os presidentes e seu conselho privativo

p.136

2.3. O surgimento dos Conselhos Gerais de província

p.148

2.4. O Conselho Geral da província de São Paulo

p.160

2.5. Os Conselhos Gerais e as Câmaras Municipais: o caso paulista

p.193

2.6. As relações entre os Conselhos Provinciais de São Paulo

p.207

Capítulo 3: Desdobramentos da luta política: a imprensa e os Conselhos Provinciais paulistas do final do Primeiro Reinado até o Ato Adicional

p.217

3.1. A “exaltação” em São Paulo: reforma constitucional, federação e república

p. 245

3.2. A Abdicação e a luta política entre os liberais paulista

p.264

3.3. "Reforma" ou "reformas"?: a lei de 12 de outubro de 1832 e a remodelação da estrutura financeira provincial

p.320

3.4. O Ato Adicional e a lei de regulamentação do exercício dos executivos provinciais: a extinção dos Conselhos Provinciais p.348

Considerações Finais p.358

Fontes e bibliografia p.364

Anexos

p.376 
Para Heidi, 
"Um homem se propõe a tarefa de desenhar o mundo. Ao longo dos anos, povoa um espaço com imagens de províncias, de reinos, de montanhas, de baías, de naus, de ilhas, de peixes, de moradas, de instrumentos, de astros, de cavalos, e de pessoas. Pouco antes de morrer, descobre que esse paciente labirinto de linhas traça a imagem de seu rosto".

Jorge Luis Borges, O Fazedor, 1960. 


\section{Introdução}

Em 9 de maio de 1831, pouco mais de um mês após a abdicação de D. Pedro, o periódico paulistano O Observador Constitucional fez cerrada defesa da atuação política das províncias no Império, que na sua opinião mereciam maior atenção da Assembléia Geral e do executivo central:

“(...) As províncias é necessário, que sejão muito ouvidas, e attendidas em todos os negocios geraes, e não menos nos particulares, que lhes dicerem respeito. Os seus Conselhos Provinciaes não se achão em effectividade, senão em muito poucas. Será bom, que os installe (...)”. ${ }^{1}$

Aparentemente uma reivindicação pontual, tal excerto revelava uma exigência do redator: a necessidade de regularizar no conjunto do território funcionamento dos Conselhos Provinciais - o Conselho da Presidência e o Conselho Geral - que, juntamente com o presidente de província, formavam os principais espaços institucionais em nível provincial durante o Primeiro Reinado e o início do período regencial. A incerteza dos rumos do recém-fundado Império tornava cada vez mais evidente para os círculos políticos da época que o sucesso de qualquer projeto de governo constitucional dependeria de mecanismos que contemplassem as províncias e seus respectivos grupos de interesse.

Pesquisas recentes têm ressaltado de modo crítico que se consolidou, em parcela da bibliografia referente ao tema da construção do Estado Nacional brasileiro desenvolveu-se no interior de um processo linear e evolutivo, balizado em uma cronologia cujos marcos seriam 1808 e 1831. Com efeito, sedimentou-se o termo Independência como fato e não como problema, atribuindo-lhe o significado exclusivo de ruptura entre Portugal e o Reino

\footnotetext{
${ }^{1}$ O Observador Constitucional, n ${ }^{148,}$ 09/05/1831.
} 
do Brasil, sendo algo necessário e que fatalmente deveria consumar-se para o "progresso" dos “brasileiros". ${ }^{2}$ Atendo-se a essa idéia, parte da bibliografia sobre a formação do Império centrou-se na separação política entre colônia e metrópole, encarando-a como um fato específico e circunscrito a uma realidade bem delimitada, esquecendo-se do seu dinamismo histórico, isto é, preterindo em certa medida as modificações internas à sociedade colonial que se processaram desde meados do século XVIII. Questões essenciais como os debates políticos, as relações de mercado, as nuanças provinciais, o papel da imprensa e os conflitos engendrados pelos diversos setores da sociedade colonial foram pouco destacados por análises que enfatizaram o rompimento político, visto como um acontecimento único, embora capaz de gerar outra etapa da história.

Na obra A astúcia liberal. Relações de Mercado e Projetos Políticos no Rio de Janeiro (1820-1824) ${ }^{3}$ a historiadora Cecilia Helena de Salles Oliveira nota que, longe de ser uma simples ruptura política que não promoveu outras mudanças senão o fortalecimento das intituladas “elites” agrárias e escravistas, a construção do Estado Nacional resultou da ação de grupos políticos distintos preocupados com a implantação das bases de um novo governo. A existência de uma sociedade matizada, formada por pequenos e grandes agricultores, comerciantes, artesãos, tropeiros, profissionais liberais, clérigos, escravos, libertos e outros segmentos sociais, fez com que o debate acerca da construção de um novo Estado representativo da Nação que se conformava assumisse inúmeras formas de expressão e luta política, como foi o caso da imprensa e das esferas de poder local que aos poucos

\footnotetext{
${ }^{2}$ Ver a esse respeito os trabalhos de LYRA, Maria de Lourdes Viana. A utopia do poderoso império: Portugal e Brasil: bastidores da política, 1798-1822. Rio de Janeiro: Sette Letras, 1994; OLIVEIRA, Cecilia Helena de Salles. A astúcia liberal. Relações de Mercado e Projetos Políticos no Rio de Janeiro (1820-1824). São Paulo, Editora Ícone e Edusf, 1999; OLIVEIRA, Cecilia Helena de Salles. A independência e a construção do Império. São Paulo: Atual, 1995; e JANCSÓ, István (org.). Independência: história e historiografia. São Paulo: Hucitec/FAPESP, 2005.

${ }^{3}$ OLIVEIRA, Cecilia Helena de Salles, op. cit., 1999.
} 
foram sendo implementadas com o objetivo de oferecer tangibilidade ao Império que se organizava. Esse debate, contudo, não se esgotou com as disputas travadas no início dos anos 1820. Ele teve continuidade nas décadas seguintes, de modo que o Primeiro Reinado e as Regências foram períodos de intensa experimentação e enfrentamento político em todo o Império, e dos quais a monarquia constitucional acabou saindo como opção vitoriosa.

Levando em consideração os variados contornos assumidos pelas lutas políticas nesse período, alguns estudos têm apontado para a importância de se analisar o papel da dimensão local, sobretudo das províncias, na configuração e viabilização do estado monárquico-constitucional com sede no Rio de Janeiro. À contracorrente de interpretações mais difundidas que tendem a compreender o nascimento do Império como o resultado de um conjunto de acordos políticos de caráter clientelista, manifestos no governo supostamente "centralizador" de D. Pedro durante o Primeiro Reinado, esses novos trabalhos vêm matizando o entendimento a respeito da estrutura política imperial a partir da ênfase no estudo da dimensão provincial, que, no limite, consistiu na principal esfera de poder local durante os primeiros anos do Império. ${ }^{4}$ Esse destaque conferido à atuação do poder local no cenário político imperial tem ampliado o conhecimento referente às diferentes províncias, possibilitando construir um painel mais completo de suas diferenças,

\footnotetext{
${ }^{4}$ Ver sobre o assunto os trabalhos de CARVALHO, Marcio Eulério Rio de. Afirmação de uma esfera pública de poder em Minas Gerais (1821-1851). Tese de doutorado apresentada ao Departamento de História da Faculdade de Filosofia e Ciências Humanas da Universidade Federal de Minas Gerais. Belo Horizonte, 2003; DOLHNIKOFF, Miriam. Caminhos da conciliação: o poder provincial em São Paulo, 1835-1840. Dissertação de mestrado apresentada ao Departamento de História da Faculdade de Filosofia, Letras e Ciências Humanas da Universidade de São Paulo. São Paulo, 1993;Construindo o Brasil: unidade nacional e pacto federativo nos projetos das elites (1820-1842). Tese de doutorado apresentada ao Departamento de História da Faculdade de Filosofia, Letras e Ciências Humanas da Universidade de São Paulo. São Paulo, 2000; O Pacto Imperial: origens do federalismo no Brasil. São Paulo: Globo, 2005; GOUVÊA, Maria de Fátima Silva. O Império das Províncias. Rio de Janeiro, 1822-1889. Rio de Janeiro: Civilização Brasileira/Faperj, 2008;"Política Provincial na Formação da Monarquia Constitucional Brasileira. Rio de Janeiro, 1820-1850, in Almanack Brasiliense (online), ${ }^{\circ}$ 07, maio/2008, pp.119-137; SLEMIAN, Andréa. Sob o império das leis: Constituição e unidade nacional na formação do Brasil (1822-1834). Tese de doutorado apresentada ao Departamento de História da Faculdade de Filosofia, Letras e Ciências Humanas da Universidade de São Paulo. São Paulo, 2006.
} 
semelhanças e peculiaridades, o que sugere olhar a construção da monarquia brasileira por um ângulo diferente: a consolidação do estado imperial no decurso do século XIX não seria o produto da cooptação dos elementos provinciais pelo governo central enraizado no Rio de Janeiro, dominador e consensualmente estabelecido. Ela seria, antes, o resultado de um complexo jogo político em que os agentes provinciais pugnaram - no parlamento, nas esferas de poder local, na imprensa e, não poucas vezes, mediante o uso de armas - no sentido de consolidarem sua participação no controle do novo Estado a ser construído em moldes liberais. ${ }^{5}$

O delineamento das bases políticas de um novo Estado foi o principal objetivo da convocação da Assembléia Constituinte de 1823 e da elaboração da Carta de 1824. Mas as repercussões de sua outorga deixaram claro que inexistia entre os agentes da época um consenso acerca da estrutura política a ser aplicado ao recém-instaurado Império. ${ }^{6}$ A criação de uma rede de poder provincial juridicamente consagrada pelo texto constitucional não tratava apenas da materialização de um arcabouço político-administrativo capaz de dar forma ao novo Estado. Por trás desse processo de normatização do estado imperial - que ocorreu paulatinamente e, por vezes, de forma errática - e do papel que as províncias desempenhariam nessa construção, subjazia a necessidade de se equacionarem os interesses locais com aqueles chamados “nacionais”, isto é, de criar lugares de representação e ação para as províncias e localidades, tornando-as construtoras dessa obra política.

Situada no interior dessas reflexões, a presente pesquisa procura analisar, simultaneamente, o debate na imprensa e a criação de espaços de poder provincial em São

\footnotetext{
${ }^{5}$ GOUVÊA, 2008, op. cit.

${ }^{6}$ COSTA, Wilma Peres. "A economia mercantil escravista nacional e o processo de construção do Estado no Brasil”, in SZMRECSÁNYI, Tamás e LAPA, José Roberto do Amaral (orgs.). História Econômica da Independência e do Império. São Paulo: Hucitec/Fapesp, 1996. pp. 147-159.
} 
Paulo em meio ao processo simultâneo de configuração da Nação e do Estado constitucional. Assim, aborda a atuação política do Conselho da Presidência (1824-1834) e do Conselho Geral (1828-34), ambos da província de São Paulo que, juntamente com a presidência da província, constituíram a base do poder provincial durante o Primeiro Reinado e os anos iniciais do período regencial, até a extinção de ambos os Conselhos, em 1834. Criado pela lei de 23 de outubro de $1823^{7}$, o Conselho da Presidência consistia um braço do executivo provincial, mas, como veremos, sua atuação política extrapolava a condição de um órgão meramente consultivo, firmando-se como importante contraponto à ação política do presidente de província. Já os Conselhos Gerais, estipulados pela Carta de 1824 e regulamentados pela lei de 27 de agosto de $1828^{8}$, funcionaram como os principais canais de representatividade política em nível provincial até a implantação das Assembléias Legislativas, em 1835.

A escolha de São Paulo como cenário para o estudo dos vínculos entre a monarquia constitucional brasileira e o papel das províncias nesse sistema político não é fortuita. O presente trabalho inspirou-se em algumas constatações feitas durante pesquisa desenvolvida no nível de Iniciação Científica entre agosto de 2003 e julho de $2005^{9}$, e que evidenciaram a existência de lacunas na bibliografia sobre São Paulo na primeira metade do século XIX. Longe de ser uma questão meramente quantitativa, a escassez de estudos mais aprofundados sobre temas como a formação dos partidos políticos e os processos eleitorais impede uma compreensão mais detalhada no que se refere à dinâmica de São Paulo, principalmente

\footnotetext{
7 “Lei de 20 de Outubro de 1823 que dá forma aos Governos das Províncias, creando para cada uma dellas um Presidente e Conselho", op. cit.

8 "Lei de 27 de Agosto de 1828 que dá regimento para os Conselhos Geraes de Provincia”, in Coleção das Leis do Império do Brasil de 1828. Rio de Janeiro: Tipografia Nacional, 1878, pp.10-24.

${ }^{9}$ OLIVEIRA, Carlos Eduardo França de. Discutindo a memória de protagonistas do Império. Estudo do Fundo Marquês de Valença pertencente ao acervo do Museu Paulista. Relatório de pesquisa em Iniciação Científica, Museu Paulista, julho 2005. Pesquisa com financiamento PIBIC/CNPq/USP.
} 
quando se tem em mente a posição central que essa localidade ocupou no processo de criação do Estado Nacional. Nesse sentido, o caso dos Conselhos Provinciais é notório. Utilizados marginalmente nas pesquisas historiográficas, os Conselhos Provinciais de São Paulo receberam pouca atenção dos historiadores enquanto objeto de estudo, embora figurem nos livros de história como exemplo da participação política dos paulistas no movimento de institucionalização da monarquia. ${ }^{10}$

Desse modo, o presente estudo tem o intuito de dialogar com o movimento de criação do Estado e Nação brasileiros, vislumbrando na análise dos Conselhos a possibilidade de ampliar o conhecimento acerca da discussão política engendrada nesse processo. Os Conselhos Provinciais representam, assim, um lugar privilegiado no interior desse debate, seja pela relação que os dois órgãos estabeleceram com outras esferas oficias de poder, como as Câmaras Municipais, o Parlamento e o Executivo, seja pelo contato travado com dimensões outras da luta política provincial, especialmente com a imprensa. Pelo fato de os Conselhos Provinciais de São Paulo também se constituíram em espaços para a confrontação de propostas e políticas públicas, eles acabam se tornando pertinente contraponto às discussões desenvolvidas pela imprensa paulista no período, que aqui será discutida, principalmente, mediante a análise dos dois primeiros jornais veiculados na província de São Paulo: O Farol Paulistano (1827-1831) e O Observador Constitucional (1829-1832).

\footnotetext{
${ }^{10}$ LEME, Marisa Saenz. "São Paulo no I Império: poderes locais e governo central”, in OLIVEIRA, Cecilia Helena de Salles; PRADO, Maria Ligia Coelho; JANOTTI, Maria de Lourdes Monaco (org.). A história na política, a política na história. São Paulo: Alameda, 2006, pp. 59-80 ; "Dinâmicas centrípetas e centrífugas na formação do Estado monárquico no Brasil: o papel do Conselho Geral da Província de São Paulo”. Rev. Bras. Hist., Jan./Jun., 2008, vol.28, n.55, pp.197-215. ISSN 0102-0188.
} 
A despeito das diferentes matrizes interpretativas que compõem as pesquisas sobre a história do Império, a imprensa periódica tem figurado entre seus estudiosos como importante instrumento de discussão política, na medida em que, além de difundir concepções e propostas voltadas para o tema da instauração do governo constitucional e dos instrumentos da cidadania, desempenhou também um papel fundamental enquanto órgão doutrinador do posicionamento político da época. ${ }^{11}$

Empregados tradicionalmente como elemento comprobatório ou elucidativo de um discurso historiográfico previamente concebido, os periódicos passaram a receber uma atenção especial, sobretudo a partir da década de 1970, por parte dos historiadores preocupados em compreender a política do Império por um viés que não aquele alinhado exclusivamente às esferas oficiais de poder. Trabalhos como os de Arnaldo Contier, Augustin Wernet e Maria Beatriz Nizza da Silva abriram importantes perspectivas de pesquisa na utilização da imprensa como objeto de estudo, na medida em que conceberam os impressos como construtores e mediadores de um universo político que, longe de se restringir ao poder institucionalizado, permeou a sociedade do século XIX em seus mais diversos âmbitos. $^{12}$

\footnotetext{
${ }^{11}$ Para obras de referência sobre a origem da imprensa na América portuguesa e no Brasil, ver RIZZINI, Carlos. O livro, o jornal e a tipografia no Brasil 1500-1822. São Paulo: Imprensa Oficial do Estado/Imesp, 1988; SODRÉ, Nelson Werneck. A história da imprensa no Brasil. Rio de Janeiro: Imprensa Brasileira, 1966; VIANNA, Helio. Contribuição à história da Imprensa no Brasil (1812-1869). Rio de Janeiro: Instituto Nacional do Livro/ Imprensa Nacional, 1945; FERREIRA, Tania Maria Bessonde da C.; MOREL, Marco; NEVES, Lucia Maria Bastos Pereira. (orgs.). História e Imprensa: representações culturais e práticas de poder. Rio de Janeiro: DP\&A/ Faperj, 2006; MARTINS, Ana Luiza; LUCA, Tania Regina de (orgs.). $\underline{\text { História }}$ da Imprensa no Brasil. São Paulo: Editora Contexto, 2008;

${ }^{12}$ CONTIER, Arnaldo. Imprensa e ideologia em São Paulo, 1822-1842: matizes do vocabulário político e social. Petrópolis: Vozes, 1979; SILVA, Maria Beatriz Nizza da. Formas de representação política na época da Independência (1820-1822). Brasília: Câmara dos Deputados, Centro de Documentação e Informação, Coordenação de Publicações, 1988; WERNET, Augustin. Sociedades políticas (1831-32). São Paulo: Cultrix, 1978.
} 
A análise da imprensa como instrumento de luta política é um dos temas centrais da obra Movimento Praieiro, 1842-1849: imprensa, ideologia e poder político ${ }^{13}$, de Izabel Marson. Para a autora, se por um lado o estudo de um impresso permite diagnosticar o perfil ideológico daqueles elementos que o sustentam, por outro evidencia a forma retóricopedagógica com que tais grupos se valeram para enunciar seus pressupostos e formas de ação sobre a organização política do Império. Deste modo, mais do que um veículo de disseminação de idéias, a imprensa tinha como objetivo formar e combater idéias, e ao mesmo tempo servir como estratégia de projeção política, uma vez que grande parte dos redatores e colaboradores que compunham os periódicos representava grupos políticos e econômicos e visava intervir nas eleições no pós-Independência.

Alguns autores também apontaram para a necessidade de avaliar a imprensa do século XIX além do conteúdo nela propagado, a fim de observar os nexos existentes entre a produção de periódicos e as modificações estruturais ocorridas no Império. Segundo Marco Morel $^{14}$, o advento de periódicos no Brasil, ao longo da década de 1820, esteve atrelado às alterações nos espaços públicos, à crescente modernização da esfera política e cultural e à construção das bases do Estado Nacional. Foi somente dentro desse contexto, isto é, no interior de um espaço público alicerçado em opiniões distintas, que a imprensa conseguiu desempenhar sua função de produtora e disseminadora de ideais políticos.

Valendo-se de referências teóricas propostas por autores como Jürgen Habermas, no que tange à problemática da esfera pública, Morel imputou ao termo espaço público um

\footnotetext{
${ }^{13}$ MARSON, Izabel. Movimento Praieiro, 1842-1849: imprensa, ideologia e poder político. São Paulo: Editora Moderna, 1980. Da mesma autora, ver também O Império do progresso: A revolução Praieira em Pernambuco. São Paulo: Editora Brasiliense, 1987.

${ }^{14}$ MOREL, Marco. As transformações dos espaços públicos: imprensa, atores políticos e sociabilidade na cidade imperial (1820-1840). São Paulo: Hucitec, 2005; MOREL, Marco; BARROS, Mariana Monteiro de. Palavra, imagem e poder: o surgimento da imprensa no Brasil do século XIX. Rio de Janeiro: DP \& A, 2003.
} 
valor polissêmico, portador de três sentidos: o da esfera ou cena pública que, não se confundindo com o Estado, constituiu uma rede de interações entre diferentes agentes históricos; o da esfera literária e cultural, conduzida pela expressão letrada e oral de parcela desses agentes; e o dos espaços físicos propriamente ditos. ${ }^{15}$ Em artigo recente, Morel elucidou as interfaces entre essas esferas e a imprensa:

"Para melhor dimensionar o estudo histórico da imprensa na primeira metade do século XIX é instigante compreendê-la como um dos mecanismos de participação política, com sua própria especificidade e ritmos, mas interligada a outros destes mecanismos que transcendiam a palavra impressa, como: pertencimento às sociabilidades (institucionalizadas ou não), lutas eleitorais e parlamentares, exercício da coerção governamental, movimentações nas ruas, mobilização de expressivos contingentes da população, recursos à luta armada (por meio de motins, rebeliões, etc.) e, sobretudo, formas de transmissão oral e manuscrita tão marcantes nas sociedades daquela época”. ${ }^{16}$

A partir das reflexões apresentadas por Morel, torna-se possível notar que, ao se relacionar com a sociedade e seu amplo sistema de representações, a imprensa surgiu como articuladora dos espaços públicos, uma vez que ela ajudou a organizar e reproduzir formas de sociabilidade que por seu turno conferiram inteligibilidade ao gradativo processo de criação do Estado Nacional. Nesse sentido, considerando que a política se inscreve na reflexão diária de uma sociedade sobre ela mesma ${ }^{17}$, cumpre destacar que o presente trabalho pretende cotejar o discurso político desenvolvido pela imprensa com aqueles

\footnotetext{
${ }^{15}$ MOREL, op. cit., 2005, p.18.

16 MOREL, Marco. "Independência no papel: a imprensa periódica”, in JANCSÓ, István (org.). Independência: história e historiografia. São Paulo: Hucitec/FAPESP, 2005, p.617.

${ }^{17}$ ROSANVALLON, Pierre. "Por uma história conceitual do político", in Revista Brasileira de História. São Paulo: APUHH/ Ed. Contexto, n³0, 1995. Trad. de Paulo Henrique Martinez, pp.39-40.
} 
propalados em outros espaços públicos, notadamente dentro da esfera oficial de poder da província de São Paulo.

Do ponto de vista do tema e da periodização adotados, essa confrontação de discursos enseja o contato com dois movimentos entrelaçados. De um lado, o da paulatina institucionalização do estado imperial a partir do cumprimento da Carta de 1824 e da implementação das instituições por ela asseguradas. De outro, o da prática política desenvolvida nessas instituições que, no tocante aos órgãos provinciais, assumiu feições distintas de acordo com as demandas e os interesses de determinados grupos locais. ${ }^{18}$ Ambos os movimentos foram pauta de discussão da imprensa periódica do período, já que essa fez da sua intervenção cotidiana um mecanismo de luta que acabou convertendo-a, em grande medida, num lugar de reflexão e atuação política plural que evidenciou para os próprios coevos a situação de permanente construção do Estado Nacional.

Levando em conta essas questões, o presente trabalho pretende articular a análise dos periódicos acima referidos com a formação da estrutura de poder provincial ao longo do Primeiro Reinado e início do período regencial, sobretudo dos Conselhos Provinciais paulistas, a fim de aprofundar a discussão e constatar possíveis evidências que permitam questionar um dos postulados mais persistentes da bibliografia sobre São Paulo no começo do Império: o de que os paulistas, até pelos menos o fim das Regências, compartilharam de um liberalismo homogêneo, “moderado”, sem grandes nuanças. Isso porque os Conselhos Provinciais constituíam fóruns de debate compostos por representantes de diversas localidades da província, ou seja, estabeleciam espaços de definição de políticas provinciais durante a formação das bases do Império, ao passo que a imprensa consistia no veículo de

\footnotetext{
${ }^{18}$ DOLHNIKOFF, Miriam. Construindo o Brasil: unidade nacional e pacto federativo nos projetos das elites (1820-1842). Tese de doutorado apresentada ao Departamento de História da Faculdade de Filosofia, Letras e Ciências Humanas da Universidade de São Paulo. São Paulo, 2000.
} 
disseminação dos projetos políticos desses homens. Nesse sentido, a proposta de problematizar a homogeneidade dos grupos políticos procura considerar a complexidade do processo de formação do Estado Monárquico e da inserção da província nesse movimento, como também as controvérsias históricas e historiográficas que envolvem a configuração do liberalismo no Brasil do século XIX. Se a projeção dos políticos paulistas na primeira metade do século XIX consolidou-se após a abdicação de D. Pedro - processo assinalado por Paulo Pereira de Castro em seu artigo A experiência republicana: $1831-1840^{19}$-, esta não se deu de forma automática, isto é, foi resultado de um constante diálogo dos políticos paulistas com a Corte e outras regiões do Império. Além disso, a ascensão política no âmbito da construção do Estado Nacional de homens como José da Costa Carvalho, Nicolau Vergueiro e Diogo Antônio Feijó trouxe consigo um malha de interesses econômicos cuja defesa foi fundamental para a projeção da província de São Paulo no delinear do Primeiro Reinado.

As fontes utilizadas na pesquisa dividem-se em seis grupos principais: atas, pareceres, resoluções e ofícios do Conselho da Presidência (1824-1834) e do Conselho Geral (1828- 1834) de São Paulo; atas da Câmara dos Deputados e do Senado do Império (1826-1834); atas do Conselho de Estado (1828-1834); Registros Gerais da Câmara Municipal da cidade São Paulo (1824-1834); periódicos, sobretudo paulistas, do Primeiro Reinado e do início do período regencial, com ênfase nos jornais O Farol Paulistano (1827-

\footnotetext{
${ }^{19}$ CASTRO, Paulo Pereira de., op. cit. Ainda que ultrapasse a cronologia da pesquisa, a exposição de Paulo Pereira de Castro é fundamental para a compreensão dos desdobramentos políticos delineados imediatamente antes e principalmente após a Abdicação de D. Pedro I. A instabilidade do momento elucida, segundo o autor, não apenas a multiplicidade de projetos políticos do período regencial e os motivos pelos quais as bases políticas do Império foram alteradas, mas também a permanência de antagonismos que remontam tanto ao início da década de 1820 como ao decorrer do Primeiro Reinado, sobretudo no que diz respeito ao debate constitucional.
} 
1831) e O Observador Constitucional (1829-1832); além de decisões do Executivo e leis aprovadas pela Assembléia Geral durante a época estudada.

Sobre esse conjunto documental, cabem aqui dois aclaramentos. Em primeiro lugar, a documentação consultada sobre o Conselho Geral de São Paulo encontra-se bastante fragmentada, não havendo, por exemplo, um registro completo das suas atas e resoluções, o que dificultou o entendimento sobre a atuação política desse órgão. ${ }^{20}$ Em segundo, as séries documentais referentes aos periódicos examinados são, de modo geral, incompletas, sem mencionar o caráter efêmero ou intermitente da maioria dos jornais da época. ${ }^{21}$ Por conseguinte, nem sempre foi possível entrelaçar a discussão dos Conselhos com a dos periódicos, tampouco acompanhar simultaneamente a trajetória dos periódicos.

A presente dissertação está dividida em três capítulos. No primeiro, o objeto de discussão será a dimensão política da imprensa periódica de São Paulo durante o Primeiro Reinado e início da Regência, com ênfase nos jornais O Farol Paulistano e O Observador Constitucional. No segundo serão analisados os Conselhos Provinciais - Geral e da Presidência - de São Paulo, atentando-se para sua atuação político-administrativa em meio à

\footnotetext{
${ }^{20}$ A documentação textual referente ao Conselho Geral da Província de São Paulo constituiu problema à parte no encaminhamento da pesquisa. Em síntese, a documentação que o Arquivo Público do Estado de São Paulo indica resguardar sobre o Conselho Geral da Província de São Paulo - sobretudo atas e pareceres - quase não consta em seus arquivos. As latas que supostamente abarcariam tais documentos (CO 55649; CO 5650; CO 5682; CO 5651) contêm, majoritariamente, atas e pareceres relativos ao Conselho da Presidência de São Paulo, e não do Conselho Geral, conforme indicam os guias. Para o presente relatório, o problema foi contornado de três maneiras. No que diz respeito às atas do Conselho Geral, foram utilizados resumos das sessões publicados pelo Farol Paulistano entre dezembro de 1828 e janeiro de 1831. Já com relação às resoluções efetivamente tomadas pelo órgão, utilizou-se um caderno manuscrito pertencente ao Arquivo Público do Estado de São Paulo que contém todos os ofícios, representações e propostas encaminhadas pelo Conselho Geral de São Paulo tanto à Assembléia Geral quanto ao governo central entre 1828 e 1831. Para o período posterior a 1831, foram utilizadas fontes do Fundo Conselho Geral da Província de São Paulo, pertencente Serviço de Documentação Textual do Acervo Histórico da Assembléia Legislativa do Estado de São Paulo, mas cujas séries documentais também se apresentam fragmentadas.

${ }^{21}$ À exceção de $O$ Farol Paulistano e de O Observador Constitucional, que contém séries mais completas, o restante dos periódicos paulistas consultados não chega a compor um conjunto documental que contemple toda a periodização da pesquisa. Com relação ao período que vai de meados de 1832 até a votação do Ato Adicional, em agosto de 1834, há poucos registros documentais da imprensa periódica paulista.
} 
composição do poder provincial paulista, e enfatizando o processo de institucionalização desses órgãos. O terceiro e último capítulo tratará de ambos os Conselhos, sobretudo após a Abdicação, articulando-os com a luta política travada entre os referidos periódicos ante questões prementes para a época, como a reestruturação financeira do Império, a reforma constitucional, o sistema federativo e a função dos governos provinciais nesse novo quadro político. 


\section{Capítulo 1}

\section{Imprensa e política nos primeiros anos do Império}

Nascida a 10 de setembro de 1808 com a publicação do primeiro número de Gazeta do Rio de Janeiro ${ }^{22}$, periódico oficial da Corte de D. João, a imprensa no Brasil, desde seu início, não se caracterizou por ser um veículo homogêneo política e ideologicamente. Se os impressos vinculados à Coroa predominaram até 1820, isso ocorreu sobretudo pela constante censura imposta pela administração real contra o advento de periódicos opostos aos seus propósitos. A imprensa desempenhou até então um papel fundamental na conformação política desse período, especialmente entre 1821 e 1823, por meio do debate constitucional e da discussão sobre os proveitos da instauração de um governo liberal com sede no Brasil. ${ }^{23}$

Com a dissolução da Assembléia Constituinte e a outorga da Carta de 1824, a imprensa periódica sofreu, entretanto, um refluxo significativo, de forma que se, em 1823, o número de jornais publicados na Corte atingira a casa dos 30 títulos, nos dois anos seguintes essa quantidade caiu para $13 .^{24}$ Em meio à perseguição política imposta pelo governo central aos seus opositores mais contundentes, especialmente aqueles grupos que questionavam a autoridade do poder imperial no Rio de Janeiro, a divisão de poderes

\footnotetext{
${ }^{22}$ A Gazeta do Rio de Janeiro circulou entre 1808 e 1822, alterando seu nome para Diário do Governo a partir de 1822. Seu principal redator foi Manuel Ferreira de Araújo Guimarães, que a redigiu até julho de 1821. Segundo Isabel Lustosa, a Gazeta era uma de jornal de cunho oficial, quase uma adaptação da Gazeta de Lisboa, pois se restringia a publicar os atos do poder central e a traduzir artigos da imprensa européia mais conservadora. Cf. LUSTOSA, op. cit., pp. 68-71. Ver, também, MEIRELLES, Juliana Gesuelli. Imprensa e poder na corte joanina: a Gazeta do Rio de Janeiro (1808-1821). Rio de Janeiro: Arquivo Nacional, 2008.

${ }^{23}$ NEVES, Lucia Maria Bastos Pereira das. Corcundas, constitucionais e pés-de-chumbo: a cultura política da independência, 1820-1822. Rio de Janeiro: FAPERJ: Revan, 2003. Ver, também, SODRÉ, op. cit., pp.50-52; OLIVEIRA, Cecília Helena de Salles, op. cit., 1999.

${ }^{24}$ IPANEMA, Marcelo; IPANEMA, Cybelle. "Imprensa na Regência: observações estatísticas e de opinião pública”, in Revista do Instituto Histórico e Geográfico Brasileiro, v.307, 1976, p.94, quadro 2.
} 
estabelecida pela Carta de 1824 e a própria legitimidade do documento jurado por D. Pedro, a imprensa de orientação liberal recebeu duros golpes. Dentre eles a prisão do baiano Cipriano Barata, redator de A Sentinela da Liberdade, em 1824, e as mortes de João Soares Lisboa, que em 1822 e 1823 havia dirigido o Correio do Rio de Janeiro, e de Frei Caneca, redator do Typhis Pernambucano, ocorridas respectivamente em 1824 e 1825, em meio à Confederação do Equador. ${ }^{25} \mathrm{O}$ encarceramento de João Mendes Vianna, redator de o Escudo da Liberdade do Brasil, ocorrido já em 1823, e a extradição de Pierre de Chapuis, redator de o Verdadeiro Liberal que contestou o modo como fora acordado o

${ }^{25}$ Cipriano José Barata de Almeida (1762-1838) era natural de Salvador. Formado em Filosofia pela Universidade de Coimbra, engajou-se na política desde jovem, participando da Conjuração Baiana de 1798 e da Revolução de Pernambuco de 1817. Em 1821, foi eleito deputado pela Bahia para as Cortes de Lisboa, cadeira que abandonou no ano seguinte. Em 1823, foi eleito deputado para a Assembléia Constituinte reunida por D. Pedro no Rio de Janeiro, porém se recusou a tomar assento em protesto contra as tendências políticas que norteavam a maioria dos políticos eleitos para a elaboração da Constituição. No mesmo ano, começou a publicar o jornal A Sentinela da Liberdade, mas foi encarcerado no ano seguinte, por ser um dos articuladores da Confederação do Equador. Libertado em 1830, retornou à Bahia, mas no ano seguinte foi novamente preso, sendo definitivamente solto em 1834, com mais de setenta anos de idade. Para a biografia de Cipriano Barata, ver MOREL, op. cit., 2001.

Joaquim da Silva Rabelo, posteriormente frei Joaquim do Amor Divino e por fim frei Caneca (17791825) era natural do Recife. Ordenando-se em 1801, cursou o Seminário de Olinda, onde freqüentou suas aulas e biblioteca, de modo que dois anos depois foi nomeado professor de retórica e geometria de seu convento, onde ainda lecionou filosofia e moral. Em 1817, participou da Revolução Pernambucana, sendo preso e enviado para a Bahia após a queda do movimento. Ao ser libertado, em 1821, pelo movimento constitucionalista do Porto, voltou para sua província natal e se engajou ativamente na política pernambucana, apoiando a formação da primeira Junta Governativa de Pernambuco, presidida pelo comerciante Gervásio Pires Ferreira, que o nomeou para a cadeira de geometria da vila do Recife. Em dezembro de 1823, após a dissolução da Constituinte, Frei Caneca fez circular o primeiro número do jornal Typhis Pernambucano, no qual criticava as medidas arbitrárias tomadas por D. Pedro e seu Ministério e defendia a instauração de um Estado liberal descentralizado. Um dos líderes da Confederação do Equador, foi preso e julgado em dezembro de 1824, sendo executado em janeiro do ano seguinte. Para a vida e obra de Frei Caneca, ver CANECA, frei Joaquim do Amor Divino. Obras políticas e literárias de frei Joaquim do Amor Divino Caneca. Organização de Joaquim de Melo. Recife: Assembléia Legislativa de Parnambuco, 1972, e CANECA, frei Joaquim do Amor Divino. Frei Joaquim do Amor Divino Caneca. Organização e introdução de Evaldo Cabral de Mello. São Paulo: Editora 34, 2001. (Coleção Formadores do Brasil)

João Soares Lisboa (?-1824) era natural de Portugal. Comerciante e jornalista, destacou-se nos acontecimentos políticos dos primeiros anos da década de 1820, ao defender os interesses dos negociantes no Rio de Janeiro, artífices, pequenos proprietários, militares, funcionários das repartições e imigrantes portugueses recém-chegados. Entre abril e outubro de 1822, publicou o Correio do Rio de Janeiro, jornal que tornaria a ser produzido entre agosto e novembro de 1823, e que teve papel importante na crítica às atitudes tomadas pelas Cortes de Lisboa, na difusão da idéia da convocação da Constituinte e na defesa por um compromisso prévio de D. Pedro com a Constituição antes mesmo da aclamação. Aliando-se à Confederação do Equador, foi morto em combate, em 1824, quando lutava contra as tropas imperiais. Para a participação de Soares Lisboa na Imprensa, ver OLIVEIRA, Cecilia Helena de Salles, 1999, op. cit., especialmente capítulos 3 e 4 . 
reconhecimento da independência ${ }^{26}$, também ajudaram a compor um quadro no qual os escritores liberais, notadamente aqueles de orientação mais "radical”, viram-se intimidados pelo governo da Corte, situação que foi potencializada pelo pouco estímulo conferido ao debate político pelas folhas alinhadas ao governo, tal como o Diário Fluminense, e pela demora na institucionalização do Parlamento.

O revigoramento da imprensa periódica deu-se a partir de 1826, e esteve estritamente associado à abertura da primeira legislatura do Império, ocorrida em maio desse ano, e à conseqüente ampliação do debate político desenvolvido no interior das esferas oficiais de poder bem como fora delas. Nesse sentido, a convocação da Assembléia Geral representou um ponto de inflexão na conformação política do governo do Primeiro Reinado que, desde 1824, vinha sendo dirigido apenas por D. Pedro, seu ministério e Conselho de Estado, fato que marcara negativamente a figura do monarca e de seu círculo político perante os demais setores envolvidos no processo de concretização do novo Estado. Com efeito, só em 1826 o número de folhas impressas na Corte saltou para 31, sendo que nos anos seguintes excetuando 1827, que ficou na casa dos 26 jornais publicados -, a tendência foi de crescimento, chegando à marca de 52, em $1830 .^{27}$

É de se notar que, afora esse interregno de dois anos entre a outorga do texto constitucional e a reunião das duas Câmaras, e as razões imediatas para que tal convocação fosse feita - especialmente a definição dos orçamentos ministeriais e de uma política fiscal

\footnotetext{
${ }^{26}$ Trata-se do folheto intitulado Reflexões sobre o tratado de independência, e a carta de lei promulgada por Sua Majestade Fidelíssima, que circulou na Corte, em 1826. Natural da França, Chapuis já havia sido redator na Espanha, no Regulador de Madri, e em Portugal, antes de fixar-se no Rio de Janeiro. Pelo fato do seu folheto ter reprovado o conteúdo do acordo de reconhecimento da independência, sobretudo no que se referia ao reconhecimento de D. Pedro na qualidade de herdeiro legítimo da coroa portuguesa, Chapius foi forçado pelo governo brasileiro a deixar o Brasil, o que de fato ocorreu ainda em 1826. Sobre o episódio, ver ARMITAGE, John. História do Brasil. São Paulo: Martins, 1972. $1^{\text {a }}$ edição:1836, pp.107-108, e SODRÉ, op. cit., pp.113-114.

${ }^{27}$ IPANEMA; IPANEMA, op. cit., p.94.
} 
adequada às necessidades do nascente Império ${ }^{28}$-, motivações subjacentes contribuíram para que o governo central pusesse em funcionamento, sob pressão e suspeição da ampla e heterogênea oposição liberal, as bases representativas da monarquia brasileira. Não obstante os projetos que pleiteavam uma monarquia constitucional com amplos poderes ao Executivo estivessem longe de ser unanimemente aceitos pelos distintos grupos políticos no início dos anos vinte, circunstância que ficara explícita no plenário de 1823, a imagem de D. Pedro, nos idos de 1826, havia perdido muito de um prestígio que já vinha declinando desde o fechamento da Constituinte e da imposição da Carta de 1824, e que sofrera um abalo sensível após o violento desfecho da Confederação do Equador. ${ }^{29}$ Conjugadas a esses fatores, outras questões colaboraram para que a imagem de D. Pedro e seu ministério sofressem continuadas críticas, dentre elas o reconhecimento do Império do Brasil mediante a assinatura do controvertido Tratado de Paz de 7 de setembro de 1825, o custeamento da guerra pela Cisplatina contra o governo de Buenos Aires, e, sobretudo, o aumento da crise financeira do Império bem como o envolvimento dúbio que o imperador mantinha com os negócios portugueses. ${ }^{30}$

Inserida nesse contexto de tensão política e debilidade financeira, a convocação da primeira legislatura significou, portanto, um momento de clivagem política para os representantes eleitos em 1824 como para seus correligionários, que viram nesse ato uma vitória do constitucionalismo, além da consubstanciação de um instrumento definitivo de conquista de espaço político no interior do processo de formação do novo Estado em moldes

\footnotetext{
${ }^{28}$ CARREIRA, Liberato de Castro. História Financeira e orçamentária do Império do Brasil desde sua fundação. Rio de Janeiro: Imprensa Nacional, 1889.

${ }^{29}$ LYRA, Maria de Lourdes Viana. O Império em construção: Primeiro Reinado e Regências. São Paulo: Atual, 2000.

${ }^{30}$ MONTEIRO, Tobias. História do Império: o Primeiro Reinado. São Paulo: Itatiana/UDUSP, 1982, vol 1, capítulos 2, 3, 9, 10 e 12 .
} 
liberais. $^{31}$ Aparentemente direta, a relação entre a convocação do Parlamento e o recrudescimento da imprensa periódica fez parte, na realidade, de um conjunto de fatores que haviam tornado a configuração política do Império demasiada complexa e até mesmo insustentável no que se referia à manutenção de uma monarquia constitucional cujas bases de representação parlamentar ainda não tinham sido instituídas. Assim, iniciados os trabalhos do Parlamento, a imprensa tornou-se veículo privilegiado de sustentação ideológica para os políticos da nação.

A maior parte dos impressos surgidos em 1826 alinhava-se aos preceitos mais gerais do liberalismo, tendência que se acentuou no ano seguinte com o acirramento do enfrentamento entre a Câmara dos Deputados, o Senado e o Ministério, especialmente no que se referia à política fiscal do Império. Se projetos importantes como o que responsabilizava o Conselho de Estado e o Ministério pelos seus atos, o estabelecimento dos Cursos Jurídicos em São Paulo e Olinda, a regulamentação dos Conselhos Gerais de província e das Câmaras Municipais, e a criação do Juizado de Paz foram discutidos por ambas as Câmaras e votados posteriormente, a definição de uma política econômica que contemplasse a questão orçamentária e tributária gerava grandes embates sobre os destinos do Tesouro do Brasil. ${ }^{32} \mathrm{O}$ aumento da dívida pública, os termos pelos quais foram adquiridos empréstimos no exterior antes da convocação do Legislativo, o crescimento das despesas com a campanha no Sul e a possibilidade de aumento da carga tributária eram

\footnotetext{
${ }^{31}$ Cf. MATTOS, Ilmar Rohloff de. “A trama dos interesses na construção da unidade política”, in JANCSÓ (org.), op. cit., p.295 e seguintes.

32 Apenas orçamentos parciais foram votados entre 1826 e 1829, de modo que só somente em 15 de novembro de 1830, na prorrogação da sessão daquele ano, é que se aprovou o orçamento geral do Império para 1831-1832, cf. "Lei de 15 de dezembro de 1830 - orça a receita fixa a despeza para o anno financeiro de 1831-1832”, in Coleção Leis do Império de 1830. Rio de Janeiro: Tipografia Nacional, 1876, pp.100-138 Para o assunto, ver DINIZ, Adalton Francisco. Centralização política e apropriação de riqueza: análise das finanças do Império brasileiro (1821-1889). Tese de doutorado apresentada ao Departamento de História da Faculdade de Filosofia, Letras e Ciências Humanas da Universidade de São Paulo. São Paulo, 2002.
} 
questões ao mesmo tempo substantivas e contraditórias, e que opunham, principalmente, deputados e ministros. Estes pleiteavam um acréscimo no orçamento para as pastas ministeriais, bem como um incremento na carga tributária, ao passo que aqueles, organizados desde 1826 numa Comissão dirigida para o exame dos negócios financeiros e diplomáticos, refutavam a ampliação de tributos e exigiam a prestação de contas do Ministério em relação a seus gastos. ${ }^{33}$

O ganho de espaço pelos liberais por meio da imprensa deu-se tanto no Rio de Janeiro como em outras províncias. Na Corte, surgiram periódicos como a Astréa (1826) e Aurora Fluminense (1827); em Minas Gerais, o Astro de Minas (1827), que teve influência de o Universal (1825); em São Paulo, o Farol Paulistano (1827); e no Maranhão, o Farol Maranhense e A Minerva, os dois criados em $1827 .^{34}$

${ }^{33}$ DOIN, José Evaldo de Mello. Dívida externa do Império. Organização e consolidação do Estado e início do processo de modernização dos instrumentos de exploração, 1824-1864. Tese de doutorado apresentada ao Departamento de História da Faculdade de Filosofia, Letras e Ciências Humanas da Universidade de São Paulo. São Paulo, 1986, 2 v.

${ }^{34}$ A Astréa circulou no Rio de Janeiro entre 17 de Junho de 1826 e 18 de agosto de 1832, e teve como redatores Antônio José do Amaral e José Joaquim Vieira Souto. Vinculado inicialmente à Tipografia Mercantil, passando a ser impressa posteriormente nas Tipografias do Diário, Torres e da própria Astréa, o periódico dirigido por Amaral e Vieira Souto circulava na Capital do Império três vezes por semana. Segundo Nelson Werneck e Marco Morel, a Astréa foi um dos principais periódicos fluminenses alinhados ao grupo dos chamados "liberais moderados", desempenhando o papel não apenas de produtor e disseminador de concepções políticas, como também de modelo para os jornais de orientação liberal surgidos após a instalação da Assembléia Geral, em 1826.

A Aurora Fluminense circulou no Rio de Janeiro entre 21 de dezembro de 1827 e 1835. Fundado por José Apolinário de Morais, Francisco Crispiniano Valdetaro e José Francisco Sigaud, teve como principal redator Evaristo Ferreira da Veiga, tornando-se à época desse um dos periódicos "liberais" de maior influência no Primeiro Reinado. Segundo SODRÉ, op. cit, p. 124, a Aurora "combatia o aulicismo, o absolutismo, os vícios administrativos, os gastos perdulários, o déficit orçamentário, as 'enfermidades morais'. Não oferecia senão doutrina; a informação era mínima, salvo quanto à política; a publicidade, nula. Defendia as prerrogativas do Legislativo; queria o progresso, lamentando a rotina de nossas indústrias, mas ressalvando que o Brasil teria de ser por muitos anos nação essencialmente agrícola”. Ou seja, a Aurora combatia os ministros e o projeto político de D. Pedro.

O Astro de Minas foi um periódico mineiro impresso em São João Del Rei entre 1827 e 1839. Redigido em seus primeiros anos por Batista Caetano de Almeida, que também fundou a primeira Biblioteca Pública da vila, figurou entre as principais folhas "liberais" de Minas Gerais no Primeiro Reinado. Cf. SODRÉ, op. cit., p.127-133.

O Universal circulou em Ouro Preto, Minas Gerais, entre 1825 e 1842. Durante o Primeiro Reinado, teve como principal redator Bernardo Pereira de Vasconcelos, que conferiu ao periódico uma postura de 
De modo geral, esses jornais se afinavam com a oposição feita pela Câmara dos Deputados ao governo de D. Pedro e, em determinados pontos, ao Senado, de forma que parte de seus redatores era composta por membros da própria Casa, como Evaristo da Veiga (Aurora Fluminense) e Batista Caetano de Almeida (Astro de Minas), deputados por Minas Gerais na segunda legislatura, Bernardo Pereira de Vasconcelos (O Universal), deputado por Minas Gerais nas duas primeiras legislaturas, José da Costa Carvalho (O Farol Paulistano), deputado pela Bahia nas duas primeiras legislaturas, Manoel Odorico Mendes (colaborador de O Farol Paulistano que já havia redigido em 1825, em São Luis do Maranhão, o liberal Argos da Lei), deputado pelo Maranhão nas duas primeiras legislaturas, e José Joaquim Vieira Souto (Astréa), deputado pelo Rio de Janeiro na segunda legislatura. ${ }^{35}$ Alguns dos nomes citados, como pode ser observado, só seriam deputados na segunda legislatura (1830-1833), fato que reitera a importância da imprensa como instrumento de projeção política.

Qualificados pela bibliografia como liberais “moderados”, terminologia utilizada pelos próprios coevos, os setores envolvidos na publicação desses periódicos bem como no estabelecimento da oposição parlamentar ao governo de D. Pedro julgavam-se adeptos da "moderação”, conceito que se apresentava, freqüentemente, mais como um instrumento analítico das diversas esferas da sociedade civil organizada do que uma posição política

oposição ao Governo, tornando-o um dos principais expoentes da imprensa "liberal” mineira do período. Cf. SODRÉ, op. cit., p.124-133.

O Farol Maranhense circulou em São Luiz de Maranhão entre 1827 e 1833. Até 1831, a folha foi redigida por José Cândido Morais, ao passo que a partir de 1832, o redator passou a ser João Francisco Lisboa. De orientação "liberal”, fez oposição ao Governo e dialogou com os periódicos da Corte. Cf. SODRÉ, op. cit., p.133. Sobre a atuação política de João Francisco Lisboa, ver JANOTTI, Maria de Lourdes Mônaco. João Francisco Lisboa, jornalista e historiador. São Paulo: Ed. Ática, 1977.

A Minerva circulou em São Luz do Maranhão entre 29 de dezembro de 1827 e 5 de março de 1829, e tendo como principal redator Davi Fonseca Pinto. Cf. SODRÉ, op. cit., p.133.

${ }^{35}$ TAUNAY, Afonso de Escragnolle. A Câmara dos deputados sob o Império. São Paulo: Imprensa Oficial do Estado de São Paulo, 1950, pp.115-122. 
rigorosamente demarcada. ${ }^{36}$ Espécie de visão de mundo baseada no "justo equilíbrio" das coisas - uma releitura, dentre outras influências, da concepção de just milieu empregada pelos liberais franceses das primeiras décadas do século XIX, que buscava fixar um ponto de equilíbrio entre a estrutura sócio-politica do Antigo Regime, o legado iluminista e a experiência revolucionária de 1789 -, a "moderação" aproximava-se, nesse sentido, das noções mais amplas da Razão ilustrada. ${ }^{37}$ No campo político, assim definiu-a a Aurora Fluminense, um dos periódicos liberais mais influente durante o Primeiro Reinado e início do período regencial:

"A moderação em política não é senão a prudência reguladora, que, modificando as opiniões sociais extremas, as chama ao justo meio-termo, ou antes que dá aos objetos o seu devido valor, sem deixar-se fascinar pelo calor do entusiasmo ou pelo prisma das paixões do momento". ${ }^{38}$

Para os "moderados" a busca pelo meio-termo da política passava, necessariamente, pela criação de um aparato jurídico-administrativo que proporcionasse ao mesmo tempo a divisão dos poderes, a criação de instituições representativas, a limitação da atuação dos governantes e a manutenção dos direitos de cidadania, sem pleitear, todavia, uma

\footnotetext{
${ }^{36}$ Vale ressaltar que os vocábulos "moderados” e "moderação” não constituem construções historiográficas elaboradas a posteriori, mas termos utilizados no interior dos círculos políticos brasileiros durante as décadas de 1820 e 1830 sob a influência do debate político-conceitual ocorrido na Península Ibérica no início do século XIX. Tanto a elaboração e execução da Constituição de Cádis (1812-1814), na Espanha, quanto a eclosão do movimento revolucionário do Porto foram permeados pela discussão em torno de um liberalismo dito "moderado" que, em linhas gerais, deveria equacionar a soberania monárquica com os demais poderes assegurados pela Constituição. A esse legado de matriz ibérica apropriado pelos políticos brasileiros soma-se uma influência liberal marcadamente francesa de autores como François Guizot e Benjamin Constant. Cf. MOREL, op. cit., 2005, p.117-118. O debate acerca do liberalismo é vasto e complexo e foge do escopo da pesquisa, mas nossas principais referências são: CARVALHO, José Murilo de. $\underline{\text { A construção da ordem: } a}$ elite política imperial. Rio de Janeiro: Campus, 1980; FRANCO, Maria Sylvia de Carvalho. Homens livres na ordem escravocrata. São Paulo: Editora Kairóz, 1983. $1^{\text {a }}$ edição 1968; BOSI, Alfredo. Dialética da colonização. São Paulo: Companhia das Letras, 1992; MARSON, Izabel Andrade. O Império do progresso: A revolução Praieira em Pernambuco. São Paulo: Editora Brasiliense, 1987.

${ }^{37}$ Ibid, op. cit., 2005, pp.119-120.

${ }^{38}$ A Aurora Fluminense, $n^{\circ}$ 563, 30/11/1831.
} 
organização social que ampliasse o espaço de cidadania já assegurado pela Carta de $1824 .{ }^{39}$ Tratava-se, como ressaltou Marcello Basile, de salvaguardar um pacto social a partir da lógica jusracionalista de autores clássicos do liberalismo como John Locke:

“Opondo-se ao jusnaturalismo aristotélico-tomista e apoiando-se no jusracionalismo de matriz lockiana, sustentavam os moderados que os direitos naturais universais dos indivíduos encontravam seus limites na organização da sociedade mediante o pacto social, e que, para além das leis naturais metafísicas, o direito racional positivo deveria, concreta e utilitariamente, conformar-se ao bem-estar da nação", ${ }^{40}$

Referências teóricas acerca da organização do Estado eram constantemente compartilhadas por redatores e seus correligionários políticos, o que não significa que convergissem para a formação de uma plataforma político-ideológica comum e claramente definida. Não obstante os “moderados” verem na Carta de 1824 a garantia da liberdade, da legalidade e da propriedade, ou seja, elementos necessários para a construção de um estado liberal, isto não lhes afiançava, necessariamente, uma univocidade política. ${ }^{41}$

Um dos pontos que melhor exemplificam a inexistência de um substrato político compartilhado entre os “moderados” está na falta de consenso entre seus representantes quanto à estrutura da monarquia brasileira. Pendendo, sem extremismos, entre a centralização e a descentralização do Estado, os “moderados” mostraram-se hesitantes para com a reforma constitucional iniciada após a Abdicação que culminou na lei de 12 de outubro de 1832 e, posteriormente, no Ato Adicional de 1834, o que contribuiu para seu paulatino enfraquecimento durante a segunda metade da década de 1830. Em novembro de

\footnotetext{
${ }^{39}$ BASILE, Marcello. "Projetos de Brasil e construção nacional na imprensa fluminense (1831-1835)", in FERREIRA; MOREL, NEVES (orgs.); op. cit.; pp.60-93.

${ }^{40}$ Ibid., p.65.

${ }^{41}$ RIBEIRO, Gladys Sabina. "Causa nacional e cidadania: a participação popular e a autonomia na imprensa carioca no início dos anos 1830”, in FERREIRA; MOREL, NEVES (orgs.); op. cit.; pp. 113-141.
} 
1834, o periódico O Justiceiro, dirigido pelo padre Diogo Feijó, indicou que duas das fraquezas dos “moderados” seriam justamente a falta de um posicionamento mais enérgico e a tendência a portar-se de forma hesitante sobre os assuntos da política:

"Este partido, o dos moderados, é poderoso, por seu número, porque conta com a nação, cujos votos e opiniões representa; pela santidade da causa que defende, que é a propriedade nacional e ainda mesmo por seus princípios, porque detesta excessos; porém, em honra da verdade, não tem sabido aproveitar-se das circunstâncias. Semelhante aos médicos da medicina expectante, esse partido não obra, pisa sempre o mesmo terreno, teme de todas as medidas, ele não enxerga em tudo quanto se lhe propõe senão fraqueza ou energia em excesso; sempre esperando, sempre irresoluto, contenta-se no momento da crise com um ato de meia medida que só se encaminha a acobertar o mal e deixá-lo criar profundas raízes. Como existe hoje, julga ter direito a existir amanhã, e a sua prova favorita é lançar em rosto aos que pressagiam mal de sua apatia”. ${ }^{2}$

Na realidade, a constante busca por um meio termo nas ações políticas ocultava um problema de natureza mais profunda, que era o da multiplicidade de usos e interpretações do liberalismo. ${ }^{43}$ De todo o modo, a atuação dos “moderados” dentro e fora das esferas oficiais de poder acabou sendo crucial para sua consolidação como força política dotada de alguns princípios mais ou menos comuns. Porta-vozes da oposição ao governo de D. Pedro, os “moderados” não questionavam as diretrizes básicas asseveradas pela Carta de 1824, embora vislumbrassem contrabalançar a preeminência do monarca por meio da ampliação da atuação da Câmara dos Deputados na política imperial. Ao defenderem o cumprimento desse documento, apregoavam a monarquia constitucional representativa, a participação

\footnotetext{
${ }^{42}$ O Justiceiro, $\mathrm{n}^{\circ} 01$, 07/11/1834.

${ }^{43}$ GUIMARÃES, Lucia Maria Paschoal. "Liberalismo moderado: postulados ideológicos e práticas políticas no período regencial (1831-1837)”, in PEIXOTO, Antonio Carlos; GUIMARÃES, Lucia Maria Paschoal; PRADO, Maria Emilia (orgs.). O liberalismo no Brasil Imperial: origens, conceitos e prática. Rio de Janeiro: Editora Revan, 2001.
} 
contundente do Legislativo, a legitimidade das ações políticas e a idéia de que as mudanças político-administrativas fossem operadas de forma gradual e dentro das esferas oficiais de poder. $^{44}$

Concomitantemente à expansão do discurso oposicionista liberal, correligionários do Governo também lançaram mão de jornais voltados para a defesa de seus interesses e projetos. A Gazeta do Brasil e o Jornal do Comércio, ambos nascidos em 1827, foram juntamente com o Diário Fluminense, jornal do Governo desde 1824, alguns dos principais representantes daqueles periódicos cuja preocupação central residia na defesa, notadamente da conduta dos ministros, o que lhes rendeu por parte dos redatores liberais o rótulo de "folhas ministeriais" ou do "governo". ${ }^{45}$ Por servirem aos interesses do Governo, o que entre outras coisas significava ser uma espécie de "testa-de-ferro" do mesmo, as folhas governistas não explicitavam um programa político-ideológico definido, o que não significa que fossem desprovidas de algum. Diziam-se constitucionais e defensores da Carta de 1824, mas suas principais características eram publicar atos ministeriais e notícias estrangeiras,

${ }^{44}$ CASTRO, Paulo Pereira de. “A 'experiência republicana', 1831-1840”, in HOLANDA, Sérgio Buarque de (org.). História Geral da civilização brasileira, tomo II, “O Brasil Monárquico”, vol.2, São Paulo, Difusão Européia do Livro: 1978, pp.315-352.

${ }^{45}$ A Gazeta do Brazil surgiu a 30 de maio de 1827 e encerrou suas atividades no dia 5 de janeiro do ano seguinte. Impressa na cidade do Rio de Janeiro em tipografia própria localizada na rua da Conceição, a Gazeta circulava às quartas e sábados, sendo vendida a 80 réis, cf. SODRÉ, op. cit., p.144. A direção do periódico ficava por conta de João Maria da Costa e José Joaquim de Carvalho que, sob a epígrafe "Quem quer ser livre, deve ser escravo da lei”, conferiam à Gazeta um estilo combativo para com os periódicos liberais. Cf. MOREL, op. cit., 2005, p.134.

Fundado conjuntamente por Pierre e Émile Plancher, respectivamente pai e filho, Joseph Sigaud, Julio Cezar Muzzi e Francisco de Paula Britto, o Jornal do Comércio era impresso na Tipografia Imperial, à rua da Alfândega, $n^{\circ}$ 47. Além de se dedicar à publicação de preços de gêneros de importação e exportação, movimento de navios e notícias nacionais e estrangeiras, o Jornal do Comércio, surgido a $1^{\circ}$ de outubro de 1827, notabilizou-se pela sua participação nos debates políticos do período, situando-se ao lado do Governo. Editor, publicista e livreiro francês, Pierre Plancher se tornou Impressor Imperial ainda em 1824, cf. MOREL, op. cit., 2005, p.

Jornal oficial do Governo, o Diário Fluminense surgiu em 21 de maio de 1824, vindo a encerrar suas atividades em 23 de abril de 1831. Impresso diariamente na Imprensa Nacional, teve como redatores Manuel Ferreira de Araújo Guimarães, até 30 de abril de 1830, e, posteriormente, Januário da Cunha Barbosa. As três primeiras edições do periódico, impressos nos dias 18, 19 e 20 de maio de 1824, vieram a público com o título de Diário do Governo. No dia 21 do mesmo mês o nome do periódico foi alterado para Diário Fluminense. Cf. Anais da Biblioteca Nacional. Rio de Janeiro, 1965, v.85, p.42. 
ocultar ou justificar medidas tomadas pelo Execuivo e investir contra a Câmara dos Deputados e seus defensores, o que deixava entrever uma ênfase na noção de soberania monárquica em detrimento da nacional ou popular. Mas apesar de serem frequentemente associados pelos seus adversários ao absolutismo monárquico, os grupos que davam sustentação política ao imperador não rejeitavam de todo o liberalismo. De modo geral, assumiam alguns dos postulados liberais clássicos - tal como a representação, a divisão de poderes e os direitos de cidadania -, mas que ficariam sob a tutela de um Estado que situarse-ia entre o absolutismo e o constitucionalismo monárquico. ${ }^{46}$

Em contrapartida ao que ocorria com os impressos liberais, a maior parte dos redatores que advogavam em favor do governo de D. Pedro não era formada de parlamentares, mas por indivíduos - em geral homens de letras, polígrafos - ligados às redes de influência do imperador, como o baiano Manuel Ferreira de Araújo Guimarães, fundador de o jornal literário e político O Patriota (1813), que apoiara o governo joanino, João Maria da Costa, publicista português radicado no Rio de Janeiro, e Pierre Plancher, respectivamente redatores do Diário Fluminense, Gazeta do Brazil e Jornal do Comércio. Segundo Otávio Tarquínio de Souza, esses jornais eram costumeiramente financiados por membros do governo. A Gazeta, por exemplo, recebia apoio de Francisco Gomes da Silva, oficial do Gabinete Imperial e amigo próximo de D. Pedro. ${ }^{47}$

Redatores liberais e governistas atacavam-se uns aos outros com regularidade. Utilizando-se de instrumentos retóricos (vocábulos depreciativos, expressões populares, argumentações tendenciosas, etc.) que concebiam seus oponentes como um “outro” que deveria ser combatido por ser diametralmente oposto a suas convicções, tais redatores

\footnotetext{
${ }^{46}$ NEVES, op. cit. Sobre aspectos da imprensa governista, ver VIANNA, op. cit.

${ }^{47}$ SOUSA, Otávio Tarquínio de. A vida de D. Pedro I. Rio de Janeiro: José Olympio Editora, 1957, v.2, p.721.
} 
forjaram uma certa bipolarização na imprensa do período, que de um lado seria protagonizada pelos “pedreiros-livres”, “carbonários” ou "liberais por excelência”, e de outro pelos “corcundas”, “absolutistas” e “pés-de-chumbo”. ${ }^{48}$ Como ressaltou Reinhart Koselleck, uma unidade de ação política só se constitui a partir de conceitos identitários criados com o objetivo de delimitar o campo de atuação das diferentes forças em jogo. Além do aparato conceitual que o determina, um grupo político invariavelmente lança mão de terminologias que rotulam seus adversários, de modo a forjar uma distinção políticoideológica por antítese. $^{49}$

A tendência era, destarte, unificar os periódicos oponentes em um grupo homogêneo, o que simplificava o processo de identificação e combate do outro, bem como o espectro político ou a matização de propostas e interesses, tal como proferiu o Diário Fluminense, em março de 1829, claramente se referindo ao Universal, ao Astro de Minas, ao Farol Paulistano, ao Farol Maranhense e à Astréa:

“Temos razões bem fortes para clamar aos nossos concidadãos que se ponham em guarda contra as sugestões desses gritadores Universais, Astros de pestífera influência, Faróis que só conduzem a estuosos cachopos, Astréias sem justiça, sem pejo e sem tino, e outros cometas de mau agouro". 50

Após a Abdicação, aqueles que constituíram a base governista do Primeiro Reinado passaram a compor um grupo que ficou conhecido na imprensa ao longo da década de 1830 como "caramuru" ou "restaurador". Segundo os "moderados", os “caramurus" seriam

\footnotetext{
${ }^{48}$ MOREL, op. cit., 2005, SODRÉ, op. cit

49 KOSELLECK, Reinhart. “A semântica histórico-política dos conceitos antitéticos assimétricos”, in KOSELLECK, Reinhart. Futuro passado: contribuição à semântica dos tempos históricos. Trad. de Wilma Patrícia Maas e Carlos Almeida Pereira. Rio de Janeiro: Contraponto/Puc-Rio, 2006, pp.191-231.

${ }^{50}$ Diário Fluminense, 12/03/1829.
} 
formados majoritariamente por portugueses e "absolutistas" que desejavam a volta de D. Pedro para o Brasil e a restauração da monarquia nos moldes do Primeiro Reinado. ${ }^{51}$ Tal definição, contudo, era demasiado simplista, cabendo aqui alguns esclarecimentos.

Em primeiro lugar, a nomenclatura "caramuru”, que remetia à idéia do português que se impôs ao nativo americano, era aceita e utilizada por seus próprios correligionários, a exemplo de O Caramuru, periódico publicado entre 1832 e 1833 sob a direção de Davi da Fonseca Pinto, e que se tornou num dos principais veículos impressos desse grupo. Em segundo, até pelo menos o final de 1832 a maioria das folhas "caramurus" não chegou a defender explicitamente a retomada do trono brasileiro por D. Pedro, de modo que periódicos fluminenses como A Trombeta, O Carijó e O Grito dos Oprimidos negaram peremptoriamente o rótulo de "restauradores", e inclusive acusaram os "moderados" de se valerem da idéia de restauração como artimanha de luta política. Só a partir de 1833, com a exacerbação da luta política entre "moderados” e "caramurus”, é que alguns periódicos mostraram-se favoráveis à volta de D. Pedro. Em terceiro, a idéia de restauração, comumente veiculada pelos "caramurus", era polissêmica, significando mais do que o retorno do ex-monarca. Ela expressava tanto a probabilidade de fortalecimento do governo central, recompondo parte da estrutura política do Primeiro Reinado, quanto o reforço do poder dos grupos que haviam apoiado o Governo de D. Pedro. Como notou Marco Morel, a concepção de "restaurar" continha, nas primeiras décadas do século XIX, o sentido de regenerar, ou seja, de criar algo novo e não apenas recuperar uma situação anterior, supostamente perdida. ${ }^{52}$

\footnotetext{
${ }^{51}$ BASILE, op. cit., 2006.

${ }^{52}$ MOREL, op. cit., 2005, p.131.
} 
Em parte influenciados pela chamada experiência regalista portuguesa (18281834), que reeditou práticas do Antigo Regime, como por exemplo a divisão jurídica da sociedade em três ordens (nobreza, clero e povo), os “caramurus” valorizavam a supremacia monárquica diante do afã reformista que tomou conta dos círculos políticos após a Abdicação, interpretada inclusive como uma manobra ilegal dos “moderados” para alcançarem o poder. Diferentemente daqueles que de alguma forma se intitulavam liberais, os “caramurus” foram contrários, até mesmo às vésperas da votação do Ato Adicional, à alteração da Carta de 1824, opondo-se à extinção do Poder Moderador, do Conselho de Estado e do Senado, bem como da implantação de reformas que promovessem maior projeção de interesses locais e provinciais junto ao poder central. ${ }^{53}$

Além de “moderados” e “caramurus”, um outro grupo político tomou forma ao longo do Primeiro Reinado por meio da imprensa periódica. Pouco antes da Abdicação, mas sobretudo após essa, surgiram jornais com um perfil distinto, “exaltado”, que tornou mais plural o debate até então encabeçado pelas folhas de oposição e governistas. O agravamento da situação financeira do Império, simbolizada pela extinção do Banco do Brasil, em 1829; o envolvimento cada vez mais explícito de D. Pedro com a questão sucessória do trono português e a tomada de medidas questionáveis pelo Governo, como a criação de uma Comissão Militar em Pernambuco para o julgamento de um grupo de revoltosos, o que rendeu uma denúncia feita pela Câmara dos deputados ao Ministro e Secretário de Estado dos Negócios da Guerra Joaquim de Oliveira Álvares, em 1829, fizeram com que os representantes liberais da intitulada ala “exaltada” alargassem sua ação política e, conseqüentemente, sua inserção na imprensa.

\footnotetext{
${ }^{53}$ MOREL, op. cit., 2005; NEVES, op. cit.
} 
De aproximadamente 1828 até a Abdicação, vieram à tona periódicos como a Nova Luz Brasileira (1828), de Ezequiel Corrêa dos Santos e João Batista de Queiroz, o Tribuno do Povo (1829), de Francisco Chagas de Oliveira França, a Sentinela do Serro (1829), de Teófilo Ottoni, a Gazeta Paraibana (1828), a Abelha Pernambucana (1829), e o Repúblico (1830), esses três últimos dirigidos por Antonio Borges da Fonseca. Isso não significou, contudo, uma diminuição no surgimento dos periódicos “moderados”, haja vista o advento do mineiro Eco do Serro (1828), do paraense A Voz da Autonomia (1828), do rio-grandense Constitucional Rio-Grandense (1829), da goiana Matutina Meiapotense (1830) e do paulista O Observador Constitucional (1829), que mais tarde alinhar-se-ia às propostas políticas dos “exaltados”.

Em comparação aos “moderados”, os “exaltados” não compunham uma frente parlamentar nem ocupavam cargos de destaque na magistratura. Eram em sua maioria profissionais liberais, funcionários públicos, militares e pequenos e médios comerciantes, como o boticário Ezequiel Corrêa dos Santos, o publicista Antonio Borges da Fonseca e o tipógrafo Paula Brito. ${ }^{54}$ Com a abertura dos Cursos Jurídicos em Olinda e São Paulo, em 1828, alguns estudantes tornaram-se redatores, como Francisco Bernardino Ribeiro, de $A$ Voz Paulistana, surgida em 1831, e aliada aos “exaltados”.

Embora também tivessem como principal alvo de suas críticas o Ministério e o círculo político de D. Pedro, as folhas “exaltadas”, ao contrário das “moderadas”, não questionavam somente aqueles que estavam no governo e a forma como governavam, mas as próprias bases jurídico-administrativas do novo Estado, realimentando um debate que era

\footnotetext{
54 BASILE, op. cit., 2001, pp.22-23. Ver também COSTA, Emília Viotti da. “A consciência liberal nos primórdios do Império”, in Da Monarquia à República: momentos decisivos. $5^{\mathrm{a}}$ ed. São Paulo: Brasiliense, s.d.
} 
candente desde as discussões ocorridas no plenário da Constituinte de 1823, como notou Maria de Lourdes Viana Lyra:

“Eram todos críticos ferrenhos do governo e foram logo identificados como órgãos “exaltados”, pela inflamada defesa da descentralização dos mecanismos de atuação das instituições imperiais. Ou seja, combatendo a excessiva centralização do exercício da política e da administração do Império, que o caracterizava como Estado fortemente unitário, e pleiteando o equilíbrio na distribuição e a independência na atuação dos poderes estabelecidos, além de defenderem a autonomia das províncias e, conseqüentemente, maior espaço de atuação política aos membros da coletividade nacional”. ${ }^{5}$

Ao enfatizar a necessidade das reformas constitucionais, a eficácia dos princípios federativos e a importância de ampliarem-se as bases de participação política, os “exaltados” afastaram-se dos “moderados”, criticando-os inclusive pelo seu caráter “retrógrado” e “estacionário”, o que refletia a composição heterogênea dos liberais do Primeiro Reinado, como também alargava a discussão via impressos para além da antinomia entre “liberalismo” e “despotismo”, ${ }^{56}$ Estabeleceu-se, a partir daí, um enfrentamento entre as próprias folhas liberais, especialmente no tocante às reformas na Carta de 1824 e à defesa dos princípios federativos, que aumentou sensivelmente após a Abdicação, quando os “moderados”, em princípio, passaram a comandar os principais postos do Governo. ${ }^{57}$ Assim, no entender de Ezequiel Corrêa dos Santos, redator de A Nova Luz Brasileira, a luta dos “exaltados” dar-se-ia, também, contra os próprios “moderados”:

\footnotetext{
${ }^{55}$ LYRA, op. cit., p.55.

${ }^{56}$ WERNET, 1972, op. cit., p.56.

${ }^{57}$ CASTRO, op. cit.
} 
“O exaltado que é homem de bem irrita-se em presença do Déspota, que com escárnio, ou sem ele, faz injustiça e despreza a um mortal desvalido, cujos direitos inauferíveis posterga à prepotência sustentada pela traição. O moderado, porém, quando é honrado, nunca se irrita senão pelos seus interesses pessoais e domésticos, e olha para a perda das Liberdades Públicas e para as violências que sofre o pobre, e desvalido, não com o prazer do cortesão e moderado fingido; mas com uma criminosa apatia [...] o exaltado irritase vendo a indiferença do moderado pela Causa Pública, quando a combina com a sua desesperação pela perda dos interesses”. ${ }^{58}$

Inspirada da experiência política européia e americana dos anos 1820 e 1830, quando o debate em torno da soberania do Legislativo versus soberania do governante ganhou destaque, a noção de “exaltação” não foi de todo aceita pelos “exaltados” brasileiros, uma vez que ela estava associada à idéia de excesso político, o que se contrapunha à “soberania da razão”, um dos pilares do discurso liberal nas primeiras décadas do século XIX. ${ }^{59}$ Os “moderados”, por sua vez, valeram-se da conotação negativa do termo “exaltação” para denegrir seus adversários políticos. Em agosto de 1831, o jornal O Farol Paulistano publicou um excerto supostamente traduzido de J. Droz e extraído de O Patriota Brasileiro que comparava a eficácia política da "moderação” com o “vício” inerente à “exaltação”:

“Os espíritos inspirados pela moderação, estão por isso mesmo em relação com a verdade, e com o interesse geral, ao mesmo tempo que os espiritos exaltados se afastão necessariamente do util, e do verdadeiro. Nas tormentas, por que fomos obrigados a atravessar, sempre dei mais consideração ao caráter do que ás opiniões dos homens, e só agora é que eu posso ver, que fui mais justo, e me enganei menos, do que se tivesse tomado outra base para os meus juizos.

Uma das maiores desgraças para a Sociedade, é a grande difficuldade, que ha em julgarmos a moderação, e a exaltação independente das idéas, a que sempre as achamos

\footnotetext{
${ }^{58}$ A Nova Luz Brasileira, n 160, 17/08/1831, Apud BASILE, op. cit., 2006, p.68.

${ }^{59}$ MOREL, op. cit., 2005, p.99-101.
} 
ligadas. Todavia a exaltação em si é um vicio, e a moderação é por se mesma uma virtude, principiaremos então a instruir-nos. ${ }^{60}$

Em contrapartida, em 1831, após a Abdicação, o periódico paulistano O Observador Constitucional rejeitou o rótulo de “exaltado" e disse ser representante da "verdadeira moderação”:

"Dois Partido existem hoje no Brazil; um, que á força do uso que tem feito da palavra moderação, se tem chamado o Moderado, quando bem analisada sua conducta, acharíamos ser impróprio dar-se-lhe tal nome; outro, que pela energia, e franqueza tem sido denominado Exaltado; nome que lhe tem sido dado pelo primeiro, e que lhe é também impróprio, pois que a sua conducta tem sido a da verdadeira Moderação. Veremos d'onde nascessem ambos, e igualmente a sua marcha.

Até fins de 1829 a opposição, que se havia formado na Câmara dos Srs. Deputados, e que era sustentada só pela união dos Brazileiros, não era, senão uma barreira fraca, que se havia levantado ao Poder; mas ella em breve tornou-se respeitável pela divisão. A marcha sempre traidora do Governo de D. Pedro tinha produzido a união dos Brazileiros, porem as tentativas de Absolutismo sempre inutilizadas pelos Liberaes, e sempre renovadas pelos traidores, se tendo apresentado debaixo do Ministério Clementino [José Clemente Pereira] com o aspecto mais horroroso, tinhão levado os Brasileiros a desesperação, tendo lhes apurado o ultimo gráo de paciencia. O Brazil tinha posto suas esperanças na Representação de 1830. Sempre illudido, e atraiçoado pelo espaço de nove annos, elle reclamava com justiça de seus Novos Representantes uma maneira nova de atacar, ou vencer por meio de medidas enérgicas, que esta Representação devia apresentar.

A questão das eleições do Rio Grande do Sul, a admissão do Sr. Jose Clemente offerecião matéria, para que se fizesse ver ao Governo, que os Brazileiros se achavão promptos ao combate, e que a luta entre o Poder, e a Nação devia terminar pela queda de um d'elles. Então dividiu-se a Opposição: uns tomarão a resolução de continuar com a marcha anterior; e pretextarão sua conducta sustentando o principio de que - o direito de livre eleição do Povo deveria ser respeitado, e por conseqüência, que taes eleições erão validas, e

${ }^{60}$ O Farol Paulistano, n ${ }^{\circ} 381,24 / 08 / 1830$. 
que o Sr. Jose Clemente devia tomar assento: outros tomarão a resolução de atacar o Poder desvairado em qualquer parte, em que se elle achasse, e fundando a sua opinião - no mesmo princípio da livre eleição do Povo, sustentarão, que taes eleições devião considerar-se n'ullas, como o devera ser, e que o Sr. Jose Clemente não deveria ter assento, porque havia atacado as Liberdades d'aquelle mesmo Povo, que o havia nomeado anteriormente de sua Liberdade.

A Câmara dos Srs. Deputados, que constava até então de dois partidos, achou-se ainda assim dividida; pois que o partido dos inimigos da Pátria, que se viu acossado pelo Partido exaltado (verdadeiro moderado) na escolha dos males, que teve a fazer, - se sustentaria seu posto antigo com o perigo de tudo perder nas votações, ou se quebraria por si na esperança de ganhar alguma coisa, já que não podia esperar tudo, uniu-se amfim ao Partido d'aquelles, que tinhão mostrado, querer seguir ainda a conducta da Opposição antiga, isto é - só bradar contra o poder, nada obrar, apelar para o tempo, e Providencia Divina, e d'elles esperar tudo. D’aqui nasceu o triunfo do Partido chamado Moderado, e que chamaremos melhor, da Moderação fingida, em todas as questões (...). ${ }^{61}$

Divergências sobre o emprego do termo “exaltação” foram recorrentes e revelavam mais do que uma querela semântica. Assim como os “moderados”, os "exaltados” careciam de uma plataforma política homogênea e possuíam diferenças programáticas importantes ${ }^{62}$, como por exemplo sobre a conquista da autonomia pelas províncias. Questão essencial para os “exaltados”, a discussão em torno do estatuto político provincial realimentou um debate crucial para a construção da Nação - o do papel das províncias e dos poderes locais na constituição do Estado imperial -, temática em pauta em 1823, retomada em 1826, e que ganhou força com as discussões em torno da regulamentação das Câmaras Municipais e dos Conselhos Gerais de província, cujos regimentos foram aprovados em $1828{ }^{63}$ Mas apesar de

\footnotetext{
${ }^{61}$ O Observador Constitucional, $\mathrm{n}^{\circ} 170,12 / 08 / 1831$.

${ }^{62}$ RIBEIRO, op. cit., p.129.

${ }^{63}$ WERNET, 1972, op. cit., p.56-61; MOREL, op. cit.,2005, p.100-117.
} 
haver um anseio comum por uma reestruturação da esfera local, a forma para se atingir tal objetivo não era consensual entre os “exaltados”. 64

Com relação aos trechos acima aludidos de $O$ Justiceiro e $O$ Observador Constitucional, é interessante observar o emprego da palavra “partido”. Trabalhos recentes têm dado ênfase para o fato de que, até meados do século XIX, o vocábulo partido esteve revestido muito mais de uma conotação pejorativa - sinônimo de "bando”, “facção” ou grupo de pessoas que seguiam ou favoreciam a opinião de alguns - do que positiva, associada a um corpo político solidamente constituído e dotado de um programa definido. ${ }^{65}$ Em janeiro de 1831, o redator de O Farol Paulistano reclamava da facilidade com que indivíduos trocavam de “partido” ou dele se valiam para se promover politicamente:

“É pasmosa a facilidade com que os partidos entre nós metharmofozeão os de seus partido, e os do contrario; como os passão de um para o outro, como os levão ás nuvens, o porem nos abismos de um momento para outro, n’um abrir e feixar d'olhos. E quanta injustiça por ahi vae em tudo isso! e quanto mal não pode resultar d' essa facilidade em adoptar gente do partido contrario ao nosso gremio! E quanta de repetir pessoas, que erguirão sempre as bandeiras, que seguimos, só por simples suspeitas, por inconsiderados, por ninharias, que nada valem, e o que mais é, ás vezes e não poucos, por intriguinhas miseraveis! (...)”. ${ }^{66}$

Mas como assinalou a historiadora Lucia Pereira das Neves, desde o início da década de 1820 a utilização do termo "partido” já apresentava traços de uma postura partidarista. ${ }^{67}$ Nessa mesma linha, Marco Morel observou que periódicos como O Caramuru e $O$

\footnotetext{
${ }^{64}$ Veja-se, por exemplo, a problemática em torno da "federação" e da "república”, tratada no capítulo 3.

${ }^{65}$ MOREL, op. cit., 2005; HÖRNER, Erik. Guerra entre pares: a "revolução liberal" em São Paulo, 18381844. Dissertação de mestrado apresentada ao Departamento de História da Faculdade de Filosofia, Letras e Ciências Humanas da Universidade de São Paulo. São Paulo, 2005.

${ }^{66}$ O Farol Paulistano, ${ }^{\circ}$ 437, 11/01/1831.

${ }^{67}$ NEVES, op. cit., p.194.
} 
Exaltado, publicados no Rio de Janeiro no começo da década de 1830, esboçaram em suas páginas algumas reflexões no sentido de conferirem aos partidos um estatuto mínimo de organização política. Se os trechos de O Justiceiro e O Observador supracitado não parecem caminhar inteiramente para nenhuma dessas direções, ele ao menos deixa entrever que os partidos agiriam como co-definidores da esfera política imperial e, concomitantemente, definidos por ela.

Ao longo deste trabalho veremos que a utilização da palavra partido pelos agentes da época foi ora revestida de um sentido mais amplo ora atrelada a demandas circunstanciais da luta política. Recursivamente identificados como representantes de "partidos" distintos, “moderados”, “exaltados” e “caramurus” (anteriormente “governistas”) constituíram um campo de forças antagônicas que na realidade não engendrou frentes partidárias ou grupos políticos coesos, mas que em função de suas diferenças político-ideológicas acabaram definindo o espaço da luta política durante o Primeiro Reinado e os primeiros anos da Regência, e contribuíram para delinear, também, o tema do papel das províncias na organização do Império.

\subsection{Tipógrafos, redatores e leitores}

Se por um lado os debates desenvolvidos pelos jornais nas décadas de 1820 e 1830 serviam como forma de arregimentação do público leitor, sobretudo de votantes e eleitores, por outro fortaleciam os elementos envolvidos diretamente na edição dos periódicos. Pelo fato de a imprensa periódica necessitar de uma infra-estrutura material permanente, a solidez dos vínculos entre os agentes envolvidos na impressão de uma folha tornava-se 
essencial para a manutenção de tais empreendimentos, necessidade essa que, de certo modo, possibilitava o delineamento de grupos com concepções políticas comuns. ${ }^{68}$

Manter um periódico à época exigia alguns pré-requisitos básicos. Além do oneroso maquinário constituído geralmente por um prelo e outros componentes - tais como aparelhos de fundir “tipos” (letras), balas, cavaletes, componedores, galés, martelos, mochos e serrotes $^{69}$-, o bom andamento de uma tipografia resultava da soma de esforços humanos que deveria assegurar a elaboração, publicação e distribuição dos impressos. De modo geral, os tipógrafos ou impressores, redatores e colaboradores constituíam a tríade para a publicação de um periódico, ao passo que os assinantes, correspondentes e leitores fechavam o circuito que o tornava integrante de um espaço público literário.

Diferentemente do tipógrafo, que era responsável apenas pela manutenção da infraestrutura material da tipografia, o redator agrupava funções que iam desde a organização formal do jornal até a definição do conteúdo por ele propalado. Ao escrever a maior parte dos artigos e determinar o formato do periódico, acabava personificando-o e funcionando como seu porta-voz principal, de modo que o debate travado na imprensa da época configurava-se menos institucional, isto é, entre diferentes jornais, do que numa discussão estabelecida entre redatores. ${ }^{70}$ Isso não significa, entretanto, que se tratasse de querelas

${ }^{68}$ OLIVEIRA, Cecilia Helena de Salles, 1999, op. cit., pp.148-150. Partindo de perspectiva teóricametodológica e objetivo distintos, o historiador norte-americano Robert Darton acredita que, para os séculos XVIII e XIX, a análise do funcionamento de uma tipografia explicita o próprio movimento de criação, transmissão e publicação de textos, possibilitando assim um maior entendimento da função social dos impressos. Cf. DARNTON, Robert. O beijo de Lamourette: Mídia, cultura e revolução. Trad. port. São Paulo: Companhia das Letras, 1990, p. 124.

${ }^{69}$ Componentes citados no "Inventário da Tipografia de o Universal", de 1835. Cf. MOREIRA, Luciano da Silva. Imprensa e política: espaço público e cultura política na província de Minas Gerais, 1828-1842. Dissertação de mestrado apresentada ao Departamento de História da Faculdade de Filosofia e Ciências Humanas da Universidade Federal de Minas Gerais. Belo Horizonte, 2006, p.102.

70 No âmbito do debate travado pela imprensa, era comum que redatores celebrassem a saída de seus opositores da direção de um jornal ou até mesmo elogiassem as características de seu substituto. A mudança de redator significava, em última estância, a possibilidade de alteração do perfil de uma folha. Em maio de 1830, por exemplo, uma nota inserta no Farol Paulistano comentou com entusiasmo a saída de Manuel Ferreira de 
pessoais, mas que os redatores arvoravam-se da qualidade de intérpretes da sociedade e representantes de uma determinada postura ou ação propositiva.

A centralidade da figura do redator e da sua função intelectual estavam atreladas a uma mudança geral no perfil do "homem de letras” que, a partir do século XVIII, sobretudo com a criação, difusão e re-interpretação das idéias ilustradas na Europa e América, identificou-se cada vez mais com a dimensão prática da vida humana. Buscando meios para intervir na sociedade e alterá-la, esses homens arrogavam-se o estatuto de missionários da razão, do esclarecimento e da civilização, de modo a conceberem a imprensa como um veículo privilegiado e marcadamente pedagógico de ação política. ${ }^{71}$

A utilização da imprensa como meio de criação, propagação e combate de idéias conferia ao redator um caráter eminente público, ainda que os artigos impressos nos periódicos fossem majoritariamente anônimos. Conhecidos também como “publicistas”, os redatores faziam de sua condição uma via de projeção social notadamente associada às carreiras políticas. Lideranças importantes entre os liberais do Primeiro Reinado e início do período regencial - como José da Costa Carvalho (O Farol Paulistano), Bernardo Pereira de Vasconcelos (O Universal) e Evaristo da Veiga (A Aurora Fluminense) - valeram-se da imprensa para se promoverem enquanto homens envolvidos com a “coisa pública” e com o “progresso” das instituições políticas do Império. Não se tratava, evidentemente, de uma relação de causa e efeito na qual a imprensa garantiria o sucesso político do redator, mas como assinalou Marco Morel, de uma inter-relação das vias legais de prática política dos

Araújo Guimarães, então redator do Diário Fluminense. Ao discorrer sobre seu sucessor - Januário da Cunha Barbosa -, o Farol depositou esperanças em sua atuação, em função do caráter "moderado" dos números recentemente publicados e da defesa que ele se propusera a fazer da "doutrina constitucional”, cf. $O$ Farol Paulistano, no 343, 15/05/1830.

${ }^{71}$ PALLARES-BURKE, Maria Lucia Garcia. The Spectator, o teatro das luzes - diálogo e imprensa no século $\underline{X V I I}$. São Paulo: Hucitec, 1995, pp.14-15. 
primeiros anos do Império, onde manobrá-las consistia num instrumento fundamental de auto-afirmação dentro de um sistema monárquico-constitucional representativo:

“(...) a atividade de redator ou publicista era, como o nome diz, pública. Característica que se reforçava nesta fase do século XIX: homens de letras eram com freqüência homens públicos, isto é, seguiam carreira política. Esta intersecção entre uma esfera literária (baseada no uso privado da razão), a ocupação de espaços públicos de sociabilidade (por meio das associações [...]) e a gestão da coisa pública (administração do Estado) explica-se na medida em que os letrados, baseados nas distinções acima citadas e dos instrumentos de saber e poder a que tinham acesso, constituíam camada restrita da população que se apresentava como apta para manejar os cordões do poder da sociedade”, ${ }^{72}$

Os redatores eram auxiliados por colaboradores, indivíduos que embora fossem desvinculados oficialmente de uma folha, ajudavam-na por meio do envio de artigos que corroborassem com a inclinação política da mesma. Categoria equívoca para os próprios $\operatorname{coevos}^{73}$, o colaborador amalgamava características do redator e do correspondente, visto que seus textos, quando publicados, apareciam freqüentemente como artigo principal do periódico e, ao mesmo tempo, podiam conter a indicação de que haviam sido enviados por alguém. Pouco estudada pela bibliografia referente ao tema, talvez em função da sua condição quase sempre circunstancial e anônima, a figura do colaborador era vital para a

\footnotetext{
${ }^{72}$ MOREL, 2005, op. cit., p.184.

${ }^{73} \mathrm{Na}$ imprensa brasileira da primeira metade do século XIX, ser “colaborador" significava, em linhas gerais, contribuir com artigos próprios ou excertos de obras traduzidas para um determinado periódico. O problema reside no fato de que o ato de colaborar podia ser constante ou esporádico, configurando assim perfis dessemelhantes de envolvimento com um dado órgão impresso. Numa nota inserta no Farol Paulistano de 5 de Janeiro de 1828, cujo objetivo era responder a algumas afirmações feitas pela Gazeta do Brazil a seu respeito, Nicolau Vergueiro deixou transparecer o caráter impreciso de um colaborador: "Imputa-me [a Gazeta do Brazil] ser eu o author da Correspondencia das falas, que vêm na Astréa. Esta imputação é falsa, ainda que seria desculpavel , como adivinhação; porque n'ella se contem proposições, que em outro tempo publiquei pela imprensa, e ainda as tenho por verdadeiras. Numera-me entre os Collaboradores da Astréa. Se é ser collaborador d'um Periodico, mandar-lhe algumas correspondencias, quando o caso o pede, para n'elle se publicarem, é verdade que tenho sido collaborador da Astréa, como o tenho sido de outros Periódicos”.
} 
manutenção de uma folha, já que a maior parte dos redatores desempenhava outras funções fora da tipografia, e necessitava de auxiliares, mesmo que temporários, que dessem sustentação ao periódico.

Os correspondentes também eram de fundamental importância. No nosso entender, sua diferença em relação ao colaborador estava menos na estreiteza de vínculos com o redator e a tipografia do que no conteúdo do texto publicado. No caso dos periódicos paulistas estudados, enquanto os artigos enviados pelos colaboradores se revestiam de um tom impessoal para tratar de assuntos de natureza mais ampla - especialmente sobre o jogo político ocorrido na Corte -, aqueles redigidos pelos correspondentes se aferravam a questões mais particulares, atreladas especialmente às disputas políticas locais, daí seu tom recorrente de protesto.

Parte dos correspondentes era formada por assinantes do próprio periódico, o que para Marco Morel não constituía um fato banal, mas sim um significativo ato político. Em princípio, assinar um periódico revelava as orientações políticas com as quais o assinante demonstrava interesse. Em decorrência disso, o autor acredita ser pertinente a hipótese de que as vendas avulsas eram mais comuns, pois reduziam a cumplicidade do comprador em relação ao periódico adquirido. ${ }^{74}$ No entanto, é preciso tomar um certo cuidado para que não se racionalize em demasia a figura do assinante, isto é, que se confira a ele um caráter exclusivamente objetivo vinculado aos interesses apregoados pelo periódico assinado. O próprio redator de O Farol Paulistano assinalou, em junho de 1827, o perigo de se atribuir a um indivíduo “os mesmos sentimentos” políticos do periódico de que ele é “subscriptor” ${ }^{75}$

\footnotetext{
${ }^{74}$ Cf. MOREL, op. cit., 2005, p.212.

${ }^{75}$ O Farol Paulistano, no 23, 27/06/1827.
} 
Nesse sentido, é provável que redatores e colaboradores criassem uma forma de assinar periódicos de seus opositores.

À contracorrente do que ocorreria num momento posterior, quando os impressos assumiriam aos poucos a qualidade de empreendimentos capitalistas, os anúncios insertos no período estudado não tinham como finalidade principal angariar recursos para os diretores de uma folha ou para os donos da tipografia, mesmo porque, ao que parece, não eram maioria aqueles que cobravam seus anunciantes. ${ }^{76}$ Nesse sentido, além de representar um leitor em potencial, o anunciante auxiliava no processo de ganho de credibilidade e espaço por parte dos periódicos, visto que a inserção de anúncios figurava como uma maneira de firmar os jornais como veículos associados ao interesse público, amalgamando num único suporte, o impresso, o debate político e as demandas cotidianas dessa sociedade.

Embora o número de leitores nessa época fosse restrito devido aos altos índices de analfabetismo da população, é prudente não se tomar a figura do leitor de forma estrita, mormente numa sociedade onde a modernização dos espaços públicos ainda constituía um processo, e que portanto congregava práticas e códigos culturais heterogêneos, próprios do momento de superação do Antigo Regime. ${ }^{77}$ Deste modo, ao mesmo tempo em que eram recorrentemente lidos em voz alta em praças públicas, residências ou sociedades - o que aumentava consideravelmente seu público receptor ${ }^{78}-$, os periódicos foram ganhando, paulatinamente, um sentido novo: o de se assemelharem aos livros. O Correio Braziliense, de Hipólito José da Costa, e o Revérbero Constitucional Fluminense, de Joaquim Gonçalves

\footnotetext{
${ }^{76}$ Dentre os periódicos consultados, apenas o Universal publicou uma nota sobre o custo de um anúncio, que ficava por 20 rs a linha, cf. O Universal, ${ }^{\circ} 1,16 / 07 / 1827$.

${ }^{77}$ HABERMAS, Jürgen. Mudança estrutural da Esfera Pública: investigações quanto a uma categoria da sociedade burguesa. Trad.: Flávio R. Kothe. Rio de Janeiro: Tempo Brasileiro, 1984.

${ }^{78}$ Sobre a oralidade na imprensa periódica do período, ver NEVES, op. cit., OLIVEIRA, Cecília Helena de Salles, 1999, op. cit.; SILVA, Maria Beatriz Nizza da, op. cit.
} 
Ledo e Januário da Cunha Barbosa, já haviam apresentado uma característica que se tornaria comum nos periódicos do Primeiro Reinado - a paginação continuada em seus números -, o que estimulou a encadernação dos impressos e a afirmação de unicidade e durabilidade até então concernentes aos livros. ${ }^{79}$

Os jornais e livros se diferiam, entrementes, num ponto central que ia além da estrutura formal, objetivos e usos: o acesso pelo leitor. Comparado a um livro, que em meados da década de 1820 chegava facilmente a custar 8\$333 - renda média que um votante de eleições primárias necessitava arrecadar por mês para no final do ano poder atingir os $100 \$ 000$ necessários ao direito de voto -, um periódico era vendido entre 40 e 80 réis, isto é, por menos do que um escravo de ganho geralmente recebia por um dia de trabalho na cidade do Rio de Janeiro, o que dá uma certa dimensão da acessibilidade dos jornais para os diversos setores da sociedade. ${ }^{80}$ Estes, que na sua maior parte careciam de uma instrução regular franqueada pelo Estado e de condições materiais para adquirirem livros, tinham nos periódicos um mecanismo inconteste de inserção social. Em sua História do Brasil, publicada no Rio de Janeiro em 1837, o negociante inglês John Armitage já sublinhara tal importância:

“Se na Europa, onde há tantos e tão variados meios de adquirir instrução, a ascendência da imprensa periódica é em toda a parte sentida e reconhecida, com maior razão sua influência no Brasil é mais preponderante, visto que nele os periódicos são os únicos veículos de instrução que existem”. ${ }^{81}$

\footnotetext{
${ }^{79}$ PALLARES-BURKE, op. cit., p.14.

${ }^{80}$ MOREL, op. cit., 2005, p.39.

${ }^{81}$ ARMITAGE, John. História do Brasil. São Paulo: Martins, 1972. $1^{\text {a }}$ edição:1836, p.153.
} 
Ainda que permeada pelos referenciais europeus de civilização da primeira metade do século XIX e por uma leitura alinhada com as propostas políticas do grupo liberal que saíra vitorioso após a Abdicação, a fala supracitada do negociante inglês revelava, mesmo que com um pouco de exagero, a importância dos periódicos como ferramenta de instrução da população, que no caso se referia menos às habilidades escolares formais do que ao acesso à esfera pública ou à política.

\subsection{O surgimento da imprensa em São Paulo}

Tendo o Rio de Janeiro como seu ponto de partida, a imprensa no Brasil se alastrou aos poucos pelas demais localidades, como pela Bahia (1811), Pernambuco (1817), Maranhão (1821), Minas Gerais (1823), Ceará (1824), Paraíba (1826) e São Pedro do Rio Grande do Sul (1827). ${ }^{82}$ Nesse sentido, é pertinente frisar que, a despeito da importância de São Paulo durante o processo de Independência, foi somente a 7 de fevereiro de 1827, com o surgimento do Farol Paulistano, que a imprensa periódica se enraizou. Antes da publicação do jornal dirigido por José da Costa Carvalho, houve algumas tentativas frustradas de se estabelecer um periódico com circulação regular na província, sendo a primeira e mais importante delas resultado da diligência de Antônio Mariano de Azevedo Marques, o Mestrinho, cujo jornal manuscrito O Paulista, lançado em 1823, em poucos meses teve suas atividades encerradas. ${ }^{83}$

\footnotetext{
${ }^{82}$ Nas demais províncias do Império, a imprensa demorou mais a se estabelecer, tal como em Goiás (1830), Santa Catarina (1831), Alagoas (1831), Sergipe (1832), Rio Grande do Norte (1832), Espírito Santo (1840), Paraná (1853) e Amazonas (1854), cf. SODRÉ, op. cit.

${ }^{83}$ SODRÉ, op. cit., pp.100-101. Por ser manuscrito, o Paulista possuía um sistema singular de funcionamento que foi explicitado em seu primeiro número. Werneck Sodré transcreveu-o: "Como, desgraçadamente, não tem sido possível a província de São Paulo obter um prelo para se comunicarem e disseminarem as idéias úteis e as luzes tão necessárias a um país livre, para dirigir a opinião pública, cortando pela raiz os boatos que os
} 
Segundo Afonso de Freitas, as primeiras iniciativas oficiais para o estabelecimento de uma tipografia em São Paulo datam do início da década de 1820. Em 8 de janeiro de 1823, a Junta Diretora da Tipografia Nacional expediu uma portaria ordenando o encaixotamento para São Paulo de um de seus antigos prelos, a fim de que se instalasse uma tipografia na capital paulista. Esta, por conta da fábrica de ferro Ipanema, poderia futuramente substituir o prelo de madeira por um de metal, assinalou a Junta. Ordenava-se, também, que fossem contratados artífices especializados para a montagem do prelo. O conteúdo da portaria foi aprovado por ofício do governo imperial em 25 de fevereiro do mesmo ano, que ainda solicitou que o prelo e os trabalhadores embarcassem para São Paulo assim que possível. ${ }^{84}$

A bibliografia referente ao tema pouco se debruçou sobre os desdobramentos dessas medidas que, ao que parece, não foram cumpridas. Um dos indícios disso é que o tipógrafo contratado para a montagem da tipografia, Gaspar José Monteiro, protestou em diversas petições sobre o não cumprimento do acordo, mas todas elas foram indeferidas pelo governo central. Este ainda fez o mesmo com os pedidos e as informações que lhe foram dirigidas pela Junta Governativa de São Paulo sobre a situação do envio do prelo. ${ }^{85}$

Em 11 de junho de 1824, cerca de dois meses após tomar posse da presidência da província de São Paulo, Lucas Antonio Monteiro de Barros enviou um ofício a Mariano José Pereira da Fonseca, futuro Marques de Maricá, na época Ministro na Fazenda, solicitando o envio do maquinário conforme fora acordado anteriormente. Um ponto

malévolos não cessam de espalhar para conseguir seus fins ocultos, é mister lançar mão do único meio que nos resta. Deverá pois ser suprimida a falta de tipografia pelo uso de amanuenses, que serão pagos por uma sociedade patriótica, e aos quais incumbe escrever o número de folhas, que devem ser repartidas pelos subscritores no dia determinado para a sua publicação".

${ }^{84}$ FREITAS, op. cit, pp.323-325.

${ }^{85}$ Ibid., p.326-327. 
importante da fala do futuro Visconde de Congonhas do Campo residia no fato de que, se fosse necessário, particulares paulistas arcariam com os custos do prelo e do impressor, o que já demonstrava o interesse privado de determinados setores na instalação de uma tipografia:

“Sendo esta Província de São Paulo talvez a única que ainda não tem na sua capital uma oficina tipográfica, tão necessária para dar a devida extensão às ciências e fazer correr o fluxo da civilização, eu não duvido representar a V. Excia. para fazer subir à Augusta Presença de S. M. o Imperador, a fim de que se digne expedir as ordens necessárias para ser enviada quanto antes a esta cidade a Imprensa que já estava para isso destinada e pronta com todos os caracteres e seus pertences, e um Impressor para seu estabelecimento e direção; e, quando não possa vir gratuita, peço ao menos licença para a sua ereção à custa dos particulares, que não duvidam subscrevem para um fim tão interessante”. ${ }^{86}$

Em 11 de agosto do mesmo ano, o presidente de São Paulo enviou outro oficio reiterando a fala do anterior, agora direcionado para o Ministro do Império. O Imperador despachou ao Ministro da Fazenda que se enviasse a tipografia solicitada, embora em relação ao impressor fosse necessário que se consultasse a Junta da Tipografia Nacional sobre a possibilidade de haver algum disponível para ir a São Paulo. Apesar da emissão do despacho, a tipografia não foi implementada. ${ }^{87}$

\footnotetext{
${ }^{86}$ Este ofício, publicado pelo Farol Paulistano em 21 de fevereiro de 1827, pouco após seu surgimento, veio acompanhado da seguinte nota do redator: "Foi-nos facultada a cópia deste Officio, que publicamos, para que todos conheção quanta vontade tinha o Exm $^{\circ}$ Prezidente de que houvesse Imprensa nesta Província, e quanto a política do Ministério, que então nos regia, tinha illudido os dezejos e esperanças deste honrado Prezidente, órgão, muito principalmente a este respeito, de uma das melhores porções do povo Brazileiro. Portarias liberaes e grandiozas aparecerão no Diário Fluminense a cerca da Typografia, que para São Paulo devia vir, mas nada de Typografia para S. Paulo! Alguns Paulistas a fizerão comprar no Rio de Janeiro, à Imprensa Nacional, porém, quando ella estava já encaixotada para embarcar, appareceo, ou se dice haver ordem em contrario”. Em seguida, numa clara tentativa de exaltar a importância do surgimento de O Farol Paulistano diante do contexto apresentado, o redator concluiu: "E que importa tudo isso? A Cidade de S. Paulo já tem uma Typografia, e o seu tal qual Farol Paulistano”.

${ }^{87}$ TAUNAY, Affonso de Escragnolle. História da cidade de São Paulo sob o Império (1822-1831). São Paulo: Divisão do Arquivo Histórico, vol.4, 1956, pp.293-294.
} 
São pouco conhecidos os motivos do insucesso de se implementar uma tipografia mediante a iniciativa do governo provincial, de modo que o advento tardio da imprensa paulista em relação a outros centros urbanos é um assunto lacunar na bibliografia sobre São Paulo. Autores como Afonso de Freitas e Afonso Taunay, por exemplo, explicaram a questão como conseqüência da junção entre a ineficácia administrativa e falta de recursos financeiros da província e, sobretudo, da cidade de São Paulo. ${ }^{88}$

A idéia de que o advento tardio da imprensa em São Paulo foi decorrência da má administração pública e da precariedade de recursos materiais corrobora com uma das interpretações mais difundidas sobre a história da capital paulista entre meados do século XVIII e as primeiras décadas do XIX: a noção de que São Paulo, durante esse período, passou por uma fase de decadência, pobreza e isolamento. Ainda que a origem dessa compreensão seja um ponto de discórdia entre os historiadores, é sabido que desde o fim do século XIX, com a publicação de estudos como os de Afonso de Freitas e Teodoro Sampaio, ligados ao Instituto Histórico e Geográfico de São Paulo, de Spencer Vampré e Almeida Nogueira, vinculados à Faculdade de Direito do Largo São Francisco, e de memorialistas ou jornalistas como Nuto Sant’Anna e Aluisio de Almeida, tornou-se prática comum atribuir à cidade de São Paulo do início do oitocentos um perfil de atraso econômico e cultural quando comparada a outras localidades da América portuguesa e, depois, do Império. ${ }^{89}$

As pesquisas de Afonso Taunay, Ernani Silva Bruno e Richard Morse, publicadas em meados do século $\mathrm{XX}$, conferiram maior profundidade interpretativa ao

\footnotetext{
${ }^{88}$ FREITAS, op. cit; TAUNAY, 1956, op. cit; SODRÉ, op. cit.

89 FREITAS, Affonso A. de. Tradições e reminiscências paulistanas. Belo Horizonte/São Paulo: Itatiaia/Edusp, 1985 [1921]; SAMPAIO, Teodoro. "São Paulo no século XIX". Revista do Instituto Histórico e Geográfico de São Paulo. São Paulo, 1902, v.06, pp.159-205; VAMPRÉ, Spencer. Memórias para a história da Academia de São Paulo. São Paulo: Saraiva, 1925, 2 v.; NOGUEIRA, J.L. de A. A Academia de São Paulo. Tradições e reminiscências. São Paulo: Saraiva, 1977, 3v.; SANT’ANNA, Nuto. São Paulo histórico: aspectos, lendas e costumes. São Paulo: Departamento de Cultura, 1944, 6 v.; ALMEIDA, Aluisio de. Vida e morte do tropeiro. São Paulo: Martins/EDUSP, 1981.
} 
desenvolvimento histórico da capital paulista, notadamente por conta da variedade da documentação utilizada - atas de Câmara, relatos de viajantes, almanaques, jornais e documentos avulsos -, mas ainda assim não chegaram a alterar substancialmente a memória que se constituiu sobre São Paulo. Taunay tratou São Paulo das primeiras décadas do século XIX como “pacífica e modorrenta”, ao passo que Silva Bruno definiu-a como um “arraial de sertanistas” que só a partir da instalação do Curso Jurídico (1828) começaria a livrar-se do seu “longo período de decadência”, transformando-se assim num “burgo de estudantes” que, por volta de meados dos oitocentos, ganharia importância econômica com a inserção da lavoura cafeeira em terras paulistas. Richard Morse, por sua vez, compreendeu a São Paulo desse período como uma cidade em transição, que deixava de ser uma "comunidade” estruturada na economia de subsistência e na introversão sócio-cultural para dar espaço à “metrópole” mercantil do café, o que se configuraria apenas depois da metade do século $\mathrm{XIX}^{90}$

Estudos mais recentes direcionados para a compreensão da formação histórica da Capitania e depois província de São Paulo têm ajudado a relativizar a suposta pouca expressividade da capital paulista que, grosso modo, também foi projetada para o planalto paulista como um todo, ao menos até meados do século XIX. Com o auxilio desses trabalhos, é possível notar que embora a cidade de São Paulo não apresentasse nas primeiras décadas do século XIX uma projeção política e econômica similar a outros centros urbanos, a exemplo da Corte, a sua importância como núcleo regional era notória. Isto é, ainda que fosse menos expressiva que localidades como Recife e Rio de Janeiro, a cidade de São

\footnotetext{
90 TAUNAY, Affonso de Escragnolle. História da cidade de São Paulo. São Paulo: Melhoramentos, 1953; TAUNAY, Affonso de Escragnolle. História colonial da cidade de São Paulo no século XIX. São Paulo: Departamento de Cultura, 1956; BRUNO, Ernani da Silva. História e Tradições da cidade de São Paulo. Rio de Janeiro: José Olympio, 1953, 3 v.; MORSE, Richard M. Formação histórica de São Paulo. São Paulo: Difusão Européia do Livro, 1970.
} 
Paulo se inscrevia como um ponto de referência para a província como um todo e para o chamado centro-sul, ao desempenhar, concomitantemente, funções evangélico-religiosa, político-administrativa e mercantil.

Na obra Evolução da Economia Escravista de São Paulo, de 1750 a 1850 91, Francisco Vidal Luna e Herbert Klein assinalam que a bibliografia mais conhecida sobre a história paulista não se deteve suficientemente nos processos inseridos entre dois supostos marcos: o bandeirismo e o café, ora enfatizando a proeminência dos bandeirantes na ocupação do território e na descoberta das minas, ora afirmando que o dinamismo socioeconômico de São Paulo cristalizou-se a partir de 1850, com o desenvolvimento da lavoura cafeeira. A maneira grandiloqüente como foram tratados esses dois temas, aliada a uma suposta escassez de fontes referentes ao desenvolvimento socioeconômico paulista no período anterior a 1872 - ano do primeiro censo nacional - , fez com que grande parte da bibliografia considerasse esse período “intermediário” como de pouca expressividade, portador de uma estagnação social e econômica que só seria superada com a consolidação do café. 92

É interessante notar que se, por um lado, enfatizou-se a incipiência da economia paulista até meados do século XIX, esses mesmos estudos também assinalaram, contraditoriamente, o papel fundamental de políticos paulistas na construção do Estado Nacional brasileiro. Deste modo, ao desenvolver tal paradoxo, autores como Afonso Taunay e Richard Morse ofereceram indícios para que seu próprio discurso fosse relativizado. Afinal, como uma província pobre economicamente poderia fornecer quadros políticos sólidos para a construção do Império? De forma inversa, outras perguntas podem surgir.

\footnotetext{
${ }^{91}$ LUNA, Francisco Vidal; KLEIN, Herbert S.. Evolução da Sociedade e Economia Escravista de São Paulo, de 1750 a 1850. São Paulo: EDUSP, 2006.

${ }_{92}$ Ibid., pp. 15-24.
} 
Seria então a província de São Paulo economicamente menos inexpressiva do que geralmente é tratada? Ou seriam seus políticos menos influentes no Primeiro Reinado do que comumente são estudados, visto que outras partes do Império também forneceram homens essenciais para a configuração do Estado Nacional?

A análise dos aspectos econômicos de São Paulo é elemento chave na problematização da aparente polaridade entre as dimensões política e econômica do período estudado, uma vez que possibilita questionar o suposto período de "decadência” no qual se inscreveu a Capitania entre o término do movimento bandeirista e o final do século XVIII, momento em que houve um incremento econômico proporcionado pela lavoura canavieira exportadora. ${ }^{93}$ Estudos como os elaborados por Maria Thereza Petrone oferecem indícios para que esse tipo de questionamento seja feito. Em A Lavoura Canavieira em São Paulo ${ }^{94}$, a autora demonstra que o sucesso das lavouras de café a partir de 1850 só foi possível devido à infra-estrutura comercial, financeira e de transportes implementada pela cultura canavieira durante o último quartel do século XVIII e a primeira metade do século XIX. Tal infra-estrutura, contudo, só pode ser concretizada na medida em que a economia de São Paulo sofreu gradativamente uma alteração estrutural, ou seja, passou de uma configuração mais regional e voltada para o mercado interno para outra assentada na grande produção exportadora e escravista. Petrone nota que esses dois processos, ocorridos de forma simultânea e articulada, resultaram da ação dos políticos da Capitania, seja como

\footnotetext{
${ }^{93}$ Para a referida "decadência” da Capitania de São Paulo, ver PRADO JR., Caio Prado. Formação do Brasil

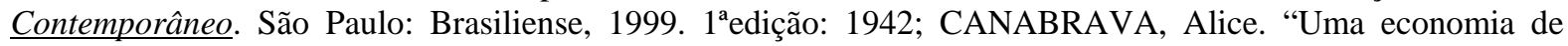
decadência: os níveis de riqueza na Capitania de São Paulo, 1765/1767”, in Revista Brasileira de Economia. Rio de Janeiro: 26(4): 95-123, out./dez., 1972; LYRA, Maria de Lourdes Viana. Dízimos Reais na Capitania de São Paulo. Contribuição à História Tributária do Brasil Colonial (1640-1750). Dissertação de mestrado apresentada ao Departamento de História da Faculdade de Filosofia, Letras e Ciências Humanas da Universidade de São Paulo. São Paulo, 1970.

${ }_{94}$ PETRONE, Maria Thereza Schorer. A Lavoura Canavieira em São Paulo. Expansão e Declino (1765-1851). São Paulo, Difusão Européia do Livro, 1968.
} 
idealizadores, seja como criadores de políticas públicas voltadas para a viabilização dos mesmos. Já na obra $O$ Barão de Iguape ${ }^{95}$, que tem como objeto de estudo a figura de Antonio da Silva Prado e o comércio de gado na primeira metade do século XIX, Petrone explicita como esse ramo da economia paulista foi um importante dinamizador econômico e político da região Centro-Sul, posto que o comércio de rezes e muares articulava os centros produtores (Rio Grande do Sul e os “Campos Gerais”) e vendedores (Sorocaba e a cidade de São Paulo) com os compradores (região planaltina paulista, Minas Gerais e, sobretudo, o Rio de Janeiro).

Trabalhos posteriores a esse, como os de Maria Luiza Marcílio, Ilana Blaj e Ana Paula Medicci questionaram diretamente a insuficiência do paradigma da "decadência” sobre São Paulo entre fins do século XVIII e início do XIX. ${ }^{96}$ Ao discutir o grande crescimento demográfico ocorrido em São Paulo entre 1690 e 1765, Marcílio notou que nesse período houve um aumento nas atividades agrícolas da Capitania, seja em decorrência do acréscimo populacional ocasionado pelo advento da exploração do ouro, seja pela transplantação da sede da América Portuguesa de Salvador para o Rio de Janeiro. Ilana Blaj, por sua vez, argumentou que o questionamento sobre a decadência paulista pode ser feito inclusive para o século XVII, visto que nesse período a economia paulista já estaria inserida numa complexa rede comercial interna à sociedade colonial que envolvia outras regiões, onde a vila de São Paulo já portaria o status de centro de trocas mercantis. Mais recentemente, ao discutir autores como Elizabeth Darwich Rabello, Iraci Del Nero da Costa, João Fragoso, Tereza

\footnotetext{
${ }^{95}$ PETRONE, Maria Thereza Schorer. $\underline{O}$ Barão de Iquape. Um empresário da época da Independência. São Paulo, Cia. Editora Nacional, 1976.

${ }^{96}$ BLAJ, Ilana. A trama das tensões. O processo de mercantilização de São Paulo colonial (1681/1721). São Paulo: Humanitas, 2002; MARCÍLIO, Maria Luiza. Crescimento demográfico e evolução agrária paulista. 1700-1836. São Paulo: Hucitec/Edusp, 2000; MEDICCI, Ana Paula. Entre a 'decadência' e o 'florescimento': capitania de São Paulo na interpretação de memorialistas e autoridades públicas (1782/1822). Dissertação de mestrado apresentada ao Departamento de História da Faculdade de Filosofia, Letras e Ciências Humanas da Universidade de São Paulo. São Paulo, 2005.
} 
Petrone, Maria Luiza Marcílio e Ilana Blaj, Ana Paula Medicci observou que o dinamismo econômico de São Paulo ao longo do século XVIII - oriundo sobretudo da produção e do comércio de produtos agrícolas -, além de colocar em dúvida a noção decadência, permite questionar o porquê da construção dessa idéia. No delinear de sua tese, Medicci assinala como o discurso da decadência produzido por autoridades públicas entre 1782 e 1822, apropriado posteriormente por parcela da bibliografia como indício da fragilidade da economia paulista, esteve intimamente associado aos interesses desses funcionários.

Considerando esse emaranhado de questões, a análise dos periódicos já citados - $O$

Farol Paulistano e O Observador Constitucional - emerge como possibilidade de compreensão do universo político paulista no momento de configuração do Império do Brasil, recurso na tentativa de mapeamento e identificação de grupos de poder local e de suas bases materiais de sustentação.

\subsection{O Farol Paulistano e O Observador Constitucional}

O Farol Paulistano surgiu em 7 de fevereiro de 1827, sob a direção de José da Costa Carvalho $^{97}$, e encerrou suas atividades em 1831, provavelmente no final do mês de junho,

\footnotetext{
${ }^{97}$ José da Costa Carvalho (1796-1860), Barão, Visconde e depois Marquês de Monte Alegre, era natural da Freguesia da Nossa Senhora da Penha, situada nos arredores de Salvador. Filho de pai homônimo e de Ignez Maria Piedade Costa, estudou Leis na Universidade de Coimbra, onde se formou em 1819. De volta ao Brasil, iniciou sua carreira pública pela magistratura, ocupando os cargos de juiz de fora e ouvidor da cidade de São Paulo entre 1821 e 1822, período em que se casou com Genebra de Barros Leite, viúva do Brigadeiro Luis Antonio de Sousa Queiróz. Sua carreira política iniciou-se quando foi eleito ao cargo de deputado pela Bahia para a Assembléia Constituinte de 1823. Ao longo do Primeiro Reinado, foi deputado pela Bahia nas duas primeiras Legislaturas. Durante esse período, foi presidente da Câmara dos Deputados (de 5 de maio a 3 de julho de 1828; de 4 de maio a 3 de julho de 1830; de 3 de agosto de 1830 a 4 de maio de 1831); VicePresidente da Câmara dos Deputados (de 4 de maio de 1827 a 5 de maio de 1828); e Primeiro Suplente da Mesa Diretora (de 2 de agosto de 1828 a 4 de maio de 1829). Ainda durante o Primeiro Reinado, Costa Carvalho foi membro regular dos Conselhos da Presidência e Geral de São Paulo. Com a Abdicação, tornou-se membro da Regência Trina Permanente, em 17 de junho de 1831. Ainda foi deputado pela Província de São Paulo na $4^{\mathrm{a}}$ Legislatura (1838-1841), com posse a 19 de maio de 1838; senador pela Província de Sergipe
} 
pouco após a eleição do futuro Marquês de Monte Alegre ao cargo de membro da Regência Trina Permanente, em 17 de junho de $1831 .^{98}$ Impresso em tipografia própria intitulada Typographia de Roa \& Cia. e situada no n ${ }^{\circ} 33$ da rua S. José ${ }^{99}$, o Farol era constituído de quatro páginas, esporadicamente seis ou oito, com dimensões de $21 \times 31 \mathrm{~cm}^{100}$ Segundo Afonso de Freitas, o primeiro impressor de o Farol foi o espanhol José Maria Roa que, trabalhando com um prelo de madeira, produzia cerca de 25 exemplares por hora, ou seja, 225 exemplares/dia numa jornada de nove horas de trabalho. ${ }^{101}$ Apesar da lógica do cálculo, é difícil precisar uma tiragem aproximada da folha, uma vez que em decorrência dos poucos recursos das tipografias na época, os problemas técnicos eram constantes e podiam comprometer a regularidade na impressão dos periódicos. Entre maio e junho de 1829, por exemplo, o Farol ficou cerca de dez dias sem ser publicado por conta da quebra do prelo da Tipografia do Farol Paulistano. ${ }^{102}$ Além da compra avulsa, que podia ser feita junto à tipografia do Farol por 80 rs., o jornal também era comercializado mediante assinaturas trimestrais. $^{103}$

(1839-1860), com posse em 4 de maio de 1839; Presidente da Província de São Paulo (de 20 de janeiro a 16 de agosto de 1842); Presidente do Senado (1842-1843); Conselheiro de Estado (a partir de 1842); Ministro e Secretário de Estado dos Negócios do Império $\left(10^{\circ}\right.$ Gabinete do $2^{\circ}$ Reinado, entre de 29 de setembro de 1848 e 11 de maio de 1852); e Presidente do Conselho de Ministros do $10^{\circ}$ Gabinete a partir de 8 de outubro de 1849. Fora da política, foi sócio do Instituto Histórico e Geográfico Brasileiro; fundador da Sociedade de Estatística do Brasil e da Associação Central de Colonização do Rio de Janeiro; membro honorário da Sociedade Auxiliadora da Indústria Nacional, da Academia Imperial das Belas-Artes e de outras associações de letras e ciências. Foi elevado a Barão (1841), Visconde com grandeza (1843) e Marquês de Monte Alegre (1854).

${ }^{98}$ É provável que o n ${ }^{\circ} 504$ (30/06/1831) tenha sido o último de o Farol Paulistano, uma vez que a bibliografia e arquivos consultados não fazem menção a números posteriores.

${ }_{99}$ O Farol Paulistano, $\mathrm{n}^{\circ}$ 12, 25/04/1827. Atualmente a rua S. José recebe o nome de Líbero Badaró. A partir do $\mathrm{n}^{\circ} 126$ (02/071828) a tipografia passou a se chamar Typographia do Farol Paulistano.

${ }^{100}$ A partir do $n^{\circ} 241$ (26/08/1829), o Farol mudou o aspecto de sua diagramação, tornando-se melhor impresso e mais legível.

${ }^{101}$ FREITAS, op. cit., 1928, p.20.

${ }^{102}$ O Farol Paulistano, $\mathrm{n}^{\circ}$ 221, 06/06/1829.

${ }^{103}$ O Farol Paulistano, no $12,1827$. 
Inicialmente o jornal circulava uma vez por semana, passando a ser bissemanal ${ }^{104} \mathrm{a}$ partir de junho de 1827 e trissemanal entre outubro de 1829 e seu término. Segundo o próprio Farol, a opção por fazer o jornal ir a público três vezes por semana - às terças, quintas e sábados - foi fruto tanto da melhoria das condições técnicas da tipografia do Farol, mediante a compra de um novo prelo, em junho de 1829, como da importância de serem abarcadas questões até então pouco contempladas pela folha, tais como as oscilações cambiais, o movimento do porto de Santos e os preços de gêneros de exportação e importação da província de São Paulo e do Rio de Janeiro. Ademais, atestava-se a importância de serem transcritos excertos de periódicos oriundos de outras províncias, de modo que a seleção de artigos operada pelo Farol redimiria seus leitores, no entender do redator, de lerem as folhas originais. ${ }^{105}$ Quanto a esse último ponto, mesmo levando em conta o significativo aumento da quantidade de periódicos editados nas diversas regiões do Império, é possível entrever uma estratégia do redator em selecionar, filtrar e publicar artigos dessas folhas que corroborassem ou não com suas idéias, tornando-as assim passiveis de uma instrumentalização discursiva e política.

Em 23 de outubro de 1829, quase três anos após o advento de O Farol Paulistano, São Paulo viu surgir seu segundo periódico impresso, O Observador Constitucional, sob a direção do médico italiano Giovanni Battista Líbero Badaró. Inicialmente produzido na Tipografia do Farol Paulistano, com dimensões de 21 x 30 cm e duas colunas por página, o Observador passou a ser impresso, em 1832, na Tipografia Patriótica, situada à rua da Esperança, tendo seu tamanho alterado para 15 x 21 cm e sua disposição para uma coluna. Nos primeiros tempos de funcionamento, o Observador podia ser assinado na própria

\footnotetext{
${ }^{104}$ Cf. indica o $\mathrm{n}^{\mathrm{o}} 20$ do Farol Paulistano, este passou a ser publicado duas vezes por semana, às quartas e aos sábados.

${ }^{105}$ O Farol Paulistano, no 247, 16/09/1829.
} 
Tipografia do Farol Paulistano, porém, em 1831, as mesmas passaram a ser feitas na loja do “Sr. Vilares”, na esquina da rua do Ouvidor com a São Bento, pelo valor de 1\$440 réis o trimestre. A partir de 1832, os interessados tiveram que fazer suas assinaturas na loja do Sr. Caetano Antonio de Morais, situada na rua Direita. O preço do exemplar avulso era de 80 réis, à semelhança de $O$ Farol e da maioria dos periódicos da época. Enquanto foi publicado pela Tipografia do Farol Paulistano, o jornal vinha a público duas vezes por semana, às segundas e sextas, ao passo que a partir de 1832 o Observador passou a circular às segundas, quartas e aos sábados. O Observador encerrou suas atividades em 1832, provavelmente no mês de julho. ${ }^{106}$

A publicação de O Observador pela Tipografia do Farol Paulistano não constituía mera causalidade. Morando no Rio de Janeiro desde 1826, Badaró mudou-se para a cidade de São Paulo em 1828, a convite de Costa Carvalho. Deste foi hóspede temporariamente, até sua mudança para um edifício na rua S. José, nas proximidades da tipografia. Além de médico e redator, Badaró ministrava aulas preparatórias de Geometria para o Curso Jurídico da cidade de São Paulo.

Similarmente a outras folhas do período, tanto o Farol quanto o Observador foram jornais compostos por diversos redatores. Ainda que aparentemente tenha ficado sob a direção de José da Costa Carvalho em todo seu tempo de duração, e que autores como S. A. Sisson creditaram ao futuro Marquês de Monte Alegre a redação de todo o periódico, o mais provável é que o Farol Paulistano tenha sido levado a cabo por diversos redatores em

${ }^{106}$ De acordo com a bibliografia e a documentação consultada, é provável que o último número de $O$ Observador Constitucional tenha vindo a público em 4 de julho de 1832. 
diferentes períodos, tal como sugeriram Afonso de Freitas e, mais recentemente, Arnaldo Contier. $^{107}$

As páginas de $O$ Farol não oferecem dados precisos em relação a essas alterações, mas sugerem que as mudanças de redator, mesmo que temporárias, foram constantes ao longo dos quase cinco anos de duração do jornal. A primeira delas, ocorrida no $\mathrm{n}^{\mathrm{o}} 12$, ou seja, pouco após a fundação do jornal, teve como justificativa a ida do redator ao Rio de Janeiro. ${ }^{108}$ Ainda em 1827, outra substituição foi efetuada, só que dessa vez a explicação residiu no fato de o redator em exercício entre o nº 12 e 38 ter adoecido gravemente. ${ }^{109}$

A alternância de redatores possibilitou ao Farol a criação de um instrumento de defesa diante das críticas eventualmente recebidas, já que a inexistência de um único responsável supostamente redimia o periódico de ser cobrado quanto à manutenção de um discurso coerente em seu todo. Não se tratava, naturalmente, de legitimar a publicação de idéias diametralmente opostas - o que de fato nunca ocorreu -, mas de justificar possíveis alterações no discurso geral do periódico. Em abril de 1830, o autor do artigo principal inseriu uma nota de rodapé na qual explicou que as posições defendidas em seu texto, por serem passíveis de controvérsia, não deveriam ser tomadas como vindas do "principal redactor" do Farol, uma vez que esse se encontrava fora da cidade de São Paulo. ${ }^{110}$ Um ano depois, já nos últimos números da folha, o então redator não discordou de uma correspondência inserta no Observador Constitucional que acusava o Farol de ser escrito

${ }^{107}$ SISSON, S.A. Galeria dos brasileiros ilustres. Brasília: Senado Federal, 1999, $1^{\text {a }}$ edição: 1948, v.1, p.84; FREITAS, op. cit.; CONTIER, op. cit.

${ }^{108}$ O Farol Paulistano, $n^{\circ}$ 12, 25/04/1827.

${ }^{109}$ O Farol Paulistano, no $39,22 / 08 / 1827$.

${ }^{110}$ O Farol Paulistano, $\mathrm{n}^{\circ}$ 331, 17/04/1830. Em linhas gerais, o artigo criticava a atitude pouco enérgica assumida pela Aurora Fluminense - periódico-chave na construção do discurso de o Farol e recorrentemente elogiado por esse - quando de sua absolvição frente às acusações do Conselheiro Francisco Gomes da Silva sobre o abuso da liberdade de imprensa pela folha fluminense. 
por redatores "interinos". ${ }^{111}$ Podendo ser considerado um momento de transformação do teor político-ideológico de o Farol - posto que esse passou a concordar com algumas propostas dos ditos "liberais exaltados", tal como reformar aspectos da Carta de 1824, como se verá mais adiante -, o período pós-Abdicação marcou um re-alinhamento discursivo na folha paulista, de modo que a aceitação desse caráter "interino" figurava menos como o reconhecimento de uma constatação externa e mais como um aval para a mudança no tom do discurso do periódico.

Nesse âmbito, torna-se difícil afirmar com precisão quais foram os redatores de $O$ Farol ao longo de sua publicação. A bibliografia e as fontes sugerem que José da Costa Carvalho e Antonio Mariano de Azevedo Marques ${ }^{112}$ tenham sido seus principais redatores, desempenhando essa função de forma descontínua, porém por um período mais longo que os demais. Costa Carvalho, que tomou posse como deputado nas duas primeiras Legislaturas da Câmara dos Deputados, retirava-se da cidade de São Paulo com freqüência regular, muito provavelmente durante o período de funcionamento da Câmara dos Deputados, entre maio e setembro, fato que pode ser constatado pelas suas ausências ao longo das sessões extraordinárias do Conselho da Presidência da província de São Paulo, que ocorriam concomitantemente às do Legislativo. ${ }^{113}$ Azevedo Marques, todavia, por não

${ }^{111}$ O Farol Paulistano, no 481, 30/04/1831.

112 Antonio Mariano de Azevedo Marques (1797-1844), o Mestrinho, era natural de São Paulo. Filho de Manoel Eufrásio de Azevedo Marques, tornou-se conhecedor de latim já em sua juventude, fazendo com que desse aulas para os integrantes do coral da Catedral da Sé, quando recebeu o apelido de Mestrinho. Em 1822, foi nomeado professor da cadeira pública de Latim e Retórica da cidade de São Paulo. Em 1828, quando da fundação do Curso Jurídico de São Paulo, ocupou a cadeira de Latim e Retórica anexa ao Curso Jurídico, cargo que desempenhou até 1835. Entre as décadas de 1820 e 1830, ocupou os cargos de escrivão da irmandade de Santa Casa de Misericórdia (1823-1825), juiz de paz, vereador, membro dos Conselhos da Presidência e Geral, vice-presidente (1837) e secretário da presidência (1839-1842), todos pela Província de São Paulo. No fim da vida, ainda ocupou o cargo de auxiliar de gabinete do Visconde de Macaé, no Rio de Janeiro.

${ }^{113}$ Embora eleito Conselheiro, José da Costa Carvalho participou de apenas três sessões da Segunda Reunião do Conselho da Presidência da Província de São Paulo, transcorrida entre 1830-1833. Cf. Atas do Conselho da Presidência da Província de São Paulo (1829-1832) (ACP). In: Boletim. São Paulo: Arquivo do Estado de São Paulo, 1961, v.15, sessões de 18/01/1831, 21/01/1831 e 26/03/1831, pp. 138-139. 
ter ocupado cargos públicos fora de São Paulo durante o tempo de funcionamento de $O$ Farol, parece ter permanecido por mais tempo na capital paulista, o que também pode ser observado pela assiduidade nas reuniões do mesmo Conselho da Presidência. ${ }^{114}$ Numa ocasião em que o Farol recebeu um ofício do Palácio do Governo de São Paulo sobre a regularização do funcionamento da Sociedade Filantrópica da capital paulista, o nome de Azevedo Marques apareceu como destinatário do documento a ser publicado, o que sugere uma participação ativa do Mestrinho da elaboração da folha de Costa Carvalho. ${ }^{115}$ Ademais, vale lembrar que Azevedo Marques ocupou a Cadeira de Latim e Retórica anexa ao Curso Jurídico entre 1828 e 1835, função que desempenhou com regularidade. ${ }^{116}$

Mais vagas são as informações a respeito da redação de O Observador Constitucional. É sabido que, além de dirigi-lo, Líbero Badaró também era seu principal redator, mas é improvável que tenha sido o único, uma vez que os artigos principais eram sempre assinados por “os redatores”. Num artigo publicado em 12 de março de 1830, Luiz Monteiro de Ornellas se colocou na condição de redator do periódico, de modo que é plausível que ele tenha sido um dos integrantes da redação de O Observador, pelo menos até a morte de Badaró. ${ }^{117}$ A bibliografia desconhece, também, quem tenha assumido a direção do periódico após a morte do médico italiano, em novembro de 1830.

Além dos redatores, o Farol Paulistano também contava com alguns colaboradores que esporadicamente lhe enviavam textos para publicação. ${ }^{118}$ Dentre estes se pode mencionar Manoel Joaquim do Amaral Gurgel, Manoel Odorico Mendes, Antonio Manoel

\footnotetext{
113 O Farol Paulistano, no 481, 16/11/1830.

114 Antonio Mariano de Azevedo Marques ocupou o cargo de Suplente do Conselho da Presidência da Província de São Paulo entre 30/06/1830 e 20/10/1831. Cf. ACP, v.15, pp.50 e 191.

${ }^{115}$ O Farol Paulistano, no 481, 16/11/1830.

116 TAUNAY, op. cit, 1956, pp.298-299.

117 O Observador Constitucional, $\mathrm{n}^{\circ} 38,12 / 03 / 1830$.

${ }^{118}$ Não foi possível observar o mesmo com relação ao Observador Constitucional.
} 
de Campos Mello, Vicente Pires da Mota, João da Silva Carrão e Nicolau Pereira de Campos Vergueiro ${ }^{119}$, muito embora nenhum deles tenha aparecido nas páginas de $O$ Farol mais que uma ou duas vezes. Assim, dado o anonimato da maior parte dos textos publicados, revela-se insustentável qualquer afirmação no sentido de arrolar um corpo permanente de colaboradores de O Farol.

Ambos os periódicos eram compostos de seis partes básicas: o artigo do interior; as correspondências; as notícias nacionais e internacionais; os anúncios; as variedades; e a seção de publicação de documentos oficiais. Embora haja números em que uma ou outra seção não apareça, o Farol não alterou de forma significativa sua estrutura durante o período no qual funcionou. Já o Observador, a partir de janeiro de 1832, quando teve sua impressão deslocada para a Tipografia Patriótica, passou a constituir-se apenas de pequenos artigos e poucos seções, caracterizando-se mais como folheto do que como jornal.

$\mathrm{O}$ artigo do interior ${ }^{120}$ era redigido tanto pelos redatores do jornal como por seus colaboradores, e representava, na maior parte das vezes, o texto principal do periódico, cedendo essa importância apenas naquelas ocasiões em que era substituído por um artigo similar retirado de outra folha alinhada com as tendências políticas de $O$ Farol ou $O$ Observador. De modo geral, tratava de questões mais abrangentes, quase sempre referentes ao andamento da política imperial, seja em sua acepção mais ampla, representada pela

\footnotetext{
${ }^{119}$ Nicolau Pereira de Campos Vergueiro (1778-1859) era natural de Bragança, Portugal. Após formar-se em Direito pela Universidade de Coimbra, em 1801, erradicou-se na América, mais precisamente em São Paulo, onde exerceu a advocacia, além de ser proprietário e comerciante. Como político, participou do Governo Provisório de São Paulo, sendo eleito deputado pela mesma Província para as Cortes de Lisboa (1821) e, posteriormente, para a Assembléia Constituinte (1823). Eleito deputado por São Paulo para a $1^{\text {a }}$ Legislatura do Império, foi substituído em 1829 pelo Desembargador João de Medeiros Gomes, uma vez que havia sido eleito senador por Minas Gerais. Ainda durante o Primeiro Reinado, foi eleito Suplente para $1^{a}$ Reunião do Conselho da Presidência e Conselheiro para a $2^{\text {a }}$, ambos pela Província de São Paulo. Após a Abdicação, foi membro da Regência Trina Provisória (1831) e ministro diversas vezes entre 1832-33 e 1847, e diretor do Curso Jurídico de São Paulo, entre 1837-1842.

${ }^{120}$ Denominação utilizada por alguns periódicos, tais como O Observador Constitucional e A Voz Paulistana, para discriminar o artigo principal dentro da folha. Arnaldo Contier, cf. CONTIER, op. cit., utilizou o termo com o mesmo sentido, também empregado aqui.
} 
esfera pública da Corte, seja em sua dinâmica mais particular, condicionada à realidade das províncias e vilas. Outra forma assumida pelo “artigo do interior” era a de um libelo político, de modo que a defesa dos “princípios liberais” e da monarquia constitucional consistia no principal eixo teórico a ser apregoado, ao passo que as tendências “absolutistas”, “despóticas” e “arbitrárias” compunham, por oposição, o principal campo teórico/prático a ser combatido. Nesse caso, os artigos recebiam nomes objetivos, de cunho pedagógico, a fim de identificar desde o princípio o teor do texto. ${ }^{121}$ Quando escrito por colaboradores, o “artigo do interior” recebia o título de “Artigo Comunicado”, podendo ser publicado junto com algum texto menor do redator. Esses artigos costumavam ser menos abrangentes quando comparados aos redigidos pelos redatores, visto que tratavam de problemáticas mais delimitadas. Textos com esse perfil crítico direcionado a situações e indivíduos específicos eram corriqueiros entre os artigos comunicados, assemelhando-se, em certa medida, com as correspondências.

As correspondências compunham uma das principais seções tanto de O Observador quanto de $O$ Farol. O redator deste por mais de uma vez alertou seus leitores de que o setor deveria ser preenchido com textos "úteis à causa pública”, e não por querelas e desafetos pessoais. ${ }^{122}$ Remetidas de diversas partes de São Paulo e até mesmo de Minas Gerais e Rio de Janeiro, as correspondências tratavam de assuntos variados, principalmente sobre a situação política ou econômica de determinada Freguesia, Vila, província e do Império como um todo. Nesse sentido, temáticas como o recrutamento militar, a infra-estrutura de

\footnotetext{
${ }^{121}$ Exemplos desses artigos são "Da monarquia constitucional e representativa” (O Farol Paulistano, $\mathrm{n}^{\circ}$ 02, 1827), "Da Tyrannia” (O Farol Paulistano, $\mathrm{n}^{\circ}$ 89, 16/02/1828), "Da liberdade individual” (O Observador Constitucional, $\mathrm{n}^{\circ}$ 27, 08/03/1830) e "Respeito à Opinião Pública" (O Observador Constitucional, $\mathrm{n}^{\circ}$ 46, 23/04/1830).

${ }^{122}$ Ver $O$ Farol Paulistano, $n^{\circ}$ s $1(07 / 02 / 1827)$ e $247(16 / 09 / 1829)$ e O Observador Constitucional, $n^{\circ}$ s 12 $(30 / 11 / 1830)$ e $16(14 / 12 / 1829)$.
} 
transportes, as eleições, a justiça e o funcionamento do governo imperial ganhavam contornos tanto particulares como mais gerais, dependendo do enfoque dado pelo correspondente, que muitas vezes se revestia de um tom reivindicatório. Havia casos nos quais os redatores teciam algum comentário sobre a temática discorrida, geralmente com a intenção de corroborar com a idéia exposta pelo correspondente, ou fazerem-se endossados por ela. ${ }^{123}$ Os correspondentes também enviavam textos laudatórios, geralmente sobre as mostras de constitucionalidade das Câmaras Municipais ou da Câmara dos Deputados, críticas gerais ao “despotismo" e ao “absolutismo”, impressões sobre a situação das instituições, excertos traduzidos e sugestões para o melhoramento da administração pública.

A despeito da heterogeneidade dos objetos tratados, bem como do número significativo de correspondências escritas em formato de artigo, a grande maioria delas se dividia em duas categorias: as que criticavam algo ou alguém e aquelas que se defendiam das acusações sofridas, contra-atacando-as ou não. Clérigos, militares, redatores, lentes do Curso Jurídico, juizes de paz, militares, capitães-mores, vereadores e ministros foram alvos constantes da pena dos correspondentes, o que demonstra uma tendência geral em tomar as pessoas públicas, sobretudo os empregados públicos, como responsáveis pelos rumos da nação. Mais do que criticarem pontos de vista, situações e atitudes, os correspondentes faziam questão de denunciar supostos abusos de autoridade e desvios de conduta no manejo da máquina pública. Urgia, segundo grande parcela desses correspondentes, a tomada de medidas legais que punissem tais homens, pois eram eles os causadores dos males da nação, e não o sistema político-administrativo em si.

Ora, se a publicação de correspondências que observavam com tanta clareza os empecilhos para o bom funcionamento do governo imperial pode sugerir, num primeiro

\footnotetext{
${ }^{123}$ Ver, por exemplo, O Farol Paulistano, nos 37 (16/08/1827) e 155 (11/10/1828).
} 
momento, uma forma de $O$ Farol e $O$ Observador assegurarem aos seus leitores um espaço próprio de enunciação, ela também permite entrever, por um outro ângulo, uma maneira indireta das folhas paulistanas acalentar em determinados questionamentos. Retirando de si a responsabilidade pela criação desses textos ${ }^{124}$, o redator de $O$ Farol deixava para que os próprios correspondentes, acusadores e acusados, esclarecessem suas posições no jornal, de modo que os debates fizeram-se recorrentes, e por vezes tiveram que ser encerrados pelo redator, que os julgou “pessoais” em demasia. A primeira dessas intervenções ocorreu já em abril de 1827, quando o redator notificou que não continuaria a "inserir tudo quanto quiserem escrever”, referindo-se a uma discussão travada por correspondência entre o ouvidor de Itu e um missivista que o criticou por seu suposto abuso de autoridade, já que isso tiraria da folha "o logar que devem ter as matérias de instrução". ${ }^{125}$

Nesse âmbito, além de sua característica marcadamente político-pedagógica, os periódicos do período, sobretudo os liberais, desempenhavam a função de espaços de denúncia contra crimes de prevaricação, abuso de poder e outras irregularidades concernentes à gestão pública, o que era geralmente feitos por correspondentes. É provável que a maior parte das denúncias malograsse em seu intento, já que muitas das acusações careciam de profundidade argumentativa, diziam respeito a desavenças pessoais ou confrontavam com interesses de grupos influentes. Ainda assim, é inegável que se criou um locus de discussão permanente nesse sentido, sem mencionar os casos em que efetivamente as denúncias publicadas pelos jornais obtiveram algum resultado. Em abril de 1829, o redator de $O$ Farol Paulistano vangloriava-se de ter publicado uma correspondência cujas

\footnotetext{
${ }^{124}$ Isso não impedia, todavia, que o periódico fosse levado a julgamento por publicar uma correspondência supostamente caluniosa. Em 1827, a Astréa foi julgada e absolvida por conta de uma correspondência que havia levantado suspeitas sobre um promotor do Rio de Janeiro, cf. O Farol Paulistano, n 74, 22/12/1827.

${ }^{125}$ O Farol Paulistano, $n^{\circ} 12,25 / 04 / 1827$.
} 
denúncias contribuíram para a remoção de Antonio Barbosa da Silva do cargo de Comandante da Freguesia do Bananal, sem deixar de reconhecer, todavia, ser comum a difusão de “calunias” pelos periódicos:

“Agora acaba de haver uma próva sem réplica da utilidade da censura pública por meio dos Periódicos.

Consta-nos que o Capitão-Mór das Áreas em cumprimento da Portaria do Exm. Presidente o Sr. Almeida Torres, informara serem verdadeiros os factos criminosos, denunciados por um nosso Correspondente, e attribuidos ao Sr. Capitão Antonio Barboza da Silva, Commandante da Freguesia do Bananal, que já fôra, segundo a Portaria que publicamos em nosso $\mathrm{N}^{\mathrm{o}}$ antecedente, removido do commando, e que sem dúvida, será processado pela emenda sua, e escarmento, que taes forem. - Em quanto não tivermos um Presidente Constitucional, em quanto não foi feita a denuncia por uma Folha pública, ião todos os habitantes do Bananal gemendo ás escondidas do Sr. Barboza, sem que seus gemidos servissem por ventura senão de agravar seus males”(...) Não duvidamos, e maldade fôra negá-lo, que muitas calúmnias, que muitas falsidades se prapalão nos Periódicos, mas também grande maldade é não reconhecer a utilidade da liberdade d'escrever, ainda com esse não pequeno inconveniente, que tem o seu correctivo na mesma imprensa, publicando o calumniado a sua defeza, ou chamando o calumniador perante o competente juizo”. ${ }^{126}$

Constatação importante é a de que enquanto o acusador se resguardava em pseudônimos, o acusado, quando respondia a uma denúncia, tinha que mostrar sua identidade, que por sinal já havia sido levada a público pelas insinuações a seu respeito. Foi justamente nesse sentido que políticos proeminentes do Império - notadamente da província de São Paulo - passaram a ocupar as páginas de $O$ Farol e de O Observador, isto é, não como propositores de idéias ou atitudes, mas como defensores de sua própria figura pública.

${ }^{126}$ O Farol Paulistano, no 202, 01/04/1829. 
Rafael Tobias de Aguiar ${ }^{127}$, Bernardo Pereira de Vasconcelos, José Arouche Toledo Rendon $^{128}$, Manuel Joaquim de Ornellas Junior e Francisco de Paula Sousa ${ }^{129}$, apenas para citar nomes de maior projeção ${ }^{130}$. Caso típico ocorreu com Antonio Mariano de Azevedo Marques, um dos principais redatores de O Farol Paulistano e integrante dos Conselhos Geral e da Presidência da província de São Paulo a partir de 1830. Em março deste ano, o Mestrinho fez publicar nas páginas de O Observador Constitucional uma correspondência na qual justificava seu pedido de dispensa do cargo de juiz de paz da Freguesia da Sé, situada na cidade de São Paulo. Alegando um “agravamento” de suas “moléstias” e uma suposta incompatibilidade entre o cargo para o qual fora eleito e suas ocupações de advogado e lente de Retórica no Curso Jurídico, Azevedo Marques utilizou-se da folha dirigida por Badaró para tornar de conhecimento público as motivações que o fizeram desistir do cargo, bem como defender-se de insinuações que surgiram sobre o assunto. ${ }^{131}$

\footnotetext{
${ }^{127}$ Rafael Tobias de Aguiar (1794-1857) era natural de Sorocaba e filho de Antonio Francisco de Aguiar e D. Gertrudes Eufrosina Aires. Em 1821, foi nomeado eleitor pela Comarca de Itu para as Cortes de Lisboa, não conseguindo, todavia, eleger-se deputado. Pela Província de São Paulo, foi eleito deputado pela $2^{\mathrm{a}}$ e $3^{\mathrm{a}}$ Legislaturas, Conselheiro do Conselho da Presidência e do Conselho Geral na $1^{\mathrm{a}}$ e $2^{\mathrm{a}}$ Reuniões. Foi presidente da Província de São Paulo em nas seguintes ocasiões: entre 17 de novembro de 1831 e 27 de maio de 1834; de 14 de setembro de 1834 até 10 de maio de 1835; e de 6 de agosto de 1840 até 14 de julho de 1841 .

128 José Arouche de Toledo Rendon (1756-1834) era natural de São Paulo e formado em Direito pela Universidade de Coimbra em 1779. De volta à América Portuguesa, dedicou-se à advocacia e iniciou sua carreira militar em 1789, em São Paulo. Em 1817, organizou os corpos de milícia destinados às campanhas do sul. Em 1822, foi promovido a marechal de campo, ano em que também ocupou o cargo de Governador das Armas de São Paulo, Província pela qual foi eleito deputado da Assembléia Constituinte de 1823. Foi ainda provedor da Santa Casa de Misericórdia, diretor do Curso Jurídico de São Paulo, entre 1828-1833, e Suplente do Conselho da Presidência de São Paulo entre 1827 e 1830. . Eleito deputado para a $1^{\text {a }}$ Legislatura do Império, não tomou assento, sendo substituído pelo brigadeiro Ignácio José Vicente da Fonseca.

${ }^{129}$ Francisco de Paula Sousa e Melo (1791-1851) era natural Natural de Itu. Filho de Antônio José de Sousa e D. Gertrudes Solidônia de Cerqueira, iniciou sua carreira política na Câmara Municipal de Itu. Eleito deputado pela Província de São Paulo para as Cortes de Lisboa, em 1821, não embarcou para Portugal por alegar doença. Pela Província de São Paulo, foi eleito deputado para a Assembléia Constituinte (1823) e a $1^{\mathrm{a}}$, $2^{\mathrm{a}}$ e $3^{\mathrm{a}}$ Legislaturas do Império. Foi ainda Conselheiro do Conselho Geral na $2^{\mathrm{a}}$ e $3^{\mathrm{a}}$ Reuniões, ambas por São Paulo. Após a Abdicação, foi senador (1833), ministro do Império (1847) e da Fazenda (1848).

${ }^{130}$ Ver, respectivamente, O Farol Paulistano, nos 70 (07/12/1827), 71 (12/12/1827), 249 (22/09/1829) e 300 (25/01/1830); e O Observador Constitucional, $n^{\circ}$ 68, 16/07/1830.

${ }^{131}$ O Observador Constitucional, $n^{\circ} 35,01 / 03 / 1830$.
} 
Houve ocasiões, por outro lado, em que os próprios periódicos entraram em conflito com algum correspondente. Em março de 1830, o Observador Constitucional publicou uma nota em que pedia esclarecimentos do pagador interino da cidade de São Paulo quanto aos procedimentos utilizados no pagamento dos empregados públicos, a fim de que eventuais “negligencias" e "irregularidades" fossem sanadas. ${ }^{132}$ Na edição seguinte, publicou-se uma correspondência do próprio pagador interino, Raimundo Pinto Homem, o qual solicitou ao redator de O Observador que esse expusesse os eventuais problemas que haviam ocorrido no pagamento dos ordenados para que ele os esclarecesse. No mesmo número, o redator respondeu ao pagador difamando-o, e elencou cinco motivos que tornavam sua conduta irregular, dentre eles o atraso nas folhas de pagamento e o beneficiamento de determinados empregados em detrimento de outros. ${ }^{133}$ Raimundo Pinto Homem respondeu aos ataques do jornal, mas Líbero Badaró, que assumiu a autoria dos artigos, não só deixou de publicar a defesa do pagador interino como encerrou a discussão com um extenso artigo rebatendo a defesa do acusado. ${ }^{134}$

A seção de notícias nacionais e estrangeiras compunha uma parte menor de $O$ Farol e de O Observador, a qual era escrita por meio de artigos ou pequenas notas. As notícias nacionais, cujo material era amiúde extraído de periódicos fluminenses, voltavam-se basicamente para acontecimentos específicos, quase sempre de conotação política, ocorridos na Corte, embora fosse recorrente a publicação de notas sobre as províncias da Bahia, Pernambuco, Maranhão, Minas Gerais e sobre os conflitos no Sul. Já Portugal, França e Inglaterra ocupavam a maioria do noticiário internacional que, comumente retirado de folhas européias, também contemplava as recém-formadas repúblicas americanas.

\footnotetext{
132 Ibidem.

${ }^{133}$ O Observador Constitucional, n 36, 05/03/1830.

${ }^{134}$ O Observador Constitucional, $\mathrm{n}^{\circ} 40,26 / 03 / 1830$.
} 
A seção de variedades constituía uma das mais diversificadas dos dois jornais paulistanos, uma vez que abarcava desde anedotas, causos e fábulas até pequenos ensinamentos morais, reflexões filosóficas e máximas políticas. A partir de meados de 1829, o Farol Paulistano começou a publicar notas sobre o movimento do porto de Santos, informações acerca da situação cambial das principais moedas européias e americanas e tabelas de preços de produtos agrícolas exportados por São Paulo e Rio de Janeiro. Em ambos os periódicos, a parte mais significativa dessa seção ficava por conta dos excertos traduzidos de autores estrangeiros, tais como Benjamin Constant, Benjamin Franklin, J.J. Rousseau, Jeremy Bentham, Visconde de Chateaubriand, Conde Lanjunais, Sully, François Guizot e Jean-Baptiste Say. ${ }^{135}$ É provável que esses fragmentos fossem retirados de obras pertencentes ao próprio Costa Carvalho, dado que a biblioteca inventariada em 1838 após a morte de sua esposa, Genebra de Barros Leite, era considerada na época uma das maiores coleções particulares da cidade de São Paulo e continha grande parte dos autores publicados no Farol Paulistano e na folha de Badaró. ${ }^{136}$

A inclusão de trechos referentes a autores estrangeiros, sobretudo europeus e norteamericanos, era uma prática comum nos periódicos da primeira metade do século XIX. ${ }^{137}$ Tal atitude desempenhava, num primeiro momento, a função de um artifício pedagógico para a disseminação de princípios políticos, visto que os periódicos facilitavam o acesso do público leitor aos autores estrangeiros por meio de dois elementos básicos: em primeiro

\footnotetext{
135 Para a relação completa dos excertos e autores inseridos no Farol Paulistano e no Observador Constitucional, ver Anexos 2 e 5.

${ }^{136}$ A relação dos títulos listados no inventário de Genebra de Barros, quase todos em francês e que totalizavam 326 volumes, encontra-se publicada em ARAÚJO, Maria Lucília Viveiros. Os caminhos da riqueza dos paulistanos na primeira metade do oitocentos. São Paulo: Hucitec, 2006, pp.171-178. Sobre o fato de a biblioteca ser uma das mais imponentes da cidade, ver OLIVEIRA, Albino José Barbosa de. Memórias de um Magistrado do Império. São Paulo: Companhia editora nacional. Série Pedagógica Brasileira: Brasiliana, v.231, 1943.

${ }^{137}$ CONTIER, op. cit.
} 
lugar, como observado, o jornal era mais barato e mais fácil de ser comprado se comparado a um livro; além disso, o formato pouco extenso dos trechos publicados fornecia a um público majoritariamente sem o hábito da leitura um texto previamente selecionado e recortado pelo redator, o que lhe conferia maior inteligibilidade. As próprias traduções, nesse sentido, não estavam livres de sofrerem manipulações e re-interpretações por parte daqueles que queriam imputar-lhe algum significado. ${ }^{138}$ Como notou o então redator de $O$ Farol, em 1828, a inserção de traduções de autores estrangeiros fazia parte de um "plano" da folha paulista para a "ilustração" de seus leitores:

"Muito tempo ha, que não damos algumas traducções aos nossos leitores, sendo esse um dos pontos do nosso plano, e conhecendo nós a muita vantagem, que d'esse trabalho póde resultar ao público, o qual pela mór parte não tem, nem pode obter certos livros já por sua raridade, já pelo seu preço, a tambem a muita gente acontece não ter algum, por desuso, e não ser essa sua profissão, outros pelo contrário, as vezes inteiramente diversa, de lêr um grosso volume, mas achando em um pequeno artigo de um Periodico aquellas verdades que se tornariam incomodas, espalhadas em um volume, as lerão com prazer, as reterão, e irão adornando o seu espirito, e ficando mais nas circunstancias de conhecerem seus deveres, e direitos, e por consequencia o que devem fazer, e exigir, e a opinião publica irá sendo por mais illustrada, mais valente e fixa, mais formidavel aos despotas, e mais proveitoza à sociedade”. 139

A tradução de autores portadores de matizes teóricas e objetivos distintos, como Rousseau, Benjamin Constant e o Visconde de Chateubriand, e a inserção sistemática dos excertos no corpo do periódico revelam, todavia, um emaranhado de aspectos que superam a

\footnotetext{
${ }^{138}$ Sobre os problemas intrínsecos ao ato de traduzir, ver ECO, Umberto. Os Limites da Interpretação. São Paulo: Perspectiva, 2000; VIEIRA, Else Ribeiro Pires (org.). Teorizando e contextualizando a Tradução. Belo Horizonte: UFMG, 1996; e BERMAN, Antoine. A prova do estrangeiro: cultura e tradução na Alemanha romântica. Bauru/ SP: EDUSC, 2002.

${ }^{139}$ O Farol Paulistano, $\mathrm{n}^{\circ} 165,19 / 11 / 1828$.
} 
atitude de "fornecer luzes” para a população. Juntamente com essa finalidade coexistia uma intenção de ordem prática que instrumentalizava o autor citado, isto é, utilizava-o seja como recurso legitimador de um discurso proferido pelo periódico seja como esclarecedor de um evento ocorrido na província de São Paulo ou em outras localidades do Império. Em setembro de 1828, ao levar a público um artigo anônimo traduzido com o título de “Principal causa da corrupção dos Príncipes”, que discorria sobre perniciosidade daqueles que adulam incondicionalmente a figura dos monarcas, o Farol não estava condenando os elementos em si causadores da degeneração política dos príncipes; estava sim criticando o círculo político de D. Pedro, por essa época notabilizado por figuras como João Carlota, Plácido Abreu e, sobretudo, pelos polêmicos Francisco Gomes da Silva - o "Chalaça” - e João da Rocha Pinto, ambos secretários do imperador. ${ }^{140}$

Os anúncios compunham a seção menos extensa da folha, o que não significa que tivessem pouca importância, dada sua constância e variedade. Anunciava-se a venda de artigos avulsos de toda sorte (livros, bebidas, móveis, vestimentas, calçados, instrumentos musicais, armas e objetos pessoais), quer por particulares quer por negociantes; a abertura ao público de novos estabelecimentos (padarias, botequins, boticas, fábrica de chapéus, vendas de secos e molhados, e lojas de artigos diversos); terrenos, casas e fazendas para a venda; avisos sobre datas nas quais correria a loteria promovida pela Santa Casa de

${ }^{140}$ O Farol Paulistano, no 149, 20/09/1828. São muitas as controvérsias em torno de Francisco Gomes da Silva e João da Rocha Pinto, tidos os integrantes do chamado "gabinete secreto" do imperador no final do Primeiro Reinado. Amigos próximos de D. Pedro e articuladores da vida íntima do monarca, ambos ganharam maior notoriedade após a morte de D. João VI, em 1826, quando a questão sucessória do trono português inscreveuse como elemento importante da política externa do governo de D. Pedro, a despeito das críticas sofridas especialmente da oposição liberal. Gomes da Silva, sobretudo, tornou-se homem de confiança do monarca no tratamento do problema, que se agravou com a usurpação da coroa portuguesa por D. Miguel, em fevereiro de 1828. A falta de clareza a respeito das efetivas atribuições conferidas aos dois secretários e a ambigüidade do monarca sobre o assunto gerou insatisfação por parte do próprio ministério - naquela época formado pelos marqueses de Barbacena, Caravelas, Rio Pardo e Paranaguá, por Miguel Calmon du Pin e pelo Visconde de Alcântara -, que negociou com D. Pedro a saída de ambos do Brasil, em abril de 1830. Sobre a atuação política de Rocha Pinto e Gomes da Silva, ver SOUSA, op. cit., v.3, capítulo XXIV, e MONTEIRO, op. cit., v.2, capítulo I. 
Misericórdia da cidade de São Paulo; e prestações de serviços diversos (advocacia, tratamento médico e dentário, aulas de línguas estrangeiras, matemática e dança, conserto de instrumentos musicais, costura e criação de cavalos). A despeito de estarem associados, em sua grande maioria, à cidade de São Paulo, alguns desses anúncios não se atrelavam diretamente ao universo paulistano, de modo que não eram raros aqueles vindos de outras localidades da província, especialmente de Santos e Itu. Os anúncios vindos de outras províncias do Império, todavia, eram publicados de forma bastante esporádica.

Os anúncios mais recorrentes eram aqueles relacionados à venda, compra e fuga de escravos. Quase sempre nomeados - inclusive por indivíduos de projeção pública, tais como Nicolau Pereira de Campos Vergueiro, José da Costa Carvalho, Rodrigo Antonio Monteiro de Barros ${ }^{141}$ e Domitila de Castro e Canto Melo, a Marquesa de Santos -, esses pequenos textos tinham como objeto, em sua maior parte, a fuga de cativos, de modo que esses eram descritos fisicamente com o intuito de serem reconhecidos e capturados. Também era comum a publicação pelo $O$ Farol e pelo $O$ Observador de notas emitidas por juizes de paz quando da captura de escravos foragidos.

O Farol além disso levava a público seus próprios anúncios, que tratavam de obras impressas postas à venda na tipografia do jornal. Excetuando o Compendio Scientifico para a Mocidade Brazileira destinado ao uso dos dois $\operatorname{sexos}^{142}$, anunciado por 2:000 rs. em 1827, o restante das obras vendidas na tipografia de $O$ Farol continha expressa conotação política. A mais abrangente delas era o Dialogo constitucional Braziliense, que agregava "todas as

\footnotetext{
${ }^{141}$ Rodrigo Antonio Monteiro de Barros (?-1844) era natural de Minas Gerais. Filho de Lucas Antonio Monteiro de Barros, o Visconde de Congonhas do Campo, tornou-se bacharel em Direito pela Universidade de Coimbra, em 1827, quando foi nomeado juiz de fora da cidade de São Paulo. Casou-se, em 1828, com Maria Marcolina Prado, ao mesmo tempo meia-irmã e prima de Antonio da Silva Prado, o Barão de Iguape. Foi deputado por São Paulo na $2^{\mathrm{a}}, 3^{\mathrm{a}}$ e $4^{\mathrm{a}}$ Legislaturas, e desembargador da Relação de Pernambuco em 1842.

${ }_{142}$ O Farol Paulistano, $n^{\circ} 75,29 / 12 / 1827$. Para a relação de todas as obras vendidas na Tipografia do Farol Paulistano, ver Anexo 3.
} 
leis e disposições regulamentares da Constituição política do Império, e das eleições”, bem como “os regimentos do Conselho d'Estado e um mui bem ornado mappa de todas as garantias, que a mesma constituição offerece effectivas aos cidadãos brazileiros”. ${ }^{143}$

A seção que publicava documentos oficiais era a única parte do jornal cujo domínio do material não era exclusivo dos dois jornais paulistas. Por ser a única na cidade até 1831, a tipografia de Costa Carvalho era obrigada, por lei, a publicar documentos oficias, como atos emitidos pela Secretaria do Governo, atas das sessões do Conselho da Presidência e do Conselho Geral, todos eles da província de São Paulo. Tais documentos eram na maior parte das vezes publicados sem qualquer comentário dos redatores, o que demonstra certa reticência dos redatores no que se refere à obrigatoriedade do serviço prestado, mais precisamente em relação aos atos do executivo do governo provincial. Em mais de uma ocasião o Farol expôs seu “incômodo” na publicação desse tipo de documentação, chegando a sugerir, “ousadamente”, que se instalasse uma tipografia do Governo direcionada para esse tipo de tarefa. ${ }^{144}$ Segundo nota publicada em julho de 1830, além de tomar o espaço do jornal, parte desses documentos tinha pouco proveito, haja vista os recorrentes atrasos no envio dos mesmos à Tipografia do Farol Paulistano, demora essa que, no caso de editais, acabava por torná-los inúteis à causa pública. ${ }^{145}$ Críticas semelhantes foram feitas pelo O Observador, que assinalou a "antiquissima data” dos documentos enviados pelo governo da província para a publicação. ${ }^{146}$

Mas nem todos os documentos publicados pelo O Farol eram lamentados pelos redatores, o que demonstra o interesse da folha de Costa Carvalho em outro tipo de

\footnotetext{
143 O Farol Paulistano, no 75 (29/12/1827) e 131 (19/07/1828).

144 O Farol Paulistano, no 250, 26/09/1829. Ver também nº 227, 08/07/1829.

145 O Farol Paulistano, n ${ }^{\circ} 366,20 / 07 / 1830$.

${ }^{146}$ O Observador Constitucional, n 68, 16/07/1830.
} 
documentação oficial que não aquela veiculada pelo Governo da província. Privilegiava-se, na esfera central, os trabalhos da Câmara dos Deputados - projetos de lei, discursos proferidos durante as sessões, pareceres emitidos pelas comissões especiais -, ao passo que na esfera local eram publicadas atas das sessões das Câmaras Municipais de São Paulo e Itu, localidade onde Costa Carvalho e seus correligionários possuíam fazendas de cana-deaçúcar e relações pessoais privilegiadas. ${ }^{147}$ Além disso, nem toda a documentação oficial publicada nos periódicos era de caráter obrigatório. Em fevereiro de 1830, o Observador Constitucional passou a publicar as atas da Câmara Municipal de Parnaíba após essa fazer uma solicitação à folha de Líbero Badaró para incluir seus trabalhos. ${ }^{148}$

Os leitores dos dois jornais compunham um grupo bastante heterogêneo, representando distintos grupos sociais. A partir das correspondências insertas na folha paulistana, é possível notar uma gama de indivíduos com ocupações diversas, tais como médicos, caixeiros, negociantes, tropeiros, clérigos, militares, professores de primeiras letras e do Curso Jurídico, estudantes e toda sorte de empregados públicos, desde fiscais de Câmaras Municipais, vereadores e juizes de fato até juizes de paz, membros do Conselho da Presidência da província de São Paulo e deputados. Tais segmentos compunham, grosso modo, o espectro de votantes e eleitores da província de São Paulo. Isso sem contar os anunciantes do jornal - padeiros, sapateiros, costureiras, donos de mercearias e outros tipos de vendedores e artesãos -, que podem ser tidos, virtualmente, como leitores das folhas paulistanas.

\footnotetext{
${ }^{147}$ HOLANDA, Sérgio Buarque de. "São Paulo”, in HOLANDA, Sérgio Buarque de. (org.). História Geral da civilização brasileira, tomo II, "O Brasil Monárquico”. São Paulo: Difusão Européia do Livro, 1964, vol.2, pp.415-472.

${ }^{148}$ O Observador Constitucional, $\mathrm{n}^{\circ} 31,12 / 02 / 1830$.
} 
Não obstante ambos os periódicos fossem impressos na cidade de São Paulo, seu meio de circulação se estendia muito além daquele circunscrito à capital da província. Ao consultar as diversas seções dos dois jornais, é possível constatar uma imbricada teia de relações estabelecida entre as folhas criadas por Costa Carvalho e Líbero Badaró e setores não radicados somente na cidade de São Paulo, como redatores de outros jornais, correspondentes, anunciantes, assinantes, leitores esporádicos e funcionários vinculados às instituições oficiais. Esses eram provenientes de outras regiões do planalto e litoral paulistas ou até mesmo de outras províncias, tais como Rio de Janeiro e Minas Gerais.

Na maioria dos casos, o contato entre o público e o jornal se dava por meio de correspondências que, se tomadas em conjunto e diacronicamente, revelam um paulatino processo de ampliação do campo de alcance de $O$ Farol e de $O$ Observador em São Paulo bem como em outras províncias. Só no ano de 1827, participaram da seção de correspondências de $O$ Farol Paulistano leitores da capital paulista, das Vilas de Santos, Cubatão, Itu, São Carlos, Porto Feliz, Itapeva, Iguape, Constituição, Sorocaba, Ipanema, e da própria cidade Rio de Janeiro. Em 1828, o perfil dos correspondentes se tornou ainda mais amplo, de modo que surgiram cartas de habitantes das Vilas de Jundiaí, Franca do Imperador, Mogi-Mirim, Curitiba, Taubaté, Areias e Lorena, como também das freguesias de São Bernardo, Nossa Senhora Conceição de Guarulhos e Cotia (pertencentes à Vila de São Paulo), e de Santo Antonio da Parahibuna, vinculada à Vila de Jacareí. Um ano depois, surgiram cartas das vilas de Mogi das Cruzes, Bananal, Guaratinguetá, Antonina, Itapetininga, Campos de Goitacases (Rio de Janeiro) e da Freguesia de Pirapora (Vila de Constituição). Em 1830, foram publicadas correspondências das Vilas de Bragança, Ubatuba, Bela, São José, Paranaguá, Atibaia, Caldas (Minas Gerais), Rezende (Rio de 
Janeiro), e da freguesia de São Roque, pertencente à Vila de Paranahyba. Com relação ao Observador Constitucional, a maior parte das correspondências publicadas advinham da própria capital paulista e das Vilas de Santos, Itu e Curitiba. Com o tempo, um volume maior de correspondências de Areias, Porto Feliz e Itu passou a ser publicado.

Esse movimento de ampliação e diversificação da seção de correspondências significava, por um lado, um aumento no número de leitores dos jornais, e por outro, uma atitude promovida por $O$ Farol e por O Observador no sentido de abrir canais de comunicação entre os periódicos e outras vozes, quer da província de São Paulo quer das demais, criando assim um espaço comum de reflexão sobre as questões tidas como pertinentes pelos redatores da folha, notadamente o andamento da administração pública no Centro-Sul do Império. É necessário, todavia, que se pondere o papel das correspondências, dado que parte delas poderia ser forjada pelos próprios redatores.

Tal abertura, contudo, não parece ter sido mera deliberação da redação de $O$ Farol e de O Observador, mas produto de uma comunhão ou mesmo de uma troca de interesses entre os jornais e o corpo de correspondentes, dado que para ampliar o seu número de leitores, o periódico tinha de conceder-lhes espaço em sua folha. Os correspondentes, por sua vez, cobravam dos periódicos que esses "lançassem suas luzes” em diferentes localidades, evocando em determinados casos os objetivos traçados pela folha em seus primeiros editoriais. Em fevereiro de 1831, o Observador Constitucional publicou um artigo sobre a vila de Mogi-Mirim, após receber, segundo o redator, seguidas solicitações de seus leitores. ${ }^{149}$ Anos antes, um correspondente anônimo de Ipanema já reclamara por uma atitude de $O$ Farol em relação à situação da Fábrica de Ferro de Ipanema:

${ }^{149}$ O Observador Constitucional, $n^{\circ} 127,18 / 02 / 1831$. 
“Sr. Redactor - No prospecto de sua Folha, prometteu-nos Vm. fallar em todos os estabelecimentos d'esta Província, fazendo chegar a mercê da luz do seu Farol, ao conhecimento do publico o bom, ou máo andamento d'elles, elogiando, ou censurando o condutor dos empregados. Mas, Sr. Redactor, já lá vão 54 nºs, e ainda não se dignou lançar um golpe de vista sobre as margens do Ypanema, subir a altura do Arassoyáva, visitar a Imperial Fabrica de Ferro!! Tão pouco lhe merece este estabelecimento colossal, o primeiro e mais interessante da Província, e talvez de todo o Brazil? Entretanto o que por lá váe!!”.150

Outras circunstâncias ajudavam a promover o alargamento do alcance dos dois periódicos paulistas. A Sociedade de Guaratinguetá, uma das muitas sociedades criadas nesse período, tinha como uma das suas prerrogativas “assignar os Periódicos d'essa província”, que poderiam ser consultados por qualquer cidadão”. ${ }^{151}$ No final de 1830, ano da fundação da Sociedade, esta enviou ao Farol um arrazoado das atividades desenvolvidas ao longo daqueles meses, dentre as quais estava a leitura pública de alguns periódicos "liberais”, tais como a Aurora Fluminense, a Voz Fluminense, o Manual das Brasileiras, o Pregoeiro, o Observador Constitucional e o própria folha de Costa Carvalho. ${ }^{152}$

O ato de assinar periódicos por um dado órgão ou instituição consistia numa prática comum na época, especialmente para as esferas oficiais de poder, como as Câmaras Municipais. Conforme a lei de $1^{\circ}$ de outubro de 1828 que regulamentou o funcionamento das municipalidades, essas ficaram obrigadas a assinar os diários dos Conselhos Gerais e das Câmaras legislativas e os periódicos que publicassem os extratos de suas sessões. ${ }^{153}$ Em agosto de 1832, o presidente da província de São Paulo enviou um ofício à Câmara

\footnotetext{
${ }^{150}$ O Farol Paulistano, no ${ }^{\circ}$ 6, 20/10/1827.

151 As diretrizes básicas da Sociedade de Guaratinguetá foram enviadas pelos seus integrantes ao Farol Paulistano por meio de um artigo comunicado que veio a público no n 313, em 04/03/1830.

152 O Farol Paulistano, no 416, 16/11/1830.

153 Cf. artigo 61 da "Lei de $1^{\circ}$ de outubro de 1828 - Dá nova fórma as Câmaras Municipaes, marca sua attribuições, e o processo para a sua eleição, e dos Juizes de Paz”, in Coleção das Leis do Império do Brasil de 1828. Rio de Janeiro: Tipografia Nacional, 1878, pp.74-88.
} 
Municipal de São Paulo solicitando informações sobre o cumprimento da referida disposição, o qual foi respondido positivamente. ${ }^{154}$

A publicação de excertos de $O$ Farol e de $O$ Observador por outros jornais consistia em mais uma forma de proliferação do discurso desses periódicos. Única folha paulista até outubro de 1829, o Farol era, segundo o Astro de Minas, um dos periódicos mais lidos do Império, sendo inclusive traduzido na Europa, fato esse que causava inveja à Gazeta do Brasil, jornal alinhado ao governo central que, como se verá adiante, foi o primeiro adversário de O Farol na imprensa:

“...mas enfim a gazeta urra de raiva, e inveja, porque apenas conta 200 assignantes, e daquelles, que publicou o nome Patrício o Sr. Ledo entretanto que a Astréa se vai regalando com os seos 1;400 assignantes, cujo N. cresce diariamente. Não esqueça a viperina lingoa da gazeta esse excellente periódico Paulistano = O Farol = mas o Farol he lido com avidez em todo o Brasil, e na mesma Europa culta, onde se tem reimpresso e em diversas lingoas”155

É manifesto que a fala do periódico contém elementos retóricos e propagandísticos, mas ainda assim revela o alcance das folhas paulistas. O próprio Astro de Minas publicaria no ano seguinte uma nota onde dizia que as folhas Farol Maranhense, Abelha Pernambucana, Diário de Pernambuco, Cruzeiro, Amigo do Povo, Gazeta Parahybana, Bahiano, Diário Fluminense, Aurora Fluminense e o Farol Paulistano estariam disponíveis “para quem quizer ler” na Biblioteca Pública de São João Del Rei. ${ }^{156}$ Um ano depois, os também mineiros O Universal e Estrela Marianense publicaram anúncios referentes ao gabinete de leitura situado na residência padre Antonio José Ribeiro, em Mariana, Minas

\footnotetext{
${ }^{154}$ Registro Geral da Câmara da cidade de São Paulo, 1832. São Paulo: Publicação Oficial do Arquivo Municipal de São Paulo, 1936, v. XXII, pp.256 e 261-262.

${ }_{155} O$ Astro de Minas, n $26,17 / 01 / 1828$.

${ }^{156}$ O Astro de Minas, $n^{\circ}$ 304, 29/10/1829.
} 
Gerais, local onde se disponibilizavam para a leitura periódicos do Rio de Janeiro, São Paulo e Minas Gerais. ${ }^{157}$

Alguns empecilhos comprometiam, entretanto, uma circulação mais regular das duas folhas paulistas. O principal deles era a precariedade das linhas de correio que, nesse período, ainda estavam se constituindo e não cobriam boa parte das freguesias das províncias. Não eram poucas as correspondências que criticavam a morosidade na emissão de cartas ou que reclamavam a implantação de uma linha regular de correios entre duas localidades. ${ }^{158}$ Em 1830, um correspondente acusou o Administrador do Correio da vila de Resende, Rio de Janeiro, de “abrir as folhas” endereçadas a estranhos, para primeiro lê-las e depois enviá-las a seus respectivos assinantes, o que ocasionava sucessivos atrasos na entrega dos jornais. $^{159}$

Partindo da primazia da “opinião” na configuração das sociedades da época, o Farol Paulistano justificou sua publicação a partir da função da imprensa, compreendendo-a como o "mais útil e preciso invento do homem” e portadora de duas características essenciais. A primeira delas, mais quantitativa, referia-se à forma rápida com que os impressos podiam disseminar idéias, atingindo assim um maior público em um menor período de tempo. A segunda, de ordem qualitativa, dizia respeito à proeminência da imprensa enquanto defensora da liberdade, da Independência do Brasil e do caráter constitucional por ela

\footnotetext{
157 SILVA, Wlamir. “A imprensa e a pedagogia liberal na província de Minas Gerais (1825-1842)”, in FERREIRA; MOREL, NEVES (orgs.) ; op. cit.; p.50.

${ }^{158}$ Ver, por exemplo, as correspondências publicadas no n ${ }^{\circ} 243$ de O Farol Paulistano, em 02/09/1829.

${ }^{159}$ O Farol Paulistano, no $311,23 / 02 / 1830$.
} 
assumido, chegando a ponto de naturalizar o meio impresso como veículo das idéias liberais vigentes no início do século XIX:

“(...) Mas quem espalha a opinião, quem a faz medrar, quem a uniforma, quem lhe ateia os gritos, quem lhe presta as suas vigorosas e longas azas com que tem percorrido em tão pouco tempo o universo inteiro?

É sem dúvida a imprensa o mais útil e preciso invento do homem, o baluarte da liberdade, o terror dos déspotas, a protetora da humanidade. O Brasil disse que queria ser livre e a sua independência foi o primeiro fruto do sistema constitucional que abraçou para nunca mais deixar (...) Foi a imprensa companheira e auxiliadora da liberdade quem fez a nossa independência. Grandes louvores e gratidão eterna aos denodados escritores que nessa época apareceram. O Brasil é independente e continua a querer ser livre...”. ${ }^{160}$

Mas seria esse, em linhas gerais, o programa que o Farol seguiria durante seus quase cinco anos de circulação, estimulado pela divisa La liberté est une encleme qui usera tous les marteaux (a liberdade é uma bigorna que desgastará todos os martelos), que acompanhava o cabeçário do jornal?

De forma unânime, autores como Afonso de Freitas, Lafayette de Toledo, Affonso de Escragnolle Taunay, Nelson Werneck Sodré, Arnaldo Contier e Augustin Wernet tomaram o Farol Paulistano como um jornal cujas orientações político-ideológicas se alinhavam com a intitulada ala "moderada” dos liberais do Primeiro Reinado e Regências, aproximando-o de outras folhas com perfil semelhante publicadas no período, tais como a Aurora Fluminense e a Astréa, do Rio de Janeiro, e o Astro de Minas e o Universal, de Minas Gerais. Imbuído do espírito daqueles que compunham a oposição ao governo de D. Pedro e que chegariam ao poder após a Abdicação, o Farol Paulistano teve como principal

\footnotetext{
${ }^{160}$ O Farol Paulistano, no 1, 07/02/1827. Grifo nosso.
} 
bandeira, segundo esses autores, a defesa dos princípios monárquico-constitucionais contra o "despotismo" e o "absolutismo" que ainda perpassavam setores da administração do Estado, notadamente do Poder Executivo. ${ }^{161}$

Por não ter sido estudado em sua completude por nenhum desses autores, o Farol Paulistano deixou de receber um tratamento minucioso de forma e conteúdo, o que simplificou o entendimento sobre seu discurso e retirou-lhe parte da historicidade intrínseca a qualquer periódico, que é o fazer-se no dia-a-dia. Atribuir à folha de Costa Carvalho uma diretriz liberal moderada inequívoca, sem atentar para as alterações ocorridas em seus artigos ao longo do tempo, acabou por tornar homogêneo aquilo que não fora outrora, ou seja, atribuiu-se um caráter rígido e constante a algo que nunca foi um dado a priori, mas sim um processo em construção permanente que se subjugou às vicissitudes da luta política deflagrada dentro e fora do Legislativo, bem como dentro e fora do governo provincial. Analisando a questão por outro ângulo, imputar ao Farol esse tipo de característica é lançar mão, também, de um raciocínio teleológico cujo sentido reside na associação entre a oposição liberal ao governo de D. Pedro e ascensão dos moderados após o 7 de abril, o que revestiria a folha paulista de uma coerência política que, de fato, não se evidenciou na leitura por nós realizada.

Não se pretende aqui refutar as peculiaridades acima mencionadas sobre a primeira folha paulista, mas entendê-las como integrantes de um movimento que se processou no transcorrer do longo do tempo da política, com rupturas e permanências, e que foi condicionado tanto pelo crescimento paulatino de seu público leitor como pela discussão levada adiante no âmbito provincial e na Corte. Num período em que a institucionalização

${ }^{161}$ CONTIER, op. cit; FREITAS, op. cit.; SODRÉ, op. cit.; TAUNAY, op. cit.; TOLEDO, op. cit; WERNET, op. cit. 
do governo e do Estado constitucionais marchou em paralelo e conflituosamente com a prática política cotidiana dos poderes locais, haja vista os problemas em torno da regulamentação e aplicação das leis sobre os Juizados de Paz, das Câmaras Municipais, dos Conselhos Gerais de província e do Código Criminal, o Farol participou do jogo político de modo sinuoso. Ou seja, equacionou seu discurso a partir dos interesses dos grupos locais a ele associados e da possibilidade de viabilização de um projeto de monarquia constitucional em bases liberais, conduta essa que nos permite matizar uma suposta univocidade da folha de Costa Carvalho.

Deste modo, o Farol Paulistano pode ser dividido em três momentos que constituem menos uma seqüência cronológica rígida do que uma sucessiva incorporação e resignificação de princípios.

O primeiro deles se deu entre o início da circulação do periódico e até por volta de maio de 1828, e teve como principais características a definição de um padrão discursivo (de forma e conteúdo), a busca por um espaço na esfera pública da imprensa periódica e a demarcação de um cenário político conflituoso, no limite bipolar, entre "liberais” e “constitucionais" versus "absolutistas" e “corcundas”. Na prática, isso significou a publicação de artigos maniqueístas e de alto teor pedagógico, o alinhamento ou o afastamento em relação aos principais periódicos em circulação na Corte e em outras províncias, e a fixação de uma leitura própria sobre o andamento dos negócios públicos do Império, adotando-se critérios valorativos para a análise dos poderes Executivo (reacionarismo do Ministério versus constitucionalismo do monarca), Legislativo (apreciação da Câmara dos Deputados versus depreciação do Senado) e Judiciário (precariedade das formas antigas versus viabilidade das inovações propostas). 
Única folha paulista em circulação durante esse período, o Farol entrou em confronto direto com periódicos fluminenses de orientação governista. Durante o ano de 1827 e os primeiros meses de 1828, o Farol Paulistano discutiu abertamente com a Gazeta do Brazil, periódico dirigido por João Maria da Costa e José Joaquim de Carvalho. Ao defender o Gabinete instituído em 15 de janeiro de $1827^{162}$, a Gazeta notabilizou-se por suas insistentes críticas feitas à Câmara dos Deputados e seus componentes, colocando-se em uma posição declaradamente pró-imperador. ${ }^{163}$

Logo após o surgimento da Gazeta do Brazil, o Farol Paulistano emitiu suas impressões acerca da nova folha fluminense, apontando para o seu caráter combativo:

“Recebemos n'este correio o $1^{\circ} \mathrm{n}^{\circ}$ da Gazeta do Brazil, novo Periodico publicado no Rio de Janeiro no dia 30 do proximo-passado (...) O novo Periodico é escripto em estilo raivoso, e virulento; e a pesar de se mascarar com o nome de Constituição, que se conhece sair-lhe menos voluntariamente da penna do que o de Jacobinismo, parece destinado a atacar tudo quanto o Brazil tem de mais caro, tudo em que elle põe suas mais seguras esperanças. Elle quer defender a torto e a direito o Ministério, e toma demaziado a peito a defesa do Ministro da Guerra, que assaz tem patenteado sua instabilidade na direção da guerra atual (...) Ataca com rancôr as Camaras, que formão a Assemblea Geral, desfigurando os fatos, e até mentindo imprudentemente, affirmando deliberações que nunca forão tomadas, antes tomadas pelo contrário (...) Espalha o alarma, nos póvos, dizendo que a Camara dos Deputados põem o pé no sanguinolento terreno do Jacobinismo; que existem Clubs da natureza a mais perigosa". ${ }^{164}$

162 O Gabinete de 15 de janeiro de 1827 foi composto pelos seguintes nomes: Visconde de São Leopoldo (Império); Marquês de Queluz (Estrangeiros e Fazenda); Marquês de Nazaré (Justiça), que foi substituído, interinamente, pelo Visconde de São Leopoldo e, posteriormente, pelo Marquês de Valença; Marquês de Lajes (Guerra); e Marquês de Maceió (Marinha), cf. JACQUES, Paulino. O governo parlamentar e a crise brasileira. [Coleção Temas Brasileiros]. Brasília: Editora Universidade de Brasileira, 1982, p.75.

${ }_{163}$ A tendência governista da Gazeta do Brasil foi assinalada, também, por Otávio Tarquínio de Sousa, Affonso de Taunay, Nelson Werneck Sodré e Marco Morel, conforme obras já citadas.

${ }^{164}$ O Farol Paulistano, no 20, 16/06/1827. 
Dentre os aspectos assinalados pelo jornal de Costa Carvalho a respeito da Gazeta, é de se notar aquele que indica a contradição da folha fluminense ao se intitular “Constitucional”, já que, segundo o redator de O Farol, seu estilo "raivoso” e "virulento” só contribuiria para "atacar” o constitucionalismo brasileiro. Ao analisar a inserção da Gazeta na imprensa periódica do período, autores como Afonso Taunay e Werneck Sodré também ressaltaram tal incoerência, especialmente por se tratar de um jornal vinculado aos "restauradores”. ${ }^{165}$ Contudo, segundo Morel, essa contradição que também esteve presente em outros periódicos defensores do Governo de D. Pedro - como o Diário Fluminense e o Despertador Constitucional Extraordinário - congrega outros elementos que a tornam mais complexa, uma vez que "constitucionalismo" e "liberalismo" desempenhavam significados distintos no vocabulário da época. Para o autor, periódicos como a Gazeta do Brasil buscavam conferir aos liberais o estatuto de “Carbonários”, “Jacobinos”, “Demagogos”, isto é, de setores que ofereciam perigos ao bom funcionamento da Carta de 1824, em especial às atribuições de poder referentes ao monarca. Em contrapartida, alguns periódicos moderados como a Astréa notaram a manobra política dos “corcundas”, que se deslocaram da posição de "anti-liberais" para a de "constitucionais", forjando assim um posicionamento político supostamente alinhado com a Carta Magna. Conforme Morel, esse pretenso “constitucionalismo” apoiava o texto de 1824 com a condição de que esse mantivesse reforçado o poder do monarca, constituindo assim uma dos eixos centrais para a compreensão do movimento restaurador do período pós-Independência. ${ }^{166}$

O momento seguinte se estendeu, aproximadamente, entre maio de 1828 e meados de 1830, e apresentou uma complexificação geral de $O$ Farol Paulistano. A investida no

\footnotetext{
${ }^{165}$ Cf. TAUNAY, op. cit., v.5, p.114; SODRÉ, op. cit., pp.114-115.
}

${ }^{166}$ Cf. MOREL, op. cit., 2005, p.134. 
conflito ideológico entre liberalismo e absolutismo refreou-se, ao passo que as críticas em relação ao Ministério ganharam força, gerando inclusive problemas jurídicos para o jornal. ${ }^{167}$ A despeito de ter mantido os juízos de valor sobre os empregados públicos e políticos, as críticas emitidas pelo Farol tornaram-se mais substantivas, incidindo sobre pontos centrais do processo de organização do aparelho estatal e da discussão vinculada ao Parlamento, tais como a regulamentação dos Conselhos Gerais e das Câmaras Municipais, a questão tributária, do Banco do Brasil e o início da elaboração do Código do Processo Criminal. Em decorrência da instalação dos Conselhos Gerais de província, em 1828, e da discussão em torno do seu regimento, a política provincial passou a ser matéria mais comum das páginas de $\mathrm{O}$ Farol, o que até então ocorrera apenas esporadicamente. Além disso, por conta da conduta hesitante do Governo em relação à sucessão do trono português e da inclinação governista de algumas folhas escritas por franceses na Corte, como por exemplo o Courrier du Brésil e o Jornal do Comércio, virou pauta recorrente do jornal paulista a crítica à intromissão dos estrangeiros nos negócios brasileiros.

O embate com os periódicos fluminenses que advogavam em favor de D. Pedro e seu governo acentuou-se. Com o Censor Brasileiro - periódico que circulou na capital do Império entre maio e julho de $1828^{168}$-, o Farol discutiu, sobretudo, a atuação do Senado na Assembléia Geral. Segundo a folha de Costa Carvalho, o Censor era "moderado nas expressões, mas nem tanto na matéria”, pois se colocava como “aliado do Senado” e reprovava os comentários de O Farol sobre a segunda Casa. O Censor condenava as

167 Em outubro de 1829, o Farol Paulistano foi “levado a juízo” por ter sido acusado de abuso de liberdade de imprensa por um artigo publicado no $\mathrm{n}^{\circ} 211$ que colocava em dúvida a honestidade do então Ministro da Fazenda Miguel Calmon. O jornal foi absolvido em fevereiro do ano seguinte. Para o acompanhamento da questão, ver os n n's 211 (06/05/1829), 257 (13/10/1829) e 313 (27/02/1830).

168 Segundo o redator de $O$ Farol Paulistano, o Censor Brasileiro tinha alguma relação com o ministro Clemente Pereira, uma vez que falas inteiras desse político eram constantemente inseridas naquele periódico, cf. O Farol Paulistano, n ${ }^{0}$ 125, 28/06/1828. Não se pode afirmar, contudo, que tal relação de fato tenha ocorrido. 
afirmações de $O$ Farol sobre o Senado por serem generalizantes, o que não condizia com sua diversidade de integrantes e de posicionamento político. O Farol acreditava, ao contrário, que suas críticas eram válidas, por não se tratar de um ataque à instituição senatorial, mas sim ao "modo de obrar" do Senado. Embora contestasse o posicionamento governista de $O$ Censor, o Farol afirmou que esse nunca atacou a Constituição. ${ }^{169}$ Em agosto de 1828 surgiu no Rio de Janeiro o periódico O Analista ${ }^{170}$, com o qual o Farol travou intenso debate, fundado muito mais na troca de ofensas do que no enfrentamento de propostas políticas. Segundo o Farol, o Analista era “anticonstitucional, inimigo dos liberais e zelozo com Portugal”, e suas matérias visavam denegrir a imagem da Câmara dos Deputados e ocultar os atos ilícitos do Ministério. Até fins de 1829, foram sucessivas as discussões sobre a atuação dos ministros e da Câmara dos Deputados. ${ }^{171}$

O terceiro e último momento de O Farol Paulistano perdurou da segunda metade de 1830, especialmente após a morte do jornalista Libero Badaró, em novembro, até junho do ano seguinte, já no final da circulação do periódico. Concebida num primeiro momento como obra de “alguns poucos” liberais mais arrojados, a questão do “exaltamento” liberal foi aos poucos ganhando espaço, tornando-se umas das temáticas centrais do jornal. Pela primeira vez os opositores de O Farol deixaram de ser exclusivamente representados por aqueles elementos afinados com o governo de D. Pedro, para advirem do próprio campo liberal, situação que se materializou no debate travado com jornais exaltados como $A$ Voz Paulistana e o Observador Constitucional na fase pós-Abdicação.

\footnotetext{
${ }^{169}$ Ver O Farol Paulistano, nos 112 (14/05/1828), 113 (17/05/1828), 125 (28/06/1828) e 129 (12/07/1828).

170 Segundo o Farol Paulistano, o Analista era de propriedade do então ministro da Fazenda Miguel Calmon du Pin e Almeida, ou por ele protegido. A despeito de seu alinhamento com o Governo, não foram encontrados elementos que comprovem a afirmação de $O$ Farol.

${ }^{171}$ Ver O Farol Paulistano, nos 142 (27/08/1828), 150 (24/09/1828), 158 (22/10/1828), 195, (07/03/1829), 201 $(28 / 03 / 1828$
} 
Nas páginas de $O$ Farol, o debate conflagrado no seio dos liberais teve como pano de fundo três problemáticas basilares que se fortaleceram após a Abdicação: a reforma da Constituição, a federação e o republicanismo. Se em princípio qualquer uma delas foi peremptoriamente refutada pelo Farol, a pouco e pouco, devido ao combate incisivo protagonizado pelas folhas exaltadas e ao próprio curso da política dentro e fora do Legislativo, o jornal de Costa Carvalho mudou sua conduta e abriu espaço para discutir a plausibilidade ou não dessas questões, tornando-se nesse ponto um periódico de aspecto mais defensivo e de contra-ataque se comparado aos anos anteriores. Evidência disso está na "mudança de opinião" que o Farol assumiu ter operado sobre determinadas reformas propostas pelos exaltados para a Carta de 1824, especificamente aquelas que almejavam suprimir o poder de negação de sanção aos atos do Poder Legislativo pelo Moderador (artigo 179, cláusula $17^{\mathrm{a}}$ ), a atribuição do Supremo Tribunal de Justiça de conhecer os delitos dos vários funcionários públicos (artigo 164, cláusula 2a) e as eleições indiretas (artigo 90).

Quanto ao Observador Constitucional, já na ocasião de seu surgimento, a 23 de outubro de 1829, o redator expôs, em linhas gerais, qual seria o programa de atuação do periódico. Este teria como objetivo tratar dos atos do Governo, defender a Carta de 1824 e a liberdade, bem como auxiliar na instrução do público leitor, sempre com "imparcialidade”:

"Deus queira que tenhamos muito para louvar. Ele bem sabe que não deixaremos escapar nem uma ocasião que se nos apresentar. O prazer de ver que todos os membros da sociedade fazem o seu dever, em qualquer posição que sejam colocados, é tão grande, tanta satisfação se acha na felicidade comum, que palavras não faltam ao escrito público, ainda menos fecundo, para louvar, enquanto o dever de censurar torna estéril, penoso e amargoroso o seu trabalho. 
Espectadores não interessados, fora das lutas das paixões locais, procuraremos de justificar o título de Observador Constitucional, usando da imparcialidade a mais severa no apresentarmos as reflexões, que nos tiverem ocasionando os fatos que virmos praticar.

A qualidade de estrangeiros nos põe na melhor situação possível para desempenharmos honrosamente e com exatidão a nossa tarefa.

Sobre os atos do governo diremos mui francamente o nosso parecer, tanto em louvor, como em contrário, sem por isso darmos nossas palavras por Evangelhos, ficando cada um livre de combater a nossa maneira de pensar, sendo que cada um pensa como sabe e como pode.

Mas se por uma parte entendemos falar com toda a franqueza, sem medo, sem receio e sem paixão, por outra evitaremos com o maior cuidado expressões indecentes, que não deturparão a nossa folha.

As nações, apesar de longínquas, têm laços que as unem mais ou menos estritamente e não devemos viver isolados n'este mundo como tatus na sua cova, sem saber o que se passa na cova do visinho e que talvez nos possa muito interessar, em conseqüência disto uma porção da nossa folha será destinada a darmos notícias bem escolhidas do que acontece de mais interessante nos outros países, principalmente do que nos possa servir de instrução, pois é melhor aprender à custa alheia, do que à nossa.

A nação precisa de instrução e mais nada; mas não é culpada se não a tem: 300 anos de escravidão, que passaram sobre ela, teriam feito pior, se os seus membros pelo seu natural brio não tivessem tido a coragem de furtar as poucas luzes, que os seus opressores lhe negavam com tanta injustiça. Mas do passado, já se não se fale; a nação é livre, é independente; os agigantados passos que nesses poucos anos ela deu na carreira da civilização são fiadores do ponto até onde ela pode chegar pelo futuro.

Instrução e mais instrução, ela é o martelo do despotismo, é o alicerce em que se funda o edifício da organização pública. Felizes nós se com esta pequena fadiga pudermos concorrer a aumentar a instrução, principalmente das classes inferiores, fazendo-lhes conhecer os seus direitos, as leis que os garantem e os meios de manter.

E para obtermos mais seguramente este fim, procuraremos dar algum artigo que tenda a explicar, quanto for possível às nossas tênues forças, os princípios e as aplicações da nova legislação do Brasil, de maneira que os inimigos da liberdade, se existem alguns, não tenham mais a excusa de dizerem que a nação não está ainda capaz disto, que a constituição é somente para os povos já instruídos, enquanto pelo contrário, nos parece que já se deve aproveitar do terreno inculto para deitar-lhe semente boa, e não esperar que as más sementes 
cresçam para obrigar os vindouros a fazerem esforços, talvez perigosos, para arrancar o que se não devia deixar crescer”. ${ }^{172}$

Da mesma forma que O Farol Paulistano, o Observador Constitucional foi entendido por alguns autores como um dos porta-vozes dos “moderados” em São Paulo durante o Primeiro Reinado, mas teria deslocado seu discurso para o campo dos “exaltados” após a mudança de seu local de impressão para a Tipografia Patriótica, em 1832. ${ }^{173}$ Outros, a exemplo de Augustin Wernet, analisaram-no como uma publicação “moderada” entre os “exaltados”, por se tratar de uma folha menos radical do que, por exemplo, a Nova Luz Brasileira. ${ }^{174}$ É comum, ainda, que estudos se valham apenas da faceta “exaltada” de $O$ Observador Constitucional, sem contrapô-la a sua inclinação “moderada” original. ${ }^{175}$

O que pode parecer uma distinção eminentemente interpretativa é, na realidade, uma conseqüência do recorte operado por cada um desses autores, que acabaram privilegiando um dado momento ou determinada característica de O Observador. Ou seja, assim como ocorre com o Farol, a inexistência de um estudo específico sobre o Observador abriu espaço para interpretações pontuais, de importância inconteste, mas que não se detiveram na historicidade do jornal fundado por Líbero Badaró.

Em termos estruturais (de forma e conteúdo), o percurso de O Observador Constitucional pode ser dividido em três momentos que, diferentemente de $O$ Farol Paulistano, apresentaram mais rupturas do que permanências. Enquanto a folha de Costa Carvalho inseriu-se, como vimos, num processo de re-significação de seu discurso a partir

\footnotetext{
${ }^{172}$ O Farol Paulistano, $\mathrm{n}^{\circ}$ 1, 23/10/1829.

${ }^{173}$ CONTIER, op. cit; FREITAS, op. cit.; TAUNAY, op. cit.; TOLEDO, op. cit;

${ }^{174}$ WERNET, op. cit., p.45.

${ }^{175}$ Ver, por exemplo, o artigo de FONSECA, op. cit. Cabe notar, entretanto, que a autora não tem como objetivo analisar o Observador Constitucional em si, mas sua apropriação por periódicos "exaltados” do Rio de Janeiro.
} 
da manutenção de um norte político mais ou menos definido, o jornal criado por Líbero Badaró passou por momentos mais marcados, ou que pelos menos se distinguiram de forma mais acentuada.

O primeiro delineou-se entre a fundação do jornal, em novembro de 1829, e a Abdicação, ocorrida em abril de 1831. Durante esse período é possível afirmar que o discurso de O Observador esteve fortemente alinhado com o de O Farol Paulistano, reforçando assim a hegemonia dos “moderados” na imprensa periódica paulista. Embora dialogassem com pouca freqüência - o que evitava, nesse sentido, uma cumplicidade demasiada entre ambas as folhas - o Observador e o Farol apregoavam por essa época os mesmos princípios políticos, o que sem dúvida proporcionou um fortalecimento mútuo, e a impressão de que todos os políticos paulistas conviviam em um campo programático homogêneo. Ainda assim, houve ocasiões em que se verificou um apoio explícito, tal como em julho de 1830, quando o redator de $O$ Farol concordou com a afirmação de $O$ Observador de que em São Paulo haveria apenas “dois ou três esquentadinhos”, numa referência depreciativa aos “exaltados” paulistas. ${ }^{176}$ Assim como o Farol, o Observador promoveu a defesa dos preceitos liberais, a observância do cumprimento da Carta de 1824, o apoio à Câmara dos Deputados e a oposição ao governo de D. Pedro.

Com tantas semelhanças, cabe aqui questionar se houve de fato alguma diferença substancial entre as folhas de Costa Carvalho e Badaró durante o período mencionado, ou se o advento de O Observador significou mais um alargamento quantitativo da imprensa “moderada” em São Paulo. De acordo com a análise documental, quer nos parecer que, se houve um elemento que distinguiu a atuação de $O$ Observador, esse foi a maneira particularmente aguda, e em certos momentos difamatória, com que a folha de Baradó

\footnotetext{
${ }^{176}$ O Farol Paulistano, $n^{\circ}$ 366, 20/07/1830.
} 
criticou as autoridades paulistas e, sobretudo, paulistanas, especialmente enquanto o médico italiano esteve à frente do jornal. O exemplo que certamente melhor elucida essa postura de O Observador diz respeito às sucessivas críticas feitas ao ouvidor da cidade de São Paulo Cândido Landislau Japi-Assu, que acabaram culminando no assassinato do médico italiano, em 20 de novembro de 1830, a mando do próprio magistrado. ${ }^{177}$

A despeito de toda a repercussão causada pela morte de Líbero Badaró, esta não alterou de imediato a forma e o conteúdo do discurso de $O$ Observador, o que reforça a idéia de que o periódico era movido por mais de um redator. Houve, sim, um certo recuo do estilo aguerrido de Líbero Badaró, mas as premissas “moderadas” continuaram inalteradas. Ao término de dezembro de 1830, quando já se arrefecera a comoção em torno do assassinato do médico italiano, o Observador continuava a destacar a "fiel observância da Lei fundamental” como a única "arca da salvação" para o Governo e para a felicidade dos brasileiros, o grande norte dos “moderados” até o 7 de abril. ${ }^{178}$

O início do segundo momento pelo qual passou o Observador Constitucional coincide com a abdicação de D. Pedro, e se estende até o encerramento de sua publicação pela Tipografia do Farol Paulistano, provavelmente em outubro de $1831 .{ }^{179}$ Nesse período o jornal manteve sua estrutura formal, mas operou uma modificação sensível, e de certo modo repentina, no interior de seu discurso, o que sugere uma alteração do corpo editorial de $O$ Observador.

\footnotetext{
177 Sobre o assassinato de Líbero e sua repercussão na capital paulista, ver SILVA, Nestor Duarte. "Líbero Badaró (contribuição para a sua biogafia)”. Revista do Instituto Histórico e Geográfico de São Paulo, v.38, 1903, pp.462-577.

${ }_{178}$ O Observador Constitucional, $\mathrm{n}^{\circ} 113,31 / 12 / 1830$.

${ }^{179}$ Pelos arquivos consultados, o último exemplar de O Observador Constitucional impresso na Tipografia do Farol Paulistano veio a público em 28 de outubro de 1831 ( $\left.n^{\circ} 191\right)$.
} 
De adepto da "moderação" o Observador passou a defender, em ritmo gradual, alguns dos preceitos básicos sustentados pelos “exaltados”. No final de abril de 1831, enquanto o Farol mantinha inabalado o seu discurso "moderado", o Observador já clamava por reformas na Carta de 1824 e a aplicação do sistema federativo na monarquia brasileira ${ }^{180}$, de modo que o embate entre as duas folhas tornou-se explícito. Embora fosse impresso na tipografia de Costa Carvalho, e a folha dirigida por esse tenha estabelecido um confronto mais direto com a "exaltada" Voz Paulistana, o Observador ajudou a acirrar as discordâncias entre os liberais paulistas, rotulando os "moderados" de "estacionários", “retrógrados" e "anti-republicanos". ${ }^{181}$ Segundo os novos redatores de O Observador, os ditos "moderados" perseguiam o "partido nacional" (os "exaltados") chamando-o de “anarquista”, assim como fizera D. Pedro em seu famoso discurso proferido em Minas Gerais às vésperas da Abdicação, e por isso colocavam-se contra a liberdade americana. ${ }^{182}$

Deve-se matizar, todavia, a radicalidade de O Observador já que, como vimos acima, os “exaltados” não compunham um grupo homogêneo. Diferentemente de periódicos como A Voz Paulistana e A Nova Luz Brasileira, que defendiam abertamente a supressão do regime monárquico com vistas à instauração de um Estado em moldes republicanos, o Observador lançou mão de um outro programa, cujo cerne esteve na sustentação de reformas a serem feitas na Carta de 1824 a partir de princípios federativos. O que estava em jogo, portanto, não era o desejo por uma república federativa à semelhança dos Estados Unidos, mas por uma monarquia federativa. ${ }^{183}$ Isso não significa que o Observador tenha refutado os princípios republicanos; muito pelo contrário, em mais de uma ocasião seu

\footnotetext{
${ }^{180}$ Ver, por exmplo, O Observador Constitucional, ${ }^{\circ} 145$, 29/04/1831.

${ }^{181}$ O Observador Constitucional, $\mathrm{n}^{\circ}$ s 170 (12/08/1831) e 171 (15/08/1831).

182 O Observador Constitucional, ${ }^{\circ}$ s 148 (09/05/1831) e 149 (13/05/1831).

${ }^{183}$ Ver, por exemplos, os “artigos do interior" de O Observador Constitucional, ns 158 (27/06/1831) e 159 $(01 / 07 / 1831)$.
} 
redator afirmou ser o governo republicano “o mais conforme à igualdade primitiva e à dignidade da espécie humana”, mas hesitou em defender sua colocação. ${ }^{184}$ Elogiou, também, a estrutura político-jurídica estados-unidense, que se tornou referência para o jornal. ${ }^{185}$ De todo o modo, o Observador constituiu importante canal de defesa de demandas compartilhadas pela maioria dos “exaltados”, como a ampliação dos poderes provinciais e a supressão do Poder Moderador. ${ }^{186}$ Não é à toa que o jornal precisou encontrar outra tipografia para continuar sua publicação, em 1832.

O terceiro e último momento vivido por O Observador Constitucional é, sem dúvida, o mais desconhecido pela bibliografia, posto que o número de exemplares que nos restou é bastante pequeno. Trata-se do período em que o jornal foi impresso pela Tipografia Patriótica, isto é, entre janeiro e, provavelmente, julho de 1832. Em primeiro lugar, a disposição do jornal sofreu uma importante alteração radical. Deixou de ser dividido em sessões para apresentar apenas artigos curtos, perdendo a diversidade de outrora para focarse exclusivamente no debate político. Em segundo lugar, é difícil precisar a orientação político-ideológica assumida pelo periódico durante esse período, embora haja indícios de que ele manteve-se alinhado aos propósitos da “exaltação”, ao menos no que diz respeito à defesa da reforma constitucional e à oposição feita aos “moderados” que tomaram o poder após o 7 de abril.

Deste modo, embora fossem tributários das concepções mais gerais do liberalismo, o Farol Paulistano e o Observador Constitucional não podem ser colocados no mesmo campo político-ideológico, especialmente em função das diferenças que ambos passaram a

\footnotetext{
${ }^{184}$ Ver, sobretudo, O Observador Constitucional, $\mathrm{n}^{\circ} 160,04 / 07 / 1831$.

185 O Observador Constitucional, n s 160 (04/07/1831), 161 (08/07/1831), 164 (18/07/1831) e 165 (22/07/1831).

${ }^{186}$ Para a defesa da supressão do poder moderador, ver O Observador Constitucional, n 146, 02/05/1831.
} 
apresentar a partir de maio de 1831. Nesse sentido, é de se notar que a existência de dois periódicos com propostas políticas distintas contrasta, de certo modo, com o perfil político de São Paulo traçado pela bibliografia sobre o período. Esboçado por autores como Affonso Taunay ${ }^{187}$, o panorama da política paulista durante o Primeiro Reinado foi tratado por Sérgio Buarque de Holanda, bem como por Augustin Wernet e Suely Robles de Queiroz. ${ }^{188}$ Conforme Buarque de Holanda, a política de São Paulo ao longo do Primeiro Reinado teria como característica uma feição homogênea, uma vez que as disputas políticas decorriam muito mais de desavenças:

“seja com for, a Província de S. Paulo guardará durante todo o Primeiro Reinado e parte da Regência uma fisionomia política apreciavelmente unitária. Podiam sobreviver as diferenças pessoais, que mal perturbariam a coerência fundamental do pensamento político. Politicamente a maré liberal conhece poucas cambiantes e não parece sofrer refluxo (...) Mesmo os antigos 'bernardistas' deixam-se contaminar pela pressão geral: não falta, entre eles, quem chegue a dizer-se republicano. José da Costa Carvalho funda, em 1827, uma folha de oposição, o primeiro jornal impresso em S.Paulo, e torna-se protetor de Badaró (...) Em verdade esse liberalismo dos paulistas natos ou adotivos, fruto de um espírito de independência que impressionava vivamente Armitage e que, segundo depoimento de Francisco Gomes da Silva, o valido do imperador, não tem igual em todo o Brasil, continuará a ser força ativa na política nacional”. ${ }^{189}$

Segundo o autor, a consolidação dos ideais liberais na política paulista foi resultado de um processo misto, marcado pelo declínio dos ideais do Antigo Regime, e por uma conduta político-administrativa que foi se adequando às mudanças estruturais que a economia paulista vinha sofrendo desde meados do século XVIII. Para ele a vila de Itu

\footnotetext{
187 TAUNAY, op. cit.

${ }^{188}$ HOLANDA, op. cit; WERNET, 1972, op. cit.; QUEIRÓZ, op. cit.

${ }^{189}$ HOLANDA, op. cit., 1964, pp.458-459.
} 
serve como exemplo paradigmático desse processo, na medida em que foi pioneira da grande lavoura comercial, do liberalismo e da emancipação nacional na província. Assim, no seu entender, a afirmação do liberalismo em São Paulo não foi resultado da mera importação de pressupostos políticos europeus desconexos da realidade da província, mas de uma lenta alteração na mentalidade dos setores econômicos que, para dar tangibilidade a seus empreendimentos cada vez mais lucrativos, encontraram nas teorias liberais um instrumento político essencial. $^{190}$

Embora o Farol Paulistano e o Observador Constitucional sejam representantes do pensamento liberal paulista, as nuanças no posicionamento político desses periódicos oferecem indícios para uma reflexão sobre a referida homogeneidade da política paulista. Se esta de fato existiu, é essencial que se busque compreender os motivos desse processo e de que forma a imprensa se inseriu nesse contexto. Por outro lado, a bibliografia mais recente tem enfatizado a maleabilidade dos princípios liberais durante a formação do Império, questionando o unitarismo dos chamados liberais "moderados", visto que os adeptos da “moderação” careciam de um programa definido como também de uma articulação mais ampla e coesa. ${ }^{191}$ No que diz respeito a São Paulo, Erik Hörner observou que a insistência na homogeneidade política da província dificultou a compreensão do cenário político mais geral do Império, como também de movimentos mais específicos como a "Revolução Liberal” de 1842. Buscando compreendê-la como um movimento que significou muito mais do que uma simples luta pelo poder, Hörner constatou no discurso dos grupos em conflito a

\footnotetext{
190 Ibidem.

${ }^{191}$ GUIMARÃES, op. cit.
} 
defesa de projetos políticos distintos no que tange às esferas tanto provincial como central, contribuindo assim para questionar a referida homogeneidade paulista. ${ }^{192}$

No capítulo seguinte veremos como, em meio a uma nuançada prática liberal, em São Paulo, formaram-se espaços representativos do poder de grupos locais por meio dos Conselhos Geral e da Presidência da província de São Paulo.

${ }^{192}$ HÖRNER, op. cit. 


\section{Capítulo 2}

\section{A construção de um governo provincial: o funcionamento do Conselho da Presidência e do Conselho Geral da província de São Paulo}

Logo no início das sessões da Assembléia Constituinte, em maio de 1823, surgiram três propostas para a regularização dos governos provinciais. ${ }^{193}$ A primeira delas, encabeçada pelo deputado por Alagoas José de Souza Mello, foi lida a 7 de maio, ao passo que dois dias depois foram apresentadas as propostas de Antonio Carlos Ribeiro Machado de Andrada e Silva e Antonio Gonçalves Gomide, ambos deputados da Constituinte por Minas Gerais. Ainda que os três projetos apresentados compactuassem com a extinção das Juntas de Governo e com a nomeação de um presidente pelo Imperador, havia algumas discordâncias substanciais entre os textos dos constituintes. Souza Mello sustentava a subordinação do Comandante das Armas $^{194}$ à presidência da província e a criação de um juizado popular eleito nas paróquias. Antonio Carlos, em contrapartida, pleiteava a independência do Comandante de armas ante o presidente da província, atrelando-o diretamente ao Imperador, e propunha a criação de um Conselho eletivo e temporário que pudesse, entre outras atribuições, suspender os magistrados. O projeto de Gomide, que não apresentava maiores detalhamentos, apostava na escolha do governador das armas pelo Imperador. $^{195}$

\footnotetext{
193 O debate delineado em 1823 constituía desdobramento de questões político-administrativas geradas nos anos de 1821 e 1821 sobre a relação das Juntas de Governo e as Cortes de Lisboa. Ficou evidente o reconhecimento da importância de se definir os governos provinciais, embora não houvesse um entendimento sobre o perfil que poderiam assumir.

${ }^{194}$ O Comandante das Armas era o chefe militar da província, sendo responsável pelas forças de terra e mar. Cf. SODRÉ, Nelson Werneck. História Militar do Brasil. Rio de Janeiro: Civilização Brasileira, 1968.

${ }^{195}$ SLEMIAN, op. cit., pp.103-104.
} 
Após discussões preliminares acerca dos três projetos, decidiu-se tomar o texto de Antonio Carlos como base para a elaboração da lei que regulamentaria os governos provinciais, o que possivelmente se explica pela abrangência do documento e pela influência política que os Andradas possuíam naquele momento. ${ }^{196}$ Prosseguindo à decisão tomada pela Casa, iniciou-se o debate, em junho de 1823, de todos os artigos contidos no projeto de Antonio Carlos. Apesar da maior parte dos artigos ter sido aprovada sem alteração alguma, muitos deles foram motivo de intensas discórdias entre os membros da Casa, tal como a dissolução das Juntas de Governo, a estipulação de um presidente executor, administrador, nomeado e demitido pelo imperador, a presença do Conselho na execução dos negócios do presidente, e a eleição dos conselheiros. ${ }^{197}$

Alguns artigos do projeto original, entrementes, tiveram seu conteúdo alterado. O artigo $9^{\circ}$, que dissertava sobre a periodicidade das reuniões do Conselho, sofreu uma mudança proposta pelo padre pernambucano Henriques de Resende. Este, levando em consideração o caráter não permanente do Conselho eletivo e a possibilidade de que o presidente pudesse decidir sem sua presença, propôs que quando os conselheiros não estivessem reunidos, o “delegado do imperador” deveria comunicá-los o mais rápido possível de suas decisões, com o intuito de que os excessos administrativos fossem coibidos. $\mathrm{O}$ artigo $16^{\circ}$, que indicava ser o governador das armas independente do presidente da província e nomeado pelo imperador, foi refutado pela maioria dos deputados, recebendo críticas de Henrique Resende, Joaquim Manuel Carneiro da Cunha e José Mariano de Albuquerque Cavalcanti. Depois de acalorados debates, e em meio ao terceiro e último

\footnotetext{
${ }^{196}$ A essa época, José Bonifácio ocupava o cargo de ministro do Império e dos Negócios Estrangeiros, ao passo que Martim Francisco detinha a pasta da Fazenda. Ambos eram, ainda, deputados na Assembléia Constituinte.

${ }^{197}$ SLEMIAN, op. cit., pp.103-113.
} 
exame do artigo, os opositores à associação das forças armadas com o governo da Corte conseguiram reunir adeptos no plenário, e por fim aprovaram a suspensão da matéria. O artigo $17^{\circ}$, que previa a suspensão dos magistrados pelo presidente da província, foi também questionado pelos constituintes. Discutido o tema, os oposicionistas ao projeto conseguiram alterá-lo, de modo a assegurar que o presidente só poderia suspender um magistrado em caso de revoltas e motins, e em Conselho. Além dessas modificações no texto original, uma emenda importante foi sugerida por Henrique Resende e aprovada em plenário: o Conselho também seria responsável pelo exame das contas da província. ${ }^{198}$

As discordâncias em torno de alguns pontos do projeto de Antonio Carlos revelavam que não havia um consenso entre os membros da Constituinte sobre a organização dos governos provinciais. Mesmo após a aprovação da proposta, artigos como o $3^{\circ}$ - que garantia a escolha do presidente da província pelo imperador - foram recorrentemente aludidos e criticados.

Em 20 de outubro de 1823, foi promulgada a lei ${ }^{199}$ que dava forma "aos Governos das províncias, criando para cada uma delas um Presidente e Conselho”. É de se notar que ela se propunha a ser um instrumento normativo “provisório”, ou seja, seu conteúdo tinha como objetivo regular temporariamente os governos provinciais, que ainda careciam de um arcabouço legislativo mais pormenorizado que a futura Constituição deveria estabelecer. Isso explica, talvez, a vitória de quase todos os pontos do projeto de Antonio Carlos, na medida em que os constituintes tinham em mente que a estrutura dos governos provinciais

\footnotetext{
198 Ibdem.

199 "Lei de 20 de Outubro de 1823 que dá forma aos Governos das Províncias, creando para cada uma dellas um Presidente e Conselho”, in Coleção das Leis do Império do Brasil de 1823. Rio de Janeiro: Imprensa Nacional, 1887, pp.10-15.
} 
seria rapidamente reformulada pela votação dos artigos da Constituição. ${ }^{200}$ É de se frisar que desde julho de 1823, após sua saída do ministério, os Andrada passaram a fazer oposição ao governo, de modo que a aprovação do projeto de Antonio Carlos deu-se num momento posterior a sua permanência no governo.

Ao abolir as Juntas Provisórias de Governo (art. 1), a lei confiava o governo provincial a um presidente indicado pelo imperador que desempenharia as funções de “executor” e “administrador” da província, sendo responsável, conforme o artigo 34, pela administração e arrecadação da Junta da Fazenda Pública, a qual também presidia. Haveria, também, um Conselho composto por seis membros eleitos da mesma forma que os deputados da Assembléia Geral, e que teria sua direção igualmente atribuída ao presidente da província. Haveria ainda um secretário, também nomeado pelo imperador, que seria responsável tanto pela Secretaria do Governo como pela do Conselho, e um vice-presidente, cujo cargo recairia sobre o conselheiro que obtivesse maior número de votos entre os membros eleitos para o Conselho. Apesar da novidade da lei, tratou-se de reiterar parte do formato político aplicado às eleições para as Juntas Provisórias de Governo, entre 1821 e 1822, em meio à Revolução do Porto. A diferença substancial reside no fato de que, nas Juntas Provisórias, o presidente também ser eleito.

Tratado pelos coevos como "Conselho da Presidência”, "Conselho do Governo” ou “Conselho Administrativo”, o Conselho assegurado pela lei de 20 de outubro de 1823 não era de caráter permanente. As sessões ordinárias seriam convocadas uma vez ao ano, de acordo com as “circunstâncias” de cada província, e durariam dois meses, sendo passíveis de prorrogação por mais um mês. Haveria também sessões extraordinárias que poderiam ser

\footnotetext{
${ }^{200}$ Essa expectativa não procedeu na prática, uma vez que a Carta de 1824 manteve a lei de 2 de outubro e a ampliou.
} 
convocadas pelo presidente ao longo do ano, a fim de tratar sobre matérias competentes tanto à presidência da província como ao Conselho. Nesse sentido, em vista da sua constância nos negócios provinciais, o Conselho ainda contava com um corpo de suplentes (art.12) constituído por aqueles que obtiveram votos na eleição para a ocupação do órgão, e que teriam como função substituir os conselheiros em causa de ausência. Não havendo uma determinação legal a respeito do número de suplentes, a quantidade deles poderia variar de acordo com a assiduidade dos conselheiros.

O Conselho da Presidência não constituía, como sugere sua nomenclatura, um órgão meramente consultivo, mesmo porque, conforme o artigo 8, o presidente tinha a competência de despachar e decidir "por si só” apenas sobre os negócios os quais a lei de 1823 não prescrevesse a cooperação do Conselho. Nas matérias de sua competência, o Conselho possuía “voto deliberativo” em relação ao presidente - e este, o de “qualidade” -, de modo que o seu caráter consultivo só seria requisitado para aqueles assuntos cujo poder de decidir estava centralizado nas mãos do presidente. Segundo o artigo 24, os “objetos” que demandavam “exame e juízo administrativo” do Conselho eram os seguintes:

“1 ${ }^{\circ}$. Fomentar a agricultura, comércio, industria, artes, salubridade, e comodidade geral.

$2^{\circ}$. Promover a educação da mocidade.

$3^{\circ}$. Vigiar sobre os estabelecimentos de caridade, prisões, e casas de correção e trabalho.

$4^{\circ}$. Propor que se estabeleçam Câmaras, onde as deve haver.

$5^{\circ}$. Propor obras novas, e consertos das antigas, e arbítrios para isto, cuidando particularmente na abertura de melhores estradas e conservação das existentes.

$6^{\circ}$. Dar parte ao Governo dos abusos, que notar na arrecadação da rendas.

$7^{\circ}$. Formar censo, e estatística da Província.

8․ Dar parte à Assembléia das infrações das Leis, e sucessos extraordinários, que tiverem lugar nas Províncias. 
$9^{\circ}$. Promover as missões, e catequese dos Índios, a colonização dos estrangeiros, a laboração das minas, e o estabelecimento de fabricas minerais nas Províncias metalíferas.

$10^{\circ}$. Cuidar em promover o bom tratamento dos escravos, e propor arbítrios para facilitar a sua lenta emancipação.

11․ Examinar anualmente as contas de receita e despesa dos Conselhos, depois de fiscalizados pelo Corregedor da respectiva comarca, e bem assim as contas do Presidente da Província.

$12^{\circ}$. Decidir temporariamente os conflitos de jurisdição entre as Autoridades. Mas se o conflito aparecer entre o Presidente e outra qualquer Autoridade, será decidido pela Relação do Distrito.

$13^{\circ}$. Suspender Magistrados na conformidade do art. 34. ${ }^{201}$

$14^{\circ}$. Suspender o Comandante Militar do comando da Força Armada, quando inste a causa publica.

$15^{\circ}$. Atender às queixas, que houve contra os funcionários públicos, mormente quanto à liberdade da imprensa, e segurança pessoal, e remetê-los ao Imperador, informadas com audiência das partes, presidindo o Vice-Presidente, no caso de serem as queixas contra o Presidente.

$16^{\circ}$. Determinar por fim as despesas extraordinárias, não sendo porém estas determinações postas em execução sem prévia aprovação do Imperador. Quanto às outras determinações do Conselho, serão obrigatórias, enquanto não forem revogadas, e se não opuserem às Leis existentes". 202

Em termos qualitativos, pode-se afirmar que as atribuições do Conselho formavam, em linhas gerais, três grupos: o primeiro deles, composto pelos “objetos” $1^{\circ}, 2^{\circ}, 4^{\circ}, 5^{\circ}, 7^{\circ}, 9^{\circ}$ e $10^{\circ}$, referia-se a um conjunto de atribuições cujo objetivo central era dotar o colegiado da capacidade de propor e deliberar sobre questões infra-estruturais da província, como

\footnotetext{
${ }^{201}$ Segundo a lei de 20 de outubro de 1823, a administração da Justiça seria independente do presidente e do Conselho (art. 33). Ainda assim, em alguns casos previstos pelo artigo 34 da mesma lei, o presidente e seu Conselho privativo poderiam suspender magistrados. Dizia o artigo 34: "Pode-se porém o Presidente em Conselho, e de acordo com o Chanceler, onde houver relação, suspender o Magistrado depois de ouvido, isto tão somente no caso em que, de continuar a servir o Magistrado, se possam seguir motins, e revoltas na Província, e se não possa esperar resolução do imperador. Feita a suspensão, dará imediatamente parte pela Secretaria da Justiça, e remeterá os autos comprobatórios da urgência e necessidade da suspensão ao Tribunal competente, para proceder-se como for de direito".

202 "Lei de 20 de Outubro de 1823 que dá forma aos Governos das Províncias, creando para cada uma dellas um Presidente e Conselho”, in op. cit., pp.12-13.
} 
fomentar a agricultura, a indústria, a exploração mineral, o comércio, a educação, a construção de estradas e a criação de sensos provinciais; promover a catequese dos índios, a colonização por estrangeiros e o bom tratamento dos escravos - bem como discutir sua emancipação gradual; e estabelecer novas Câmaras Municipais. O segundo grupo, composto pelos "objetos" $3^{\circ}, 6^{\circ}, 8^{\circ}, 11^{\circ}, 15^{\circ}$ e $16^{\circ}$, dizia respeito às atribuições que conferiam ao Conselho a natureza de um órgão fiscalizador dos negócios públicos, quer da esfera financeira (examinar as contas das Câmaras Municipais e da província; advertir o Governo sobre os abusos que notar na arrecadação da rendas; dar parte à Assembléia das infrações das Leis que ocorrerem na província; determinar por fim às despesas extraordinárias) quer da esfera político-administrativa (vigiar estabelecimentos de caridade, prisões, casas de correção e trabalho; e acatar as queixas proferidas contra os funcionários públicos, especialmente em relação à liberdade da imprensa). O terceiro grupo, por sua vez, formado pelos “objetos" $13^{\circ}$ e $14^{\circ}$, dizia respeito aos poderes do Conselho em suspender determinados funcionários públicos ligados ao Judiciário (suspender os magistrados, em conjunto com o presidente) e às forças armadas (suspender o Comandante Militar das Armas).

Conquanto não possuísse poder deliberativo em relação a algumas questões capitais - como a criação de tributos e políticas fiscais -, o Conselho da Presidência abarcava um conjunto de atribuições político-administrativas que seriam essenciais na configuração dos cenários políticos provinciais do Primeiro Reinado e início das Regências, notadamente no tocante ao estabelecimento de vínculos entre os poderes locais e central, como sublinhou Marisa Saenz Leme: 
“com segurança o que se afirma é que os poderes deliberativos do Conselho se davam em relação ao Presidente da Província; não tinha ele poderes de decisão legislativa quanto ao governo central; mas no escopo de atribuições do Conselho abriu-se sem dúvida espaço para a parcial resolução dos interesses provinciais, e, o que é bastante significativo para a época, constituindo-se ele num fórum de manifestação e pressão para que os interesses provinciais se fizessem ouvir no âmbito nacional, quer se tratasse do executivo ou da Câmara dos Deputados”. ${ }^{203}$

O alcance do poder dos Conselhos da Presidência tornar-se-ia, inclusive, tema constante entre os contemporâneos. Em 1827, num artigo explicitamente contrário à amplitude de poderes que havia sido conferida aos Conselhos pela lei de 20 de outubro de 1823, o redator de O Farol Paulistano comparou-os às extintas Juntas de Governo, bem como aos governos “policephalos” tratados por Jeremy Bentham em seus Traités de Legislation, que em uma de suas passagens discute sobre a inconveniência da divisão excessiva do poder:

N'esta lei [de 20 de outubro de 1823] procurou-se obviar à mor parte nos inconvenientes que se tinhão experimentado nos Governos de muitos, mas como estava ainda muito fresco o horror que tinhão os povos aos antigos Governos d' um só, talvez a política mandava que a nova fórma de Governos não fosse muito aproximada a essa que se tinha em horror, e eis porque subsistirão parte dos vícios ineherentes à forma dos que então se abolião. Criou-se, é verdade, um Presidente, o qual com excepção de alguns casos, maneja elle só as rédeas do Governo. Ha todavia esses casos, que vem enumerados no art. 24 da citada lei, para cuja decisão é necessária a cooperação do Conselho, o qual em todas essas matérias tem voto deliberativo, como se declara no art. 22 da mesma lei. Ora, se materias que só podem ser discutidas em Conselho à pluralidade de votos, são as mais importantes: e

\footnotetext{
${ }^{203}$ LEME, Marisa Saenz. “São Paulo no I Império: poderes locais e governo central”, in OLIVEIRA, Cecilia Helena de Salles; PRADO, Maria Ligia Coelho; JANOTTI, Maria de Lourdes Monaco (org.). A história na política, a política na história. São Paulo: Alameda, 2006, p.65.
} 
se n’ellas é que se verifica o inconveniente da responsablidade, segue-se que a dicta lei pouco ou nada acorreo aos vícios dos Governos, que abolio. ${ }^{204}$

Para o redator de $O$ Farol, o poder de deliberar constituía o problema central do Conselho da Presidência. Este, pelo fato de ter a competência de decidir sobre as matérias “mais importantes”, e de ser composto por vários membros, fazia da "pluralidade de votos” sua essência política, o que caracterizava, segundo o autor, um governo politicamente pulverizado e sem responsáveis efetivos pelos atos do Executivo, tal como havia ocorrido na época das Juntas de Governo. Prosseguindo na argumentação, o redator ressaltava que o Conselho da Presidência poderia provocar um “estado no estado” que, munido de altos poderes, se voltaria contra a opinião pública.

Por dentro dessa aparente retórica em torno da possibilidade de os Conselhos se tornarem órgãos contrários à causa pública subsistia, na realidade, uma preocupação de fundo. O redator de $O$ Farol temia que os governos provinciais, ao mesmo tempo centralizados nos Conselhos e diluídos entre seus conselheiros, ficassem à mercê dos interesses locais, colocando em risco a relação com o poder central. Afinal, dizia o redator, “se o Conselho d’Estado não tem voto deliberativo em caso algum, a mesma razão ha para os Conselhos de Governo, quando são consultados pelo Presidente, que em cada província é como o Representante ou Delegado do Imperante”. ${ }^{205}$

A lei de 20 de outubro de 1823 foi o principal instrumento político-legal referente aos governos provinciais até pelo menos dezembro de 1828, quando os primeiros Conselhos Gerais de província foram instalados. Ainda que a Carta de 1824 já os previsse - de acordo com o Capítulo 5 do Título 4 (“Dos Conselhos Gerais de Província e suas Atribuições”) -

\footnotetext{
${ }^{204}$ O Farol Paulistano, $\mathrm{n}^{\circ}$ 14, 09/05/1827.

${ }^{205} \mathrm{Ibdem}$.
} 
a implementação dos Conselhos Gerais não se deu prontamente, sobretudo por causa da demora no estabelecimento de um regimento específico para eles, que ficara, conforme o artigo 89 do capítulo supracitado, sob responsabilidade da Assembléia Geral, que somente em 27 de agosto de 1828 aprovou legislação ordinária sobre a matéria. ${ }^{206}$ Assim, mesmo que a eleição dos conselheiros gerais tenha sido convocada juntamente com aquelas para senadores, deputados, e conselheiros do Conselho da Presidência, em 26 de março de 1824, os Conselhos Gerais não foram instituídos. A presidência das províncias e seus respectivos Conselhos privativos tornaram-se, destarte, os órgãos privilegiados da política provincial. Sobre esse ponto, assinalou Andréa Slemian:

“Apesar da interpretação que a lei [de 20 de outubro de 1823] teria ressuscitado os 'antigos governadores coloniais', conforme as palavras de Cipriano Barata, e da crítica que se difundiu contra a extinção das Juntas como autoridades eletivas, ela significou, do ponto de vista da construção normativa de um arranjo político liberal, um passo importante na valorização das Províncias como espaços convergentes de poder político. Mesmo que seus governos continuassem, durante anos profundamente marcados por conflitos entre autoridades civis e militares, as bases para reivindicação de uma legitimidade já haviam sido dadas. Desenhava-se um esboço de separação de poderes da unidade política que, confirmado pela Carta do ano seguinte, servirá de base às transformações futuras”. ${ }^{207}$

A implementação dos Conselhos da Presidência, realizada depois da nomeação dos presidentes de província pelo imperador, já conforme a Carta de 1824, deu-se de acordo com a situação política de cada localidade, de modo que no Pará, por exemplo, houve embates

\footnotetext{
206 "Lei de 27 de Agosto de 1828 que dá regimento para os Conselhos Geraes de Provincia”, in Coleção das Leis do Império do Brasil de 1828. Rio de Janeiro: Tipografia Nacional, 1878, pp.10-24.

${ }^{207}$ SLEMIAN, op. cit., pp.114-115. Parte significativa das considerações de Cipriano Barata acerca dos governos provinciais encontra-se nos volumes de Sentinela da Liberdade na Guarita de Pernambuco, periódico escrito pelo médico baiano dentro do cárcere da fortaleza de Brum, em Pernambuco, após sua prisão pelas tropas do governo, a 17 de novembro de 1823. CF. MOREL, op. cit., 2001.
} 
entre o presidente daquela província e o Conselho, que se recusou a obedecer-lhe e a dar posse ao Comandante de Armas de São Luis. ${ }^{208}$ Ao que parece, no Centro-Sul do Império os Conselhos da Presidência foram organizados sem maiores atribulações ${ }^{209}$, tal como ocorreu com o da província de São Paulo.

\subsection{O Conselho da Presidência da Província de São Paulo:}

Em 20 de outubro de 1824, um ano depois da promulgação da lei que dava forma provisória aos governos provinciais, foi instaurado o Conselho da Presidência da Província de São Paulo, seguindo a Carta jurada em março. ${ }^{210}$ Os conselheiros haviam sido escolhidos meses antes, após a tomada de posse do primeiro presidente da Província, Lucas Antonio Monteiro de Barros ${ }^{211}$, em $1^{\text {o }}$ de abril de 1824. Eram eles: o Coronel Luiz Antonio Neves de

208 RAIOL, Domingos Antonio. Motins Políticos (ou história dos principais acontecimentos políticos da

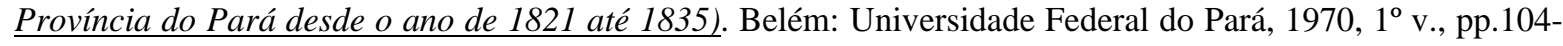
106.

${ }^{209}$ SLEMIAN, op. cit., p.205.

${ }^{210}$ Atas do Conselho da Presidência da Províncias de São Paulo (anos de 1824-1829) (ACP). In: Documentos Interessantes. São Paulo: Departamento do Arquivo do Estado, 1961, v.86, $1^{\text {a }}$ sessão preparatória do Conselho da Presidência de 20 de outubro de 1824, p.10. Consultar o Anexo 5 para todos os conselheiros, suplentes e sua participação no Conselho da Presidência.

${ }^{211}$ Lucas Antonio Monteiro de Barros (1767-1851), Barão e depois Visconde de Congonhas do Campo, era natural de Congonhas do Campo, Minas Gerais. Filho primogênito do Guarda-Mor Manuel José Monteiro de Barros e Margarida Eufrásia da Cunha Matos, seguiu jovem para Portugal onde estudou Direito da Universidade de Coimbra. Ao retornar para o Brasil, foi nomeado pelo governo joanino Ouvidor da Comarca de Vila Rica (1808); Desembargador da Relação da Bahia (1808), continuando no exercício da Ouvidoria de Vila Rica; Intendente do Ouro da Corte (1812); Desembargador da Casa da Suplicação (1814), continuando no exercício da Intendência do Ouro; Superintendente-Geral dos Contrabandos (1819); e Juiz Conservador da Companhia de Vinhos do Alto Douro. Durante a Regência e o primeiro Reinado de D. Pedro, foi nomeado Chanceler da Relação de Pernambuco (1821); Desembargador do Paço (1821); Ouvidor da Comarca de Sabará (1825). Foi eleito deputado pela Província de Minas Gerais para as Cortes de Lisboa (1821-1822) e para a Assembléia Constituinte de 1823. Foi nomeado o primeiro Presidente da Província de São Paulo, cargo que ocupou entre $1^{\circ}$ abril de 1824 e 5 de abril de 1827. Eleito senador pela Província de São Paulo em 22 de janeiro de 1826, tomou posse a 10 de maio de 1827. Recebeu o título de Barão em 12 de outubro de 1825 e de Visconde no mesmo dia e mês do ano seguinte. Ainda recebeu o título de Visconde com grandeza em 2 de junho de 1841. Cf. EGAS, Eugenio Galeria dos presidentes de São Paulo. São Paulo: Seção de obras do "O Estado de S. Paulo", 1926, v.1 (Período Monárquico), pp.25-26. 
Carvalho $^{212}$ (também eleito vice-presidente, por ter obtido o maior número de votos entre os conselheiros), o bacharel Manoel Joaquim de Ornellas, o vigário capitular Manoel Joaquim Gonçalves de Andrade ${ }^{213}$, o brigadeiro Manoel Rodrigues Jordão, o tenente coronel Rafael Tobias de Aguiar e Candido Xavier de Almeida e Souza ${ }^{214}$. Os suplentes, que em grande parte foram convocados apenas a partir de 1827, eram representados por: coronel Francisco Inácio de Souza Queiroz, Antônio José Vaz, Antonio Bernardo Bueno da Veiga, Nicolau Pereira de Campos Vergueiro, Bernardo José Pinto Gavião Peixoto, José Arouche de Toledo Rendon, Lourenço Pinto de Sá Ribas, Diogo Antônio Feijó, Manoel da Cunha de Azevedo C. S. Chicorro, Joaquim Mariano Galvão de Moura Lacerda, José Joaquim Cezar de Serqueira Leme e José Pedro Galvão de Moura e Lacerda.

Dos seis conselheiros eleitos, um deles - Manoel Joaquim de Ornellas - também havia sido escolhido deputado por São Paulo, ao passo que dentre os doze suplentes convocados, três deles - José Arouche de Toledo Rendon, Diogo Antonio Feijó e Nicolau Pereira de Campos Vergueiro - também passariam a ocupar cadeiras pela mesma Província na Câmara a partir de 1826, de modo que, durante a $1^{\text {a }}$ legislatura, quatro dos nove deputados paulistas participaram do Conselho da Presidência. Mesmo que a lei de outubro

\footnotetext{
${ }^{212}$ Luiz Antonio Neves de Carvalho (1767-1831) ocupou a vice-presidência da Província de São Paulo por duas ocasiões, entre 22 de abril e setembro de 1826, e entre 5 de abril e 18 de dezembro de 1827.

${ }^{213}$ Manoel Joaquim Gonçalves de Andrade (17??-1847) era natural da Ilha da Madeira, era filho de Nicolau Gonçalves de Andrade e D. Maria de Andrade. Formou-se em Cânones pela Universidade de Coimbra, em 1796, ano em que também foi nomeado para um canonicato vago na Sé de São Paulo. Voltando para Portugal, só retornou a São Paulo em 1802, quando ocupou os lugares de arcediago e vigário geral. Com a morte do bispo D. Mateus de Abreu Pereira, em 1824, foi nesse ano eleito vigário capitular e, em 1826, bispo

${ }^{214}$ Candido Xavier de Almeida e Souza (1748-1831) era natural de São Paulo e era filho de Luciano de Sousa Azevedo e de D. Isabel Garcia de Almeida. Desde jovem seguiu a carreira militar, assentando praça de soldado em 1762. Prestou diversos serviços na área militar: participou das expedições pra os campos de Guarapuava; foi comandante militar das vilas de Ubatuba e São Sebastião; executou, em 1792, a mando do capitão-general e governador de São Paulo, uma exploração do rio Tietê a fim de estabelecer o comércio fluvial entre a capital paulista e a região do salto de Itu; e participou expedições na região do rio da Prata. Como político, ocupou o cargo de presidente do Governo Provisório da Província de São Paulo entre 10 de setembro de 1822 e 9 de janeiro de 1823.
} 
de 1823 não indicasse, à exceção do “objeto” $8^{\circ}$ do artigo $24^{215}$, as relações entre o Conselho e a Câmara dos Deputados, a existência de membros comuns às duas instâncias de poder pode ter proporcionado uma maior amplitude de atuação na direção de assegurar os interesses, ainda que heterogêneos, de determinados grupos da Província de São Paulo.

Digno de nota é o fato de que, ao tomar posse em 1824, esses conselheiros permaneceram no Conselho até junho de 1830, quando os novos membros saídos das eleições de 1829 apresentaram seus diplomas. ${ }^{216}$ Por conta do atraso na convocação da Assembléia Geral, e da dependência legal que as eleições para conselheiros da Presidência tinham com aquelas para deputados e senadores, ocorreu um descompasso na $1^{\text {a }}$ legislatura entre o Parlamento e o Conselho, que funcionou dois anos a mais que a Câmara dos Deputados e o Senado. Não obstante a partir de 1827 a presença dos suplentes ter sido ininterrupta, conselheiros como Rafael Tobias de Aguiar, Manoel Joaquim de Ornellas e Manoel Joaquim Gonçalves de Andrade, que ocupou por três vezes o posto de vicepresidente entre 1828 e $1831^{217}$, compareceram assiduamente às sessões do Conselho até o término da $1^{\mathrm{a}}$ legislatura.

Iniciados seus trabalhos, o Conselho da Presidência foi aos poucos definindo sua estratégia de funcionamento. Convencionou-se que o período para ocorrerem as sessões ordinárias era os meses de outubro e novembro - e dezembro, no caso de prorrogação ou

\footnotetext{
${ }^{215}$ Art. 34, objeto $8^{\circ}$. "Dar parte à Assembléia das infrações das Leis, e sucessos extraordinários, que tiverem lugar nas Províncias”.

${ }^{216}$ Eleitos à semelhança dos deputados e senadores - conforme art. 10 da lei de 20 de outubro de 1823 -, os Conselheiros e Suplentes assistiram ao término da $1^{\text {a }}$ Reunião do Conselho da Presidência da Província de São Paulo em 01/05/1830. Na sessão seguinte, de 30/06/1830, abriu-se a $2^{\mathrm{a}}$ Reunião do Conselho - em consonância com a abertura da $2^{\text {a }}$ Legislatura do Império -, ocasião em que os novos Conselheiros e Suplentes eleitos começaram a tomar posse. Cf. Atas do Conselho da Presidência da Província de São Paulo (1829-1832) (ACP). In: Boletim. São Paulo: Arquivo do Estado de São Paulo, 1961, v.15, sessão de 30/06/1830, p.50.

217 Cf. MARQUES, Manuel Eufrásio de Azevedo. Apontamentos Históricos, Geográficos, Biográficos, Estatísticos e Noticiosos da Província de São Paulo. São Paulo: Comissão do IV Centenário da cidade de São Paulo, 1954, tomo 1, pp.190-191.
} 
atraso na convocação do Conselho -, provavelmente por se tratar de uma época do ano em que a Assembléia Geral, quando aberta, já havia encerrado seus trabalhos, medida que não acarretaria a ausência de alguns conselheiros que também eram parlamentares. Anos mais tarde, em meio à regulamentação dos Conselhos Gerais, a questão do período de funcionamento do Conselho da Presidência emergiu outra vez. Tendo em vista que os Conselhos Gerais tinham por obrigação legal funcionar a partir do início de dezembro, e que era considerável a possibilidade de um representante ser membro de ambos os Conselhos, novamente optou-se pela convocação ordinária do Conselho da Presidência nos três últimos meses do ano, a fim de facilitar o expediente daqueles que ocupavam cadeiras nos dois órgãos. No princípio, funcionava uma vez por semana, ao passo que a partir da 39a . sessão o número de reuniões foi dobrado e seus dias estipulados para as segundas e quintas-feiras. Os sábados seriam utilizados apenas se a afluência dos negócios aumentasse consideravelmente. $^{218}$ Em outubro de 1827, o Conselho deliberou que suas atas fossem impressas pela Tipografia do Farol Paulistano ${ }^{219}$, decisão que foi saudada por um dos correspondentes da folha de Costa Carvalho:

“Sr. Redator. Louvores mil ao nosso Exmº. Conselho do Governo por sua muito constitucional deliberação de fazer publicar por via do seu Farol as Atas de suas sessões, dando assim uma prova nada equívoca do quanto marcha, ou marchar deseja a par do Sistema Constitucional, a quem deve sua existência. Eu me congratulo pois, Sr. Redator, como os nossos cidadãos por esta bem acertada medida do Exm $^{\circ}$. Conselheiro; e tanto mais, quanto ela oferece meios, e ocasião ao Público de expender suas opiniões acerca daquelas

\footnotetext{
${ }^{218}$ ACP, v. 86, sessão de 23/10/1826, p.140.

219 “Oficio da Secretaria do Governo da Presidencia de 23 de outubro de 1827”, publicado por O Farol Paulistano, $\mathrm{n}^{\circ}$ 58, 27/10/1827.
} 
resoluções, que lhe parecem boas, seguindo-se em resultado, que o Exmº $^{\circ}$ Conselho se aproximará seguro ao melhor acerto de suas deliberações(...)”. 220

Com o andamento das sessões, o Conselho adquiriu uma sistemática no encaminhamento de suas tarefas que, de maneira geral, se dividiam em dois grupos. O primeiro deles se referia à discussão e votação dos projetos apresentados pelo presidente (ou pelo vice, no caso da ausência do primeiro) e pelos conselheiros. De acordo com o nível de complexidade da matéria apresentada, poderia haver a solicitação de um aprofundamento ou reformulação do projeto, o que acarretaria no adiamento da deliberação sobre o mesmo. Caso contrário, o Conselho decidia prontamente sobre a questão posta em votação. O segundo grupo se relacionava ao exame das indicações, representações, requerimentos e outros documentos encaminhados ao Conselho por toda sorte de setores do poder público e da sociedade, tais como representantes das Câmaras Municipais, ouvidores, juizes de paz, juizes de fora, juizes ordinários, clérigos, militares, tropeiros, comerciantes, agricultores, grupos de moradores e até mesmo escravos. Como a demanda desses documentos era grande e a especificidade das matérias não permitia que o Conselho decidisse sumariamente sobre elas, tornou-se prática comum dividi-las entre os conselheiros, que por sua vez ficavam encarregados de analisar e emitir um parecer sobre um número determinado de representações externas. Tais pareceres, que se propunham a tecer um arrazoado sobre a plausibilidade ou não dos objetos contidos nas representações, serviam como documentobase pelo qual o Conselho discutiria e, posteriormente, deliberaria sobre as matérias representadas.

${ }^{220}$ Ibid, nº 58, 27/10/1827. Não foi possível localizar o proponente da medida. 
Considerando o período de 1824 a meados de 1830, ou seja, aquele no qual operou o primeiro Conselho da Presidência da Província de São Paulo, é certo afirmar que a atuação desse órgão esteve em estrita sintonia com as atribuições que lhe foram conferidas pela lei de 20 de outubro de 1823. À exceção do "objeto" $13^{\circ}$ do artigo 24 da referida lei - que previa a possibilidade de "suspender Magistrados na conformidade do art. 34" -, o Conselho colocou em prática todas as outras atribuições que lhe foram conferidas, o que demonstra uma sólida tentativa de seus membros em estabelecer um espaço político provincial de amplo alcance para o poder executivo e para demandas de diferentes setores.

Quanto aos projetos sugeridos pelo Conselho da Presidência da Província de São Paulo, pode-se destacar que, já durante seus dois primeiros anos de funcionamento, uma gama variada de matérias foi aventada pelos conselheiros. Eram elas, majoritariamente, relativas à infra-estrutura de transportes e comunicação (proposta para abertura de estrada entre Sorocaba e o Rio Juquiá; para o conserto da estrada da Matta, que ligava São Paulo a São Pedro do Rio Grande do Sul; para a feitura de ponte sobre o rio Paraibuna; para o estabelecimento de correio público entre Itu, Sorocaba, Jundiaí e São Paulo); à educação (proposta para a difusão do método Lancaster entre as escolas de primeiras letras; para a criação de cadeiras de Gramática Latina em toda a Província); ao fomento da agricultura e à mineração (proposta para o desenvolvimento da cultura das vinhas do Distrito de Curitiba; para que se fizesse observância da lei que assegurava aos administradores e feitores das fábricas de açúcar a isenção no recrutamento militar; para que se explorasse as minas de diamante do distrito de Curitiba; para que se explorasse o ouro descoberto em Sorocaba); e à 
organização política e financeira da Província (proposta para a criação de novas vilas; proposta para prevenção de abusos e extravios nas contas públicas). ${ }^{221}$

A maior parte dos projetos sugeridos por um conselheiro recebia a aprovação dos demais. Ainda que alterações recomendadas por outros membros do Conselho fossem recorrentes, não era comum que as discussões a respeito de uma proposta se alongassem por mais de uma ou duas sessões. O alto índice de aprovações e o pouco tempo despendido em relação à maioria dos projetos podem talvez ser explicados pela própria natureza política do Conselho, já que esse era temporário, não legislativo, e contava com a colaboração de outras esferas do poder público para que suas medidas fossem implementadas, como se verá adiante. É provável, ainda, que um grupo mais ou menos coeso tenha composto a $1^{\text {a }}$ Reunião do Conselho, visto que seus membros, homens ligados à produção agrícola, comércio e carreira política, estavam ligados por laços político-ideológicos e econômicos. ${ }^{222}$

No que tange às representações enviadas ao Conselho, pode-se afirmar que tanto seus emissários quanto os assuntos por eles versados eram diversos. Quando enviadas por particulares, as representações quase sempre eram queixas - contra o abuso cometido por magistrados, militares e outras autoridades - ou requerimentos para que o Conselho decidisse sobre assuntos específicos. Em novembro de 1824, por exemplo, uma escrava da Fazenda Nacional apresentou ao Conselho um requerimento solicitando a libertação de seu filho recém-nascido, mediante o pagamento de vinte e cinco mil e seiscentos réis. Após a análise da matéria, deliberou-se que, “cumprindo ao Conselho cuidar em promover o bom tratamento dos escravos, e propôr arbitrios para a sua lenta emancipação”, cabia deferir a súplica da escrava e enviá-la à Junta da Fazenda para que essa elaborasse o título de

\footnotetext{
${ }^{221}$ ACP, v.86, sessões de 27/10/1824, pp. 13-15, 03/10/1824, pp. 15-18, 17/11/1824, pp.21-23, 24/11/1824, pp.23-25, 09/12/1824, pp.28-31, 31/10/1825, pp.77-79.

${ }^{222} \mathrm{O}$ perfil socioeconômico dos políticos paulistas será tratado no capítulo 3.
} 
emancipação da criança. ${ }^{223}$ No mesmo mês e ano, o Conselho recebeu uma representação do "Povo da nova Freguesia do Tatuí", solicitando a tomada de providências em relação ao tamanho do terreno que fora concedido por ordem imperial à instalação da dita freguesia. Uma vez que as terras cedidas faziam parte da propriedade do Hospício do Carmo da Vila de Itu, e que por isso, segundos os suplicantes, o terreno oferecido não era extenso o suficiente para a construção de suas casas, o Conselho deliberou que se enviasse ao imperador, por intermédio do presidente, um pedido de providências para solucionar a questão. ${ }^{224}$ Em outubro de 1825, depois de examinar um ofício redigido pelo capitão-mor de Mogi-Mirim acerca da incúria do Juiz Ordinário dessa mesma vila em relação à direção da cadeia pública daquela localidade, o Conselho determinou que o ouvidor da Comarca de Itu o "reprehendesse severamente". ${ }^{225}$

Em meio a representações tão distintas, onde os casos acima mencionados figuram apenas como exemplos, é possível observar um aspecto essencial que permeou as ações do Conselho da Presidência da Província de São Paulo durante todo o seu funcionamento: o múltiplo encaminhamento de suas deliberações. Ao decidir sobre uma dada representação, ou mesmo sobre a execução de um projeto, dependendo do seu conteúdo, o Conselho enviava suas resoluções aos órgãos ou estabelecimentos competentes - governo central, Câmaras Municipais, Ouvidorias, Juizados, Santas Casas, Comando das Armas, Junta da Fazenda, entre outros - para que esses as executassem. Nesse sentido, o Conselho da Presidência compôs, ao lado dos sucessivos presidentes, um aparato político-administrativo que ajudou a constituir algumas das bases da esfera executiva de poder local.

\footnotetext{
${ }^{223}$ ACP, v. 86, sessão de 03/11/1824, p.16.

${ }^{224}$ ACP, v. 86, sessão de 17/11/1824, pp.22-23.

${ }^{225}$ ACP, v. 86, sessão de 27/10/1825, p.76.
} 
Esse processo de normatização do poder provincial pela ação do Conselho da Presidência deu-se, porém, paulatinamente, de modo que há registros de resoluções tomadas pelo órgão que foram re-interpretadas pelos executores finais ou que até mesmo foram contestadas. Em meados de 1825, um grupo de moradores de Sorocaba encaminhou aos conselheiros um requerimento cujo conteúdo aludia à maneira "arbitrária” pela qual a Câmara Municipal daquela Vila tinha posto em prática a deliberação do Conselho sobre a abertura de algumas ruas. A Câmara enviou um ofício justificando suas ações, o que obrigou o Conselho a estabelecer uma série de medidas que por fim envolveram representantes oficiais da municipalidade, moradores e o ouvidor da Comarca de Itu, prolongando o assunto por mais de um ano. ${ }^{226}$ No início de 1826, o brigadeiro Joaquim José Pinto de Moraes Leme questionou por meio de um requerimento a posição tomada pelos conselheiros Manoel Joaquim de Ornellas e Manoel Joaquim Gonçalves de Andrade a respeito de uma deliberação vinda da Câmara da cidade de São Paulo em fazer demolir e reedificar os muros do quintal de sua residência. A Câmara, que anteriormente havia sido interpelada pelo brigadeiro sobre a questão, enviou a documentação referente ao caso para o Conselho, que decidiu por deliberar a favor da municipalidade. Em seu requerimento ao Conselho, o brigadeiro criticou a medida do órgão, sobretudo porque esse havia decidido com apenas dois conselheiros e um suplente, número que ele julgava insuficiente. O Conselho acabou por escusar o requerimento do brigadeiro, exortando-o sobre os termos insultantes que o mesmo usara em seu documento. ${ }^{227}$

As representações enviadas pelas Câmaras Municipais preenchiam boa parte das pautas discutidas pelo Conselho da Presidência em suas sessões. Eram geralmente

\footnotetext{
${ }^{226}$ ACP, v. 86, sessão de 3/10/1825, pp.50-52.

${ }^{227}$ ACP, v. 86, sessão de 7/04/1826, pp.135-136. Ver também sessão de 30/03/1826, p.134.
} 
documentos extensos e pormenorizados, que solicitavam do Conselho orientações sobre matérias variadas, a exemplo de um documento enviado pela Vila de Iguape, em novembro de 1825. Nessa representação, a Câmara pleiteava o envio de um mestre de Gramática Latina, a criação de um Juiz Letrado, a abertura de uma estrada entre a cidade de São Paulo e a região de Sorocaba - ou o conserto de uma antiga picada entre a Freguesia de Santo Amaro e a de Conceição de Itanhaém -, e a construção de um canal ligando a Ribeira de Iguape com o mar. Após analisar o parecer emitido pelo suplente Francisco Inácio de Souza Queiroz, o Conselho optou a favor das duas primeiras solicitações, contra a segunda - por achá-la desnecessária -, e postergou a decisão sobre a construção do canal no Iguape, uma vez que foram solicitados à Câmara maiores detalhes sobre o assunto. ${ }^{228}$

A partir de 1826, como observou Saenz Leme, o Conselho teve diversas sessões adiadas em decorrência da falta de quorum, de forma que a primeira sessão ordinária desse ano só foi ocorrer no final do mês de outubro, à revelia do que havia sido decidido ao término dos trabalhos de $1825 .{ }^{229}$ Tal atraso na convocação do órgão foi acompanhado por uma diminuição no envio de solicitações ao mesmo, quadro que se estendeu até o final de 1828, quando da implementação definitiva do Conselho Geral.

É provável que essas questões estivessem atreladas à abertura da Assembléia Geral, ocorrida em maio de 1826, embora a existência de um conselheiro e três suplentes que também eram deputados não explica, por si só, um refluxo nas atividades do Conselho, como notou Säenz Leme:

\footnotetext{
${ }^{228}$ ACP, v. 86, sessão de 3/11/1825, pp.79-86.

${ }^{229}$ Em dezembro de 1825, o Conselho da Presidência de São Paulo decidiu que as sessões ordinárias do ano seguinte começariam do dia $1^{\circ}$ de outubro, o que não se confirmou. Cf. ACP, v. 86, sessão de 3/12/1825, p.130.
} 
"No que se refere a uma relativa desaceleração das solicitações, comparativamente ao início de funcionamento do Conselho, o executivo provincial pode, de um lado, ter montado um mecanismo de atendimento para os assuntos cotidianos, uma vez encaminhada junto ao Conselho da Presidência a demanda reprimida dos anos anteriores, da intensa luta política no interior da Província; de outro, com o início do funcionamento da Assembléia Geral, para ela podem ter-se dirigido as representações e ofícios antes acumulados na direção do governo provincial”. 230

A diminuição no envio das representações não deve ser vista como um processo de esvaziamento político do Conselho, mesmo que após a abertura da Assembléia Geral a temática dos Conselhos Gerais de Província tenha logo vindo à tona, tornando incerto o futuro dos Conselhos da Presidência em todo o Império. ${ }^{231}$ No caso da Província de São Paulo, atividades importantes continuaram a ser desenvolvidas pelo órgão, dentre elas a fiscalização da situação financeira das instâncias municipais e provincial, atribuições previstas pelos objetos $6^{\circ}$ e $11^{\circ}$ do artigo 24 da lei de outubro de 1823.

O exame das finanças municipais dava-se a partir da análise dos registros contidos nos livros de “contas de receita e despeza” das Vilas, que só eram enviados ao Conselho depois de serem fiscalizados pelo corregedor da respectiva Comarca, exigência essa que tornava a apreciação dos conselheiros dependente de uma análise prévia. De todo modo, a despeito dessa conferência preliminar, foram comuns as críticas partidas do Conselho aos abusos e à falta de critério na condução das finanças por parte das municipalidades, como a que emitiu Rafael Tobias de Aguiar, em outubro de 1828, a respeito da Vila de Paranahiba. Segundo o então tenente-coronel, as contas referentes ao período de 1823 e 1827 estavam tão “mal escriptas” e apresentavam tantas falhas - mandados de despesas “confusos”,

\footnotetext{
${ }^{230}$ LEME, op. cit., p.67.

${ }^{231}$ SLEMIAN, op. cit., pp.205-206.
} 
omissão de gastos, entre outras - que o fizeram sugerir a exigência de esclarecimentos por parte da referida Câmara, o que foi aceito pelos demais conselheiros. ${ }^{232}$

A apreciação das contas da Província constituía um processo mais demorado e fragmentado, pois congregava as finanças da Junta da Fazenda, da Secretaria e Contadoria da Presidência, e de estabelecimentos diversos, como os Seminários da Glória e de Santana, a Fábrica de Ferro de Ipanema e o Jardim Botânico. Segundo artigo publicado pelo Farol Paulistano, em 1829, o exame das contas da Junta da Fazenda figurava como uma das principais atribuições do Conselho da Presidência, já que de acordo com artigo 25 da lei de 20 de outubro de 1823, o órgão teria a sua disposição para “despezas ordinárias” a oitava parte das “sobras das rendas da respectiva Província”, situação que o tornaria “sócio”, no entender do redator, da própria Junta:

“Este artigo [25] rigorosamente fallando constitue entre o Concelho Provincial, e a Juncta da Fazenda Pública uma sociedade, em que o Concelho é Sócio na oitava parte dos lucros, e por isso lhe dará incontestavelmente o direito de exigir contas da Juncta da Fazenda para saber se com effeito taes lucros houve ou não. Se os não houve, não tem o Concelho o direito de os-exigir, mas nem por isso fica dispensado o Sócio administrador de appresentar as contas. Não ha ninguém que ignore que as contas são devidas entre os Sócios, ainda que notoriamente tenhão havido prejuízos, e não lucros na Sociedade. Pode ser real, mas pode ser apparente o prejuízo, pode ser o prejuízo causado por má administração do Sócio administrador; pode ser que bem se não arrecade, e tudo isto deve ser presente ao Sócio, que tem o meio do $\mathrm{n}^{\circ} 6$ do art. 24 para providenciar. As Junctas da Fazenda fascinadas talvez com o pomposo tratamento de Magestade, que costumeiramente se-lhes-dá, se julgão fora da obrigação de appresentar estas contas, não reconhecendo a superioridade nos Concelhos Presidenciais. Verdade é que os Concelhos Presidenciais não são superiores legítimos das

\footnotetext{
${ }^{232}$ ACP, v.86, sessão de 27/11/1828, pp.207-208. Cerca de três anos antes, o conselheiro Manoel Joaquim de Ornellas já havia proposto que, em virtude da "falta da necessaria clareza e methodo das contas da receita e despeza” enviadas pelas Câmaras Municipais, era fundamental que essas enviassem, conforme previsto por lei, seus respectivos livros de finanças, o que foi positivamente votado pelo Conselho. Cf. sessão do dia 27/10/1825, p.73.
} 
Junctas da Fazenda, mas a appresentação das contas não faz a Juncta inferior ao Concelho; assim como a mesma prestação de contas não constitui um Sócio superior a outro Sócio. O Concelho não pode repreender a Juncta pelos defeitos que encontrar nas contas, mas pode usar da faculdade dos objetos $6^{\circ}$ e $8^{\circ}$ do art. 24; não é superior para mandar, para obrigar, mas é competente para apresentar”. 233

Para o redator de $O$ Farol, o que estava em jogo não era simplesmente a possibilidade de uso de recursos públicos por parte do Conselho, mas a legitimidade que o artigo 25 imputava-lhe para fiscalizar as contas da província e apontar possíveis abusos (“objeto” $6^{\circ}$ do artigo 24) na sua administração, especialmente num período em que a situação da Fazenda de São Paulo sofria com os constantes déficits e carestia de meio circulante. O próprio Ministério dos Negócios do Império já havia feito circular uma portaria, em 15 de julho de 1825, ordenando que os presidentes de província, juntamente com seu Conselho privativo, dirigissem ao governo central dados sobre abusos na administração do tesouro provincial. ${ }^{234}$

Não foram localizados registros que atestassem a efetiva utilização da oitava parte das sobras das rendas provinciais pelo Conselho da Presidência de São Paulo, direito que provavelmente não foi de execução simples. Províncias como Minas Gerais, Bahia e Pernambuco tiveram problemas no cumprimento desse princípio, especialmente pela falta de sintonia entre os governos provinciais e suas respectivas Juntas da Fazenda. Em 1827, o presidente da Bahia enviou um ofício ao Ministério solicitando que esse interviesse na remessa das “sobras” provinciais, uma vez que a Junta da Fazenda baiana se negava a fazêlo. Na maior parte dos casos, as Juntas alegavam que os cofres provinciais não contavam

\footnotetext{
${ }^{233}$ O Farol Paulistano, no 253, 03/10/1829.

${ }^{234}$ CALÓGERAS, Pandiá. A política monetária do Brasil. São Paulo: Companhia Editora Nacional, 1960. Ver, especialmente, os capítulo de 1 a 4.
} 
com o referido dinheiro, daí a impossibilidade de repassá-lo aos Conselhos da Presidência. $^{235}$

A atuação fiscalizadora do Conselho da Presidência de São Paulo não se restringia às finanças públicas. Valendo-se dos “objetos” $3^{\circ}$ (vigiar sobre os estabelecimentos de caridade, prisões, e casas de correção e trabalho), $8^{\circ}$ (dar parte à Assembléia das infrações das Leis, e sucessos extraordinários, que tiverem lugar nas Províncias), $13^{\circ}$ (suspender Magistrados na conformidade do art. 34) e $14^{\circ}$ (suspender o Comandante Militar do comando da Força Armada, quando inste a causa pública) do artigo 24 da lei de 20 de outubro de 1823, o Conselho da Presidência pôs-se a exercer, aos poucos, a função de um órgão voltado para a inspeção dos negócios públicos da Província.

Exemplo da execução desse papel do Conselho se deu em relação à instrução pública provincial. Em outubro de 1828, o conselheiro Rafael Tobias de Aguiar indicou em sessão ordinária que “muitos dos professores Públicos não cumprião os seos deveres”, mas ainda assim “obtião das Câmaras as Attestações do estilo para receberem seos honorarios”. Faziase necessário, portanto, incumbir os juizes de paz de visitarem regularmente as aulas e as escolas de seus respectivos Distritos, elaborarem um relatório sobre o observado que seria enviado às Câmaras e comunicarem o Conselho da Presidência quando fosse conveniente. ${ }^{236}$ A proposta foi aprovada duas sessões depois, acrescendo-se a emenda de que as Câmaras Municipais passariam a ter a obrigação de despachar à Secretaria do Governo uma “informação sobre tal objeto”. ${ }^{237}$

\footnotetext{
235 SLEMIAN, op. cit., pp.193-194.

${ }^{236}$ ACP, v.86, sessão de 16/10/1828, p.158.

${ }^{237}$ ACP, v.86, sessão de 22/10/1828. p.164. A título de esclarecimento, cumpre notar que, durante o Primeiro Reinado e os anos iniciais do período regencial, a maioria das províncias do Império apresentou dificuldades na implementação de cadeiras de instrução pública. Irregularidades na aquisição de diplomas, denúncias contra de professores negligentes e críticas com relação à falta de fiscalização do ensino público - sobretudo das chamadas “primeiras letras” - foram comuns às diferentes províncias do Império. Cf. MOACYR, Primitivo. $\underline{A}$
} 
Fiscalizar era acima de tudo exigir o cumprimento da lei, que se constituiu no principal norte do policiamento da coisa pública por parte do Conselho da Presidência. Em meados de outubro de 1828, Tobias de Aguiar expôs aos demais membros do Conselho que, embora as eleições para Juizes de Paz tivessem ocorrido em todas as Freguesias da Província, alguns dos juizes eleitos não haviam tomado posse do cargo, “ficando assim os Povos privados do beneficio de huma semelhante instituição”. Nesse sentido, sugeriu que as Câmaras Municipais ficassem encarregadas de comunicar o Governo da Província quando a esse respeito, a fim de que se pudesse "accorrer com as precizas providencias para a exacta observancia da Lei”. O conselheiro ainda propôs que se estabelecessem “Instrucções” para a condução dos processos pelos Juizes de Paz, já que parte deles, segundo Tobias de Aguiar, desconhecia as formas de se conduzir a instância processual, o que poderia acarretar em abuso de poder e deturpação da lei. Após algumas ponderações dos membros José Arouche de Toledo Rendon e Nicolau Pereira de Campos Vergueiro - este último solicitou “circunspecção” para a elaboração das “Instrucções” -, a matéria foi aprovada pelo Conselho. $^{238}$

Em alguns casos, a observância das leis pelo Conselho da Presidência acarretava a tomada de medidas mais drásticas. Na sessão ordinária de 27 de outubro de 1827, o Conselho da Presidência mandou suspender Francisco Antonio Diniz Junqueira do exercício do posto de Capitão-mór da Vila de Franca, acusado por diversos setores daquela Vila clérigos, soldados, pequenos comerciantes e funcionários públicos - de ter praticado “infracção das Leis e da Constituição do Império”, tais como "inobediência às ordens do governo”, “violências” para com a população, e “invasão no Poder Judicial”. A despeito do

Instrução e o Império (subsídios para a História da Educação no Brasil), 1823-1853. São Paulo: Companhia Editora Nacional, 1936.

${ }^{238}$ ACP, v.86, sessão de 16/10/1828, pp.157-158. 
conselheiro suplente Antonio José Vaz ter apontado para possíveis desordens que poderiam causar tal afastamento - argumento esse que serviu de justificativa para o seu voto em favor do acusado -, a suspensão foi aprovada pelo restante dos membros. ${ }^{239} \mathrm{O}$ caso se estenderia por mais tempo, adentrando o ano de 1828, e pelo que indicou o parecer emitido pelo conselheiro suplente Toledo Rendon, empecilhos de ordem burocrática contribuíram para a sua morosidade, de modo que o problema acabou sendo levado ao conhecimento do imperador, por decisão do Conselho da Presidência. ${ }^{240}$

Posta em perspectiva diacrônica, a $1^{\mathrm{a}}$ Reunião do Conselho da Presidência da Província de São Paulo enfeixa um conjunto de posicionamentos e procedimentos levados a termo na esfera prática do executivo provincial que, como foi visto acima, conjugaram-se tanto com o processo de institucionalização das bases político-administrativas do Império quanto com as demandas específicas da realidade paulista da década de 1820. As atividades por ele desenvolvidas revelam que, à função de órgão consultivo a serviço da presidência da Província, sobrepôs-se um espaço privilegiado de prática go. Em virtude da demora na regulamentação e convocação dos Conselhos Gerais de Província - lembrando que o congênere paulista foi instalado apenas em dezembro de 1828 -, o Conselho da Presidência compôs, juntamente com a presidência, o principal canal de discussão e prática política provinciais durante os anos iniciais do $1^{\circ}$ Reinado, fato esse que não fugiu à percepção dos coetâneos.

\footnotetext{
239 O Farol Paulistano, n63, 14/11/1827, sessão de 27/10/1827. Além dessa, outras atas do Conselho da Presidência da Província de São Paulo de 1827 encontram-se publicadas no periódico paulista.

${ }^{240}$ ACP, v.86, sessão de 08/11/1828, pp.181-182.
} 
Em dezembro de 1828, antes do término da $1^{\text {a }}$ legislatura do Império e, conseqüentemente, da $1^{\text {a }}$ Reunião do Conselho da Presidência, o Farol Paulistano publicou um artigo sobre as eleições para os futuros deputados, senadores e conselheiros de Província. Conforme o artigo, os cargos de conselheiro geral e da presidência deveriam ser ocupados por "homens de saber”, ou ao menos com "bom senso”, “constitucionais”, e que preferencialmente fossem “conhecedores da Província” e interessados na sua “prosperidade”. Além do que, os Conselhos precisavam ser compostos, na ótica do redator de o Farol, por representantes de diferentes regiões de São Paulo, pois só dessa forma as necessidades reais da Província seriam avaliadas com conhecimento de causa, ajudando também na punição dos “abusos locais”. ${ }^{241}$

Embora as atas do Conselho da Presidência não explicitem de que forma as atividades eram divididas entre seus membros, há indícios de que havia uma tendência, que não chegava a constituir regra geral, em encaminhar certas pautas para aqueles conselheiros ou suplentes que tinham alguma relação com a localidade ou região com a qual se relacionava a matéria em discussão. Caso significativo ocorreu nesse sentido com o curitibano Lourenço Pinto de Sá Ribas, empossado como suplente em agosto de 1828, e que na época trabalhava para Antonio da Silva Prado, futuro Barão de Iguape, na coleta dos dízimos, do imposto do Cubatão de Paranaguá e na arrecadação da Vila do Príncipe, próxima à Curitiba. ${ }^{242}$ Desde seu ingresso no Conselho, Sá Ribas emitiu uma série de indicações e pareceres sobre os melhoramentos a serem feitos nos caminhos da Comarca de Curitiba, sobretudo naqueles que serviam as Vilas do Príncipe, Antonina, Castro e

\footnotetext{
${ }^{241}$ O Farol Paulistano, no $175,24 / 12 / 1828$.

${ }^{242}$ PETRONE, op. cit., 1976, p.49.
} 
Curitiba. ${ }^{243}$ Em meio a essas atividades, Sá Ribas também examinou as contas da Câmara da Vila de Curitiba e propôs a criação de cadeiras de primeiras letras na Freguesia de S. José dos Pinhas (Comarca de Curitiba). ${ }^{244}$

Era comum, aliás, que um membro do Conselho apresentasse projetos de melhoria de infra-estrutura para sua localidade de origem e/ou de interesse econômico. Natural de Sorocaba, Rafael Tobias de Aguiar era um importante comerciante de reses e muares na região, além de deter negócios no ramo da cobrança de impostos de animais e tavernas, chegando o receber o título de Tesoureiro Administrador de Sorocaba entre 1826 e $1829 .^{245}$ Quando conselheiro, propôs a abertura de um correio na sua cidade natal e o estabelecimento de uma povoação na Estrada da Matta, um dos principais caminhos que ligava São Paulo às áreas sulinas criadoras de animais. ${ }^{246} \mathrm{O}$ brigadeiro Manoel Rodrigues Jordão, por sua vez, proprietário de extensas plantações de cana-de-açúcar na região do chamado "quadrilátero do açúcar”, sugeriu no mesmo ano que fosse feita a reedificação de ranchos nas estradas que serviam Itu, São Carlos e Porto Feliz. ${ }^{247}$

Esses casos, se vistos em conjunto, acabam por elucidar uma questão fundamental a respeito da natureza política das Províncias no Império, e que já ecoara no excerto de $O$ Farol Paulistano acima referido. Ao discursar em favor de uma bancada de conselheiros que coligisse representantes de diversas regiões da Província, divisando nessa pluralidade de vozes uma estratégia para viabilizar o “progresso” dos paulistas e, concomitantemente, para

\footnotetext{
${ }^{243}$ Ver, por exemplo, ACP, v.86, sessões de 25/10/1828, pp.167-168; 09/10/1828, pp.179-180; e 12/11/1828, pp.183-184.

${ }^{244}$ Ver, respectivamente, ACP, v.86, sessões de 27/11/1828, pp.208-209, e 12/11/1828, p.185.

245 PETRONE, op. cit., 1976, p.128. Segundo a autora, e no que tange à cobrança de impostos sobre animais em Sorocaba, Tobias de Aguiar prosseguiu uma atividade que remontava a seu bisavô e, mais proximamente, ao seu pai, Antônio Francisco de Aguiar (p.144). Sobre a figura de Rafael Tobias de Aguiar, ver ALEIXO IRMÃO, José. Rafael Tobias de Aquiar: o Homem, o Político. Sorocaba: Fundação Ubaldino do Amaral, 1992, e HÖRNER, op. cit.

${ }^{246}$ Ver, respectivamente, ACP, v.86, sessões de 27/10/1824, p.13, e 10/11/1824, p.19.

${ }^{247}$ ACP, v.86, sessão de 15/12/1824.
} 
abrandar os abusos de poder nas pequenas esferas, o redator de o Farol expôs a problemática do elemento "localista" na política provincial, bem como dos conflitos entre os interesses ditos públicos com aqueles particulares. ${ }^{248}$

É difícil mensurar, tendo-se como objeto de análise as atividades do Conselho da Presidência de São Paulo, em que medida os interesses provinciais se sobrepuseram aos locais e vice-e-versa. Ao que parece, houve uma intersecção entre ambas as esferas que se manifestou ora na atuação dos conselheiros ora na lógica da distribuição das atividades entre os membros do Conselho, tal como pode ter ocorrido em relação a Lourenço Pinto de Sá Ribas e Rafael Tobias Aguiar nas ocasiões mencionadas. Havia casos, entretanto, que os interesses pessoais pareciam se mostrar com mais força. Notemos dois deles.

Cerca de um ano após a convocação da $1^{\text {a }}$ Reunião do Conselho da Presidência de São Paulo, Nicolau Pereira de Campos Vergueiro apresentou ao presidente da Província e aos conselheiros uma memória relativa à construção de duas novas estradas, uma ligando as Vilas de Constituição e Jundiaí, e a outra cobrindo o trecho entre Araraquara, Morro Azul e São Carlos. Embora o Conselho tenha deliberado a favor das duas propostas, inclusive incumbindo Vergueiro da inspeção do caminho que ligaria Constituição a Jundiaí, um conselheiro, o brigadeiro Manoel Rodrigues Jordão, e um suplente, o coronel Francisco Inácio de Souza Queiroz, recusaram-se a votar, pois se deram por “suspeitos” em relação à matéria, termo empregado na época para dizer que um indivíduo tinha envolvimento pessoal com determinada pauta em discussão. Francisco Inácio alegou que era proprietário de dois

\footnotetext{
248 Sobre esse aspecto, Miriam Dolhnikoff atentou para a não similaridade entre os termos "local” e "provincial”, observando o caráter mais restrito do primeiro - atrelado às ambições e disputas pessoais de pequena abrangência ocorridas nas freguesias e vilas - e o alcance mais amplo do segundo, que se reportava à inclusão da Província na composição de um Império em moldes liberais, bem como ao papel a ser por ela exercido na estrutura política imperial. Cf. DOLHNIKOFF, Miriam. O Pacto Imperial: origens do federalismo no Brasil. São Paulo: Globo, 2005.
} 
engenhos na região e sua sogra de um, de modo que o Conselho aprovou a abstenção de voto do Coronel. O brigadeiro Jordão, por sua vez, declarou que a estrada para o Morro Azul “viria talvez a passar pelo seo engenho”. O caráter incerto da alegação do brigadeiro fez com que o Conselho deliberasse que a “suspeição” requerida só seria aceita caso ela se confirmasse no desenrolar dos estudos referentes à “dita picada”. ${ }^{249}$

Opor-se ao traçado de estradas em construção consistia numa atitude corriqueira entre os próprios donos de terras, o que pode ser encarado como um exemplo da interpenetração das esferas pública e privada ocorrida na política do Primeiro Reinado, da qual os Conselhos da Presidência não ficaram alheios. As alegações eram quase sempre análogas àquelas anunciadas pelo brigadeiro Jordão, ou seja, estabelecia-se uma contraposição entre as intenções da administração e determinados interesses pessoais. Havia, é certo, quem defendesse a supressão de tais embargos, mas o fato é o que problemas desse tipo perduraram até mesmo depois de 1836, quando se promulgou uma lei em favor da desapropriação de terras por utilidade pública. ${ }^{250}$

Para a $2^{a}$ Reunião do Conselho da Presidência da Província de São Paulo, que oficialmente teve início em $1^{\circ}$ de outubro de $1830^{251}$, os conselheiros eleitos foram: Manuel Joaquim de Ornellas, Diogo Antonio Feijó, José da Costa Carvalho, Manoel Joaquim

\footnotetext{
${ }^{249}$ ACP, v.86, sessão de 07/02/1825, pp.39-40.

${ }^{250}$ HOLANDA, op. cit, 1964, p.462.

${ }^{251}$ ACP, v.15, sessão de 01/10/1830, p.68. Na realidade, a convocação dos membros da $2^{a}$ Reunião já vinha sendo feita, em caráter extraordinário, desde 30 de maio de 1830, cf. ACP, v.15, sessão de 30/06/1830, p.50. Com efeito, a data de $1^{\circ}$ de outubro marca o início das sessões ordinárias do Conselho da Presidência.
} 
Gonçalves de Andrade, Rafael Tobias de Aguiar e Nicolau Pereira de Campos Vergueiro. ${ }^{252}$ Dos seis membros, três já haviam ocupado o posto de conselheiro na Reunião passada Ornellas, o bispo Andrade e Tobias Aguiar - e dois o cargo de suplente - Vergueiro e Feijó -, de modo que apenas Costa Carvalho não havia ainda tido participação direta do Conselho. A incidência de conselheiros também eleitos deputados para a $2^{\text {a }}$ legislatura do Império aumentou, passando de um para quatro. Costa Carvalho pela Bahia, e Tobias de Aguiar, Ornellas e Feijó por São Paulo, sendo o dois últimos eleitos pela segunda vez consecutiva.

Os suplentes eleitos, por sua vez, foram Antonio Bernardo Bueno da Veiga, José Arouche de Toledo Rendon, Bernardo Jose Pinto Gavião Peixoto e Jose Pedro Galvão de Moura e Lacerda, que já haviam ocupado o cargo na legislatura passada, ao passo que pela primeira vez o fizeram Manoel Joaquim do Amaral Gurgel, Antonio Mariano de Azevedo Marques, Jozé Manoel de França, Joaquim Joze Moraes e Abreu, Francisco Alves Ferreira do Amaral, Jose Matias Ferreira de Abreu, José de Almeida Leme, Lourenço Justiniano Ferreira, Jose Gomes de Almeida e Manoel Inocêncio de Vasconcelos. ${ }^{253}$ Nenhum deles foi eleito deputado para a $2^{\mathrm{a}}$ legislatura, cargo que foi alcançado, além dos referidos conselheiros, pelo ex-suplente Lourenço Pinto de Sá Ribas e pelo secretário do governo paulista Joaquim Floriano de Toledo ${ }^{254}$.

A permanência de vários políticos no âmbito do Conselho da Presidência não significou, no entanto, uma continuidade inexorável da estrutura de funcionamento do órgão. Entre fins da primeira e início da segunda Reunião, alterações substanciais foram

\footnotetext{
${ }^{252}$ MARQUES, op. cit., pp.192-193.

${ }^{253} \mathrm{Ibdem}$.

${ }^{254}$ Joaquim Floriano de Toledo (1794-1875) era flho do cirurgião Francisco de Paula Xavier de Toledo, iniciou jovem na carreira política. Deputado por São Paulo na $2^{\mathrm{a}}, 3^{\mathrm{a}}$ e $4^{\mathrm{a}}$ Legislaturas, foi seis vezes presidente interino da Província de São Paulo, de 16 a 23 de maio de 1848, de 24 de outubro a 7 de novembro de 1864, de 18 de julho a 3 de agosto de 1865, de 3 de março a 8 de novembro de 1866, de 12 de outubro de 1866 a 24 de abril de 1867, e de 24 de abril a 29 de julho de 1868. Foi Secretário do Governo da Província de São Paulo entre 1824 e 1830.
} 
sofridas pelo Conselho, que em parte estavam condicionadas pela gradual institucionalização política e jurídica do Império. Ao fortalecimento político da Câmara dos Deputados, que deslocou para aquela Casa determinadas demandas políticas locais, somaram-se a criação dos juizados de paz, em 1827, e a regulamentação do funcionamento dos Conselhos Gerais de Província e das Câmaras Municipais, ambos ocorridos em 1828.

Em primeiro lugar, a figura do suplente passou a desempenhar uma importância similar a dos conselheiros, dadas às recorrentes ausências dos membros efetivos, o que pode ser explicado tanto pela mobilização política cada vez maior em torno do Rio de Janeiro como pelo envolvimento desses homens em outras atividades políticas. No ano de 1830, por exemplo, os suplentes ocuparam as cadeiras dos conselheiros por quase o ano todo, até mesmo nas sessões ordinárias, ao passo que membros como Costa Carvalho, Vergueiro e Ornellas pouco figuraram durante a $2^{\mathrm{a}}$ Reunião. Tal quadro se aprofundou ainda mais no ano subseqüente, em seguida à aprovação pela Regência do decreto de 12 de agosto de $1831^{255}$, que proibiu os membros dos Conselhos da Presidência e das Câmaras Municipais serem também, simultaneamente, dos Conselhos Gerais. Posteriormente à promulgação da resolução, alguns suplentes optaram por ocupar cadeiras no Conselho Geral, atitude que fez com que o da Presidência suspendesse por quase dois meses suas atividades para legalizar a situação de novos suplentes. $^{256}$

Em segundo lugar, com a implementação do Conselho Geral da Província de São Paulo, ocorrida em dezembro de 1828, o Conselho da Presidência alterou parte da sua sistemática de trabalho. A principal atribuição dos Conselhos Gerais era, segundo a Carta de

\footnotetext{
255 "Decreto de 12 de agosto de 1831 - declara que os membros dos Conselhos das Províncias e os das Câmaras Municipais não o podem ser dos Conselhos geraes”, in Coleção das Leis do Império do Brasil de 1831. Rio de Janeiro, Tipografia Nacional, 1876, p.46.

${ }^{256}$ ACP, v.15, sessões de 20/10/1831 e 12/12/1831.
} 
1824, "propor, discutir e deliberar sobre os negócios mais interessantes de suas províncias; formando projetos peculiares e acomodados às suas localidades e urgências”257 competências que de certo modo já haviam sido asseguradas ao Conselho da Presidência pela lei de 20 de outubro de 1823 -, o que implicou na adequação de atividades para evitar superposições.

Na prática, o Conselho da Presidência eximiu-se de algumas funções que até o momento tinham sido habituais na sua agenda de trabalhos. Se até 1828 o órgão ocupara boa parte de suas sessões com a discussão de projetos elaborados tanto pelo presidente como pelos conselheiros, a partir de 1829 houve um decréscimo significativo na apresentação de propostas, especialmente daquelas direcionadas para a melhoria da infra-estrutura da Província. As representações oriundas das Câmaras Municipais e de particulares que tinham como finalidade encaminhar alguma medida propositiva, como a criação de cadeiras de primeiras letras ou a construção de estradas, também viram-se reduzidas em quantidade. Além disso, em virtude da lei que regulamentou o funcionamento das Câmaras Municipais ${ }^{258}$, foram os Conselhos Gerais que passaram a fiscalizar as contas da autoridade municipal. ${ }^{259}$

Esses casos lançam luz sobre outra alteração ocorrida no perfil do Conselho da Presidência entre o fim da $1^{\mathrm{a}}$ Reunião e o início da ulterior. Em verdade, trata-se menos de

\footnotetext{
${ }^{257}$ Cf. Artigo 81 da "Constituição Política do Império do Brasil” in BONAVIDES, Paulo \& AMARAL, Roberto (orgs.). Textos políticos da História do Brasil. Brasília: Senado Federal, 2002, v.1 (Formação/Império), doc. 318.3. Disponível no site www.cebela.org.br.

258 "Lei de $1^{\circ}$ de outubro de 1828 - Dá nova fórma as Câmaras Municipaes, marca sua attribuições, e o processo para a sua eleição, e dos Juizes de Paz", in Coleção das Leis do Império do Brasil de 1828, op. cit., pp.74-88.

${ }^{259}$ Em 1833, após receber uma representação da Câmara Municipal da Vila de Areias sobre a situação do saldo de suas rendas, o Conselho da Presidência pediu que a municipalidade recorresse ao Conselho Geral, "visto ser de sua attribuição tomar conta das rendas das respectivas Camaras”, cf. Atas do Conselho da Presidência da Província de São Paulo (1832-1834) (ACP). In: Boletim. São Paulo: Arquivo do Estado de São Paulo, 1962, v.16, sessão de 18/04/1833, pp.145-146.
} 
uma mudança do que da exacerbação de uma característica preexistente: a de arbitrar sobre os problemas relativos à administração pública provincial. Ao atenuar sua função de órgão proponente de medidas/projetos de maior alcance, o Conselho da Presidência dedicou-se ao encaminhamento de conflitos e tensões engendrados no âmbito da esfera jurídicoadministrativa provincial, bem como no intercurso desta com a sociedade, de forma que as representações sobre querelas envolvendo particulares e os chamados “conflitos de jurisdição” entre as autoridades tornaram-se objetos privilegiados de apreciação.

No tocante à questão das disputas envolvendo particulares, é paradigmático um caso ocorrido em outubro de 1830. Nesta época, recebeu o Conselho da Presidência o requerimento de Fidélis José da Silva, um Alferes Quartel Mestre da Vila de Curitiba, cujo intuito era solicitar a sua isenção do cargo de Escrivão do Juiz de Paz da mencionada Vila. Segundo o Alferes, a Câmara de Curitiba estava compelindo-o a servir o cargo, muito embora ele já tivesse apresentado à autoridade municipal um "Documento" assinado pelo seu "Chefe" no qual indicava que Fidélis já estava comprometido com a guarda do armamento do Regimento de Cavalaria de $2^{\mathrm{a}}$ Linha da Vila de Curitiba. Após examinar o parecer do suplente Joaquim Jozé de Moares Abreu, que expendeu ser justa a solicitação do Alferes, o Conselho decidiu a favor do mesmo, chamando a atenção para a importância do serviço militar por ele prestado. ${ }^{260}$ É de se frisar que, neste caso e em outros semelhantes, o Conselho da Presidência deliberou sobre a matéria sem a intervenção de outra esfera de poder.

Quanto às contendas entre autoridades, a situação era mais complexa e morosa, de modo que grande parte das matérias, após deliberação do Conselho da Presidência, acabava sendo despachada ao imperador, tal como ocorreu no conflito de jurisdição entre o ouvidor

\footnotetext{
${ }^{260}$ ACP, v.15, sessão de 18/10/1830, pp.94-95.
} 
da Comarca de São Paulo, Cândido Landislau Japi-Assu, e o juiz de fora da capital paulista, Joaquim Alexandre Antonio Alvim, em 1830. Ao receber os papéis referentes às queixas feitas pelo juiz de fora sobre a conduta tomada pela Ouvidoria na prisão de um individuo no bairro da Luz, o conselheiro Diogo Antonio Feijó indicou que os mesmos fossem remetidos ao ouvidor para que esse elaborasse sua defesa até a próxima reunião do Conselho, o que foi aprovado pelos demais membros. Na sessão seguinte, apresentada a defesa do ouvidor, deliberou-se que o conselheiro Manoel Joaquim do Amaral Gurgel a examinasse e emitisse um parecer. Uma semana depois, o Conselho decidiu de acordo com o parecer, fazendo cumprir a sentença do juiz de fora. Por fim, a resolução foi encaminhada tanto ao corregedor da Comarca de São Paulo quanto ao imperador. ${ }^{261}$

Levando-se em conta outros casos que obtiveram desfechos similares ao do juiz de fora de São Paulo, faz-se mister sublinhar que, não obstante a lei de 20 de outubro de 1823 prever que a atribuição de decidir os conflitos de jurisdição entre as autoridades fosse uma solução temporária para o problema em questão (objeto $12^{\circ}$, art.24), o Conselho da Presidência acabou atuando determinantemente na condução dos desentendimentos entre diferentes esferas da administração pública. Nesse sentido, vale ressaltar que, mesmo com a criação do juizado de paz ${ }^{262}$, em 1827, e com os amplos poderes conferidos aos respectivos juizes eleitos, a reordenação da magistratura no Império demorou a se consolidar, posto que o novo Código de Processo Criminal só seria concluído anos mais tarde, no final de 1832. Assim, nesse ínterim, o Conselho da Presidência operou como importante interlocutor e

${ }^{261}$ ACP, v.15, sessões dos dias 15/11/1830, 18/11/1830 e 25/11/1830.

262 "Lei de 15 de outubro de 1827 - Crea em cada uma das freguezias e das capellas curadas um Juiz de Paz e supplente", Cf. Coleção das Leis do Império, op. cit. Segundo a referida lei, previa-se que cada freguesia passaria a ter um juiz de paz eleito do mesmo modo que os vereadores. As atribuições conferidas aos juizes de paz eram variadas, dentre elas iniciar um processo criminal, julgar pequenos conflitos, fiscalizar as posturas policiais das Câmaras Municipais, fazer destruir quilombos e comandar as forças armadas em caso de ameaça à ordem estabelecida. Sobre o juizado de paz no Império, ver Cf. FLORY, Thomas. El juez de paz y el jurado em el Brasil imperial. México: Fondo de Cultura Econômica, 1986. 
mediador das autoridades judiciárias, criando inclusive uma jurisprudência frente à interpretação das leis e situações que não mais podiam ser analisadas pelas práticas passadas.

\subsection{Os presidentes e seu conselho privativo}

Se a convivência entre os integrantes, ao que parece, não foi conflituosa a ponto de embargar os trabalhos do Conselho, aquela estabelecida com os sucessivos presidentes da Província de São Paulo também não parece ter apresentado maiores problemas.

No tocante a Lucas Antonio Monteiro de Barros, o primeiro presidente da Província de São Paulo e cujo governo se estendeu entre $1^{\circ}$ de abril de 1824 e 5 do mesmo mês de 1827, o relacionamento estabelecido foi aparentemente produtivo. Figura assídua no Conselho, Monteiro de Barros propôs projetos que de fato foram implementados, tal como a instalação do Seminário da Glória - destinado à instrução de meninas órfãs -, a fundação de uma biblioteca pública para a cidade de são Paulo, e a restauração do Jardim Público da cidade (chamado até então de Jardim Botânico, e que havia sido fundado em 1799 pelo capitão-general Antonio Manoel de Mello Castro e Mendonça). ${ }^{263}$ Em abril de 1825, Rafael Tobias de Aguiar propôs que fosse dirigido às Câmaras Municipais da Província um ofício elogiando o desempenho do presidente até então. ${ }^{264}$ Para o redator de O Farol Paulistano, Congonhas do Campo foi responsável pela harmonização política da Província, dirimindo as rivalidades e aplicando a justiça com imparcialidade:

\footnotetext{
${ }^{263}$ ACP, ver, respectivamente, sessões de 24/11/1825, 09/12/1825, 27/10/1825.

${ }^{264}$ ACP, sessão de 03/10/1825, pp.50-51.
} 
"Ele consolidou todos os partidos, fez esquecer as rivalidades, intrigas e harmonizou a Província, e até fez perder de memória os odiosos nomes de tamoyo e pé-de-chumbo, que tão injustamente (pela maior parte) se cruzavam de partido a partido; e só a igualdade na distribuição da mais imparcial justiça para com uns e outros foi o salutar anódino que sarou uma chaga, que metia medo a quem via os progressos que diariamente ia fazendo”. 265

É difícil dimensionar as implicações subjacentes à atitude de Tobias Aguiar e à fala de O Farol. Levando-se em conta, todavia, que ao Barão de Congonhas do Campo foram creditados esforços para a abertura e conserto de estradas em toda a Província, e que homens como Tobias Aguiar e José da Costa Carvalho faziam parte de importantes grupos econômicos - o primeiro era proprietário na região de Sorocaba e comerciante de reses e muares, ao passo que o segundo tinha fazendas de açúcar e café na região de Itu, São Carlos e Campinas -, o incremento da construção de uma infra-estrutura de transportes e comunicação adequada constituía uma forma de assegurar os interesses desses grupos. Vale frisar, nesse sentido, que Monteiro de Barros teve participação importante na abertura, em 1827, da estrada que ligava Santos a Cubatão. ${ }^{266}$

O sucessor de Congonhas do Campo foi o bacharel em Leis Thomaz Xavier Garcia de Almeida $^{267}$, que ocupou a presidência da Província de 19 de dezembro de 1827 até 18 de

${ }^{265}$ O Farol Paulistano, $n^{\circ} 10,11 / 04 / 1827$.

${ }^{266}$ Em 17 fevereiro de 1827, durante o governo de Lucas Antonio Monteiro de Barros, finalizou-se a estrada por terra que ligava Santos à Cubatão e que havia sido iniciada pelo antigo governador da Capitania de São Paulo Antonio Manoel de Mello Castro e Mendonça, no final do século XVIII. Com cerca de $13 \mathrm{~km}$ de extensão, o caminho exigiu a implementação de quatro pontes, que se situavam em determinados locais onde o "entulhamento" não foi possível. Após a conclusão da obra, tornou-se possível a construção de ranchos e pousos ao longo do caminho entre Cubatão e Santos, iniciativa que se conjugava em grande medida com os interesses dos setores articulados com a produção e comercialização do açúcar do planalto. Cf. PERALTA, Ines Garbuio. O Caminho do Mar: subsídios para a História de Cubatão. Cubatão: Prefeitura Municipal de Cubatão, 1973.

${ }^{267}$ Thomaz Xavier Garcia d'Almeida (1792-1870) era natural do Rio Grande do Norte. Formado em Direito pela Universidade de Coimbra, foi nomeado, já no Brasil, aos cargos de Juiz de Fora da vila do Recife (1821); Provedor da Fazenda dos Defuntos e Ausentes, Resíduos e Capelas do Recife; Ouvidor da cidade do Recife (1824); Provedor da Fazenda dos Defuntos e Ausentes, Resíduos e Capelas do Recife (1825); Desembargador da Relação da Bahia (1827). Em 19 de dezembro de 1827 foi nomeado presidente da província de São Paulo, 
abril de 1828. Segundo artigo publicado no Farol Paulistano na ocasião da tomada de posse de Garcia de Almeida, as intenções do novo presidente não destoavam das do seu antecessor:

“Segunda feira 17 do corrente entrou n'esta Cidade o Exm Sr. Thomaz Xavier Garcia de Almeida, Presidente d'esta Provincia (...) S. Exc. Traz sem dúvida optimas intenções, e nos consta, que as estradas vão ser objecto de seus cuidados e disvellos. Este é o maior bem que S. Exc. Póde fazer aos Paulistas, pois alem das razões geraes que cabem a todos os povos acerca de transito, communicações, e transportes, a Provincia de São Paulo está em muito peculiares circunstancias para mais instantemente reclamar do seu Governo a maior actividade e pressa na facilitação dos meios de transportar seus gêneros. Estradas de carro desde as Villas, que produzem os generos de exportação indispensaveis se fazem até o pico da serra, a qual deve ser explorada cuidadosamente e pelos dados, que já temos para também se tornar transitavel de carro. Não duvidamos que seja esse o primeiro empenho do Exm $^{\circ}$ Sr. Garcia d' Almeida, a quem d'esde já afiançamos, se assim o fizer, as bênçãos, os louvores, e reconhecimento de todos os Paulistas”. ${ }^{268}$

A curta presidência de Thomaz Xavier Garcia de Almeida foi seguida pela de José Carlos Pereira de Almeida Torres ${ }^{269}$, que ocupou o cargo ente 13 de janeiro e 9 de março de 1829, e de 10 de outubro desse ano até 14 de abril do seguinte. Assíduo nas reuniões do Conselho da Presidência, Almeida Torres teve participação efetiva na condução do processo

cargo que ocupou até 18 de abril de 1828. Foi deputado pela província de Pernambuco na primeira legislatura do Império (1826-1829) e na $5^{\text {a }}$ (1843-1844). Foi nomeado Presidente de Província três vezes, ocupando o cargo em São Paulo, Pernambuco e Bahia. Cf. EGAS, op. cit., pp.29-30. Em virtude das Atas referentes ao ano de 1827 e aos primeiros meses de 1828 não terem sido encontradas nos arquivos pesquisados, foram poucas as informações obtidas em relação ao sucessor de Congonhas do Campo no que diz respeito a sua atuação no Conselho da Presidência.

${ }^{268}$ O Farol Paulistano, n $73,19 / 12 / 1827$.

269 José Carlos Pereira de Almeida Torres (1799-1850), segundo Visconde de Macaé, era natural de Salvador. Filho do desembargador José Carlos Pereira e Ana Zeferina de Almeida Torres, formou-se em Direito. Foi Presidente de Província em três oportunidades, ocupando o cargo no Rio Grande do Sul (entre 8 de janeiro a 29 de março de 1831) e três vezes em São Paulo (ente 13 de janeiro e 9 de março de 1829 e de 10 de outubro desse ano até 14 de abril do seguinte, e de 17 de agosto de 1842 a 27 de janeiro de 1843). Ocupou a cadeira de senador do Império de 1843 a 1850. Foi elevado a Visconde em 1829, obtendo a grandeza de Macaé em 1847. Cf. EGAS, op. cit., pp.33-34. 
de acomodação dos colonos alemães nas imediações da freguesia de Santo Amaro, na capital paulista ${ }^{270}$, bem como no acompanhamento das obras referentes à estrada que ligava Cubatão à Vila de Santos. Expendeu, ainda, a respeito de queixas encaminhadas por empregados públicos, da alta nos preços dos gêneros de primeira necessidade em São Paulo e do pagamento de dízimos pelas populações. ${ }^{271}$ No entanto, iniciativas como essas não fizeram de seu governo objeto de chancela unânime. Após a remoção de Almeida Torres da presidência da Província de São Paulo para a de São Pedro do Rio Grande do Sul, o Farol Paulistano publicou um artigo no qual se eximia de emitir juízos sobre o ex-presidente, embora destacasse que sua saída fosse “conveniente a ele, e talvez à Província”:

“Consta que o Sr. Jose Carlos Pereira de Almeida está despachado presidente da Província de S. Pedro do Sul, e que para esta nossa vem o Sr. Aureliano de Sousa e Oliveira Coutinho, que foi juiz de Fora em S. João d’El Rei, e ultimamente Ouvidor da Commarca de Ouro Preto, Deputado pela Provincia de Minas Gerais.

Nada diremos do Sr. Jose Carlos, senão que d'ora em diante era mesmo mais conveniente a elle, e talvez á Província, que elle não continuasse a regel-a.

Quanto ao seu Sucessor não podemos aventurar juiso: suas acções como presidente o classificão. Nesta Provincia só não é bom presidente quem não o quer ser; ser Constitucional franco, e illustrado, eis o segredo de agradar aos Paulistas. A Provincia de S. Paulo não é dirigida por tres ou seis homens, tem uma grande massa de proprietarios, independentes, e sizudamente amigos da liberdade Constitucional, e da ordem, que se não move a arbitrio de quem o quer fazer; e esta massa forte e sizuda é quem dá a esta Provincia esse caracter respeitavel, que ella tem sempre apresentado, e que tanto ódio dos mandões de todas as

\footnotetext{
${ }^{270}$ Sobre o tema da inserção de famílias alemãs na cidade de São Paulo na primeira metade do século XIX, ver PETRONE, Pasquale. Aldeamentos paulistas. São Paulo: Edusp, 1995; SIRIANI, Sílvia Cristina Lambert. Uma São Paulo alemã : vida quotidiana dos imigrantes germânicos na região da capital paulista (1827-1889). Dissertação de mestrado apresentada ao Departamento de História da Faculdade de Filosofia, Letras e Ciências Humanas da Universidade de São Paulo. São Paulo, 2001; RIBEIRO, Evanice Maria Högler. Os alemães dos núcleos coloniais de Santo Amaro e Itapecerica da Serra (1831/1914). Tese de doutorado apresentada ao Departamento de História da Faculdade de Filosofia, Letras e Ciências Humanas da Universidade de São Paulo. São Paulo, 2002;

${ }^{271}$ Ver, sobre essas questões, ACP, sessões de 04/11/1829, 07/11/1829 e 23/12/1829.
} 
monarchias lhe tem desafiado. Se alguns d'elles atribuem tudo a alguns poucos habitantes da Provincia, emprestando-lhe uma preponderancia, que deshonra a massa geral dos habitantes, é unicamente para melhor encobrirem seus erros, e porventura crimes, e para terem defeza fácil nas banaes desculpas - alguns intrigantes, alguns poucos homens, que querem dobrar todas as autoridades aos seus caprichos, forão os que me malquistarão na Província.

Venha pois o Sr. Aureliano; e se quiser tomar por modelo algum dos seus antecessores, cuidamos que incontestavelmente merece a preferencia o Sr. Visconde de Congonhas do Campo. Não dizemos que foi isento de defeitos, e nem é dado aos homens aspirar, ou pretender a perfeição mas foi bem bom Presidente. E ninguém dirá, que foi escravo do tal punhado de intregantes; fez bem reaes á Provincia; não se encostou a partido algum (o que não fez nem um dos seus sucessores) antes pelo contrario, ou desmanchou, ou mitigou os existentes, e isto conseguiu admnistrando recta e imparcial justiça a uns e a outros; promoveu a instrução publica quando entendeu e poude; fez estabelecimentos uteis, e de caridade; foi muitissimo solicito em facilitar os transportes, melhorando as estradas existentes, e fazendo abrir outras. Este é um dos mais seguros caminhos que tem os Presidentes d'esta Provincia de alcansarem o amor dos povos d'ela. Em fim era economico, assiduo no trabalho, e mais que tudo não deu um só exemplo de immoraidade, ou indecencia. Outro tanto, e muito menos ainda, não poderíamos dizer dos outros, sem que nos arriscássemos a um desmentido formal, sem replica. Quem souber das nossas relações actuaes com o homem de quem fallamos, não nos taxará de parcial”. ${ }^{272}$

O cerne do artigo era, na realidade, cogitar um perfil desejado de presidente para São Paulo, lançando sugestões a Aureliano Coutinho, o presidente indicado Uma nova remissão à figura de Congonhas do Campo, portanto, não era gratuita, e muito menos eram as características sublinhadas pelo redator sobre um setor específico por ele identificado entre os "Paulistas”, isto é, os proprietários de terra alinhados a uma concepção liberal de estado monárquico. De acordo com o artigo, era essa "massa forte e sizuda” que conferia respeitabilidade à Província; por conseguinte, um bom presidente teria que contemplar as demandas desses homens, como por exemplo dar ênfase à construção e à manutenção de

\footnotetext{
${ }^{272}$ O Farol Paulistano, $\mathrm{n}^{\circ}$ 406, 23/10/1830. Grifo do redator do jornal.
} 
estradas, o que garantiria uma infra-estrutura de transportes adequada para o escoamento das lavouras de mercado do planalto paulista.

Aureliano de Souza e Oliveira Coutinho ${ }^{273}$ tomou posse da presidência da província em 5 de janeiro de 1831, e nela permaneceu até 16 de abril do mesmo ano. Com apenas quatro participações em sessões do Conselho, uma vez que seu governo situou-se fora do período regular de funcionamento do órgão, Oliveira Coutinho foi quem por menos tempo ocupou o governo provincial no $1^{\circ}$ Reinado. Nas sessões extraordinárias do Conselho da Presidência que convocou não chegou a propor atividades ou projetos de autoria própria, mas por outro lado conferiu espaço para a admissão de professores de primeiras letras, para a leitura de representações e para os negócios relacionados à melhoria do "Caminho de Santos”. 274

Com a saída de Oliveira Coutinho da presidência poucos dias após a Abdicação, foram necessários cerca de dois meses para que outro nome assumisse o cargo. Indicado pela Regência Trina Provisória, o coronel do Exército Manoel Theodoro de Araújo Azambuja $^{275}$ governou a Província de 20 de junho a 16 de novembro de 1831. Promover o "progresso" do comércio e da agricultura bem como beneficiar as estradas eram, segundo discurso proferido na ocasião de sua posse, seus principais objetivos. ${ }^{276}$ Por essa época, o

\footnotetext{
${ }^{273}$ Aureliano de Souza e Oliveira Coutinho (1800-1855), Visconde de Sepitiba, era natural de Vila Real da Praia Grande, hoje Niterói, Rio de Janeiro. Filho do Coronel de Engenheiros Aureliano de Souza Coutinho e Francisco Flávia Proença Coutinho, formou-se em Direito pela Universidade de Coimbra, em 1825. De volta à América, iniciou-se na magistratura como Juiz de Fora e Ouvidor em São João Del Rei e Ouro Preto. Iniciou sua carreira política após seu regresso ao Rio de Janeiro. Ali foi deputado pela segunda legislatura (18301833). Foi ainda presidente da Província de São Paulo (1830), Juiz de Órfãos e Intendente Geral da Polícia do Rio de Janeiro. Na década de 1830, foi ministro da Justiça, dos Negócios Estrangeiros e senador do Império entre 1842 e 1855. Cf. SISSON, op. cit.

${ }^{274}$ Ver ACP, v.15, sessões de 18/01/1831, 21/01/1831, 26/03/1831 e 11/04/1831, pp.135-142.

${ }^{275}$ Manoel Teodoro de Araújo Azambuja (1780-1859), Coronel do Exército, era natural do Rio de Janeiro. Filho do capitão Manoel de Araújo Gomes e Ana Felícia de Figueredo Araújo, entrou para a tropa de primeira linha aos 14 anos. Foi presidente da Província de São Paulo entre 20 de junho e 17 de novembro de 1831.

${ }^{276}$ Pronunciamento de Manoel Teodoro de Araújo Azambuja na ocasião de sua posse, publicado em $O$ Observador Constitucional, nº 158, 27/06/1831.
} 
periódico O Observador Constitucional teceu alguns comentários positivos sobre o novo presidente, relembrando os serviços por ele prestado no Rio de Janeiro:

“Tem finalmente S. Paulo a sua testa um bom esposo, bom pai, bom cidadão. Na qualidade de juiz de paz da freguezia de S.José, da cidade do Rio de Janeiro, o sr. Manoel Theodoro mereceu sempre o amor dos seus com-parochianos, e louvores da bocca de todos os homens amantes do Brasil, e das novas instituições (...) Algumas difficuldades porem encontrará o sr. Presidente na promoçao dos bens que promette fazer à provincia, mas a sua Constancia poderá vencer muitos obstáculos, se não todos, e é essa constancia que nós esperamos, que tenha o sr. Presidente”. 277

Recorrente envolvimento nos negócios provinciais teve Araújo Azambuja, não obstante sua presidência relativamente breve. Além de ter trabalhado no sentido de garantir a manutenção da ordem pública em meio à reviravolta política eclodida pelo 7 de abril, Araújo Azambuja teve participação ativa na condução dos negócios relativos ao aprimoramento da infra-estrutura provincial. Em concordância com seu conselho privativo, propôs medidas referentes ao conserto do trecho serrano do Caminho do Mar, à melhoria das condições de moradia das internas do Seminário da Glória e à remoção de Oficiais do Estado Maior do Comando das Fortalezas, tendo em vista baixar os gastos do Tesouro Provincial. $^{278}$

À retirada de Araújo Azambuja sucedeu-se a presidência de Rafael Tobias de Aguiar, a mais extensa de todo o período, e que durou de 17 de novembro de 1831 a 27 de maio de 1834 , e de 14 de setembro deste ano até 10 de maio de $1835{ }^{279}$ Figura de destaque entre os “moderados” paulistas, Tobias de Aguiar já havia sido eleito uma vez deputado

277 O Observador Constitucional, no $158,27 / 06 / 1831$.

${ }^{278}$ Ver ACP, v.15, sessões de 22/06/1831 a 20/10/1831, pp.146-188.

${ }^{279} \mathrm{O}$ intervalo na presidência de Tobias Aguiar entre maio e setembro de 1834 deve-se ao fato desse político ter tomado assento na Câmara dos Deputados pela primeiro ano da $3^{\mathrm{a}}$ legislatura. 
(1830-1833), duas vezes conselheiro da presidência (1824-1829 e 1830-1833) e duas vezes conselheiro geral (1828-1829 e 1830-1833. Nos quase cinco anos de funcionamento de $O$ Farol Paulistano, Tobias Aguiar foi o único conselheiro da presidência de São Paulo a ser saudado pela folha. ${ }^{280}$

O desempenho de Tobias de Aguiar junto ao Conselho da Presidência foi constante e diversificado, de modo que as atividades destacadas a seguir figuram como exemplos de uma atuação mais complexa e plural. No campo da instrução pública, Tobias de Aguiar deu procedência aos exames para professores de $1^{\mathrm{a}} \mathrm{s}$ letras e à abertura de novas vagas; com relação à infra-estrutura de transportes, enfatizou a realização de consertos em estradas, sobretudo nas Vilas de Itu, São Carlos, São Paulo, Sorocaba, Constituição e Santos; no que tange à ordem pública e à estrutura militar da Província, promoveu a organização de corpos das Guardas Municipais e da Guarda Nacional, e de Companhias de Infantaria; na esfera financeira, fez valer o sistema de fixação das despesas provinciais de acordo com as leis de orçamento do Império; na jurídica, articulou a implantação do Código do Processo Criminal, operou a divisão dos Termos e Comarcas em toda a Província e conferiu espaço à apuração das acusações sobre abusos de poder recebidas pelo Conselho da Presidência; propôs, ainda, nomeações de empregados públicos, a melhoria do serviço de correios entre a capital paulista e o Rio de Janeiro, e medidas relativas à modernização da alfândega da Vila de Santos. Similarmente ao seu predecessor, Tobias de Aguiar buscou ajustar o andamento dos negócios provinciais à política aplicada pela Regência nos seus primeiros anos,

\footnotetext{
${ }^{280}$ Na ocasião, o Farol Paulistano publicou a seguinte nota: "Temos a satisfação de anunciar aos nossos concidadãos a chegada do ilustre Conselheiro o Sr. Rafael Tobias de Aguiar no dia 17, o qual vem tomar assento no Conselho da Presidência, aumentando assim as bem fundadas esperanças, que já tínhamos do profícuo resultado que terão os trabalhos da presente Sessão, pois é bem conhecida de todos a energia, com que este honrado patrício nosso, sempre estranho a considerações particulares, propugna pelos interesses da Província”. Cf. O Farol Paulistano, nº 56, 20/10/1827.
} 
corroborando assim, grosso modo, com a "ala moderada” que chegara ao poder com a retirada de cena do imperador. ${ }^{281}$

Motivo de controvérsia nos primeiros anos do Império, a figura do presidente de Província não poucas vezes foi tratada com reserva pelos coetâneos, em grande medida por causa da imposição feita pela Carta de 1824 de que os chefes do executivo provincial seriam indicados pessoalmente pelo imperador (art. 165). A discussão da matéria gerou polêmica já na época da aprovação da lei de 20 de outubro de 1823, e deputados como o pernambucano Luis Inácio de Andrade Lima e os baianos José Joaquim Carneiro de Campos e Antonio Ferreira França retrataram-na como um instrumento de cerceamento do poder provincial pelo governo central. ${ }^{282}$ No transcorrer das três primeiras legislaturas foram aventados projetos de lei direcionados para a marcação de poderes dos presidentes de Província, questão que perpassou tanto o debate sobre a reforma constitucional quanto a elaboração do Ato Adicional.

Parcialmente reproduzida pela bibliografia, sobretudo por aqueles trabalhos que realçaram a participação dos liberais na construção do Estado Nacional, a idéia de que os presidentes de Província seriam “delegados” ou “representantes” a serviço do monarca pelo fato de serem por ele escolhidos é, contudo, meia verdade, e os próprios Conselhos da Presidência ensejam essa relativização. Isso porque, atribuindo a esses órgãos uma ingerência considerável sobre os negócios provinciais, a lei de 20 de outubro de 1823 acabou imputando às Províncias um poder compartilhado, onde a figura do presidente dividiu com os conselheiros alguns dos atos do executivo provincial. A garantia de serem os

\footnotetext{
${ }^{281}$ A atuação política mais ampla do presidente Rafael Tobias de Aguiar dentro do Conselho da Presidência será analisada, igualmente, no capítulo seguinte.

${ }^{282}$ Ver sessões de 17/06/1823 e 11/10/1823 do Diário da Assembléia Geral Constituinte e Legislativa do Império do Brasil: 1823 (DAG). Brasília, Centro do Senado Federal, 1973, v.1, p.229; e v.3, p..226. Disponível no site www.camara.gov.br
} 
seis conselheiros eleitos da mesma forma que os deputados e senadores, e do cargo de vicepresidente ser ocupado pelo membro mais votado aumentava ainda mais o alcance político do Conselho; além do que, na ausência do presidente e do vice, o conselheiro que havia recebido o maior número de votos ocuparia a presidência da Província. ${ }^{283}$ Ademais, enquanto o presidente de Província poderia ser escolhido pelo imperador em qualquer localidade do Império - o que na prática ocorreu na maior parte das Províncias ${ }^{284}$-, um conselheiro necessitava ter mais de 30 anos e residir, no mínimo, há seis anos na Província a qual representava. ${ }^{285}$ Isso significava, entre outras coisas, o estabelecimento de um corpo representativo composto pelos setores das próprias Províncias e, por conseguinte, a fixação dos interesses políticos locais à administração provincial.

Em São Paulo, a atuação dos presidentes dividiu espaço com a dos vice-presidentes, que por sinal não foi pequena. Somados os períodos em que os vices ocuparam o posto máximo da Província, chega-se a um total aproximado de três anos e meio, ou seja, por volta de um terço do tempo no qual atuou o Conselho da Presidência de São Paulo, o controle do executivo provincial ficou nas mãos de homens escolhidos pelos colégios eleitorais espalhados por toda a Província. Ao cabo de quase dez anos de funcionamento do Conselho da Presidência, por seis vezes um vice chegou a tomar assento na cadeira de presidente, sendo um deles por três ocasiões. ${ }^{286} \mathrm{O}$ vigário capitular e depois bispo diocesano Manoel

\footnotetext{
${ }^{283}$ Cf. arts. 9, 10 e 17 da "Lei de 20 de Outubro de 1823, que dá forma aos Governos das Províncias, creando para cada uma dellas um Presidente e Conselho", in op. cit., p.

${ }^{284}$ TAPAJÓS, Vicente. Organização política e administrativa do império. [Coleção História administrativa do Brasil, v.9]. Brasília: FUNCEF, 1984.

${ }^{285}$ Cf. art. 11 da "Lei de 20 de Outubro de 1823, que dá forma aos Governos das Províncias, creando para cada uma dellas um Presidente e Conselho", in op. cit., p.11.

${ }^{286}$ Foram eles: Luis Antonio Neves de Carvalho, de 22 de abril de 1826 até setembro do mesmo ano, e de 5 de abril até 18 de dezembro de 1827; Manuel Joaquim Gonçalves de Andrade, entre 18 de abril de 1828 e outubro do mesmo ano; entre 10 de março e 9 de outubro de 1829; e de 15 de abril de 1830 até 4 de janeiro de 1831; Manuel Joaquim de Ornellas, de 5 de outubro de 1828 até 12 de janeiro de 1829; e Vicente Pires da Mota, entre 28 de maio e 13 de setembro de 1834. Cf. MARQUES, Manuel Eufrásio de Azevedo. Apontamentos
} 
Joaquim Gonçalves de Andrade ocupou a presidência da Província entre 18 de abril de 1828 e outubro do mesmo ano, entre 10 de março e 9 de outubro de 1829, e de 15 de abril de 1830 até 4 de janeiro de 1831, acumulando um total de quase dois anos à frente da Província de São Paulo no Primeiro Reinado.

Dado curioso é o de que embora tenha conseguido votação expressiva para as duas primeiras Reuniões do Conselho da Presidência, Gonçalves de Andrade nunca chegou a exercer função na Assembléia Geral, perfil destoante dos demais conselheiros, que via de regra ocupavam, concomitantemente, cadeiras nos dois Conselhos (da Presidência e Geral) e no Parlamento, como deputados. É crível que Gonçalves de Andrade não tenha se candidatado ao cargo de deputado, talvez por não corroborar com o posicionamento político daqueles que compunham a Câmara, o principal foco de oposição ao Governo no $1^{\circ}$ Reinado. Há registros de que como, enquanto vice-presidente, entrou em atrito com portavozes da oposição ao Executivo em São Paulo. ${ }^{287}$ Em agosto de 1830, Gonçalves de Andrade comunicou ao Marquês de Caravelas, então ministro do Império, que o jornalista italiano Líbero Badaró vinha sendo responsável por contínuos “ataques e chincalhagens” às autoridades. Pouco tempo antes, partindo de uma denúncia sua, o ministério havia proibido que na cidade de São Paulo fossem encenadas peças de teatro que atentassem contra a ordem pública e as autoridades, e que haviam sido anunciadas pelo O Observador Constitucional. Ademais, ao imputar a Costa Carvalho a responsabilidade por ter acolhido Badaró na cidade de São Paulo, o bispo acabava por insinuar, mesmo que não diretamente, uma suposta cumplicidade entre ambos os redatores:

Históricos, Geográficos, Biográficos, Estatísticos e Noticiosos da Província de São Paulo. São Paulo: Comissão do IV Centenário da cidade de São Paulo, 1954, tomo 1, pp.190-191.

${ }^{287}$ GAETA, Caetano. Líbero Badaró - O sacrifício de um paladino da liberdade. São Paulo: Estabelecimento Gráfico E. Cupolo, 1944. 
"Ilmo. E Exmo. Sr. Marquês de Caravelas: Recebi a Portaria de 21 do mês pp. Pela qual S.M. Imperial, em conseqüência do anúncio publicado no Observador Constitucional n.62 de 25 do mesmo mês findo, é servido ordenar, que eu proíba porem-se em cena os dois Entremezes ali anunciados, e quaisquer outras Peças, cujo fim seja desautorizarem Corporações ou Autoridades, as quais pelo contrário se devem respeitar, e que outro informe eu se dei as convenientes providencias para obstar a representação das mencionadas (...) Por outra parte sou por ora de parecer que o anúncio do Observador não foi se não um improviso de seu Redator, o qual é um italiano de nome Badaró, que em 1828 para aqui mandou o Deputado Dr. Costa Carvalho, e entrou nesta Cidade com o título de grande Médico, mas esse crédito em breve tempo desapareceu. Depois não tendo ainda chegado o Professor de Geometria, ele se ofereceu para ensinar Ciência gratuitamente; eu lho permiti, e lhe franquei uma Aula nos baixos da Casa do Governo, de fato ensinou perto de um ano, com a desgraça de que nenhum dos seus discípulos aproveitou. Por fim não se verificando nele o verso Latino - Dat Galenus opus etc. - passou por acaso a Redator daquela Folha, que tem extração pelos continuados ataques e chincalhagens às Autoridades, e pelas correspondências de intrigas de que é cheia; sendo estas as matérias que a gente miúda lê com apetite, ao menos por ser o que pode entender (...). ${ }^{288}$

Em outra oportunidade, entretanto, a situação foi diferente. Manoel Joaquim de Ornellas, deputado eleito para a $1^{\text {a }}$ legislatura (1826-1829), ocupou a vice-presidência da Província de 5 de outubro de 1828 até 12 de janeiro de 1829. No pouco tempo em que ficou na dianteira da Província, Ornellas teve participação importante na organização da $1^{\text {a }}$ Reunião do Conselho Geral de São Paulo, em dezembro de 1828, como se verá no tópico seguinte.

As fontes consultadas não nos permitiram distinguir claramente a conduta de cada presidente perante os conselheiros, nem constatar se os vice-presidentes estabeleceram uma relação de outra ordem com os mesmos. É certo, porém, que o Conselho da Presidência de

\footnotetext{
${ }^{288}$ Apud GAETA, op. cit., pp.75-76.
} 
São Paulo, independentemente de quem esteve a sua frente, serviu mais como um contrapeso ao poder do chefe do executivo provincial do que como um órgão exclusivamente subordinado às iniciativas presidenciais, mesmo que isso não tenha chegado a fomentar um enfrentamento de pontos de vista ou práticas políticas. Tal característica ganhou maior destaque após a instalação, no final de 1828, do Conselho Geral de São Paulo, órgão que deslocou para si não apenas algumas das atribuições do Conselho da Presidência, mas a discussão mais ampla em torno da criação de uma um poder legislativo nas Províncias.

\subsection{A organização dos Conselhos Gerais de Província}

Se a lei de 20 de outubro de 1823 foi de importância crucial para a organização dos governos provinciais durante os primeiros anos do Império, uma outra instituição foi criada no ano seguinte, pela Carta de 25 de março de 1824, a fim de compor a estrutura políticoadministrativa das Províncias: os Conselhos Gerais de Província. Dado que, além de provisória, a lei de 20 de outubro tinha como objetivo primordial contemplar a esfera executiva do poder provincial, lacunas ainda haviam permanecido, após a dissolução da Constituinte, no que se referia à consolidação de canais efetivos de representação nas Províncias.

A Carta outorgada reconhecia e garantia a todos os cidadãos o direito de "intervir nos negócios de sua província” que fossem "imediatamente relativos a seus interesses particulares”. ${ }^{289}$ Tal direito seria assegurado pelas Câmaras Municipais e pelos Conselhos

\footnotetext{
${ }^{289}$ Cf. art.71, Capítulo V - “Dos Conselhos Gerais de Província e suas Atribuições”, da “Constituição Política do Império do Brasil” in BONAVIDES, Paulo \& AMARAL, Roberto (orgs.), op. cit., p.183.
} 
Gerais de Província, sendo esses últimos criados legalmente a partir daquele momento (art.72).

Os Conselhos Gerais deveriam ser instaurados em todas as Províncias, exceto naquela em que estivesse sediada a capital do Império. Nas mais populosas (Pará, Maranhão, Ceará, Pernambuco, Bahia, Minas Gerais, São Paulo e Rio Grande do Sul) contariam com vinte e um membros, ao passo que nas demais seriam treze integrantes (art.73). Esses seriam eleitos na mesma ocasião e da mesma forma que os deputados e senadores, de modo que a permanência de cada membro no Conselho estaria condicionada à duração de cada legislatura, à semelhança do que ocorria com os Conselhos da Presidência (art.74). Os Conselhos Gerais contariam, ainda, com um presidente e um secretário, ambos escolhidos por aclamação pelos seus membros (art. 78).

As sessões dar-se-iam uma vez por ano, com a duração de dois meses, podendo ser prorrogadas por mais um, caso a maioria dos conselheiros deliberasse nesse sentido (art. 77). No dia da instalação dos Conselhos Gerais, prevista por lei para o $1^{\circ}$ de dezembro de cada ano, os presidentes de Província fariam um discurso cujo objetivo era discorrer sobre o estado dos negócios públicos e instruir os conselheiros a respeito das providências necessárias a serem tomadas na administração provincial (art. 80).

Os Conselhos Gerais teriam como principal atribuição “propor, discutir e deliberar sobre os negócios mais interessantes de suas províncias; formando projetos peculiares e acomodados às suas localidades e urgências” (art. 81), podendo inclusive receber projetos elaborados pelas Câmaras Municipais (art. 82). Não estariam incumbidos de deliberar a respeito de propostas que recaíssem sobre a esfera dos "interesses gerais da nação”, dos 
“ajustes de umas com outras províncias”, da “execução das leis” e sobre aquelas questões cuja iniciativa deveria partir exclusivamente da Câmara dos Deputados (art. 83).

As resoluções dos Conselhos Gerais seriam remetidas "diretamente ao Poder Executivo, pelo intermédio do presidente da província” (art. 84). No caso da Assembléia Geral achar-se reunida por essa época, as resoluções ser-lhes-iam enviadas e revertidas como "projetos de lei a obter a aprovação da assembléia por única discussão em cada câmara” (art. 85). Entretanto, nos períodos de recesso do Parlamento, o imperador poderia mandar executar "provisoriamente" as resoluções ou suspender seu juízo sobre a matéria (arts. 86 e 87). Tanto as resoluções provisoriamente executadas quanto aquelas temporariamente suspensas pelo imperador teriam como destino a Assembléia Geral após sua reabertura, a fim de serem discutidas (art. 88).

Incontornável, essa dupla subordinação - à Assembléia Geral e ao Executivo balizava o alcance político do novo órgão: aos Conselhos Gerais não caberia legislar, mas sim propor matérias que, revertidas em projetos de lei, teriam que necessariamente passar pelo poder decisório dos legisladores e do governo central. Como será observado adiante, os Conselhos Gerais foram recebidos pelos próprios coetâneos como o prenúncio de um legislativo provincial. Por ora vale sublinhar que os Conselhos Gerais estavam inscritos, na própria estrutura da Carta de 1824, como braços do Legislativo, mesmo porque o capítulo que versava sobre tais órgãos foi incluso no Título IV (“Do poder legislativo”).

Embora o artigo 89 indicasse que o método de funcionamento dos Conselhos Gerais fosse determinado, futuramente, por um "regimento" a ser elaborado pela Assembléia Geral, as críticas à matéria foram concomitantes à circulação do Projeto de Constituição entre as Câmaras Municipais e à outorga da Carta constitucional, ambas ocorridas em 1824. Em $1^{\circ}$ 
de fevereiro, a Câmara Municipal de Itu enviou ao imperador algumas "Reflexões” sobre o Projeto de Constituição. Em relação aos Conselhos Gerais, os vereadores ituanos - dentre os quais Diogo Antonio Feijó - propuseram duas alterações que visavam ampliar seus poderes. Em primeiro lugar, reivindicavam que os Conselhos Gerais também pudessem elaborar leis, a fim de auxiliarem no expediente da Assembléia Geral. Em segundo lugar, sustentavam que os Conselhos Gerais deveriam ter o direito de exigir a execução das leis por parte dos presidentes de Província. $^{290}$

Crítica das mais incisivas em relação à maneira como foram concebidos os Conselhos Provinciais partiu de Frei Caneca, um dos principais opositores à Carta outorgada de 1824 e líder da Confederação do Equador. As censuras do clérigo recifense recaíram sobre os artigos 84 a 88 do Capítulo $5^{\circ}$ da Carta de 1824, especialmente no tocante à vinculação dos Conselhos Gerais com a Assembléia Geral e o Imperador, que a seu ver era demasiada centralizadora e ineficaz para os governos provinciais. Ademais, reprovou o artigo 83 no que dizia respeito aos Conselhos Gerais não poderem deliberar sobre a execução das leis no âmbito provincial:

“Os Conselhos das províncias são uns meros fantasmas para iludir os povos; porque devendo levar suas decisões à assembléia geral e ao executivo conjuntamente, isto bem nenhum pode produzir à província; pois que o arranjo, atribuições e manejo da assembléia geral faz tudo em último resultado depender da vontade e arbítrio do Imperador, que arteiramente avoca tudo a si e de tudo dispõe a seu contento, e pode oprimir a nação do modo mais prejudicial, debaixo das formas da lei. Depois, tira-se aos Conselhos o poder de projetar sobre a execução das leis, atribuição esta que parece de suma necessidade ao conselho, pois que este, mais que nenhum outro, deve estar ao fato das circunstâncias, do

\footnotetext{
290 "Reflexões dirigidas ao imperador sobre o projeto da Constituição - ofício da Câmara de Itu de $1^{\circ}$ de fevereiro de 1824", in BONAVIDES, Paulo \& AMARAL, Roberto (orgs.). Textos políticos da História do Brasil. Brasília: Senado Federal, 2002, v.1, documento 68.6 (Disponível no site www.cebela.org.br).
} 
tempo, lugar, etc. de sua província, conhecimentos indispensáveis para a cômoda e frutosa aplicação das leis”. ${ }^{291}$

Com a convocação do Parlamento, em 1826, e a paulatina institucionalização do Estado Nacional, a problemática do funcionamento dos governos provinciais logo veio à tona, de modo que algumas propostas sobre a matéria foram apresentadas já nas primeiras sessões da Câmara dos Deputados. Em 18 de maio de 1826, o deputado pelo Ceará Manoel José de Albuquerque propôs com urgência que os Conselhos Gerais de Província tivessem seus trabalhos regulamentados conforme prescrevia à Constituição, o que foi aprovado. ${ }^{292}$ Concomitantemente, o Senado também discutia a questão. Em 11 de julho de 1826, leu-se na Câmara dos Deputados o projeto sobre os Conselhos Gerais elaborado pelo Senado, que já continha emendas sugeridas por uma comissão. O documento expunha desde a sistemática ordinária do Conselho até a forma de organizar suas sessões, discussões, propostas, comissões, votações e admissão de empregados. ${ }^{293}$

A leitura do texto gerou conflitos entre os deputados. Alguns foram contrários à concepção de que os conselheiros deveriam ser responsáveis pelos seus atos no Conselho, isto é, de que poderiam ser julgados pelo exercício de suas funções. O sistema de votação dos Conselhos, por sua vez, também suscitou polêmica. Francisco de Paula Souza e Mello e José Ricardo da Costa Aguiar ${ }^{294}$ - ambos deputados por São Paulo - defenderam que a

\footnotetext{
${ }^{291}$ CANECA, Frei. “Crítica à Constituição outorgada”, in Ensaios Políticos. Rio de Janeiro: PUC, 1976, p.72.

292 Anais do Parlamento Brasileiro. Câmara dos Deputados (1826-1834). Rio de Janeiro: Tipografia de Hipólito José Pinho e Cia., 1874-1879, tomo 1, sessão de 18/05/1826, pp.81-82.

${ }^{293}$ Ibid., tomo 3, sessão de 11/07/1826, pp.112-126.

294 José Ricardo da Costa Aguiar de Andrada (1787-1846) era natural de Santos, e filho do coronel Francisco Xavier da Costa Aguiar e de Bárbara Ribeiro de Andrada, irmã de José Bonifácio de Andrada e Silva. Formado em Direito pela Universidade de Coimbra, em 1810, dedicou-se sobretudo à magistratura, chegando ao posto de ministro do Supremo Tribunal de Justiça, 1828. Foi deputado por São Paulo nas Cortes de Lisboa, em 1821, na Assembléia Constituinte de 1823, e na $1^{\text {a }}$ Legislatura do Império.
} 
votação dos conselheiros deveria ser “aberta”, e não “fechada” como sugerira o projeto original dos senadores. $^{295}$

No dia em que o texto do Senado chegou ao plenário da Câmara, o também deputado por São Paulo Diogo Antonio Feijó apresentou um amplo projeto sobre “administração e economia das Províncias” que tratava, entre outras questões, da autoridade dos presidentes de Província e da organização dos Conselhos Gerais. Estes, na ótica de Feijó, deveriam ser investidos de maiores poderes a fim de contrabalançar o do executivo provincial. O projeto do padre paulista foi expedido à comissão de leis regulamentares, mas sua discussão foi temporariamente suspensa, em 1827..$^{296}$

A divergência de opiniões quanto ao funcionamento e estrutura dos Conselhos Provinciais tornou o encaminhamento da matéria moroso e indefinido. Em vista disso, o deputado mineiro Bernardo Pereira de Vasconcelos propôs, que os membros da Câmara retirassem suas emendas ao projeto elaborado pelo Senado e aprovassem o texto original. ${ }^{297}$ Havia aqueles, entretanto, como o representante baiano Antonio Ferreira França, que não concordavam com a medida. Diante de posicionamentos tão ambivalentes, evocou-se o recurso da reunião das duas Casas para deliberar sobre assunto, conforme determinava a Constituição nos casos em que a discordância não fosse resolvida. ${ }^{298}$

Passaram-se dois anos sem que a reunião das duas Casas fosse convocada ou que alguma providência sobre a matéria se concretizasse. Em maio de 1828, o deputado por Pernambuco Manoel Caetano de Almeida Albuquerque recomendou uma resolução com o mesmo teor daquela apresentada dois anos antes por Vasconcelos, argumentando que apenas

\footnotetext{
${ }^{295}$ SLEMIAN, op. cit., p.147.

296 Ibid., p.148.

${ }^{297}$ Ibid., p.150.

${ }^{298}$ Ibid., p.151.
} 
as "províncias do sul” estavam "gozando dos benefícios da Constituição”, sendo necessário, pois, estabelecer "sem demora" os Conselhos Provinciais. ${ }^{299}$ Um ano antes, em 1827, o próprio Vasconcelos sugerira que a pauta fosse por hora deixada de lado, porque matérias prementes como a criação dos juizados de paz e do novo regimento para as Câmaras Municipais ainda não tinham recebido a devida atenção dos representantes da nação. ${ }^{300}$

As discussões perduraram até que, em 27 de agosto de $1828^{301}$, aprovou-se o regimento para os Conselhos Gerais de Província tal como havia sido concebido originalmente pelo Senado, com apenas uma emenda feita pelo deputado baiano Luis Paulo de Araújo Bastos, a qual assegurava à Câmara dos Deputados a iniciativa de elaborar um projeto alternativo referente à matéria. Nesse sentido, é difícil indicar uma "vitória" do Senado ante à Câmara dos Deputados, já que a primeira Casa buscaria aprovar, mais tarde, aspectos importantes referentes ao alcance político dos Conselhos Gerais, como se verá adiante. Ainda assim, o regimento foi bastante comentado pelos círculos políticos e pela imprensa. Cerca de dois meses após a aprovação do regimento, o Farol Paulistano publicou um excerto retirado de A Aurora Fluminense assegurando concordar "em tudo" com o redator do periódico fluminense, a essa época o deputado por Minas Gerais Evaristo da Veiga:

299 Anais do Parlamento Brasileiro. Câmara dos Deputados (1826-1834) (APB), op. cit., sessão de 10/05/1828, p.42. A idéia de que a instalação dos Conselhos Gerais abrandaria de algum modo a tensão envolvendo as "províncias do norte" ganhou coro entre os círculos políticos da época. Não cabe aqui discutir a questão, mas há indícios de que os Conselhos Gerais, do ponto de vista dos políticos do período, auxiliariam em escala provincial o processo de normatização do novo Estado. Numa nota referente à re-abertura dos trabalhos do Parlamento, em maio de 1828, o redator de O Farol Paulistano observou a importância da implantação dos Conselhos Gerais para as províncias nortistas: “A organização das Camaras Municipaes entrou logo na Ordem dos trabalhos, bem como os Conselhos Geraes de Província. A respeito d'estes foi, parece, cortado o nó górdio, e agora não terá o Senado mais motivo de retardar esta instituição, que se não der algum alívio às Províncias do Norte, que gemem debaixo do mais pesado jogo, então muito triste futuro lhe antolhamos”. Cf. O Farol Paulistano, n ${ }^{\circ}$ 117, 1828.

${ }^{300}$ SLEMIAN, op. cit., p.151.

301 "Lei de 27 de Agosto de 1828 que dá regimento para os Conselhos Geraes de Provicia", in Coleção das Leis do Império do Brasil de 1828, op. cit., pp.10-24. 
“(...) Um Império, cujos limites se estendem por tantos centos de legoas, e onde o centro não pode de um jacto levar a vitalidade e a administração em todos os pontos, necessariamente devia definhar, sem essas Assembléas locaes, que acudissem as primeiras precisões das Províncias, e illustrassem o Corpo Legislativo sobre suas circunstancias, males e especificos para estes males. É justamente o que nós temos visto acontecer no Brazil, cujos membros dispersos parecião regidos por differentes normas de existencia política (...) Não dizemos que os Conselhos Geraes de Província produzão d'esde já todos os bens que enunciamos; muitas causas coincidem para que os seos resultados practicos se neutralisem não poucas vezes. Mas o habito de intervir nos negócios da comunidade, a publicidade das discussões, d'onde saltão sentelhas, que se communicão a toda a cadêa social, promettem quanto antes incalculável beneficio, afastando da nossa pátria esse ferrenho egoísmo, que tudo pulverisa e anniquila (...) Nas Províncias próximas, como Minas, São Paulo, Espírito Santo, e mesmo na Bahia nós não encontramos difficuldade para que os Conselhos se reunão no $1^{\circ}$ de Dezembro corrente, expedindo-se a tempo as competentes ordens”. 302

Endossadas pelo Farol Paulistano, as reflexões elaboradas pela Aurora Fluminense inclinavam-se para a idéia de que os Conselhos Gerais serviriam como balizas para a definição da esfera política provincial, bem como ajudariam a compor uma uniformidade político-administrativa do Império, que ainda não se consolidara em virtude da vastidão territorial e das “differentes normas de existencia política” que regiam as Províncias. Os Conselhos Gerais não potencializariam as diferenças regionais; ao contrário, porque similares institucionalmente, desempenhariam o papel de “Assembléas locaes” que ilustrariam a Assembléia Geral sobre as “circunstancias” e os “males” de cada Província. Algumas de suas resoluções poderiam ser neutralizadas, mas o "habito de intervir nos negócios da comunidade” já auxiliaria no processo gradual de uniformização política das Províncias. Em outros termos, o artigo dizia respeito ao espaço de representação local e sua

\footnotetext{
${ }^{302}$ O Farol Paulistano, no 159, 23/10/1828, excerto retirado de a Aurora Fluminense.
} 
interlocução com o governo central por outro meio que não o Executivo. No mês seguinte à publicação do referido excerto, o Farol anunciou a venda do regimento dos Conselhos Gerais em sua tipografia, por 100rs, e, em dezembro do mesmo ano, iniciou a publicação do resumo das atividades do órgão. ${ }^{303}$

Com cento e quinze artigos divididos em oito Títulos - "Do Presidente e Secretário”, “Das sessões”, “Das propostas”, “Das discussões”, “Das comissões”, “Do modo de votar”, "Das pessoas empregadas no serviço do Conselho" e "Da polícia” -, o regimento para os Conselhos Gerais formalizou seu funcionamento ordinário e ainda acrescentou algumas atribuições que apenas haviam sido esboçadas pelo Capítulo $5^{\circ}$ da Carta de 1824. De acordo com o artigo 26 (Título II), por exemplo, os Conselhos Gerais deveriam se reunir todos os dias da semana, exceto aos domingos e dias santos. Um dos principais aspectos contemplados pelo regimento foi o da forma como seriam trabalhadas as propostas elaboradas pelos membros dos Conselhos Gerais, bem como das representações emitidas pelas Câmaras Municipais ou por qualquer cidadão. Toda proposta deveria passar, obrigatoriamente, por três leituras, que discutiriam suas “vantagens” ou “inconvenientes”, a pertinência de seus artigos, e a necessidade de eventuais alterações no projeto original (arts. 52 a 70, Título IV). As representações enviadas pelas Câmaras Municipais seriam despachadas a uma comissão permanente (art.71, Título V) encarregada de analisá-las e transformá-las em propostas (arts. 43 a 46, Título II).

\footnotetext{
${ }^{303}$ Ver, respectivamente, O Farol Paulistano, no 168, 29/11/1828, e nº 171, 10/12/1828. A publicação das atas dos Conselhos Gerais - mesmo na forma de excertos ou resumos - constituiu prática comum entre os periódicos de orientação liberal do período.
} 
Instalados com maior ou menor dificuldade de acordo com a conjuntura política de cada Província, os Conselhos Gerais permaneceram como pauta constante nas discussões feitas pela Câmara dos Deputados, que havia ficado de elaborar um projeto a respeito da matéria. Não obstante sua gradual institucionalização, os Conselhos Gerais ainda careciam de um arcabouço legal que garantisse a eficácia de suas deliberações, principalmente porque essas dependiam da intermediação do poder decisório da Assembléia Geral e, por vezes, do governo central. $^{304}$

A Câmara dos Deputados utilizou como projeto alternativo para os Conselhos Gerais parte daquele apresentado por Diogo Antonio Feijó em 1826, de modo que parcela significativa de suas deliberações foi no sentido de ampliar a autonomia desses órgãos e de concebê-los como um contraponto político à autoridade dos executivos provinciais. Ao longo de 1828, medidas importantes foram aprovadas sobre a matéria antes que o texto fosse remetido à apreciação do Senado: a) os presidentes de Província teriam como obrigação prestar aos Conselhos Gerais os devidos esclarecimentos sobre suas deliberações; b) os conselheiros não seriam responsáveis pelo exercício de sua função, embora a Assembléia Geral pudesse, futuramente, marcar sua responsabilidade; c) os conselheiros cujo soldo ou ordenado fosse considerado baixo passariam a receber um subsídio pela sua participação no Conselho; d) os Conselhos Gerais ficariam incumbidos, assim como já o eram o presidente de Província e o Conselho da Presidência desde a lei de 20 de outubro de 1823, de fiscalizar

\footnotetext{
${ }^{304}$ Para se ter uma idéia, a lei de 27 de agosto possuía lacunas com relação à própria padronização no envio das propostas pelos Conselhos Gerais. Apenas em agosto de 1831, quase na metade da $2^{\mathrm{a}}$ Reunião dos Conselhos Gerais, decretou-se o modelo de como deveriam ser encaminhas as decisões desses órgãos ao Governo. Cf. "Decisão do Ministério do Império de 9 de agosto de 1831 - declara a maneira por que devem ser remettidas ao Governo as propostas dos Conselhos Geraes de Provincia, bem como as representações dos mesmos Conselhos, e as dos particulares”, in Coleção das decisões do Governo do Império do Brasil de 1831. Rio de Janeiro: Tipografia Nacional, 1876, p.182.
} 
a receita e despesa provinciais e de enviar à Assembléia Geral um parecer sobre a questão. $^{305}$

Apesar da aprovação dessas emendas e do envio do projeto à segunda Casa, a Câmara dos Deputados manteve-se empenhada no debate em torno dos Conselhos Gerais, mesmo porque alguns pontos basilares da estrutura política desses órgãos não haviam sido esmiuçados. Em abril de 1829, após a chegada à Câmara dos Deputados das primeiras propostas enviadas por um dos Conselhos Gerais - nesse caso, o de Minas Gerais -, realimentou-se a discussão sobre como elas seriam trabalhadas pelos representantes da nação. Ainda em 1829, convencionou-se que seriam criadas comissões direcionadas para o exame dessas matérias, debatendo-se qual seria o poder de ingerência do Parlamento nos Conselhos Gerais. $^{306}$

Quando do desdobramento da discussão, retornou à Câmara o projeto por ela organizado sobre as atribuições dos Conselhos Gerais, mas esse só voltaria ao plenário no ano seguinte, no início da $2^{\mathrm{a}}$ legislatura. Algumas emendas foram feitas ao projeto original, dentre elas a suspensão do direito dos Conselhos Gerais exigirem esclarecimentos dos presidentes de Província a respeito de suas deliberações, e a proibição de que deputados e senadores desempenhassem, simultaneamente, o cargo de conselheiros. Ainda que alguns deputados tenham se mostrado favoráveis às emendas indicadas pelos senadores, todas elas foram rechaçadas pela maioria dos representantes da Câmara. Conseqüentemente, a incongruência de idéias entre a Câmara dos Deputados e o Senado barrou a aprovação do

\footnotetext{
${ }^{305}$ SLEMIAN, op. cit., pp.154-156. Com relação à emenda proposta pelo deputado por São Paulo Francisco de Paula Souza e Mello sobre os Conselhos Gerais terem como atribuição fiscalizar a receita e despesa das Províncias, alguns representantes da Casa votaram contra por acreditarem que ela extrapolava as características que a Carta de 1824 havia conferido a esses órgãos. Segundo o deputado cearense Manoel do Nascimento Castro, competia aos Conselhos Gerais apenas "propor, discutir e deliberar e não administrar”, ato que pela lei de 20 de outubro de 1823 havia sido conferido ao Conselho da Presidência.

${ }^{306}$ Ibid., pp.157-158.
} 
projeto, fazendo com que não voltasse mais à pauta. Uma das razões para a não convocação de uma reunião conjunta entre as duas Casas pode ter sido a de que, no ano seguinte, em meio às vicissitudes políticas geradas pela abdicação de D. Pedro e da instalação da Regência, surgiu como questão candente a possibilidade de uma reforma constitucional e, logo, a reformulação dos governos provinciais. ${ }^{307}$

Embora o projeto alternativo elaborado pela Câmara dos Deputados não tenha êxito, é digna de nota a luta desta Casa pela ampliação dos poderes dos Conselhos Gerais. Nesse sentido, uma das discussões mais acirradas ocorridas na Câmara durante a $2^{\mathrm{a}}$ legislatura referiu-se à ingerência que o Legislativo teria sobre as decisões dos Conselhos Gerais. Segundo o artigo 85 da Carta de 1824, os projetos encaminhados à Assembléia Geral pelos Conselhos Gerais deveriam passar por uma discussão antes de serem aprovados ou não. Havia, contudo, uma questão fundamental que a legislação ainda não tocara: teriam os legisladores o direito de fazer emendas às propostas enviadas pelos Conselhos Gerais?

A matéria, discutida no decurso da sessão de 1830, gerou antagonismos entre os deputados. Os defensores de que as propostas não deveriam sofrer emendas pelos parlamentares provinham, sobretudo, das Províncias do norte, como o pernambucano Luiz Francisco de Paula Cavalcanti e o baiano Ernesto Ferreira França, embora não se possa afirmar que houvesse uma polarização de opiniões de acordo com o local de origem de cada membro da Casa. Em linhas gerais, afirmavam que não caberia à Assembléia Geral intervir nas resoluções dos Conselhos Gerais, pois caso contrário estaria sendo violado o princípio básico desses órgãos, que era o de propor medidas cujos interesses eram especificamente provinciais, e não nacionais. Em contrapartida, nomes importantes das Províncias do Centro-Sul, como os deputados Evaristo da Veiga, Diogo Antonio Feijó e Bernardo Pereira

\footnotetext{
${ }^{307}$ Ibid., p.163.
} 
de Vasconcelos defendiam a preeminência do Parlamento ante os Conselhos Gerais e, por conseguinte, o direito da feitura de emendas pela Assembléia Geral. Após intenso debate e apertada votação, venceu a indicação de que os projetos remitidos pelos Conselhos Gerais ao Parlamento não sofreriam emendas feitas pelos deputados e senadores, sendo passíveis apenas de aprovação ou reprovação. Ficou a cargo dos senadores, ainda, decidir sobre como procederiam sobre a matéria. ${ }^{308}$

A discussão a respeito das emendas lançou luz sobre a própria natureza política desses órgãos. O fato de não estarem juridicamente subordinados ao executivo provincial e de figurarem, grosso modo, como o principal canal de representação política das Províncias asseverado pela Carta de 1824, fez com que alguns deputados, como o pernambucano Francisco de Paula Cavalcanti de Albuquerque, encarassem os Conselhos Gerais como “câmaras parciais”, uma vez que seus projetos dependiam da aprovação final da Assembléia Geral. ${ }^{309}$ Em outras palavras, o que estava em jogo era uma tendência acalentada por alguns parlamentares em atribuir dimensão legislativa, ainda que subjacente e indireta, aos Conselhos Gerais.

\subsection{O Conselho Geral da província de São Paulo}

A instalação dos Conselhos Gerais não se processou de maneira uniforme pelas diversas Províncias do Império. No caso da Bahia, foi necessária a intervenção do ministério do Império, em dezembro de 1829, para que se realizasse a reunião do Conselho Geral baiano daquele ano. Embora os conselheiros baianos atribuíssem à falta de membros

\footnotetext{
${ }^{308}$ Ibid., pp.163-170.

${ }^{309}$ APB, sessão de 14/05/1829, p.69.
} 
exigidos por lei o motivo para a não abertura do Conselho, o ministério ordenou sua imediata convocação para uma sessão preparatória, e que assim continuasse até completar o número de conselheiros determinado pela Carta de 1824. ${ }^{310}$ Situação análoga ocorreu no início de 1830, no Maranhão, que teve as atividades do seu Conselho Geral interrompidas temporariamente pelo não comparecimento de boa parte dos conselheiros. Folhas liberais como O Farol Maranhense, A Aurora Fluminense e O Farol Paulistano lamentaram a não instalação do Conselho Geral do Maranhão. ${ }^{311}$

Ceará, Sergipe e Espírito Santo também tiveram como problema constante o não comparecimento dos membros eleitos, o que pode ser explicado por motivos diversos. Além da distância entre o local de residência de parte dos conselheiros e as capitais, e da ausência de gratificação (diferentemente do que ocorria com aqueles que compunham os Conselhos da Presidência), houve inicialmente um relativo descrédito para com a natureza política dos Conselhos Gerais, que era eminentemente propositiva, e não legislativa. ${ }^{312}$ Havia, ainda, a exigência formal do reconhecimento dos diplomas dos membros do Conselho, que por vezes era morosa e acarretava no atraso do ingresso de alguns integrantes.

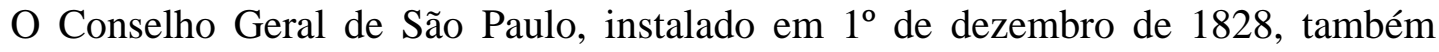
conviveu com o problema da baixa freqüência dos conselheiros, sobretudo na $1^{\mathrm{a}}$ Reunião (1828-1830) $)^{313}$, embora em apenas uma ocasião a falta de quorum impossibilitou a

\footnotetext{
310 "Decisão do ministério do Império de 29 de dezembro de 1829 - sobre a reunião do Conselho Geral da Província da Bahia”, in Coleção das decisões do Governo do Império do Brasil de 1829. Rio de Janeiro: Tipografia Nacional, 1877, pp.232-233. Apesar da investida ministerial, foi somente a partir de 28 de fevereiro de 1830 que o Conselho Geral da Bahia passou a funcionar regularmente. Para o funcionamento do Conselho Geral na Bahia, ver CASTRO, Renato Berbert de. História do Conselho Geral da Província da Bahia, 18241834. Salvador: Assembléia Legislativa do Estado da Bahia, 1984.

${ }^{311}$ O Farol Paulistano, $n^{\circ} 331,17 / 04 / 1830$.

312 SLEMIAN, op. cit., p.213. Para o caso baiano, ver CASTRO, Renato Berbert de. História do Conselho Geral da Província da Bahia, 1824-1834. Salvador: Assembléia Legislativa do Estado da Bahia, 1984.

${ }^{313}$ Assim como o Conselho da Presidência, o Conselho Geral tinha seu período de duração atrelado às legislaturas do Império. Pelo fato de o Conselho Geral de São Paulo ter sido implementado em 1828, isto é,
} 
realização de uma sessão. ${ }^{314} \mathrm{O}$ número de membros presentes variou, nos dois primeiros anos de duração do Conselho, entre 12 e 16 - dos vinte e um previstos por lei -, mas a tendência geral foi um aumento da presença dos conselheiros e suplentes ao longo da $2^{\mathrm{a}}$ e $3^{\mathrm{a}}$ Reuniões.

A primeira sessão do Conselho Geral contou com a presença de 14 conselheiros e do então vice-presidente da Província Manoel Joaquim de Ornellas. Deliberou-se, nesse dia, que o posto de presidente do Conselho seria ocupado pelo bispo Manuel Joaquim Gonçalves de Andrade e o de secretário por Diogo Antonio Feijó. Para presidir a comissão permanente encarregada de analisar as representações das Câmaras Municipais foi escolhido o conselheiro Antonio Paes de Barros ${ }^{315}$, ao passo que para a comissão de polícia foi eleito o membro José Manoel da Luz. ${ }^{316}$

Dentre os vinte e um conselheiros e seis suplentes eleitos para a $1^{\mathrm{a}}$ Reunião do Conselho Geral de São Paulo, nove deles já haviam ocupado ou ocupavam assento no Conselho Presidência da mesma Província - sendo cinco como conselheiros e quatro como suplentes. ${ }^{317}$ Ou seja, muitos desses homens foram, concomitantemente, conselheiros e/ou

como dois anos de atraso em relação à $1^{\mathrm{a}}$ legislatura (1826-1829), a duração da sua $1^{\mathrm{a}}$ Reunião foi reduzida. A rigor, a $1^{\text {a }}$ Reunião do Conselho Geral de São Paulo deu-se entre 01/12/1828 e 09/02/1830, em virtude da prorrogação última sessão.

${ }^{314}$ A sessão de 13 de janeiro de 1829 deixou de ocorrer porque apenas 10 conselheiros compareceram, não atingindo o mínimo exigido - a metade do número dos membros - pela Carta de 1824 (art.78). Ver O Farol Paulistano, $\mathrm{n}^{\circ} 307$, sessão de 14/01/1829.

${ }^{315}$ Antonio Paes de Barros (1791-1876), futuro Barão de Piracicaba, era natural de Natural de Itu, e filho do capitão Antonio de Barros Penteado e de Maria de Paula Machado, respectivamente da família Paes de Barros e Jorge Velho. Em 1819, casou-se com Gertrudes Eufrosina Aires de Aguiar, irmã do Brigadeiro Rafael Tobias de Agiar, no mesmo ano em que seu irmão Bento Paes de Barros - futuro barão de Itu -, casou-se com Leonarda, irmã de Gertrudes. Antes de ser deputado pelo Império, havia sido eleito segundo suplente às Cortes de Lisboa, em 1821. Foi eleito suplente na $1^{\mathrm{a}}$ e $2^{\mathrm{a}}$ Legislaturas do Conselho do Governo da Presidência de São Paulo, e membro efetivo da $1^{\mathrm{a}}, 2^{\mathrm{a}}$ e $3^{\mathrm{a}}$ Legislaturas do Conselho Geral da Província. Na Assembléia Provincial, foi eleito membro na $1^{\mathrm{a}}$, $4^{\mathrm{a}}$ e $6^{\mathrm{a}}$ Legislaturas

${ }^{316}$ O Farol Paulistano, $n^{\circ} 169,03 / 12 / 1828$.

${ }^{317}$ Para a $1^{\text {a }}$ Reunião do Conselho Geral de São Paulo (1828-1829) foram eleitos os seguintes conselheiros: Rafael Tobias de Aguiar, Diogo Antonio Feijó, Manuel Joaquim do Amaral Gurgel, Manoel Rodrigues Jordão, Francisco Inácio de Souza Queirós, João Crisóstomo de Oliveira Salgado Bueno, Luís Antonio Neves de Carvalho, João Gonçalves Lima, Manuel Joaquim de Ornellas, Bernardo José Pinto Gavião Peixoto, Lourenço 
suplentes em ambos os Conselhos, situação que parece ter ocorrido em outras Províncias do Império, a notar por uma decisão ministerial de junho de 1830 , na qual se consentiu a ocupação dos dois cargos simultaneamente. ${ }^{318}$ Essa situação só viria a ser alterada em 1831, quando se proibiu tal acúmulo de funções.

Alguns ainda já haviam tomado assento como deputados pela $1^{\text {a }}$ legislatura, como Diogo Antonio Feijó, Manoel Joaquim de Ornellas e João Crisóstomo de Oliveira, por São Paulo, e José da Costa Carvalho, pela Bahia. Esse último, embora eleito apenas suplente, foi juntamente com Manoel Joaquim do Amaral Gurgel o mais votado para o cargo de conselheiro geral na capital paulista, cidade onde ampliara seu prestígio político após a fundação de O Farol Paulistano. ${ }^{319}$

\section{Relação dos conselheiros mais votados para a $1^{\text {a }}$ Reunião do Conselho Geral da Província de São Paulo (1828-1830): ${ }^{320}$}

$1^{\circ}$ ) Rafael Tobias de Aguiar, tenente-coronel - 185 votos. Na época, era conselheiro da $1^{\text {a }}$ Reunião do Conselho da Presidência da Província de São Paulo.

Pinto de Sá Ribas, José Gonçalves da Silva, Cláudio José Machado, Manuel José da Costa, Joaquim José Pinto de Moraes Leme, Valério de Alvarenga Ferreira, Manuel Joaquim Gonçalves de Andrade, Antonio Paes de Barros, Antonio José de Macedo Sampaio, Eleutério da Silva Prado e Anastácio de Freitas Trancoso. Ocuparam o posto de suplente José da Costa Carvalho, José Manuel da Luz, Joaquim José de Moraes Abreu, Cândido Gonçalves Gomide, Inácio Marcondes de Oliveira Cabral e Francisco Álvares Machado de Vasconcelos. Cf. MARQUES, op. cit., pp.194-195.

318 “Decisão do Ministério do Império de 11 de junho de 1830 - declara que um membro do Conselho da Presidência pode sel-ô também do Conselho Geral”, in Coleção das decisões do Governo do Império do Brasil de 1831, op. cit., p.98.

${ }^{319}$ No colégio eleitoral da capital paulista, aqueles que receberam mais votos para o cargo de conselheiro geral foram: José da Costa Carvalho (109), Manoel Joaquim do Amaral Gurgel (109), Diogo Antonio Feijó (108), Rafael Tobias de Aguiar (106), Joaquim José de Moraes (105), Manoel Joaquim de Ornellas (99), Bernardo Jose Pinto Gavião (99), Jose Antonio dos Reis (87), Jose Manoel da Luz (78), Francisco de Paula Sousa (76), Candido Gonçalves Geraldo (74), Antonio Paes de Barros (73), Valério de Alvarenga Ferreira (71), Antonio Mariano de Azevedo Marques (70), Francisco de Paula Simões (64), Jose Correa Pacheco (58), João da Silva Machado (55), Antonio Bernardes Bueno (53), Idelfonso Xavier Ferreira (?), Francisco de Paula Oliveira (45), Manuel Dias de Toledo (45). Cf. O Farol Paulistano, nº 176, 30/12/1828.

${ }^{320}$ Registro Geral da Câmara da cidade de São Paulo de 1824-1826. São Paulo: Publicação oficial do Arquivo Municipal de São Paulo, 1922, vol.XVIII, pp.493-494. 
$2^{\circ}$ ) João Chrisostomo de Oliveira Salgado, vigário - 120 votos. Na época, era deputado por São Paulo na $1^{\mathrm{a}}$ legislatura.

$3^{\circ}$ ) João Gonçalves Lima, vigário - 117 votos.

$4^{\circ}$ ) Manuel Joaquim de Ornellas, bacharel -117 votos. Na época, era deputado da $1^{\mathrm{a}}$ legislatura e conselheiro da $1^{\text {a }}$ Reunião do Conselho da Presidência, ambos pela Província de São Paulo. Durante o período entre 5 de outubro de 1828 e 12 de janeiro de 1829, ocupou o posto de vice-presidente da Província de São Paulo.

$5^{\circ}$ ) Bernardo José Pinto Gavião Peixoto - 116 votos. Na época, era suplente da $1^{\text {a }}$ Reunião do Conselho da Presidência da Província de São Paulo.

$6^{\circ}$ ) Lourenço Pinto de Sá Ribas - 116 votos. Na época, era suplente da $1^{\text {a }}$ Reunião do Conselho da Presidência da Província de São Paulo.

$7^{\circ}$ ) Cláudio Jose Machado, capitão-mor - 108 votos.

$8^{\circ}$ ) Manuel Jose da Costa, sargento-mor - 104 votos.

$9^{\circ}$ ) Antonio Bernardo Bueno da Veiga, capitão - 104 votos. Na época, era suplente da $1^{\text {a }}$ Reunião do Conselho da Presidência da Província de São Paulo.

$10^{\circ}$ ) Valerio Alvarenga Ferreira, padre - 98 votos.

$11^{\circ}$ ) Manuel Joaquim Gonçalves de Andrade, bispo - 97 votos. Na época, era deputado pela $1^{\text {a }}$ legislatura e conselheiro da $1^{\text {a }}$ Reunião do Conselho da Presidência, ambos pela Província de São Paulo.

$12^{\circ}$ ) Diogo Antonio Feijó, padre - 96 votos. Na época, era deputado pela $1^{\text {a }}$ legislatura e suplente da $1^{\text {a }}$ Reunião do Conselho da Presidência, ambos pela Província de São Paulo.

$13^{\circ}$ ) Manuel Joaquim do Amaral Gurgel, padre - 93 votos.

$14^{\circ}$ ) Antonio Paes de Barros, capitão - 92 votos.

$15^{\circ}$ ) Anastácio de Freitas Trancoso, coronel - 87 votos.

$16^{\circ}$ ) Eleutério da Silva Prado, capitão-mor - 86 votos.

$17^{\circ}$ ) Ignácio Marcondes de Oliveira Cabral, padre - 85 votos.

$18^{\circ}$ ) Vitoriano Moreira da Costa, capitão-mor - 80 votos.

$19^{\circ}$ ) Antonio Jose Pinto, vigário - 78 votos.

$20^{\circ}$ ) Joaquim Jose de Moraes e Abreu, coronel - 77 votos.

$21^{\circ}$ ) José Manuel da Luz, sargento-mor - 74 votos.

$22^{\circ}$ ) Joaquim Mariano Galvão de Moura e Lacerda - ?. Na época, era suplente da $1^{\text {a }}$ Reunião do Conselho da Presidência da Província de São Paulo. 
Na ocasião de sua instalação, o Conselho Geral de São Paulo reportou-se diretamente ao imperador para comunicar o episódio, enfatizando menos as atribuições práticas do novo órgão do que seu papel institucional associado ao cumprimento da Carta de 1824 - o “Código Sagrado” - e do regimento interno de 27 de agosto de 1828. Só a partir da execução desses dois aparatos legais é que se concretizaria a função política dos Conselhos Gerais, que era a de conceder a todos os cidadãos o direito de intervir nos negócios de suas respectivas províncias:

"Senhor,

O Conselho Geral da Prov ${ }^{\mathrm{a}}$. de S. Paulo installado no $1^{\mathrm{o}}$ do corrente, em virtude do art. 80 da Constituição do Império e da Ley de 27 de Agosto do prezente anno, que fez pôr em execução o mencionado artigo, se apressa a participar sua installação a V.M.I., como ao Supremo chefe da Nação, e arender-lhe a mais cordial gratidão em nome dos Povos, q. reprezenta, por esta tão grande instituição, a mais firme garantia da liberdade dos Povos. Sim, Augusto Senhor, V.M.I. constituído á frente da heróica Nação Brasileira, de que é Perpetuo Defensor, e querendo imperar sobre subditos, que fossem homens, offereceu-lhes hum Projecto de Constituição, que os Povos fizerão sua aderindo a ella, e jurando-a como Constituição Política do Império. He n’este Código Sagrado, q. V.M.I., reconhecendo em Sua Sublime Razão, que os homens entrando em Sociedades políticas não perdem jamais seus Direitos nacturais, consagrou no Art.71, o principio de Direito Publico Universal = que todo o cidadão tem o direito de intervir nos negocios de suas Provincias; como aqueles que mais interessão a felicidade particular, da qual essencialmente se prende a felicidade publica. Mas faltava ainda huma Ley regulamentar, que fizesse pôr em andamento a preciosa instituição dos Conselhos Geraes de Provincia, e V.M.I. sancionou de imediatamente a Lei de 27 de agosto (...)”. ${ }^{321}$

\footnotetext{
321 “Representação enviada para D. Pedro sobre a instalação do Conselho Geral de São Paulo”, Registro de propostas, ofícios e representações, que subiram à Presença de S.M.I. e da Assembléia Geral Legislativa (RPR). Arquivo Público do Estado de São Paulo, pp.02-03.
} 
A Câmara dos Deputados foi igualmente comunicada da convocação do Conselho Geral de São Paulo, só que por meio de um outro ofício, de conteúdo diferente, o que demonstra a preocupação do órgão paulista no modo de se relacionar com cada instância de poder. Além de enaltecer o novo órgão enquanto parte do processo institucionalização do Estado Nacional, o texto fez questão de ratificar o estatuto representativo dos Conselhos Gerais que lhes assegurava, entre outras atribuições, a possibilidade de desenvolver "Projectos de Lei” e denunciar “qualquer falta de Justiça”; ou seja, características que legalmente estavam amarradas à ingerência da Assembléia Geral. Forjando para os paulistas uma identidade liberal unívoca, o ofício ressaltou, ainda, a diligência dos representantes da nação na aprovação do regimento interno para os Conselhos Gerais, que funcionariam na qualidade de “Guarda da Constituição”:

“Augustos, e Dignissimos Senhores Representantes da Nação = Possuido do nobre enthusiasmo pelas propriedades da Pátria, enthusiasmo que formou sempre o Caracter paulistano, o Concelho Geral da Provincia de São Paulo em nome dos Povos, q. representa, tem a gloria de apparecer hoje ante a Augusta Assemblea da Nação, rendendo as devidas graças pela Lei, q. fez pôr em execução os Conselhos Geraes das Provincias, outorgados pela Constituição politica do Império. Os Paulistas, Augustos Legisladores, tão obedientes á Lei, quanto ciosos de seus sagrados direitos, apreciando em seu justo valor esta tão grande instituição, saudarão com prazer o dia, em que virão reunida na Capital da Província sua representação Provincial: seus corações se espaçarão em seus feitos vendo estabelecida a maior garantia de seus direitos, o primor d'obra da Constituição, o remate do edificio social erguido com a Independencia do Império. Honrado com a confiança dos seus comprovincianos, interprete de seus sentimentos, este Conselho se apressa a portentar seu reconhecimento, e gratidão pela tão suspirada Lei do Regimento interno; e protesta a face da Nação, em desempenho de seus deveres, trabalhar, quanto em suas forças couber, para ministrar-vos Projectos de Lei adequados às circunstancias d'esta Provincia, q. tão brindada pela Natureza, talvez por algum mao fado, não tem chegado á aquelle grão de importancia, de que há capaz e, levando ao vosso conhecimento qualquer infração de Lei, qualquer falta 
de Justiça; os males em fim, q. pesem talvez sobre os povos d'esta Provincia, para que, como Guarda da Constituição, deis os promptos remedios, q. convierem, caberá também a este Conselho alguma parte da gloria, q. vos está reservada a de elevações a Província de S. Paulo ao cumulo da grandeza, e prosperidade de que é digna (..)”. ${ }^{322}$

O Senado, por sua vez, recebeu apenas uma cópia do ofício encaminhado à Câmara dos Deputados. Fato curioso, até porque foi o regimento elaborado pelos senadores que a Assembléia Geral por fim adotara para os Conselhos Gerais. Mas num contexto em que a relação entre as duas casas acirrava-se cada vez mais, a presença de quatro deputados na $1^{\text {a }}$ Reunião do Conselho Geral de São Paulo - Diogo Antonio Feijó, Manuel Joaquim de Ornellas, João Chrysostomo de Oliveira e José da Costa Carvalho - parece ter influenciado na decisão.

A implementação do Conselho Geral de São Paulo gerou manifestações de diferentes setores da sociedade paulista. O Farol Paulistano, na época o único periódico produzido na Província, noticiou a instalação do Conselho Geral de São Paulo dois dias após a primeira sessão. O redator creditou o sucesso na abertura do órgão a Manoel Joaquim de Ornellas, naquele momento deputado e vice-presidente da Província de São Paulo, em virtude de sua “boa vontade, diligencia e disvellos”, e de seu posicionamento contrário aos “abusos do velho systema”. O mesmo redator ponderou, em contrapartida, sobre a eficácia imediata do Conselho Geral, ressaltando a inexperiência de seus membros ante um tipo de trabalho nunca feito outrora, o que poderia interferir em seus resultados:

“A instalação do Conselho Geral d'esta Província foi sobre maneira aparatosa, e acompanhada de grande entusiasmo ao povo d'esta Capital. Illuminações, bandos de muzica

\footnotetext{
${ }^{322}$ RPR, "Representação enviada para a Câmara dos Deputados sobre a instalação do Conselho Geral de São Paulo”, p.02.
} 
pelas ruas tocando, e acompanhando o Hyno patriótico, fogos, publicos testemunhos de prazer que fervi aos corações dos nossos Concudadãos (...) Não podemos deixar de elogiar a boa vontade, diligencia, e disvellos do actual Excel. Vice-Presidente o Sr. Manoel Joaquim d’Ornellas. Este honrado cidadão mostra, que apezar de seus avançados annos tem o coração novo, não carunchado pelos abusos do velho systema. Tem sido mui bom Deputado, e agora se tem mostrado mui bom Vice-Presidente. Talvez que maiores dificuldades tivessem aparecido à instalação do Concelho Geral se elle não mostrasse tão decidido por ella. Honra, e louvores lhe sejam dados. A Câmara d'esta Cidade também se prestou diligente ao que estava da sua parte; e nos é de muito prazer podermos fazer-lhe justiça, que a não mortifique. Temos bem fundadas esperanças, de que alguns fructos colha a Província desta reunião, apesar de que nos corpos deliberativos o $1^{\circ}$ anno de sua existência é o menos fructifero: a falta de materiaes preparados e mesmo a pouca, ou nem-uma dexteridade em um trabalho nunca feito, e por muito poucos visto fazer, são estorvos necessários, e que muito acanhão os resultados; mas enfim, principio querem as couzas, e ja teve principio a mais excellente de todas as instituições que nos outorgou o nosso Código sagrado, a nossa Constituição”. ${ }^{323}$

O Farol Paulistano passou a publicar os resumos das atividades do Conselho Geral de São Paulo a partir do ano seguinte, tarefa que continuou a desempenhar mesmo após advento de O Observador Constitucional, em outubro de 1829. Prática comum entre os periódicos do Império, a publicação das atas do Conselho Geral foi uma das principais pautas editoriais de A Matutina Meyapontense, folha goiana de orientação liberal que circulou entre 1830 e $18344^{324}$ O próprio ministério do Império, numa decisão tomada a 13 de março de 1830, fez circular que fossem impressas as atas desses órgãos, ainda que reconhecesse a ausência de uma legislação ordinária que a tornasse obrigatória. ${ }^{325}$ No caso de O Farol, a opção por levar a público os resumos das atas ao invés do seu conteúdo

\footnotetext{
${ }^{323}$ O Farol Paulistano, $n^{\circ}$ 169, 03/12/1828. Além dessa nota, a folha de Costa Carvalho publicou no n $^{\circ} 174$ (20/12/1828) uma correspondência, provavelmente oriunda de São Carlos, louvando a instalação do Conselho Geral de São Paulo.

${ }_{324}^{324}$ Ver, a título de exemplo, A Matutina Meyapontense, ${ }^{\circ}$ s 01-10, de 1830.

325 "Decisão do Ministério do Império de 13 de março de 1830 - manda que as actas das sessões dos Conselhos Geraes sejam impressas, embora haja lei que não o ordene”, in Coleção das decisões do Governo do Império do Brasil de 1830. Rio de Janeiro: Tipografia Nacional, 1876, p.56.
} 
completo parece ter comprometido a eficiência do serviço prestado. Em fevereiro de 1831, o suplente Joaquim Pereira de Barros teve uma correspondência inserida na folha paulista em que solicitava ao redator para que esse publicasse em sua completude uma proposta por ele feita na sessão de 23 de janeiro daquele ano, já que a mesma havia sido parcialmente referenciada num dos resumos impressos pelo periódico. A proposta foi publicada integralmente pelo O Farol ao lado da correspondência de Pereira de Barros. ${ }^{326}$

A Câmara Municipal da cidade de São Paulo também se manifestou a favor da convocação do Conselho Geral de São Paulo. Em ofício remetido ao órgão recéminstaurado, os vereadores da capital paulista imputaram aos Conselhos Gerais a condição de baluartes da Carta de 1824:

“A Camara desta Imperial cidade bem conhecendo as vantangens, que a esta Provincia resultarão da reunião do seu Conselho Geral a melhor, a mais importante de todas as instituições que nos outorga a Constituição do Império vem felicitar ao mesmo Conselho Geral por sua installação. A Camara olhando não só para a instituição em si mesma, mas também aos dignos membros que compõem tão respeitável corporação, está intimamente convencida de que esta Provincia prosperará muito mais do que prosperaria se não tivesse um conselho de cidadãos tão conspícuos, todos desvelados em promover a publica prosperidade - A Camara desta imperial cidade protesta prestar-se a tudo que for de utilidade publica fornecendo a este Conselho as representações que julgar convenientes ao bem dos povos que ella representa.

Queira o Conselho Geral desta Provincia acceitar os seus respeitos, e alta consideração - São Paulo em vereança de 6 de dezembro de mil oitocentos e vinte e oito Francisco de Paula Xavier de Toledo - Antonio Cardoso Nogueira - José Rodrigues Vellozo

\footnotetext{
${ }^{326}$ O Farol Paulistano, nº465, 01/02/1831. Em linhas gerais, a proposta de Pereira de Barros tratava sobre a proibição das salvas de artilharia em todos os fortes do litoral da Província por motivos de festas, mesmo que nacionais.
} 
de Oliveira - Antonio Justiniano de Souza - Está conforme. São Paulo, 20 de dezembro de 1828. O escrivão da Câmara Manuel Benedito de Toledo”. 327

Felicitações de outras Câmaras Municipais da Província também chegaram ao conhecimento do Conselho Geral de São Paulo, ocorrência que se tornou comum nos períodos de abertura e fechamento do órgão. ${ }^{328}$ Mais do que uma formalidade política, as Câmaras necessitavam estreitar seus laços com o Conselho Geral que, como veremos adiante, tinha como uma das suas principais faculdades dirigir parte da política municipal.

O expediente ordinário do Conselho Geral de São Paulo iniciou-se logo após a implementação do novo órgão. De maneira geral, sua agenda era composta de três grandes atividades: conceber projetos relativos ao melhoramento dos negócios da Província, bem como analisar propostas semelhantes encaminhadas ao Conselho por terceiros; apurar denúncias provindas de particulares, magistrados e políticos sobre abusos de poder, negligência e descumprimento da Constituição; e examinar as representações, indicações, posturas e contas remitidas pelas Câmaras Municipais.

Para discutir a forma como eram trabalhadas as matérias no Conselho Geral, tomemos como exemplo, inicialmente, a elaboração e o desdobrar dos projetos criados pelos conselheiros sobre a Província de São Paulo. A despeito de seu curto período de duração, a $1^{\mathrm{a}}$ Reunião do Conselho Geral foi palco de um grande número de propostas por parte de seus membros. Diogo Antonio Feijó, secretário do Conselho e um dos membros mais ativos nos primeiros anos de funcionamento do órgão, propôs a criação de um regulamento para as escolas de primeiras letras, um projeto de Estudos Elementares para a Província, o

327 "Registro de um officio da Câmara ao Conselho Geral desta Provincia”, in Registro Geral da Câmara da cidade de São Paulo de 1824-1826, op. cit., pp.519-520.

${ }^{328}$ Ver, por exemplo, a felicitação oferecida ao Conselho Geral de São Paulo pela Câmara de Municipal de Taubaté, em janeiro de 1829, e pela de Guaratinguetá, em dezembro de 1830. Cf. O Farol Paulistano, ns 183, sessão de 12/01/1829, e 427, sessão de 06/12/1830. 
estabelecimento de cadeiras de filosofia pela Província, a igualdade de custas jurídicas em toda as vilas e freguesia de São Paulo, dentre outras iniciativas. ${ }^{329}$ O capitão Antonio Bernardo Bueno da Veiga, outro conselheiro bastante participativo na $1^{\text {a }}$ Reunião, apresentou projetos sobre o problema das divisas da Província de São Paulo com Minas Gerais, a abertura e melhoramento de estradas, e criação de cemitérios fora dos templos da cidade de São Paulo. ${ }^{330}$ José da Costa Carvalho, por sua vez, propôs entre outras medidas quatro projetos atinentes à escravidão, mais especificamente sobre o tratamento dos escravos por seus senhores, a polícia a respeito dos cativos, a prevenção contra crimes por esses cometidos, e um código penal exclusivo para a escravaria. ${ }^{331}$ Tais propostas, quase sempre atreladas à dinâmica infra-estrutural da Província, tinham como principais objetivos sugerir a criação ou melhoramento de determinado objeto, de maneira que foram recorrentes propostas relativas à criação de vilas, freguesias e cadeiras de ensino, à melhoria de estradas e ao incremento do universo material da Província de São Paulo.

Esses projetos pouco diferem, a um primeiro olhar, daqueles desenvolvidos até o momento pelo Conselho da Presidência da Província, e a mesma impressão pode emergir se tomarmos como referência os trabalhos relativos à apuração de denúncias e à análise das finanças das Câmaras Municipais. No entanto, posto que os dois Conselhos constituíam órgãos com atribuições políticas distintas, cabe aqui a seguinte questão: no que se distanciava, a rigor, o estatuto das propostas criadas por cada Conselho, notadamente daquelas que pouco ou nada se diferiam em seus conteúdos e objetivos?

\footnotetext{
${ }^{329}$ Ver, respectivamente, O Farol Paulistano, no 171, sessão de 03/12/1828; nº 172, sessão de 10/12/1828; $n^{\circ}$ 183, sessão de 05/01/1829; e n 185, sessão de 17/01/1829.

${ }^{330}$ Ver, respectivamente, O Farol Paulistano, no 171, sessão de 03/12/1828; n ${ }^{\circ}$ 174, sessão de 17/12/1828; ${ }^{\circ}$ 183, sessão de 05/01/1829; e n 185 , sessão de 15/01/1829.

${ }^{331}$ Ver O Farol Paulistano, no 185 , sessão de 22/01/1828.
} 
As diferenças entre as propostas criadas por ambos os Conselhos tinham início no próprio ato de elaboração das matérias. Por ser parte constituinte do executivo provincial, o Conselho da Presidência detinha um grupo privilegiado de informações acerca dos negócios públicos da Província, ao passo que o Conselho Geral necessitava solicitar ao governo paulista, ininterruptamente, os dados necessários para a confecção dos seus projetos. Nesse sentido, tornou-se pauta quase que diária do Conselho Geral de São Paulo o requerimento de informações ao executivo da Província. Só nos meses de dezembro de 1828 e janeiro do ano seguinte, aprovaram-se pedidos solicitando ao governo provincial informações a respeito de assuntos como o estado das cadeiras de gramática latina, a utilidade das aulas de teologia e moral, os procedimentos de trabalho utilizados pela Junta da Fazenda, a forma como era feito o processo de recrutamento de milicianos, a origem e o estado atual do Jardim Botânico, e a necessidade de transformarem-se determinadas freguesias em Vilas. ${ }^{332}$

Um segundo elemento diferenciava o tratamento das propostas nos dois Conselhos. O fato de possuir um regimento próprio e limites políticos bem delimitados fez do Conselho Geral da Província de São Paulo um órgão mais sistemático em seu funcionamento do que o Conselho da Presidência. Além da submissão obrigatória às três leituras, os projetos eram geralmente enviados para comissões especificas que os analisavam, acrescentavam emendas ou refutavam-nos, à semelhança do que ocorria nas sessões do Parlamento. Durante os dois primeiros anos de funcionamento do Conselho Geral, várias comissões foram criadas a fim de abordar pautas como o Caminho do Mar, as instituições beneficentes, a criação de um banco provincial e a questão dos combatentes paulistas na campanha do Sul.

Ainda levando em conta o sistema de trabalho do Conselho Geral, é pertinente destacar que alguns projetos esbarravam nos limites impostos pela legislação ordinária. Em

\footnotetext{
${ }^{332}$ Ver O Farol Paulistano, $\mathrm{n}^{\circ} \mathrm{s} 171$ a 185, sessões de 02/12/1828 a 22/01/1829.
} 
dezembro de 1828, por exemplo, a comissão encarregada da Divisão Estatística da Província assinalou que o projeto apresentado por Lourenço Pinto de Sá Ribas sobre a abertura de um istmo entre Paranaguá e Cananéia era de competência do executivo provincial, e não do Conselho Geral. ${ }^{333}$

O cerne do problema residia, todavia, em duas questões, sendo a primeira delas o alcance das resoluções tomadas pelo Conselho Geral. Sem poder legislativo e executivo, mas dotado de faculdade propositiva, o Conselho Geral de São Paulo esteve à mercê do poder decisório do governo central e da Assembléia Geral para a cristalização de parcela significativa de seus trabalhos. ${ }^{334}$ Isso significava que de todas as propostas aventadas durantes o expediente do Conselho Geral, só vieram a se concretizar aquelas que, primeiramente, foram aprovadas em sessão até sua redação final, e, posteriormente, sancionadas em caráter provisório pelo imperador ou em definitivo pela Assembléia Geral. Neste último caso, a proposta tinha ainda que aguardar a anuência imperial para ser posta em prática.

O segundo ponto referia-se à origem dos recursos que seriam despendidos para por em execução as resoluções dos Conselhos Gerais. Ao contrário dos Conselhos da Presidência, que por lei detinham a oitava parte das sobras das rendas provinciais para seus gastos ordinários, os Conselhos Gerais não possuíam nenhum suporte legal que lhes assegurasse uma renda fixa para o cumprimento de suas resoluções. ${ }^{335}$ Para Miriam Dohlnikoff, a inexistência de recursos financeiros por parte dos Conselhos Gerais, sobretudo de uma competência tributária, representou uma perda significativa de sua autonomia Em

\footnotetext{
${ }^{333}$ Ver O Farol Paulistano, n 174, sessão de 18/12/1828.

${ }^{334}$ Será discutido, mais adiante, que nem todos os trabalhos do Conselho Geral dependiam da intervenção do imperador ou do Parlamento, tal como foi o caso do manejo da política municipal.

${ }^{335}$ DOLNIKOFF, 2005, op. cit., p.60.
} 
novembro de 1830, o ministério do Império fez circular uma decisão alegando que não cabia ao Governo disponibilizar recursos para a implantação das resoluções dos Conselhos Gerais, de modo que o mais provável é que o dinheiro fosse extraído das próprias Juntas da Fazenda Provinciais (depois Tesourarias Provinciais). ${ }^{336}$ Essa inconsistência orçamentária pode ter sido um dos motivos pelos quais, como veremos adiante, muitas das matérias deliberadas pelo Conselho Geral de São Paulo acabaram não sendo aprovadas pela Assembléia Geral, uma vez que a concretização de boa parte das propostas passava, necessariamente, pelo dispêndio de recursos.

No decurso da $1^{\mathrm{a}}$ Reunião do Conselho Geral de São Paulo, doze propostas foram dirigidas ao governo central - aos ministros ou diretamente ao Imperador - ou à Assembléia Geral para serem submetidas à aprovação. Foram elas: 1- proposta para a mudança do Registro de Curitiba das Margens do Iguaçu para o Negro; 2- proposta para a criação de aulas de filosofia nas vilas de Curitiba, Itu e Taubaté (Diogo Antônio Feijó); 3- proposta para a criação de uma cadeira de medicina e cirurgia na cidade de São Paulo (Manuel Joaquim do Amaral Gurgel); 4- proposta para o estabelecimento de aulas de $1^{\mathrm{a}} \mathrm{s}$ letras pelo método lancasteriano nas vilas de Curitiba, Itu e Taubaté; 5- proposta sobre a civilização dos índios, tendo-se como objetivo o estabelecimento do comércio entre indígenas e moradores das Vilas de Castro, Guarapuava, Faxina e Itapetininga; 6- proposta sobre a elevação da dotação do Seminário de Sant’Anna e ordenado de sua diretoria (Cláudio Jose Machado); 7proposta sobre a elevação da dotação do Seminário da Glória e ordenado de sua diretoria (Cláudio Jose Machado); 8- proposta para a criação de uma tipografia nacional na Província de São Paulo (José da Costa Carvalho); 9- proposta para a criação de diversas capelas em

\footnotetext{
336 "Decisão do Ministério do Império de 23 de novembro de 1830 - declara não competir ao Governo o recurso das Resoluções dos Conselhos Geraes", in Coleção das decisões do Governo do Império do Brasil de 1831, op. cit., p.153.
} 
freguesias; 10- proposta para a criação de algumas freguesias em Vilas; 11- proposta para estabelecer a igualdade de medidas em toda a Província, em conformidade com aquelas utilizadas na capital do Império; 12- Proposta para serem pagos no lugar da sua residência todos os empregados públicos da província de São Paulo que moram fora da capital paulista. 337

Digna de ressalva é a proposta para a criação de uma tipografia nacional na Província de São Paulo, apresentada pela primeira vez na sessão de 23 de dezembro de 1829 e aprovada em definitivo cerca de um mês depois. ${ }^{338}$ Seu texto final indicava o seguinte:

“A publicidade em todos os seos actos hé da essencia do Governo Representativo. Este principio, que se não pode pôr em duvida por muito sabido, faz occiosa qualquer demonstração da utilidade da Proposta, que o Conselho Geral tem a honra de levar á Augusta Presença de Sua Majestade o Imperador , cuja sanç̧ão supplica e espera.

\section{Artigo I}

Haverá na Capital da Província de S. Paulo uma Typografia Nacional, que sirva para a regular publicação dos actos da administração, trabalhos do Conselho Geral e das Camaras Municipaes.

\section{Artigo II}

O Governo da Província fica authorisado a dispender a somma preciza para a compra, e mais despezas da mencionada Typografia.

Paço do Conselho Geral de S. Paulo, 8 de fevereiro de 1830. Manoel Joaquim de Ornellas. Diogo Antonio Feijó”. 339

\footnotetext{
${ }^{337}$ Essas propostas estão contidas num caderno manuscrito pertencente ao Arquivo Público do Estado de São Paulo, (CO 6148), cuja primeira página apresenta a seguinte inscrição, assinada pelo então secretário do Conselho Geral da Província de São Paulo, Diogo Antônio Feijó: "Este livro servirá para se registrarem todas as propostas, officios e representações que subirem a presença S.M.I. e da Assembléia Geral Legislativa”. Em síntese, trata-se de uma listagem elaborada pela secretaria do Conselho Geral de São Paulo que congrega as tipologias documentais acima referidas produzidas durante o período de dezembro de 1828 a janeiro de 1831 . Quando possível, explicitou-se entre parênteses o nome do autor da proposta original.

${ }^{338}$ Ver, respectivamente, O Farol Paulistano, no ${ }^{\circ}$ 290, sessão de 23/12/1829, e 315, sessão de 26/01/1830.

${ }^{339}$ RPR, "Proposta para a creaçao de huma Typografia Nacional Nesta Província”, Cx. L06148, Livro 3, p.14.
} 
O conteúdo da proposta era claro. Argumentando ser a publicidade um dos pilares dos governos representativos, tinha-se como objetivo instaurar na Capital paulista uma tipografia direcionada para a divulgação dos trabalhos do executivo provincial, do Conselho Geral e das Câmaras Municipais. Conforme o artigo segundo, o governo provincial ficaria autorizado a gastar o montante necessário para a compra da oficina tipográfica bem como para sua manutenção.

Difícil é saber se por trás de uma aparente iniciativa em levar a público os atos do governo provincial jaziam interesses de outra ordem. Mais intrigante ainda é o fato de que seu proponente foi ninguém menos que José da Costa Carvalho, dono da única oficina tipográfica em terras paulistas até aquele momento. É provável que tanto o diretor de $O$ Farol Paulistano como aqueles que apoiavam sua folha vislumbrassem no projeto da tipografia oficial certa estratégia editorial, isto é, uma forma de fixar um órgão exclusivamente voltado para a publicação de questões inerentes à esfera política oficial e, conseqüentemente, de desvincular as iniciativas tipográficas particulares dessa obrigação. Nesse ponto, ganham mais sentido as queixas feitas pelo Farol (ver capítulo 1) sobre a obrigatoriedade da publicação de documentos oficiais do governo da Província, já que estes ocupavam, segundo o redator, parte considerável de cada número do periódico. É possível, ainda, que a tipografia oficial acabasse servindo de suporte para a defesa de interesses privados.

Aprovada sem maiores contestações por parte dos demais conselheiros ${ }^{340}$, a proposta para a criação de uma tipografia oficial já havia sido aventada pouco tempo antes pelo

\footnotetext{
${ }^{340}$ Ao que tudo indica, apenas o conselheiro Rafael Tobias de Aguiar sugeriu algum tipo de restrição à proposta inicial de Costa Carvalho. No dia da aprovação da proposta pelo Conselho Geral, Tobias de Aguiar indicou que a despesa a ser feita com a instalação da tipografia deveria ser limitada. A indicação não foi incluída na redação final da proposta. Ver O Farol Paulistano, n 306, sessão de 12/01/1830.
} 
Conselho da Presidência de São Paulo, e ao que parece com propósitos similares. Em outubro de 1828, o conselheiro da presidência Manuel “Bispo” Joaquim Gonçalves de Andrade sugeriu em sessão que se criasse uma Imprensa Nacional em São Paulo, uma vez que a única tipografia da Província não daria conta da publicação das atas dos Conselhos da Presidência e Geral, bem como dos atos do Governo:

“O Sr. Bispo, ponderando não ser possível que a única Tipografia, que existe nesta Capital possa dar ao prelo as Actas do Conselho do Governo, e Geral da Província, assim como todos os actos do referido Governo, imprimindo-se ao mesmo tempo os Compendios, e outros papeis pertencentes ao Curso Juridico, como a experiencia tem mostrado, indicou, que se pedisse a S. M. o Imperador o Haver por bem Mandar estabelecer nesta dita Capital huma Imprensa Nacional, remettendo-se com todos os objectos para isso necessários, o indispensável compozitor; o que foi unanimemente aprovado”. ${ }^{341}$

A despeito da aprovação unânime, a proposta não foi posta em prática, nem o tema voltou a ser pauta do Conselho da Presidência até o término de seu funcionamento, em 1834. ${ }^{342}$ Destino semelhante teve aquela veiculada pelo Conselho Geral no ano seguinte. Enviada diretamente para o governo central, sem aprovação anterior da Assembléia Geral, a proposta não foi sancionada pelo monarca, que suspendeu seu juízo sobre a matéria. ${ }^{343}$ Em janeiro de 1832, o então ministro do Império José Lino Coutinho comunicou à Secretaria do Conselho Geral de São Paulo que a resolução havia sido rejeitada pelo Senado. ${ }^{344}$ Ao que tudo indica, a matéria não foi retomada.

\footnotetext{
${ }^{341}$ ACP, v.86, sessão de 12/11/1828, p.185.

${ }^{342}$ Em 22 de julho de 1829, o Farol Paulistano publicou uma nota afirmando que uma tipografia nacional estava prestes a ser instalada na cidade de São Paulo: "Dizem que já está prompta a Typographia, e justo o Compositor, que o governo manda para esta Cidade: Deos a traga a salvamento, e se publique uma Folha do Governo”. Cf. O Farol Paulistano, n 231, 22/07/1829. A despeito da nota, a tipografia não foi implantada.

${ }^{343}$ Ver O Farol Paulistano, n 424, sessão de 02/12/1830.

${ }^{344}$ Fundo Conselho Geral da Província do Acervo Histórico da Assembléia Legislativa do Estado de São Paulo (FCGP), GI.009, саixa 24.
} 
Há registros de que pouco menos da metade das propostas encaminhadas pelo Conselho Geral na $1^{\text {a }}$ Reunião foi aprovada pela Assembléia Geral e, posteriormente, sancionada pelo imperador. Em 6 de dezembro de 1830, o monarca sancionou cinco das doze propostas encaminhadas até então pelo Conselho Geral de São Paulo. ${ }^{345}$ Cumpre frisar, neste ponto, que o ato de mandar executar de uma só vez um certo número de medidas provenientes de um determinado Conselho Geral foi prática recorrente do imperador, quer com relação ao órgão paulista quer com os congêneres de outras Províncias.

É certo, outrossim, que D. Pedro suspendeu seu juízo sobre algumas matérias que foram dirigidas diretamente ao governo central pelo Conselho sem a aprovação prévia da Assembléia Geral, tal como ocorreu com as propostas para o estabelecimento de aulas de primeiras letras pelo método lancasteriano e para a criação de algumas cadeiras de filosofia na Província de São Paulo. Demonstrando interesse na tramitação das matérias, o Conselho Geral enviou ao ministro do Império um comunicado no qual acusava ter recebido da Secretaria de Estado dos Negócios do Império um ofício indicando que o monarca havia suspendido seu juízo sobre a execução de ambas. Mesmo com a negativa, o órgão paulista afirmou ter recebido “mui respeitosamente” a resposta do imperador. ${ }^{346}$

Outras matérias, por sua vez, não foram sancionadas apesar de terem sido aprovadas pelos representantes da nação, como foi o caso da proposta para que fossem pagos em casa todos os empregados públicos da Província de São Paulo que morassem fora da capital paulista. Embora o ministro da Fazenda na época - Antonio Francisco de Paula Holanda e

\footnotetext{
${ }^{345}$ Atas do Conselho de Estado (1823-1834) (ACE), in RODRIGUES, José Honório (dir.). Atas do Conselho de Estado: obra comemorativa do sesquicentenário da instituição parlamentar. Brasília: Centro Gráfico do Senado Federal, 1973-1978, v.1. Ver, respectivamente, 56a sessão (06/12/1830), pp.141-144. As propostas aprovadas foram: proposta sobre a civilização dos índios; sobre a elevação da dotação do Seminário da Glória e ordenado de sua diretoria; sobre a criação de diversas capelas em freguesias; sobre a criação de algumas freguesias em vilas; e sobre o estabelecimento da igualdade de medidas em toda a Província.

${ }^{346}$ RPR, "Para o Exmº. Ministro do Império”, p.14.
} 
Cavalcanti - tenha sugerido aprovação dessa proposta durante reunião do Conselho de Estado, os demais ministros, à exceção do Marquês de Lages, apontaram para a possibilidade de ocorrerem abusos por parte dos administradores da rendas nacionais caso a medida fosse posta em prática. Em meio à declarada oposição da maioria de seus conselheiros com relação à aprovação da matéria, D. Pedro optou por “meditar” mais sobre o assunto, que ao que parece não voltou mais à tona. ${ }^{347}$

Houve situações, ainda, em que propostas enviadas pelo Conselho Geral de São Paulo acabaram esbarrando na falta de agilidade ou descaso das instâncias competentes para sua análise. Em sessão de 9 de dezembro de 1830, já iniciada a $2^{\mathrm{a}}$ Reunião do Conselho Geral, aprovou-se o requerimento do conselheiro suplente Joaquim Pereira Barros para que se solicitasse à Câmara dos Deputados a rápida deliberação sobre o projeto para a criação de cadeiras de filosofia na Província de São Paulo, matéria que não recebera a aprovação do monarca quando do seu envio para o Ministério. A proposta também havia sido encaminhada pelo Conselho à Assembléia Geral em janeiro de 1829, ainda na $1^{\text {a }}$ Reunião do Conselho. ${ }^{348}$

As resoluções do Conselho Geral de São Paulo não ficavam restritas à veiculação de propostas. Durante a $1^{\text {a }}$ Reunião do Conselho, foram enviadas para o Rio de Janeiro cerca de vinte documentos, entre representações e ofícios, dos quais merecem destaque: 1representação sobre a necessidade de providências na nomeação de juizes ordinários, de órfãos e seus suplentes; 2- representação sobre a igualdade de custas judiciais em toda a Província; 3- representação contra o ex-ouvidor da cidade de São Paulo Manoel da Cunha de Azevedo Coutinho Souza Chichorro; 4- representação sobre o empréstimo de recursos a

\footnotetext{
${ }^{347}$ ACE, 56 a sessão (06/12/1830), p.144.

${ }^{348}$ Ver O Farol Paulistano, no 427, sessão de 07/12/1830. Algumas dessas resoluções serão tratadas mais adiante.
} 
Antonio Termaesies, para o cultivo da vinha; 5- representação sobre o cunho da moeda de

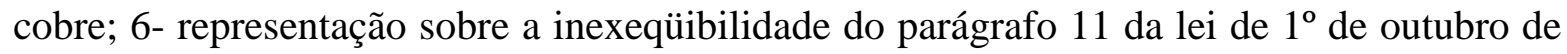
1828 acerca da proibição da venda de pólvora dentro das povoações; 7- representação sobre o grande número de oficiais de Estado Maior e sobre o método de reparar as injustiças nas promoções de militares por meio de outras novas; 8- representação sobre a Provisão do Tesouro Público de 5 de junho de 1829; 9- representação pedindo certos terrenos de Cubatão para servirem de pastagem de animais de tropa; 10- ofício agradecendo a S. M. I. por ter dissolvido a trama dos absolutistas articulada no Rio de Janeiro. ${ }^{349}$

Como é possível constatar, parte das representações enviadas pelo Conselho Geral de São Paulo assemelhava-se com as já mencionadas propostas. Mas enquanto estas se apresentavam, majoritariamente, como projetos de infra-estrutura de longo prazo, as representações se caracterizavam, em grande medida, por serem instrumentos de intervenção política imediata, atrelados às necessidades pontuais da administração pública provincial ou geral. Nesse sentido, a prática política dos Conselhos Gerais se aproximava com aquela desenvolvida pelos Conselhos da Presidência.

A representação sobre a necessidade de medidas com relação à nomeação de juízes ordinários, de órfãos e seus suplentes é exemplar nesse sentido. Alegando ter como objetivo evitar possíveis “dificuldades e embaraços” na execução das futuras eleições para juízes ordinários, de órfãos e seus suplentes, uma vez que havia a "falta de providências legislativas” que regulassem tais eleições, o Conselho Geral de São Paulo solicitou tanto ao governo central como à Assembléia Geral medidas que esclarecessem a questão. A lei de $1^{\circ}$ de outubro de 1828 havia alterado as disposições referentes às eleições para tais cargos e o cumprimento das antigas regras eleitorais acarretaria problemas de ordem político-jurídica

\footnotetext{
${ }^{349}$ RPR, pp.02-24.
} 
em toda a Província, elemento esse que reforçaria a plausibilidade, no entender do Conselho Geral paulista, de sua representação. Não obstante as argumentações do Conselho Geral, o imperador suspendeu seu juízo sobre a matéria, remetendo-a para a Assembléia Geral, a qual também não deliberou sobre a mesma. ${ }^{350}$

Comparativamente às propostas elaboradas pelo mesmo Conselho, há poucos registros, na documentação consultada, sobre o destino que tiveram as representações da $1^{\mathrm{a}}$ Reunião, o mesmo ocorrendo com as subseqüentes. Uma das causas disso se deve ao fato, quem sabe, de que nem todas as representações eram passíveis de aprovação, como nos casos de denúncias contra particulares, de agradecimentos ou de solicitações de medidas ao governo central ou à Assembléia Geral, situações em que não havia de fato a veiculação de alguma resolução propositiva por parte do Conselho Geral. É provável, também, que por serem menos detalhadas e padronizadas do que as propostas (lembremos que estas tinham artigos, à semelhança dos projetos de lei do Parlamento), as representações poderiam conter algum tipo de lacuna, impeditivo ou incompatibilidade de ordem jurídico-política que acabavam tornando-as objetos de deliberação mais intrincados, sem mencionar o fato de que nem o governo nem a Assembléia Geral tinham poder de alterar seus conteúdos.

Os próprios registros indicam para essa direção, a começar pelo já mencionado insucesso no pedido de providências para a eleição de juizes ordinários e de órfãos, malogro que se repetiu com outras representações. Na sessão do Conselho Geral de São Paulo de 22 de dezembro de 1829, leu-se um oficio enviado pelo ministro da Justiça sobre a representação que o órgão paulista fizera ao governo central pleiteando a igualdade de custas jurídicas para toda a Província. Segundo o documento, o ministério optou por repassar à Assembléia Geral a deliberação sobre a matéria, que por sinal também não foi

\footnotetext{
${ }^{350}$ Ver O Farol Paulistano, no 290, sessão de 22/12/1829.
} 
aprovada em plenário. ${ }^{351}$ No final do ano seguinte, já tendo início a 2 ${ }^{\mathrm{a}}$ Reunião do Conselho, D. Pedro suspendeu seu juízo com relação a mais três representações - sobre o empréstimo de 2:000\$000 ao húngaro Antonio Termaesies para o desenvolvimento da cultura da vinha; sobre a Carta Régia de 5 de novembro de 1808 acerca da escravização dos índios; e sobre a alteração do parágrafo 11 do artigo 66 da lei de $1828 .^{352}$ Esta última foi reprovada em definitivo pela Câmara dos Deputados no mês seguinte ${ }^{353}$. Ao que parece, as demais representações tiveram o mesmo destino.

O fracasso de parte expressiva das representações enviadas pelo Conselho Geral de São Paulo em sua $1^{\text {a }}$ Reunião não deve ser apreendido como um indicativo de ineficiência do órgão paulista, mesmo porque, conforme visto anteriormente, quase a metade das propostas formuladas pelos conselheiros gerais obteve sanção do imperador. Ele aponta, sim, para a necessidade de relativizarmos o alcance efetivo dos Conselhos Gerais como instituição e atentarmos para as limitações inerentes a esses órgãos, que, no nosso entender, estiveram arraigadas na própria estrutura política que lhes foi imputada, notadamente na inexistência de uma ingerência verdadeiramente legislativa. O que nos conduz, novamente, à discussão sobre o desfecho das resoluções dos Conselhos Gerais, isto é, sobre a participação do governo central e, sobretudo, da Assembléia Geral na aprovação das matérias.

A importância do Parlamento no encaminhamento das resoluções tomadas pelos Conselhos Gerais já havia sido assegurada pela Carta de 1824 (arts. 85 e 88), o que na prática se verificou de maneira ainda mais intensa. Em primeiro lugar, ao suspender seu juízo sobre determinadas matérias, o imperador deixava à Assembléia Geral o papel de deliberar sobre tais resoluções, restando àquele a sanção ou veto finais. Em segundo, ao

\footnotetext{
${ }^{351}$ Ver O Farol Paulistano, no 290, sessão de 22/12/1829.

${ }^{352}$ Ver O Farol Paulistano, n ${ }^{\circ} 424$, sessão de 02/12/1830.

${ }^{353}$ Ver O Farol Paulistano, no 437, sessão de 04/01/1831.
} 
menos no que diz respeito ao Conselho Geral de São Paulo, foram exceções os casos em que o governo central barrou alguma decisão da Assembléia Geral com relação às representações do referido órgão.

Diante de tal proeminência do Parlamento, cabe aqui uma pergunta: por que nem todas as resoluções enviadas à Assembléia Geral passaram por votação na $1^{\text {a }}$ Reunião do Conselho Geral de São Paulo, lembrando que os conselheiros Diogo Antonio Feijó, Manoel Joaquim de Ornellas e João Crisóstomo de Oliveira e o suplente José da Costa Carvalho também haviam tomado assento como deputados, os três primeiros por São Paulo e o último pela Bahia, pela $1^{\text {a }}$ legislatura do Império?

Excetuando as dificuldades comuns à implantação de qualquer novo órgão, a ausência de uma estreita sintonia entre a Assembléia Geral e o Conselho Geral de São Paulo pode ter ocorrido, em parte, em virtude de uma certa incongruência de prioridades - talvez mais do que de interesses - entre parlamentares e conselheiros provinciais, mesmo porque alguns desses ocupavam, como vimos, ambos os cargos. Além do que, alguns dos projetos levados adiante pelos legisladores revestiam-se de maior envergadura e interesse político se comparados às resoluções emitidas pelos Conselhos Gerais das diversas Províncias do Império. Dentre os projetos de lei discutidos no Parlamento no ano de 1828, pode-se destacar os da reforma das Câmaras Municipais, da abolição da lei dos morgados, da reforma da polícia, da igualdade de direitos de importações para todas as nações, da lei do orçamento e da própria regulamentação do funcionamento dos Conselhos Gerais de Província. $^{354}$ Em novembro de 1829, isto é, quase um ano depois de instalado o Conselho Geral de São Paulo, o periódico paulistano O Observador Constitucional teceu alguns comentários sobre os trabalhos feitos até ali pelo órgão, argumentando que muitos deles

${ }^{354}$ Cf. ARMITAGE, op. cit., p.158. 
deixaram de ser aprovados porque a Assembléia Geral estivera sobrecarregada de atividades nesse período:

“ (...) Muitas forão as propostas, e todas à Província utilíssimas, que no anno passado sahírão do seio do Concelho, e muito he para sentir que os difficeis, arduos, e melindrosissimos trabalhos de que foi sobre-carregada n’este ano a Augusta Assembléa Geral, tenhão impedido que fossem mettidas em execução (...)”. 355

Os efeitos desse acúmulo de funções foi diagnosticado pelos próprios legisladores. Em junho de 1831, a Câmara dos Deputados decidiu que os sábados fossem exclusivamente reservados para os trabalhos relativos aos Conselhos Gerais. ${ }^{356}$ Mas se a Assembléia Geral tinha participação efetiva no que se refere à deliberação sobre as resoluções do Conselho Geral de São Paulo, este era o responsável, por outro lado, pela quantidade moderada de matérias efetivamente produzidas, o que numericamente reduzia ainda mais a probabilidade de aprovação das iniciativas do órgão paulista. O problema foi percebido pelos próprios membros do Conselho Geral, de modo que no início da sessão seguinte, o conselheiro Antonio Mariano de Azevedo Marques propôs a criação de uma comissão especial incumbida apenas de analisar projetos, indicações e outros trabalhos que ficaram pendentes das sessões anteriores. A proposta recebeu aprovação com a emenda do conselheiro Valério de Alvarenga Ferreira, o qual sugeriu que os trabalhos pendentes fossem remetidos para cada membro do Conselho Geral. ${ }^{357}$

A existência de problemas como esses parece não ter comprometido o funcionamento regular do Conselho Geral de São Paulo. Na ocasião do encerramento da $1^{\text {a }}$

\footnotetext{
${ }^{355}$ O Observador Constitucional, $\mathrm{n}^{\circ}$ 12, 30/11/1829.

${ }^{356}$ APB, sessão de 25/07/1831, p.178.

${ }^{357}$ Ver O Farol Paulistano, no 425, sessão de 02/02/1830.
} 
Reunião do Conselho Geral de São Paulo, o então presidente da Província José Carlos Pereira de Almeida Torres comentou sobre o trabalho desenvolvido pelos conselheiros entre dezembro de 1828 e fevereiro de 1830, avaliando, sobretudo, o esforço do órgão na melhoria da infra-estrutura da Província, mais especificamente a preocupação com as estradas, a instrução primária e a inserção do indígena na economia provincial. Além disso, Almeida Torres mencionou a aprovação de diversas posturas advindas das Câmaras Municipais e defendeu, para a Reunião seguinte, a permanência da cooperação vinda da parte do executivo provincial com relação às atividades do Conselho Geral. Por fim, o funcionamento regular deste ajudava a consagrar, no entender do presidente, o funcionamento do sistema constitucional e representativo do novo Estado:

“Convidado para assistir ao Solemne acto do encerramento da presente Sessão, eu venho cheio da maior satisfação manifestar ao Concelho, interpretando, sem receio de enganar-me, os sentimentos dos habitantes d'esta Província, que mui gratos, e lizongeiros devem ser para todos elles os esforços, e fadiga empregadas durante este período da sustentação de suas garantias, e proposição das medidas mais convenientes para o melhoramento dos negócios Provinciaes.

As providencias adoptadas para o mais amplo, e seguro socorro na educação da mocidade desvalida de um, e outro sexo a creação das novas Cadeiras de instrucção primaria, a adopção, e approvação dos planos para as novas obras, que tem de assegurar um mais fácil, mais cômodo e permanente transito para o primeiro, e mais importante Porto da Província o melhoramento da sorte, e condição dos índios e a grande tarefa em fim do exame, e approvação das Posturas de muitas das Camaras Municipaes, alem de outros objectos de commodidade pública, são motivos sufficientes, que justificam a minha asserção, e tem de grangear aos homens honrados Membros do Conselho os verdadeiros, e bem merecidos votos de gratidão de seus Constituintes.

Embora se-nos-offereça diante dos olhos o espaço, e o variado quadro das outras necessidades públicas, que demandão desde já as devidas e promptas providencias; todos 
sabemos, que nem tudo cabe em tão curto espaço de tempo, e nem este póde ser, como cumpre, tão bem approveitado no recente estabelecimento das nossas Instituições.

O Governo da Província, Senhores, não menos exulta do prazer quando exprimindo taes sentimentos, toma no progresso, e resultado d'estes trabalhos a parte, que lhe deve caber pela sua franca e legal cooperação, bem convencido, que d'esta união nasce a fôrça necessária, indispensável para se chegar ao único fim commum, qual da Felicidade Publica. Nem outros podem ser os seus desejos, nem-uma outra a sua marcha, como Agente de um Poder tanto mais sublime, mais nobre, mais poderoso, e permanente, quanto é Elle mesmo verdadeira, e puramente uma das Delegações da briosa Nação, a que temos a honra de pertencer.

Debaixo de tão favoráveis auspícios os novos Membros eleitos, que tem na próxima futura Sessão se ornar este recinto, possuídos dos mesmos sentimentos de patriotismo, como creio, seguindo tão nobre exemplo, e trilhando tão bem encetado caminho dos seus antecessores, poderão sem dúvida fazer cada vez mais saborear aos briosos Paulistas os fructos de uma das mais bellas e ricas Instituições, que nos consagrou o Liberal Código da nossa Regeneração Política, fazendo levantar ainda mais, se é possível, nos peitos verdadeiramente Brasileiros aquelle enthusiasmo da glória pelo constante amor, fidelidade, respeito, e obediência devidos ao Magnânimo Monarcha, que nos Rege, o Immortal Fundador do Império, Libertador do Brazil, e seu Perpetuo Defensor, a Quem cumpre render incessantes graças, como primeiro Author dos incalculáveis benefícios, que gosamos. São Paulo, 9 de fevereiro de 1830”. 358

A atuação do Conselho Geral de São Paulo não fugiu aos olhos da imprensa paulista da época. Antes do término da $1^{\text {a }}$ Reunião, o Farol Paulistano publicou uma nota sobre sua prorrogação por mais alguns dias, ressaltando tanto a quantidade como a qualidade dos trabalhos feitos pelo órgão até aquele momento:

“O Concelho Geral d’esta Província se prorrogou por mais oito dias para concluir os muitos trabalhos, que estavão quase concluídos. Tornamos a repetir, o Concelho Geral tem

\footnotetext{
${ }^{358}$ O Farol Paulistano, no 320, 16/03/1830.
} 
trabalhado não mal, e muito. Bastantes Posturas, bastantes contas das Câmaras, algumas Representações, e Resoluções sobre objectos de grande utilidade Provincial”. ${ }^{359}$

No final do mesmo ano, por volta de dez meses após a publicação dos comentários do redator de $O$ Farol, deu-se a abertura da $2^{\text {a }}$ Reunião do Conselho Geral de São Paulo, que funcionou entre $1^{\circ}$ de dezembro de 1830 e janeiro de 1833. Para o cargo de conselheiro foram eleitos Rafael Tobias de Aguiar, Manuel Joaquim de Ornellas, Bernardo José Pinto Gavião Peixoto, Valério de Alvarenga Ferreira, Diogo Antonio Feijó, Manuel Joaquim do Amaral Gurgel, Antonio Paes de Barros, Antonio José de Macedo Sampaio, José da Costa Carvalho, Antonio Mariano de Azevedo Marques, Francisco de Paula Souza e Melo, José Antonio dos Reis, José Manuel da Luz, Joaquim José de Moraes Abreu, Cândido Gonçalves Gomide, João da Silva Machado, José Correa Pacheco e Silva, Inácio Marcondes de Oliveira Cabral, José Inocêncio Alves Alvim, Vicente Pires da Mota, Antonio Bernardo Bueno da Veiga e Francisco Álvares Machado de Vasconcelos ${ }^{360}$. Já os suplentes foram Francisco Inácio de Souza Queirós, João Crisóstomo de Oliveira Salgado Bueno, Lourenço Pinto de Sá Ribas, Cláudio José Machado, Manuel José da Costa, Manuel Joaquim Gonçalves de Andrade, Joaquim Pereira Barros, Jose Antonio Pimenta Bueno, Joaquim Silvério de Castro Sousa Medronho, Antonio Rodrigues de Campos Leite, Manuel Dias de Toledo e Antonio Martins dos Santos. ${ }^{361}$

Nove dos conselheiros eleitos já haviam ocupado o mesmo cargo na reunião passada e seis como suplentes, de modo que mais de $70 \%$ dos conselheiros escolhidos para

\footnotetext{
${ }^{359}$ O Farol Paulistano, $\mathrm{n}^{\circ} 302,30 / 01 / 1830$.

${ }^{360}$ Francisco Álvares Machado de Vasconcellos (1776-1846) era natural de Porto Feliz, São Paulo, era filho de filho de Teobaldo Machado e Vasconcelos e Maria Álvares da Silva Bueno. Cirurgião médico, um dos pioneiros da oftalmologia no Brasil, também percorreu carreira política. Foi deputado por São Paulo na $3^{\mathrm{a}}$, $4^{\mathrm{a}}$ e $6^{a}$ Legislaturas. Em 1840, foi presidente da Província do Rio Grande do Sul.

${ }^{361}$ MARQUES, op. cit., vol.1, pp.194-195.
} 
comporem a $2^{\mathrm{a}}$ Reunião já tinham participado da antecedente. Os números tornam-se ainda mais contundentes se notarmos que, dos nove suplentes eleitos, seis deles tinham ocupado a cadeira de conselheiro na $1^{\mathrm{a}}$ Reunião. Ou seja, 21 dos 27 membros eleitos para a $1^{\mathrm{a}}$ Reunião (entre 21 conselheiros e 6 suplentes) foram conselheiros ou suplentes na reunião seguinte. Partindo de dados como esses, não é de se espantar que, além de reiterarem a base da $1^{\text {a }}$ Reunião do Conselho Geral, os mesmos políticos também estivessem inseridos no Conselho da Presidência de São Paulo. Cinco dos seis conselheiros eleitos para a $2^{\mathrm{a}}$ Reunião do Conselho da Presidência de São Paulo também o foram para a reunião de mesmo número do Conselho Geral. ${ }^{362}$ Além disso, sete deputados paulistas eleitos para a $2^{\text {a }}$ legislatura também compuseram a nova Reunião do Conselho Geral, sendo seis deles como conselheiros (Rafael Tobias de Aguiar, Manuel Joaquim de Ornellas, Diogo Antonio Feijó, Antonio Paes de Barros, Francisco de Paula Souza e Melo e José Correa Pacheco e Silva ${ }^{363}$ ) e um como suplente (Lourenço Pinto de Sá Ribas).

A permanência maciça de integrantes da $1^{\mathrm{a}}$ Reunião não deve ofuscar, todavia, o surgimento de homens que, se por essa época não detinham ainda a proeminência política conquistada anos depois, fizeram do Conselho Geral de São Paulo um espaço de prática e projeção política. Alguns eram ou haviam sido alunos do Curso Jurídico de São Paulo -

\footnotetext{
${ }^{362}$ O único conselheiro da Presidência que não chegou a ser eleito para o Conselho Geral foi Nicolau Pereira de Campos Vergueiro. Este, ocupando o lugar de senador desde 1829, também não tomou assento do Conselho da Presidência de São Paulo.

363 José Corrêa Pacheco e Silva (1778-1836) era natural de Itu e formado em Direito pela Universidade de Coimbra. Exerceu o cargo de juiz de fora e ouvidor geral da cidade de São Paulo de setembro de 1822 a março de 1825. Entre 10 de setembro de 1822 e 9 de Janeiro de 1823, foi membro do Governo provisório de São Paulo criado pela carta régia de 25 de junho de 1822, acumulando a função de secretário. Deputado por São Paulo na $1^{\mathrm{a}}, 2^{\mathrm{a}}$ e $3^{\mathrm{a}}$ legislaturas, ainda foi membro do Conselho Geral da Província de São Paulo em 1830.
} 
como Vicente Pires da Mota e Jose Antônio Pimenta Bueno -, personagens que ocupariam lugares de destaque após 1834 e, sobretudo, no $2^{\text {o }}$ Reinado. $^{364}$

Do ponto de vista da forma e conteúdo, os trabalhos levados adiante na $2^{\text {a }}$ Reunião indicam para uma certa continuidade da estrutura criada nos anos anteriores. Com relação à instrução pública, por exemplo, aprovou-se uma proposta sobre a criação de cadeiras de primeiras letras nas freguesias de Cotia, Caçapava, S. Bento, Queluz, Pirapora, Capivari, Conde, São José dos Pinhais, Palmeiras, Ponta Grossa, Chiririca, na Vila de Castro e nas colônias alemãs de Santo Amaro e da Entrada da Mata. Encaminhada à Assembléia Geral e ao governo central em fevereiro de 1831, a proposta foi aprovada pelos parlamentares ${ }^{365}$ e, em seguida, sancionada pela Regência em outubro do mesmo ano. ${ }^{366}$ Decidiu-se, também, em favor da supressão das cadeiras de Teologia Dogmática e Moral, de História Eclesiástica, e de Latim dos moços do Coro da Sé, na capital paulista. Ao contrário da resolução anterior, esta não obteve sucesso nas instâncias superiores.

\footnotetext{
${ }^{364}$ Vicente Pires da Mota (1779-1882) era natural da cidade de São Paulo e, quando do seu ingresso no Curso Jurídico, em 1828, Pires da Mota da já era presbítero. Tornou-se bacharel em 1832 e, no ano seguinte, foi nomeado lente substituto interino, tal como ocorrera com outros colegas de curso e política, como Manoel Joaquim do Amaral Gurgel e Manoel Dias de Toledo. Em 1833, foi nomeado lente catedrático de direito civil. Como político, iniciou sua carreira como conselheiro da $2^{\mathrm{a}}$ Reunião do Conselho Geral (1830-1833) e da $3^{\mathrm{a}}$ Reunião do Conselho da Presidência (1834), ambos pela Província de São Paulo. Após o Ato Adicional (1834), foi deputado por São Paulo à Assembléia Provincial nos biênios de 1834-35,1836-37,1838-39 e 1840-41.Mais tarde, foi presidente da Província de São Paulo de 16 de outubro de 1848 a 27 de agosto de 1851 e de 16 de outubro de 1862 a 3 de fevereiro de 1864. Foi presidente, ainda, nas Províncias de Pernambuco (entre 26 de abril e 17 de junho de 1848), Ceará (entre 20 de fevereiro de 1854 a 11 de outubro de 1855), Minas Gerais (entre 13 de junho de 1860 a 2 de outubro de 1861) e Santa Catarina (entre 17 de novembro de 1861 a 24 de setembro de 1862). Em 1850 recebeu o título de conselheiro de Estado. Cf. AMARAL, Antonio Barreto do. Dicionário de História de São Paulo. [Coleção Paulística]. São Paulo: Governo do Estado, 1980, pp.321-322.

Jose Antônio Pimenta Bueno (1803-1878), Marquês de São Vicente, era natural de Santos. Filho de José Antônio Pimenta Bueno e Mariana Benedita de Faria e Albuquerque, formou-se em Direto pelo Curso Jurídico de São Paulo. Na política, ocupou diversos cargos, tais como membro da $2^{\mathrm{a}}$ e $3^{\mathrm{a}}$ Reuniões do Conselho Geral de São Paulo, entre 1830 e 1834, presidente da Província do Mato Grosso (entre 1836 e 1838), deputado geral (entre 1845 e 1847), presidente da Província do Rio Grande do Sul (de março a novembro de 1850), senador do Império (de 1853 a 1878) e ministro de diversas pastas, todas elas no $2^{\circ}$ Reinado. Sobre Pimenta Bueno, ver SÃO VICENTE, Marquês de. Marquês de São Vicente. [Coleção Formadores do Brasil]. Organização e introdução de Eduardo Kugelmas. São Paulo: Editora 34, 2002.

365 "Decreto de 13 de outubro de 1831 - crêa cadeiras de primeiras letras em diversas comarcas da Provincia de S. Paulo", in Coleção das Leis do Império do Brasil de 1831, op. cit., Parte Primeira, pp.135-136.

${ }^{366}$ ACE, 78ª sessão (08/10/1831), pp.189-191.
} 
Se matérias inéditas foram ventiladas, propostas antigas ganharam novos impulsos. Em fevereiro de 1831, num ofício enviado ao Senado, o órgão paulista solicitou a análise de um pedido para criação de cadeiras de filosofia em algumas freguesias e de uma escola médico-cirúrgica na capital da Província, propostas que já haviam sido remetidas à Assembléia Geral em janeiro de 1829, mas que não obtiveram aprovação. Fazendo questão de explicitar a reincidência de ambas as propostas, o Conselho Geral se disse conhecedor da "afluencia de negocios d'alta monta” que chegavam à Assembléia Geral, o que por certo a privou de deliberar sobre tais resoluções. ${ }^{367}$ Note-se aí uma cobrança, ainda que velada, com relação à agilidade na aprovação das decisões tomadas pelo Conselho Geral de São Paulo. O fato é que pouco adiantou a requisição do órgão paulista, que mais uma vez viu as duas propostas não alcançarem êxito.

A organização político-administrativa da Província permaneceu, também, como uma das preocupações do Conselho Geral paulista. Em julho de 1832, a Assembléia Geral aprovou a decisão do Conselho Geral em elevar à categoria de vila as freguesias de Santo Amaro, São João de Capiravi, São Bento, Santa Izabel, Santo Antonio de Paraibuna, São Roque e Bananal. ${ }^{368}$ Em março do mesmo ano, a Regência já mandara executar provisoriamente uma resolução do Conselho sobre a supressão das paróquias criadas nas aldeias de Pinheiros, Ibuí, São Miguel, Itaquaquecetuba e Itapecerica. ${ }^{369}$ A eliminação da freguesia de Araçariguama foi aprovada pelo Conselho Geral, mas a Regência suspendeu juízo sobre a matéria, indicando que se "reservasse para as Câmaras” a resolução. ${ }^{370}$

\footnotetext{
${ }^{367}$ RPR, “Oficio pedindo a creação de Cadeiras de Filosofia em algumas Vilas das Provincias, e huma escola Medico-Cirurgica nesta Capital”, p.39

368 "Decreto de 10 de julho de 1832 - erige em villas varias freguezias na Provincia de S. Paulo", in Coleção das leis do Império do Brasil de 1832. Rio de Janeiro: Tipografia Nacional, 1874, Primeira Parte, pp.23-24.

${ }^{369}$ ACE, 86 ${ }^{a}$ sessão (16/03/1832).

${ }^{370} \mathrm{ACE}, 105^{\mathrm{a}}$ sessão (15/03/1833), pp.259-262. Em 1831, havia sido aprovada pelo Conselho Geral de São Paulo a extinção de outra freguesia, a do Bom Jesus, Cf. RPR, "Proposta para a extinção da freguesia do Bom
} 
Já presentes anteriormente, as matérias vinculadas à esfera clerical atingiram maiores proporções na $2^{\mathrm{a}}$ Reunião, de modo que pelo menos onze propostas foram aprovadas nesse sentido pelo Conselho Geral. ${ }^{371}$ A maior parte delas não se traduzia, contudo, em projetos de infra-estrutura mais ampla, mas em expedientes práticos referentes ao cotidiano dos eclesiásticos, que por sua vez estavam representados nas cadeiras do Conselho Geral por nomes como Diogo Antônio Feijó, Manuel Joaquim do Amaral Gurgel, João Chrisostomo de Oliveira Salgado, Valério Alvarenga Ferreira, Ignácio Marcondes de Oliveira Cabral e Vicente Pires da Mota. Mas nem por isso houve uma admissão sistemática de propostas que iam ao encontro de interesses do corpo eclesiásticos paulista, mesmo porque, como se sabe, esse não chegava a compor uma plataforma coesa em termos religiosos ou políticoideológicos. ${ }^{372}$ Assim, o que se viu foi a aprovação de matérias que ora favoreciam membros da Igreja - tal como a que eximia os párocos de pagar pensão à capela imperial - ora limitavam sua ação, como no caso da resolução que previa que os padres não poderiam sair de suas respectivas freguesias sem permissão do governo provincial. Uma correspondência inserta no periódico O Farol Paulistano enalteceu a resolução tomada pelo Conselho Geral sobre a supressão do pagamento de licenças pelos párocos para poderem pregar e confessar,

Jesus desta Capital”, pp.31-32. A resolução não foi aprovada nem pelo governo central nem pela Assembléia Geral.

${ }^{371}$ Foram elas: proposta sobre a residência dos párocos; sobre as fábricas das igrejas matrizes; sobre a isenção por parte dos párocos no pagamento de pensão à capela imperial; sobre a sepultura dos cadáveres dos fiéis; sobre as licenças para a exposição do santíssimo sacramento; sobre as licenças que tiveram os sacerdotes para pregar e confessar; sobre a catequese e civilização dos índios; sobre o pagamento de conhecenças pelos párocos; sobre a autorização aos párocos e capelães curados a passar certidões sem dependência de despacho; sobre erigir em freguesia duas capelas curadas na Província de São Paulo; e sobre a concessão da gratificação de $100 \$ 000$ além da côngrua ao pároco de Guarapuava, e a de 240\$000 ao vigário encomendado.

${ }^{372}$ Lembremos aqui, por exemplo, a distinção entre clero regular e secular, além do Padroado. Sobre o assunto, ver LACOMBE, Américo Jacobina. “A Igreja no Brasil Colonial”, in HOLANDA, Sergio Buarque de (org.). História Geral da Civilização Brasileira, tomo II. São Paulo: Difel, 1985, v.2; HOORNAERT, Eduardo. Formação do Catolicismo Brasileiro (1500-1800). Petrópolis: Vozes, 1978. $2^{\mathrm{a}}$ edição; DORNAS FILHO, João. O padroado e a Igreja Brasileira. São Paulo/ Rio de Janeiro/ Recife: Companhia Editora Nacional, 1938; AZEVEDO, T. Igreja e Estado em Tensão e Crise: a conquista espiritual e o Padroado na Bahia. São Paulo: Ática, 1978. 
e sugeriu que outras medidas fossem tomadas a fim de regulamentar a atuação do clero. ${ }^{373}$ Mesmo com tamanha movimentação, há registro de que a Assembléia Geral aprovou apenas duas resoluções do Conselho Geral desse tipo, uma para a criação de duas capelas curadas e outra marcando gratificações a eclesiásticos de Guarapuava. ${ }^{374}$ De forma provisória, o governo central anuiu somente a resolução a qual autorizava os párocos e capelães curados a passar certidões sem despacho. $^{375}$

A canalização de esforços para campos específicos não minimizou o costume de lidar com temáticas múltiplas. À guisa de exemplificação, em fevereiro de 1831 aprovou-se uma representação sobre a abolição do castigo da chibata infligido aos soldados e uma proposta sobre o tratamento dos escravos velhos ou enfermos. ${ }^{376}$ Mas tal variedade de resoluções parece não ter surtido o efeito esperado no que diz respeito à sua efetiva aplicação. Em janeiro de 1832, a Secretaria da Câmara dos Deputados enviou ao Conselho Geral de São Paulo uma listagem com resoluções tomadas pelo órgão paulista que ainda estavam pendentes na primeira Casa. Treze das dezessete medidas arroladas ainda não havia entrado em discussão, apesar da maioria delas ter sido enviada ao Rio de Janeiro há cerca de um ano. ${ }^{377}$ Assim, rastreando o percurso de propostas e representações, verificou-se que, confrontada com a anterior (que por sinal teve uma duração menor), a $2^{\mathrm{a}}$ Reunião teve um percentual inferior de medidas aprovadas pela Assembléia Geral ou executadas provisoriamente pelo Governo.

\footnotetext{
${ }^{373}$ O Farol Paulistano, nº446, 03/02/1831.

374 "Decreto de 16 de agosto de 1832 - erige em freguezia duas capellas curadas na Província de S. Paulo”, in Coleção das leis do Império do Brasil de 1832, op. cit., p.59, e "Decreto de 17 de agosto de 1832 - concede a gratificação de $100 \$ 000$ além da congrua ao Parocho de Guarapuava na Província de S. Paulo, e a de $240 \$ 000$ ao Vigario encommendado, que fizer as suas vezes”, in Ibid., pp.59-60.

${ }^{375}$ ACE, $105^{\mathrm{a}}$ sessão (15/03/1833), pp.259-262.

${ }^{376}$ RPR, "Representação sobre a abolição do castigo da chibata infligido aos soldados", p.27; "Proposta sobre o tratamento dos escravos velhos enfermos", p.38.

${ }^{377}$ FCGP, "Relação das Resoluções do Conselho Geral da Província de São Paulo, cuja decisão acha pendente na Câmara dos Deputados”, RP32.001, caixa 24.
} 
Os motivos dessa queda foram, provavelmente, similares àqueles que já haviam trazido problemas ao longo da $1^{\text {a }}$ Reunião na aprovação final de propostas. Imersos em questões de fundo para a estruturação do Estado Nacional - tal como as votações das leis de orçamento e da Regência, a criação da Guarda Nacional, a reforma constitucional, a reestruturação financeira do Império e a implantação do novo código de processo criminal -, os parlamentares da $2^{\mathrm{a}}$ legislatura (1830-1833) parecem ter relegado a um plano secundário a aprovação de medidas oriundas dos Conselhos Gerais de Província como um todo. Mesmo após a Abdicação, quando setores importantes da chamada ala liberal moderada passaram a ocupar cargos estratégicos no Governo, as resoluções advindas dos Conselhos Gerais não ganharam uma atenção sensivelmente maior. É provável que essa situação tenha ampliado as pressões para que os Conselhos Gerais se tornassem Assembléias Legislativas. ${ }^{378}$

Mas a atuação dos Conselhos Gerais não deve ser medida apenas pela cristalização ou não de suas propostas, já que nem todas as suas atribuições estavam atreladas à ingerência do Legislativo e do Executivo. Os Conselhos detinham uma atribuição políticoadministrativa singular que não se atinha propriamente à esfera provincial, mas à municipal. Tratava-se do controle exercido pelos Conselhos Gerais sobre a as atividades desenvolvidas pelas Câmaras Municipais.

\subsection{Os Conselhos Gerais e as Câmaras Municipais: o caso paulista}

\footnotetext{
${ }^{378}$ No capítulo seguinte discutir-se-á os nexos entre a institucionalização do Estado Nacional pós-Abdicação e o funcionamento dos Conselhos Gerais.
} 
Durante o período colonial, as Câmaras Municipais representaram um dos pilares da estrutura política, administrativa e jurídica da América portuguesa. ${ }^{379}$ Ainda que alguns historiadores tenham questionado ${ }^{380}$ sua preeminência no processo de colonização luso, é certo que atribuições como a aplicação da lei, a determinação de impostos, a imposição de normas, a administração dos bens municipais, a arrecadação das rendas locais e a nomeação de funcionários públicos fizeram das Câmaras fóruns de representações cujo papel foi inconteste no movimento de ocupação das terras americanas, bem como na estruturação dos poderes políticos locais.

Com o desencadeamento dos processos de Independência e construção do Estado Nacional, as Câmaras Municipais começaram a perder força, especialmente pelo fato de que se sobrepôs à municipalidade uma outra esfera de poder político, que por sinal foi fundamental para a viabilização da monarquia: o poder provincial. ${ }^{381}$ Nesse ponto, a construção dos governos provinciais, iniciadas com as Juntas de Governo, fez-se necessária não apenas para atender às demandas institucionais de uma nascente monarquia representativa; ela serviu, também, como mecanismo de afirmação política dos grupos regionais no interior do processo de formação do Império brasileiro. ${ }^{382}$ No entanto, o

\footnotetext{
${ }^{379}$ Sobre a importância das Câmaras Municipais no processo de colonização português na América, ver entre outros BOXER, Charles R. O império marítimo português, 1415-1825. Trad. Port. Anna Olga de Barros Barreto. São Paulo: Companhia das Letras, 2002 [1 $1^{\mathrm{a}}$ edição 1969], especialmente capítulo 12; Portuguese society in the tropics - the municipal councils of Goa, Macao, Bahia and Luanda, 1510-1800. Madison: University of Wiscosin Press, 1965; GARCIA, Rodolfo. Ensaio sobre a História Política e Administrativa do Brasil:1500-1810. Rio de Janeiro/Brasília: José Olympio/MEC, 1975; RUSSEL-WOOD, A. J. R. "O poder local na América Portuguesa”, in Revista de História, v.55, n¹09, São Paulo, 1977, pp.25-79.

${ }^{380}$ Ver, por exemplo, FAORO, Raymundo. Os Donos do Poder. Porto Alegre: Globo, 1958.

${ }^{381}$ HOLANDA, Sergio Buarque de. "A herança colonial - sua desagregação”, in HOLANDA, Sergio Buarque de. (org.). História Geral da civilização brasileira, tomo II, "O Brasil Monárquico". São Paulo: Difusão Européia do Livro, 1965, vol.1, pp.09-39; SOUZA, Iara Lis Carvalho. "A adesão das Câmaras e a figura do imperador”. Revista Brasileira de História, v.18, n.36, São Paulo, 1998; GODOY, Mayr. A câmara municipal, uma estrutura política do poder legislativo na ordem local brasileira. São Paulo, 1978; BANDECHHI, Pedro Brasil. “O município no Brasil e sua função política”. Revista de História. São Paulo, n.90, arb.jun.,1972, pp. 495-530.

${ }^{382}$ JANCSÓ, István; PIMENTA, João Paulo., op. cit.
} 
entendimento sobre o papel dos governos provinciais na composição do estado imperial dividiu opiniões e, como se verá adiante, tornou-se uma das problemáticas centrais em fins do Primeiro Reinado e início do período regencial, quando o debate em torno da reforma da Carta de 1824 ganhou força.

A definição do poder das Câmaras Municipais foi selado com a promulgação da lei de $1^{\mathrm{o}}$ de outubro de $1828^{383}$, cujo texto fora elaborado pelo Senado e aprovado pelos deputados com poucas emendas. A partir dela, as Câmaras Municipais ficariam reduzidas à “corporações meramente administrativas”, deixando de exercer qualquer tipo de “jurisdição contenciosa” (art.24, Título II). Em suma, as Câmaras Municipais foram esvaziadas de sua capacidade jurídica, ficando proibidas de determinar suas respectivas diretrizes administrativas e fiscais. $^{384}$

Provimentos e posturas municipais deveriam passar pela aprovação dos Conselhos Gerais - o que incluía eventuais emendas e alterações de conteúdo - para serem postos em vigência (art.39, Título II). No que tange à esfera financeira, marcou-se que as Câmaras Municipais seriam obrigadas, anualmente, a prestar suas contas aos Conselhos Gerais, de modo que esses provessem sobre elas como achassem conveniente (art. 46, Título II). Na prática, os Conselhos Gerais ficaram responsáveis pela fiscalização das finanças tal como já vinham fazendo os Conselhos da Presidência, conforme se analisou anteriormente.

\footnotetext{
383 "Lei de $1^{\text {o }}$ de outubro de 1828 - Dá nova fórma as Câmaras Municipaes, marca sua attribuições, e o processo para a sua eleição, e dos Juizes de Paz”, in op. cit., pp.74-88. Em verdade, outras iniciativas já haviam sendo tomadas pelo Governo e Parlamento com o intuito de minorar a força das municipalidades. A lei de 22 de setembro de 1828, além de abolir o tribunal da Mesa de Consciência e Ordens, extinguiu o do Desembargo do Paço, que era por onde se expediam assuntos da economia municipal. Cf. HOLANDA, Sergio Buarque de. "A herança colonial - sua desagregação", in HOLANDA, Sergio Buarque de. (org.). História Geral da civilização brasileira, tomo II, "O Brasil Monárquico”. São Paulo: Difusão Européia do Livro, 1965, vol.1, p.24.

${ }^{384}$ MAIA, João de Azevedo Carneiro. O município, estudos sobre administração local. Rio de Janeiro: Tipografia G. Leuzinguer \& Filhos, 1883.
} 
Os Conselhos Gerais funcionariam, ainda, como mediadores da prática políticoadministrativa das Câmaras e fiscalizadores do cumprimento da lei na esfera municipal. Obras públicas de "grande importância", no caso de envolverem particulares, deveriam ser remetidas aos Conselhos Gerais como propostas (art.47, Título II). O mesmo encaminhamento teriam as iniciativas das Câmaras cuja finalidade era aumentar suas rendas (art.77, Título IV). Já as denúncias contra “infrações na Constituição”, "prevaricações” ou “negligencias” de quaisquer empregados públicos deveriam ser encaminhadas ao presidente da Província, bem como aos Conselhos Gerais (art. 58, Título II), que também apurariam as reclamações com relação aos maus tratos com escravos (art. 59, Título II). Se por ventura os “cidadãos” se sentissem "agravados pelas deliberações, acórdãos e posturas das Camaras”, poderiam comunicar sua insatisfação aos Conselhos Gerais (art.73, Título III). ${ }^{385}$

Prescritas por lei, as relações entre as Câmaras Municipais e os Conselhos Gerais eram complexas e nuançadas. O historiador Márcio Eurélio de Carvalho notou, para o caso de Minas Gerais, a constante cobrança das Câmaras Municipais quanto à implantação do Conselho Geral mineiro. ${ }^{386}$ No que diz respeito ao Conselho Geral de São Paulo, o contato desse órgão com as diversas municipalidades da Província deu-se de forma ininterrupta, valendo-se das distintas atribuições asseguradas quer pela Carta de 1824 quer pelos regimentos que regulavam os Conselhos Gerais e as Câmaras Municipais. A expectativa em torno do entrosamento entre os dois órgãos esteve presente na própria imprensa paulista da época, a exemplo de nota inserida no Observador Constitucional, em novembro de 1829, às vésperas do início do segundo ano de funcionamento do Conselho Geral de São Paulo:

\footnotetext{
${ }^{385}$ Ibid., pp.79-86.

${ }^{386}$ CARVALHO, Marcio Eulério Rio de. Afirmação de uma esfera pública de poder em Minas Gerais (18211851). Tese de doutorado apresentada ao Departamento de História da Faculdade de Filosofia e Ciências Humanas da Universidade Federal de Minas Gerais. Belo Horizonte, 2003.
} 
“(...) Não menor numero de projectos philantropicos esperamos neste anno d'esta sabia reunião, que sendo a segunda trabalhará com mais acerto principalmente sobre os materiaes que as Camaras Municipaes das differentes Villas terão de lhe fornecer (...)”.387

A aprovação de posturas figurava como uma das principais atividades desenvolvidas pelos Conselhos Gerais com relação às Câmaras Municipais. Em linhas gerais, as posturas consistiam num conjunto de medidas formuladas e aprovadas pelos integrantes de cada Câmara (os vereadores) a respeito da condução da administração municipal. Pela lei de $1^{\circ}$ de outubro de 1828, elas se transformaram no principal instrumento legal das municipalidades, sendo inclusive publicadas por alguns periódicos da época, juntamente com as atas das Câmaras. No caso da Câmara Municipal da cidade de São Paulo, aquelas posturas aprovadas pelo Conselho Geral de São Paulo chegaram a ser impressas e vendidas na Tipografia do Farol Paulistano separadamente dos periódicos ali publicados. ${ }^{388}$ Em dezembro de 1830, o suplente Jose Antonio Pimenta Bueno sugeriu que as Câmaras Municipais comprassem uma tipografia para imprimirem seus trabalhos, com o objetivo de torná-los públicos e de facilitarem o expediente do Conselho Geral. ${ }^{389}$ Dois anos mais tarde, o mesmo Conselho recomendou a todas as Câmaras Municipais que compilassem suas posturas aprovadas pelo órgão, mandassem-nas imprimir e as vendessem pelo menor preço possível, a fim de que essas chegassem “ao conhecimento dos habitantes dos seus municípios”. 390

Ao menos no caso paulista, a aprovação de posturas municipais tornou-se o trabalho que preenchia a maior parte do expediente de trabalho dos conselheiros, já que era uma

\footnotetext{
${ }^{387}$ O Observador Constitucional, $\mathrm{n}^{\mathrm{o}} 12,30 / 11 / 1829$.

${ }^{388}$ O Farol Paulistano, no 335, 27/04/1830.

${ }^{389}$ Ver O Farol Paulistano, no 433, sessão de 20/12/1830.

390 “Officio do Secretário do Conselho Geral à Camara”, in Registro Geral da Câmara Municipal de São Paulo, 1832, op. cit., p.32.
} 
atribuição exclusiva desse órgão. ${ }^{391}$ Além da quantidade de municipalidades, requeria-se dos conselheiros um trabalho de análise, alteração, admissão ou supressão de artigo por artigo de cada postura. Mesmo com as constantes emendas feitas pelos conselheiros, a aprovação de posturas por parte do Conselho Geral de São Paulo foi maciça e abrangente, ficando difícil precisar se houve um beneficiamento de algumas Câmaras Municipais em detrimento de outras. De 1830, dois anos após a instalação dos Conselhos Gerais, há registros referentes à aprovação de posturas das Câmaras de São José, São Carlos, Paranaguá, Cananéia, Taubaté, Nova do Príncipe, São Luis do Paraitinga, Porto Feliz, Jundiaí, Mogi das Cruzes, Cunha, Lorena, Curitiba, São Vicente, São Paulo, Mogi-Mirim, Itapeva, Guaratuba, Guaratinguetá, Franca do Imperador, Conceição de Itanhaém, Bragança, Atibaia, Bela da Princesa e São Paulo. $^{392}$

Mesmo com essa expressiva aprovação de posturas, é provável que algumas delas tenham sido cumpridas pelas administrações municipais antes mesmo de sua aprovação pelo Conselho Geral. Em 25 de outubro de 1831, a Assembléia Geral decretou que as Câmaras Municipais estavam proibidas de executar suas posturas antes da aprovação pelos Conselhos Gerais. Nas ocasiões em que tanto estes como a Assembléia Geral não estivessem em funcionamento, as posturas deveriam ser remetidas para os presidentes de Província em reunião com o Conselho da Presidência, a fim de que esses mandassem executá-las provisoriamente. ${ }^{393}$ Extensível às demais Províncias do Império - daí a abrangência do decreto -, a execução das posturas antes de sua aprovação pode ter se dado, em parte, pelo

\footnotetext{
${ }^{391}$ Nem os presidentes de Província, a partir de 1831, tinham o poder de intervir na aprovação das posturas municipais. Cf. "Decisão do Ministério do Império de 17 de agosto de 1831 - declara que os Presidentes das Provincias nenhuma ingerência têm nas posturas das Câmaras Municipaes, as quais somente são sujeitas à approvação dos Conselhos Geraes”, in Coleção das decisões do governo de 1831, op. cit., p.190.

${ }^{392}$ Cf. "Posturas Municipais" de 1830 pertencentes ao Fundo Conselho Geral da Província do Acervo Histórico da Assembléia Legislativa do Estado de São Paulo (FCGP), caixas 17, 18 e 19.

393 "Decreto de 25 de outubro de 1831 - Prohibe a execução de posturas municipaes antes de sua approvação", in Coleção das Leis do Império do Brasil de 1831, op. cit., Parte Primeira, pp.146-147.
} 
curto período de funcionamento dos Conselhos Gerais, que talvez não conseguissem dar conta da análise de todo o material que lhes era enviado.

O exame das finanças municipais consistia em outra atividade recursiva a ser desenvolvida pelos Conselhos Gerais. Segundo a historiadora Andréa Slemian, Pernambuco, Ceará e Minas Gerais tiveram problemas com a prestação de contas pelas municipalidades, que se indispuseram com Conselhos Gerais, sendo provável que o mesmo tenha ocorrido com as demais Províncias do Império. ${ }^{394}$ No caso da Província de São Paulo, o Conselho Geral exigiu, amiúde, que as Câmaras Municipais detalhassem mais minuciosamente suas contas, a fim de que essas fossem aprovadas com maior rigor e rapidez. ${ }^{395}$ Neste sentido, assim como acontecera anteriormente com o Conselho da Presidência, a análise financeira das Câmaras Municipais pelo Conselho Geral de São Paulo não foi tarefa de execução simples, em virtude da falta de dados precisos sobre o estado das finanças e, sobretudo, da ausência de um critério de prestação de contas comum a todas as municipalidades. Ciente desse quadro desfavorável, o suplente José da Costa Carvalho sugeriu, em janeiro de 1830,

\footnotetext{
${ }^{394}$ SLEMIAN, op. cit., pp.220-222.

395 Veja-se, por exemplo, o ofício enviado pela Secretaria do Conselho Geral de São Paulo à Câmara Municipal de São Paulo, em fevereiro de 1830, a respeito da prestação de contas pela Câmara paulistana: "Ilmos. Srs. - Tendo o Conselho Geral examinado as contas por VV. Sas. Submettidas à sua revisão, e approvação desde 6 de março até o fim de setembro do anno findo o mesmo notou $1 .^{\circ}$ - Que na 1.a conta tomada desde janeiro até 30 de abril faltam os rendimentos das cabeças de rezes das freguezias de Santo Amaro, e igualmente de MBoy, Itapecerica, e Juquery; e o rendimento das entradas das aguardentes das freguezias de Juquery, Conceição, Penha, São Miguel, e Ó. 2. ${ }^{\circ}$ - Que na 2.a tomada ao Procurador transacto Antonio Justiniano de Souza só se mencionam os rendimentos das cabeças das freguezias de Itapecerica, e Ó, faltando os das outras. $3 .^{\circ}$ - Que, quanto á conta dos rendimentos das entradas das aguardentes das differntes freguezias, não vêm nella os de Juquery, São Bernardo, Concição, Penha, São Miguel, e Braz. $4 .^{\circ}$ - Que, quanto á 2.a e 3.a. contas, tomadas ao actual Procurador desde o $1 .^{\circ}$ de agosto té 30 de setembro do anno próximo passado, faltam na receita os rendimentos das cabeças de rezes de todas as freguezias, á excepção da de São Bernardo; os rendimentos das entradas de aguardentes das freguezias de Juqueri, Ó, Conceição, São Miguel, e Penha; por que o alli mencionado pertence ao anno da Câmara transacta. Á vista pois das apontadas faltas resolveu o Conselho, que se pedisse a VV. Sas. os necessários esclarecimentos, afim de poder ultimar o exame das referidas contas. Deus guarde a VV. Sas. Paço do Conselho $1 .^{\circ}$ de fevereiro de 1830 - Ilmos. Srs. Da Câmara Municipal desta cidade de São Paulo - Manuel Joaquim de Amaral Gurgel”. Cf. "Officio do secretario do Conselho Geral à Câmara lido em sessão de 3 de fevereiro de 1830, sobre as contas", in Registro Geral da Câmara Municipal de São Paulo, 1829-1830. São Paulo: Publicação Oficial do Arquivo Municipal de São Paulo, 1923, v.XX, pp.273-274.
} 
que a comissão voltada para as matérias referentes às Câmaras Municipais propusesse um modelo pelo qual as municipalidades formalizassem suas receitas e despesas, o que foi aprovado. $^{396}$ Passados alguns meses, o Conselho Geral fez circular entre as Câmaras Municipais uma resolução que visava formalizar a prestação de contas pelos municípios. ${ }^{397}$

No ano seguinte, um decreto de proporções drásticas foi aprovado pelo Parlamento com o intuito de minorar tais dificuldades mediante a fixação de algumas regras quanto à organização das contas municipais, demonstrando que o problema não se circunscrevia à Província de São Paulo. ${ }^{398}$ Com o decreto, as contas municipais tiveram seu ano financeiro regulado entre o $1^{\circ}$ de outubro e o último dia de setembro do ano seguinte, devendo ser entregues nas respectivas capitais das Províncias em todo o $1^{\circ}$ de dezembro, para daí sim serem remetidas aos Conselhos Gerais. Além disso, as Câmaras passaram a ter que prestar suas contas minuciosamente, discriminando arrecadações, gastos, dívidas e balanços para cada período abordado, sendo passíveis de multa caso não cumprissem com essas exigências.

\footnotetext{
${ }^{396}$ Ver O Farol Paulistano, no 304, sessão de 07/01/1830.

${ }^{397}$ Não foi possível estabelecer a sessão exata na qual foi aprovada essa resolução do Conselho Geral de São Paulo; é certo, todavia, que ela se deu entre janeiro e fevereiro de 1830. Com a resolução, fixaram-se as seguintes diretrizes, que se encontram transcritas num ofício enviado pelo Conselho Geral de São Paulo à Câmara Municipal da Capital paulista, lido em sessão de 16 de abril de 1830: “1. Que as Camaras, na mesma occasião da remessa das suas contas, enviem uma relação das rendas, que formam o fundo da sua receita, podendo vir como observação á margem, ou no fim do mesmo mappa, declarando se são arrematadas, ou administradas. $2 .^{\circ}$ que na mesma occasião venha uma relação das suas dívidas activas e passivas. $3 .^{\circ}$ que de todas as obras novas, e concertos que se fizerem, excedendo a $10 \$ 000$, se proceda a avaliação por pessoas intelligentes da materia, e se as ponha em praça a quem por menos fizer, e não havendo quem as arremate, que mandem fazel-as a jornal na fórma do artigo 47 da lei do $1 .^{\circ}$ de outubro de 1828 , fazendo-se menção da avaliação. $4 .^{\circ}$ que as contas sejam remettidas immediatamente depois de tomadas as do $3 .^{\circ}$ trimestre de cada anno, a fim de ter o Conselho tempo de examinal-as. 5. ${ }^{\circ}$ finalmente, que as Camaras remettam ao mesmo Conselho as contas dos annos transactos, que se não acharem examinadas, e sancionadas pelo governo, e que affirmem em seus officios com certidão do secretario o ultimo anno, em que foram approvadas. Deus guarde a Vossas Mercês. Paço do Conselho Geral de São Paulo, 8 de fevereiro de 1830 - Senhores da Camara Municipal desta Cidade de São Paulo - Manuel Joaquim do Amaral Gurgel, secretario”. Extraído de Registro Geral da Câmara Municipal de São Paulo, 1829-1830, op. cit., pp.327-28.

398 "Decreto de 31 de outubro de 1831 - fixa regras para a contabilidade municipal e tomada das respectivas contas”, in Coleção das Leis do Império do Brasil de 1831, op. cit., Parte Primeira, pp.175-176.
} 
Ainda no que tange ao campo financeiro, é de se registrar o movimento contínuo das Câmaras Municipais na busca pelo aumento de suas rendas, atitude essa assegurada pela lei de $1^{\circ}$ de outubro de 1828 (art. 77). Em 1829, a Câmara Municipal de Itu solicitou ao Conselho Geral a permissão para a criação uma loteria para o Hospital de Lázaros, a fim de que essa fornecesse as rendas necessárias para sua manutenção. ${ }^{399}$ Três anos mais tarde, os vereadores de Areias pediram permissão para que a Câmara Municipal pudesse vender o prédio da cadeia pública daquela Vila para arrecadar recursos. ${ }^{400}$

Além de manejar as esferas político-administrativa e financeira das Câmaras Municipais, o Conselho Geral de São Paulo serviu, à maneira do Conselho da Presidência, como um espaço dedicado à apuração de denúncias contra crimes de abuso de poder, irregularidades na conduta da coisa pública e desrespeito à Constituição. Em 1830, a Câmara Municipal de Mogi-Mirim apresentou uma denúncia contra o juiz de paz de Casa Branca, por este ter absolvido de multa eleitores que não haviam comparecido à eleição para vereador. Durante seu funcionamento o Conselho Geral recebeu denúncias contra ouvidores, juízes (de órfãos, ordinários e de paz), clérigos e militares. ${ }^{401}$

Mas diferentemente do que ocorria no Conselho privativo do presidente da Província, onde as decisões eram tomadas mais agilmente, o Conselho Geral tinha que analisar as denúncias, redigi-las em forma de representações, submetê-las à aprovação dos demais conselheiros, enviá-las para a Assembléia Geral ou ao governo central, para aí sim ganharem ou não uma concretude legal. Nesse sentido, e em meio às várias denúncias recebidas pelo Conselho Geral de São Paulo, sobretudo contra empregados públicos,

\footnotetext{
${ }^{399}$ FCGP, CF29.004, caixa 01.

${ }^{400}$ FCGP, CF32.074, caixa 15.

${ }^{401}$ FCGP. Ver, por exemplo, os documentos CP32.024, caixa 14; CP31.094, caixa 13; CP31.093, ESP 230; CP31.087, caixa 13; e CP31.073, caixa 13, referentes à denuncias contra juizes de paz nas Vilas de Jundiaí, Ubatuba, Taubaté, Sorocaba e São Paulo.
} 
foquemos nossa atenção num caso específico que, dada a sua amplitude, pode desnudar algumas das relações que se constituíam entre essas esferas de poder.

Em 21 de abril de 1830, invocando o artigo 58 da lei de $1^{\circ}$ de outubro de $1828^{402}$, a Câmara Municipal da capital paulista remeteu ao Conselho Geral de São Paulo uma denúncia contra o reverendo Hygino Francisco Teixeira, na época vigário colado da freguesia de São Bernardo, por conta de seus “desleixos” e “abusos” cometidos na paróquia de sua responsabilidade:

"Na conformidade do artigo 58 da lei do $1^{\circ}$ de outubro de 1828 a Camara Municipal desta imperial cidade leva ao conhecimento do Conselho Geral, tendo-o já feito ao Exmo. Sr. presidente da Província a accusação feita pelo fiscal da freguezia de São Bernardo contra os desleixos e abusos praticados pelo vigario collado da mesma freguezia o reverendo Hygino Francisco Teixeira com os documentos que a reforçam, o que tudo consta da copia inclusa assignada pelo secretario interino Jose Xavier de Azevedo Marques, afim de que o mesmo Conselho dê a este respeito as providencias que achar de justiça”. 403

A acusação, também enviada ao conhecimento do executivo provincial, fora originalmente despachada ao presidente da Câmara Municipal de São Paulo pelo fiscal da freguesia de São Bernardo Manoel Rodrigues de Barros, a 12 de março de 1830. A queixa já havia sido publicada no próprio mês de março pelo jornal O Farol Paulistano:

"Esta Freguezia, digna de melhor sorte, tem sido victima do desleixo, e completo abandono, com que tem sido tractada pelo Vigario Teixeira; ja em o anno pp. muito soffremos, quando elle contra as leis divinas, e humanas, preferio antes ser Secretario

\footnotetext{
${ }^{402}$ Dizia o artigo 58: "Darão parte annualmente, ou quando convier, ao presidente da Província e Conselho Geral das infraç̧ões da Constituição, e das prevaricações, ou negligencias de todos os empregados”, Cf. "Lei de $1^{\circ}$ de outubro de 1828 - Dá nova fórma as Câmaras Municipaes, marca sua attribuições, e o processo para a sua eleição, e dos Juizes de Paz", in op. cit., pp.82.

403 “Participação feita pela Câmara ao Conselho Geral contra o vigário de São Bernardo”, in Registro Geral da Câmara Municipal de São Paulo, 1829-1830, op. cit., p.343.
} 
particular de S. Ex. R., do que residir na sua Parochia, como mui expressamente lhe dicta a lei natural (...) Volviam-se estes dias em paz, quando o Sr. Vigário prestando ouvidos aos remorsos, que na calma das paixões não deixam de dar tractos às consciências mais callejadas, resolveu-se a vir tomar assento na sua Parochia (...) Mas que desgraça!!! (...) o Sr. Vigario, nem por decencia, quis estar ao menos oito dias entre seus freguezes (...). ${ }^{404}$

Após receber a denúncia da Câmara Municipal, o Conselho Geral de São Paulo trabalhou na sua apuração. Em 26 de janeiro de 1831, endossando a posição dos denunciantes, enviou uma representação ao monarca para que esse decidisse sobre o futuro do referido vigário. Este foi acusado pelo Conselho de "prevaricação”, o mesmo ocorrendo com o Vigário Geral da referida freguesia, que o havia defendido, segundo os conselheiros, por meio de um “patronato” imparcial, que só corroborava com as denúncias contra o acusado. Como se tratava de um caso de justaposição entre as esferas judicial e executiva, os conselheiros afirmaram que estavam “cumprindo o artigo $83 \S 4^{\mathrm{a}}$ da Constituição”, que por seu turno exigia que os Conselhos Gerais enviassem à Assembléia Geral e ao Poder executivo questões dessa natureza. ${ }^{405}$

Não foi possível esclarecer o desenlace do episódio, conquanto sua relevância esteja, todavia, menos na concretização da denúncia do que na teia de relações por ela estabelecida. Analisada por um viés mais amplo, intercomunicações como essa foram essenciais para a construção de uma prática política em nível local, na medida em que proporcionaram o contato de diferentes vozes do espaço público paulista. Mais significativo ainda é o fato de que casos assim nos patenteiam como o início do processo de formação do Império gestou um jogo institucional que, permeado por brechas político-administrativas de um Estado

\footnotetext{
${ }^{404}$ O Farol Paulistano, no 322, 20/03/1830.

${ }^{405}$ RPR, “Representação sobre o Parocho da Frega . de S. Bernardo”, p.26.
} 
ainda nascente, deixou espaço para que órgãos como os Conselhos Gerais atuassem de acordo com cada situação ou conjuntura política.

Nesses termos, ofuscada pela retórica do cumprimento da lei subsistia a possibilidade do Conselho Geral de São Paulo manipular a política municipal de uma outra forma, no sentido de selecionar as matérias que seriam levadas adiante, bem como de transpor para as várias localidades da Província demandas relativas a uma determinada municipalidade. Em outras palavras, uma das formas de conduzir a política provincial podia se dar, até certo ponto, por meio da articulação das administrações municipais.

É exemplar neste ponto a resolução aprovada pelo Conselho Geral de São Paulo sobre a inexeqüibilidade do parágrafo 11 do artigo 66 da lei de $1^{\circ}$ de outubro $1828^{406}$, segundo o qual estava proibida a venda de pólvora ou de qualquer artefato explosivo em locais que não fossem despovoados e marcados pelas Câmaras Municipais. De acordo com o Conselho Geral, após refletir “maduramente sobre a representação da Câmara da Vila de S. Carlos, em que fez ver o quanto hé inexeqüível o $§ 11$ do artigo 66 da Lei de $1^{\circ}$ de outubro de 1828”, o órgão constatou que o parágrafo mencionado era danoso para “toda a Provincia”, já que a falta de acessibilidade à pólvora prejudicava a "caça” de animais e o “comércio” entre os habitantes, criando uma situação propícia para a “violação da lei”. 407 Assim, tomando como ponto de partida a realidade de uma municipalidade específica, o Conselho Geral alargou-a para o restante da Província, adequando-a num formato de política pública em nível provincial. Via de duas mãos, esse processo também servia, ao menos em

${ }^{406}$ Dizia o referido parágrafo: "Exceptua-se a venda de polvora, e de todos os generos susceptiveis de explosão, e fabrico de fogos de artificio, que pelo seu perigo, só se poderão vender, e fazer nos lugares marcados pelas Câmaras, e fora de povoado, para o que se fará conveniente postura, que imponha condemnação, aos que contravierem. Cf. parágrafo 11, art. 66, Título II da "Lei de $1^{\circ}$ de outubro de 1828”, in op. cit., p.84.

${ }^{407}$ RPR, "Representação sobre a inexequibilidade do $\S 11$ do artigo 66 da lei de $1^{\circ}$ de outubro 1828 acerca da prohibição da venda de pólvora dentro das Povoações”, p.16. Para a representação feita pela Câmara de São Carlos que foi enviada ao Conselho Geral de São Paulo, ver FCGP, CP30.043, caixa 11. 
tese, para que as Câmaras pleiteassem iniciativas mais amplas, que saíssem do âmbito municipal e pudessem de algum modo atenuar as limitações políticas impostas pela lei de $1^{\circ}$ de outubro de 1828. A representação foi remetida pelo Conselho Geral a 8 de fevereiro de 1830, mas não chegou a ser anuída pela Assembléia Geral. ${ }^{408}$

Pouco estudado pela bibliografia sobre o Império, o controle da administração municipal pelos Conselhos Gerais foi tão importante quanto a proposição de medidas atinentes aos negócios provinciais, a começar pelo tempo e esforço despendidos nessa atividade que, por ser menos grandiloqüente, passou desapercebida pela maioria dos estudiosos que se debruçou sobre o funcionamento desse órgão. Em verdade, tratava-se de dirigir unidades administrativas que compunham, no limite, o alicerce políticoadministrativo de cada Província, uma vez que se a redução de poderes pela lei de $1^{\circ}$ de outubro esvaziou a estrutura municipal, não o fez a ponto de negá-la; houve sim, paralelamente ao enfraquecimento da esfera municipal, uma transposição de ingerências para os Conselhos Gerais, que passaram a desempenhar parte das atribuições anteriormente detidas pelas municipalidades, na qualidade de órgãos subordinadores das Câmaras Municipais.

É conveniente, portanto, não confundirmos a diminuição da autonomia das municipalidades com a extinção do poder municipal em si, pois esse não se dissipou. Mesmo porque, nos primeiros anos do Império as Câmaras Municipais continuaram a se portar, em alguns pontos, como outrora. Representações remetidas diretamente ao Rio de Janeiro ou ao Conselho da Presidência persistiram mesmo após a lei de $1^{\circ}$ de outubro, sendo

\footnotetext{
${ }^{408}$ Ver O Farol Paulistano, no 437, sessão de 04/01/1830.
} 
algumas delas, aliás, conflitantes com as decisões tomadas pelos Conselhos Gerais. ${ }^{409}$ Em março de 1830, a Câmara Municipal de Porto Alegre despachou um ofício à Assembléia Geral contestando a deliberação tomada pelo Conselho Geral do Rio Grande do Sul em desaprovar as soluções recomendadas pelos vereadores a fim de aumentar as rendas da Câmara porto-alegrense. Os vereadores propuseram que a matéria fosse reconsiderada pelos legisladores do Império, em face da urgência da matéria. ${ }^{410}$ Situações semelhantes ocorridas entre as Câmaras Municipais e os Conselhos Gerais se estenderam por outras partes do Império, como nas Províncias do Ceará, Sergipe, Minas Gerais e Espírito Santo. ${ }^{411}$

Para a Província de São Paulo não foram localizados nas fontes consultadas documentos que atestassem um grande enfrentamento das Câmaras com o Conselho Geral ou até mesmo com o executivo provincial, mas há sinais de que a relação travada entre ambos teve suas desarmonias. Em contrapartida à constatação de irregularidades na prestação das contas municipais, que de alguma maneira limitou a atuação das Câmaras, estas agiram muitas vezes de forma irregular, descumprindo prazos de envio de documentos, colocando em prática posturas ainda não aprovadas pelo Conselho Geral e deixando de por em prática ordens e recomendações advindas das instâncias superiores, o que gerou reprimendas. Em março de 1831, o então presidente Aureliano de Sousa Coutinho fez circular um ofício no qual censurava a negligência das Câmaras Municipais com relação à conservação das estradas da Província, notando que essas não cumpriram as "enérgicas recomendações" feitas pelo governo provincial nesse sentido. A existência de "Posturas" e de um “Regimento” próprio comporia um arcabouço legal que, segundo Sousa Coutinho,

\footnotetext{
409 Veja-se, por exemplo, a representação enviada pela Câmara da Vila de Itapetininga ao Conselho da Presidência de São Paulo, em outubro de 1829, a respeito da concessão de terrenos devolutos. Cf. ACP, v. 86, sessão de 21/10/1829, p.258.

${ }^{410}$ SLEMIAN, op. cit., p.222.

${ }^{411}$ Ibid., pp.220-223.
} 
seria suficiente para que as Câmaras tomassem medidas sobre esse "objecto da maior importância”. 412

Disciplinar as Câmaras Municipais constituiu, aliás, preocupação constante entre os legisladores dos primeiros anos do Império, que viram na minimização do poder municipal uma forma de coibir os excessos dos grupos locais, os quais se chocavam com o projeto de Estado liberal acalentado por boa parte dos membros da Câmara dos Deputados das primeiras legislaturas. ${ }^{413}$ Em 1830, Diogo Antonio Feijó publicou pela tipografia do periódico fluminense A Astréa seu Guia das câmaras municipais do Brasil no desempenho de seus deveres por um deputado amigo da instituição, uma espécie de manual pedagógico destinado à instrução dos membros da administração municipal, definindo conceitos - o que era uma "postura”, por exemplo - e explicando como proceder em cada atividade relativa às Câmaras Municipais. ${ }^{414}$

\subsection{As relações entre os Conselhos Provinciais de São Paulo}

Nos tópicos anteriores, procurou-se reconstituir os elementos básicos que estiveram por trás da criação dos Conselhos da Presidência e Geral da província de São Paulo, enfatizando a maneira pela qual eles fundamentaram a atuação de ambos órgãos, que aos poucos se firmaram como importantes fóruns de discussão e prática política no âmbito da esfera pública provincial. Ressaltou-se, também, que a performance dos dois Conselhos

412 “Officio do Exmo. presidente da Província á Camara”, in Registro Geral da Câmara Municipal de São Paulo, 1830-1831. São Paulo: Publicação Oficial do Arquivo Municipal de São Paulo, 1936, v.XXI, pp.91-92.

${ }^{412}$ ACP, v.15, sessão de 01/10/1830, p.69.

${ }^{413}$ CATELLI JR., Roberto. Poder local: consolidação e revolta. Sorocaba 1823-1842. Dissertação de mestrado apresentada ao Departamento de História da Faculdade de Filosofia, Letras e Ciências Humanas da Universidade de São Paulo. São Paulo, 1993.

${ }^{414}$ FEIJÓ, Diogo Antônio. Guia das câmaras municipais do Brasil no desempenho de seus deveres por um deputado amigo da instituição. Rio de Janeiro: Typografia D’Astréa, 1830. 
nada teve de isolada, visto que seus respectivos campos de ação entraram em contato, de forma prevista ou não pelos aparatos legais que os criaram, com outras instâncias oficiais de poder, bem como com a recém-instituída imprensa periódica paulista.

No entanto, mais difícil de compreender pelas fontes consultadas é a relação que os Conselhos Provinciais travaram entre si, embora uma confrontação entre as atividades por eles desenvolvidas nos permite notar uma afinidade de preocupações por parte de ambos os órgãos. A elaboração de propostas relacionadas ao incremento da infra-estrutura provincial e o zelo pelo cumprimento das leis são exemplos disso, mas elas não explicam, por si só, de que forma os Conselhos se articulavam. Parte constitutiva do executivo provincial e funcionando regularmente desde 1824, o Conselho da Presidência foi quem ensaiou, ao que tudo indica, as primeiras tentativas em criar uma teia de relações entre os dois órgãos, ou antes delimitar um campo de ação para ambos. Até mesmo porque, como já se ressaltou, a implantação do Conselho Geral de São Paulo alterou as atividades do Conselho da Presidência, que passou por um processo de readaptação da sua prática administrativa.

Assim, como forma de oferecer tangibilidade a esse novo quadro, o Conselho da Presidência começou a remeter ao Conselho Geral aquelas representações as quais julgava de competência do novo órgão. Em dezembro de 1829, após analisar uma proposta da Junta da Fazenda para a compra de dois ranchos na estrada de Santos para Cubatão, o Conselho se disse convencido do beneficio de tal empreendimento, mas resolveu encaminhá-lo à apreciação do Conselho Geral, ou seja, a quem competia deliberar sobre o assunto. ${ }^{415}$ Situação semelhante ocorreu em novembro do ano seguinte, quando se despachou ao Conselho Geral um ofício da Câmara Municipal de Guaratinguetá sobre a necessidade de

\footnotetext{
${ }^{415}$ Atas do Conselho da Presidência da Província de São Paulo (1829-1832) (ACP). In: Boletim. São Paulo: Arquivo do Estado de São Paulo, 1961, v.15, sessão de 29/12/1829, p.30.
} 
construir uma ponte no rio Paraíba. ${ }^{416}$ Em outubro de 1832, após acusar o recebimento de algumas posturas municipais elaboradas pela Câmara Municipal de São Vicente, o Conselho da Presidência deliberou ser mais conveniente repassá-las para o Conselho Geral, cuja próxima reunião estava na iminência de ocorrer. ${ }^{417}$

O contato entre os dois Conselhos não terminava por aí. Em fevereiro de 1830, o Conselho da Presidência recebeu um ofício do Secretário do Conselho Geral a respeito de uma resolução tomada por esse órgão sobre a criação de escolas de primeiras letras nas Freguesias de São Bernardo e Casa Branca. Após ler a matéria, o Conselho da Presidência decidiu que as cadeiras fossem postas em concurso, medida que foi repetida dois meses mais tarde em relação a um ofício semelhante sobre a Freguesia de Nossa Senhora da Ajuda de Caçapava. $^{418}$ Em novembro do mesmo ano, o Conselho da Presidência recebeu um requerimento de um grupo de moradores de São Carlos que lhe pedia a prorrogação do prazo de pagamento, estipulado pelo juiz de paz daquela Vila, de uma multa aplicada pelo Conselho Geral. Embora o pedido tenha sido recusado sob a alegação de que não competia ao governo "suspender os procedimentos judiciaes", cumpre observar a forma como os campos de ação dos Conselhos se interpenetravam. ${ }^{419}$

Os Conselhos compartilharam, pelo menos até agosto de 1831, membros em comum, dado esse que não deve ser desprezado. Se é arriscado falar em termos de uma complementaridade intencional entre os trabalhos de cada órgão, há indícios de que matérias consideradas importantes pelos políticos paulistas da época foram aventadas em ambos os Conselhos. A questão do cunho da moeda de cobre na província de São Paulo é elucidativa

\footnotetext{
${ }^{416}$ ACP, v.15, sessão de 25/11/1830, p.131.

${ }^{417}$ ACP, v.16, sessão de 25/10/1832, p.67.

418 ACP, v.15, sessões de 10/02/1830, pp.39-40, e 01/04/1830, pp.45-46. Vale lembrar que, segundo o objeto $2^{\circ}$ do artigo 24 da lei de 1823, cabia ao Conselho da Presidência “promover a instrução da mocidade”.

${ }^{419}$ ACP, v.15, sessão de 15/11/1830, p.118.
} 
nesse sentido, servindo para mostrar como em alguns casos certas matérias foram defendidas tanto por conselheiros gerais como da presidência.

Ainda que a situação financeira da província de São Paulo no Primeiro Reinado careça de estudos mais aprofundados, é certo que essa não esteve imune aos problemas referentes à arrecadação e ao repasse de recursos ao governo central, e que teve como problema recorrente a falta de meio circulante. ${ }^{420}$ Se já com a volta de D. João VI para Portugal, em 1821, o meio circulante tornara-se escasso na maioria das províncias - uma vez que o monarca e sua Corte levaram para a Europa o grosso das moedas de ouro e pedras preciosas do Banco do Brasil -, anos depois, com D. Pedro no comando do Império brasileiro, a circulação de moedas consistia num problema de primeira ordem. O papel emitido pelo Banco do Brasil só circulava no Rio de Janeiro e, com certas restrições, em São Paulo e Bahia. A moeda de cobre, por sua vez, conhecida como o "bilhão”, oscilava de peso de acordo com cada província. ${ }^{421}$

A despeito desse entrelaçamento de problemas, não foram encontradas menções de um enfrentamento direto entre o Conselho da Presidência ou Geral e a Junta da Fazenda de São Paulo, tal como ocorreu entre órgãos congêneres de províncias como Minas Gerais e Pernambuco. ${ }^{422}$ Pelo contrário, há sinais de que o presidente, os Conselhos e a Junta da

\footnotetext{
${ }^{420}$ Até a o cumprimento da lei de 4 de outubro de 1831, quando as Juntas da Fazenda foram substituídas pelas Tesourarias Provinciais, foram constantes as indicações da Junta da Fazenda da província de São Paulo a respeito da precaredade do sistema financeiro paulista. Em dezembro de 1830, por exemplo, alegando que nunca estivera tão "critico o estado do Cofre da Fazenda", a Junta paulista ordenou que o administrador dos dízimos de miunças da vila de Santos remetesse à Tesouraria Geral, "sem perda de tempo", "quaesquer quantias" que estivessem a seu cargo provenientes daquela fonte de renda. Cf. ofício emitido pela Junta da Fazenda de São Paulo em 4 de dezembo de 1830 e publicado por $O$ Farol Paulistano, n 427, 11/12/1830.

${ }^{421}$ DEVESA, Guilherme. "Política tributária no período imperial”, in HOLANDA, Sérgio Buarque de. (org.). História Geral da civilização brasileira, tomo II, "O Brasil Monárquico". São Paulo: Difusão Européia do Livro, 1985, vol.4, pp.60-84. Sobre a questão da circulação de moeda no Primeiro Reinado, ver MARSON, Izabel. Moedas e História no Brasil, 1500-1889. São Paulo: Empresa das Artes, 1989.

${ }^{422}$ SLEMIAN, op. cit., p.212.
} 
Fazenda de São Paulo, em meio ao agravamento da situação financeira da província ${ }^{423}$, trabalharam em conjunto no encaminhamento de uma estratégia para o manejo do tesouro provincial - nomeadamente sobre a cunhagem de moedas -, chegando a posicionar-se de forma conflitante com a política do Ministério da Fazenda.

Em 23 de agosto de 1825, o Ministério da Fazenda havia permitido que a província de São Paulo fizesse a cunhagem de 20 contos de réis anuais em chapinhas de cobre de 40 rs pela Casa de Fundição de São Paulo. Quatro anos mais tarde, Miguel Calmon du Pin e Almeida, então ministro da Fazenda e presidente do Tesouro Nacional, advertiu a Junta da Fazenda paulista, pois essa tinha posto em circulação, entre 1826 e 1829, a quantia de 228:173\$800 rs., valor que excedia o acordado anteriormente por decreto. ${ }^{424} \mathrm{O}$ Conselho da Presidência, por sua vez, após enumerar inúmeros gastos concernentes à administração da província - despesas com ordenados de tropas, empregados públicos e eclesiásticos, como também com a manutenção e construção de estradas, a campanha no Sul e a colônia alemã recém-instaurada no sul da capital paulista - decidiu em sessão extraordinária de agosto de 1829 enviar ao imperador um pedido para que a Junta da Fazenda de São Paulo pudesse cunhar acima de 20:000\$ rs. por ano, a fim de que o governo proporcionasse a "conservação da boa ordem” e a "manutenção da tranqüilidade pública”, além de evitar as "prevaricações” dos funcionários públicos. ${ }^{425}$

Ao que tudo indica, o pedido do Conselho da Presidência não surtiu efeito. Em decisão de 30 de setembro de 1829, o ministério da Fazenda mandou cessar o cunho da moeda de cobre na província de São Paulo. Na ocasião, o ministério criticou veementemente

\footnotetext{
${ }^{423}$ Cf. CALÓGERAS, op. cit.

${ }^{424}$ PETRONE, Maria Thereza Schörer $O$ Barão de Iguape. Um empresário da época da Independência. São Paulo, Cia. Editora Nacional, 1976, p.114.

${ }^{425}$ ACP, v.86, sessão de 20/08/1829, pp.236-237.
} 
a Junta da Fazenda da província de São Paulo, que havia delegado a particulares algumas das fases da operação de cunhagem do cobre, o que resultou em prejuízos sensíveis na qualidade da moeda produzida. A Junta de São Paulo foi responsabilizada pelo ocorrido, ficando obrigada a indenizar a Fazenda Nacional pelo prejuízo causado e a repassar para a Casa da Moeda da Corte todos os cunhos e máquinas utilizadas para a fundição. ${ }^{426}$

Cerca de três meses após a decisão do Governo, o Conselho Geral de São Paulo enviou ao imperador uma representação solicitando nova permissão para a cunhagem de cobre na capital paulista. Dizendo-se “testemunha do mal” que começava a sofrer a província de São Paulo pela "falta do cunho de cobre”, o Conselho Geral afirmou que os gastos com a “tropa” e com outros “empregados públicos” diminuíam a quantidade do meio circulante, tornando mais atribulado, por conseguinte, o "comercio interno com outras Villas”. Os conselheiros indicaram ser necessário, portanto, “restabelecer quanto antes o cunho de cobre” na cidade de São Paulo, com as “restrições” que o imperador julgasse apropriadas. $^{427}$

A representação do Conselho Geral não conseguiu restituir aos paulistas o cunho de cobre que, aliás, tornou-se cada vez mais centralizado na Casa da Moeda do Rio de Janeiro. ${ }^{428}$ Durante o final do Primeiro Reinado e o início do período regencial, o Governo estabeleceu, paulatinamente, uma estrutura de cunhagem, remessa e troca de moedas de

\footnotetext{
426 "Decisão do Ministério de Fazenda de 30 de setembro de 1829 - manda cessar o cunho de cobre na Provincia de São Paulo", in Coleção das decisões do Governo do Império do Brasil de 1829. Rio de Janeiro: Tipografia Nacional, 1877, pp.149-150.

${ }^{427}$ RPR, "Representação sobre o cunho da moeda de cobre”, 30/12/1829, pp.15-16.

${ }^{428}$ Por essa época, outras Casas da Moeda foram gradualmente encerrando suas atividades por ordem do Governo. A Casa da Moeda da Bahia, por exemplo, parou a cunhagem de moedas em 1830; a de Cuiabá, em 1833. Cf. GONÇALVES, Cleber Baptista. Casa da moeda do Brasil : 290 anos de história, 1694-1984. Rio de Janeiro: Impr. Gráfica Ed., 1984.
} 
cobre que abrangia as diversas províncias do Império. ${ }^{429}$ No caso de São Paulo, a Regência autorizou, a partir de 1833, a troca das moedas de cobre cunhadas na capital paulista e em outras províncias por cédulas impressas no Rio de Janeiro. ${ }^{430}$

O que importa aqui, todavia, é o fato de que os Conselhos, formadores da estrutura de político-administrativa provincial de São Paulo, trabalharam visando um objetivo comum, o que denota a existência de laços de interesses entre ambos os órgãos bem como de estratégias para o alcance de determinadas finalidades. Cabe questionar, contudo, se tal aproximação se processou apenas no plano administrativo, ou, em outros termos, se a atuação política dos Conselhos não se deu em outros níveis. Se interpretados apenas pelo viés do gerenciamento da máquina pública, os Conselhos acabam sobressaltando como órgãos fundamentalmente centrados na dimensão prática da administração pública, no sentido de terem se configurado como espaços de discussão e proposição de medidas que contemplassem as necessidades provinciais e municipais, em meio às disputas políticas e econômicas que perpassavam cada província durante o Primeiro Reinado e início do período regencial. No tocante aos Conselhos Gerais, é possível confirmar essa idéia, especialmente por meio da análise dos trabalhos do Legislativo e do Conselho de Estado, e estendê-la para a maioria das províncias do Império, posto que não foi apenas o Centro-Sul - região que seguramente deu maior sustentabilidade ao governo do Rio de Janeiro durante o período que participou do processo de normatização dos governos provinciais. Até mesmo a Bahia e o Maranhão, que como se viu apresentaram problemas na implementação dos seus

\footnotetext{
${ }^{429}$ Ver, nesse sentido, as medidas tomadas pela pasta da Fazenda no período, como por exemplo: "Decisão do Ministério da Fazenda de 15 de novembro de 1830", in Coleção das decisões do Governo do Império do Brasil de 1830, op., cit., p.146; e "Decisão do Ministério da Fazenda de 22 de novembro de 1833 - sobre o troco da moeda de cobre, na Província de S. Paulo", in Coleção das decisões do Governo do Império do Brasil de 1833, op. cit., p.518.

${ }^{430}$ Ver ACP, v.16, sessões de 21/11/1833, p. 259, e de 11/12/1833, pp.269-270.
} 
respectivos Conselhos Gerais entre 1829 e 1830, tiveram suas propostas regularmente aprovadas pela Assembléia Geral, ocorrendo o mesmo com as demais províncias, sem exceção. Só em outubro de 1831, a título de exemplo, foram aprovadas propostas emanadas dos Conselhos Gerais de São Paulo, Minas Gerais, Espírito Santo, Goiás, Mato Grosso, Bahia, Pernambuco, Alagoas, Paraíba e Sergipe. ${ }^{431}$

Por trás desse quadro subsiste, entretanto, uma realidade ao mesmo tempo complexa e menos explícita, cuja reconstrução a partir das fontes se dá de forma mais sinuosa. Tratase do modo como os Conselhos Gerais e da Presidência se impuseram como porta-vozes de questões mais amplas no interior do cenário político da época, atuando como instrumentos de luta que transcenderam a esfera propriamente local e participaram, dentro da legalidade, da composição das forças políticas do Império. Atentando para o caso paulista, quer nos parecer que durante todo seu funcionamento os Conselhos Geral e da Presidência se comportaram como órgãos que, embora estruturados para operar no campo provincial, acabaram resvalando, direta e indiretamente, em questões comuns às demais províncias do Império, como também na própria relação entre os governos provinciais e central.

Em linhas gerais, os chamados “Conselhos Provinciais” trabalharam, cada um a sua maneira, no sentido de estabelecerem um movimento contínuo de normatização e aperfeiçoamento da estrutura política provincial, que, num âmbito maior, conjugou-se ao gradativo - e muitas vezes errático - processo de institucionalização da máquina administrativa que viabilizou a construção do Estado Nacional com base numa monarquia

${ }^{431}$ ACE, ver 78 ${ }^{\text {a }}(08 / 10 / 1831)$ e 79a(25/10/1831) sessões, pp.189-191. 
constitucional. Quanto aos Conselhos Gerais, por exemplo, há vestígios de que houve uma certa aproximação entre órgãos congêneres de diferentes Províncias, mas que não se manifestou em forma de um contato direto. Tratou-se, antes, da apropriação recíproca entre os Conselhos Gerais de medidas tomadas por um ou outro órgão. Em outubro de 1832, o governo regencial sancionou uma proposta do Conselho Geral da Paraíba aprovada pela Assembléia Geral que consistia na reedição de uma resolução do Conselho da Província de São Paulo sancionada em 1830 - que igualava suas medidas às do Rio de Janeiro -, só que nesse caso aplicada à Província da Paraíba. ${ }^{432}$ No ano seguinte foi a vez de São Paulo utilizar o mesmo artifício. O órgão encaminhou à Assembléia Geral uma resolução que objetivava estender aos paulistas uma deliberação oriunda do Conselho Geral de Minas Gerais a respeito dos terrenos diamantinos, conseguindo aprovação em maio de $1833 .{ }^{433}$ Em julho do mesmo ano, a Assembléia Geral aprovou uma decisão do Conselho Geral de Santa Catarina que estendia a essa Província uma resolução tomada pelo seu congênere paulista sobre a abertura e reparo de estradas. ${ }^{434}$

Em São Paulo, resoluções voltadas para a padronização de atividades concernentes ao poder público - tais como a elaboração de representações, a prestação de contas e a tributação dos processos judiciais - foram acompanhadas de esforços que aspiravam a equiparar outras esferas da sociedade, como a militar e os sistemas de medidas, monetário e educacional. Em outras palavras, o governo provincial de São Paulo contribuiu para a paulatina e contraditória uniformização do estado imperial, dando coro ao projeto de um

\footnotetext{
${ }^{432}$ ACE, 96ª sessão (02/10/1832), pp.233-235.

433 "Decreto de 31 de maio de 1833 - Faz extensiva à Província de S. Paulo a Resolução Legislativa de 25 de Outubro de 1832 sobre terrenos diamantinos na Província de Minas Gerais”, in Coleção das Leis do Império do Brasil de 1833. Rio de Janeiro: Tipografia Nacional, 1873, Parte Primeira, pp.01-02.

434 "Decreto n.13 de 26 de julho de 1833 - Faz extensiva à Província de Santa Catharina a Resolução do Conselho Geral S. Paulo sancionada por Decreto de 10 de Julho de 1832, sobre a abertura de estradas, e melhoramentos das existentes”, in Coleção das Leis do Império de 1833, op. cit., Parte Primeira, p.18.
} 
regime monárquico-constitucional sediado no Rio de Janeiro. Paulatina porque o que podemos vulgarmente chamar de unidade nacional não se verificou antes de meados no século XIX, e pesquisas recentes sobre a configuração política das Províncias do Império nas primeiras décadas do oitocentos têm convergido cada vez mais para esse ponto. ${ }^{435}$ Conturbada em virtude do intenso debate que mobilizou a esfera pública da época sobre os rumos do novo Estado, e dos sucessivos movimentos sociais, sendo boa parte deles armado, que permearam os primeiros anos do Império, como as “Guerras da Independência”, que agitaram Bahia, Pará, Maranhão e Piauí entre 1822 e 1823; a Confederação do Equador (1824); a Abrilada (1831), Setembrada (1831), Novembrada (1832) e a Cabanada (1832 a 1835), em Pernambuco; as revoltas militares de 1831 e a Cabanagem (1832 a 1835), em Alagoas; o movimento restaurador capitaneado por Pinto madeira (1831 a 1833), no Ceará; a instauração da República de São Félix (1831 e 1832), na Bahia; a Abrilada e a Setembrada, ambas ocorridas em 1831, no Maranhão; além dos motins em Minas Gerais, sobretudo em 1832, Mato Grosso, Pará e Piauí. ${ }^{436}$

Resta saber qual foi a atuação política que tiveram os Conselhos Provinciais de São Paulo diante desse quadro, isto é, de que maneira esses órgãos usaram de sua força política para influírem no encaminhamento dos acontecimentos daquele momento, e como a imprensa periódica paulista interagiu nesse processo. Sobre essa questão central buscará refletir o capítulo seguinte.

\footnotetext{
${ }^{435}$ Ver a esse respeito os artigos sobre a situação política das províncias do Império em meio no início do processo de formação do Estado Nacional publicados em JANCSÓ, 2005, op. cit.

${ }^{436}$ JANOTTI, Maria de Lourdes Mônaco. A balaiada. [Coleção tudo é história]. São Paulo: Editora Brasiliense, 1987, pp.24-25.
} 


\section{Capítulo 3}

\section{Desdobramentos da luta política: a imprensa e os Conselhos Provinciais paulistas do final do Primeiro Reinado até o Ato Adicional}

A pouco mais de seis meses da abertura da $1^{\text {a }}$ Reunião do Conselho Geral de São Paulo, o periódico O Farol Paulistano publicou um artigo sobre a escolha de Nicolau Vergueiro para representar Minas Gerais no Senado, ocorrida em meados de 1828. Lançando mão de uma suposta imparcialidade, o redator de $O$ Farol ressaltou os aspectos positivos e negativos do novo cargo para o ex-deputado, em face da situação política do Império:

“Já se não pode duvidar da acertadissima escolha que fez S.M.I. do illustre Defensor dos nossos direitos o Sr. Vergueiro para Senador do Império pela Provincia de Minas Geraes; mas qual será a influencia que terá esta nomeação, e escolha na felicidade publica? Lucrará a Nação Brasileira com a passagem deste digno Varão da Camara dos Deputados para a Camara dos Senadores? Eis uma questão que, em nosso entender, não é de fácil resolução. Nós apresentaremos aqui o pró e o contra, e deixaremos, talvez, aos nossos leitores o julgamento. O Senado é composto em grande parte de homens do velho regime; de homens, que ainda estão lucrando com os abusos e que por consequencia, affectando muita prudencia nas reformas, querem alongar a época suspirada da queda dos dictos abusos, e da diminuição de seus interesses. O Sr. Vergueiro tem sido na Camara dos Deputados forte e constante defensor das prerrogativas, que a Constituição deu a dicta Câmara, e por essa rivalidade, que desgraçadamente tem dividido as duas Secções do Corpo Legislativo, não será, talvez, ou certamente muito bem visto por uma grande parte do Senado, e todo o mundo sabe que a desafeição cerra sempre as portas a convicção, e muitas vezes produz a obstinação, e acinte. A Câmara dos Deputados perde um homem de grande valor em qualquer relação, que considerado seja, ao mesmo tempo que é duvidoso se no Senado poderá ao menos por ora fazer os mesmos serviços, que fazia na sua antiga Camara. O Sr. Vergueiro mesmo vendo as difficuldades, que se lhe hão de necessariamente apresentar, 
talvez prudentemente se acanhe, e não dê toda a expansão, latitude, e franqueza ás suas opiniões; e os menos expertos, os desconfiados, e ainda mais os seus inimigos, os da publica prosperidade minem o seu credito, e o fação talvez perder em poucos dias o que lhe tem custado muitos annos, muitas fadigas, muitos desgostos a adquirir. Tudo isto nos parece exacto; muito peso julgamos nesta reflexão ultima; mas pelo outro lado também não se podem razões fortes e de pezo. No Senado ha, nem se póde, nem se deve pôr em duvida muitos homens probos, desinteressados, e amigos da nova incomparavelmente melhor ordem de cousas, mas talvez senão tenhão ainda desenvolvido, porque muito pouca gente tem a fortuna de ser propria para se pôr á frente das reformas, e de vencer o habito do antigo, do visto, do praticado: estes homens tendo um appoio, um guia, um chefe, que reúna como o Sr. Vergueiro, a maior probidade, mais sincero desinteresse, a maior solidez, e fecundidade de argumentos, e razões, e decidida coragem, e invariável caráter, provavelmente o seguirão, e marchará provavelmente o Senado mais nas vistas do novo systema; e lucrará a causa publica. Uma das causas, que entendemos ser a mais poderosa para o andamento anterior do Senado, é a pouca familiarização com as doutrinas novas; porque ainda que muitos, ou quase todos os Senadores as tenhão lido, e muitos as lerão, todavia o hábito, os interesses, os costumes cortesãos etc. etc. não terão deixado ver alguns em suas verdadeiras côres. O Senado pode ir sendo com esta, e outras nomeações semelhantes, reformado, e melhorado. Custa bastante ir de encontro á razão, a verdade forte, e digamos apresentada, e por isso bons effeitos devemos esperar da admissão do Sr. Vergueiro ao Senado. Na Câmara dos Deputados elle faz falta, mas o amor de gloria, mas as reeleições, mas o grande numero de oppositores, que ali tem o Ministério nos dão esperanças de que não seja irreparável a perda, e mesmo não será tão grande a falta.

Apesar de tudo não ousamos dar o nosso voto: os nossos Leitores pezam as razoes expendidas e formem o seu juizo". 437

Analisada por um viés mais amplo, a dicotomia apresentada pela folha paulistana expõe, em síntese, um dos pontos que permeou o debate político nos primeiro anos do Império, especialmente entre a outorga do texto constitucional e a abdicação de D. Pedro,

\footnotetext{
${ }^{437}$ O Farol Paulistano, $n^{\circ}$ 119, 07/06/1828. Na época da publicação do artigo, o Ministério era formado por Pedro de Araújo Lima (Império), João Carlos Augusto de Oyenhausen (Estrangeiros), Lúcio Soares Teixeira de Gouveia (Justiça), Miguel Calmon Du Pin e Almeida (Fazenda), Diogo Jorge de Brito (Marinha) e Bento Barroso Ferreira (Guerra). Cf. JACQUES, op. cit., pp.75-76.
} 
em abril de 1831. Para os chamados liberais “moderados”, que por esse período formavam o principal grupo de oposição ao governo bragantino, a chave para o sucesso do "novo systema” não residiria na criação de um novo aparato jurídico-administrativo, pois esse já estava dado pela Carta de 1824. Ela encontrar-se-ia, sim, na maneira como esses instrumentos legais seriam implementados, utilizados e articulados entre si, a fim de proporcionar aos liberais sua escalada ao poder e de fazer frente aos simpatizantes de um sistema de governo que recusava a ampla atuação dos cidadãos nos negócios públicos. Especificamente em relação ao Senado, a oposição feita pelos liberais durante o Primeiro Reinado tocava em dois pontos básicos: na forma como D. Pedro escolhera os primeiros senadores e nos próprios nomes selecionados. ${ }^{438}$

De acordo com a Carta de 1824, o processo eleitoral relativo ao Senado ocorreria da mesma maneira que aquele estabelecido para a Câmara dos Deputados, mas com algumas diferenças que tornavam o acesso à primeira Casa mais restrito. Para preencher o cargo de senador era necessário contar com mais de 40 anos (contra os 25 solicitados para um concorrente à segunda Casa), possuir renda anual de oitocentos mil réis (o dobro do exigido para um deputado) e, preferencialmente, ter proporcionado “serviços à pátria” (art. 45), qualidade essa que conferia certo valor à vida política pregressa dos concorrentes. Diferentemente dos deputados, que eram eleitos pela contagem total de votos dos eleitores (que por sua vez haviam sido escolhidos pelos votantes), os senadores mais votados eram arrolados em listas tríplices, de onde o imperador escolheria "o terço na totalidade da lista" (art. 43). Além disso, diversamente dos deputados, que eram temporários, os senadores eram

438 TAUNAY, Afonso de Escragnolle. O Senado do Império. Brasília: Senado Federal, 1978. $1^{\text {a }}$ edição 1941. 1978. 
vitalícios (art. 40), característica que foi duramente criticada pelos liberais “exaltados” durante os primeiros anos do Império.

A nomeação da primeira bancada senatorial por D. Pedro, referendada pelo gabinete ministerial em 21 de janeiro de 1826, gerou conflitos. Em primeiro lugar, nem todas as províncias elaboraram listas tríplices conforme a Constituição. De acordo com Manoel Jacinto Nogueira da Gama, futuro Marquês de Baependi, que na época escreveu uma monografia sobre a formação do Senado do Império $^{439}$, as províncias da Bahia, Minas Gerais, São Paulo, Rio de Janeiro, Santa Catarina, São Pedro do Rio Grande do Sul, Mato Grosso e Goiás elaboraram listas incompletas as quais continham indivíduos que já constavam em listas para outras localidades, ou até mesmo indicavam concorrentes falecidos. Deste modo, feitas as primeiras escolhas, ficaram essas províncias destituídas de um aparato necessário para a composição do Senado. Para os casos da Bahia, Minas Gerais, Santa Catarina e São Pedro do Rio Grande do Sul, a solução encontrada por D. Pedro e o Ministério foi a de utilizar as listas tal como foram enviadas ao Executivo. Já São Paulo, Rio de Janeiro, Mato Grosso e Goiás tiveram uma parte de seus senadores escolhida das listas originais e a outra metade de listas suplementares que foram feitas incluindo-se os cidadãos imediatamente mais votados aos originalmente listados. ${ }^{440}$

Em segundo lugar, a designação dos membros do Senado por D. Pedro fez com que concorrentes que obtiveram votações expressivas ficassem de fora da primeira Casa. Em Goiás, Joaquim Xavier Curado (futuro Conde de São João das Duas Barras), com 33 votos, viu Francisco Maria Gordilho Veloso de Barbuda (futuro Marquês de Jacarepaguá), que nem estava arrolado na lista inicial e contava com apenas 20 votos, ser escolhido para

\footnotetext{
439 Taunay não indica o nome nem a data da monografia de Nogueira da Gama.

440 TAUNAY, op. cit., 1978, pp.56-57.
} 
representar a província no Senado. Tal escolha gerou descontentamentos entre os goianos a ponto de o Conselho da Presidência de Goiás e de algumas Câmaras Municipais manifestarem-se contra a nomeação, embora sem sucesso. Na Cisplatina, o imperador escolheu ninguém menos do que o último da lista tríplice, que contava com quase a metade dos votos dos dois outros competidores. Caso semelhante ocorreu com as Alagoas, que teve o Marquês de Barbacena - apenas o quarto colocado, com 67 votos -, eleito senador diante de Inácio Acioli de Vasconcelos, que recebera 147 votos. $^{441}$

Na prática, a composição do Senado por D. Pedro constituiu uma articulação política em prol do monarca e de seu Ministério. Todos os dez integrantes do Conselho de Estado formado em 13 de novembro de 1823 e confirmado pela Carta outorgada foram nomeados senadores por D. Pedro, que já os elevara à condição de Viscondes, a 12 de outubro de 1824, e de Marqueses, dois anos depois. ${ }^{442}$ Aliás, dentre os cinqüenta e sete senadores nomeados por D. Pedro durante o Primeiro Reinado, havia quatorze Marqueses, dois Condes e oito Viscondes. Quando da escolha dos senadores, em janeiro de 1826, cinco dos seis ministros que compunham o gabinete do monarca - São Leopoldo, Inhambupe, Caravelas, Baependi e Paranaguá - também tomaram assento no Senado.

Com relação à província de São Paulo, a não indicação de candidatos associados aos liberais foi patente. Figuras de destaque na política paulista da década de 1820, como

\footnotetext{
${ }^{441}$ Ibdem.

${ }^{442}$ O Conselho de Estado formado por D. Pedro em 13 de novembro de 1823 era formado por João Severiano Maciel da Costa (futuro Visconde e Marquês de Queluz); Luiz José de Carvalho e Melo (futuro Visconde da Cachoeira); Clemente Ferreira França (futuro Visconde e Marquês de Nazaré); Mariano José Pereira da Fonseca (futuro Visconde e Marquês de Maricá); José Gomes da Silveira Mendonça (futuro Visconde de Fanado e Marquês de Sabará); Francisco Vilela Barbosa (Visconde e Marquês de Paranaguá); José Egídio Álvares de Almeida (barão, e futuro Visconde e Marquês de Santo Amaro); Luiz Antonio Pereira da Cunha (futuro Visconde e Marquês de Inhambupe); Manoel Jacinto Nogueira da Gama (futuro Visconde, Conde e Marquês de Baependi); José Joaquim Carneiro de Campos (futuro Visconde e Marquês de Caravelas). Com o falecimento de Cachoeira, substituiu-o o Marquês de Lages, o mesmo ocorrendo com Nazaré, que foi sucedido pelo Visconde de São Leopoldo. Este se exonerou em 1830, sendo substituído por Barbacena. Após a morte de Nazaré, entrou em seu lugar o Marquês de São João da Palma. Cf. TAUNAY, 1978, op. cit.
} 
Nicolau Pereira de Campos Vergueiro, Manuel Joaquim de Ornellas e José Arouche de Toledo Rendon, viram concorrentes bem menos votados - alguns deles nem constantes na lista - serem escolhidos para preencherem o cargo de senadores, como podemos depreender da tabela abaixo:

\section{Relação dos candidatos mais votados para o Senado na ocasião das eleições para a $\mathbf{1}^{\mathrm{a}}$ legislatura do Império (1826-1829): ${ }^{43}$}

$1^{\circ}$ ) Nicolau Pereira de Campos Vergueiro - 263 votos.

$2^{\circ}$ ) Manuel Joaquim de Ornellas - 253 votos.

$\left.3^{\circ}\right)$ Francisco das Chagas Santos ${ }^{444}-215$ votos.

$4^{\circ}$ ) Manuel Martins do Couto Reis - 166 votos.

$5^{\circ}$ ) Cândido Xavier de Almeida e Sousa - 161 votos.

$\left.6^{\circ}\right)$ José Arouche de Toledo Rendon - 154 votos.

* $7^{\circ}$ ) Lucas Antônio Monteiro de Barros (depois Barão e Visconde de Congonhas do Campo) - 151 votos. Nomeado

$8^{\circ}$ ) Sebastião Luiz Tinoco da Silva - 147 votos. Nomeado senador por Minas Gerais.

*9º D. Francisco de Assis Mascarenhas (Conde e depois Marquês de São João da Palma) -140 votos. Nomeado.

$10^{\circ}$ ) João Carlos Augusto de Oyenhausen (depois Visconde e Marquês de Aracati) - 135 votos. Nomeado senador pelo Ceará.

$11^{\circ}$ ) Estevão Ribeiro de Rezende (depois Barão, Conde e Marquês de Valença) - 130 votos. Nomeado senador por Minas Gerais.

$12^{\circ}$ ) D. Nuno Eugênio de Lossio e Seiblitz - 116 votos. Nomeado senador por Alagoas.

*D. José Caetano da Silva Coutinho (bispo do Rio de Janeiro e Capelão-mor) - 115 votos. Nomeado.

\footnotetext{
${ }^{443}$ Ibid., pp.176-177.

${ }^{444}$ Francisco das Chagas Santos (?-?), marechal de campo, já havia sido membro da Assembléia Constituinte em 1823. Foi, também, eleito deputado pela $1^{a}$ legislatura do Império (1826-1829). Nomeado comandante das armas da província de São Paulo em 1829, ocupou o mesmo posto na Corte em 1830 e 1838 . Foi nomeado presidente da Província do Rio Grande do Sul em 1837, e membro da Sociedade promotora da Indústria Riograndense
} 
João Ferreira de Oliveira Bueno - 113 votos.

*José Feliciano Fernandes Pinheiro (depois Visconde de São Leopoldo) - 108 votos. Nomeado.

José Joaquim Carneiro de Campos (depois Visconde e Marquês de Caravelas) - 87 votos. Nomeado senador pela Bahia.

Manuel Joaquim Gonçalves de Andrade (depois bispo de São Paulo) - ? votos.

Se Lucas Antônio Monteiro de Barros gozava de certa popularidade entre os paulistas, o mesmo não se pode dizer de José Caetano da Silva Coutinho e José Feliciano Fernandes Pinheiro, que nunca haviam ocupado cargos políticos na província. O próprio Francisco de Assis Mascarenhas, governador de São Paulo entre 1816 e 1818 - período no qual a província sofrera com o recrutamento para a Campanha do Sul -, deixara de atuar de forma mais visível no cenário politico paulista desde sua saída do governo.

Não era à toa, portanto, a insatisfação dos liberais “moderados” paulistas ante o grupo de representantes escolhidos pelo imperador, situação que foi parcialmente remediada com a nomeação de Vergueiro para a bancada senatorial mineira, em 1828, após a morte do Marquês de Sabará. Em 1833, já em tempos da Regência Trina Permanente, foi a vez de Francisco de Paula Souza e Melo ocupar assento por São Paulo no Senado, depois do falecimento de D. José Caetano da Silva Coutinho. De qualquer forma, durante todo o Primeiro Reinado e os anos iniciais do período regencial, os “moderados” não tiveram uma bancada senatorial que os representasse, o que refletiu, como veremos, na relação que Câmara dos Deputados, os Conselhos Provinciais e a imprensa periódica travaram com o Senado e o governo central.

O ponto crucial da hesitação sobre os rumos da vida política de Vergueiro residi, conforme o redator de O Farol, na seguinte equação: de um lado, a entrada de Vergueiro 
para o Senado poderia ser estrategicamente perigosa, uma vez que essa Casa seria majoritariamente composta por "homens do velho regime”, o que por sua vez ofuscaria a força política de um dos líderes da oposição moderada ao Governo; de outro, a ida de Vergueiro poderia encetar uma reformulação das bases políticas do Senado, ampliando assim o leque de participação política dos “moderados”. ${ }^{445}$ Em ambos os casos, porém, o princípio argumentativo era o mesmo: o acesso ao poder se daria por meio da legalidade das ações, ou seja, pela utilização das possibilidades dispostas pela Carta de 1824. Tal argumento era freqüentemente utilizado pelos grupos de oposição ao governo, o qual era considerado o detentor do uso da violência, seja política seja de coerção física.

Desde 1826, quando o Imperador e o Ministério passaram a repartir o poder imperial com o Legislativo, o cumprimento e a regulamentação da Constituição tornaram-se a força motriz da atuação da Câmara dos Deputados, sendo um dos elementos que norteou a polarização de forças cunhada pela imprensa liberal da época, e que consolidou qualificações como “moderados”, “exaltados” e “corcundas”, como indicado no $1^{\circ}$ capítulo.

Diversamente do que ocorreria mais tarde, já no Segundo Reinado, quando o debate sobre as diferentes noções de parlamentarismo ganharia destaque dentro e fora das esferas oficiais de poder, a luta política desenvolvida nas primeiras legislaturas do Império pautouse numa dimensão outra, a de como viabilizar um governo constitucional, preocupação essa que foi um dos pilares da consolidação do legalismo que marcou o advento dos Estados Nacionais pós-Revoluções Industrial e Francesa. ${ }^{446} \mathrm{O}$ próprio exercício do poder pelos

\footnotetext{
${ }^{445}$ Anos mais tarde, já terminada a $3^{\text {a }}$ legislatura do Império, o periódico O Justiceiro externou um raciocínio semelhante sobre a paulatina transformação na composição do Senado: “O Senado é de eleição popular; não tem número excessivo, nem seu número é ilimitado; com o tempo far-se-á a limpeza necessária, outro tanto não podia acontecer na França”, cf. O Justiceiro, nº 01, 07/11/1834.

${ }^{446}$ A respeito da ênfase dada à esfera legal no processo de construção dos Estados Nacionais ibero-americanos, ver ANINO, Antonio (et. alli.). De los imperios a las naciones: Iberoamérica. Zaragoza, IberCaja, 1994.
} 
parlamentares se canalizou para esse ponto, de modo que as sucessivas mobilizações em torno da votação de algumas das principais matérias do período - como os regimentos para as Câmaras Municipais e Conselhos Gerais, o Código Criminal e as primeiras leis de orçamento - ativeram-se ao fato de que elas haviam sido prescritas pela Constituição. A partir do cumprimento desta estariam lançados não apenas os canais de participação política que serviriam como guardiões da liberdade e como formas de acesso ao poder, mas também os mecanismos limitantes do exercício dos poderes Executivo e Moderador. ${ }^{447}$

A atuação da Câmara dos Deputados foi largamente explorada pela bibliografia como uma das manifestações mais contundentes de oposição ao governo de D. Pedro. Personagens como Diogo Antonio Feijó, Bernardo Pereira de Vasconcelos e Antonio Francisco de Paula Holanda e Cavalcanti foram citadas amiúde por suas respectivas performances na Assembléia Geral, quer como proponentes de projetos de lei quer como defensores da causa liberal, entrando em choque com o Senado e Ministérios. Menos ênfase foi dada, entretanto, à atuação que tiveram outras esferas oficiais de poder como, por exemplo, os Conselhos Provinciais, sobre o andamento do debate político sucedido no Rio de Janeiro a respeito dos rumos do Império. Mas se homens como Feijó, Vasconcelos, Holanda e Cavalcanti também chegaram a ocupar, à mesma época em que foram deputados, os cargos de conselheiro geral ou da presidência em suas províncias de origem, é pertinente indagar se os referidos Conselhos ofereceram sustentabilidade, em nível provincial, ao projeto político de monarquia constitucional com sede no Rio de Janeiro, como também à oposição feita no Parlamento pelos deputados ao governo de D. Pedro.

Tomando-se o caso paulista, é possível observar sólidos indícios de que ambos os Conselhos atuaram nesse sentido, seja estendendo o debate político da Corte para o âmbito

${ }^{447}$ MATTOS, op. cit., p.274. 
provincial seja fazendo da província uma força política capaz de interagir na construção do novo Império em bases liberais. As próprias carreiras políticas dos deputados e conselheiros paulistas convergiam, ao menos teoricamente, para essa intersecção de interesses: mais da metade de todos os políticos que tomaram assento nas três primeiras legislaturas do Império, bem como nas Reuniões do Conselho da Presidência e Geral pela província ocuparam, simultaneamente ou não, cargos em mais de um desses órgãos. ${ }^{448}$ Alguns deles, como Rafael Tobias de Aguiar, Diogo Antonio Feijó, Manuel Joaquim de Ornellas e Lourenço Pinto de Sá Ribas foram empossados nos três órgãos mencionados. A tabela abaixo permite que visualizemos, ao longo do tempo, o trânsito desses homens na Câmara dos Deputados e nos Conselhos Provinciais:

\footnotetext{
${ }^{448}$ Este número poderia ter sido bem maior se não fosse o já mencionado Decreto de 12 de agosto de 1831, o qual proibiu que os membros dos Conselhos das Províncias e das Câmaras Municipais ocupassem assento nos Conselhos Gerais.
} 
Tabela que contém os membros das três primeiras legislaturas do Império, e dos Conselhos da Presidência e Geral pela

\section{província de São Paulo:}

\begin{tabular}{|c|c|c|c|c|c|c|c|c|c|}
\hline Nome & $\begin{array}{c}1^{\mathrm{a}} \\
\text { legislatura } \\
\text { do Império } \\
(1826- \\
1829)\end{array}$ & $\begin{array}{c}2^{\mathrm{a}} \text { legislatura } \\
\text { do Império } \\
(1830-1833)\end{array}$ & $\begin{array}{c}3^{\text {a }} \text { Legislatura } \\
\text { do Império } \\
\text { (1834-1837) }\end{array}$ & $\begin{array}{c}1^{\text {a }} \text { Reunião do } \\
\text { Conselho da } \\
\text { Presidência } \\
\text { (1824-1829) }\end{array}$ & $\begin{array}{c}2^{\text {a }} \text { Reunião } \\
\text { do Conselho } \\
\text { da } \\
\text { Presidência } \\
\text { (1830-1833) }\end{array}$ & $\begin{array}{c}3^{\text {a }} \text { Reunião } \\
\text { do Conselho } \\
\text { da } \\
\text { Presidência } \\
(1834)\end{array}$ & $\begin{array}{c}1^{\text {a }} \text { Reunião } \\
\text { do } \\
\text { Conselho } \\
\text { Geral } \\
\text { (1828- } \\
1839)\end{array}$ & $\begin{array}{c}2^{\text {a }} \text { Reunião } \\
\text { do } \\
\text { Conselho } \\
\text { Geral } \\
\text { (1830- } \\
1833)\end{array}$ & $\begin{array}{c}3^{\mathrm{a}} \\
\text { Reunião } \\
\text { do } \\
\text { Conselho } \\
\text { Geral } \\
(1834)\end{array}$ \\
\hline Nicolau Pereira de Campos & & & & & & & & & \\
\hline Vergueiro, Bacharel & $\mathrm{X}$ & & & $X(s)$ & $\mathrm{X}$ & & & & \\
\hline $\begin{array}{l}\text { Rafael Tobias de Aguiar } \\
\text { (1794-1857), Brigadeiro } \\
\text { Manoel Joaquim de }\end{array}$ & & $\mathrm{X}$ & $\mathrm{X}$ & $\mathrm{X}$ & $\mathrm{X}$ & $\mathrm{X}$ & $\mathrm{X}$ & $\mathrm{X}$ & \\
\hline Ornellas, Bacharel & $\mathrm{X}$ & $\mathrm{X}$ & & $\mathrm{X}$ & $\mathrm{X}$ & & $\mathrm{X}$ & $\mathrm{X}$ & \\
\hline $\begin{array}{c}\text { Diogo Antonio Feijó, } \\
\text { Padre } \\
\text { Lourenço Pinto de Sá }\end{array}$ & $\mathrm{X}$ & $\mathrm{X}$ & & $X(s)$ & $\mathrm{X}$ & & $\mathrm{X}$ & $\mathrm{X}$ & \\
\hline Ribas & & $\mathrm{x}$ & $\mathrm{X}$ & $X(s)$ & & & $\mathrm{x}$ & $X(s)$ & \\
\hline $\begin{array}{c}\text { Francisco de Paula Souza e } \\
\text { Mello } \\
\text { José Corrêa Pacheco e }\end{array}$ & $\mathrm{X}$ & $\mathrm{X}$ & & & & & & $\mathrm{X}$ & $\mathrm{X}$ \\
\hline $\begin{array}{c}\text { Silva (1778-1836), } \\
\text { Bacharel } \\
\text { José Ricardo da Costa }\end{array}$ & $\mathrm{X}$ & $\mathrm{X}$ & & & & & & $\mathrm{X}$ & \\
\hline $\begin{array}{l}\text { Aguiar de Andrada (1787- } \\
\text { 1846), Magistrado } \\
\text { Francisco das Chagas }\end{array}$ & $\mathrm{X}$ & & & & & & & & \\
\hline $\begin{array}{c}\text { Santos, Marechal de } \\
\text { campo } \\
\text { João Crisóstomo de }\end{array}$ & $\mathrm{X}$ & & & & & & & & \\
\hline $\begin{array}{c}\text { Oliveira Salgado Bueno, } \\
\text { Padre }\end{array}$ & $\mathrm{X}$ & & & & & & $\mathrm{X}$ & $\mathrm{X}(\mathrm{s})$ & \\
\hline Antonio Paes de Barros & & $\mathrm{X}$ & & & & & $\mathrm{X}$ & $\mathrm{X}$ & $\mathrm{X}$ \\
\hline
\end{tabular}


(1791-1876), Barão de Piracicaba em 1854

Rodrigo Antonio Monteiro de Barros (?-1844),

Magistrado

Joaquim Floriano de

Toledo (1794-1875),

$$
\text { Coronel }
$$

Luiz Antonio Neves de

Carvalho, Coronel

Candido Xavier de

Almeida e Souza

Manoel Joaquim

Gonçalves de Andrade,

Vigário Capitular e bispo.

Manoel Rodrigues Jordão, Brigadeiro

Francisco Inácio de Souza Queiroz

Antônio José Vaz

Antonio Bernardo Bueno

$$
\text { da Veiga }
$$

Bernardo José Pinto

Gavião Peixoto

José Arouche de Toledo Rendon

Manoel da Cunha de

Azevedo C. S. Chicorro Joaquim Mariano Galvão de Moura Lacerda

Jose Joaquim Cezar de Serqueira Leme

Jose Pedro Galvão de Moura e Lacerda

Jose da Costa Carvalho Manoel Joaquim do

Amaral Gurgel

Antonio Mariano de 
Azevedo Marques

Jose Manoel de França

Joaquim Jose Moraes e Abreu

Francisco Alves Ferreira do Amaral

Jose Matias Ferreira de Abreu

José de Almeida Leme Lourenço Justiniano

Ferreira, Cônego

Jose Gomes de Almeida, Cônego

Manoel Inocêncio de Vasconcelos

Vicente Pires da Mota, Padre

Joaquim José dos Santos Silva, Capitão

José Manoel da Silva, Major

Jose Manuel da Luz

Manoel Dias de Toledo (1802-1874), lente de

$$
\text { Direito }
$$

Francisco Álvares

Machado de Vasconcelos (1776-1846), médico

Valério de Alvarenga

$$
\text { Ferreira, padre }
$$

$$
\text { Sá, padre }
$$

(1798-?), bispo

João Gonçalves Lima

José Gonçalves da Silva 


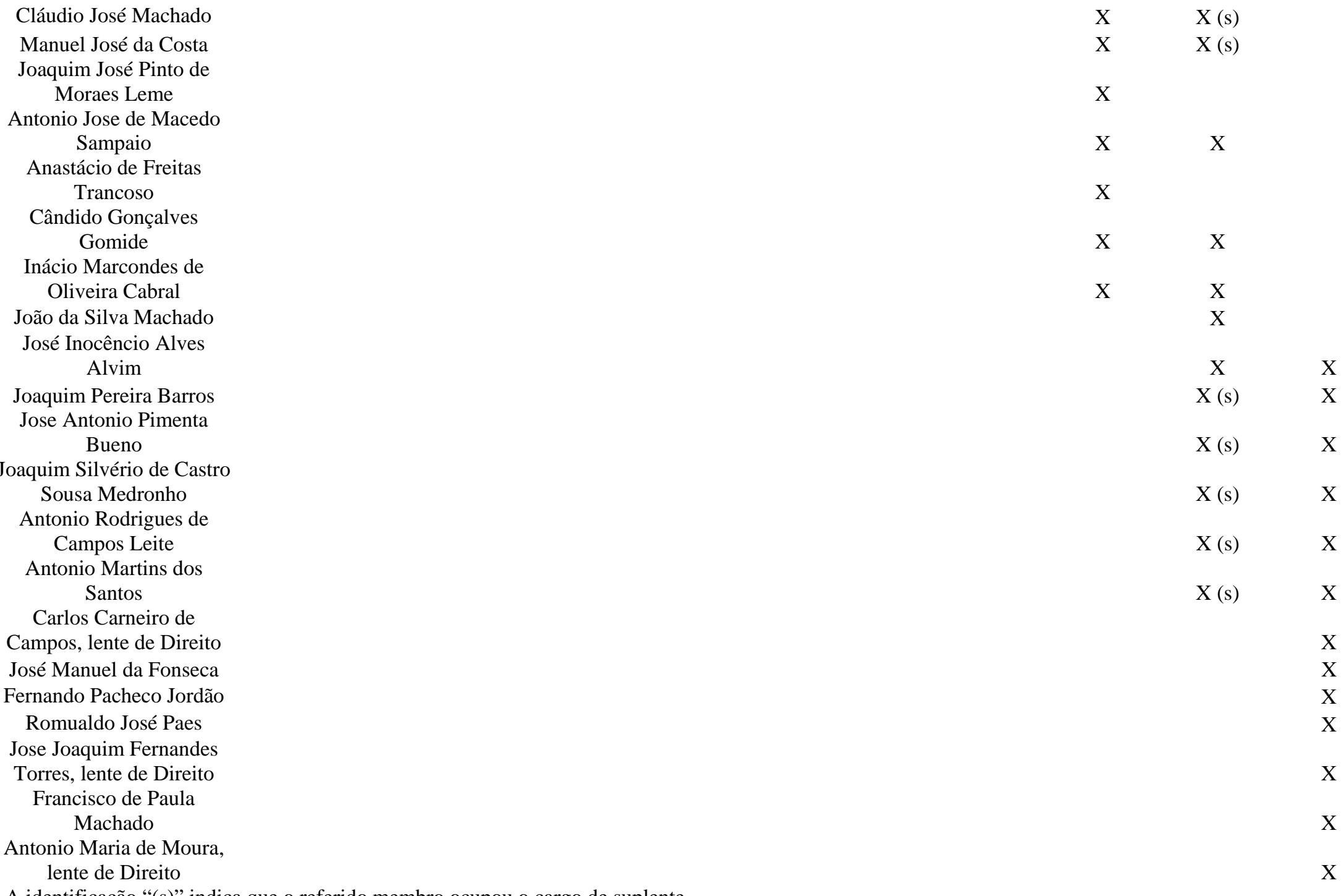


Se membros dos Conselhos Provinciais paulistas também atuavam na Câmara dos Deputados, não é de admirar que o comportamento político dos Conselhos Provinciais estivesse atrelado à discussão no parlamento, especialmente a partir de 1829, quando a oposição daquela Casa ao Governo e Senado ganhou mais força. Em janeiro de 1830, o Farol Paulistano publicou a seguinte nota:

“A Proposta do Sr. Machado, que em nosso Correspondente fez publicar n'este mesmo $\mathrm{N}^{0}$ mostram assaz os bons sentimentos do Concelho todo, e de toda a Província de São Paulo, com mui poucas e mui deshonrosas excepções”. 449

A “proposta” a que se referiu o redator de O Farol era, na realidade, um ofício sugerido pelo conselheiro Cláudio José Machado que consistia num agradecimento em nome do Conselho Geral de São Paulo ao imperador, por este ter desmobilizado uma suposta “trama” organizada pelos “absolutistas”. Apesar do caráter vago do documento, é muito provável que ele remetesse à mudança ministerial ocorrida em 4 de dezembro de 1829, que na ocasião refreou, ao menos em parte, a série de insinuações sobre o círculo de relações de D. Pedro, acusado de intransigência política e de estar vinculado à questão sucessória do trono português. ${ }^{450}$

O novo Ministério - composto pelos Marqueses de Caravelas (Império), Barbacena (Fazenda) e Paranaguá (Marinha), pelo Visconde de Alcântara (Justiça), pelo Conde do Rio Pardo (Guerra) e por Miguel Calmon (Negócios Estrangeiros) - punha um desfecho, ainda que provisório, na política ministerial levada adiante por Clemente Pereira nos dezoito meses anteriores, que fora marcada por críticas e denúncias feitas pela oposição liberal,

\footnotetext{
${ }^{449}$ O Farol Paulistano, no 302, 30/01/1830.

${ }^{450}$ MONTEIRO, op. cit., pp.170-173; PORTO, Costa. O Marquês de Olinda e o seu tempo. São Paulo/ Belo Horizonte: Edusp/ Itatiaia, 1985, pp.64-65.
} 
como conservar o alto índice de estrangeiros na tropa brasileira, nomear portugueses a empregos públicos de forma ilícita, estabelecer uma estreita relação com o chamado “Gabinete Secreto” de Francisco Gomes da Silva e permitir, tacitamente, abusos de poder e descumprimentos da Carta de 1824. Chegou-se a aventar que Clemente Pereira, ao temer a ascensão do Parlamento, estaria tramando um golpe absolutista juntamente com setores do Rio de Janeiro, Bahia e Pernambuco. ${ }^{451}$

Dentre as medidas de impacto do novo Ministério, pode-se destacar a portaria baixada pelo Visconde de Alcântara, em 12 de dezembro de 1829, que procedeu contra a Sociedade da Coluna e do Trono de Pernambuco ${ }^{452}$, uma organização secreta criada por grupos pernambucanos e acusada pelos liberais de compactuar com o absolutismo. O ministério da Guerra também tomou algumas providências com visibilidade pública, como o afastamento de oficiais acusados de “corcundismo” em algumas províncias do Império. ${ }^{453}$ Sobre o suposto malogro de um golpe contra a ordem estabelecida, o Observador Constitucional publicou um artigo exaltando o fracasso de “projetos tão horríveis” almejados pela "hydra do absolutismo”, e defendeu a manutenção do trono constitucional como promotor da “união” e da felicidade dos cidadãos. ${ }^{454}$

O Conselho Geral de São Paulo, na ocasião, apresentando-se como “órgão fiel de seus habitantes”, invocou uma pretensa homogeneidade política da província de São Paulo

\footnotetext{
451 A atuação do ministério de Clemente Pereira fica explícita na forma como foram conduzidos alguns incidentes ocorridos nas Províncias do Império. Enquanto que os motins liberais de Ipujoca e Afogados, ocorridos em Pernambuco em 1829, foram rigorosamente julgados por uma comissão militar, o coronel Pinto Madeira foi conservado no comando militar do Ceará após ter feito um pronunciamento em favor do absolutismo. Cf. MONTEIRO, op. cit., p.173.

${ }^{452}$ A Sociedade Secreta da Coluna do Trono foi criada em 1829, no Recife. Dela participariam alguns dos redatores dos periódicos "caramurus" O Cruzeiro e O Amigo do Povo, como os padres Francisco Ferreira Barreto e Jose Marinho Falcão Padilha. Cf. FONSECA, Silvia Carla Pereira de Brito. "Federação e república na Sociedade Federal de Pernambuco (1831-1834), in Saeculum - Revista de História. João Pessoa, n.14, jan./jun. de 2006, pp.57-73. Disponível no site: http://www.cchla.ufpb.br/saeculum. Acesso em julho de 2008. ${ }_{453}$ SOUSA, op. cit., pp.20-24.

${ }^{454}$ O Observador Constitucional, nº?, 18/12/1829.
} 
e sentenciou que “correr às armas seria um movimento unânime” entre os paulistas, caso a “facção dos absolutistas” coagisse o imperador a dissolver o regime monárquicoconstitucional:

"Senhor = O Conselho Geral da Província de S. Paulo, órgão fiel de seus habitantes, tem a honra de vir significar a V.M.I. o jubilo, que transborda em seos corações por verem salva a Nação, e com ella o Throno de V. Magestade do abysmo, que lhes cavava a mizeravel, mas sempre activa faç̧ão dos absolutistas. Não he que os Paulistas temessem receber ferro das mãos de hum punhado de imbecis, ou perversos; eles descendem d'antepassados, para quem a liberdade, a independencia, e o seo Monarcha eram objectos santos, em que não deixavam tocar enquanto vivos. Mais ilustrados, porem não menos bravos que seos maiores, os Paulistas d'hoje não esperarião em seo solo os rebeldes, antes no momento, em que lhes constasse, que as avenidas do Throno se achavão por elles tomadas, a Província se transformaria em massa para desempecel-as, e para arrancar a sagrada pessoa de V.M.I. a qualquer coação, que traidores lhe quissem impor; chefes não lhes seriam precizos, por que ao grito $=$ Paulistas, querem fazer-vos escravos $=$ correr às armas seria um movimento unânime. Mas estes sentimentos tão concordes com o Brasileiro e Constitucional coração de V.M.I., e já por vezes manifestados mesmo por V.M. não privão, que a Provincia de S. Paulo applauda os meios tão simples, quanto efficazes, com que V.M. desfez a trama liberticida, antes que huma pinga de sangue dos malvados poluisse o terreno da liberdade; elles não privão que os Paulistas bem digão a V.M.I. por ter assediado de si a homens, que por sua conducta equivoca, e suspeita de conveniencia com os monstros, tinhão incorrido na exacração publica, e só com isto dissipou-se a tempestade; se não fosse assim, talvez com o sangue impuro dos malvados se misturasse o sangue dos bons Brasileiro, e então a liberdade teria custado mais caro.

Digne-se pois V.M.I. aceitar os parabens, os puros votos e os sinceros agradecimentos das habilidades da Província de S. Paulo, que o Conselho Geral cabalmente interado, que são estes, e não outros os seos sentimentos, tem a honra de levar ante o throno de V.M.I., assegurando a V.M.I., que os Paulistas hão de sustentar a Monarchia Constitucional a despeito dos maiores sacrificios, e que o despotismo não levantará jamais seu Throno, senão sobre as ossadas do derradeiro Paulista (...)”. 455

${ }^{455}$ RPR, “Oficio agradecendo a S.M.I. ter desfeito a trama dos absolutistas”, pp.12-13. 
Encaminhado para o monarca no início de fevereiro de 1830, o ofício foi respondido no mesmo mês por intermédio do ministro do Império, o qual certificou que D. Pedro ouviu com agrado os votos de agradecimento oferecidos-lhes pelo Conselho Geral. ${ }^{456} \mathrm{O}$ Observador Constitucional notificou a recepção das felicitações oferecidas pelo monarca, reiterando que a ação de D. Pedro foi decisiva para a desmobilização dos “Columnistas Clementinos":

“Consta-nos por pessoas fidedignas que a felicitação que o Concelho Geral enviou a S. M. I. e C., por haver lançado em terra o partido absolutista, que querião levar o Brazil ao antigo governo de ferro, fora recebido por S. M. I. com especial agrado. Não era de esperar menos do philantropico Coração de tão Magnânimo Monarca, que só tem a lei por guia que vela da felicidade do povo que contente e satisfeito o Elegeo. Servis Columnistas Clementinos, envergonhai-vos, cubri-vos de eterna vergonha, pois sois olhados com infâmia, com desprezo pela Nação, que ainda por piedade vos conserva em seu seio. Percão de uma vez as esperanças, que no Brazil, não vegeta mais a terrível, e assolarada planta do absolutismo". ${ }^{457}$

Ao final do mesmo ano, com a $2^{\text {a }}$ Reunião já em andamento, o Conselho Geral de São Paulo deu novas mostras de seu envolvimento com questões mais amplas da política imperial, mas desta vez com o foco voltado para uma matéria estritamente associada à luta política deflagrada na Assembléia Geral. Os conselheiros formularam três representações distintas - uma para cada Casa do Parlamento e outra para o imperador - enaltecendo o cumprimento do artigo 61 da Carta de 1824 pelo Legislativo e Executivo. Ocorrido em setembro de 1830, o evento é considerado por alguns historiadores como uma das

\footnotetext{
${ }^{456}$ Ver O Farol Paulistano, no ${ }^{\circ}$ 425, sessão de 02/02/1830.

${ }^{457}$ O Observador Constitucional, ${ }^{\circ} 38,12 / 03 / 1830$.
} 
principais conquistas da oposição liberal ao governo de D. Pedro durante o Primeiro Reinado, uma vez que possibilitou a votação da primeira lei de orçamento do Império. ${ }^{458}$

O artigo aludido afirmava que se a Câmara dos Deputados não aprovasse as “emendas” ou “adições” do Senado, ou vice-versa, e que ainda assim a "câmara recusante” achasse que o projeto fosse importante, essa poderia requerer, “por uma deputação de três membros”, a reunião das duas Casas, que seria realizada na Câmara dos Senadores, deliberando-se em favor do resultado da discussão. ${ }^{459}$

Uma vez que o Senado deveria ser numericamente composto, por exigência da Carta de 1824, pela metade de membros em relação à Câmara dos Deputados (art.41), a possibilidade de reunir as duas Casas figurava para a oposição parlamentar - quase toda ela formada por deputados - como uma forma de ter suas matérias aprovadas e sem grandes alterações vindas da bancada senatorial. Acalentado pelos deputados desde a abertura do Parlamente, o artifício foi constantemente apregoado pela imprensa liberal da época. Em fevereiro de 1827, o redator de O Farol Paulistano assinalou numa nota que se fosse mantido o sistema de “votação por Câmaras”, infalivelmente ruiriam a Constituição e a forma de Governo “tão felizmente estabelecida no Brazil”, em decorrência das constantes divergências entre as duas Casas. A evocação do artigo 61 seria, portanto, uma saída para a morosidade na aprovação das leis. ${ }^{460}$

Sem precedentes até aquele momento, a execução do artigo 61 foi resultado da intensa ofensiva liberal capitaneada pela Câmara dos Deputados na sessão de 1830 - e com grande lastro em periódicos como O Farol Paulistano, O Observador Constitucional e A

\footnotetext{
${ }^{458}$ Cf. ARMITAGE, op. cit.; CUNHA, op. cit.; MONTEIRO, op. cit.; SOUSA, op. cit.

459 Cf. artigo 61 da "Constituição Política do Império do Brasil", in BONAVIDES, Paulo \& AMARAL, Roberto (orgs.), op. cit.

${ }^{460}$ O Farol Paulistano, ${ }^{\circ} 13,02 / 05 / 1827$.
} 
Aurora Fluminense. A matéria já havia causado grandes discórdias entre governo, deputados e senadores, sendo o principal motivo do encerramento precoce da sessão de 1829. Na Fala do Trono de 2 de maio de 1830, o imperador solicitou que naquela sessão as duas Casas dessem atenção especial aos negócios da Fazenda e da Justiça, que eram de interesse vital para o progresso do Império.

A estrutura orçamentária do Império tornou-se pauta privilegiada entre os legisladores, mas incongruências de opiniões entre Câmara e Senado - especialmente no que tange aos gastos ministeriais - fez com que D. Pedro convocasse, no dia do encerramento da Assembléia Geral de 1830, uma reunião extraordinária com início em 8 de setembro e cujo objetivo era concluir a lei do orçamento, além de organizar um Banco Nacional e aprovar um código criminal e processual. Este tinha como projeto-base o texto elaborado por Bernardo Pereira de Vasconcelos que desde 1828 já vinha sendo alvo de discussão parlamentar, sendo assim aprovado pelas duas Casas e, posteriormente, sancionado pelo imperador. As propostas apresentadas sobre a criação de um Banco Nacional foram rejeitadas pelos deputados, de modo que o assunto, sem muito empenho pelo Senado, perdeu força e saiu de cena. Restava ainda a lei do orçamento que, longe de gerar um consenso, permanecia dividindo opiniões entre senadores e deputados. Estes sugeriram cortes sensíveis nas pastas ministeriais bem como a exclusão de várias fileiras do Exército, ao passo que aqueles defendiam o aumento dos valores orçados pelos deputados para as forças de terra e marinha. ${ }^{461}$

As folhas liberais criticaram duramente a posição dos senadores ante a votação da lei do orçamento, uma vez que esses estariam protelando-a, propositadamente, até o final na sessão extraordinária, o que aumentaria as chances dos deputados, na eminência de verem

${ }^{461}$ ARMITAGE, op. cit., pp.193-196, SOUSA, op. cit., pp.66-71. 
a pauta novamente ficar para o ano seguinte, aprovarem-na com as emendas senatoriais. Segundo artigo publicado por O Farol Paulistano, em novembro de 1830, essa era uma prática comum do Senado, e a única solução para combatê-la era a invocação do artigo 61 da Constituição. ${ }^{462}$

O prolongamento da discórdia mobilizou os deputados, que criaram uma comissão formada por Bernardo Pereira de Vasconcelos, Antonio Paulino Limpo de Abreu e José Lino Coutinho para sugerir ao Senado a convocação de uma sessão conjunta entre as duas Casas, invocando o artigo 61 da Constituição. Apesar das manobras em evitar a junção das duas Casas, o Senado acabou por acatá-la, e a reunião teve lugar entre 17 e 20 de setembro do mesmo ano. Os deputados, em maior número que os senadores (75 contra 37), conseguiram barrar parte significativa das emendas senatoriais, e passar por aprovação a primeira lei de orçamento do Império e aquela que fixava as forças de mar e terra. ${ }^{463}$

O Farol Paulistano assinalou que as leis do orçamento e da fixação das forças de mar e terra fizeram “diminuir as despesas” da nação, proporcionando um "verdadeiro augmento de receita”. Segundo a folha paulistana, a aprovação de ambas as leis fez “florescer” o "Systema Representativo". ${ }^{464}$ Em direção semelhante, o Observador Constitucional argumentou que a utilização do referido artigo havia sido “fructo da opinião pública”, e que ajudaria a poupar “muitos contos de reis”. 465

Encaminhadas pelo Conselho Geral de São Paulo em 11 de dezembro de 1830, as representações sobre a execução do artigo 61 não escondiam as orientações políticoideológicas que as motivavam. Sucinta, a representação remetida ao Senado limitou-se a

\footnotetext{
462 O Farol Paulistano, no 411, 04/11/1830.

${ }^{463}$ Cf. ARMITAGE, op. cit.; CUNHA, op. cit.; MONTEIRO, op. cit.; SOUSA, op. cit.

${ }^{464}$ O Farol Paulistano, no 429, 16/12/1830.

465 O Observador Constitucional, ${ }^{\circ}$ 109, 13/12/1830.
} 
parabenizá-lo genericamente, rendendo-lhe “veneração e reconhecimento”, sem distinguir os trabalhos específicos dos senadores. ${ }^{466}$ Em contrapartida, a representação despachada à Câmara dos Deputados, que na época contava com sete conselheiros gerais paulistas, marcou a importância do esforço de seus membros, e os objetivos alcançados com a observância do artigo 61:

“(...) Sim, Augustos e Digníssimos Srs, incansáveis em servir a Pátria, vós acabais de conseguir a verdadeira intelligenica, e observância do art. 61 da Constituição do Império; acabais de facilitar a consecução de Leis importantes, que o Brasil espera, algumas das quaes tantas fadigas e trabalhos vos tem já custado; acabais em fim de dar um impulso forte a liberdade, e propriedade da Nação, que vos abençoa. Vós, melhor que ninguém, Srs., estais convencidos, de que sobra a razão a Província de S. Paulo para alegrar-se com este fructo de vossa coragem, firmeza, e sabedoria: vós, melhor que ninguém, conheceis a crise, de que a Nação está livre, e livre sem o menor sacrifício: graças vos sejão dadas! (...)”467

Com relação à representação despachada ao imperador, o Conselho Geral de São Paulo optou por valorizar o episódio da convocação extraordinária da Assembléia por D. Pedro, mostrando-se favorável a utilização dessa atribuição do Poder Moderador (art. 101 da Carta de 1824):

“ (...) V.M. pois que em todas as crises do Brazil tem sempre hum dos principais motores d'hum desfexo feliz, e venturozo, q. nesta ainda teve a melhor parte pelo opportuno emprego d'huma das mais preciosas atribuições do Poder Moderador, qual a de convocar extraordinariamente a Assemblea Geral, V. M. será amplamante recompensada de

\footnotetext{
466 RPR, ““Felicitação a Camara dos Senhores Senadores acerca da literal observancia do art. 61 da Constituição do Império”, p.39.

467 RPR, "Felicitação a Camara dos Senhores Deputados acerca da literal observancia do art. 61 da Constituição do Império”, p.38.
} 
seus desvelos, vendo-se a testa d'huma Nação florecente, rica e poderosa, e sentindo o seo Throno cada vez mais firme, pois terá por base - o amor e gratidão dos Brasileiros (..)”. 468

Levando em consideração essas intervenções feitas pelo Conselho Geral de São Paulo, é possível sugerir que o órgão paulista firmou-se, a pouco e pouco, como defensor da monarquia constitucional representativa, interlocutor do Legislativo e Executivo, e adepto da conduta política levada adiante pela Câmara dos Deputados. Sobre esse aspecto discorreu a historiadora Marisa Saenz Leme:

“De modo novo para o que até então se verificara nas relações dos paulistas com o governo central, quando as exposições políticas se davam de modo indireto, o Conselho Geral de São Paulo realizou manifestações explicitamente políticas, apresentando seu pensamento sobre as relações entre província e o centro, a articulação dos poderes Legislativo e Executivo, e os fatos mais imediatos da política na corte”. ${ }^{469}$

Embora não possuíssem concretude deliberativa ou legislativa, representações desse porte serviam para que os grupos ocupantes do Conselho Geral de São Paulo dessem o tom do posicionamento político-ideológico do órgão, superando suas atribuições puramente locais e dialogando com a esfera públicas do Império, seja com outras instâncias oficiais de poder seja com a imprensa periódica. Nesse âmbito, o forjar constante de uma homogeneidade política da província de São Paulo fixou uma retórica geradora de no mínimo duas implicações. De um lado, o Conselho Geral projetou-se como porta-voz da sociedade paulista, no sentido de representar o corpo dos cidadãos da província. De outro,

\footnotetext{
${ }^{468}$ RPR, "Representação pela qual o Conselho Geral se congratula com S.M.I. sobre a observância do art. 61 da Constituição do Império”, pp.25-26.

${ }^{469}$ LEME, Marisa Saenz. "Dinâmicas centrípetas e centrífugas na formação do Estado monárquico no Brasil: o papel do Conselho Geral da Província de São Paulo”. Rev. Bras. Hist., Jan./Jun., 2008, vol.28, n.55, p.205.
} 
encobriram-se possíveis discordâncias políticas em São Paulo, quer para o governo central, para as demais províncias, quer para os próprios paulistas.

O Conselho da Presidência de São Paulo, por seu turno, portou-se de forma distinta sob esse aspecto. Não fez parte de sua agenda, por exemplo, emitir juízos ou quaisquer tipos de representação sobre questões de maior amplitude da política nacional. Além de uma discreta manifestação de fidelidade ao imperador na ocasião de sua abertura, em outubro de $1824^{470}$, não há registros, ao menos em ata de sessão, de que o Conselho da Presidência de São Paulo tenha canalizado esforços para esse tipo de atividade.

Isso não significa, todavia, que o Conselho da Presidência tenha sido alheio à defesa dos preceitos monárquico-constitucionais, tampouco que tenha questionado o Rio de Janeiro como centro do Império. Órgão privativo do presidente, o Conselho da Presidência fez da sua própria prática executiva uma ferramenta de adesão ao projeto liberal de estado monárquico com sede na Corte fluminense. Excetuando os casos de explícito endosso ao modelo político em voga, como no episódio em que o presidente José Carlos Pereira de Almeida Torres propôs que um dos conselheiros fosse enviado ao Rio de Janeiro para representar os “sentimentos” do "Povo Paulistano” pela chegada da imperatriz D. Amélia de Leuchtemberg, e prestar sua "lealdade, amor e adesão” ao trono de D. Pedro ${ }^{471}$, foi no dia a dia da prática política que o Conselho da Presidência mostrou seu posicionamento em favor do cumprimento da Carta de 1824.

Tal inclinação ficaria mais evidente a partir do final de 1830 . No dia $1^{\circ}$ de outubro deste ano, na abertura da $2^{\mathrm{a}}$ Reunião do Conselho da Presidência de São Paulo, o vicepresidente da província Manuel Joaquim Gonçalves de Andrade fez um discurso, como de

\footnotetext{
${ }^{470}$ ACP, v.86, sessão de 20/10/1824, p.11.

${ }^{471}$ ACP, v.86, sessão de 04/11/1829, p.266.
} 
praxe para aquele tipo de ocasião, a respeito do estado dos negócios provinciais. No início da sua fala, antes de discorrer sobre os objetos de interesse para a nova Reunião, Gonçalves de Andrade se disse satisfeito com o “feliz andamento” que o “Systema Politico” atingira na província, fazendo com que seus habitantes alcançassem o “real empossamento” dos seus “direitos Políticos”:

"Ilmos e Exmos Snres. - Coube-me mais esta vez ver-me reunido a tão dignos e benemeritos Conselheiros, e de abrir esta primeira Sessão Ordinaria correspondente á Segunda Legislatura, a fim de nella tratar-se dos interesses publicos d'esta Provincia, em cuja tarefa este Governo espera do seu Patriotismo e saber efficazmente coadjuvado, e os povos verem desempenhada a confiança, que poz em tão Ilustres Membros. Em cumprimento pois da Lei, eu passo a indicar aquillo, que me parece mais istante a reclamar as providencias d' este Conselho, reservando para as Sessoens outros negocios que tambem são de interesse publico. Principiarei por congratular-me com este Conselho pelo prezente acto de sua reunião, e bem assim de poder informá-lo do feliz andamento nesta Provincia do Systema Politico, que felizmente nos rege, cujas vantagens praticamente se fazem todos os dias sentir nos diversos ramos da publica administração, e já tem proporcionado aos póvos o real empossamento de seus direitos Políticos por elles tão ambicionados, e á sombra do qual se achão tranquillos”. ${ }^{472}$

Em meio ao acirramento das tensões envolvendo “exaltados”, “moderados” e “caramurus”, o Conselho da Presidência de São Paulo passou a lançar mão de uma função até então invocada apenas pontualmente, que era a de equacionar e amainar as turbulências de ordem política deflagradas na Província, sobretudo na capital. Componentes de toda sorte, como o acirramento da oposição ao imperador, os avanços parlamentares para a implementação da magistratura eletiva e a dissolução dos “batalhões de estrangeiros” por D. Pedro haviam tornado instável o ambiente político dos principais centros do Império,

\footnotetext{
${ }^{472}$ ACP, v.15, sessão de 01/10/1830, p.69.
} 
fazendo com que os governos locais tomassem providências para a manutenção da ordem pública. ${ }^{473}$ No caso de São Paulo, as mobilizações nas praças e ruas em torno da queda do rei Carlos $X^{474}$, na França, tiveram sérias implicações, que resultaram na prisão de diversos manifestantes pelo ouvidor Cândido Ladislau Japi-Assu e na morte do médico italiano Líbero Badaró, redator de O Observador Constitucional, crime que fora cometido por soldados alemães licenciados dos já então extintos "batalhões de estrangeiros”, em 20 de novembro de $1830 .{ }^{475}$

Diante de tantas ocorrências, o Conselho da Presidência tomou algumas resoluções. A 8 de outubro de 1830, convocou-se uma sessão extraordinária cujo intuito era discutir, nas palavras do suplente Antonio Mariano de Azevedo Marques, as “scenas desagradáveis” e até mesmo a possibilidade de "alguma revolução" que colocavam em risco a cidade de São Paulo. O mesmo suplente propôs algumas indicações para que o governo da Província não ficasse "na ignorancia de coisas de tamanho vulto", dentre elas que se exigisse do ouvidor um diagnóstico circunstanciado da situação e que o Conselho declarasse sessão permanente até que ficasse inteirado da natureza dos fatos, o que foi unanimemente aprovado pelos demais membros. ${ }^{476} \mathrm{Na}$ sessão seguinte, decidiu-se que a ata da sessão anterior e outros documentos nela expostos fossem remetidos ao imperador, e que se

\footnotetext{
${ }^{473}$ CUNHA, Pedro Octávio Carneiro da. “A fundação de um império liberal”, in HOLANDA, Sérgio Buarque de. (org.). História Geral da civilização brasileira, tomo II, “O Brasil Monárquico”. São Paulo: Difusão Européia do Livro, 1965, vol.1, pp.379-404.

${ }^{474}$ Durante seu governo (1826-1830), Carlos X dissolveu a Câmara e alterou trechos da Constituição francesa, atitudes que foram duramente criticadas pela oposição e que motivaram a eclosão de uma "revolução liberal" expressão utilizada pelos próprios coevos franceses -, que findou com a queda do monarca. Cf. HOBSBAWN, Eric J. A Era das Revoluções (1789-1848). Trad. Port. de Maria Tereza Lopes e Marcos Penchel De Rio de Janeiro, Paz e Terra, 1982.

475 SILVA, Nicolau Duarte. "Libero Badaró (contribuição para a sua biografia)", in Revista do Instituto Histórico e Geográfico de São Paulo, v.28, 1932, pp.462-577.

${ }^{476}$ ACP, v.15, sessão de 08/10/1830, pp.83-85.
} 
oficiasse ao Comandante interino das Armas de São Paulo Carlos Maria de Oliva para que esse informasse ao Conselho sobre a tropa de $1^{\mathrm{a}}$ linha. ${ }^{477}$

Os procedimentos levados a cabo pelo Conselho da Presidência foram repreendidos pelo governo central, que os classificou como “desregrados” e “illegais”. Em ofício lido na Câmara dos Deputados em 23 de outubro, o ministro do Império comunicou o desagrado do Governo em relação à forma como a situação estava sendo conduzida pelo Conselho da Presidência de São Paulo e pela Câmara Municipal da capital paulista, que poderia acarretar num "motim” ou “revolta”. O ministro solicitou, ainda, que os deputados dispensassem o quanto antes Aureliano de Souza e Oliveira Coutinho de seu cargo de deputado, para que esse ocupasse a presidência da Província de São Paulo:

"Illmo. e Exmo. Sr. - S. Magestade Imperial me ordena participe a V. Exc. Para ser presente a Camara dos Senhores Deputados: $1^{\circ}$. Ter chegado ao Governo a noticia (posto que ainda não official, com muitos caracteres de verdadeira) que de alguns actos desregrados, e criminozos, praticados na Cidade de S. Paulo por moradores della, no dia, e noite de cinco do corrente com perturbação da publica tranqüilidade, dos quaes o Ouvidor procurou judicialmente como lhe cumpria, se tem seguido procedimentos, também desregrados, e illegaes das Câmaras Municipal e do Conselho do Governo da Provincia, que extraordinariamente se reunirão, suscitando-se conflicto entre as authoridades, e commoções entre os Cidadãos, que poderão talvez degenerar em motim, ou revolta; $2^{\circ}$. ter julgado o Governo indispensável que saia quanto antes a tomar conta da administração daquella Provincia o Presidente que para ella se acha nomeado Aureliano de Souza e Oliveira. E porque he membro da Câmara dos Srs. Deputados, torna-se por isso necessario que a mesma Câmara determinando, como é de se esperar de sua Sabedoria, a dispensa delle continuar a assistir ás Sessões, o habilite a partir logo que pelo Governo lhe for ordenado". ${ }^{478}$

\footnotetext{
${ }^{477}$ ACP, v.15, sessão de 11/10/1830, pp.86-87.

${ }^{478}$ Ofício publicado por O Farol Paulistano, no 415, 13/11/1830.
} 
Em meio à efetuação da dispensa de Oliveira Coutinho, a Comissão de Constituição e Poderes da Câmara dos Deputados discordou do ajuizamento feito pelo Ministério sobre a atuação do Conselho da Presidência e da Câmara Municipal de São Paulo. Segundo os deputados, a análise dos documentos encaminhados pelo ministro do Império sobre o ocorrido permitia deduzir que os dois órgãos haviam agido "legalmente”, e que o estopim dos desentendimentos teria sido a conduta “arbitraria” e "anticonstitucional” do ouvidor Cândido Ladislau Japi-Assu para com as manifestações louvando a queda de Carlos X na França. Tais mobilizações populares, no entender da Comissão, haviam sido legítimas e deveriam ser “imitadas” pelos “amantes da liberdade”:

“(...) O Ministro viu n’aquelles documentos materia para firmar-se na idéia de terem havido actos criminosos nos habitantes de S. Paulo; de ter o Ouvidor procedido, como lhe cumpria; de ter a Camara Municipal, e o Conselho do Governo obrado illegalmente; viu conflictos de jurisdição entre as Autoridades, comoções entre os Cidadãos, e finalmente perigo de motim, ou revolta. Ao contrário a Comissão pela matéria dos mesmos documentos viu que as luminárias, bandas de Musica, e mais, demonstrações de alegria praticadas pelos habitantes de S. Paulo, pelo derribamento do Governo tyranno, e anti-Constitucional da França, bem longe de serem actos criminosos são os mesmos practicados por muitas pessoas n'esta Capital, na Bahia, e em muitos outros lugares, e que deverão ser imitados por todos os amantes da Liberdade debaixo da formula do Systema Monarchico-Representativo: que o Ouvidor da Câmara classificando estes actos por algazzara como se expressa em seu Officio, inda, assim obrou arbitraria, antiConstitucional, e até impoliticamente, procedendo a sua Devassa em casos, que a Lei não marca, e por conseguinte foi quem lançou o alarme na Cidade de S. Paulo, pondo os ânimos dos habitantes em sustos e desconfianças: que a vista de tal procedimento do Ouvidor a Câmara Municipal procedeu legalmente pondo-o em Sessão Extraordinária para dar parte ao Governo da Provincia desta infracção da Constituição, como lhe incumbe a Lei de sua 
creação no Art. 58; que o Conselho Presidencial obrou, como lhe cumpria, reunindo-se extraordinariamente para cuidar da tranqüilidade publica (...). ${ }^{479}$

O posicionamento da Câmara dos Deputados foi endossado pelos dois periódicos paulistas em circulação na época, que cederam espaço para a publicação da representação da Comissão de Constituição e Poderes. O redator de O Observador Constitucional justificou a inserção do documento para que esse conquistasse a "maior publicidade possivel”, ao passo que o Farol Paulistano observou que, caso os membros da Comissão de Constituição estivessem em São Paulo naquela ocasião, eles não teriam feito considerações diferentes sobre os fatos. ${ }^{480}$

\subsection{A “exaltação” em São Paulo: reforma constitucional, federação e república.}

Após o assassinato de Badaró, as medidas tomadas pelo Conselho da Presidência de São Paulo tornaram-se mais contundentes. Em 22 de novembro de 1830, o Conselho autorizou o pedido do comandante das armas Carlos Maria de Oliva para esse fazer municiar suas tropas, tendo em vista a “effervescencia d'huma parte do povo”. O comandante, que inclusive participou da sessão extraordinária a mando do Conselho, expôs os problemas envolvendo o ouvidor Japi-Assu, que fora acusado de ter mandado matar o médico italiano, e que estava sendo ameaçado por “alguns do povo”. O Conselho, alegando a necessidade de “acalmar os ânimos excandecidos” e garantir a "segurança” do referido

ouvidor, deliberou que o comandante ficasse responsável por sua integridade. ${ }^{481}$ Tais

\footnotetext{
479 Representação publicada em O Farol Paulistano, no 415, 13/11/1830, e em O Observador Constitucional, $n^{0} 102,19 / 11 / 1830$.

${ }^{480}$ Ibidem.

${ }^{481}$ ACP, v.15, sessão de 22/10/1830, pp.124-125.
} 
medidas receberam o apoio de O Observador Constitucional, que após a morte de Badaró passou a ser escrito por outros redatores:

"O Concelho do Governo tomou medidas favoráveis ao dezejo, e tranqüilidade publica, e bastou que os Paulistas esperassem alguma coisa do Governo Provincial para restabelecer-se o sossego; até então mostrarão coragem, querião que fosse executada a Justiça, e que não se evadisse o criminoso; mas depois que tiverão provas de que se procedera pelos meios legaes, e com actividade, perderão o antigo receio (...)”" 482

Mas ao que parece as manobras do governo provincial para manter o "sossego" da Província não foram acolhidas unanimemente pelos paulistas. Em carta publicada pelo $O$ Farol Paulistano em 30 de novembro de 1830, Antonio Mariano de Azevedo Marques se defendeu de acusações feitas a ele e ao Conselho da Presidência com relação a um suposto exagero no uso da força para manter a ordem pública em São Paulo:

"Sr. Redactor = Chegou-me a notícia, que alguns por ahi accusão de ter na Sessão do Conselho do Governo, que se reunio extraordinariamente na tarde do dia 22, não só exagerado os procedimentos criminosos do Povo, mas também proposto que se fizesse dispersar a este por força, armada de pólvora e bala. Esta accusação, a mais singular e extravagante, que a meu ver se tem feito jamais a homem algum, não deve passar sem resposta, porque n'estes momentos, em que uma tal agitação anima os espíritos, a credulidade de alguns se dilata por uma maneira inconcebível; e a singularidade e extravagancia das accuzações, em vez de ser um obstáculo, parece antes um passaporte franco para se ellas fazerem acreditar. Direi pois o que houve n’este negocio, e ver-se-há o como é fácil apresentar não’um ponto de vista criminoso e impopular as coisas as mais innocentes do mundo, e talvez as mais populares.

Logo que se abriu a Sessão, e que foi lido o ofício do Exmo. Commandante das armas, que dera motivo a convocação, encetei eu a discussão confirmando o seu contexto,

${ }^{482}$ O Observador Constitucional, $\mathrm{n}^{\circ}$ 104, 26/11/1830. 
menos do que dizia respeito ao facto particular da resistência a escolta por um paizano, sobre o qual disse que suspendia o meo juizo, temendo que elle tivesse sido desfigurado aos olhos do S. Exmo. (...) Disse mais, que era preciso que uma tal agitação cessace immediatamente, porque se até alli nada de funesto havia occorido, outro tanto se não podia esperar, caso continuasse a irritação do Povo. Acrescentei que nenhum menos efficaz para restabelecer a publica tranqüilidade, do que o emprego da força e das medidas violentas: e conclui que me parecia opportuno que o Sr. Conselheiro Feijó, e algumas outras pessoas de inteira confiança publica, reunissem os seus esforços, e empregassem todas as vias de persuasão para acalmarem o Povo, mas que tudo se fizesse immediatamente. Até me offereci para cooperar n'este sentido; e o mais é, que uma hora mais tarde tive a satisfação de reconhecer que os officios por mim empregados não forão totalmente infructiferos.

Empenhara que fosse a discussão, e não sei se achando-se já presente o Exmo. Commandate Militar, ocorreu dizer eu em sustentação de não sei que opinião, que havia emitido = que eu não duvidava da possibilidade de dispersar-se o Povo por via da força armada, mas que isto em vez de ser um remedio, era antes o mal que cumpria atalhar, e que o Conselho não estava reunido, senão para evitar necessidade de se recorrer a um tal extremo. Mas esta mesma possibilidade da dispersão, eu já a tinha tinha attenuado, ou attenuei-a então (...) reflectindo, que nunca a tropa me parecera menos disposta, do que agora, a aggredir ao Povo.

Tudo isto, Sr. Redactor, parece que não equivale a um conselho de fazer dispersar o Povo a força de pólvora e bala, e se algumas pessoas que tiverem dado prazo a essa calumniosa censura que se me fez, tomarem o trabalho de confrontar a expozição que acabo de fazer com papel (na verdade pouco apparente, mas nunca interrompido), que tenho representado na sociedade, sem duvida que acharão mil vezes mais provável, que as coisas se passassem como digo, do que como forão inculcadas por esses que se ostentão agora meus detractores, e cujos motivos ignoro, pois nem sei quem elles sejão.

Dando logar na sua folha a esta correspondência, muito me obrigará, Sr. Redactor. Seu attento venerador. Antonio Mariano de Azevedo Marques. ${ }^{483}$

Mais do que uma defesa, a correspondência de Azevedo Marques era um sintoma de que a situação política da Província de São Paulo se agravara, e que grupos antagônicos

${ }^{483}$ O Farol Paulistano, $n^{\circ}$ 422, 30/11/1830. 
coabitavam a esfera pública paulista. Articulados à luta política da Corte, onde a cada dia os “exaltados” ganhavam mais espaço por meio de jornais como O Repúblico, O Tribuno do Povo e A Nova Luz Brasileira, setores da sociedade paulista passaram a defender com mais veemência alguns dos preceitos apregoados pelos grupos mais radicais entre os liberais. $^{484} \mathrm{O}$ assassinato de Badaró, noticiado por todo o Império, tomou proporções inesperadas, e sua morte passou a ser associada pelos “exaltados” à luta pela liberdade política.

Mesmo sem formarem um grupo homogêneo, os chamados liberais “exaltados” compartilhavam de uma premissa essencial que lhes permitiu constituir uma frente de oposição ao Governo diversa daquela feita pelos “moderados”: o desejo por alterações estruturais nas bases políticas do Estado imperial que, no limite, modificariam conteúdos da Carta de 1824. De modo geral, as mudanças almejadas pelos “exaltados” tinham como objetivo estabelecer uma divisão mais eqüitativa dos poderes constitucionais, alargar a autonomia das províncias e aumentar as noções de cidadania. Se de um lado combatiam o Poder Moderador, a vitaliciedade do Senado e o Conselho de Estado, por outro pleiteavam que as províncias tivessem o direito de escolher seus próprios presidentes, que nelas fossem criadas órgãos legislativos e que as rendas locais fossem retidas nos cofres provinciais. ${ }^{485}$. Mesmo diante dessa pluralidade programática, alguns pontos-chave acabaram sedimentando-se entre os "exaltados", sendo o principal deles o tema da reforma constitucional, que trazia em seu bojo questões essenciais como a federação e a república. $^{486}$

\footnotetext{
${ }^{484}$ WERNET, op. cit.

485 CASTRO, op. cit; O Império em construção: projetos de Brasil e ação política na Corte regencial. Tese de doutorado apresentada ao PPGHIS da Universidade Federal do Rio de Janeiro, 2004.

${ }^{486}$ BASILE, op. cit., 2006.
} 
Isso não significa, contudo, que houvesse uma concordância acerca dessas matérias, especialmente no que tangia às formas de organização do Estado. Havia periódicos "exaltados" - como o Observador Constitucional, por exemplo - que defendiam um regime monárquico sustentado em bases federativas; outros, como o Tribuno do Povo, pleiteavam a adoção do sistema republicano. Segundo Marcello Basile, as folhas "exaltadas” eram majoritariamente republicanas, além de quase todas serem adeptas da federação. ${ }^{487} \mathrm{O}$ problema é que tanto a noção de federação como a de república não eram consensuais, abrigando vários sentidos. Vejamos, primeiramente, o caso da república.

Polissêmica já em sua origem na Antiguidade Clássica, a palavra república politéia em grego e res publica em latim - demorou a ter seu significado restrito à idéia de uma forma específica de governo. Somente após as Revoluções Francesa e, sobretudo, Americana, é que o conceito de república começou a despir-se do sentido de um governo qualquer regulamentado por leis que visassem o bem público para se aproximar, cada vez mais, das noções representatividade e democracia. ${ }^{488}$ Ainda assim, como notou o historiador Modesto Florenzano, ao longo das primeiras décadas do século XIX o conceito de república permaneceu incerto e em muitos casos foi associado a projetos e experiências de organização do Estado que tinham como objetivo instaurar um sistema de governo com maiores níveis de participação política. ${ }^{489}$ Foi relacionada, também, com a idéia de apologia da liberdade e da igualdade de direitos, ganhando uma forte conotação

\footnotetext{
${ }^{487}$ Ibidem, p.77.

488 MATTEUCCI, Nicola. "República”. In: BOBBIO, Norberto; MATTEUCCI, Nicola; PASQUINO, Gianfranco. Dicionário de Política. Brasília: UnB, 1986, pp.1108-1110.

${ }^{489}$ FLORENZANO, Modesto. "República (na segunda metade do século XVIII - História) e Republicanismo (na segunda metade do século XX - historiografia)”, in lio, v. 14-15, 2006, pp. 33-52.
} 
ideológica. ${ }^{490}$ Em direção semelhante, e tendo em vista a configuração da política imperial, ressaltou Sérgio Buarque de Holanda:

“Antes de 1870, o nome de republicano fora dado, com ou sem propriedade, a quem quer que se extremasse na crítica do governo e do imperador. Durante o primeiro reinado e a menoridade não eram muito precisas as linhas entre "exaltados” e "republicanos". 491

Tais considerações não querem dizer que a república enquanto sistema de governo diverso da monarquia não estivesse presente no debate político ao longo do Primeiro Reinado e início das Regências. O caráter por vezes hesitante da discussão pública em torno do sistema republicano não se dava pelo fato de que inexistisse um substrato político para tal. Defender a república como forma de governo em meio impresso era um ato anticonstitucional, além de ser considerado crime tanto pelo Código Criminal de 1830 como pela lei de 20 de setembro de 1830, a qual versou sobre o abuso da liberdade de imprensa e que proibiu quaisquer "ataques dirigidos a destruir o Sistema Monárquico Representativo”. ${ }^{492}$ Desse modo, foi comum os “exaltados” utilizaram o termo república de forma ambivalente, ora se referindo à acepção clássica do termo - a res publica (coisa pública) do direito romano -, que projetava as noções de interesse público ou de bem comum sob qualquer forma de governo, ora tocando diretamente na idéia de regime

\footnotetext{
${ }^{490}$ VENTURI, Franco. Utopia e Reforma no Iluminismo. Bauru: Edusc, 2003.

${ }^{491}$ HOLANDA, Sérgio Buarque de. "Da Constituinte Constituída", in HOLANDA, Sergio Buarque de (org.). História Geral da civilização brasileira, tomo II, "O Brasil Monárquico”. São Paulo: Difusão Européia do Livro, 1977, vol.5, pp.259-260.

492 FONSECA, Silvia Carla Pereira de Brito. "Apontamentos para o estudo da linguagem republicana na conformação de identidades políticas na imprensa regencial fluminense”, in FERREIRA; MOREL, NEVES (orgs.); op. cit.; p.101.
} 
republicano, no qual o chefe supremo seria eleito por um tempo determinado. ${ }^{493}$ Apenas depois da Abdicação os periódicos “exaltados” passaram a defender mais abertamente a república como regime específico de governo, a exemplo de O Repúblico, periódico fluminense dirigido por Borges da Fonseca. Na ocasião de seu surgimento, em outubro de 1830, o jornal alegou que seu título aludiria apenas à defesa do "bem público” e nada mais, ao passo que após o 7 de abril foram comuns os artigos que fizeram apologia da república. $^{494}$

Um dos pontos utilizados por muitos “exaltados” a fim de diferenciar a república da monarquia residia na legitimidade da soberania do chefe do Executivo. Enquanto a "monarquia eletiva” ou a "monarquia sui generis" - termos empregados pelas folhas “exaltadas” com o sentido de república - se pautaria na eletividade e temporariedade do cargo máximo do Executivo, que virtualmente poderia ser ocupado por todos aqueles considerados cidadãos, a monarquia tal como estabelecida no Brasil tinha seu chefe executivo cercado por um conjunto de distinções e privilégios questionáveis, baseados na hereditariedade monárquica, um princípio cuja essência carecia de qualquer legitimidade popular. Títulos e honrarias eram freqüentemente condenadas pelos que sustentavam a república, e vistos como incompatíveis com esse sistema político. ${ }^{495}$

Igualmente impreciso era o conceito de federação, que já vinha sendo pauta de discussão nos círculos políticos do Rio de Janeiro e demais províncias desde os anos 18201821, e que naquela época foi retomada com a emenda ao projeto de Constituição proposta pelo deputado Ferreira França, o qual sugeriu que o Império do Brasil fosse organizado

\footnotetext{
493 BASILE, op. cit., 2006, p.77.

${ }^{494}$ FONSECA., op. cit., p.103.

${ }^{495}$ FONSECA, op. cit., pp.109-10. Ver ainda, a título de exemplo, o artigos publicado em O Repúblico, nº 59 $(13 / 07 / 1830)$.
} 
pelo princípio da "confederação" ${ }^{496}$ De acordo com Sergio Buarque de Holanda, o princípio federativo - e, sobretudo, o modelo de federação implementado pelos Estados Unidos - obteve respaldo em parte dos grupos provinciais pelo fato de as chamadas "forças centrífugas” terem sido elementos constitutivos da colonização portuguesa e, posteriormente, do jogo político que se desdobrou ao longo do processo de formação do Estado nacional, o que rendera aos poderes locais um grau considerável de autonomia política. Assim, apesar das dessemelhanças entre as instituições norte-americanas e o legado colonial português, a federação no Brasil ganhou eco, segundo Buarque de Holanda, em virtude da existência de uma longa experiência de relativa fragmentação políticoadministrativa vivenciada pelos grupos locais. ${ }^{497}$

Mas o que seria para os políticos brasileiros do Primeiro Reinado e início do período regencial a federação ou o sistema federativo? Um Estado cujas partes federadas detivessem um relativo nível de autonomia política e econômica ante o governo central, mesmo que subordinados à soberania do governo central? Ou uma forma velada de defesa da república? Em verdade, a discussão em torno da federação acentuou-se pari passu com fortalecimento político dos "exaltados" ao final do Primeiro Reinado, o que talvez tenha contribuído para aumentar as confusões sobre o termo. Mesmo um defensor da autonomia legislativa como Bernardo Pereira de Vasconcelos, um dos deputados que formulou o Ato Adicional, demonstrou por inúmeras vezes seu receio com relação ao termo federação, que, na sua opinião, ensejava mais a idéia de soberania do que de autonomia local. ${ }^{498}$ Já Martim Francisco Ribeiro de Andrade e seu irmão José Bonifácio teceram críticas cerradas à

${ }^{496}$ HOLANDA, op. cit., 1965, pp.16-17.

${ }^{497}$ Ibid., p.20.

${ }^{498}$ De acordo com Otávio Tarquínio de Sousa, Bernardo Pereira de Vasconcelos temia que a federação degenerasse em desagregação das várias partes do Império”, cf. SOUSA, Otávio Tarquínio de. História dos fundadores do Império do Brasil. Rio de Janeiro: José Olympio Editora, 1960, v.5, "Bernardo Pereira de Vasconcelos”, sobretudo capítulos 4, 5 e 6. 
federação, concebendo-a como incompatível com o regime monárquico-constitucional, uma vez que este teria como principais características a centralização e a unidade política, ao contrário do sistema federativo, que se pautaria no princípio da autonomia local. Outros, como o senador cearense João Antônio Rodrigues de Carvalho, acreditavam que a disparidade entre a realidade norte-americana, fonte de inspiração para os defensores da federação, e brasileira seria o principal empecilho para a sua implementação no estado imperial. ${ }^{499}$

Até a aprovação da lei que regulamentaria os princípios da reforma constitucional, em 1832, a federação foi recorrentemente identificada como sinônimo de república. Se por um lado é certo que os adversários políticos dos “exaltados” se valeram da indefinição do termo para associá-lo ao sistema republicano e, conseqüentemente, depreciá-lo ante àqueles que advogavam a favor da monarquia, por outro os próprios defensores da federação só passaram a conceituá-la com maior exatidão após a Abdicação. Por diversas vezes o redator de O Repúblico utilizou o termo federação em substituição ao de república, e esta como uma antinomia do sistema monárquico. Já a Matraca dos Farroupilhas pregava que a implantação do sistema federativo significaria um primeiro passo para uma paulatina instituição do sistema republicano. ${ }^{500}$ Em meio a tantos usos do termo, acabou por difundir-se a idéia geral de que se implantada no Brasil, a federação acarretaria, necessariamente, numa ampliação dos poderes provinciais, sobretudo os de ordem legislativa e fiscal. Como veremos adiante, a apropriação da federação pelos liberais “moderados” promoveu um afastamento dessa com a república.

\footnotetext{
499 DOLHNIKOFF, op. cit., 2005, p.66-69.

${ }^{500}$ FONSECA, op. cit., p.111.
} 
Se a morte de Libero Badaró exacerbou os ânimos da “exaltação” em São Paulo, o governo provincial manteve-se firme no apoio ao sistema monárquico-constitucional jurado em 25 de março de 1824. Quando do início da $2^{\text {a }}$ Reunião do Conselho Geral de São Paulo, o vice-presidente Manoel Joaquim Gonçalves de Andrade discursou, à semelhança de como fizera no Conselho da Presidência dois meses antes, acerca do andamento dos negócios provinciais. Num dado momento de sua fala, após explanar sobre a falta de dados precisos a respeito da situação da infra-estrutura provincial, o vice-presidente incluiu a convocação do Conselho Geral no processo de gradativa sedimentação do sistema monárquicoconstitucional pelo qual passava a província de São Paulo:

“Eu me congratulo com-vosco, Senhores, pelo progressivo andamento do Systema Constitucional, e pela segurança com que posso affirmar, e vós o sabeis, que o Povo Paulistano, cuja firmeza de carater é incontestavel, propugnará sempre pela causa da liberdade legal, e primeiro faltarão as leis physicas da natureza de que retrogadará elle uma só linha do Systema Monarchico Constitucional, que felizmente nos rege”. 501

O discurso lido no Conselho Geral foi bem acolhido pelo O Farol Paulistano. Em nota publicada em dezembro de 1830, o redator da folha paulistana elogiou a fala do bispo Gonçalves de Andrade, seja por ter discorrido sobre as “maiores necessidades” da província de São Paulo seja por ter evidenciado os “sentimentos constitucionais” do vice-presidente. O redator aditou, ainda, sua impressão positiva a respeito do Conselho Geral de São Paulo; este, além ser formado por "boa gente, patriota, instruida”, estaria se debruçando sobre

501 "Discurso do Exmo. Vice-presidente da Provincia lido na abertura do Conselho Geral”, publicado em $O$ Farol Paulistano, no 428, 14/12/1830. 
matérias de primeira ordem para a província. Em última instância, a convocação da $2^{\mathrm{a}}$ Reunião do Conselho Geral paulista simbolizava, na ótica do redator, mais uma vitória da monarquia constitucional na conformação política do Império:

“O discurso do Exmo. Vice-presidente na abertura da actual Sessão do Conselho Geral desta Provincia, publicada em o nosso precedente n. ${ }^{\circ}$ lhe faz muita honra, não só pelos sentimentos constitucionais, que muito claramente apresenta, como porque toca nas maiores necessidades desta Provincia com muito descernimento, e sizo. É muito bom, que o Povo todo saiha, e veja claramente, que o Governo da Província está convencido, de que o Systema Monarchico Constitucional se acha inhabalavelmente enraizado no coração dos Paulistas; e que o Governo Geral oiça esta verdade, hoje, talvez, já não dolorosa para elle, proferida, não, por alguns d'esses a quem a sua menos boa fé tem chamado e mandado chamar demagogos, revolucionários, anarchistas \&c (...)”. 502

Presente nos excertos acima citados, a percepção de que um progressivo enraizamento do sistema monárquico-constitucional estaria ocorrendo na província de São Paulo trazia em seu bojo, novamente, a idéia da necessidade do cumprimento da Carta de 1824, só que agora reforçada de um novo elemento: haveria, segundo as fontes, uma ampla aceitação do novo “Systema” entre os paulistas - identificados em massa como liberais -, e o próprio funcionamento dos Conselhos Provinciais seria a prova manifesta desse sentimento. Ademais, o tom enfático dessas argumentações não era inócuo. Enaltecer o liberalismo e a Carta de 1824 servia para estabelecer um contraponto ao governo de D. Pedro, classificado de antiliberal, como também aos “exaltados”, que pregavam alterações no texto constitucional.

${ }^{502}$ O Farol Paulistano, no 429, 16/12/1830. 
Assim como ocorrera no Rio de Janeiro, Minas Gerais e em outras localidades do Império, a conquista de espaço pela “exaltação” foi rechaçada pelos “moderados” paulistas. Porta-voz deste grupo, o Farol Paulistano publicou, em dezembro de 1830, um artigo em que refutava um dos pontos principais aventados pelos “exaltados": a feitura de reformas na Carta de 1824. Disposto na seqüência de um trecho extraído de um periódico francês que defendia estar no cumprimento das constituições a chave para o alcance de um bom governo, o artigo de $O$ Farol foi categórico no seu repúdio a qualquer alteração do texto constitucional brasileiro, tido como suficiente, se bem executado, para a "felicidade do Brazil”. Juntamente com a salvaguarda da Constituição, que deveria ser seguida à risca para não colocar em perigo a segurança da monarquia constitucional representativa, o Farol Paulistano buscou minimizar a força dos "exaltados", que na sua opinião estariam reduzidos a alguns “poucos homens” situados no Rio de Janeiro:

"Este artigo, que traduzimos de um Jornal Francez, parece-nos que alguma applicação póde ter entre nós. Toca um quinhão ao nosso Governo, que o merece, porque ainda se não tem querido fazer bem nacional, unico modo, não só de manter a paz publica, executando a Constituição, e as leis, a seguindo a direcção que as luzes do seculo tem irrevogavelmente dado ás sociedades do século 19, e mormente ás sociedades americanas; mas mesmo de segurar a actual forma de governo, sem convulções funestas a todo o Brazil, e talvez ainda mais funestas ao Poder actual. Toca tambem um quinhão a certos homens, que talvez amando muito a liberdade, estão desvairados, e vão desvairando a publica opiniao. Algumas folhas, mormente da Capital, são orgãos d' esses poucos homens. Posto que a sua influencia seja pequena; posto que tenhamos por certo, que ellas não farão progressos n'esta Provincia, que abunda em bom senso; todavia cumpre, que se não deixem a solta vagar; porque muitos incautos há, e é mais facil desvairal-os. A forma actual de Governo, que todos temos jurado, por que todos juramos a Constituição; a Constituição tal qual é, tem feito, pode fazer, e hade continuar a fazer a felicidade de Brazil. Se ella mal executada; se ella muitas vezes infrigida, assim mesmo é a fonte de todos os 
melhoramentos, que não se pode negar, que temos obtido, desde 1826, no curto prazo de 5 annos, como não será ella capaz de a fazer d’hora em diante, quando melhor observada, quando vencidas já grande parte, e as mais fortes resistencias, que se lhe opunhão? Pelo que temos andado em 5 annos no começo, calculemos o que andaremos d'hora em diante quando já temos carreira feita, e concluamos se é preciso correr os riscos de uma mudança qualquer, que ella seja, por mais lisonjeiras, que possão ser as cores d' esse futuro, que se nos ostenta. Não abolir nem em uma virgula da Constituição que juramos; procurar legalmente, com mais ou menos energia segundo o caso e pedir que sua execução seja completa; o mais que tudo não recuar uma só linha de terreno que temos ganhado, e nem ao menos pôrmo-nos no risco de o perder, e o nosso dever, dever, que a santidades dos nossos juramentos imperiosamente exige, que o interesse geral do Brazil reclama, que a tranquilidade e segurança publica, e individual solicitão (...)”. 503

Esforços como esse não conseguiram barrar o fortalecimento de vozes contrárias ao discurso de O Farol. Dois fenômenos ocorridos no âmbito da imprensa periódica paulista indicam para uma expansão dos ideais “exaltados” em São Paulo nesse período, sendo o primeiro deles o surgimento, em janeiro de 1831, de A Voz Paulistana, periódico redigido pelo estudante do Curso Jurídico de São Paulo Francisco Bernardino Ribeiro, e cujas propostas se alinhavam aos setores mais radicais da "exaltação”. O segundo foi o processo de radicalização do discurso de O Observador Constitucional (ver capítulo 1). Se entre 1829 e 1830 o periódico manteve uma postura “moderada”, após a Abdicação houve um deslocamento de sua orientação político-ideológica para a ala “exaltada” dos liberais.

O advento de A Voz Paulistana complexificou a imprensa periódica paulista. De oposição ao governo de D. Pedro, a folha de Bernardino Ribeiro questionou algumas das assertivas comumente pronunciadas pelos “moderados" paulistas, tal como a de que a província de São Paulo era constituída por grupo coeso política e ideologicamente. A Voz

${ }^{503}$ O Farol Paulistano, n ${ }^{\circ} 431,21 / 12 / 1830$. Grifo nosso. 
passou a defender, também, pontos até aquele momento refutados ou propositadamente pouco comentados pelos demais folhas paulistas, como a reforma da Constituição, o sistema federativo e, em alguns momentos, a república. ${ }^{504}$ Seu estilo combativo para com os “moderados” lhe rendeu constantes citações por parte periódicos “exaltados” da Corte, a exemplo de O Repúblico e A Nova Luz Brasileira. ${ }^{505}$

O surgimento de A Voz Paulistana foi noticiado com reticência pelo O Farol, o qual afirmou que "ser amante da pátria” não bastava para desempenhar um bom papel enquanto redator, numa referência velada a Bernardino Ribeiro. Ao comentar sobre o n ${ }^{\circ} 2$ de $A$ Voz, o redator de $O$ Farol criticou algumas das afirmações ali contidas, sobretudo aquelas que insinuavam estar a província de São Paulo dividida politicamente, e que dentro dos próprios liberais haveria discordâncias. A folha de Costa Carvalho contestou, ainda, as críticas de A Voz no tocante à suposta existência de um “estilo ditactorio” nos jornais paulistas, que tentariam manipular a “opinião pública” da província:

“(...) apenas informaremos ao nosso Collega algumas coisas, que pela leitura do seu artigo $3^{\circ}$. e ultimo nos parece o estarem encommodando; talvez por ainda menos bem informado, o que acontece a todos, quando principião. Nessa Provincia os Liberaes são unidos; e se alguns se não gostam por motivos particulares, tudo isto se cala na presença do interesse publico, que arremessa para longe os motivos particulares, ficando só em campo corações abrazados pelo amor da liberdade Constitucional (...) Nunca hade haver unanimidade de sentimentos, que é quimera; mas maioria, e muito grande de vontade para a consolidação do Systema Liberal no Brazil” (...) Se o nosso Collega estivera mais bem informado, veria, que não há pretenções algumas a ser despota das opiniões; que não se emprega estilo ditactorio nesta Provincia; que os que emittem aqui sua opinião publicamente, a não dão, na fraze de Montaigne, como boa, mas somente como sua; que é muito natural, (e tanto que tambem acontece o mesmo ao nosso Collega) que cada um gosta

\footnotetext{
504 TAUNAY, op. cit., 1961; TOLEDO, op. cit; FREITAS, op. cit; WERNET, op. cit.

${ }^{505}$ FONSECA, op. cit., pp.110-11.
} 
de ver que as suas opiniões são muito seguidas; e se não é por dezejo de as ver seguidas, porque é que as emittem?”. 506

No mês seguinte, a Voz Paulistana publicou um artigo em defesa da federação, afirmando que essa era desejada pela maioria dos cidadãos de todo o Império. O Farol Paulistano contra-atacou menosprezando a folha adversária:

“Com a devida vênia. Como soube a Voz Paulistana que o voto geral da Nação inteira é contra o systema Unitario, e pelo federativo! Queira Deos que não nos venha por ahi um chuveiro de delicados epithetos, rematando com uma Alma vil e aduladora! A Voz Paulistana não é hypocrita moderada, e por isso não anda la procurando palavrinhas; pão pão, queijo queijo. Se lhe vem ao bico da penna alma vil e aduladora; sae alma vil $e$ aduladora, embora o mereça ou não o sujeito a quem ella dirie; isto é que é franqueza, isto é que é não ser hypocrita moderado. Valha-nos Deos com esta gente, que desacredita o honroso nome de liberal com grosserias intoleraveis. Preguem muito embora as doutrinas, que quizerem, mas sejão decentes, comedidos, civis em suas expressões. A grosseria não fica bem a ninguém; quem as pratica cae em desprezo necessariamente”. ${ }^{507}$

Pela mesma época, o periódico “exaltado” A Matraca dos Farroupilhas elencou aqueles jornais que, segundo ele, seriam favoráveis à república ou “federação do Equador”, termo que também designava o sistema republicano:

“Engana-se o Regente quando afirma que só dois Periódicos pregam a Federação do Equador, visto que a Matraca, O Clarim, O Republicano, O Filho da Terra, O Republicano de Sempre Viva, A Nova Luz, A Voz Paulistana, O Fluminense, O Monitor, A Sentinela da Liberdade, O Tribuno do Povo, Republicano Federal, Voz da Liberdade etc. pregaram sempre o sistema republicano ou a Federação do Equador”. ${ }^{508}$

\footnotetext{
${ }^{506}$ O Farol Paulistano, no 439, 15/01/1831.

${ }^{507}$ O Farol Paulistano, no 455, 21/02/1831.

${ }^{508}$ A Matraca dos Farroupilhas, n $11,21 / 02 / 1831$, apud FONSECA, op. cit., p.102.
} 
A preocupação de $O$ Farol em combater a Voz aumentou gradativamente. Em 26 de fevereiro de 1831, pela primeira vez o sistema federativo recebeu um tratamento mais contundente da folha de Costa Carvalho. ${ }^{509}$ Para isso, publicou um excerto sobre a federação de François Guizot (1787-1874), futuro primeiro-ministro na Monarquia de Julho (1830-1848) e um dos principais nomes dos chamados liberais “doutrinários”, grupo de intelectuais e políticos franceses que se opuseram à Restauração na França (1815-1830) e apoiaram boa parte do reinado de Luís Filipe (1830-1848). ${ }^{510}$ Segundo o historiador Marco Morel, os doutrinários desejavam, de modo geral, implementar uma monarquia constitucional ao mesmo tempo forte e respeitadora das diferentes forças que compunham as sociedades, concepção essa que dialogava com as aspirações de parte dos liberais do Primeiro Reinado, que se viam imersos num Estado em construção clivado por diferentes interesses. $^{511}$

De acordo com o excerto traduzido, o sistema federativo era o mais difícil de se estabelecer, visto que ele consistia em “deixar a cada localidade, a cada sociedade particular, toda a porção de governo que lhe pode tocar, e em não lhe tirar senão a porção indispensável para manter-se a sociedade geral, para a levar ao centro dessa mesma sociedade, e constituí-la sob a forma de governo central”. ${ }^{512}$ Aparentemente o mais simples, o sistema federativo seria na realidade o mais complexo, já que para conciliar os interesses locais com os do governo central requeria-se um alto grau de “razão”, “moralidade” e

\footnotetext{
${ }^{509}$ O Farol Paulistano, no 454, 26/02/1831.

510 LEFORT, Claude. “Guizot: o liberalismo polêmico”, in LEFORT, Claude. Desafios da escrita política. Trad. de Eliana Melo de Souza. São Paulo: Discurso Editorial, 1999, pp.113-140.

${ }^{511}$ MOREL, op. cit., 2005, pp.44-46.

512 O Farol Paulistano, no 454, 26/02/1831.
} 
“civilização” de uma sociedade. Estágio que, no entender do redator de O Farol, o Império brasileiro ainda não atingira.

Mais cauteloso quanto à federação foi o Observador Constitucional, que a partir de março de 1831 começou a se aproximar do tema. Para o redator o problema residia no tratamento da questão, pois muitos dos defensores da federação estavam detratando aqueles que não a desejavam, o que configuraria uma injustiça para com homens que sempre estiveram à frente das “fileiras liberais”. Segundo o redator de O Observador, esse tipo de conduta desagregaria os liberais, colocando em risco a estabilidade política do Império:

"De proposito havemos guardado silencio sobre a questão mui importante da Federação, que tanto hoje em dia agita os espiritos; e talvez fosse melhor para nós continuarmos em nossa taciturnidade a tal respeito; não que temamos, emittindo nossa fraca opinião, desagradar a aquelles, que esta questão divide; mas por conhecermos nossa debilidade, e estarmos convencidos, que nossa cooperação de pouco, ou nada pode servir ao partido, que seguimos. Entretanto como este nosso comportamento poderia em fim vir a ser mal interpretado, e attribuindo a differente causa, julgamos, que já nos não convinha perseverar nelle por mais tempo. E de certo, ou julgamos a Federação necessaria a felicidade do Brazil, ou somos de opinião, que qualquer grande reforma politica, em nossas actuaes circunstancias, longe de produzir bem algum, produziria pelo contrario grandes males; ora porque razão não manifestaremos nossa maneira de pensar, seja ella qual for, a cerca destas duas hypoteses? Diremos pois em algum de nossos seguintes numeros nossa fraca opinião a respeito da Federação.

Perdoem-nos agora alguma cousa, que possamos á dizer sobre a maneira pouco conveniente, e mesmo pouco decente, com que tem sido debatida esta questão. Um fogo excessivo tem excandecido os espiritos, nenhuma prudencia tem presidido a discussão, os animos tem-se exasperado; e como é, que no meio de excessos se pode descubrir a verdade? Forão postos em esquecimento o pouco patriotismo, os serviços relevantes, o carater sempre firme, sempre o mesmo de Cidadãos dignos, por estes titulos de toda a consideração. Não se tem respeitado homens, que até o dia de hoje marcharão sempre a frente das fileiras liberaes, e ajudarão efficazmente o Brazil a ganhar as victorias, que para 
sempre livrarão a Patria do horrendo Governo absoluto. Tem-se baralhado as ideas, e as palavras tem recebido significação diferente: liberal, e corcunda, termos, que outrora designavão, o primeiro o Cidadão amante das liberdades Patrias, o segundo o miseravel sevandija escravo do poder, desgraçadamente applicão-se hoje para designar o que gosta, ou não gosta da Federação: e assim basta dissentir um pouco da opinião de certa gente a este respeito para ser immediatamente brindado com o feio nome de corcunda.

É assim que se comportam os verdadeiros amigos da Liberdade? Onde está a justiça, companheira inseparavel desta filha do Céo? Se hoje em dia, que ainda temos todos os motivos para estar alerta contra os tramas de um Governo, que se há mostrado desde o principio hostil ás Instituições livres, nós os filhos da Liberdade já começamos a dividirnos, e a fazer violenta guerra uns aos outros, talvez sem prevermos, que nossas divisões são outras tantas victorias para esse mesmo Governo; o que seria, se...!!!

Deixemo-nos de divisões, e em lugar de perseguirmos os que pensão diferentemente de nós, mostremo-nos verdadeiros liberais trabalhando a porfia para a felicidade de nossa Patria, e esta é a melhor prova, que podemos dar, de nosso amor á Liberdade”. 513

Mesmo com o aumento de vozes discordantes, o Farol Paulistano reiterou sua posição contrária à reforma constitucional, argumentando que a Carta de 1824 continha elementos tão ou mais liberais do que aqueles presentes na Charte de 1830, isto é, no texto constitucional elaborado pelos liberais franceses após a queda de Carlos X e com base na revisão da Constituição da França de $1814 .{ }^{514}$ De acordo com o redator de O Farol, questões que foram objeto da revisão presidida pelos liberais franceses - tais como a liberdade religiosa, a idade mínima para o voto, a responsabilidade dos ministros e a criação de uma guarda nacional - já eram asseguradas pelo texto constitucional brasileiro,

${ }^{513}$ O Observador Constitucional, $\mathrm{n}^{\mathrm{0}}$ 131, 04/03/1831.

${ }^{514}$ Em linhas gerais, a Carta francesa de 1830 promoveu as seguintes mudanças com relação à Constituição de 1814: extinguiu-se o poder do rei de fomentar leis; o voto censitário foi ampliado a partir da redução dos rendimentos anuais exigidos para o eleitorado; os títulos nobiliárquicos deixaram de ser hereditários; o catolicismo deixou de ser a religião oficial do Estado; e a bandeira tricolor (azul, branca e vermelha) foi restituída à nação francesa. Cf. GODECHOT, Jacques. Les constitutions de la France depuis 1789. Paris, Garnier-Flammarion, 1970. Ver, também, ROSANVALLON, Pierre. La monarchie impossible. Les Chartes de 1814 et de 1830. Paris: Fayard, 1994. 
de modo que esse não precisava ser alterado. O processo de institucionalização dos Conselhos Gerais foi inclusive considerado pelo redator como exemplo da amplitude de liberdades oferecida pela Carta de 1824:

"Deve-se reformar a Constituição, deve-se mudar de systema, por isso que a Constituição actual não offerece garantia a liberdade: eis o que se quer dizer quando se prega a federação, eis o que expressamente se tem dicto, e eis o que cumpre examinar com madureza e circunspecção.

Para demonstrar que a nossa Constituição nôs-outorga sobejas garantias, faremos rapidamente, mas com a clareza que nôs-for possivel, a comparação das garantias, que temos com as que para si quizerão os Francezes depois da gloriosa revolução de 1830.

(...) Sobre a responsabilidade dos ministros. Já temos sobre isso muito boa lei, que merece elogios de nações extrangeiras. O Codigo também estabelece penas contra os agentes secundarios.

Já temos preposição para a criação de guardas Nacionaes; nem a Constituição a essa criação se oppoem.

Temos Conselhos Geraes, e cada vez se vai alargando mais a esfera de suas attribuições, e este ano adquirirão uma importantíssima, qual a de examinarem, e fazerem observações sobre a conta da receita e despeza feita, e orçamento da fatura de suas respectivas Provincias.

Temos Câmaras Municipaes optimamente organizadas, com muitas e excelentes attribuições, que sasonadas pelo tempo, e pelo derramamamento das luzes farão muitíssimo a favor da liberdade da Nação, e da prosperidade do seu paiz.

(...) Todas estas garantias, e ainda muito menos do que estas que nós temos, tem feito a felicidade da Inglaterra, e farão a da França. E porque não farão a do Brazil? Precisará o Brazil, mal acabada ainda uma revolução, começar outra? Uma revolução é sempre uma das maiores desgraças, ainda quando é certo o seu bom exito; quanto mais quando elle é incertissimo. Sem extrema necessidade não há homem cordato que arrisque a tantos males: a liberdade ficaria muito cara, não porque a liberdade seja cara por qualquer preço; mas porque pode ser comprada mais barata. Se a nossa Constituição ainda tem 
algumas faltas, essas vão desaparecendo, com o andar do tempo, elemento necessário em todas as couzas $(\ldots) .^{515}$

A discussão travada na imprensa paulista tornou-se mais sofisticada a partir de 1831, principalmente após a Abdicação, quando o debate sobre os rumos do Império ganhou uma amplitude ainda maior. De todo modo, anteriormente à ida de D. Pedro para Portugal a província de São Paulo já apresentava posicionamentos conflitantes acerca da estrutura política do Império, enfrentamento esse que descortinava duas questões fundamentais: de um lado a homogeneidade política de São Paulo, tantas vezes anunciada por integrantes da ala “moderada” daquela província, mostrou-se um artifício retórico frágil e improcedente, ao menos para aquele momento. De outro, o advento de A Voz Paulistana e a paulatina aproximação de O Observador Constitucional com os “exaltados” inaugurou um novo período no âmbito da imprensa periódica paulista, marcado pela coexistência de jornais com orientações político-ideológicas distintas e pelo enfrentamento entre os liberais paulistas.

\subsection{A Abdicação e a luta política entre os liberais paulistas}

Em discurso proferido no Senado a 28 de maio de 1832, o então senador Nicolau de Campos Vergueiro chamou a atenção de seus colegas de plenário para a existência de um vínculo causal entre a abdicação do imperador, ocorrida a 7 de abril do ano anterior, e a dissolução da Assembléia Constituinte por D. Pedro, datada de 12 de novembro de $1823 .{ }^{516}$

\footnotetext{
${ }^{515}$ O Farol Paulistano, no 460, 08/03/1831.

516 Anais do Senado do Império do Brasil. Rio de Janeiro/ Brasília, 1826-1889 (Disponível no site www.senado.gov.br), sessão de 28 de maio de 1832, p.137 e seguintes.
} 
A "intima relação" entre os dois episódios advinha, segundo Vergueiro, do recrudescimento de algumas reivindicações que haviam sido tolhidas com o fechamento da Constituinte, como uma maior independência das províncias ante ao governo central, a reformulação do artigo que tornava vitalício o cargo de senadores e a extinção do Conselho de Estado. Pronunciado num momento em que o debate sobre a reforma constitucional já estava em curso, o que tornava interpretações desse porte instrumentos de legitimação de uma proposta reformista, a fala de Vergueiro portava, entretanto, uma constatação de primeira ordem: a abdicação do monarca não tivera nada de circunstancial; ela ocorrera, antes, em função do desdobrar da política desenvolvida pelo governo central e da incompatibilidade de interesses entre diferentes grupos engajados no processo de construção do novo Estado. Tanto não foi de última hora a ida de D. Pedro para Portugal que tal solução já havia sido aventada por Benjamin Constant, em carta ao imperador de 1827. Para o pensador suíçofrancês, caso o problema da sucessão do trono português se agravasse, seria prudente que D. Pedro saísse do Brasil, deixando aqui uma Regência que mantivesse a monarquia e a dinastia no poder, e partisse em direção ao velho continente para resolver o futuro de Portugal. ${ }^{517}$ De todo modo, a retirada de cena do imperador constituiu, em verdade, o desenlace de um conjunto de problemas de ordem interna e externa que vinha acometendo o governo do Império, e que redobrou sua força após a abertura do Parlamento, em 1826, quando se consagrou um novo momento dentro da oposição ao imperador e ao círculo político que lhe cercava.

Às vésperas da Abdicação, o governo de D. Pedro vinha sendo questionado pela oposição com relação a sua atuação política, a exemplo da política externa do Império. O

\footnotetext{
${ }^{517}$ MOREL, Marco. O período das Regências (1831-1840). Rio de Janeiro: Jorge Zahar Editora, 2003, pp.1112. Ver também BARBOSA, S. M. “Autoridade e Poder Real: Benjamin Constant e a Carta Constitucional Portuguesa de 1826”. Locus: Revista de História, Juiz de Fora, v. 10, pp. 7-22, 2004.
} 
insucesso da Campanha do Sul, que findou com a perda do território da Cisplatina, gerou prejuízos aos cofres brasileiros e à economia daquelas províncias que sofreram com o recrutamento de combatentes, como foi o caso de São Paulo. ${ }^{518}$ Já o envolvimento cada vez maior de D. Pedro na questão sucessória do trono luso aumentou a desconfiança da Câmara dos Deputados, que assistiu às seguidas demonstrações do monarca em favor de portugueses refugiados no Brasil em virtude do golpe articulado por D. Miguel. Alguns passaram a viver às custas do Estado por meio de pensões; outros, a preencher cargos públicos, em certos casos irregularmente. Por essa mesma época, cerca de duzentos soldados portugueses aliados ao monarca na luta pela retomada do trono português fixaram residência no Rio de Janeiro, também por conta dos cofres públicos. ${ }^{519}$ Se o embate entre portugueses e brasileiros havia sido um problema crucial no decurso da década de 1820, do final desta até a Abdicação houve um acirramento do antilusitanismo por parte dos liberais, que se valeram dos impressos para firmarem seu descontentamento. Em novembro de 1830, o Farol Paulistano publicou um artigo no qual acusava os portugueses recentemente radicados na América de serem partidários da reunificação entre Portugal e Brasil. ${ }^{520}$ Meses antes o mesmo jornal publicara uma nota em que associava a chegada de novas levas de portugueses à disseminação de projetos de “recolonização” e “absolutismo”. 521 Além disso, em virtude dos portugueses dominarem boa parte das casas de comércio situadas na capital do Império, a chegada de novos contingentes lusos acarretaria, pelo menos em tese, uma concentração ainda maior das atividades mercantis em suas mãos, possibilidade que

\footnotetext{
${ }^{518}$ PIMENTA, João Paulo G. Estado e Nação no Fim dos Impérios Ibéricos no Prata, 1808-1828. São Paulo: Editora Hucitec/ Fapesp, 2002.

${ }^{519}$ Sobre os conflitos entre portugueses e brasileiros no Primeiro Reinado, ver RIBEIRO, Gladys. $\underline{\text { A liberdade }}$ em construção: identidade nacional e conflitos antilusitanos no Primeiro Reinado. Rio de Janeiro: Relume Dumará, 2002.

${ }^{520}$ O Farol Paulistano, $\mathrm{n}^{\circ}$ 17, 18/11/1830.

${ }^{521}$ O Farol Paulistano, $\mathrm{n}^{\circ}$ 352, 12/06/1830.
} 
preocupava determinados setores, sobretudo aqueles emergentes, que ainda não detinham o poder político suficiente para assegurarem seus interesses, como os produtores agrícolas e comerciantes de tropas de animais do Sul de Minas Gerais e São Paulo. ${ }^{522}$

O principal ponto de discórdia com relação ao reinado de D. Pedro estava, no entanto, na composição, organização e conduta de seu Governo. Nesse sentido, não é demais ressaltar que parcela significativa da base social que conferiu apoio ao governo de D. Pedro durante o Primeiro Reinado fazia parte daqueles setores cuja fortuna e projeção política já vinham se consolidando desde o final do século XVIII e, notadamente, no decurso do período joanino. Militares de alta patente, magistrados, agricultores exportadores e negociantes de grosso trato os quais antes mesmo da revolução do Porto já comungavam da idéia de se criar um Império no Brasil e que, progressivamente, se uniam por laços mercantis e de parentesco, protagonizaram o projeto separatista entre Portugal e Brasil e ainda serviram de alicerce político para a Regência de D. Pedro e o Primeiro Reinado. $^{523} \mathrm{O}$ que particularmente interessa aqui é o fato de que esse enraizamento múltiplo de interesses em terras americanas foi um dos vetores centrais no encaminhamento das relações entre Brasil e Portugal e, posteriormente, na instalação das bases do futuro Império brasileiro. Assim, figuras como Nogueira da Gama (Marquês de Baependi), José da Silva Lisboa (Visconde de Cairu), Carneiro da Cunha (Marquês de Caravelas), Maciel da Costa (Marquês de Queluz), Barbosa Vilela (Marquês de Paranaguá) e Caldeira Brant (Marquês de Barbacena) foram personagens ativas na arregimentação política em torno de D. Pedro durante a década de 1820, ajudando na formação da nobiliarquia brasileira forjada pelo

\footnotetext{
522 Ver LENHARO, Alcir. As tropas da moderação: o abastecimento da Corte na formação política do Brasil:1808-1842. Rio de Janeiro: Biblioteca Carioca, 1993. $1^{\text {a }}$ edição: 1979, especialmente capítulos 2 e 5.

${ }^{523}$ OLIVEIRA, Cecilia Helena de Salles. "Tramas políticas, redes de negócios”, in JANCSÓ, István. Brasil: formação do Estado e da Nação. São Paulo/Ijuí: Hucitec/Fapesp/Editora UniJuí, 2003, pp.389-406.
} 
monarca e, principalmente, na composição das pastas ministeriais, do Conselho de Estado e do Senado. Em troca dos serviços prestados à máquina pública - que iam desde o financiamento na construção de estradas, passando pela composição da magistratura até o fornecimento de apoio político e militar -, muitos foram agraciados com extensas faixas de terra no vale do Paraíba, que ao longo da primeira metade do século XIX tornou-se no principal centro produtor de café do Império. ${ }^{524}$

É de se lembrar, todavia, que tanto a separação entre Portugal e Brasil quanto as iniciativas referentes à criação de um Estado autônomo com sede no Rio de Janeiro e sob o governo de D. Pedro só obtiveram sucesso devido ao amplo apoio franqueado por grupos que vinham ascendendo economicamente desde o final do século XVIII, especialmente no Centro-Sul da América portuguesa, mas cuja projeção política ainda se encontrava atada à esfera local, quadro esse que não se alterou substancialmente com a instauração do Império brasileiro. Donos de engenhos de cana-de-açúcar, produtores e comerciantes de gêneros de primeira necessidade, criadores e negociantes de tropas de burro, esses homens, especialmente oriundos de Minas Gerais e São Paulo, tiveram papel fundamental nos debates ocorridos na Cortes de Lisboa, na viabilização do Fico e no endosso à Carta de 1824, mas não chegaram a ser arregimentados por D. Pedro para a constituição de seu Governo. Assim, a despeito de sua participação inconteste nos primeiros passos para o estabelecimento do regime monárquico-constitucional brasileiro, esses setores não foram

\footnotetext{
${ }^{524}$ LENHARO, op. cit. Em sentido semelhante, Alan K. Mancherster assinalou que a burocracia nascida no período joanino foi um dos pilares que conferiu um mínimo de solidez política ao Primeiro Reinado: "A criação do mecanismo de um estado soberano no Brasil, paralelo e igual ao protótipo em Lisboa, produziu uma burocracia nacional centralizada que contava com o Rio de Janeiro como fonte de autoridade. Ao mesmo tempo, a burocracia das províncias expandiu-se no interior da estrutura da tradicional administração colonial absolutista, agora com seu foco no Rio de Janeiro. Esta burocracia, nacional e provincial, proporcionou uma estrutura administrativa já pronta, com pessoal treinado para um Brasil independente”, Apud SOUZA, op. cit., p.51.
} 
recrutados para o Ministério, tampouco para o Senado e Conselho de Estado. Eles acabaram organizando-se nas esferas de poder as quais dependiam exclusivamente de processos eleitorais, tais como a Câmara dos Deputados, os Conselhos Provinciais e as Câmaras Municipais. ${ }^{525}$ Ainda que em nível provincial, tais grupos também vinham se firmando por meio de laços de parentesco e negócios. Citemos alguns casos da província de São Paulo.

Manoel Rodrigues Jordão, membro na $1^{\text {a }}$ Reunião dos Conselhos da Presidência e Geral de São Paulo, foi um dos principais agricultores, arrematadores de contrato e negociantes paulistas do começo do século XIX, possuindo fazendas de cana-de-açúcar, café, algodão e gêneros de subsistência em Itu, Constituição (Piracicaba), Bananal, Pindamonhangaba, Caçapava, Paraibuna e Itapetininga, além de chácaras na capital paulista. Era casado com Gertrudes Galvão de Oliveira e Lacerda, irmã do marechal de campo Joaquim Mariano Galvão de Moura Lacerda, suplente na $1^{\mathrm{a}}$ Reunião do Conselho da Presidência, e detentor de engenhos e fazendas de criação de animais em Constituição e Araraquara, bem como de propriedades na região do Brás, na cidade de São Paulo. ${ }^{526}$ Antônia Joaquina Mendes da Silva, prima de Jordão, era esposa do coronel Joaquim José dos Santos, negociante de escravos e proprietário de terras em Jundiaí, e cujo filho, Joaquim José dos Santos Filho, exerceu o cargo de conselheiro da presidência em 1834. Já Ana Vicência Rodrigues Jordão, irmã do brigadeiro Jordão, casou-se com Antonio da Silva Prado, com quem teve um filho, homônimo do pai e futuro Barão de Iguape, que se tornou um dos principais arrematadores de contratos e comerciantes de reses e muares da Província de São Paulo nas primeiras décadas do século XIX. Maria Marcolina Prado,

\footnotetext{
${ }^{525}$ Ibidem, pp.28-31.

${ }^{526}$ ARAÚJO, op. cit., pp.153-156.
} 
prima do Barão de Iguape, contraiu matrimônio com um dos filhos de Lucas Antônio Monteiro de Barros (Visconde de Congonhas do Campo e primeiro presidente da Província de São Paulo), o magistrado Rodrigo Antonio Monteiro de Barros, dono de uma sociedade de comércio de bestas em Moji das Cruzes e que chegou a ser deputado pela bancada paulista na $1^{\mathrm{a}}$ legislatura do Império. ${ }^{527}$

Outros importantes vínculos familiares e de negócios foram selados pela união dos ituanos Barros Leite com os Souza Queiróz. O brigadeiro Luis Antônio de Souza Queiróz, um dos homens mais ricos de São Paulo no início do século XIX, possuidor de mais de sete engenhos, de um grande plantel de escravos e de extensas faixas de terra na região de São Carlos, casou-se, em 1797, com Genebra de Barros Leite, filha de Antonio de Barros Penteado e irmã de Antônio Paes de Barros, deputado por São Paulo na 2a legislatura do Império e membro das três Reuniões do Conselho Geral de São Paulo. Após a morte do marido, a viúva Genebra de Barros Leite casou-se, em 1822, com José da Costa Carvalho, na época ouvidor da capital paulista, mas que ao longo dos primeiros anos do Império ocupou, entre outros cargos, o de membro do Conselho Geral ( $2^{\mathrm{a}}$ e $3^{\mathrm{a}}$ Reuniões) e da Presidência ( $2^{\mathrm{a}}$ Reunião) da Província de São Paulo. Por meio do matrimônio, tornou-se proprietários de fazendas na área de Itu e São Carlos, de antiga propriedade do brigadeiro Luis Antônio. 528

Francisco de Paula Sousa e Melo, deputado pela $2^{\mathrm{a}}$ e $3^{\mathrm{a}}$ legislaturas do Império e conselheiro geral na $2^{a}$ e $3^{a}$ Reuniões, em ambos os casos pela Província de São Paulo, casou-se com Maria de Barros Leite, também irmã de Antonio Paes de Barros. Já o coronel

\footnotetext{
527 PETRONE, op. cit., 1976; MARQUES, op. cit.; TAUNAY, op. cit., 1956.

528 PUNTSCHART, Willian. Negócios e negociantes paulistas. Tese de doutorado apresentada ao Departamento de História da Faculdade de Filosofia, Letras e Ciências Humanas da Universidade de São Paulo. São Paulo, 1998.
} 
de milícias Francisco Inácio de Souza Queiróz, filho da paulista Isabel Inácia da Conceição e do português Francisco Antonio de Souza, e membro dos Conselhos da Presidência (1 ${ }^{\mathrm{a}}$ Reunião) e Geral ( $2^{\mathrm{a}}$ e $3^{\mathrm{a}}$ Reuniões) de São Paulo, casou-se com sua prima Francisca Miquelina de Souza Queiróz, filha do brigadeiro Luis Antônio. Paralelamente à carreira militar, Francisco Inácio foi negociante de alimentos e escravos e dono de engenhos na região de São Carlos. ${ }^{529}$ Rafael Tobias de Aguiar, deputado pela $2^{\mathrm{a}}$ e $3^{\mathrm{a}}$ legislaturas do Império, membro do Conselho da Presidência e do Conselho Geral na $1^{\mathrm{a}}$ e $2^{\mathrm{a}}$ Reuniões e presidente da província de São Paulo entre 17 de novembro de 1831 e 27 de maio de 1834, comandava negócios relativos à criação e comercialização de animais na região de Sorocaba, ramo similar ao do curitibano Lourenço Pinto de Sá Ribas, duas vezes deputado ( $2^{\mathrm{a}}$ e $3^{\mathrm{a}}$ legislaturas) e membro dos Conselhos da Presidência (suplente na $1^{\mathrm{a}}$ Reunião) e Geral (membro na $1^{\mathrm{a}}$ Reunião e suplente na $2^{\mathrm{a}}$ ). O coronel Anastácio de Freitas Trancoso, membro na $2^{\text {a }}$ Reunião do Conselho Geral de São Paulo, possuía plantações de chá no sítio da Freguesia do Ó, na capital paulista, além de propriedades nas imediações das estradas para Campinas e Santos. O padre Diogo Antonio Feijó era proprietário de engenhos de açúcar na região de Itu e, na região da capital paulista, era um dos principais cultivadores de chá. ${ }^{530}$ Foi duas vezes deputado por São Paulo (2 ${ }^{\mathrm{a}}$ e $3^{\mathrm{a}}$ legislaturas), membro do Conselho da Presidência ( $1^{\mathrm{a}}$ e $2^{\mathrm{a}}$ Reuniões) e do Conselho Geral ( $1^{\mathrm{a}}$ e $2^{\mathrm{a}}$ Reuniões). ${ }^{531}$

Os dados acima elencados ajudam a elucidar o perfil econômico e de relacionamentos de parte dos políticos paulistas que compuseram os espaços de poder representativo atrelados à província de São Paulo do Primeiro Reinado até a promulgação do Ato Adicional. Além de ocuparem os principais ramos da economia paulista, esses

\footnotetext{
${ }^{529}$ Ibidem.

530 TAUNAY, op. cit., 1956.

${ }^{531}$ DELATORRE, op. cit.
} 
políticos estreitavam seus vínculos pessoais por meio de matrimônios estratégicos, os quais ajudavam a criar grupos de interesses comuns. Mais do que isso, figuras como Diogo Antônio Feijó, José da Costa Carvalho e Rafael Tobias de Aguiar divisaram nas sucessivas convocações do Parlamento um modo de abrir espaços políticos na Corte, ampliando sua rede de negócios e projeção política. A cada novo ano legislativo o enfrentamento entre Câmara dos Deputados e governo se acentuava. Já a instabilidade do governo de D. Pedro mostrava-se patente, também, na constante sucessão ministerial. De 1822 a 1831, nove gabinetes foram montados pelo monarca, e no mais das vezes eles foram parcialmente alterados por meio da substituição de um ou outro ministro. ${ }^{532}$

Em fevereiro de 1831, D. Pedro partiu para Minas Gerais com o objetivo de acalmar um dos principais focos de oposição ao Governo e resgatar seu prestígio político ante os mineiros. No entanto, a estadia do monarca foi tensa, circundada por demonstrações de apoio e, concomitantemente, por manifestações contra o poder imperial. No dia 22 daquele mês, D. Pedro fez sua famosa proclamação "aos mineiros em geral e a todos os povos do Brasil”, discurso em que apontou para a existência de um “plano revolucionário” organizado em torno de um "partido descentralizador”, o qual aproveitara-se das circunstâncas do momento para, por meio da imprensa, investir contra o Governo e concitar “os povos à federação”.

A proclamação feita por D. Pedro em Minas Gerais foi acolhida com reserva pelos seus opositores. Em São Paulo, após transcrever a fala do monarca, o Farol Paulistano criticou as atitudes recentes do Governo, que na sua opinião vinha agindo de forma pouco contundente para a salvaguarda do "Systema Constitucional”. Ao contrário, dava mostras de que pretendia derrubá-lo, o que se tornava evidente nas estreitas relações com Portugal,

\footnotetext{
${ }^{532}$ JACQUES, op. cit.
} 
no desempenho dos Ministérios e na relação conturbada que o Governo estabelecera com a oposição. O redator ponderou, ainda, que a imprensa periódica havia sido um dos alvos da proclamação, à semelhança das perseguições feitas aos redatores oposicionistas um ano antes na França de Carlos X. Mas a despeito de reconhecer os excessos que algumas folhas cometiam, o redator argumentou que estes só ocorriam em conseqüências de abusos maiores protagonizados pelo Governo. Nesse sentido, a retórica posta em prática pelo $O$ Farol buscava mais uma vez cristalizar a idéia de que o problema atual do Império não residia no modelo político por ele adotado, mas naqueles que o comandavam, de modo que alterações substanciais, tal como uma “revolução” ou a adoção da “federação”, seriam desnecessárias. A fim de minimizar as divergências político-ideológicas entre aqueles que se situavam contra D. Pedro e seu círculo político, o redator de O Farol observou que o propalado “partido desorganizador” nada mas seria do que a somatória daqueles que acima de tudo defendiam a "liberdade”:

"O Governo teme um partido desorganizador, e o Governo não cuida em desmanchar esse partido? E como é que um governo cuida em desmanchar um partido que se levanta contra si? É com proclamações, cujas palavras e promessas já forão muitas vezes ouvidas, e muitas vezes violadas? Não está ahi essa collecção do Plancher cheia de Proclamações tão mal escriptas quanto abundantes de palavrórios Constitucionaes? Depois de se dizer que o Brazil nada mais queria de Portugal, e o Governo do Brazil não forcejou tanto por ver se tornava a unir os dois Estados para sempre separados? Quando se dizia que a árvore da Liberdade devia ser regada com o sangue dos tyrannos, não se forcejava a queda do Systema Constitucional, e não se preparavão os ferros para os mais notáveis cultores d'essa mimosa árvore? Quem mais acreditará em palavras, em promessas, em juramentos de certa gente? (...) Não é com Proclamações que os governos desmanchão partidos, não é com Proclamações, que os governos evitam revoluções. Palavras não adubam sopas; é obrando muito recta, muito francamente em sentido Nacional. 
(...) É contra a imprensa periódica, que mis se afana a Proclamação: também o manifesto dos Ministros de Carlos X na França contra a imprensa periódica e que mais se occupava. Há excessos, há abuso na imprensa, não há duvida: mas porque há esses excessos, e esses abusos? É porque um abuso promove o outro. Os excessos, os abusos do governo tem irritado os ânimos, e os ânimos irritados saem muito freqüentemente da órbita do dever (...) Mas qual é esse partido contra quem se proclama? Aonde está elle? Nós não o vemos. O que vemos é querer-se a liberdade, e não se achando ella no actual systema, qual devera, ou poderá ser, por culpa de uma serie de Mistérios ineptos e perversos, attribue-se ao systema a falta, que do systema não é, mas sim dos que ou não executão, ou o falsificão, o que é muito peior ainda; e por isso desejão uma mudança, que julgão remédio a essa tão sentida, e com razão tão lastimada falta de maior porção de liberdade que já poderíamos gosar. Mas, qual é o remédio? É mostrar, que com este mesmo systema se pode optimamente conseguir esse com tanta justiça desejado fim (...) Nós não queremos a federação, que já temos combatido, porque a julgamos imprópria; mas queremos a liberdade, e toda quanta é possível que os homens gozem em sociedade (...). ${ }^{533}$

O Observador Constitucional publicou um artigo de A Aurora Fluminese que, em sentido semelhante ao Farol Paulistano, criticara o teor da proclamação do monarca, vista como equivocada. Embora tivesse a reforma da "Lei do Estado” como uma ambição “imprudente” que iria abalar o “respeito que cumpre ter pela Constituição”, o redator de A Aurora reconheceu que não havia nada de ilegal na proposição da mesma, desde que ela fosse elaborada com amparo da Carta de $1824 .^{534}$

O regresso de D. Pedro para a Corte foi acompanhado de violentos conflitos que se espalharam pelas ruas da capital do Império entre os dias 11 e 13 de março, e que ficaram conhecidos como as “Noites das Garrafadas”. Retratados geralmente como um embate entre portugueses e brasileiros em torno da figura de D. Pedro, tais conflitos foram o resultado, na realidade, de um conjunto de tensões e disputas de ordem política e

\footnotetext{
${ }^{533}$ O Farol Paulistano, no 666, 24/03/1831.

${ }^{534}$ O Observador Constitucional, n ${ }^{\circ} 137,28 / 03 / 1831$.
} 
econômica cuja face mais evidente foi o acirramento do antilusitanismo por parte de grupos nacionais e a polarização entre partidários e opositores do imperador. ${ }^{535}$

A animosidade dos conflitos aumentou, culminando no enfrentamento físico entre seus participantes. Setores intitulados "liberais" acusaram os portugueses de uso imoderado da violência contra os brasileiros e de manifestarem apoio à D. Miguel e D. Maria II. As autoridades policiais foram igualmente criticadas por conta de sua suposta conivência com os portugueses. No dia 17 de março, um grupo de 23 deputados reuniu-se na casa do representante mineiro José Custódio Dias e elaborou uma representação para o Governo exigindo que este tomasse medidas imediatas para tranqüilizar a situação da capital do Império. A publicação do texto pela imprensa acirrou ainda mais os ânimos no Rio de Janeiro, ao mesmo tempo em que os episódios ocorridos no início de março se espalhavam pelas demais províncias.

Em São Paulo, a notícia dos tumultos na Corte foi recebida com apreensão. De acordo com o Farol Paulistano era necessário ter “toda a vigilância possível” com relação aos portugueses que residiam em solo paulista, a despeito da maioria deles não apresentar perigo. Seriam tomadas “medidas fortes” caso necessário, mas o ideal era defender o “Systema brasileiro” sem "agressividade”. 536 Já o Observador Constitucional foi mais incisivo. Ao afirmar que o Brasil deixara de ter um Governo, já que esse nada fazia pela causa nacional, o redator de O Observador convocou os brasileiros às “armas” para ficarem de prontidão em relação ao desdobrar dos acontecimentos na Corte:

"Brasileiros às armas, sois traídos. Um partido infame de portugueses absolutistas tem ousado levantar o colo no Rio de Janeiro. Tem-se enchido de impropérios, e coberto de

\footnotetext{
${ }^{535}$ RIBEIRO, 2002, op. cit.

${ }^{536}$ O Farol Paulistano, no 408, 29/03/1831.
} 
vergonha o nome brasileiro. As autoridades que deviam velar na tranqüilidade se têm mostrado indiferentes, tem-se procurado desarmar a tropa brasileira. Tem-se animado este partido absolutista. Sois livres, e suportais insultos do estrangeiro?

O que é para vós a Liberdade? É um nome vão ou uma realidade? Ah, se tendes por um nome meramente, descei do vosso orgulho, entregai os pulsos aos ferros, abraçai os opressores. Mas se tendes por uma realidade... vossa honra, vossa nacionalidade estão ofendidas, às armas, a vingança só nos resta. O governo do Brasil não dá satisfações a brasileiros. Os brasileiros a devem ter exigido pelas armas. Destes nossas minas ao estrangeiro, tendes atrasado o nosso comércio, consumido a nossa riqueza”.

(...) Brasileiros, nós não temos mais Governo, nossa força. E Opinião Publica o devem supror. A obediência é só devida a Lei, e o Governo que a não respeita tem perdido o caráter do Governo. O Brasil é Soberano, a esse compete pôr por terra os pérfidos que aproveitando-se da força e auctoridade que lhes demos, ingratos as tem voltado contra nós.

(...) Às armas, Brazileiros, basta já de sofrimentos. Correi a alistarvos na Sociedade dos Defensores da Liberdade e Independência. 700 cidadãos livres ahi se achão alistados, e promptos a resistir as oppressoes, todas as classis ahi se tem assignado, a causa interessa a $\operatorname{todos}(\ldots) .^{537}$

A Sociedade dos Defensores da Liberdade e da Independência mencionada pelo redator de O Observador havia surgido na capital paulista a 29 de março de 1831, em meio à chegada de notícias sobre a situação política da Corte. De acordo com seu estatuto, a Sociedade tinha como objetivo principal auxiliar as autoridades na manutenção da ordem e da tranqüilidade, influindo assim no tratamento dos negócios públicos quando a integridade do Império fosse postas em perigo. Articulada em um Conselho composto por 18 membros que representava os demais sócios, a Sociedade dos Defensores agia por meio do envio de ofícios às autoridades, especialmente às Câmaras Municipais e aos governos provinciais, cobrando atitudes ou sugerindo-as. ${ }^{538}$

\footnotetext{
${ }^{537}$ O Observador Constitucional, n ${ }^{\circ} 133,01 / 04 / 1831$.

538 Para a Sociedade dos Defensores da Liberdade e Independência Nacional e outras sociedades políticas paulistas do período, ver WERNET, op. cit.
} 
Em função da instabilidade política do momento, a Sociedade dos Defensores foi bem recebida pelos círculos políticos paulistas. O Farol Paulistano analisou seu surgimento como uma resposta aos "funestos acontecimentos" da Corte, e dias depois publicou o estatuto completo da Sociedade. ${ }^{539}$ O Observador Constitucional, por sua vez, assinalou que a nova Sociedade estava pronta para “coadjuvar a ação das autoridades a bem da ordem, na conformidade de um de seus artigos de seus estatutos”. ${ }^{540}$ Iniciada na capital paulista, a Sociedade dos Defensores alastrou-se pelo restante da província de São Paulo. Em julho já existiam congêneres nas vilas de Santos, Itu, Porto Feliz, Piracicaba, Campinas, Atibaia, Bragança, Mogi-Mirim, Parnaíba, São Roque, Sorocaba, Jacareí, Taubaté, Guaratinguetá, Vila Príncipe, Iguape e Jundiaí. Ela inspirou, também, a fundação da Sociedade Defensora da Liberdade e da Independência Nacional do Rio de Janeiro, ocorrida maio de 1831, pouco após a Abdicação.

As Sociedades Defensoras tiveram importante papel político nos momentos que imediatamente antecederam e sucederam a abdicação de D. Pedro, especialmente porque se tratava de um período em que a Assembléia Geral encontrava-se fechada, e parte dos parlamentares encontravam-se em suas províncias de origem. A ênfase na ação por meios legais, na manutenção do regime monárquico-constitucional e no repúdio a mudanças que convulsionariam a ordem social deixou claro que as Sociedades Defensoras coadunariam com os preceitos dos “moderados", que aliás compunham a base política dessas organizações.

\footnotetext{
${ }^{539}$ O Farol Paulistano, nos 469 (31/03/1831) e 471 (07/04/1831).

${ }^{540}$ O Observador Constitucional, $\mathrm{n}^{\circ} 133,11 / 04 / 1831$.
} 
D. Pedro abdicou em favor de seu filho Pedro de Alcântara, de apenas cinco anos de idade, na madrugada do dia 7 de abril de 1831. Ainda pela parte da manhã os parlamentares que se encontravam no Rio de Janeiro reuniram-se em sessão extraordinária da Assembléia Geral para instituírem uma Regência Trina Provisória, conforme previsto pela Constituição. O momento era delicado e exigia certa dose de conciliação, de modo que os regentes escolhidos representavam, por assim dizer, três grupos importantes da sociedade imperial: o general do exército Francisco de Lima e Silva, os militares; José Joaquim Carneiro da Cunha, o círculo político de D. Pedro; e Nicolau de Campos Vergueiro, os liberais “moderados".

A notícia da abdicação de D. Pedro chegou em São Paulo em 15 de abril de $1831 .^{541}$ No dia seguinte o Farol Paulistano publicou um resumo dos antecedentes que culminaram na saída do monarca, sem ocultar sua satisfação com o ocorrido. Em sintonia com os articuladores da Regência, a folha dirigida por Costa Carvalho alertou para a necessidade de se preservar a "União", de "calar todos os partidos", de depositar "toda a confiança na Assembléa Geral” e de obedecer as "Leis” e as “Autoridades”, numa clara tentativa de cooptar o público leitor para o projeto político que se instalara no Rio de Janeiro. Em paralelo, a ênfase na manutenção da “ordem”, do “juizo" e da "união" demonstrava o receio de que alterações mais profundas, desejadas pela ala liberal mais radical, ganhassem coro entre os paulistas:

“(...) Não podemos deixar de expender algumas das muitas considerações, que occorrem a vista deste quadro verdadeiramente grande e encantador. Um Monarca não

\footnotetext{
${ }^{541}$ WERNET, op. cit., p.32.
} 
achar partido algum que o defenda, se quer por um momento!! Ser abandonado por todos?! É precizo para que isto aconteça, que muito mao fosse o seu Governo!! A Constituição prescreve que a Regencia Provizoria, que jurou entregar o Governo à Regencia, que depois fosse competentemente nomeada. Talvez se não nomeasse Ministerio, e se abdicasse na esperança bárbara, de que a guerra civil rompesse no intervallo até a nomeação da Regencia, e talvez por causa d'essa importante nomeação; mas esse ultimo mal não pode conseguir quem tanto mais fez. A Regência provizoria compõem-se de homens que devem merecer a nossa confiança. Do Sr. Márquez de Caravellas sempre tivemos muito bom conceito; do Sr. Vergueiro ninguem duvida, dizem-nos que ultimamente fez tantos, e tão importantes serviços, que resgatou e de sobra qualquer má impressão, que podesse haver a seu respeito. E o que nos resta fazer agora? Ter União; calar todos os partidos; depositar toda a confiança na Assembléa Geral, e guiarmo-nos pelos dictames dos nossos Representantes. Já não ha o motivo de nossos receios, dos nossos sustos, das nossas desconfianças, não mais receios, não mais sustos, não mas desconfianças: o passado, passado, vida nova, e com ella União, ordem, juizo. Mostremo-nos dignos da Liberdade, que a Providencia nos deu gratuitamente, e que quazi sempre tem vendido por alto preço de sangue as demais nações. Se nos não uniremos cordialmente, se não conservarmos em ordem, obedecendo as Leis, e as Autoridades, que em nome dellas, e por elas governarão, pode ser que nos desapareça n'um momento o precioso mimo de que gozamos; talvez, que não’um momento se disfarça todo este edifício magnífico, e encantador. Mas nós esperamos, que haja União, haja ordem, que haja juizo. Hontem todos os corações ficarão cheios das mais lizongeiras esperanças; tanto enthusiasmo, tanto fogo, tanto amor à Liberdade nunca se vio com tanta ordem, com tanta dignidade como hontem nesta Cidade. Logo que apareceu a felicíssima noticia ás nove horas da manhã grandes magotes do povo por toda a parte davão os mais enthusiasmados e mais legaes vivas; houve Te-Deum na Cathedral á tarde, e um digno sacerdote emigrado da Ilha da Madeira improvizou uma oração gratulatoria, que ao mesmo tempo honrão os seus talentos, o seu liberalismo, e a sua educação. Bandas de Muzica acompanhando o Hyno cantado por pessôas de classes precorrerão todas as ruas da Cidade. A noite todas as cazas se illuminarão espontaneamente, e reinava a mais completa tranqüilidade (...). ${ }^{542}$

${ }^{542}$ O Farol Paulistano, n $475,16 / 04 / 1831$. 
Dois dias depois foi a vez de O Observador Constitucional manifestar-se sobre a abdicação do imperador. Em tom de júbilo, o redator noticiou a retirada de cena de D. Pedro, retratado como o "causador de todos os males” e o mantenedor da "tyrannia no Brazil”. Mais adiante, aconselhou que seus leitores continuassem mostrando-se “dignos da liberdade”, e por isso obedecessem às autoridades e confiassem, sobretudo, na atuação da Assembléia Geral, a qual não poderia querer outra coisa que não fosse o "maior bem do Brazil”. Além de reivindicar a proeminência do Parlamento, o que de certa forma restringia a participação de outras esferas de poder no encaminhamento da situação, o redator de o Observador clamou para que ninguém emitisse “qualquer opinião” que se afastasse do “Regime jurado”. A defesa do sistema monárquico-constitucional prescindia, portanto, qualquer atitude a ser tomada futuramente:

“Brazileiros! A estas hora já não existe em meio de nós o causador de todos os males. Aquelle que com a mais doces palavra procurou sempre illudir nossa boa fé, mas que com as peiores obras desde muito nos fez abrir os olhos, depois de emprega toda a sorte de traições para firmar a tyrannia no Brazil, objecto constante de todos os seus votos, ExImperador succumbio victima de sua mesma perfidia (...) Brazileiros! Continuemos a mostrar-nos dignos da liberdade, que gozamos, conservando sempre o mais religioso respeito ás leis, e obedecendo as Autoridades que d'hoje em diante não podem obrar senão em nomes d'ellas. Sobretudo, fundemos toda a nossa esperança na Assembléa Geral, que não pode querer outa coisa, que não seja o maior bem do Brazil. Ninguém seja tão inonsiderado entre nós, que ouse emittir qualquer opinião, que se afaste um ápice do Regime jurado. Temos representantes esclareidos, homens formados na escola da Liberdade, e que conhecem a fundo as necessidades do Brazil: a elles toca interpretar, e manifestar a vontade Nacional por mei das leis, que lhes dictar sua sabedoria. Prestar prompto obsequio a elles, é dever de todo o Brazileiro, que se pesa de amar a Pátria, e a 
Liberdade. Aquelle, que não obrar assim, é indigno de ter uma Pátria, é indigno da Liberdade”. ${ }^{543}$

Menos cautela passou a ter o Farol Paulistano. O apoio à Regência e o repúdio às reivindicações dos “exaltados”, sobretudo com relação à federação, logo se tornaram pautas centrais de O Farol, o qual aproveitou para atacar a Voz Paulistana, que por sua vez havia sugerido, logo após a Abdicação, a proclamação de uma República Federativa no Brasil. Para o redator de $O$ Farol, a maioria dos paulistas nem sequer aprovavam as "doutrinas federativas":

“Amigo sincero do meu país, amante de tudo que pode concorrer ao seu benefício, vejo-me obrigado a lançar mão da pena, não para persuadir o senhor redator d’A Voz Paulistana, mas para declarar as doutrinas federativas que aquele senhor assoalha e prega. Nós que não há muito estivemos em vários lugares da província, que fomos testemunha do seu entusiasmo contra os inimigos de nossa Liberdade e Independência, reunindo-se em associações, que tratamos de perto com a gente sisuda e esperta desses lugares, vemos que foi exuberante o prazer de ver-se por terra o monstro assolador de nossa Pátria: contudo nunca a ninguém (a não ser um menino) jamais se lembrou de proclamar entre nós a Federação. Pelo contrário, ouvimos muita gente boa lamentar que o senhor redator da chamada Voz Paulistana não empregasse seus talentos em coisa mais útil. Fomos testemunha nunca assaz bem exprimido do prazer da notícia da abdicação. Mas só o senhor redator d’A Voz Paulistana é que lembrou de dar "Vivas” e à República, enquanto nós ouvimos todos os bons paulistas darem "Vivas” à Regencia". 544

Para o redator de O Farol, tanto a "Federação” como as "reformas na Constituição" seriam “meros pretextos” utilizados por aqueles que as defendiam para levarem adiante uma "revolução", raciocínio esse que encontraria explicação em dois motivos.

\footnotetext{
${ }^{543}$ O Observador Constitucional, n ${ }^{\circ} 142,18 / 04 / 1831$.

${ }^{544}$ O Farol Paulistano, no 476, 19/04/1831.
} 
Primeiramente, a “mania da federação” supostamente nascera na capital do Império, onde a idéia de que as províncias ganhassem maior independência seria um contra-senso, posto que o centro da nação tenderia a organizá-las em torno de si. Além disso, aqueles que pugnavam pela federação em São Paulo não seriam paulistas legítimos, mas indivíduos oriundos de outras partes do Império. ${ }^{545}$

A idéia de que o sistema federativo e a reforma constitucional seriam meios para uma revolução e não fins concretos e juridicamente assentados pode ser um elemento importante para o esclarecimento do porquê dos “moderados" terem aceitado ambas as reivindicações mais tardiamente. Além de ser um argumento retórico circunstancial de condenação à prática política dos “exaltados”, a negação desses pontos poderia significar, também, um receio por parte dos “moderados” do que estaria por trás de uma eventual reforma da Constituição com base em princípios federativos. Afinal, conforme visto anteriormente, o termo federação era equívoco, e sua adequação ao regime monárquicoconstitucional incerta.

No número subseqüente, o Farol manteve a posição em favor da Regência, que segundo sua opinião vinha se ocupando das “necessarias mudanças na administração”. Aprovou a nomeação para comandante interino das armas da Corte do brigadeiro José Joaquim de Lima e Silva, irmão do “mui digno” regente Francisco de Lima e Silva; a mudança no comando da polícia do Rio de Janeiro, que teve como empossado Antonio Joaquim da Costa Gavião ${ }^{546}$; e o recolhimento à Corte dos comandantes das armas de São Paulo e Alagoas, bem como a demissão do de Minas Gerais. Quanto ao debate sobre a

\footnotetext{
${ }^{545}$ Ibidem.

${ }^{546}$ Antonio Joaquim da Costa Gavião já havia sido governador das armas pela Província do Mato Grosso, em 1826. Cf. "Officios sobre a estatistica, defesa e administração da província de Matto-Grosso de 1824 a 1826”, in Revista do Instituto Histórico e Geográfico Brasileiro, t.XX, 1857, p.384.
} 
federação, o redator de $O$ Farol asseverou que seus artigos vinham demonstrando que o caminho para o "systema unitario" era a "monarchia constitucional", e que nesse sentido tanto fazia a província de São Paulo ser governada por um paulista ou por um baiano. De acordo com o mesmo redator, os "federalistas" estariam "dominados por um Provincialismo exclusivo" ${ }^{547}$

Os artigos publicados pelo jornal dirigido por Costa Carvalho geraram controvérsias nos círculos políticos de São Paulo, a ponto de o próprio redator de $O$ Farol assumir que muito "vociferou-se" sobre seus escritos contra a Voz. ${ }^{548}$ Embora até aquele momento nunca houvesse compactuado com o advento do sistema republicano, tampouco defendido a federação ou qualquer tipo de alteração na Constituição, o Observador Constitucional saiu em defesa de A Voz Paulistana num artigo que apelava para reivindicações políticas de fundo, e que passariam pela reforma da "Lei Fundamental". Iniciava-se, a partir desse momento, uma viragem no discurso da folha fundada por Líbero Badaró, que progressivamente passou a aderir alguns pontos do heterogêneo programa político dos “exaltados”, especificamente com relação à necessidade da feitura de reformas na Carta de 1824 e da implementação de um sistema federativo:

"Para que falar com tanta acrimonia contra as reformas da Constituição, e mesmo contra a federação? Poderá São Paulo trilhar por si uma estrada diferente da que trilharam o Rio de Janeiro e mais províncias? Não é para aquele que todas têm voltado as suas vistas? Sabe-se já se o Rio de Janeiro não quer as reformas e a federação? No caso que as queira, São Paulo quererá ficar estacionário, quando a capital para onde ele tem voltado suas vistas caminha por diante? O Farol mesmo nos pinta a reprovação geral pelos extemporâneos “vivas” da Voz. Para que pois falar mais nisso? Para que dizer que os que pregam as

\footnotetext{
${ }^{547}$ O Farol Paulistano, no 477, 23/04/1831.

${ }^{548}$ Ibidem.
} 
reformas são revolucionários? E os que não as pregam não se poderiam chamar estacionários? Para que tocar em princípios monárquicos e sustentá-los? Não se sabe, que foi este decantado princípio sustentado pela Santa Aliança, quem produziu as maiores desgraças da Europa? No meio do geral contentamento pela queda do tirano do Brasil, com os olhos unicamente fitos em conseguir a união de todos os brasileiros, e sua comum cooperação para o complemento da maior vitória, a realização de essencialíssimas reformas que se devem fazer necessariamente na nossa Lei Fundamental, vimos aparecer um artigo no Farol n ${ }^{\circ}$ 476, o qual no meio de muitas opiniões absurdas trouxe consigo o gérmen da desunião e do descontentamento. Esforça-se o autor do artigo para provar que a federação e as reformas na Constituição são em muito menos pretextos para a revolução. Ele apresenta duas razoes:

$1^{\text {a) }}$ Ter nascido a questão da federação na Corte onde, por maneira nenhuma podia haver interesse de que as províncias ganhassem porção de alguma independência da mesma Corte.

$2^{a}$ ) Que desta cidade dos que instam, pela federação nenhum é paulista, e talvez nenhum aqui estabelecido.

São notáveis estas duas provas. O autor do artigo teve sobeja ignorância, e talvez se pudesse dizer má-fé, quando deixou de conhecer que poderia haver um brasileiro, nãofluminense - redator do Republico - propusesse a federação com o fim de promover assim melhor a felicidade de todas as províncias igualmente, e não com o fim de revolucionar o Brasil... O autor lança o mesmo odioso sobre todos os que querem quaiquer reformas na Constituição. Cremos que o voto geral não propende para que uma das reformas, ou ao menos nós não decidimos absolutamente por essa reforma, porém cremos também que nenhum brasileiro digno deste nome ousará opor-se a muitas que são necessárias na nossa Lei Fundamental, e ainda mesmo a tirar-se dela todos os elementos monárquicos preponderantes para os substituir por democráticos. Pode-se mostrar que um monarca não é só um bicho de sete cabeças como o autor do artigo não quer que seja, mas de cem cabeças...

Mas este não foi o nosso fim. O nosso único fim é fazer saber ao público pelo mesmo canal pelo qual o autor do artigo desacreditou os paulistas, e semeou a discórdia entre eles e o corpo acadêmico, que os paulistas, bem longe de serem tardos e morosos nas reformas, que são necessárias na Constituição, eles as desejam avidamente, e que os membros do corpo acadêmico ainda que com razão profundamente doídos de que suas sinceras demonstrações de entusiasmo pela Liberdade sejam intituladas estonteamentos e 
frioleiras, de que sejam apelidados de perturbadores da ordem e da pública tranqüilidade e de se queira excluí-los de participarem dos negócios públicos, por não gozarem dos direitos políticos”. 549

As “duas razoes” anteriormente apresentados pelo O Farol de que a federação e a reforma constitucional seriam pretextos para uma ação revolucionária foram re-utilizadas pelo O Observador como arma política. Ainda no mesmo exemplar, lançando mão de uma retórica sagaz, o redator de O Observador inverteu a posição na qual o Farol se colocara até aquele momento. De defensor da liberdade e da ordem o Observador imputou-lhe as qualidades de estacionário e desinformado, quer por ter confundido o clamor de reformas com “revolução" quer por ter afirmado que os simpatizantes da federação quase inexistiam em São Paulo. Ao final do artigo, o redator de Observador publicou um abaixo assinado por 92 paulistas que admitiam “com muito bom grado a todas as reformas Constitucionais

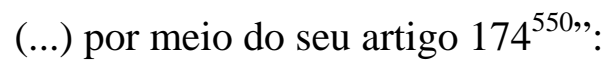

“Os abaixo assinados, amigos sinceros do seu paiz que se prezão de bons Paulistas, serios, sizudos, e expertos, mas nunca desconfiados, cabeçudos, ou teimosos, espantados com a leitura dos Communicados do N. 476 do Farol Paulistano, julgão do seu mais imperioso dever, levar ao conhecimento de todo o respeitavel publico d'esta, e das outras Provincias do Brazil, que as doutrinas estacionarios ou retrogadas, pregadas, e aconselhadas n’esses communicados, são falsas e não são professadas pelos abaixo assignados, e nem por uma grande parte dos serios e sizudos Paulistas da Cidade, e Villas, que muito tem avançado na carreira da civilização, e que não cedem em virtudes cívicas a seus irmãos das outras Provincias. Os abaixo assignados encherão-se de uma nobre, indignação, vendo que o verdadeiro caracter de seus Comprovincianos fora n’esses communicados tão atrozmente

${ }^{549}$ O Observador Constitucional, n ${ }^{0}$ 145, 29/04/1831.

${ }^{550}$ Assinalava o art. 174 da Constituição: "Se, passados quatro anos depois de jurada a Constituição do Brasil, se reconhecer que algum dos seus artigos merece reforma, se fará a proposição por escrito, a qual deve ter na Câmara dos Deputados, e ser apoiada pela terça parte deles”. Cf. “Constituição Política do Império do Brasil”, in BONAVIDES, Paulo \& AMARAL, Roberto (orgs.), op. cit. 
assoberbado, figurando-se-o com muito abaixo do - ANDAMENTO AMERICANO: esquecendo-se, que desde os começos da regeneração politica do Brazil, a Provincia de S. Paulo sempre marchou, ao menos, a par das outras na deligencia do aperfeiçoamento social, o que com bastantes factos poder-se-hia exuberantemente demonstrar; mas bastará mencionar-se, que quando se offereceu a Constituição, ainda como projecto, muita foi a hesitação em aceital-a tal qual, e que a Camara da illustre e patriotica Villa de Ytú apresentara muitas emendas, já então em 1824, no sentido das reformas, que hoje tem sido reclamadas por meio de muitos periodicos de todo o Brazil.

Os abaixo assignados adherirão pois de muito bom grado a todas as reformas Constitucionais, que a sabedoria e patriotismo da Assembléa Geral fizer na Constituição por meio do seu artigo 174, pois esperão, que os Augustos e Dignissimos Representantes da Nação não se descuidarão de promover a maior somma de felicidade de seus constituintes.

Finalmente os abaixo assignados tendo visto nos mencionados communicados com grande magoa sua, talvez desapreciado o patriotismo, e amor a liberdade de uma porção de jovens Brasileiros, aqui residentes, patenteão solemnente, que um mui grande numero de Paulistas coincide nos mesmos sentimentos, os quaes longe de aviltar honrão sobremaneira a indole liberal de todos os Americanos”. 551

${ }^{551}$ O Observador Constitucional, $\mathrm{n}^{\circ}$ 145, 29/04/1831. As noventa e duas assinaturas foram de: Jose Antonio dos Reis, Marcelino Ferreira Bueno, Bento Thomaz Gonçalves, Francisco Manoel das Chagas, Thomaz Jose Muniz, Benjamim Jose Gonçalves, Francisco Antonio d'Almeida Mello, Manoel Dias de Toledo, Filipe Correa Pacheco e Silva, Manoel Francisco de Vasconcelos, Joaquim Firmino Pereira Jorge, Jose Batista da Silva Bueno, Joaquim Otavio Nebias, Francisco Antonio d' Oliveira, Jose Maria de Souza, Padre Bento Antonio de Barros, Antonio Bazilio de Souza Barros Painguá, Jose Gaspar dos Santos Lima, Antonio Ribeiro d’ Escovar, Antonio Jose Pessoa, Matheus Fernandes Cantinho, João Nepomuceno de Almeida, Antonio Mariano dos Santos, Mariano Rodrigues de Souza Mello, Manoel Constantino de Camargo, Manoel Rodrigues d’ Almeida Barbosa, João Manoel de Almeida Barbosa, Izidoro Fernandes Cantinho, Francisco Augusto de Oliveira Muniz, Francisco de Assis Pupo, João Crisóstemo Pupo, Joaquim Teobaldo Machado de Oliveira, Martim Gonçalves Gomide, Antonio Manoel de Campos Melo, Manoel Nunes Ramalho, Joaquim Inácio Ramalho, Antonio Nunes Ramalho, Francisco Nunes Ramalho, Jose Álvares Machado e Vasconcelos, Joaquim de Sousa Guimarães, Francisco Xavier de Assis, Jose Pereira Jorge, Joaquim Jose de Macedo Rangel, Manoel Arcângelo de Oliveira, Ildefonso Xavier Ferreira, Jose Xavier Ferreira, Joaquim Fernandes Cantinho, Carlos Jose da Silva Teles, Joaquim Fernando da Fonseca, Antonio Rodrigues de Almeida Jordão, Francisco de Assis Pinheiro Prado, João Francisco de Andrade, Francisco de Assis Leite, Manoel Joaquim Leite Penteado, Bento Jose Labri, Manoel de Camargo e Oliveira, Amaro Jose Soares, Jose da Silva Monteiro, Lourenço de Melo Franco, Francisco de Paula Gomes, Joaquim, Mariano da Rocha e Silva, Tomé Manoel de Jesus Varela, Antonio Pinto da Silva, Felix Jose da Cunha, Jose Antonio Pinto Guedes, Amaro Jacinto de Cerqueira César, Lucio Manuel Felix do Santos Capelo, Antonio Correa Bueno, Manoel de Campos Penteado, João Vicente Rodrigues de Vasconcelos, Francisco Jacinto de Pereira Jorge, Jacinto Eliadoro de Vasconcelos, Joaquim Teodoro de Oliveira, Francisco de Paula Conceição, Antonio Joaquim de Macedo, Manoel Jose Vaz, Francisco Jorge de Paula Ribeiro, Miguel Antonio de Godoi, Inocêncio Jose Rodrigues de Vasconcelos, Pedro da Silva Gomes, Manoel de Meireles Freire, Leão José de Sena, José Custódio da Siqueira Bueno, Luiz Antonio de Alvarenga, Emilio Paulo de Carvalho, Joaquim Antonio Rodrigues de Vasconcelos, Fernando Pacheco Jordão, Francisco Benedito de Oliveira Matos, Manoel de 
Dentre os noventa e dois presentes no abaixo assinado, apenas o conselheiro geral José Antonio dos Reis ${ }^{552}$ e o suplente Manoel Dias de Toledo - ambos eleitos para a $2^{\mathrm{a}}$ Reunião do Conselho Geral de São Paulo - ocupavam naquele momento cargos de destaque na política provincial. Alguns deles despontariam na cena política mais tarde, como Fernando Pacheco Jordão ${ }^{553}$, membro da $3^{\mathrm{a}}$ Reunião do Conselho Geral de São Paulo; Mariano Rodrigues de Souza Mello e Martim Gonçalves Gomide, deputados pela $8^{\text {a }}$ legislatura da Assembléia Provincial; e o próprio Manoel Dias de Toledo, duas vezes presidente da província de São Paulo.

Além de José Antonio dos Reis e Manoel Dias de Toledo, colegas de turma entre 1828 e 1831, outros onze estudantes do Curso Jurídico de São Paulo deixaram seus nomes no abaixo assinado: Marcelino Ferreira Bueno, Jose Gaspar dos Santos Lima, Francisco de Assis Pupo, Antonio Manoel de Campos Melo e Emilio Paulo de Carvalho haviam se matriculado no Curso Jurídico em 1829, ao passo que Joaquim Otavio Nebias, João Manoel de Almeida Barbosa, Martim Gonçalves Gomide, Joaquim Inácio Ramalho, Ildefonso

Castro Moreira, Bernardo Justino da Silva, João Jose Moreira, João Crispiniano Soares, Tomaz Gonçalves Gomide, Leocadio Rodrigues de Carvalho, Antonio de Oliveira e Arruda.

552 Jose Antonio dos Reis (1798-1876), bispo de Cuiabá em 1831, era natural de São Paulo. Ordenado presbítero em 1825, ingressou na primeira turma do Curso Jurídico de São Paulo, em 1828, recebendo o título de bacharel em 1832. Em 1829, exerceu o cargo de fiscal da Câmara Municipal de São Paulo. No ano seguinte, foi bibliotecário público da capital paulista. Na política, foi membro do Conselho Geral de São Paulo ( $2^{\mathrm{a}}$ Reunião) e deputado pela bancada paulista na $3^{\mathrm{a}}$ e $4^{\mathrm{a}}$ legislaturas do Império. Cf. MARQUES, op. cit., v.2, pp.50-51.

${ }^{553}$ Fernando Pacheco Jordão (?-1858) era natural de Itu. Filho de Elias Antônio Pacheco e Antônia Clara Jordão - irmã do brigadeiro Manoel Rodrigues Jordão -, estudou leis em Coimbra, onde obteve o título de bacharel. De volta para América, foi nomeado juiz de fora e da alfândega de Santos, posto que serviu até 1830. Foi, também, juiz de fora da cidade de São Paulo, juiz de direito em Itu (1833), desembargador da Relação do Maranhão (1842-1854). Na política, foi membro da $3^{\text {a }}$ Reunião do Conselho Geral de São Paulo e deputado pela $5^{\mathrm{a}}$ e $9^{\mathrm{a}}$ legislatura da Assembléia Provincial e Geral. Cf. MARQUES, op. cit., v.1, p.272. 
Xavier Ferreira, Antonio Rodrigues de Almeida Jordão e João Crispiniano Soares faziam parte da turma do ano de $1830 .^{554}$

Embora ainda não apresentasse a importância que deteria na segunda metade do século XIX, o Curso Jurídico de São Paulo proporcionou, em seus anos iniciais, um fórum de discussão de idéias jurídicas, políticas e artísticas, contribuindo para isso o ingresso de alunos e professores de diferentes partes do Império. ${ }^{555}$ A própria categoria “estudante”, atualmente associada à idéia de juventude, deve ser relativizada para esse período. Ao lado de um Joaquim Otavio Nebias, nascido em 1811, faziam parte do corpo discente homens como Ildelfonso Xavier Ferreira (1795-18??) e José Antonio dos Reis (1798-1876), que por sua vez eram contemporâneos de Manoel Joaquim do Amaral Gurgel (1797-1864) e Antonio Mariano de Azevedo Marques, também alunos do Curso Jurídico, representantes da "moderação" paulista. Os “exaltados”, aliás, foram comumente associados pela imprensa “moderada” à juventude, numa tentativa de menosprezar sua força e ressaltar sua inexperiência política. Num artigo publicado antes da Abdicação, o redator de $O$ Farol afirmou que a maior parte das pessoas que defendiam as reformas da Constituição não sabia como era a política no “tempo antigo”, e por isso não conseguia medir os progressos obtidos com a execução Carta de $1824 .^{556}$

Outros setores da sociedade paulista também estavam representados na lista de assinaturas. Antonio Mariano dos Santos era tenente, tendo sido inspetor do Caminho do Mar no início da década de 1820. Tomaz Gonçalves Gomide era cirurgião. Manoel Joaquim Leite Penteado, capelão-mor do hospital militar na capital paulista, travara relações próximas com Líbero Badaró. Além de alferes, Tomé Manoel de Jesus Varela

\footnotetext{
${ }^{554}$ Cf. VAMPRÉ, op. cit., v.2, pp.102-165.

555 NOGUEIRA, op. cit.

${ }^{556}$ O Farol Paulistano, no 455, 21/02/1831.
} 
fabricava tecidos na cidade de São Paulo. João Jose Moreira, português de nascimento, negociava fazendas. Lucio Manuel Felix do Santos Capelo era farmacêutico e Matheus Fernandes Cantinho procurador, ambos na capital da Província. Francisco Augusto de Oliveira Muniz chegou a ser juiz de fora em Iguape, e Manoel de Campos Penteado aposentou-se como general. ${ }^{557}$

O acirramento do debate em torno da federação e da reforma constitucional culminou na reestruturação do campo de luta política na imprensa paulista. O Farol Paulistano, que após a Abdicação mantivera-se firme no repúdio a qualquer alteração à Carta de 1824, foi aderindo a algumas das reivindicações anteriormente associadas aos “exaltados”. ${ }^{558}$ Digno de nota é o fato de que a alteração do discurso de $O$ Farol coincidiu com escolha de seu diretor, José da Costa Carvalho, para compor a comissão de deputados que elaboraria um primeiro projeto de reforma constitucional, em maio de 1831. Neste mês, o Farol publicou um artigo em que alterava sua argumentação em favor das reformas e da federação. Sobre o sistema federativo afirmou a folha de Costa Carvalho:

“ (...) entendemos muito pouco da Federação do $n^{\circ} 17$ da Voz, bem que muito nosagrade, pois com ella evitaremos a separação das Províncias, conservaremos a integridade do Brasil, e faremos uma só Nação livre e respeitável. É a primeira vez que vemos na Voz alguma explicação do que é Federação; não nos pareceu mal”. 559

Segundo o Farol as reformas deveriam ser feitas com base no artigo 174 da Constituição, solução já aventada por setores intitulados “exaltados” como o jornal $O$

\footnotetext{
557 TAUNAY, op. cit., 1956; ARAÚJO, op. cit., MARQUES, op. cit.

558 Por essa época, aliás, o Farol já vinha sendo acusado de anti-reformista por periódicos de outras províncias, como por exemplo O Mentor das Brasileiras, de Minas Gerais. Cf. O Mentor das Brasileiras, $\mathrm{n}^{\circ}$ 61, 1831.

${ }^{559}$ O Farol Paulistano, $n^{\circ}$ 482, 03/05/1831.
} 
Observador Constitucional, que passou, aliás, a constituir referência para a folha de Costa Carvalho na condução do debate em torno da reforma constitucional. A 7 de maio de 1831, o Farol publicou um artigo baseado em algumas propostas de reforma veiculadas por $O$ Observador em seu $\mathrm{n}^{0}$ 143. Em primeiro lugar, o redator de $O$ Farol acenava para a possibilidade de se retirar do Poder Moderador o seu direito de veto absoluto das decisões do Legislativo, ingerência que na sua opinião estava muito mais próxima das "velhas monarchias da Europa” do que de um estado liberal. Para o mesmo redator, o artigo 164 da Constituição também merecia uma revisão de conteúdo. De acordo com o parágrafo segundo do referido artigo, caberia ao Supremo Tribunal de Justiça "conhecer dos delitos e erros de ofício que cometerem os seus ministros, os da relação, os empregados no corpo diplomático e os presidentes das províncias”, o que significaria, no entender do redator, a cristalização de um “juízo privativo” facilmente corruptível e que privilegiaria homens já dotados de grande poder. O artigo 90, sobre o processo eleitoral no Império, também demandava modificações. Para o redator de $O$ Farol, o sistema de eleições indiretas trazia consigo "alguns inconvenientes", como o de deixar para um número muito de reduzido de pessoas a escolha efetiva de seus políticos. E sentenciou: "Se o Governo é representativo, se a Nação é que nomeia seus representantes, ella que os nomeie de facto" ${ }^{560}$

O fato de $O$ Farol ter aderido a algumas propostas de reforma serviu de arma política para seus adversários. A Voz Paulistana criticou-o por sua mudança de opinião e acusou-o de entrar em "contradição” com seus exemplares anteriores. Diante disso, afirmou esperar que $O$ Farol não voltasse a modificar suas considerações, a fim de evitar futuras incoerências. A folha de Costa Carvalho defendeu-se das acusações afirmando que sempre desejara alterações na Constituição, e que "sem intenção alguma” seus artigos acabaram

\footnotetext{
${ }^{560}$ O Farol Paulistano, n ${ }^{\circ} 484$, 07/05/1831.
} 
produzindo uma idéia contrária. Com relação à “mudança de opinião”, o redator de O Farol contestou a argumentação de $A$ Voz e, em certa medida para justificar as supostas alterações ocorridas em seu discurso, afirmou que "sempre” modificaria o conteúdo de seus artigos caso “boas razões” o convencessem:

“(...) no pedido que nos faz o Sr. da $V o z$ para que nunca mais mudemos de opinião; pelo contrário; mudaremos sempre que boas razões nos convenção de estarmos em erro, muito mais se isto for feito por quem tem consciência da superioridade de sua lógica; só trabalharemos para que taes mudanças em nós não se fação por motivos de ambição ou de interesse."561

Concomitantemente ao desdobramento da luta política na imprensa, o poder provincial paulista teve que se haver ante às circunstâncias do momento. Uma vez que a composição do poder provincial, sobretudo dos Conselhos Geral e da Presidência, era de ampla maioria “moderada”, verificou-se a tentativa de garantir suporte político à Regência, que aos poucos viu setores paulistas ocuparem cargos estratégicos do Executivo imperial, a exemplo de Vergueiro, Costa Carvalho e Feijó. Isso significava que políticos de São Paulo passariam a influir de maneira decisiva na materialização do projeto político daqueles que ascenderam ao Governo após a Abdicação.

No tocante à atuação do Conselho da Presidência de São Paulo, esta se fez ainda mais incisiva no controle da ordem pública. Se o clima era de incerteza e instabilidade política, as iniciativas partidas do Conselho convergiram para uma tentativa de se conservar o poder político provincial na esfera da legalidade, e de franquear apoio ao recéminstaurado governo regencial. Após ficar quase dois meses sem ser convocado, o Conselho

${ }^{561}$ O Farol Paulistano, ${ }^{\circ}$ 486, 14/05/1831. 
se reuniu em 21 de maio de 1831 para discutir sobre os "tumultos" e as "assoadas nocturnas” que, segundo o juiz de paz da freguesia da Sé, José Antônio dos Reis, ainda aconteciam na cidade de São Paulo após o 7 de abril. De acordo com o juiz de paz, não era possível coibir os responsáveis pelos tumultos, pois sua força era "superior a toda outra que se lhe opunha”, e contava com “muita condescendência e cooperação dos militares, particularmente do Setimo Batalhão”, além da presença de “estudantes”. A convite do vicepresidente da província Manoel Joaquim Gonçalves de Andrade, participaram da sessão extraordinária do Conselho da Presidência o comandante das armas, o comandante dos batalhões da guarnição e os juízes de paz da capital paulista. Questionado sobre uma possível cooperação de militares nas “assoadas” ocorridas na capital, o comandante das armas afirmou que as patrulhas não tinham entrado em ação pois nenhum "flagrante delicto" ocorrera de fato, e que não havia motivo algum para "desconfiarem de seus soldados”. O Conselho decidiu, diante de tais alegações, que a partir dali o comandante das armas enviaria tropas diariamente aos juizes de paz da capital, para que esses dessem instruções de policiamento. Resolveu-se, também, que ficaria à disposição do comandante das armas 1.400 cartuchos para serem distribuídos aos batalhões e corpos de guarda. ${ }^{562}$

O Farol Paulistano comentou o desfecho da sessão extraordinária louvando a disciplina dos “briosos Soldados Paulistanos”, num claro intuito de minimizar a força dos incidentes ocorridos. Seu redator afirmou, ainda, que "taes magotes" haviam “desapparecido” nas últimas noites”. ${ }^{563}$ É mais provável, todavia, que agitações semelhantes continuaram a ocorrer na capital paulista, de forma que menos de um mês depois, a fim de controlar a situação em toda a Província, o recém-nomeado presidente

\footnotetext{
${ }^{562}$ ACP, v.15, sessão de 21/05/1831, pp.142-144.

${ }^{563}$ O Farol Paulistano, no 490, 23/05/1831.
} 
Manoel Theodoro de Araújo Azambuja convocou extraordinariamente o Conselho da Presidência, que tomou um conjunto de medidas as quais envolviam a cooperação dos juizes de paz, juízes criminais e Câmaras Municipais:

“O Exmo. Sr. Presidente declarou aberta a Sessão, e bem assim que havia convocado o Conselho para esta Sessão extraordinária a fim de se resolver sobre o negócio urgentíssimo de promover-se a tranqüilidade Pública, e a Polícia desta Província, para o que appresentou redigida uma circular contendo vários artigos, para ser expedida aos Juizes de Paz da mesma Provincia, e outras as Câmaras, ambas tendentes aquelle fim, as quaes entrando em discussão, e soffrendo mui pequenas alterações forão approvadas, e passarão pela maneira seguinte: $-1^{\circ}$ Que os Juizes de Paz passem a fazer o quanto antes o alistamento dos homens livres de suas Freguezias: $2^{\circ}$ Que extrahião huma relação das pessoas que podem ser eleitores, e daquellas que lhes merecem confiança: $3^{\circ}$ Que lhes entreguem tantas armas, quantas forem precizas para armarem os indivíduos da lista apurada: $4^{\circ}$ Que o armamento seja conservado em poder dos ditos indivíduos, até que a segurança Pública o exija, ou se organizem as Guardas Nacionais. $5^{\circ}$ Que o Juizes de Paz fação responsáveis aos mesmos pelo abuzo que fizeram d'arma, que se lhes confiar, e que a entreguem no estado em que a receberem promptas e limpas: $6^{\circ}$ Que juizes de paz se prestem auxiliar com a força armada civil e militar aos cidadãos que requisitaram, a fim de punirem os seus e escravos; e no caso que estes resistão, procedão na conformidade das leis: $7^{\circ}$ Ordenarão aos seus officiaes de quarteirões, ou delegados, que auxiliem qualquer senhor de escravos que requisitar não havendo tempo de fazer ao Juiz: $8^{\circ}$ Formarão segunda relação dos vadios, os farão corrigir na conformidade da lei de paz: $9^{\circ}$ Os Juizes de Paz farão appresentar ao Juiz Criminal quaesquer indivíduos suspeitos, e todo aquelle que der noticioas que possão perturbar socego Público para proceder contra elles em conformidade da lei: $10^{\circ}$ finalmente, que remettetão as indicadas relações ao Governo, e igualmente participem tudo o mais occorrer em seus respectivos destrictos. ${ }^{564}$

O clima de instabilidade política era ainda maior na Corte, onde decisões de primeira ordem foram tomadas com a finalidade de manter a segurança pública e organizar

${ }^{564}$ ACP, v.15, sessão de 22/06/1831, pp.146. 
o governo regencial. ${ }^{565}$ No Parlamento, aprovou-se em 14 de junho de 1831 aquela que ficou conhecida como a "Lei da Regência”, e que na prática estabeleceu os procedimentos eleitorais para a Regência Trina Permanente e estipulou seu espaço de atuação. ${ }^{566}$ Numa clara tentativa de limitar sua intervenção política, a Assembléia Geral retirou da Regência o direito de utilizar algumas das principais atribuições do Poder Moderador, dentre elas dissolver a Câmara dos Deputados, conceder anistia, honras, títulos e ordens militares, e nomear conselheiros de Estado, com exceção nos casos em que ficassem três ou menos integrantes. De resto, a Regência poderia se valer do Poder Moderador e do Executivo imperial, contanto que obtivesse referenda dos ministros. Segundo Cecilia Helena de Salles Oliveira, o resultado da Lei da Regência explicitava os embates entre membros da Câmara dos Deputados e elementos que haviam dado suporte ao governo de D. Pedro, mas que ainda se encontravam no Senado e no Conselho de Estado. ${ }^{567}$

Logo ficou claro que os liberais “moderados” tomariam a dianteira do controle da máquina pública a partir dali, o que de fato se consubstanciou na escolha dos membros da Regência Trina Permanente, em 17 de junho de 1831, formada pelos deputados José da Costa Carvalho e João Bráulio Muniz, e novamente pelo general Francisco Lima e Silva. Maioria na Câmara dos Deputados e com presença marcante nos Conselhos Provinciais e Câmaras Municipais, especialmente em São Paulo e Minas Gerais, os “moderados” se viram fortalecidos diante dos “exaltados” - com pouca representatividade nas esferas

\footnotetext{
${ }^{565}$ Diversas medidas foram tomadas pela Regência Trina Provisória com o intuito de assegurar a ordem pública e o status quo político. Ver, por exemplo, "Decisão do Ministério da Guerra de 26 de abril de 1831 exige um relatório exacto dos estabelecimentos e obras militares em todas as Provincias", in Coleção das decisões do governo de 1831, op. cit., p.63.

566 "Lei de 14 de junho de 1831 - sobre a forma de eleição da Regência Permanente e suas atribuições", in Coleção das Leis do Império de 1831, op. cit., Parte Primeira, pp.19-23.

${ }^{567}$ OLIVEIRA, Cecilia Helena de Salles. "O Conelho de Estado e o complexo funcionamento do governo monárquio no Brasil do século XIX”, in almanack brasiliense, n5, maio/2007, p.46. Disponível em www.almanack.usp.br. Acesso em janeiro/2008.
} 
oficiais de poder - e dos “caramurus”, que vinham se reestruturando após a Abdicação. Em pouco tempo rotulada pela imprensa liberal de "revolução gloriosa de 7 de abril”"568, a Abdicação foi retratada pelos "moderados" como a etapa final de um processo revolucionário e não como o início de um, de modo que periódicos como o fluminense $O$ Independente, dirigido por Joaquim José Rodrigues Torres, vaticinaram: “a revolução acabou enfim com a abdicação”. ${ }^{569}$ Note-se aí que o emprego da palavra revolução, que já por essa época adquirira o sentido de uma ruptura social em direção ao futuro, atrelava-se à idéia de negação ao reinado de D. Pedro e, simultaneamente, à concepção de que após a Abdicação instalara-se um novo governo. Assim, para os “moderados”, o prolongamento da "revolução" incorreria, inevitavelmente, na desagregação entre as províncias e na dissolução da estrutura política do Império, cabendo então encerrá-la. ${ }^{570}$

Enquanto isso, a medida em que iam conquistando espaço na sociedade paulista, sobretudo na cidade de São Paulo, os “exaltados” passaram a refinar seu embasamento conceitual, tratando de expor com maior minúcia temas centrais de seu amplo e heterogêneo programa político, tal como era caso da federação. De acordo com o Observador Constitucional, o sistema federativo seria um conglomerado de associações dotadas de autonomia mas subordinadas a um governo central, estrutura essa que o Império já possuiria em certo grau, em virtude da existência dos Conselhos Provinciais. Mas para aperfeiçoar a federação era imperativo aumentar os “direitos” das Províncias, ou seja, retirar do governo central aqueles de soberania “interna” e deixar-lhes somente os de atribuição “externa”. Tomando como exemplo os Estados Unidos da América do Norte, o redator de O Observador sustentou que o alargamento da autonomia provincial não geraria

\footnotetext{
${ }^{568}$ Ver, por exemplo, o jornal Aurora Fluminense, n $470,11 / 04 / 1831$.

${ }^{569} \mathrm{O}$ Independente, $\mathrm{n}^{\circ} 2,06 / 05 / 1831$.

${ }^{570}$ MOREL, op. cit., 2005, pp.126-127.
} 
desagregação, já que as províncias, preocupadas com seus negócios, vislumbrariam na “união” com as demais um mecanismo para salvaguardar a sua integridade e a de todo o Império:

“Em numeros anteriores nós temos fallado de passagem da Federação; entretanto nós não temos ainda apresentado nossa opinião sobre esta matéria, o que agora faremos.

Nada mais lato do que a palavra Federação. Ella se pode definir em geral um complexo de pequenas Associações ligadas por um governo Geral. Ella é susceptível de graduações, e pode se dizer tanto mais perfeita quanto cada um d'essas pequenas Associações adquire, ou possue maior somma de direitos, mais imperfeita quanto ellas os possuem em menor numero.

Uma Nação dividida em Províncias, ou estados etc. tendo cada uma d'estas um Governo, que as administre, embora seja elle dependente em todo d'um Governo Central, esta Nação possue comtudo o Governo Federativo; pois que ella não é, senão uma colleção de associações, bem que com muito poucos direitos de ser.

O Governo actual do Brazil é um Governo Federativo; e um Governo Federativo algum tanto já aperfeiçoado; pois que as Províncias tem seus Conselhos Provinciaes, que possuem uma somma bem que diminuta de direitos; podendo tractar de certos negócios particulares etc.: e a proporção que estes Conselhos, ou Associação, que compõem as Províncias, tirarem das mãos do Governo Geral mais direitos para aumental-a, temos que a Federação se vai aperfeiçoando; tem que com a vulgarizaçãp de princípios, com o augmento de população, e civilização toque a sua perfeição; isto é, subtraia ao Governo Geral todos os direitos que constituem a sua Soberania interna, deixando-lhe só os de sua Soberania externa. É a este por excellencia, que se chama o Governo Federativo; que se pode definir a reunião de muitas pequenas Associações, que tem o seu Governo particular, ligadas por um Governo Geral.

D’aqui já mui bem poderão ver nosos leitores com quanta sem razão se tem argumentado no Brasil contra a doutrina da Federação. A questão não pode versar sobre o ponto de que devera ou não ser o Governo do Brazil Federativo, sim se a Federação, que nos já temos, deverá ou não ser mais aperfeiçoada: isto é se as Províncias deverão, ou não ter maior somma de direitos (...) 
Diremos agora alguma coisa a respeito do Governo Federativo em geral. É elle bom? Para o provar bastará só lembrarmos-nos, que é esse sistema de Governo, que tem feito a felicidade de um Povo, que hoje no mundo inteiro é olhado, como modello das Sociedades bem constituídas. Embora se diga, que este sistema, dividindo um todo em muitas partes, e dando á cada uma d’ellas as obrigações, que possuía o tempo, necessariamente devera infraquecel-o; e que cada uma das partes perde então, por si também um todo; embora se diga também, que a rivalidade, resultado da independência é uma tal forma de Governo o gérmen da destruição; pois que cada uma das partes movida pelos seus interesses, tende a desobrigar-se do que se deve, e a separar-se da união, aonde julga haver um princípio, que a pertende escravisar. O Governo dos Estados-Unidos tem mostrado, que estes raciocínios não passão de meras conjecturas, ou mentalidades, e que na pratica o contrario sucede.

A força que se diz, perde o todo pela divisão em varias partes, aumenta-se, pelo contrário, quando cada uma dessas partes interessacas na sua segurança, considera que a sua força é na união; e que ella separada pode mais perder, pois que a união das outras tem força muito maior, com que possa subjugar. ${ }^{571}$

A idéia de que o Brasil já estaria dotado de um “Governo Federativo” agradou o redator de O Farol Paulistano, que teceu longas considerações sobre o artigo publicado pelo Observador:

“ O Observador (...) traz no seu N.158 um artigo acerca do Governo Federatvo, que é digno de ser lido por todos aquelles que de boa fé desejão o melhoramento das nossas instituições sociaes. Sobre tudo é digna de notar-se a seguinte proposição - o Governo actual do Brasil é um Governo Federativo, e um Governo Federativo algum tanto já aperfeiçoado - e d'aqual segue a mostrar como é que as nossas Províncias ganhando pouco a pouco direitos sobre o Governo Geral pelo que toca á sua administração interna, ir-se-há aperfeiçoando o systema federal, até que as mesmas Províncias se constituão como Estados Independentes, relevando somente d'um centro commum pelo que toca aos negócios externos com as demais associações externas.

${ }^{571}$ O Observador Constitucional, $\mathrm{n}^{\circ}$ 158, 27/06/1831. 
Foi este sempre o nosso modo de ver as coisas do Brazil, sua Constituição actual, e as reformas d'esta, hoje unanimente reclamadas por todos os Brazileiros, e que só o não tinhão sido por alguns, que a todos os respeitos merecem o nome de bons brasileiros, em quanto o tocar n'uma virgula da Constituição era um precedente funestissimo para esse Poder Tyramnio e tão justamente detestado ir avante em seus planos de dominação absoluta.

Mas depois de uma revolução gloriosa, que em vão alguns perversos tem querido manchar, depois que uma longa minoridade nos collocou uma posição muito diversa, ficou sendo lícito aspirar ás reformas que convem ao nosso estado de civilização, á região de que fazemos parte, e as outras circunstancias que nos são peculiares.

Se porém o nosso Governo já alguma coisa tem de Federativo, como muito bem diz o Observador; se foi esse o principal motivo porque foi avidamente acceita pelos Brazileiros a Constituição que nos rege; se essa isca com que nos quis engordar a má-fé do offertante d'ella, e outra de se poder reformar a Constituição pelos mesmos meios por ella prescriptos, e sem dependência d’uma nova dissolução dos laços sociaies, érão predicados que tornavam a mesma Constituição, se não perfeita para o tempo, em que foi jurada, e muito menos para o de agora, ao menos muito boa, e melhor que quazi todas que (...) por esse mundo; se tendo a Câmara dos Deputados, que pela sua marcha no sentido da ultima gloriosa revolução, e pelo ardor (só temperado pela necessária prudencia) com que se ocupa de reformar tudo quanto é vicioso, de curar todas as chagas do Brazil, tem feito calar os mais exagerados, e ainda os próprios ambiciosos que tem um resto de pudor; que necessidade tínhamos nós de reformar a Constituição por via d’uma nova revolução? Para que serviria uma Assembléa Constituinte, que alguns apontão como necessária? de que maneira se havia de formar essa Assembléa, sem primeiro declararem-se rotos esses mesmos laços sociaes? E que ganharia o Brazil em interromper por espaço d'antes a factura de leis particulares, de códigos, e de tantos outros melhoramentos, em cuja marcha vae agora avançando, sem esforços, a par da reforma de seu Código Fundamental? E tudo isto é suppondo ainda que a mudança de todo o pacto social se fizesse d'uma vez sem commoções, sem dissidências, sem as Províncias quererem tirar cada um para seu lado, sem mil outros inconvenientes emfim, que são fáceis de conceber por todo aquelle que reflecte, ou que sabe ao menos a significação das palavras que se serve.

Tínhamos pois muita razão quando propugnávamos para que as reformas fossem feitas dentro da órbita Constitucional; era pois muitíssimo exato o que dizíamos acerca da aptidão que tem a nossa actual Constituição para se melhorar e aperfeiçoar como de si 
mesma, e muito mas depressa do que se lhe fosse substituída de repente uma outra. O que se diz o Observador acerca de ser o Governo já Federativo, ou encerrar ao menos em si um tal elemento, é applicável a tudo quanto se possa desejar de mais illimitado na ordem Democrática; os elementos da Democracia também estão ahi todos na Constituição, como já por mais d'uma vez havemos dicto, e por devagar que se marche, poderemos ir ter em muito pouco tempo a uma Republica Federativa, se isto se julgar indispensável á ventura dos povos. Em uma palavra proclamando-se por já por via d'uma revolução o Governo Republicano, teríamos infalivelmente com o nome de Republica, em um estado d’anarchia, cujo termo não seria fácil adaptar, que o império absoluto d’um Déspota Militar, ou coisa que o valha; marchando-se nas reformas pelos tramites da Constituição, teremos em breve, todas as garantias da mais perfeita Democracia (...)”. ${ }^{572}$

O cerne do artigo de $O$ Farol era demonstrar, partindo da premissa apontada pelo $O$ Observador de que o Brasil já apresentava traços de um “Governo Federativo algum tanto já aperfeiçoado”, que uma possível alteração no sistema monárquico-constitucional dar-seia “dentro da órbita Constitucional”, ou seja, de forma gradual, ancorada juridicamente pela Carta de 1824 e sem a necessidade de uma "nova revolução”, da convocação de uma “Assembléa Constituinte” ou da aplicação de um novo texto constitucional. Ao instrumentalizar o discurso de O Observador a seu favor, o redator de O Farol argumentou, quer nos parecer com o intuito de amainar as divergências entre "moderados" e “exaltados”, que a realização de reformas “pelos tramites da Constituição” traria, futuramente, as garantias da “mais perfeita Democracia”, sem grandes convulsões sociais.

Em verdade, aos poucos a reforma constitucional deixou de ser uma aspiração exclusiva dos “exaltados" para ser aceita, ainda que parcialmente, pela ala liberal “moderada”, atitude que em certa medida pode ser entendida como um alinhamento circunstancial dos mantenedores da Regência com uma oposição que crescia

${ }^{572}$ O Farol Paulistano, no 504, 30/06/1831. 
gradualmente. $^{573}$ A reforma constitucional e, sobretudo, o debate acerca do sistema federativo ganharam uma conotação positiva para os "moderados", que, em meio à instabilidade política da época, viram na ampliação dos poderes provinciais uma forma de garantirem-se no poder e assegurarem a continuidade do regime monárquico-constitucional representativo. Em suma, para os “moderados" a federação havia se tornado um instrumento político que possibilitaria consubstanciar, ainda que provisoriamente, interesses distintos acerca da organização da máquina pública, e ainda assim viabilizar a concepção de um Estado forte em moldes liberais. Isso não quer dizer, entretanto, que a federação tenha sido amplamente aceita pelos “moderados”. Mais tarde, já em 1833, Evaristo Ferreira da Veiga afirmaria por meio de A Aurora Fluminense que esta se declarara em favor da federação não por convicção de princípios, mas por que se deveria “aceitar francamente” aquilo que era amplamente reivindicado. ${ }^{574}$

Após os comentários publicados pelo O Farol, o Observador deu prosseguimento à sua argumentação no número seguinte do jornal, e enfatizou que num sistema federativo a “civilização” e a “indústria” do Império tenderiam a aperfeiçoar-se, pois a existência de associações autônomas dinamizaria o funcionamento de um Estado que vinha se mostrando impotente diante da sua imensidão e da falta de recursos para gerir as províncias eqüitativamente. Mas a despeito de defender a federação, o redator reconheceu que o Brasil não teria os "homens” e a "moralidade” necessários para que fosse instalada uma “Federação Republicana”, isto é, um regime republicano, distanciando-se neste ponto da ala mais radical dos “exaltados”, que via na república uma solução imediatamente viável para o

\footnotetext{
${ }^{573}$ CASTRO, op. cit.

${ }^{574}$ A Aurora Fluminense, n718, 07/01/1833.
} 
Brasil. Para o mesmo redator, o caminho a trilhar seria, portanto, o de aperfeiçoar o sistema federativo, o que na prática se resumiria no aumento de poderes das províncias:

“Tambem que esta forma de Governo é a mais própria para o desenvolvimento da civilização, e da industria, quem o poderá duvidar? Em um estado imenso, onde um só centro de poder vigia os interesses d'um Povo, a sua influencia fraca fracamente favorece a industria, e a civilização dos pontos distantes d'esse centro; e a industria, e a civilização encontrando demora nos socorros, que se-lhes devem prestar retardar-se em seu desenvolvimento. Alem diso, os diversos pontos do Estado, fiados no igual direito, que elles tem a protecção do centro, descanção, e quase nunca trabalhão por adquirir vantangens, em que excedão uns aos outros: com isto a industria se demora, a civilização se retarda só a indolência ninguém ignorará. O descorçoamento também ahi apparece. As contribuições, e tributos, que pesão sobre o povo por nem-um bem visível são suavisados. Sommas, e sommas sahem de diversos pontos, e ellas sendo absorvidas pelo Governo central, uma obra, uma coisa qualquer não apparece, com que ao menos o triste povo se console de as ter augmentado com suas fadigas e suores.

Ainda isto não é tudo: as auctoridades, distantes desse Poder, que as tem enviado à esses pontos remotos, certas de que as queixas de suas arbitrariedades serão pela distancia mal ouvidas do Poder Central, desenvolvem, e apresentão sem rebuço todo o seu mão humor. Debalde um povo levanta suas vozes, ellas se perdem no immenso espaço que o separa do Poder; com isto esssas Autoridades redobrão seus furores, em um povo que tem inultilmente clamado por justiça tendo tido por resposta o silencio, ou franqueia, e se larga ao furor dos despotas, ou insurge por livrar-se da oppressão: em qualquer dos casos seus interesses são atacados, elle deve perder.

Tudo ao contrario succede nos Governos Federativos. Este Governo não sendo senão uma grande Sociedade composta de muitas pequenas Sociedades, que tem cada uma seu Governo particular, e que são todas ligadas por um governo Geral, apresenta todas as vantagens, e presta todos os socorros, de que a civilização, e o desenvolvimento das faculdades humanas necessitem. Nele um braço protector acompanha todo o Cidadão: as suas instrucção são lhe pagas, sem que elle saia o liminar de sua casa.

O indefferentismo, e indolencia ahi não reinão. Apezar de ter direito á exigir do Poder Geral a mesma Protecção, os diversos pontos da união observão, e conhecem, que elles serão tanto mais felizes, quanto mais trabalharem para o ser. A emulação não tarda a 
apparecer; e ella, sendo o móvel das grandes accções, traz comsigo a prosperidade dos Estados. Apparecendo ella faz prodígios; os homens, movidos por um interesse immediato é seus trabalhos; applicão todos os seus esforços para adquirirem vantagens os de um sobre os de outro ponto: uma luta então entre todos se levanta, e em resultado todos promovem a civilização, a industria, a felicidade de sua Pátria: e no meio desta luta, quando no interno de cada um dos Pontos todos se applicão a promovel-as, o Governo Geral como collorado em uma elevada guarita vigia os interesses de sua grande família, defende-a do inimigo extenso, alimenta em todos os pontos a alma vivificadora das Sociedades, sustenta-lhes a Liberdade.

Porem, se tudo isto é certo não o é menos, que nesta mais, que em qualquer outra forma de Governo se tem necessidade de homens instruídos, e que sejão capazes de dirigir os negocios de sua Patria; que nesta mais, que em qualquer outra forma de Governo se necessitão de bons costumes, e de uma moralização perfeita na massa da população. Terá já o Brazil estes homens? Não. Terá já o Brasil esta moralização? Não. Se achará ja o Brazil em um estado de civilização capaz de formar uma Federação Republicana? Não.

(...) Esta substituição porem se irá operando pouco a pouco, e a proporção que homens novos, e hábeis appareção; ella não levara muitos annos; muito deve adiantar-se nestes seis, ou sete. N'este intermédio pode muito aperfeiçoar-se a moralização, e bons costumes do Povo, pois que os tendo, como devemos esperar, o Governo, aquelle, que sempre participa de suas qualidades os tera também.

É só quando poderemos ser perfeitamente Republicanos, é só quando a nossa Federação poderá talvez ser ao todo aperfeiçoada.

Si hoje não podemos pois a ter tal, tenhamol-a n'aquelle grão, que é compatível com a nossa civilização, e costumes; isto é, demos mais direitos as Províncias, mais attribuições as Assembléas Provinciaes, tornando aquellas mais independentes do Poder Geral. Isto tem mostrado querer fazer a Camara dos Srs. Deputados; com isto podemos contar (...). ${ }^{575}$

Com este artigo e o anterior o Observador Constitucional definiu com maior clareza seu posicionamento no tocante à reforma constitucional e à federação. A despeito do caráter sinuoso e fluido do debate travado pelos jornais da época, é possível sugerir que o

${ }^{575}$ O Observador Constitucional, nº 159, 01/07/1831. Grifo nosso. 
Observador Constitucional distinguiu-se entre o multifacetado campo político dos “exaltados” por meio da defesa de uma monarquia federativa onde as províncias teriam uma relativa independência do governo geral. A idéia de que fossem conferidas "mais attribuições" às "Assembléas Provinciaes" seria o elemento central da reforma constitucional, a ser feita com base na Carta de 1824. Com isso descartava-se a hipótese da implementação imediata de um sistema republicano/federativo à semelhança daquele em vigor os Estados Unidos da América, tornando a solução republicana uma realidade a médio e longo prazos, quase teleológica, a ser conquistada aos poucos e em meio ao amadurecimento político da sociedade brasileira.

É provável que por traz desse discurso legalista não houvesse uma recusa completa à implementação mais imediata da república, tal como sempre se colocaram os “moderados”. Nesse sentido, a manutenção do regime monárquico poderia ser uma arma retórica para aproximar-se do público leitor e mostrar-lhe, de forma indireta, as vantagens de um regime republicano. De todo o modo, a aceitação da monarquia constitucional era um ponto de aproximação com os "moderados" - haja vista as considerações feitas pelo $O$ Farol - e um elemento distintivo em relação aos “exaltados” mais radicais, representados em São Paulo pela Voz Paulistana.

As considerações publicadas no no 159 de $O$ Observador não obtiveram resposta de O Farol Paulistano, que teve sua circulação suspensa dias depois. Conforme se observou no primeiro capítulo, a interrupção na publicação de O Farol Paulistano esteve relacionada, possivelmente, com a ocupação do cargo de regente permanente por seu diretor, José da Costa Carvalho, em junho de 1831. Em nota publicada no início de julho, o redator de $O$ Observador opinou que caso o Farol continuasse a ser publicado, alguma "coisa desairosa" 
cairia sobre seu “redator proprietário”, o regente José da Costa Carvalho. ${ }^{576}$ Nesse sentido é provável que o crescimento da oposição ao Farol tenha enfraquecido sua imagem política e colocado em perigo a de seu proprietário, de modo que o encerramento das atividades do jornal possa ter sido uma estratégia de defesa.

Enquanto isso, no Rio de Janeiro, a discussão em torno da reforma constitucional e da probabilidade da monarquia brasileira ser reestruturada em moldes federativos passou a ocupar lugar de destaque dentro do Parlamento. Se de um lado a vacância do trono foi entendida pelos “moderados” como a chance definitiva de alcançarem o poder, de outro havia a possibilidade de reestruturá-lo político-juridicamente conforme seus interesses. Mas a questão era mais intrincada do que isso, posto que a instabilidade gerada pela Abdicação ampliara o espectro social de atuação política ou, melhor dizendo, alargara o horizonte de demandas por transformações na estrutura do Estado Nacional. A pressão advinda principalmente dos setores liberais mais radicais fez com que os “moderados”, a essa época maioria na Câmara dos Deputados, trouxessem para si a direção das alterações que seriam feitas na monarquia brasileira, todas elas dentro da legalidade e com base na Carta de $1824 .^{577}$

Um dos primeiros deputados a sugerir modificações no texto constitucional foi o baiano Antonio Ferreira França, que já havia sido eleito pela sua província natal na legislatura anterior. No início de maio de 1831 surgiu uma discussão em torno da criação de um Conselho Geral na província do Rio de Janeiro, mas que foi barrada por inconstitucionalidade, pois o artigo 72 da Carta de 1824 proibia a instalação daquele órgão na capital do Império. Segundo Ferreira França, por esse e outros motivos - que se

\footnotetext{
${ }^{576}$ O Observador Constitucional, $\mathrm{n}^{\circ}$ 160, 04/07/1831.

${ }^{577}$ CASTRO, op. cit.
} 
resumiam à ampliação de poderes da esfera provincial - era necessário alterar a Carta de 1824 para torná-la “perfeita”. No dia 6 do mesmo mês, José Cesário de Miranda Ribeiro, deputado por Minas Gerais, apresentou um requerimento cujo objetivo era criar uma comissão especial encarregada de propor as reformas constitucionais de acordo com os artigos 175, 176 e 177 da Carta de 1824. Isto é, primeiro seriam discutidos os artigos a serem alterados; depois, as alterações passariam pelas duas Casas e seriam sancionadas na forma de lei; esta, por fim, serviria como base para a discussão a ser feita pela legislatura seguinte, a única com poderes efetivos de aprovar a reforma constitucional em definitivo. ${ }^{578}$

Parcela dos deputados criticou tais propostas sob o pretexto de que trariam instabilidade ao regime estabelecido. O baiano Lino Coutinho e o pernambucano Luiz Francisco de Paula Cavalcanti de Albuquerque chamaram a atenção para o fato de que eventuais alterações na Carta de 1824 poderiam causar a desagregação entre as províncias, pois ressaltariam os poderes locais. Ainda assim, a proposta de Miranda Ribeiro foi aprovada por grande maioria. Para a comissão incumbida de apresentar o conjunto de reformas a serem feitas na Constituição foram eleitos os deputados José da Costa Carvalho, pela Bahia, Francisco de Paula Sousa e Melo, por São Paulo, e o próprio José Cesário Miranda Ribeiro. ${ }^{579} \mathrm{Na}$ época, o redator de O Observador Constitucional sugeriu que as Câmaras Municipais apresentassem à Assembléia Geral os pontos que julgassem essenciais no encaminhamento da reforma constitucional. ${ }^{580}$ É possível depreender, dessa recomendação, uma tentativa de minar a exclusividade na discussão da reforma constitucional do Parlamento, estendendo-a a outras esferas de poder representativo.

\footnotetext{
${ }^{578}$ SLEMIAN, op. cit., pp.231-232.

${ }^{579}$ Ibidem.

${ }^{580}$ O Observador Constitucional, n 152, 27/05/1831.
} 
A comissão apresentou o projeto de reforma constitucional na sessão ordinária de 25 de julho de 1831. Em síntese, seu conteúdo propunha mudanças que alterariam radicalmente a estrutura política do Império. Este seria transformado em uma associação ligada por laços federativos, embora se mantivesse o regime monárquico. O Poder Moderador, o Conselho de Estado e o Senado vitalício estariam suprimidos. O tempo de duração das legislaturas seria diminuído de quatro para dois anos, e as rendas do Império divididas em gerais e provinciais. Em substituição à Regência Trina seria estabelecido o cargo de regente uno. Na esfera provincial, criar-se-iam no lugar dos Conselhos Gerais as Assembléias Provinciais, que teriam o poder de legislar sobre questões locais, inclusive sobre a estrutura orçamentária e tributária.

O projeto de reforma foi interpretado de maneiras distintas pelos círculos políticos da época. Poucos dias após sua apresentação em plenário, o Observador Constitucional publicou uma apreciação da proposta apresentada pela comissão. Para o seu redator, o núcleo do projeto assentava-se na “divisão do Império em Províncias”, mais especificamente nas relações entre poder local e central. A extinção do Conselho de Estado e do Senado vitalício, bem como a criação das Assembléias provinciais e do cargo de regente uno garantiriam à nação o “princípio Republicano das Representações populares, eletivas e temporárias", tornando o atual governo uma "monarchia de nome”, um estado transitório para a república:

“ (...) A Monarchia, em uma palavra está quase redusida a uma Monarchia de nome, e que é fácil extinguir de todo, logo que os elementos, de que se compõem a nossa população, e outros differentes, que lutão no meio do estado, se tornarem mais homogêneos, tornando-se uma massa mais volumosa, e compata, que seja capaz de opporse a invasões do arbitrário, e aos desvarios populares, que alguma coisa tem com este de 
commum; logo finalmente que conhecido melhor o ponto para onde todos nos devemos voltar, e caminhar, por meio das luzes d'aqui em diante adquiridas, que devem augmentarse n’uma razão, e com uma rapidez espantosa, menor contrariedade appareça a respeito dos meios, que se devem empregar, para chegarmos com brevidade, ao ponto desejado dos Brasileiros, a uma Republica unida, fundada sobre bons estáveis, que não podem se outras, senão a Liberdade, e a Justiça, palavras synonymas”. 581

A leitura feita pelo O Observador corroborava com as expectativas de parte dos “exaltados” que vislumbrava na reforma constitucional uma estratégia de amoldar, gradativamente, a política brasileira ao sistema republicano. Não é de admirar, nesse sentido, que o projeto tenha recebido censuras na Câmara dos Deputados. O baiano Antônio Pereira Rebouças concebeu o projeto como radical em demasia e “anticonstitucional”. ${ }^{582}$ Em virtude das discussões suscitadas pelo texto original, Miranda Ribeiro apresentou um outro mais sucinto, por ele mesmo redigido, mas que na essência continha os mesmos pontos do projeto original.

Em meio à discussão da reforma na Câmara dos Deputados, a cidade do Rio de Janeiro tornou-se palco de sucessivas agitações promovidas por setores associados aos “exaltados”, que após o 7 de abril vinham se sentindo afastados do poder pelos “moderados”. Jornais como O Tribuno do Povo e A Nova Luz Brasileira incitavam em seus artigos a convocação de uma Assembléia Constituinte para a realização das reformas. ${ }^{583}$ No início de julho, a escolha de Diogo Feijó para a pasta da Justiça, com amplos poderes de repressão, foi recebida com desagrado pelos “exaltados”. Estes, por sua vez, continuaram se mobilizando com intuito de aumentar sua influência nos negócios públicos, cooperando no levante do $26^{\circ}$ Batalhão de Infantaria do Exército da cidade do Rio

\footnotetext{
${ }^{581}$ O Observador Constitucional, n 165, 29/07/1831.

${ }^{582}$ SLEMIAN, op. cit., p.240.

${ }^{583}$ BASILE, op. cit., 2001.
} 
de Janeiro, sob o comando do major Liberato José, no dia 12 de julho. A sublevação foi logo sufocada pelo governo central, mas no dia seguinte eclodiu outra rebelião, tendo como protagonistas a $1^{\mathrm{a}}$ e $2^{\mathrm{a}}$ companhias de polícia do Rio de Janeiro. Desta vez, parte significativa da guarnição da Corte aderiu aos revoltosos, de modo que apenas a artilharia da marinha, o primeiro corpo de artilharia de posição e parcela do segundo corpo mantinham-se leais ao governo. Outros setores da sociedade fluminense aderiram à revolta, que se concentrou no Campo de Honra da capital do Império, tomando proporções consideráveis. ${ }^{584}$

As circunstâncias eram delicadas e exigiam medidas emergenciais, fazendo com que o governo regencial apelasse para a ajuda de outras províncias, a exemplo de Minas Gerais e São Paulo, que até o momento haviam manifestado apoio à Regência. Em 15 de julho, a Secretaria de Estado dos Negócios da Guerra despachou ao presidente da província de São Paulo uma determinação solicitando o envio de dois ou três Batalhões de Infantaria e um Regimento de Cavalaria de segunda linha para auxiliar na contenção da revolta. ${ }^{585}$ Dias depois o presidente Manuel Teodoro de Azambuja deliberou, em conjunto com seu conselho privativo, que marchasse de São Paulo ao Rio de Janeiro um único batalhão de 600 praças, comandado por um tenente-coronel, e que duas Companhias de Artilharia Montada da vila de Santos se destacassem em direção à Corte. ${ }^{586}$

O redator de O Observador Constitucional contestou a determinação do governo regencial, a começar pela falta de informações que justificassem um pedido de tal monta. Em segundo lugar, solicitar o envio de tropas de São Paulo, uma província a qual o Governo sempre conferira "pouco cuidado” aos "braços úteis de seus habitantes”, era uma

\footnotetext{
${ }^{584}$ Ibid., op. cit., 2001, pp.92-93.

${ }^{585}$ WERNET, op. cit., p.03.

${ }^{586}$ ACP, v.15, sessão de 27/07/1831, pp.154-155.
} 
forma de agravar o "atrasamento" de sua indústria e agricultura. Além disso, o redator aventou a hipótese de ilegalidade na determinação, visto que o Governo não poderia arregimentar tropas milicianas para fora de suas províncias, a não ser em casos de necessidade, o que ainda não se confirmara. Mas a preocupação central do redator era, entretanto, com os envolvidos na revolta. Se além de milicianos houvesse o "povo" amotinado, seria “necessário attendê-lo”. Ao contrário da Regência Provisória, que segundo o redator pouco obrara e não fora “senão um espantalho", a nova Regência deveria mostrar a sua preocupação com o andamento dos negócios públicos. ${ }^{587}$

Os “moderados” paulistas ofereceram, em contrapartida, franco apoio à Regência. Logo após o recebimento da determinação ministerial pelo governo provincial, as Sociedades Defensoras espalhadas na província de São Paulo promoveram um alistamento voluntário - que quase atingiu a casa de 2.000 elementos - com a finalidade de fazer marchar ao Rio de Janeiro um grupo de civis para auxiliar no abafamento da revolta. Além da congênere paulistana, efetuaram alistamentos as Sociedades Defensoras de Jacareí, Mogi-Mirim, Lorena, Sorocaba, Atibaia, Taubaté, São José, São Carlos, Guaratinguetá, Pindamonhangaba, S. Luis, Itanhaém, Itu, Capela Curada de Serra Negra, Una, São Roque, Constituição, São Sebastião, Vila Bela e Itapetininga. Doações em dinheiro para a manutenção das “tropas” também chegaram de diversas vilas da província. ${ }^{588}$

Tanto o apoio do governo como o das Sociedades Defensoras não chegaram a concretizar-se de fato, posto que as tropas do governo regencial conseguiram minar a revolta em fins de julho. Após a rejeição da Câmara dos Deputados às exigências dos revoltosos, sendo a principal delas a expulsão para fora do Império de 89 "inimigos da

\footnotetext{
${ }^{587}$ O Observador Constitucional, n ${ }^{\circ}$ 165, 29/07/1831.

${ }^{588}$ WERNET, op. cit., pp.105-106.
} 
nação”, como os marqueses de Paranaguá, Baependi, Aracati, Santo Amaro e Maceió, a Regência controlou a situação e suspendeu o envio de tropas em auxílio. De qualquer forma, ficava evidente a força da "moderação" na província de São Paulo, manifestada quer pelo executivo provincial quer pelas Sociedades Defensoras. No entanto, também se tornava nítida a instabilidade política do governo dos “moderados”, contestado mesmo após a eleição da Regência Trina Permanente.

Em São Paulo, os "moderados” buscaram combater o crescimento da "exaltação" por meio da fundação de novos periódicos. A 6 de agosto de 1831, mais de um mês após o fechamento das atividades de $O$ Farol Paulistano, veio a público o primeiro número de $O$ Novo Farol Paulistano, periódico redigido pelo aluno de direito José Manuel da Fonseca e que tinha como principal colaborador o também acadêmico João da Silva Carrão. ${ }^{589}$ A permanência do nome "Farol Paulistano" em combinação com o adjetivo "novo" pode ter sido uma tentativa em readequar a antiga folha dirigida por Costa Carvalho às circunstâncias daquele momento, recuperando sua força política. O Novo Farol manteve o discurso moderado de seu antecessor, como é possível observar em seu programa de atuação:

"Pregaremos constantemente obediência às leis, respeito às autoridades constituídas. Nas sociedades políticas, tudo quanto se desvia do caminho traçado pelas leis, cedo ou tarde traz a ruína das mesmas sociedades. Quando olhamos para o estado atual do Brasil, e queremos entrever no futuro, qual deva ser sua sorte, sentimos uma espécie de terror (...) Um espírito de vertigem tem-se derramado; propagam-se princípios sobversivos de ordem social; exaltam-se paixões perigosas e procura-se tudo transtornar. Os laços da obediência ao governo estão desfeitos. Brasileiros, a estrada que seguimos, só pode conduzir-nos à ruína da pátria e, dessa mesma liberdade a quem todos dedicamos cultos.

${ }^{589}$ TAUNAY, op. cit., 1961, p.148. 
Unamo-nos, ponhamos de parte rivalidades infundadas e trabalhemos de comum acordo da prosperidade do nosso Brasil (...)”. 590

O Observador Constitucional não noticiou o advento de O Novo Farol Paulistano. No entanto, cedeu espaço de seu jornal para a publicação de um artigo redigido por F. S. B. Garcia, um dos ex-redatores de $A$ Voz Paulistana, a qual encerrara suas atividades dias antes, provavelmente porque seu último número seria levado a júri por ter “exorbitado as leis da decência, e do decoro”. O ex-redator defendeu-se daqueles que o fariam ir a julgamento, afirmando que a única coisa que fizera desde o início da publicação de $A$ Voz foi utilizar a imprensa para divulgar “sua opinião”, no caso a implementação da “Federação”. No seu entender, a melhor alternativa para o Brasil após a abdicação do monarca teria sido a convocação de uma Constituinte, já que “caindo o tirano immediatamente deveria cair tudo o que lhe pertencesse, e com muito mais razão a Constituição, obra sua”. Esse caminho talvez evitasse as “scenas de tristeza” que vinham ocorrendo no Império, como o desfecho dos acontecimentos deflagrados em julho no Rio de Janeiro, sob o comando dos "bravos do Campo de Honra”:

“Onde em minha folha tenho exorbitado as leis da decência, e do decoro? Seria exorbitar o ter eu n'esta Provincia proposto, e sustentado a Federação, não obstante a grande opposição, que sempre encontrei do velho Farol? Seria exorbitar, a coragem, e franqueza com que escrevi n’aquelle tempo de nefanda memória, expondo-me a perigos incalculáveis, sendo ameaçado como a todos é bem conhecido? Avesado a impunidade! Seria por ventura um crime, haveria criminalidade durante a estada do ex-imperador? Se assim fosse, todos os bravos do Campo da Honra serião criminosos, a mesma brilhante revolução seria illegal. Asesado a impunidade! Seria por ventura um crime a liberdade, que tem qualquer de expandir pela imprensa sua opinião, quando esta não seja nociva a

${ }^{590}$ O Novo Farol Paulistano, n¹, 06/08/1831., Apud WERNET, op. cit., p.68. 
Sociedade? Parece-me que não. Eis o que tenho feito, eis o que pratiquei em um supplemento da Voz, logo que aqui chegou a faustissima noticia da queda do tirano, persuadido que medida alguma convinha então mais ao Brazil do que uma Constintuinte, certo de que caindo o tirano immediatamente deveria cair tudo o que lhe pertencesse, e com muito mais razão a Constituição, obra sua, e talvez o Brazil tivesse tomado outra direcção, talvez mesmo não e tivesse presenciado essas scenas de tristeza, que tem tido logar, se se tivesse adoptado a medida apontada (...). ${ }^{591}$

Após o advento de O Novo Farol Paulistano e o encerramento das atividades de $A$ Voz Paulistana, o jornal A Aurora Fluminense pronunciou-se sobre a nova configuração da imprensa periódica paulista. Segundo a folha dirigida por Evaristo da Veiga, a chegada de O Novo Farol Paulistano pregaria a “doutrina da legalidade” e os "dogmas constitucionais”, dois dos pilares do discurso “moderado”. Já a Voz Paulistana, promotora de desordens na cidade de São Paulo à semelhança do que fazia A Nova Luz Brasileira na capital do Império, teve sua interrupção acolhida com agrado pelo redator de A Aurora. Quanto ao Observador Constitucional, o mesmo redator atribuiu-lhe características semelhantes ao de A Voz. Conforme observado no primeiro capítulo, era comum que os redatores da época homogeneizassem o discurso político de seus adversários, a fim de minimizar suas nuanças e generalizar seus supostos pontos fracos:

“Em São Paulo saiu à luz O Novo Farol Paulistano, desde mais tempo esperado. Os dois números que recebemos por este correio, são muito bem escritos e sustentam com vigor as doutrina da legalidade e da ordem enfim os dogmas constitucionais que formam a base da organização de todos os estados livres, e sem os quais nenhuma hora aí poderia darse a liberdade. A Voz Paulistana se despede até que venha nova tipografia. Não trabalhou pouco para a desordem e foi em São Paulo, salvo as indecências, o que é na Corte a Nova Luz. Segundo ela, o intitulado povo e tropa do Rio de Janeiro só quer a proscrição de certos indivíduos, porém quer-se legalmente. E um estudante do Curso Jurídico escreve

${ }^{591}$ O Observador Constitucional, $\mathrm{n}^{\circ}$ 171, 15/08/1831. 
semelhantes disparates. Proscrição legal num país livre, aonde há garantias constitucionais que não devem ser violadas. A Voz Paulistana fez bem em interromper a sua carreira, até para ver se neste intervalo, ganha o repouso de cabeça que parece ser-lhe muito preciso.

O Observador Constitucional que é mais bem escrito do que $A V o z$, mas que professa com pouca diferença as mesmas doutrinas (...)”. 592

Pela mesma época veio a público o jornal O Paulista, também impresso na Tipografia do Farol Paulistano, e cuja orientação política se alinhava igualmente aos “moderados”. Logo em seu primeiro número, o Paulista deu mostras que seu programa político discutiria as reformas da máquina pública com base na Carta de 1824, contestando qualquer pretensão republicana:

"Se os senhores republicanos olhando para as diversas formas de governo ou antes olhando para os diferentes graus de civilização, por onde necessariamente devem os povos passar, até poderem-se constituir em repúblicas, governo sem dúvida adaptado àquele povo que tem adquirido o maior grau de aperfeiçoamento físico e moral, querem dizer que se acham dignos de habitar entre tais povos ou que é feliz um povo, quando tem contraído hábitos e virtudes tais, que se possam governar republicanamente, não achamos desacerto o seu pensar. Mas se quer dizer que instituamos hoje no Brasil uma república, achamos tal proposição errônea, impolítica e inatendível (...) A Constituição que nos rege, reformados alguns artigos, ainda é hoje a tábua da nossa salvação. Cidadãos estrangeiros. Descansai no recinto de vossas casas. Continuai vosso comércio, continuai respeitando as leis e, contai seguras as vossas vidas e vossas propriedades. A lei vos protege. O Paulista vos defende. Os paulistas são amigos de todo o mundo, menos dos inimigos da liberdade e da ordem”. 593

Ainda em 1831, surgiu na capital paulista o Correio Paulistano, periódico dirigido pelo negociante José Gomes Segurado e impresso na Tipografia do Farol Paulistano. Além de combater jornais como O Observador Constitucional, o Correio entrou em confronto

\footnotetext{
${ }^{592}$ A Aurora Fluminense, n 521, 24/08/1831, Apud WERNET, op. cit., p.45.

${ }^{593}$ O Paulista, nº 1 , 26/09/1831.
} 
com folhas que se aproximavam dos “caramurus”, como o Carijó e o próprio O Caramuru. Defendeu o governo central e provincial, bem como os Conselhos Geral e da Presidência da província de São Paulo, vindo a encerrar suas atividades no final de $1832 .{ }^{594}$

Concomitantemente à renovada ofensiva promovida pelos “moderados” contra os “exaltados” por meio da imprensa, o governo da província de São Paulo deu prosseguimento ao seu apoio à Regência que, aliás, vinha substituindo os presidentes de província por representantes mais próximos da ala “moderada” dos liberais. Manoel Inácio de Melo e Souza, deputado pela bancada mineira na $1^{\text {a }}$ legislatura, foi destinado para a presidência de Minas Gerais, ocupando o posto até 1833. Em São Paulo, Rafael Tobias de Aguiar assumiu a presidência em de novembro de 1831, e nela permaneceu até 1834. Para a presidência da Bahia a Regência nomeou Honorato José de Barros Paim, eleito deputado por aquela província para a $2^{\mathrm{a}}$ legislatura, sendo substituído em 1832 por Joaquim José Pinheiro de Vasconcelos. O deputado pernambucano para a $2^{\text {a }}$ legislatura Francisco de Carvalho Pais de Andrade foi eleito presidente de sua província natal, cargo que preencheu até o final do ano seguinte. Note-se que, diversamente do que ocorrera durante o governo de D. Pedro, os presidentes nomeados pela Regência Trina Permanente advinham da Câmara dos Deputados e tinham estreitas relações com a província a qual passariam a dirigir.

No tocante ao Conselho da Presidência de São Paulo, as deliberações feitas pelo órgão buscaram coibir eventuais convulsões sociais na Província, o que corroborava com a conduta política implementada por parte dos liberais que ascenderam ao poder após a queda de D. Pedro. Nesse sentido, o Conselho da Presidência desempenhou importante papel na viabilização das forças coercitivas criadas pelo governo central e com vistas à manutenção

${ }^{594}$ TAUNAY, op. cit., 1961, p.147. 
da ordem interna, tal como foram as Guardas Municipais Permanentes e, sobretudo, a Guarda Nacional.

Criadas por decreto da Regência Trina Provisória a 5 de junho de $1831^{595}$, as Guardas Municipais Permanentes eram compostas por esquadras voluntárias situadas em cada distrito de paz. Instituídas, em princípio, para o policiamento da Corte, as Guardas Municipais foram instaladas na capital paulista após requisição do deputado por São Paulo Rodrigo Antonio Monteiro de Barros, feita junto ao então Ministro da Justiça Diogo Feijó, tendo como justificativa o clima político instável da Província. ${ }^{596}$ Assim, pouco tempo depois da promulgação da lei de 10 de outubro de $1831^{597}$, que tornou os presidentes de Província aptos para, em reunião com seu conselho privativo, criar corpos de Guardas Municipais, o então presidente da Província Rafael Tobias de Aguiar propôs em sessão ordinária do Conselho da Presidência algumas resoluções referentes à matéria. O político sorocabano julgava necessário que se criasse uma Companhia de Infantaria de 100 praças e 30 soldados de cavalaria, número que avaliava ser "indispensavel para a manutenção da tranqüilidade publica”, o que foi acordado pelo Conselho. ${ }^{598}$

Mais recorrentes foram os cuidados do Conselho da Presidência com a criação das praças que ajudariam a compor a Guarda Nacional, órgão criado por lei a 18 de agosto de $1831^{599}$, e que se tornou a principal força coercitiva do governo central durante o período

\footnotetext{
595 "Decreto de 14 de junho de 1831 - Crêa em cada districto de paz um corpo de guardas municipaes divididos em esquadras”, in Coleção das Leis do Império do Brasil de 1831. Rio de Janeiro: Tipografia Nacional, 1875, Segunda Parte, pp.16-18.

${ }^{596}$ FERNANDES, Heloisa Rodrigues. Política e segurança. Força Pública do Estado de São Paulo: fundamentos histórico-sociais. São Paulo: Alfa-Ômega, 1974, pp.68-70.

597 "Lei de 10 de outubro de 1831 - Autoriza a creação de corpos de guardas municipaes voluntarios nesta cidade e Províncias”, in Coleção das Leis do Império do Brasil de 1831. Rio de Janeiro: Tipografia Nacional, 1878, Parte Primeira, pp.129-130.

${ }^{598}$ ACP, v.15, sessão de 15/12/1831, p.193.

599 "Lei de 18 de agosto de 1831 - Crêa as Guardas Nacionaes e extingue os corpos de milicias, guardas municipaes e ordenanças”, in Coleção das Leis do Império do Brasil de 1831, op. cit., Parte Primeira, pp.4974. Segundo artigo $1^{\circ}$, Título I, as Guardas Nacionais foram criadas para "defender a Constituição, a
} 
regencial. Constituindo uma milícia nacional de caráter centralizado, uma vez que seus corpos estavam subordinados, em última estância, ao ministro da Justiça, além dos presidentes de província e juizes criminais e de paz, a Guarda Nacional também comportava uma feição fragmentada, posto que sua organização se dava, até a promulgação do Ato Adicional, por município, e seu alistamento ficava a cargo dos juizes de paz. ${ }^{600}$

Aos governos provinciais e Conselhos da Presidência cabia participação efetiva na implantação das guardas nacionais. Embora sua organização se desse em nível municipal, sob a supervisão dos juizes de paz, cabia aos presidentes de Província, em reunião com o Conselho da Presidência, mandar agrupar os guardas nacionais de dois ou mais municípios caso algumas Vilas não comportassem a formação de Batalhões ou Companhias (artigo $3^{\circ}$, Capítulo I, Título I). Se por ventura as guardas nacionais tomassem “deliberações sobre os negócios públicos” ou resistissem às “requisiçoes legaes das autoridades municipaes, administrativas ou judiciarias”, o presidente de Província, em reunião com seu conselho privativo, poderia suspendê-las (artigo 5º Capítulo I, Título I). Além disso, os presidentes de província, sempre em reunião com os Conselhos da Presidência, estavam habilitados a fiscalizar a implementação das guardas nacionais de infantaria (artigo 32º Capítulo II, Título I), suspender oficiais (artigo 60 , Capítulo IV, Título I) e interferir nas ordens do serviço ordinário das guardas nacionais (artigo $71^{\circ}$, Capítulo VI, Título I). ${ }^{601}$

No dia-a-dia das atividades do Conselho da Presidência de São Paulo ganhou atenção especial uma outra atribuição prevista pela lei de 18 de agosto de 1831. De acordo

Liberdade, Independencia, e Integridade do Imperio; para manter a obediência ás Leis, conservar, ou restabelecer a ordem, e a tranquilidade publica; e auxiliar o Exercito de Linha na defesa das fronteiras, e costas".

${ }^{600}$ CASTRO, Jeanne Berrance de. A milícia cidadã: a Guarda Nacional de 1831 a 1850. São Paulo: Editora Nacional, 1979.

${ }^{601}$ Cf. "Lei de 18 de agosto de 1831 - Crêa as Guardas Nacionaes e extingue os corpos de milicias, guardas municipaes e ordenanças", in Coleção das Leis do Império do Brasil de 1831, op. cit., pp.46-74. 
com o artigo $43^{\circ}$, Capítulo III, Título I, os presidentes de Província, reunidos com seus conselheiros da Presidência, poderiam solicitar a criação de companhias, seções de companhias, esquadrões ou corpos de cavalaria nos lugares em que julgassem convenientes. Mediante uma listagem elaborada pelos juizes de paz que contemplasse os indivíduos “em circunstancias de serem eleitos”, o Conselho deliberava quantas companhias ou esquadrões de cavalaria seriam criadas numa vila, distrito ou freguesia, bem como o número de praças que as comporiam. A primeira menção à organização das companhias de cavalaria deu-se em dezembro de $1831^{602}$, de modo que, a partir de 1832 , a matéria tornou-se pauta constante nas reuniões do Conselho. Só no mês de janeiro foi deliberada a instalação de companhias de cavalaria nas Vilas de Cunha, Pindamonhangaba, Guaratinguetá, Porto Feliz e na cidade de São Paulo, mais especificamente nas freguesias da Sé, Santa Ifigênia e São Roque. ${ }^{603}$

A intervenção do executivo provincial na disposição das “milícias cidadãs” não se processou, todavia, sem atribulações. Mais tarde, em relatório lido aos conselheiros na ocasião da abertura das sessões ordinárias de 1832 do Conselho da Presidência, o presidente Rafael Tobias de Aguiar afirmou ter tido “difficuldades” na organização das Guardas Nacionais, seja com aquelas que se encontravam “apenas alistadas” seja com os “oficciaes eleitos”, julgando até que a lei deveria ser “retocada”, ${ }^{604}$ Algumas mudanças legais de fato ocorreram no período, reforçando ainda mais a atuação dos executivos locais na organização das guardas nacionais. Com o decreto de 16 de fevereiro de $1833^{605}$, os

\footnotetext{
${ }^{602}$ ACP, v.15, sessão de 12/12/1831, p.196.

${ }^{603}$ ACP, v.15, sessões de 12/01/1832, p.209; 16/01/1832, p.211; 19/01/1832, p.214; 23/01/1832, p.217.

${ }^{604}$ Atas do Conselho da Presidência da Província de São Paulo (1824-1834) (ACP) In: Boletim. São Paulo: Arquivo do Estado de São Paulo, 1962, v.16, sessão de 01/10/1832, pp.43-44.

605 "Decreto de 16 de fevereiro de 1833 - Marca os vencimentos dos cornetas, tambores e clarins das Guardas Nacionaes do Rio de Janeiro”, in Coleção das Leis do Império do Brasil de 1833. Rio de Janeiro: Tipografia Nacional, 1873, Parte Segunda, p.33.
} 
Conselhos da Presidência tornaram-se habilitados para marcar o soldo dos cornetas, tambores e clarins dos corpos nacionais de suas respectivas Províncias. O órgão paulista não demorou a evocar a lei, e definiu o salário de tais categorias ainda em junho de $1833 .{ }^{606}$

Em fins de 1831, a situação política do Império encontrava-se indefinida. A despeito de alguns posicionamentos contrários, o projeto elaborado por Miranda Ribeiro foi aprovado na Câmara dos Deputados com ampla maioria em 13 de outubro de 1831, o que significava a vitória temporária de reivindicações de fundo, como a implementação de uma monarquia federativa, a criação de Assembléias Provinciais, a supressão do Conselho de Estado e da vitaliciedade do Senado, e a instauração do cargo de regente uno. Restava ainda a apreciação do projeto pelo Senado, que deixou a tarefa para o ano legislativo de 1832.

Em São Paulo, a posse de Rafael Tobias de Aguiar na presidência da província, ocorrida a 17 de novembro, ajudou a fortalecer a posição dos “moderados”, que ainda contavam com três periódicos recentes a seu favor, O Novo Farol Paulistano, O Correio Paulistano e O Paulista, todos eles impressos na tipografia de José da Costa Carvalho. Além disso, por essa mesma época o Observador Constitucional teve sua publicação pela Tipografia do Farol Paulistano interrompida, provavelmente por conta de divergências político-ideológicas entre seus mantenedores e a folha fundada por Líbero Badaró.

Enfraquecidos na imprensa, os “exaltados” paulistas organizaram-se na Sociedade Federal da cidade de São Paulo, fundada em 6 de dezembro 1831 e influenciada por suas congêneres baiana e fluminense, e cujos objetivos eram "promover o andamento da

${ }^{606}$ ACP, v.16, sessão de 01/06/1833, pp.158-159. 
Federação por todos os meios ditados pela razão e pela Justiça” e "auxiliar o Poder legislativo na consolidação do sistema federal”. ${ }^{607}$ Criada após o desaparecimento da Sociedade Defensora da capital paulista, a Sociedade Federal conseguiu arregimentar nomes importantes dentro da sociedade paulistana, como o negociante Antonio da Silva Prado e o sargento-mor Joaquim José Silva. Figuras como Cândido Gonçalves Gomide, José Gomes de Almeida e Manuel Costa de Almeida, anteriormente filiados à Sociedade Defensora de São Paulo, também se ligaram à nova Sociedade. Alguns dos seus membros, a exemplo de José Antônio dos Reis, Manoel Joaquim Leite Penteado e Idelfonso Xavier Ferreira, haviam participado do abaixo assinado publicado pelo $O$ Observador Constitucional, pouco depois da Abdicação, a favor das reformas na Carta de 1824. Diante disso, e a fim de coibir o crescimento da nova associação, o presidente da província Rafael Tobias de Aguiar sugeriu, embora sem sucesso, a proibição do ingresso de estudantes do Curso Jurídico na Sociedade Federal entre seus integrantes. ${ }^{608}$

A Sociedade Federal de São Paulo foi alvo de acusações por parte dos periódicos “moderados”. O Novo Farol Paulistano criticou-a por intervir em negócios concernentes à Assembléia Geral, e rechaçou qualquer utilidade da nova Sociedade, visto que "as idéias federativas” já haviam sido assimiladas com a “exatidão necessária”, ou seja, tendo como base legal a Constituição. Ademais, segundo o redator, o Império já teria “outras Sociedades de eleição popular”, a exemplo das Câmaras Municipais e dos Conselhos Gerais, que com “mais peso” poderiam emitir representações ao Parlamento. ${ }^{609}$ Ao que parece, o segundo secretário da Sociedade Federal, Jaime da Silva Teles, fora encarregado de montar uma comissão cujo objetivo seria elaborar um novo projeto de reforma

\footnotetext{
${ }^{607}$ WERNET, op. cit., pp.113-116.

${ }^{608}$ Ibidem.

${ }^{609}$ O Novo Farol Paulistano, no 40, 21/12/181.
} 
constitucional a ser enviado à Câmara dos Deputados, diferente daquele aprovado em 13 de outubro de $1831 .^{610}$

\section{3. “Reforma” ou “reformas”?: a lei de 12 de outubro de 1832 e a remodelação da estrutura financeira provincial}

Pouco mais de um mês após o início de sua primeira sessão desde a Abdicação, em ofício destinado à Câmara dos Deputados de 20 de janeiro de 1832, o Conselho Geral de São Paulo manifestou seu apoio ao que chamou de “majestosa revolução" e, em conformidade com a recente adesão dos “moderados” à reforma constitucional, reconheceu a necessidade de alterar o "Pacto Fundamental":

“O Conselho Geral da Provincia de S. Paulo reunindo-se pela primeira vez depois do glorioso dia 7 de abril julga de seo vigoroso dever manifestar perante esta Augusta Câmara a exultação q. sentiu a Provincia inteira á primeira noticia de tam majestosa revolução.

Os Paulistas, senhores, que se jactão a não serem jamais segundos em amor á liberdade, a independência e a pátria que, as viu nascer, sentirão que d'esse dia datavão todas as prosperidades para a Grande Nação de que fazem parte. Nem podia ser d' outra maneira, porque com elementos corrompidos das monarchias da velha Europa, ahi tolerados pela dura lei da necessidade, não é que se podia fazer a ventura d' um povo todo elle Americano. Assim é que tínhamos uma Constituição, q. consagrava sim os mais preciosos direitos do homem em sociedade, que era sim melhor que quase todos as outras, quando não por outros títulos, ao menos porque prescrevia a maneira, por onde ella mesma se podia reformar: mas essa Constituição, longe de ser accomodada às precisões d'um povo, senhor de vastas regiões, apenas serviu e ainda foi ventura para enraizar a planta da liberdade, e para generalizar esse espirito publico, que fez o 7 de abril, e que ensina aos

\footnotetext{
${ }^{610}$ WERNET, op. cit., p.120.
} 
Governos a não trilharem outra vereda que não seja a indicada pela Rainha das Nações, a Opinião Pública.

O povo paulistano sentiu pois redobrar seo regozijo, quando soube que o primeiro cuidado d' esta Augusta Câmara depois d' aquela gloriosa revolução foi ocupar-se das reformas do Pacto Fundamental, que essa mesma reclamava em todos os pontos do Brazil, assim como da abolição d'esse títulos, d'essas vãs decorações, resto do Feudalismo que o Brazil descendia, e que por uma singular contradição só forão para elle criados depois $\left({ }^{*}\right)$ e não menos devia acabar; d'esses títulos criados, sem se saber como, e sem que appareça o acto legislativo, que lhes deu existencia.

O Brazil, Senhores, não quer mais nem aristocracia, nem privilégios, nem ficções: é isto uma verdade comprovada pelo testemunho unânime de todo quantos não medram á sombra d' esses velhos abusos, que acabam sempre por desagradar a Nação. E se distinções são precisas, se homens há que não podem viver sem nobreza, bem vasto compo lhes offerece para obterem-a, a própria Constituição actual, quando afiança recompensas, quando chama aos cargos mais importantes os que tem talentos e vertudes. Que os homens ambiciosos attivem esses dons de que a Natureza foi pródiga n’um clima feliz: e os sufrágios de seus concidadãos lhes provarão que elles são nobres, muito melhor do que podem fazer nomes e títulos vãos, que os proprios, a quem elles decorão, nos não sabem definir.

Os paulistas portanto se reconhecem no ardor, com que esta Augusta Câmara tem promovido tam salutares reformas, que ella é ainda a mesma, que em 1830 diluiu as bases do carunchoso, mas ainda assim medonho edifício da velha arbitrariedade. Elles estão certos de que os seos Augustos Representantes vão redobrar de coragem e patriotismo n’uma causa, hoje felizmente aplanada, e q. além das reformas propostas, e que apenas puderão ser indicadas em tam curto espaço, outras virão ainda e ao mesmo tempo coroar as esperanças do Brazil, sobretudo as que tendessem a melhor organizar o Poder Judiciário, esse Poder cujos abusos tem lançado tam profundas raízes, q. fazem desacorçoar os ânimos ainda os mais esperançosos.

Nem vos detenhão, senhores, esses prelúdios de anarquia, fructos da esperança illudida, a ambição frustrada de paixões mal satisfeitas. Os homens q. não pensão, imaginarão que a revolução de 7 de abril fora feita para cada um d'elles de per si somente; mesmo os que com ella devião perder, porque era tempo de cessarem os abusos (*) É um resultado necessario, infallivel, de todas as revoluções; mas elles se desenganavão por fim, a sede q. há de lei, de ordem, e de liberdade, absorvará todos esses mesquinhos cálculos 
individuaes de miseros egoistas. Elles poderão sim compellir os Augustos Representantes da Nação a mais árduos e aturados trabalhos; elles poderão por suas pertenções audaciosas divertir a attenção do Corpo Legislativo para outros objectos instantes, para medidas promptas, que tendão abaldar os planos horrorosos de uns, e vencer o emperramento de outros; mas o patriotismo, Senhores, tudo supera, e a gratidão d’um povo generoso é mais que sufficiente recompensa para corações bem formados.

Eis, Augustos e Dignissimos Senhores, nossos sentimentos e as esperanças que animão o brioso povo de S. Paulo; e por isso o Conselho Geral congratulando-se cordialmente convosco, Senhores, por tam faustos sucessos, descança na sabedoria do Corpo Legislativo, que as reformas legaes em breve operadas encherão os votos dos bons Brazileiros. ${ }^{611}$

Diferentemente da Sociedade Federal paulista, que se propusera a elaborar um projeto de reforma alternativo, o Conselho Geral de São Paulo, na qualidade de principal órgão representativo provincial, admitiu que a Assembléia Geral detivesse a responsabilidade de encaminhar a reforma constitucional, e ao que parece não tomou nenhuma atitude no sentido de influenciar sobre o conteúdo das matérias a ser discutido no Parlamento. Mesmo assim, a representação supracitada indicava o posicionamento do Conselho Geral paulista com relação aos caminhos para se chegar à reforma, que corroboravam com a idéia dos “moderados” em restringi-la ao Legislativo e adequá-la ao sistema monárquico-constitucional. Os “moderados” paulistas continuaram, aliás, tecendo censuras à Sociedade Federal. O Paulista taxou-a de instituição composta por "proletários e miseráveis”, numa clara tentativa de reduzir a expressividade política de seus membros. ${ }^{612}$

\footnotetext{
${ }^{611}$ FCGP, RR32.003, caixa 30. As indicações “(*)” significam rasura ou impossibilidade de transcrição do documento por danificação.

${ }^{612}$ CONTIER, op. cit., p.90.
} 
Já o Observador Constitucional saiu em defesa da Sociedade Federal e criticou a atitude do “Paulistinha”, visto como um “difamador” das idéias federativas. ${ }^{613}$

Ainda em janeiro, o Conselho Geral de São Paulo novamente demonstrou seu apoio os projeto político dos "moderados”. Tendo em vista não "arriscar" a "tranquilidade” em que se encontrava a Província de São Paulo, o Conselho Geral solicitou à Assembléia Geral que essa mantivesse Rafael Tobias de Aguiar como chefe do Executivo paulista mesmo durante o período de funcionamento da Assembléia Geral, uma vez que o político sorocabano ocupava, também, a cadeira de deputado pela $2^{a}$ legislatura do Império. De acordo com o Conselho, num momento em que a eclosão de uma "nova revolução" ainda era possível, nada mais coerente do que manter um governo "forte e de inteira confiança dos povos”, já que a indicação de Tobias Aguiar à presidência da província de São Paulo, feita no ano anterior, coincidira "perfeitamente" com a escolha dos paulistas com a escolha do povo”. Para isso, o Conselho Geral interpretou à sua maneira o artigo $34^{614}$ da Carta de 1824, o qual dava poderes à Assembléia Geral de liberar um deputado ou senador para ocupar outra "comissão" caso fosse necessário para manter a "segurança publica" ou o "bem do Estado":

“Augustos e Digníssimos Senhores Representantes da Nação,

O Conselho Geral da Provincia de S. Paulo, solicita mais que tudo pela tranqüilidade de sua Provincia, porque esta convencido q. sem ordem, sem tranqüilidade, sem respeito a Lei e as autoridades, tudo são sonhos pueris, ou calculos da ambição e da

${ }^{613}$ O Observador Constitucional, $\mathrm{n}^{\circ}$ 203, 19/01/1832.

${ }^{614}$ Afirmava o art. 34: "Se por algum caso imprevisto, de que dependa a segurança pública ou o bem do Estado, for indispensável que algum senador ou deputado saia para outra comissão, a respectiva câmara o poderá determinar”. Cf. “Constituição Política do Império do Brasil”, in BONAVIDES, Paulo \& AMARAL, Roberto (orgs.), op. cit. 
malvadeza, vem reprezentar a esta Augusta Camara q. para se não arriscar esta tranqüilidade a primeira condição é sem duvida o conservar-se a testa da administração provincial um homem da inteira confiança de seos concidadãos.

Esta condição verifica-se, mais talvez do que em nenhuma outra, na pessoa do actual Presidente Rafael Tobias de Aguiar, pois sem falar nas suas qualidades pessoaes, ou em quaesquer outros motivos que possão ser dictos ao Governo a acertada escolha que dela fez para reger a Provincias, o certo é q nascido e residente nela, ele tem merecido os votos de seos comprovincianos para todos os cargos de eleição popular, e particularmente para o Conselho do Governo, onde é o membro mais votado, de maneira que a sua nomeação para Presidente tem de notavel e tem de (...) do Governo seja dicto o coincidir perfeitamente com a escolha do povo. Todavia, essa mesma confiança do povo fez com que elle fosse também eleito para Deputado da Nação, o que induz a uma interrupção na administração, que é sempre fatal ao avanço e prosperidade da Provincia, ainda mesmo em tempos ordinários. Presentemente porém que acabamos d sair d’uma revolução tam gloriosa, quanto extensa em seos resultados; presentemente que todos os interesses frustrados appelão para uma nova revolução, que é o mesmo que dizer conspiração para desorganizar, se ao menos se lembrarem talvez do que é que farão depois, prezentemente, Senhores, a necessidade de um Governo forte e de inteira confiança dos povos, é uma necessidade primaria, e vital, porque é somente um governo tal que pode manter a um povo na órbita da Lei, uma linha fora da qual já não há mesmo salvação para o Brasil.

E se a sizudez e bravura dos Paulistas, essas virtudes que levarão seu nome a regioens longínquas, são hoje ainda as mesmas na grande maioria delas, se essas virtudes afiansão a derrota completa, e prompta como o raio, de todos aqueles que querem a pilhagem em nome da liberdade; isso não tira que ensaios de pilhagem sejão um mal para a Provincia: os Paulistas querem paz, e tranqüilidade e não querem colher loyros a custa de homens que tem o nome de Brazileiros.

É para previnir esses laivos ensangüentados que o Conselho Geral toma a liberdade de requerer, que o atual Presidente da Provincia seja conservado na administração, ainda durante o tempo dos trabalhos legislativos, e que para isso se ponha em pratica o que determina o art. 34 da Constituição do Império” 615

${ }^{615}$ FCGP, RR32.005, caixa 30. 
Ao que tudo indica, o pedido para a conservação de Rafael Tobias de Aguiar na presidência de São Paulo foi acatado pela Assembléia Geral, bem como pelo governo regencial, posto que nenhum vice-presidente assumiu interinamente o Executivo provincial paulista durante o período de funcionamento da sessão do Parlamento de 1832. O mesmo se deu no ano seguinte, apesar de não terem sido encontrados registros de que haja ocorrido um pedido similar por parte do Conselho Geral de São Paulo. Somente em 1834, com a $3^{\text {a }}$ legislatura do Império já em andamento, Tobias de Aguiar deixou de presidir a província durante o período de trabalho do Parlamento, para onde fora reeleito deputado por São Paulo. ${ }^{616}$

Além de se pronunciar diretamente ao Governo e à Assembléia Geral, o Conselho Geral de São Paulo, na qualidade de principal canal de representação política na esfera provincial, franqueou espaço para o recebimento de manifestações oriundas de diferentes setores da sociedade paulista sobre o novo estado das coisas. Em fevereiro de 1832, a Comissão Permanente do Conselho Geral de São Paulo - formada por três conselheiros, dentre eles Antonio Mariano de Azevedo Marques e Vicente Pires da Mota - emitiu um ofício para a Sociedade Defensora da Liberdade e Independência da Vila de Jacareí agradecendo as felicitações por ela enviadas na ocasião da instalação do órgão paulista, e endossando o clamor pelas “reformas da Constituição” da sociedade jacareiense:

“A Comissão permanente examinando o officio da Sociedade Defensora da Liberdade e Independência da Villa de Jacarehy, em que felicitando-se com este Conselho pela sua installação, protesta pela firmeza dos principos e sentimentos, de que já deixa provas, pelos seo ardente amor á liberdade, mas d'uma liberdade que tanto conheça seos inalienaveis direitos, quanto seos deveres sagrados, e finalmente pelo quanto ansea as

\footnotetext{
${ }^{616}$ Entre 28 de maio e 13 de setembro de 1834, a presidência de São Paulo foi ocupada pelo vice Vicente Pires da Mota. Cf. MARQUES, op. cit., 191.
} 
reformas da Constituição do Estado, imperiosamente exigidas pelas nossas circunstancias actuaes com tanto q. sejão feitas pela Assembléa Geral, único órgão legitimo da vontade Nacional; é de parecer que o dito officio tem todo o direito a ser recebido com muito especial agrado por este Conselho que já tem feito solemne profissão de identicos princípios”. ${ }^{617}$

Que a decisão dos “moderados” em aceitar a revisão parcial da Carta de 1824 tornara-se algo concreto já não restava muitas dúvidas, especialmente após a aprovação do projeto de reforma de 13 de outubro de 1831. Mas ao invés de acatar as mais variadas aspirações reformistas, os “moderados” buscaram dar o tom da mudança, e nesse sentido o Federalista, periódico impresso na Tipografia do Farol Paulistano a partir de 1832 e redigido pelo acadêmico José Inácio Teixeira da Mota, constitui um caso interessante. Apesar de seu nome remeter diretamente ao ideário “exaltado”, o Federalista foi um órgão "moderado" que se valeu do afã reformista para readequar o eixo das transformações, particularmente a questão da federação. De forma contundente, o Federalista minimizou a acepção republicana do termo federação ressaltando suas possíveis vinculações com o sistema monárquico:

“A escolha da denominação desta folha tem por fundamento a persuasão de que esta província deseja ardente e sinceramente as reformas no sentido federativo, bem como que elas sejam efetuadas unicamente pelos meios legais, isto é, por aqueles meios que marca a Constituição do Estado (...) Se pois é verdade que o princípio ou o sistema federativo é dominante no Brasil, resta-nos agora indagar se do desenvolvimento desse princípio como se crê geralmente, nasce a satisfação das necessidades das províncias (...)" ${ }^{618}$

\footnotetext{
${ }^{617}$ FCGP, CP32.022, caixa 14, oficio de 7 de fevereiro de 1832.

${ }^{618}$ O Federalista, ${ }^{\circ} 1,19 / 02 / 1832$.
} 
No Parlamento, o tema da reforma constitucional veio à baila logo no início do ano legislativo de 1832, no mês de maio. Martim Francisco Ribeiro de Andrade, deputado pelo Rio de Janeiro, criticou veementemente o projeto aprovado em 12 de outubro do ano anterior, visto por ele como subversivo e prejudicial ao regime monárquico. Honório Hermeto Carneiro Leão, deputado por Minas Gerais, observou que a imposição dos princípios federativos era desnecessária porque a Constituição já os assegurara de alguma forma, dando certa liberdade política às Províncias. ${ }^{619}$

As emendas feitas pelos senadores contrariavam boa parte do conteúdo aprovado pelos deputados. Matérias como a instauração de uma monarquia federativa e a supressão do Poder Moderador, do Conselho de Estado e do Senado vitalício foram refutadas pelos senadores, como também o foram os artigos que criavam a Regência Una e reduziam o tempo de legislatura dos deputados para dois anos. Assim, os únicos pontos de convergência entre as duas Casas tocavam na questão da transformação das atribuições dos Conselhos Gerais e da reformulação das rendas do Império.

Como era de se esperar, a recepção das emendas senatoriais pelos deputados acentuou as discordâncias existentes entre os representantes da primeira Casa. Francisco Gê Acaiaba Montezuma, suplente de José Costa Carvalho, endossou as alterações feias pelos senadores, que segundo ele estariam preocupados com a integridade do sistema monárquico-constitucional. Antonio Pereira Rebuças, deputado pela Bahia, também apoiou as emendas do Senado, ressaltando a importância do Poder Moderador e incompatibilidade entre monarquia e federação. Algumas lideranças liberais organizaram-se em torno de Feijó, então ministro da Justiça, e articularam um golpe de Estado - mais tarde conhecido como golpe de 30 de julho - que tinha como objetivo instaurar um Assembléia Constituinte

${ }^{619}$ CASTRO, op. cit. 
e aprovar o projeto de reforma tal como fora elaborado pelos deputados. O insucesso da manobra não atenuou o descontentamento da maioria dos deputados para com as ementas feitas, que exigiu uma reunião conjunta entre as duas Câmaras. ${ }^{620}$

Da reunião das duas Casas, ocorrida entre 17 e 28 de setembro, resultou a aprovação da lei de 12 de outubro de $1832^{621}$, cujo objetivo era fornecer aos deputados da próxima legislatura (1834-1837) a base legal pela qual seria encaminhada a reforma da Carta de 1824. A lei não indicava as alterações propriamente ditas, mas o eixo de discussão a ser seguido pelos futuros parlamentares. Seus principais pontos marcavam as seguintes possibilidades de reforma: o Senado poderia vir a reunir-se independentemente dos deputados; criar-se-ia um Conselho Geral na capital do Império; os Conselhos Gerais poderiam ser transformados em Assembléias Legislativas Provinciais; a Regência poderia tornar-se unitária e eletiva e o Conselho de Estado suprimido.

O texto final aprovado contemplou parte das matérias propostas por deputados e senadores. Estes conseguiram manter o caráter vitalício de seus mandatos e suprimirem o artigo que tornava a monarquia brasileira uma associação federativa, ao passo que aqueles tornaram possível a supressão do Conselho de Estado, órgão ao qual os setores provinciais não tinham acesso, a eletividade do cargo de regente uno sob o mesmo procedimento eleitoral para a escolha de senadores e deputados, e, principalmente, a transformação dos

${ }^{620}$ SOUSA, Otávio Tarquínio de. História dos fundadores do Império do Brasil, v.8, "Tres Golpes de Estado”. São Paulo/ Belo Horizonte: Edusp/ Itatiaia: 1988. Participação decisiva no fracasso do golpe teve Honório o deputado por Minas Gerais Honório Hermeto Carneiro Leão, futuro Marquês do Paraná. Segundo Tarquínio de Sousa, quando a Câmara dos Deputados já estava inclinada a aprovar o parecer que a tornaria uma Assembléia Constituinte, Honório Hermeto articulou uma intervenção que produziu uma reviravolta de opinião, de modo que o parecer acabou sendo refutado pela maioria dos deputados. Embora apoiasse a Regência, Honório Hermeto se mostrara reticente quanto às reformas da Carta de 1824 desde o início do debate sobre o tema, especialmente com relação à aplicação dos princípios federativos.

621 "Lei de 12 de outubro de 1832 - ordena que os Eleitores dos Deputados para a seguinte Legislatura, lhes confiram nas procurações, faculdade para reformarem alguns artigos da Constituição”, in Coleção das Leis do Impéri de 1832, op. cit., pp.106-107. 
Conselhos Gerais em Assembléias Legislativas Provinciais. Senador pela Bahia, o experiente Visconde de Cairu observou que a criação das Assembléias Provinciais - pela qual votou contra - consistia no cerne da proposta reformista apresentada aos senadores pelos deputados, pois na sua opinião caberia a ela “destruir a soberania nacional para estabelecer soberanias provinciais”. ${ }^{622}$

A lei de 12 de outubro de 1832 marcava os rumos da reforma constitucional, mas essa só seria efetivamente conduzida na terceira legislação do Império, a iniciar-se em maio de 1834, para quem sabe ter seus resultados prontos para entrarem em vigor em 1835. Tendo conhecimento desse obstáculo legal e da incerteza sobre rumos da política imperial naquele momento, Regência e Parlamento, sobretudo a Câmara dos Deputados, esforçaramse para criar alguns pilares jurídico-administrativos que serviriam, simultaneamente, como elementos de transição para um governo pós-reforma constitucional, como laboratório para os conteúdos a serem discutidos na revisão da Carta de 1824, e como garantia de que alguns passos seriam dados no sentido do aperfeiçoamento de um estado em moldes liberais, independentemente do desfecho da alteração do texto constitucional. Embora a bibliografia costume divisar um elo direto entre a lei de 12 de outubro de 1832 e o Ato Adicional, sendo este conseqüência da primeira, cumpre notar que nesse ínterim a fluidez e a indefinição do cenário político do Império fizeram com que os representantes da nação se valessem do aparato institucional já existente para criarem condições para uma mudança política por meios legais. Os governos provinciais, um dos aspectos basilares do projeto de reforma constitucional, foram alvo de medidas que repercutiram tanto na elaboração do Ato Adicional como nos anos finais da Regência. Por conseguinte, os Conselhos Provinciais viram-se novamente na iminência de terem suas ingerências reformuladas, embora agora

${ }^{622}$ DOLHNIKOFF, op. cit., 2005, p.94-95. 
não se tratasse de um aprimoramento institucional de ambos os órgãos, mas de inseri-los dentro de um processo maior de reestruturação do Estado nacional.

Digno de ressalva é o fato de que embora tenha franqueado apoio explícito ao governo regencial, os Conselhos Provinciais paulistas não assistiram a uma alteração radical de seu funcionamento após a Abdicação. Não é possível afirmar, por exemplo, que o Conselho da Presidência impôs maiores limites à atuação do presidente da Província, nem que as resoluções tomadas pelo Conselho Geral obtiveram maiores índices de aprovação. Por outro lado, assegurar que a prática de ambos os Conselhos permaneceu a mesma após a Abdicação é ocultar algumas mudanças, não tão sutis assim, as quais foram ofuscadas pela grande mobilização em torno do debate da reforma constitucional que culminou na promulgação do Ato Adicional, em 1834. Mudanças essas que ocorreram em todo o Império, não se restringindo à Província de São Paulo.

No que tange aos Conselhos Provinciais, a atuação das Regências Trina Provisória e Trina Permanente foi, de modo geral, restrita. Num momento em que o tema da reformulação da esfera política provincial estava na ordem do dia, medidas foram tomadas com o intuito de minorar os descontentamentos com relação à eficácia desses órgãos enquanto a reforma constitucional estava em andamento na Assembléia Geral. A situação era delicada, pois se tratava de dois órgãos que, independentemente de suas diferenças formais, há muito eram identificados dentro e fora do Parlamento como vias distintas de se fazer política. Como vimos no capítulo anterior, enquanto o Conselho da Presidência era entendido como um órgão componente do governo provincial e atrelado ao Executivo, o Conselho Geral figurava como o principal canal de representação popular existente nas Províncias, não sendo à toa, aliás, que o debate sobre a criação das Assembléias Províncias tenha se dado com base na ampliação dos poderes políticos desses órgãos. Para o governo 
regencial era preciso, portanto, manter os governos provinciais em alinhamento com o Executivo e, ao mesmo tempo, dar coro às reivindicações que desejavam maiores poderes aos Conselhos Gerais.

O Conselho da Presidência foi alvo de resoluções que ora aumentaram ora reduziram sua esfera de poder. Poucos meses após a Abdicação, o Ministério da Fazenda baixou uma decisão impondo limites à atuação dos Conselhos da Presidência na fiscalização das contas dos presidentes de província. ${ }^{623}$ Menos de dois anos depois, o Ministério do Império decidiu que os presidentes de Província passariam a ter, além do voto de qualidade, o voto deliberativo em sessões do Conselho da Presidência, resolução que diminuía o poder de decisão dos conselheiros eleitos. ${ }^{624}$ Por decreto de 22 de agosto de 1833, ficou resolvido que os presidentes poderiam decidir temporariamente sobre os negócios que necessitavam da presença do seu conselho privativo, caso esse não tivesse condições de se reunir ou as matérias a deliberar fossem urgente, medida essa que também aumentava o poder dos chefes do Executivo provincial em detrimento de seus conselheiros. $^{625}$ Por outro lado, em decisões de julho e outubro de 1833, o Ministério do Império reiterou o poder dos Conselhos da Presidência com relação à suspensão e responsabilização de magistrados que descumprissem a lei. ${ }^{626}$ Tais decisões parecem ter

623 "Decisão do Ministério da Fazenda de 28 de setembro de 1831 - sobre os limites das attribuições do Conselho do Governo no exame das contas dos presidentes de Província”, in Coleção das decisões do governo de 1831, op. cit., p.228.

624 "Decisão do Ministério do Império de 10 de abril de 1833 - declara que nas decisões do Conselho do Governo, compete aos Presidentes de Provincia além do voto de qualidade o voto deliberativo que compete aos demais membros, in Coleção das decisões do Governo do Império do Brasil de 1833. Rio de Janeiro: Tipografia Nacional, 1873, p.121.

625 "Decisão do Ministério do Império de 22 de agosto de 1833 - declara que os negócios, commetidos aos Presidentes em Conselho depois da Lei de 20 de outubro de 1823, podem ser resolvidos temporariamente pelos Presidentes quando houver urgencia, e não se puderem reunir os membros do Conselho”, in Coleção das decisões do Governo do Império do Brasil de 1833, op. cit., p.324.

626 "Decisão do Ministério da Justiça de 17 de julho de 1833 - o Presidente e o Conselho de Província são competentes para suspender os respectivos magistrados por falta de cumprimento de deveres”, in Coleção das decisões do Governo do Império do Brasil de 1833, op. cit., p.267; "Decisão do Ministério da Justiça de 17 de 
surtido efeito, já que, em 1834, três juízes de paz foram suspensos pelo Conselho da Presidência de São Paulo por descumprirem seus deveres. ${ }^{627}$

Dado que o primeiro projeto de reforma constitucional viera à tona na Câmara dos Deputados em julho de 1831, e que um de seus pontos principais era justamente transformar os Conselhos Gerais em Assembléias Legislativas Provinciais, a atuação do governo regencial quanto a esses órgãos não foi extensa, o que pode ser notado pela pequena quantidade de decretos partidos da Regência a respeito deles. Em junho de 1833, o Ministério do Império decidiu que os presidentes de província seriam obrigados a fornecer aos Conselhos Gerais os documentos que esses julgassem necessários para o desempenho de suas funções. ${ }^{628}$ Tal decisão tinha o intuito de viabilizar as ações dos Conselhos Gerais e aproximá-los dos executivos provinciais.

É curioso assinalar que a principal alteração sofrida pelos Conselhos Provinciais durante o período regencial não foi fruto de uma legislação destinada especificamente a ambos, mas da iniciativa do Parlamento em remodelar a estrutura financeira do Império, o que acabou incidindo, conseqüentemente, na participação desses órgãos no manejo das contas provinciais. Pouco enfatizado pela bibliografia, o estudo da organização financeira das províncias antes da criação das Assembléias Legislativas oferece indícios para o entendimento de questões que vão além da estrutura orçamentária e fiscal do Império. Ele permite, também, lançar luz sobre um movimento intrínseco aos primeiros anos da formação da esfera provincial do Estado Nacional brasileiro: ao mesmo tempo em que

outubro de 1833 - aos presidentes de Província em Conselho, compete suspender e fazer responsabilizar os Magistrados que não cumprem a lei e as ordens dos mesmos Presidentes”, in Coleção das decisões do Governo do Império do Brasil de 1833, op. cit., p.432.

${ }^{627}$ Ver ACP, v.16, sessões de 08/03/1834, p.292; 22/03/1834, pp.298-301; e 14/10/1834, p.385.

628 "Decisão do Ministério do Império de 7 de junho de 1833 - declara que os Presidentes de Provincia devem fornecer aos Conselhos Geraes os documentos que por estes lhes forem pedidos para desempenho de suas funções”, in Coleção das decisões do Governo do Império do Brasil de 1833, op. cit., p.205. 
viabilizou a construção de uma esfera política provincial, a regulamentação das instituições previstas pela Carta de 1824 revelou seus próprios limites e, por conseguinte, a possibilidade de instauração de novos projetos de gestão do Estado.

A Carta de 1824 não detalhou o funcionamento da Fazenda Nacional, bem como da sua relação com as províncias. ${ }^{629}$ Apenas estipulou que a receita e a despesa da Fazenda Nacional estariam encarregadas ao Tribunal do Tesouro Nacional que, por sua vez, mediante a elaboração de legislação específica, seria o órgão responsável por regular, administrar, arrecadar e contabilizar as finanças do Império, em "recíproca correspondência” com as “tesourarias e autoridades das províncias” (art. 170). Detentora do poder Legislativo do Império (art. 13), a Assembléia Geral tinha como atribuição “fixar anualmente as despesas públicas e repartir a contribuição direta” (arts. 15 e 171). Ao Ministério da Fazenda cabia apresentar anualmente à Câmara dos Deputados uma proposta orçamentária de todas as despesas públicas do ano futuro, bem como da importância de todas as contribuições e rendas públicas. Para isso, o ministro da Fazenda deveria primeiramente apresentar aos deputados um balanço geral da receita e despesa do Tesouro Nacional do ano anterior. ${ }^{630}$ Como é de se notar, a Carta de 1824 privilegiou a dimensão orçamentária da estrutura financeira do Império. Ainda assim, apesar dessas premissas legais, o processo orçamentário demorou a se consolidar no Primeiro Reinado, tornando-se uma das principais controvérsias políticas da $1^{\mathrm{a}}$ legislatura do Império. Entre a convocação do Parlamento e o fim da $1^{\text {a }}$ legislatura, em 1829, dois orçamentos parciais - referentes à

\footnotetext{
${ }^{629}$ DINIZ, op. cit.

630 “Constituição Política do Império do Brasil”, in BONAVIDES, Paulo \& AMARAL, Roberto (orgs.), op. cit.
} 
Província do Rio de Janeiro e à Corte - foram aprovados, de modo que apenas em 15 de dezembro de 1830 o Império conheceu sua primeira lei de orçamento. ${ }^{631}$

A estrutura financeira interna das províncias não recebeu maior atenção da Carta outorgada. Enquanto aguardava sua regulamentação a partir do artigo 170 da Carta de 1824, o sistema de arrecadação e despesas das províncias esteve durante todo o Primeiro Reinado subordinado às Juntas da Fazenda, órgãos que remontavam ao período colonial e cuja origem estava atrelada às iniciativas da Coroa lusitana com relação à reestruturação do Império português ultramarino ao longo da segunda metade do século XVIII. Criadas em 1769 em substituição às provedorias-mor, as Juntas da Fazenda promoveram uma alteração significativa nas relações administrativas entre as Capitanias e o governo central, posto que elas estavam subordinadas diretamente a Lisboa e não mais ao Rio de Janeiro, como ocorria à época das provedorias. Durante seu período de funcionamento, as Juntas sofreram inúmeras alterações, sobretudo após a transplantação da sede da monarquia portuguesa para o Rio de Janeiro, em 1808. Em meio aos processos de Independência e construção do Estado Nacional brasileiro, as Juntas da Fazenda permaneceram com as incumbências básicas que desempenhavam antes do rompimento definitivo com Portugal, ou seja, organizar a arrecadação das rendas do Império, pagar as despesas e remeter o saldo ao Tesouro Público do Rio de Janeiro. ${ }^{632}$

O sistema de organização das Juntas da Fazenda foi pauta constante nos círculos políticos do Primeiro Reinado e no início do período regencial. Em artigo publicado em fevereiro de 1830, o periódico O Farol Paulistano argumentou que uma das necessidades

\footnotetext{
${ }^{631}$ CARVALHO, José Murilo de., op. cit.

${ }^{632}$ Cf. DINIZ, op. cit., pp.150-153. Para a estrutura formal das Juntas da Fazenda no período colonial, ver SALGADO, Graça. Fiscais e Meirinhos: a administração do Brasil colonial. Rio de Janeiro: Nova Fronteira, 1985.
} 
de “maior urgencia” em todo o Império era a mudança da “forma de administração" da Fazenda Pública, sobretudo nas províncias. Em primeiro lugar, as Juntas da Fazenda reuniam-se duas ou três vezes por semana, um número reduzido na opinião do redator de $O$ Farol. Em segundo, sua formação seria falha. Composta por um presidente (o mesmo da província), um ouvidor, um juiz de fora, um tesoureiro e um escrivão assessorado por uma contadoria, as Juntas da Fazenda congregariam, segundo o redator de O Farol, indivíduos compromissados com outras atividades que não as do tesouro provincial. ${ }^{633}$

Fatores como o questionamento do sistema administrativo das Juntas da Fazenda e o agravamento da situação financeira do Império contribuíram para que fosse aprovada a lei de 4 de outubro de $1831^{634}$. Com ela estavam extintos o Tesouro Nacional, o Conselho da Fazenda e as Juntas da Fazenda Provinciais, órgãos que foram substituídos pelo Tribunal do Tesouro Público Nacional e pelas Tesourarias Provinciais. Composto por um presidente, um inspetor geral, um contador geral e um procurador fiscal, todos por nomeação do imperador, o Tesouro Público Nacional tinha como principal atribuição deter a "suprema direcção e fiscalização da receita e despeza nacional; inspecionando a arrecadação, distribuição, e contabilidade de todas as rendas publicas, e decidindo todas as questões administrativas, que a taes respeitos possam ocorrer”. ${ }^{635}$ As Tesourarias Provinciais, por seu turno, criadas no lugar das Juntas da Fazenda de Província, eram formadas por um inspetor de fazenda, um contador e um procurador fiscal, e tinham como função central

\footnotetext{
${ }^{633}$ O Farol Paulistano, n 309, 18/02/1830.

634 “Lei de 4 de outubro de 1831 - Dá organização ao Thesouro Publico Nacional e ás Thesourarias Publicas das Provincias”, in Coleção das Leis do Império do Brasil de 1831, op. cit., Parte Primeira, pp.103-127.

${ }^{635}$ Ibid., p.104, cf. “objeto" $1^{\circ}$ do artigo $6^{\circ}$ do Capítulo II - "Das atribuições do Tribunal”.
} 
dirigir a "administração, arrecadação, distribuição, contabilidade, e fiscalização de todas as rendas publicas da Provincia”, ${ }^{636}$

Além de remodelar a estrutura do Tesouro Nacional bem como das suas repartições provinciais, a lei de 4 de outubro de 1831 contemplou as relações entre os governos locais e o órgão administrador do seu tesouro - ou seja, a Tesouraria Provincial -, estreitando-as. Segundo o artigo 54 (Capítulo I, Título $3^{\circ}$ ), os inspetores de fazenda ficariam à disposição dos presidentes de Província para que esses solicitassem, em reunião com o Conselho da Presidência, quaisquer informações e esclarecimentos sobre o estado da Fazenda Pública. Já o artigo 56 previa que nenhuma arrematação de contrato ou de despesa pública fosse feita sem a aprovação do presidente em reunião com o mesmo Conselho. ${ }^{637}$ Menos de um ano após a promulgação da lei de 4 de outubro já haviam sido instaladas as Tesourarias Provinciais de São Paulo, Minas Gerais, Bahia, Alagoas, Pernambuco, Rio Grande do Norte, Santa Catarina e Rio Grande do Sul, ao passo que as restantes estavam em processo de implementação. ${ }^{638}$

Uma das matérias mais significativas previstas pela lei de 4 de outubro versava sobre a interferência dos governos de província no uso da receita provincial. Segundo o artigo 57, aos inspetores de fazenda provinciais competia levar ao conhecimento do presidente, em Conselho, o balanço da receita e despesa do ano anterior, como também o orçamento do ano futuro aprovado no Parlamento. O presidente, reunido em Conselho, depois de analisar os aspectos “material” e “moral” dessa documentação, remeteria para o Tribunal do Tesouro um parecer sobre a mesma. Os mesmos documentos, de acordo com o

\footnotetext{
${ }^{636}$ Ibid., p.115, cf. artigo 46 do Capitulo I - "Da formação, e atribuição das Thesourarias de Província” - do Título $3^{\circ}$.

${ }^{637}$ Ibid., p.117.

${ }^{638}$ CARREIRA, op. cit., pp.221-222.
} 
artigo 58, seriam enviados para os Conselhos Gerais de Província, que repassariam aos inspetores de Fazenda de Província “reflexões” e "representações” sobre a matéria que por ventura quisessem levar ao conhecimento da Assembléia Geral ou do Poder Executivo. ${ }^{639}$

Um mês depois de promulgada a referida lei, aprovou-se no Parlamento a lei do orçamento para o ano financeiro de $1832-1833^{640}$, a 15 de novembro de 1831. Diferentemente daquela que fixara o orçamento para 1831-1832, a lei de 15 de novembro determinou que os presidentes seriam os responsáveis, em reunião com seus respectivos Conselhos privativos, por dirigirem os gastos provinciais previstos legalmente.

Na prática, e no que tange às esferas de atuação do presidente da Província de São Paulo e de seu Conselho privativo, a lei que remodelou o Tesouro Nacional, conjugada à de 15 de novembro de 1831, forneceu ao executivo provincial ferramentas legais para o manejo, mesmo que parcial e indireto, das rendas da Província. Embora a autonomia tributária das Províncias só concretizar-se-ia após a promulgação do Ato Adicional, quando as Assembléias Provinciais ficaram responsáveis por elaborar os orçamentos de suas respectivas Províncias, é de se notar que se franqueou aos Conselhos da Presidência uma participação ativa no processo de organização e racionalização dos gastos da máquina pública provincial, como ocorreu com a Província de São Paulo.

Em sessão extraordinária do Conselho da Presidência em agosto de 1832, o presidente Rafael Tobias de Aguiar indicou que, para executar as disposições asseguradas pela lei de 15 de novembro de 1831 referentes às despesas provinciais de São Paulo, era

\footnotetext{
${ }^{639}$ Ibdem., cf. artigos 57 e 58.

640 “Lei de 15 de novembro de 1831 - orça a receita e fixa a despeza para o anno financeiro de 1832-1833”, in Coleção das Leis do Império do Brasil de 1831, op. cit., Primeira Parte, pp.229-257.
} 
necessário exigir do Inspetor da Tesouraria da Província ${ }^{641}$ um documento explicitando as contas do ano anterior, pois só assim os conselheiros conseguiriam determinar, de acordo com a lei, as “referidas despezas”, o que foi aprovado. ${ }^{642}$ A matéria voltaria a emergir dois meses mais tarde, quando o Inspetor da Tesouraria ainda não tinha enviado os documentos solicitados. Desta vez, evocou-se o artigo $57^{643}$ da lei de 4 de outubro de 1831, o que foi novamente aprovado.

Não há registros sobre o envio de tais documentos pelo Inspetor da Fazenda, mas tudo indica que eles foram despachados ao presidente da Província de São Paulo, de modo que, em 29 de novembro de 1832, o Conselho da Presidência finalmente emitiu seu parecer sobre as despesas que pelos “Cofres da Fazenda Pública” poderiam ser feitos no ano financeiro de 1832-1833. Para tanto, havia sido constituída uma comissão específica para a conclusão do parecer, que por sua vez foi elaborado como base na lei de orçamento de 15 de novembro de 1831 . $^{644}$

As primeiras leis de orçamentos do Império, como se sabe, discriminavam não apenas o montante que poderia ser gasto por cada Província, mas também, em linhas gerais, em quais campos os governos locais poderiam utilizá-lo. A província de São Paulo, que até 1834 oscilou entre o $5^{\circ}$ e $6^{\circ}$ maior orçamento de todo o Império - ficando atrás somente do Rio de Janeiro, Minas Gerais, Bahia, Pernambuco e, em 1832-1833 e 1833-1834, do

${ }^{641} \mathrm{O} 1^{\circ}$ Inspetor da Fazenda de São Paulo - rigorosamente da Tesouraria da Província de São Paulo - foi Luis Antonio da Silva Freire, que tomou posse em 01/07/1832. Até 1834, seus sucessores foram João Gomes Machado Corumbá e Miguel Archanjo Ribeiro de Castro. Extraído de www.receita.fazenda.gov.br/Memoria/administracao/reparticoes/1822a1970/tesou_fazenda.asp. Acesso em novembro de 2008.

${ }^{642}$ ACP, v.16, sessão de 18/08/1832, pp.26-27.

643 “Os Inspetores da Fazenda de Província levarão ao conhecimento do Presidente em Conselho da respectiva província, o balanço da receita, e despeza do anno findo, e o orçamento do anno futuro, para este remetter para o Tribunal do Thesouro, com o seu parecer, depois de fazer o exame material, e moral delles; e na Corte, e Provincia do Rio de Janeiro, ao Inspetor Geral do Thesouro", cf. "Lei de 4 de outubro de 1831 - Dá organização ao Thesouro Publico Nacional e ás Thesourarias Publicas das Provincias", in op. cit., pp.117.

${ }^{644}$ ACP, v.16, sessão de 29/11/1832, pp.102-106. 
Maranhão -, tinha suas despesas habitualmente divididas entre 11 e 14 subitens: com a Presidência e seu Conselho privativo; com o Corpo Legislativo; com o expediente do Conselho Geral; com o Curso Jurídico; com os seminários e instrução pública; com a Biblioteca Pública e o Jardim Botânico; com a Fábrica de Ferro de Ipanema; com os professores de Saúde e vacina; com a civilização e catequese dos índios; com o Diretor Geral das Minas; com as obras públicas; com as paróquias; e com despesas eventuais. Ocasionalmente prescreviam-se gastos específicos - como a compra de livros para a Biblioteca Pública, prevista pela lei do orçamento do ano de 1831-1832-, mas se tornou costume manter as balizas estipuladas pela primeira lei de orçamento do Império, promulgada a 15 de dezembro de $1830 .{ }^{645}$

O Conselho da Presidência de São Paulo, portanto, baseando-se na lei do orçamento de 15 de novembro de 1831, elaborou um parecer que destrinchava, ponto a ponto, os gastos previstos por lei, enfatizando aqueles a serem feitos com ordenados, tais como o do presidente da Província, conselheiros, professores, oficiais, administrador dos índios, diretor geral das minas e de outros cargos subentendidos pela mesma lei. Em relação às despesas previstas com obras públicas, o Conselho não as especificou, alegando ser conveniente "esperar pelas informações exigidas pelo Exmo. Snr. Presidente”. ${ }^{646} \mathrm{Na}$ prática, o não detalhamento do uso desses recursos acabou por se mostrar uma estratégia do Conselho da Presidência em equacionar os gastos da Província com as condicionantes de

\footnotetext{
${ }^{645}$ Cf. "Lei de 15 de dezembro de 1830 - orça a receita fixa a despeza para o anno financeiro de 1831-1832”, in Coleção Leis do Império de 1830. Rio de Janeiro: Tipografia Nacional, 1876, pp.100-138; "Lei de 15 de novembro de 1831 - orça a receita e fixa a despeza para o anno financeiro de 1832-1833”, in Coleção Leis do Império de 1831, op. cit., pp.229-257; "Lei de 24 de outubro de 1832 - orça a receita e fixa a despeza para o anno financeiro de 1833-1834", in Coleção Leis do Império de 1832, op. cit., pp.131-173; "Lei de 8 de outubro de 1833 - orça a receita e fixa a despeza geral e provincial do Imperio para o ano financeiro de 18341835”, in Coleção Leis do Império de 1833. Rio de Janeiro: Tipografia Nacional, 1872, pp.66-101.

${ }^{646}$ ACP, v.16, sessão de 29/11/1832, p.106.
} 
uma obra pública (interesse político, urgência, viabilidade, etc.), de modo que o método levado a cabo pelo órgão foi deliberar, aos poucos, as despesas com esse tipo de matéria.

Quanto aos Conselhos Gerais, a lei de 4 de outubro de 1831 atribuiu-lhes uma função fiscalizadora sobre os demais órgãos envolvidos na organização das finanças provinciais. Do mesmo modo que a Câmara dos Deputados (art.105), os Conselhos Gerais ficaram encarregados de nomear, anualmente, uma comissão incumbida de analisar os documentos referentes ao gerenciamento das finanças provinciais e informar sobre sua legalidade (art. 106) ${ }^{647}$ Percebe-se, nesse ponto, a intenção dos parlamentares em atribuir aos próprios representantes das províncias o direito de vigiarem o manejo das contas provinciais.

Antes da aprovação da lei de 4 de outubro de 1831, entrara em discussão um polêmico projeto de lei que visava alterar não apenas a relação das províncias com suas respectivas despesas, como também re-ordenar a estrutura de arrecadação do Império. Constituindo desdobramento da discussão em torno da reforma constitucional e da plausibilidade da implantação de um sistema federativo, tal projeto de lei propunha, em síntese, a divisão das despesas públicas em "gerais” e “provinciais”. Estas seriam reguladas pelos presidentes de província, ao passo que aquelas permaneceriam sob a tutela do ministro da Fazenda.

Por conta da votação das bases da reforma constitucional, a discussão do projeto foi prolongada até o final do ano seguinte, quando foi aprovada a lei de 24 de outubro de $1832 .{ }^{648}$ Além de orçar a receita e fixar a despesa do Império para o ano de 1833-1834, a lei

\footnotetext{
647 "Lei de 4 de outubro de 1831 - Dá organização ao Thesouro Publico Nacional e ás Thesourarias Publicas das Provincias", in op. cit., p.124.

648 "Lei de 24 de outubro de 1832 - orça a receita e fixa a despeza para o anno financeiro de 1833-1834", in Coleção das Leis do Império de 1832, op. cit., pp.131-173.
} 
de 24 de outubro estabeleceu "outras proveniências sobre a administração e arrecadação da Fazenda”. As rendas públicas, que até o momento eram arrecadadas pelo Tesouro Nacional, ficaram divididas em "Receita Provincial” e "Receita Geral”. Enquanto a esta passaram a pertencer as principais rendas oriundas das províncias - tais como as alfandegárias (de importação, exportação, baldeação e reexportação), além de outras vinte fontes asseguradas por lei -, à receita provincial foram relegados "todos os impostos ora existentes não comprehendidos na receita geral”. ${ }^{649}$

Para a historiadora Maria de Lourdes Viana Lyra, a nova classificação das rendas era uma forma do governo central aumentar sua receita a partir do re-direcionamento de parte importante das rendas provinciais para os cofres do Tesouro Público Nacional:

“Com a classificação das fontes de receita geradoras das rendas públicas, o governo fazia com que todas as províncias contribuíssem com os gastos do Império, velha aspiração só agora realizada, livrando-se do desgaste dos apelos quase nunca atendidos para o envio dos saldos provinciais e ainda invertia o sentido da dependência financeira entre centro e províncias do Estado imperial. Ou seja, ao classificar como pertencentes à “receita geral” os impostos geradores de maior fonte de renda, o governo retirava das províncias mais ricas sobretudo Bahia, Pernambuco e Maranhão - o montante dos rendimentos nelas gerados pela exportação de açúcar, algodão, fumo e cacau, produtos de maior peso na balança comercial até então (...) Assim, a nova política de arrecadação das rendas aumentava substancialmente a receita geral, alcançando um montante quase três vezes maior do que o teto máximo do rendimento referente à receita provincial. Além disso, representava um corte aproximado de mais da metade do que era arrecadado, e até então retido, nas províncias”. 650

${ }^{649}$ Ibid., pp.168-170, cf. Títulos IV (“Receita Geral”, capítulo único) e V (“Receita Provincial”, capítulo único).

${ }^{650}$ LYRA, op. cit., pp.83-84. 
No que diz respeito à relação das Províncias com sua receita, a lei de 24 de outubro de 1832 também impôs algumas mudanças, reduzindo a ingerência dos executivos provinciais na matéria e aumentando, em contrapartida, a dos Conselhos Gerais. Em verdade, o projeto de lei original previa que as receitas provinciais fossem reguladas pelos presidentes de província, mas a matéria foi suprimida após ser duramente criticada por membros da Câmara dos Deputados, como Venâncio Henriques de Resende, Honório Hermeto Carneiro Leão e Diogo Duarte da Silva, respectivamente representantes por Pernambuco, Minas Gerais e Santa Catarina. ${ }^{651}$ Esses alegaram que tal medida fortaleceria em demasia a figura do presidente e, ao mesmo tempo, enfraqueceria os Conselhos Gerais. O próprio ministro da Fazenda na época - Bernardo Pereira de Vasconcelos -, que participou ativamente na discussão da lei de 24 de outubro de 1832, endossou essa opinião, afirmando que tal proeminência do presidente da província só poderia ser efetivada após uma reforma da Constituição, onde o executivo provincial fosse contrabalançado por um outro poder. ${ }^{652}$ Em sintonia com a nova legislação, o Ministério da Fazenda baixou uma decisão, no ano seguinte, marcando as instruções para as províncias melhor organizarem seus balanços e orçamentos. ${ }^{653}$

A lei de 24 de outubro de 1832 ampliou a ingerência dos Conselhos Gerais no manejo das receitas provinciais da seguinte forma. De acordo artigo 86, a receita e despesa provinciais seriam a partir dali fixadas pelos Conselhos Gerais, "sob o orçamento dos presidentes de Província”. O artigo 87 marcava que, no dia da abertura dos Conselhos Gerais, os presidentes apresentariam um relatório com o "orçamento da receita, e despeza

\footnotetext{
${ }^{651}$ APB, t.1, sessões de 28 e 29 de julho de 1831, p.181 e seguintes.

${ }^{652}$ SLEMIAN, op. cit., pp.235-237.

653 "Decisão do Ministério da Fazenda de 2 de maio de 1833 - dá instruções para melhor organização dos balanços e orçamentos das Provincias”, in Coleção das decisões do Governo do Império do Brasil de 1833, op. cit., pp.158-159.
} 
provincial, e as contas do anno findo", ficando à disposição dos “Conselhos” para esclarecimentos. Depois de organizados, os orçamentos seriam remetidos à Câmara dos Deputados para serem corrigidos e aprovados pela Assembléia Geral (artigo 88). Segundo o artigo 90, caso as rendas provinciais não fossem suficientes para suprir suas despesas, os Conselhos Gerais poderiam representar à Câmara dos Deputados, indicando quais os objetos que poderiam “soffrer alguns impostos, sem maior gravame dos povos”, ou aqueles que poderiam ser "substituídos por outros, com vantagem da renda, e dos contribuintes”. O mesmo poderia ser feito com relação à Receita Geral arrecadada nas Províncias. ${ }^{654}$

No ano seguinte à aprovação da lei de 24 de outubro o Conselho Geral de São Paulo passou a trabalhar de acordo com suas novas funções. Inúmeros documentos foram produzidos (solicitações, pareceres, pedidos, etc.) pelo órgão paulista com o intuito de racionalizar a elaboração de receita e despesas da província. ${ }^{655}$ Em janeiro de 1833, a Comissão da Fazenda do Conselho Geral de São Paulo - da qual participava Antonio Mariano de Azevedo Marques - propôs que fosse solicitado ao governo da província o balanço do ano anterior para que os conselheiros gerais findassem a organização do orçamento da receita e despesa para o ano financeiro de $1834-1835 .{ }^{656}$ O orçamento foi terminado em fins de janeiro e remetido para uma comissão do Conselho da Presidência de São Paulo encarregada de revê-lo. A comissão elogiou a redução de despesas feita pelo Conselho Geral em face do “deficit” da fazenda provincial:

“A Commisão encarregada de rever os orçamentos de Receitas e Despesa, tanto Geral, como Provincial para o anno financeiro, que hade deccorer do $1^{\circ}$ de julho de 1834

\footnotetext{
654 “Lei de 24 de outubro de 1832 - orça a receita e fixa a despeza para o anno financeiro de 1833-1834”, in op. cit., cf. artigos 87, 88 e 90, pp.170-171.

${ }^{655}$ Ver, por exemplo, FCGP, CF33.038, caixa 31.

${ }^{656}$ FCGP, CF33.041, caixa 09.
} 
ao ultimo de junho de 1835 julga impossível reduzir mais as despesas do q o fez o Conselho Geral, com quanto aliás esteja convencida de que tal he a necessidade a mais urgente da Provincia e talvez de todo o Imperio. A impossibilidade desta reducção provem de q a maior parte das despesas supérfluas são fundadas em Lei q ainda quando derrogadas deixão direito individuaes, q cumpre respeitar. Taes são as despesas com o pessoal do Exercito, cuja officialidade hoje pela maior parte sem emprego, custa ainda a Nação as enormes sommas, q se vem no respectivo Orçamento. Na falta pois de remedios para evitar já o deficit da Receita geral, a comissão hé de parecer q este Governo não tem mais a faser do q remetter do Tribunal do Thesouro Nacional o orçamento Provincial fixado pelo Conselho Geral, e as reflexões do mesmo acerca do orçamento Geral, unindo seus votos aos q patrioticamente fez o mesmo Conselho Geral para a reducção das despesas, acrescentandose q este Governo se nutre ainda de algumas esperanças de q o deficit não seja tão considerável, como aparece, visto q passão a arrematar-se as rendas q admittem esse methodo de percepção. ${ }^{657}$

Pelo artigo 85 da lei de 24 de outubro as rendas provinciais, depois de devidamente arrecadadas e organizadas, seriam “distribuídas” pelos presidentes de província em reunião com seus respectivos conselhos privativos. Desse modo, não obstante a referida lei ter ampliado a ingerência dos Conselhos Gerais na organização das finanças provinciais, quer nos parecer que os Conselhos da Presidência aprofundaram sua participação na destinação das verbas públicas, o que pelo menos foi possível depreender do congênere paulista. Em fevereiro de 1833, após solicitação das Câmaras Municipais da cidade de São Paulo e da Vila de Santos, o Conselho da Presidência de São Paulo deliberou, “em conformidade da Lei do orçamento”, que fossem entregues $600 \$ 000$ à primeira e $300 \$ 000$ à segunda para a “sustentação dos presos pobres no corrente anno financeiro”. ${ }^{658}$ Em outubro do mesmo ano, o Conselho nomeou o sargento-mór Francisco Leandro para o cargo de inspetor da Estrada de Nazareth para a capital paulista, e deliberou que lhe confiassem $50 \$ 000$ para o

\footnotetext{
${ }^{657}$ ACP, v.16, sessão de 27/02/1833, p.135.

${ }^{658}$ ACP, v.16, sessão de 16/02/1833, p.118.
} 
encaminhamento da obra. ${ }^{659}$ No mês seguinte, resolveu-se conceder à Câmara Municipal de Bananal a quantia de 500\$000 para a conclusão da estrada que ligava aquela Vila à Ilha Grande, de acordo com a "ley do Orçamento para obras publicas”. ${ }^{660}$ Entre 1833 e 1834, foram recorrentes as resoluções tomadas pelo Conselho da Presidência de São Paulo quanto ao dispêndio de recursos públicos direcionados para a viabilização de obras de infraestrutura e outras iniciativas das administrações provincial e municipal.

As leis de 15 de novembro de 1830, 4 de outubro de 1831 e 24 de outubro de 1832 foram responsáveis pela racionalização e sofisticação da estrutura financeira do Império. ${ }^{661}$ Em 1833, o então ministro da fazenda Cândido José de Araújo Viana anunciou uma melhoria na arrecadação pelos cofres do Rio de Janeiro, em virtude da maior participação das rendas oriundas das Tesourarias Provinciais. ${ }^{662}$ Iniciava-se, aos poucos, a construção de novas ferramentas de extração e repasse de recursos por parte do governo, bem como de instrumentos direcionados para a participação das províncias na estrutura financeira do Império. Por mais que a classificação das rendas do Império em “gerais” e “provinciais” tenha assegurado à Corte lugar privilegiado na direção da estrutura financeira imperial, tornando-se inclusive num dos elementos que alimentaria a eclosão de inúmeras sublevações em diferentes pontos do território nacional no decurso da década de 1830, a ação legislativa que se consubstanciou nas primeiras leis de orçamento, na criação do

\footnotetext{
${ }^{659}$ ACP, v.16, sessão de 05/10/1833, p.203.

${ }^{660}$ ACP, v.16, sessão de 11/11/1833, p.244.

${ }^{661}$ DINIZ, op. cit.

${ }^{662}$ CARREIRA, op. cit., p.226.
} 
Tribunal do Tesouro Público Nacional, das Tesourarias Provinciais e na divisão de recursos dos cofres públicos lançava luz para o fato de que qualquer passo a ser dado no sentido de estabelecer uma normatização da máquina pública imperial acarretaria no aparelhamento jurídico-administrativo das províncias. Assim, a questão não recaía apenas sobre o aumento do nível de participação das províncias no manejo das suas contas, mas também sobre a necessidade dos políticos do Império reconhecerem que esse somente lograria como um estado monárquico-constitucional caso fossem criados mecanismos político-administrativos adequados às realidades provinciais, e que garantissem aos poderes locais uma certa margem de autonomia para geri-los.

Até a votação do Ato Adicional, os Conselhos Provinciais permitiram um constante acúmulo de experiências político-administrativas em nível local, o que inegavelmente conferiu maior densidade à futura discussão em torno da criação das Assembléias Legislativas Provinciais, bem como àquela sobre o estabelecimento de um regimento para a atuação dos presidentes de província. Cotejando a legislação parlamentar referente à estrutura financeira provincial com a atuação dos Conselhos Provinciais paulistas, foi possível verificar um movimento duplo e gradual do ponto de vista do aparelhamento dos espaços de ação política nas províncias: de um lado os Conselhos Gerais passaram a ter maior participação na marcação das receitas e despesas provinciais e na fiscalização dos órgãos envolvidos no manejo das contas das províncias, o que significou um sensível aumento de poderes por parte dos governos locais se comparado ao regimento de 27 de agosto de 1828, que nenhuma menção trazia sobre o tema. De outro, os executivos provinciais - quer o presidente quer seu conselho privativo - viram-se cada vez mais dotados de elementos legais direcionados para a organização dos orçamentos provinciais e para a utilização dos recursos das províncias. Em suma, a questão da fiscalidade ajudou a 
delimitar com maior precisão os dois principais espaços de poder político das províncias. Ao mesmo tempo em que a faculdade de propor, largamente garantida pela lei de 23 de outubro de 1823, foi sendo retirada do executivo, a cada nova lei os Conselhos Gerais passaram a apoderar-se dela, assemelhando-se em ritmo crescente aos órgãos legislativos. Sobre esse ponto cabe lembrar, mais uma vez, que a Carta de 1824 havia inserido os Conselhos Gerais no Título $4^{\circ}$, destinado ao "Poder Legislativo” do Império, e desde então a sua transformação em Assembléias Legislativas percorreu com freqüência os debates políticos da época.

É de se notar, todavia, que a alteração do papel dos Conselhos Provinciais na estrutura financeira das províncias ao longo dos primeiros anos da década de 1830 não foi um fenômeno isolado; ele fez parte, antes, de um amplo processo de constituição dos poderes provinciais com base no cumprimento da Carta de 1824. Muito embora a reforma constitucional e, mais precisamente, a instalação das Assembléias Provinciais sejam recorrentemente tratadas pela bibliografia como elementos que solaparam os Conselhos Provinciais $^{663}$, contrapondo-lhes uma realidade institucional totalmente nova, cabe aqui a ressalva de que a tanto a votação da lei de 12 de outubro de 1832 como a aprovação do Ato Adicional foram direta e indiretamente ancoradas na experiência política daqueles órgãos, que por seu turno tiveram parte de suas atribuições modificadas durante o período em que funcionaram, não formando, portanto, instituições monolíticas. Sugere-se aqui, deste modo, que as alterações proporcionadas pela reforma constitucional com relação aos governos provinciais constituíram menos uma negação efetiva dos Conselhos Provinciais, especialmente dos Conselhos Gerais, do que um desdobramento de uma atividade

\footnotetext{
${ }^{663}$ Ver, por exemplo, DEBES, Célio. "Estrutura política e legal dos governos paulistas de 1821 a 1834”, in Revista do Instituto Histórico e Geográfico de São Paulo, v.65, 1968; DOLHNIKOFF, op. cit., 2005.
} 
parlamentar amplamente influenciada pelo debate travado nos círculos políticos do Império - a exemplo da imprensa periódica - que vinha se desenvolvendo desde o Primeiro Reinado, e que ganhou força após a Abdicação.

Some-se a isso o fato de que parcela importante dos elaboradores e defensores do Ato Adicional foi constituída justamente por representantes de São Paulo e Minas Gerais, que não por acaso vivenciaram o pleno funcionamento de seus respectivos Conselhos Provinciais. A experiência acumulada nesses anos certamente forneceu indicações preciosas para a elaboração de uma nova organização institucional.

\subsection{O Ato Adicional e a lei de regulamentação do exercício dos executivos provinciais: a extinção dos Conselhos Provinciais}

Prevista pela lei de 12 de outubro de 1832, a discussão sobre a reforma constitucional iniciou-se logo no inicio da $3^{\circ}$ legislatura do Império, em maio de 1834 . Em São Paulo, a “moderação” aumentava sua influência política. Paula Souza havia sido feito senador um ano antes, e nenhuma grande surpresa ocorrera nas eleições para a $3^{\mathrm{a}}$ legislatura, bem como para a $3^{\mathrm{a}}$ Reunião dos Conselhos Provinciais paulistas. Segundo Augustin Wernet, apenas no colégio eleitoral da vila de Santos, em articulação com os Andradas, os “exaltados” superaram os “moderados”. ${ }^{664}$ A Sociedade Federal de São Paulo, principal lócus de discussão dos “exaltados” paulistas que interrompera suas atividades em fins de 1832, não voltou a funcionar. O fortalecimento dos “moderados” em São Paulo também se fez notar na imprensa, que nesse momento ainda estava circunscrita apenas à

\footnotetext{
${ }^{664}$ WERNET, op. cit., p.129.
} 
capital paulista. ${ }^{665}$ A bibliografia consultada não menciona que tenham existido jornais “exaltados” ou “caramurus” publicados na cidade de São Paulo entre o final de 1832 e 1834, o que possivelmente configurou um monopólio da palavra impressa periódica pelos “moderados”. Bernardino José Ribeiro (ex-Voz Paulistana), um dos principais redatores “exaltados” de São Paulo em 1831, tornara-se desde 1833 integrante do corpo de redação de O Novo Farol Paulistano, o único jornal paulista de circulação regular entre meados de 1832 e a votação do Ato Adicional, e que manteve sua orientação “moderada”.

Em junho de 1834, na Câmara dos Deputados, uma comissão especial encarregada de elaborar o projeto final sobre a matéria com base na lei de 12 de outubro apresentou os resultados de seus trabalhos. ${ }^{666} \mathrm{O}$ texto contava com trinta artigos e tinha como principal ponto a criação das Assembléias Legislativas Provinciais e a definição de seu funcionamento. Ele marcava, também, as novas atribuições dos presidentes de província, a instauração de uma Regência Una, além de garantir a supressão definitiva do Conselho de Estado. $^{667}$

Poucos dias após a apresentação do projeto pela comissão, o deputado por Minas Gerais José Custódio Dias propôs uma medida que causou grande polêmica entre os deputados. Para o padre mineiro, a reforma deveria ser discutida e votada apenas pela primeira Casa, uma vez que se os senadores interferissem no encaminhamento da matéria seu resultado seria pouco profícuo, à semelhança do que ocorrera na votação da lei de 12 de outubro de 1832, quando a proposta de reforma sofreu diversas emendas do Senado. Tal

\footnotetext{
${ }^{665}$ Após seu surgimento na capital paulista, a imprensa demorou a se espalhar nas demais localidades da Província, tal como em Sorocaba (1842), Santos (1841), Itu (1849), Guaratinguetá (1859), Campinas (1860), Taubaté (1861) e Pindamonhangaba (1863), cf. TOLEDO, Lafayette de. "Imprensa Paulista”, in Revista do Instituto Histórico e Geográfico de São Paulo. São Paulo: Typografia do Diário Oficial, v.3, 1898.

${ }^{666}$ A comissão era formada pelos deputados Francisco de Paula Araújo e Almeida (Bahia), Bernardo Pereira de Vasconcelos (Minas Gerais) e Antônio Paulino Limpo de Abreu (Minas Gerais). Cf. APB, t.1, sessão de 07/06/1834, pp.104-106.

${ }^{667}$ Ibidem.
} 
exclusividade da Câmara na condução da reforma foi endossada por Luiz Francisco de Cavalcanti de Albuquerque, Ernesto Ferreira França e Francisco de Paula Araújo e Almeida, respectivamente deputados por Pernambuco e Bahia. Evaristo da Veiga, então representante pelo Rio de Janeiro, assinalou que se as reformas fossem novamente vetadas pelo Senado o Império poderia encerrar-se numa "guerra civil”. Não obstante deputados como Francisco de Souza Martins (Piauí), Antônio Pedro da Costa Ferreira (Maranhão), Manoel Maria do Amaral (Bahia) e Antônio Peregrino Maciel Monteiro (Pernambuco) terem acolhido a proposta como um tipo de "golpe de estado", essa foi aprovada sem maiores problemas, o que demonstrava uma descrença explícita dos deputados com relação à efetiva adesão dos senadores à reforma da Carta de 1824. Caberia apenas aos representantes da primeira Casa, destarte, encaminharem o processo reformista. ${ }^{668}$

O primeiro artigo discutido pelos deputados foi aquele que garantia a criação de Assembléias Legislativas em cada uma das províncias. Como era de se esperar, inúmeros embates surgiram em meio à discussão da matéria, a começar pela natureza desses novos órgãos. Ernesto Ferreira França sugeriu uma emenda a qual evidenciasse que as Assembléias substituiriam os Conselhos Gerais, que na sua opinião teriam atribuições mais amplas do que os que os órgãos a serem criados, posto que a Carta de 1824 não impusera limites precisos sobre o que os conselheiros gerais poderiam ou não deliberar. O deputado baiano Francisco Gonçalves Martins apoiou a emenda de seu conterrâneo, em virtude das Assembléias representarem, segundo ele, uma restrição do poder político local. É interessante observar que o poder de legislar, teoricamente o grande avanço das Assembléias com relação aos Conselhos Gerais, não era necessariamente concebido como uma melhoria entre os deputados. Em sessão de junho de 1834, o pernambucano Holanda

${ }^{668}$ SLEMIAN, op. cit., pp.264-265. 
de Cavalcanti e Albuquerque apreciou as Assembléias Legislativas como "sinônimos” dos Conselhos Gerais. ${ }^{669}$ Talvez um dos motivos que fizesse com que a ingerência legislativa das Assembléias perdesse força entre os deputados residisse na incerteza de que as leis aprovadas em nível provincial fossem de fato implementadas. Em outros termos, questões importantes ainda precisavam ser votadas para dar tangibilidade ao poder legislativo provincial, como a de quem teria o poder de sancionar ou vetar as medidas aprovadas pelas Assembléias.

A criação de esferas de poder provincial dotadas de competência legislativa permanecia, ainda assim, como o cerne do projeto das novas Assembléias, e experiência de cerca de seis anos de Conselhos Gerais mostrara aos políticos do Império que tal inovação ia além do fato de as localidades legislarem sobre seus negócios. Sem dúvida sua grande limitação, a ausência de poder legislativo por parte dos Conselhos Gerais havia gerado uma perigosa zona de intersecção político-administrativa entre tais órgãos e os executivos provinciais - dos quais os Conselhos da Presidência tinham um papel importante -, o que dificultou a definição do real campo de atuação de cada um desses espaços de poder.

Não menos conflituosa foi a discussão acerca da marcação do número de representantes que teria cada Assembléia. Segundo o projeto original, cada província só poderia alterar o número de seus representantes - a ser fixado pela reforma - por meio de legislação votada pelo Parlamento. O deputado pelo Rio Grande do Norte Francisco de Brito Guerra argumentou que o número de elementos que comporia as Assembléias deveria ser modificado por lei provincial, no que foi seguido pelo maranhense Antonio Pedro Costa Ferreira, que criticou a teor centralizador da proposta elaborada pela comissão. O tempo de duração do funcionamento dos novos órgãos também gerou controvérsias. De acordo com o

${ }^{669}$ Ibid., p.266. 
projeto original, as legislaturas provinciais acompanhariam o período de trabalhos da Assembléia Geral. Novamente foi Antonio Pedro Costa Ferreira quem contestou o teor da matéria, e sugeriu que cada província decidisse sobre a duração de suas respectivas legislaturas, sendo apoiado por Francisco de Souza Martins e Jerônimo Martiniano Figueira de Mello. ${ }^{670}$

O advento de inúmeras propostas de emenda ao projeto original - quase todas elas denunciadoras de um suposto cerceamento da autonomia local - exigiu que os representantes da comissão e seus adeptos explicitassem com maior clareza os objetivos da proposta de reforma. Ainda no mês de junho Francisco de Paula Araújo afirmou que o projeto da comissão tinha por intuito estabelecer a união das províncias em torno de um centro político a ser representado pela Corte, e que, portanto, a reforma constitucional não subverteria de todo a ordem das coisas, especialmente o papel do Rio de Janeiro como ponto de união entre as províncias. Aos poucos, esse raciocínio tornou-se o eixo central da argumentação daqueles que defendiam a aprovação do projeto tal como fora estabelecido pela comissão, e que passou a ganhar adeptos. Sob a bandeira da “moderação” e do repúdio aos “excessos”, políticos como Bernardo Pereira de Vasconcelos difundiram a idéia de que a reforma traria em seu bojo um afrouxamento dos laços que atavam as províncias ao centro do Império, concedendo maiores poderes às primeiras, e não uma supressão do sistema monárquico-constitucional tal como fora estipulado pela Carta de $1824 .{ }^{671}$

Em forma de um Ato Adicional à Carta de 1824, a lei da reforma constitucional foi sancionada em 12 de agosto de 1834, com ampla vitória do projeto elaborado pela

\footnotetext{
${ }^{670}$ Ibid., pp.269-273.

${ }^{671}$ SOUSA, Otávio Tarquínio de., op. cit., v.5, capítulo 6.
} 
comissão. ${ }^{672}$ A partir dela foram criadas as Assembléias Legislativas Provinciais, em substituição aos Conselhos Gerais. Às Assembléias competia legislar sobre as divisões civil, judiciária e eclesiástica, que se desdobrariam em pautas como a instrução pública, a fixação de despesas municipais e provinciais, a criação e supressão de empregos e ordenados, a realização de obras públicas, a organização de regimentos internos, a feitura de empréstimos e a administração dos bens provinciais. Em conjunto com os executivos provinciais, ficaram encarregadas de produzir estatísticas, fomentar a catequese e civilização dos índios e tomar medidas com relação à sublevações, invasões e subversões. Caberia às Assembléias, também, solicitar a suspensão temporária de magistrados e de decidir sobre eventuais processos nos quais estivessem pronunciada a figura do presidente de província. As Câmaras Municipais ficaram subordinadas às Assembléias, que passariam a ter o direito fixar, repartir e fiscalizar suas finanças, bem como intervir na nomeação de cargos públicos e na construção de obras públicas. Os integrantes da Assembléia seriam deputados eleitos da mesma forma que os membros para o Parlamento, com a diferença que seu mandado seria de apenas dois anos. ${ }^{673}$ Com a duração de dois meses, suas sessões poderiam ser prorrogadas pelos presidentes de província quando esses julgassem pertinente. As leis aprovadas teriam como destino o presidente da província, a quem ficou reservado o direito de sancioná-las, e de remetê-las ao imperador para sua aprovação definitiva.

Se comparadas aos Conselhos Gerais, as Assembléias Gerais apresentavam duas grandes inovações: em primeiro lugar, detinham poder legislativo e independente da

\footnotetext{
672 "Lei de 12 de agosto de 1834 - faz algumas alterações e addições à Constituição Política do Império, nos termos da Lei de 12 de outubro de 1832”, in Coleção das Leis do Império do Brasil de 1834. Rio de Janeiro: Tipografia Nacional, 1866, Parte Primeira, pp.16-42.

${ }^{673}$ Criaram-se três categorias para estipular o número de deputados de cada província, de acordo com critérios populacionais. Rio de Janeiro, Bahia, Pernambuco, Minas Gerais e São Paulo elegeriam 36 deputados; GrãoPará, Maranhão, Ceará, Paraíba, Alagoas e Rio Grande de São Pedro teriam direito a 28 cadeiras, e as demais províncias apenas 20.
} 
ingerência da Assembléia Geral. Em segundo, contariam na maior parte das províncias com mais membros que os Conselhos Gerais, ampliando assim o leque de representatividade política dos grupos locais. No mais, as duas instituições se pareciam em muitos pontos, especialmente com relação às suas atribuições administrativas. Certo grau de similaridade entre os Conselhos Gerais e as Assembléias Provinciais foi notado pelos próprios coevos. Por volta de três meses após a promulgação do Ato Adicional, o Justiceiro, periódico impresso em São Paulo sob a direção de Diogo Feijó, publicou um artigo em que traçava uma linha evolutiva entre os Conselhos Gerais e os órgãos que os sucederam. Tidos como “germes” das Assembléias Provinciais, os Conselhos Gerais teriam apresentado como grandes entraves a sua dependência em relação à Assembléia Geral - esfera perpassada por “rivalidades” entre seus membros - e a carestia de recursos para manter seus membros e estrutura, o que limitou o bom funcionamento desses órgãos :

“(...) Os Conselhos Gerais foram os germes das Assembléias Provinciais; a sua concepção porém foi mesquinha, atendendo-se à vastidão do Brasil e à grande extensão de suas províncias. Encarregados somente de propor suas necessidades à Assembléia Geral, que jamais as podia bem avaliar, encontrando-se em seus membros rivalidades, indiferença e falta de conhecimentos locais, acrescendo a influência de negócios gerais que anualmente lhe absorve quatro a cinco meses de sessão, vinham a ser uma quase nulidade. Nem era possível que os conselheiros conservassem por muito tempo o fogo do patriotismo entre tantos sacrifícios que lhes custara uma proposta ou desprezada, ou honrosamente abandonada. Acanhados em suas discussões por faltar-lhes a irresponsabilidade, impossibilitados muitos por falta de subsídio que os ajudasse a viver na capital, longe dos recursos que facilmente obteriam de suas fazendas, aconteceu, não raras vezes, que os Conselhos Gerais deixaram de reunir-se, ou com muitos poucos membros, ou foi necessário recorrer a suplentes que bem limitado número de votos obtiveram (...)”674.

${ }^{674}$ O Justiceiro, $\mathrm{n}^{\circ}$ 4, 27/11/1834. O artigo completo encontra-se transcrito em FEIJÓ, Diogo Antônio. Diogo Antônio Feijó . Organização e prefácio de Jorge Caldeira. São Paulo: Editora 34, 1999. (Coleção Formadores do Brasil), pp.124-127. 
Além da criação das Assembléias Provinciais, o Ato Adicional confirmou duas indicações da lei de 12 de outubro de 1832. O Conselho de Estado foi extinto e aprovou-se que a Regência seria partir dali seria governada por um regente uno, eleito da mesma forma que os senadores e deputados.

Historiadores repartem opiniões acerca do sentido político do Ato Adicional. A interpretação mais comum é a de que ele representou uma vitória da oposição liberal à estrutura política consolidada durante o Primeiro Reinado, ampliando a autonomia das províncias com relação ao centro do Império, que posteriormente malograria com o “Regresso" conservador. ${ }^{675}$ Já autores como Miriam Dolhnikoff acreditam que o Ato Adicional foi a forma encontrada pelos políticos da época para de um lado permitir a inserção dos grupos locais na direção da máquina pública e, de outro, garantir a manutenção da integridade do estado imperial. ${ }^{676}$ Em contrapartida, pesquisas como a de Maria de Lourdes Viana Lyra apontam para uma limitação essencial da lei de 12 de agosto de 1834, o que a tornaria bem menos inovadora. Trata-se do fato de que embora tenha viabilizado uma efetiva descentralização política, o Ato Adicional não promoveu o mesmo no que tange à estrutura fiscal do Império, impondo-se como um dos principais pontos evocados pelos levantes contra o governo regencial até a Maioridade. ${ }^{677}$

O fato é que, como ressaltou Maria de Fátima Gouvêa, o Ato Adicional só pode ser entendido em sua complexidade por meio da prática política que o sucedeu, notadamente a

\footnotetext{
${ }^{675}$ Ver, por exemplo, MATTOS, Ilmar Rohllof de. O tempo saquarema. A formação do Estado imperial. São Paulo: Hucitec, 2004; FAORO, op. cit.; HOLANDA, 1965.

${ }^{676}$ DOLHNIKOFF, op. cit., 2005, especialmente capítulo 2.

${ }^{677}$ LYRA, Maria de Lourdes. "A unidade brasileira: uma questão preliminar no processo de independência”. Revista do IEB, 1992, n ³4, pp.121-138”. Para considerações mais aprofundadas sobre o tema, ver Centralisation, système fiscal et autonomie provinciale dans l'Empire brésilien : la province de Pernambuco, 1808-1835 . Tese de Doutorado apresentada à Universidade de Paris X. Paris, 1985.
} 
partir do exame do funcionamento das Assembléias Provinciais. ${ }^{678}$ Além disso, seu entendimento deve ser conjugado à análise de uma lei bem menos enfatizada pela bibliografia, a qual regulamentou a esfera de atuação dos presidentes de província. Promulgada em 3 de outubro de 1834 a partir de um projeto elaborado pelo Senado, a lei que criou um regimento para os presidentes de província complementou o Ato Adicional, definindo assim o novo perfil institucional das províncias. ${ }^{679}$

O regimento aprovado alterou sensivelmente alguns pontos-chave da lei de 23 de outubro de 1823, que até então constituía a base legal dos executivos provinciais. Aos presidentes, que seriam escolhidos pelo imperador, caberia executar as leis, fiscalizar a atuação dos empregados públicos e de suas respectivas repartições, prover cargos, conceder licenças, denunciar ao governo central quaisquer problemas que embaraçassem suas atividades, decidir temporariamente conflitos de jurisdição e suspender qualquer funcionário acusado de abuso. ${ }^{680}$

Ao se confrontar as duas leis é possível notar que se por um lado o Ato Adicional deu maior autonomia às províncias - alargando o poder dos Conselhos Gerais e transformando-os em Assembléias Provinciais -, por outro o regimento para os presidentes extirpou qualquer possibilidade de se consolidar um canal de representatividade no âmbito dos executivos provinciais, o que na prática acabou fornecendo aos “delegados do imperador” um campo de atuação muito mais amplo e centralizador do que existira ao longo do Primeiro Reinado e nos primeiros anos do período regencial. Isso porque os Conselhos da Presidência, que como vimos desempenhavam atribuições que iam além de

\footnotetext{
${ }^{678}$ GOUVÊA, op. cit., 2008.

679 “Lei de 3 de outubro de 1834 - Dá regimento aos Presidentes de Provincia, e extingue o Conselho da Presidencia”, in Coleção das Leis do Império de 1834, op. cit., pp.53-56.

680 Ibidem.
} 
um órgão meramente consultivo, foram definitivamente suprimidos, ao passo que o vicepresidente deixou de ser o conselheiro da presidência mais votado para ser escolhido pelo ministro dos Negócios do Império a partir de uma lista de seis nomes elaborada pelos deputados das Assembléias Provinciais a cada nova Legislatura. Nesse sentido, o saldo das reformas de 1834 foi bem menos radical do que se havia aventado nos idos de 1831-32, visto que propostas como a extinção do veto absoluto pelo imperador, a escolha dos presidentes de província por eleição, a supressão da vitaliciedade do Senado e a implantação de uma monarquia federativa não obtiveram êxito. 


\section{Considerações finais}

Este trabalho pretendeu lançar luz sobre o delineamento de espaços de poder na província de São Paulo em meio ao processo de organização do Império e da monarquia constitucional, mediante a análise do significado político dos Conselhos Provinciais e do seu entrelaçamento com a imprensa paulista da época, entre 1824 e 1834.

É possível propor que a importância dos Conselhos Provinciais na política local, aos menos em São Paulo, foi bem maior do que a bibliografia geralmente tem anotado. Se as leis que os criaram ou regulamentaram já davam mostras de que os Conselhos teriam ampla ingerência sobre os negócios provinciais, as alterações jurídico-administrativas por eles sofridas durante seu funcionamento e as suas respectivas atuações confirmaram a proeminência de ambos os órgãos no sentido da garantir aos grupos provinciais canais de participação política. Os Conselhos Provinciais auxiliaram na execução do projeto de governo asseverado pela Carta de 1824 e, juntamente com a presidência, concretizaram-se como as principais esferas de poder nas províncias durante o Primeiro Reinado e o início do período regencial.

Parte significativa dos membros desses órgãos também atuava na Câmara dos Deputados, o que colocou os Conselhos paulistas em sintonia com o debate levado adiante pelos deputados nas primeiras legislaturas, fazendo com que influenciassem no encaminhamento de questões mais amplas da política imperial. As fontes consultadas sugerem que os Conselhos não fizeram oposição explícita ao governo de D. Pedro, mas, em função da diferença de tratamento que eles conferiram ao Executivo, ao Senado e à Câmara dos Deputados, ficou patente a convergência de interesses desses órgãos com a luta política capitaneada pelos deputados no Parlamento. Em contrapartida, é possível compreender o 
porquê dos Conselhos paulistas, após a Abdicação, passarem a apoiar o governo regencial que, em grande medida, foi sendo constituído por ex-deputados, alguns deles oriundos da província de São Paulo e que já haviam sido conselheiros provinciais, a exemplo de Diogo Antonio Feijó, José da Costa Carvalho e Nicolau Pereira de Campos Vergueiro. No sentido inverso, as Regências Trina Provisória e Permanente valeram-se da condição da província de São Paulo para estabelecer um importante ponto de sustentação para o governo central.

O contato dos Conselhos Provinciais com o Legislativo e, sobretudo depois da Abdicação, com o Executivo, bem como a experiência acumulada nos anos de funcionamento desses órgãos ofereceu aos políticos da época um rico arsenal de reflexão e prática política o qual, quer nos parecer, influenciou de forma decisiva na discussão em torno da reforma constitucional que culminou na elaboração do Ato Adicional e na regulamentação do cargo de presidente de província, ambos efetivados em 1834. Tal relação tornou-se mais clara por meio do cotejo da legislação referente aos Conselhos Provinciais, votada no início dos anos 1830, com o modo como seus congêneres paulistas foram modificando seu perfil de atuação, processo esse que ajudou a demarcar com maior exatidão a competência política dos Conselhos Gerais, do Conselho da Presidência e do presidente de província.

Isso nos faz sugerir que os Conselhos Provinciais serviram, ainda, como campos de experimentação política para os legisladores do Império enquanto a reforma constitucional foi sendo debatida nos anos 1831-1834, o que daria ao Ato Adicional, comumente assinalado pela bibliografia como um ponto de clivagem na organização do estado imperial, um sentido de ruptura sim, mas de uma ruptura ancorada na experiência política local da qual muitos deputados haviam sido conselheiros provinciais e, a exemplo do sorocabano Rafael Tobias de Aguiar, presidentes de província. Lembremos que o próprio Bernardo 
Pereira de Vasconcelos, membro dos Conselhos Geral e da Presidência de Minas Gerais, província que também assistiu ao funcionamento pleno de ambos os órgãos, foi um dos principais mentores do Ato Adicional.

Uma outra dimensão da luta política em São Paulo foi engendrada pela imprensa, espaço privilegiado de discussão que nos permitiu nuançar a fala dos políticos paulistas pertencentes aos Conselhos no período considerado. Se até meados de 1830 a imprensa de São Paulo, representada pelo O Farol Paulistano e O Observador Constitucional, notabilizou-se pela oposição feita ao governo de D. Pedro, ressaltando ambos os redatores a necessidade de se respeitar o regime constitucional diante dos abusos de poder do Ministério e do Conselho de Estado, depois disso o cenário político paulista tomou contornos mais complexos. Sem representantes “caramurus” ou "restauradores”, a imprensa paulista foi palco de acirrada luta entre liberais “exaltados" e "moderados”, que teve como cerne de discussão o delineamento de um governo constitucional, sem a presença marcante do Duque de Bragança.

Nesse sentido, o estudo da imprensa periódica paulista permitiu questionar a suposta homogeneidade política da província, pressuposto forjado pelos políticos “moderados” e que foi reiterado, posteriormente, por parcela da bibliografia que tematizou a história de São Paulo na primeira metade do século XIX. Confrontando os discursos de periódicos como o Farol Paulistano e O Observador Constitucional, foi possível observar nuanças nas práticas liberais, especialmente no período entre 1830 e 1832, quando “moderados” e “exaltados” protagonizaram os principais enfrentamentos políticos na província. Assim, longe de constituir um reduto da “moderação”, a província assistiu à defesa de projetos distintos de organização do Estado, de modo que vocábulos como 
“república”, “federação”, “monarquia federativa” e “monarquia constitucional” passaram a fazer parte do debate no período.

Ainda com relação à imprensa, é de se notar que o Farol Paulistano e o Observador Constitucional não constituíram periódicos destinados à discussão dos debates promovidos no Rio de Janeiro, tal como o Diário da Câmara dos Deputados à Assembléia Legislativa do Império do Brasil, publicado entre 1826 e 1830, a Revista Semanaria dos Trabalhos Legislativos da Câmara dos Srs. Deputados, órgão oficial que circulou em 1828, e o Observador das Gallerias da Assemblea Geral, periódico impresso durante o ano de $1830{ }^{681}$ Ainda que seus respectivos conteúdos se relacionassem, majoritariamente, com a luta política processada na Corte, sobretudo no Parlamento, ambos os periódicos foram aos poucos ampliando seu leque editorial e, por meio do aprimoramento das seções, articularam aspectos variados da sociedade na qual estavam inseridos, desde questões atinentes à política e à economia da cidade e província de São Paulo até reflexões sobre instrução pública, religião, inovações tecnológicas e conduta moral. Ao mesmo tempo em que se configuraram como ferramentas da luta política, tanto O Farol quanto O Observador conformaram uma determinada cultura política ${ }^{682}$ moldada pelos princípios liberais que transcendeu a esfera oficial/institucional e se estendeu para a observação e apreciação dos demais planos da sociedade.

\footnotetext{
${ }^{681}$ VIANNA, Helio. Contribuição à história da Imprensa no Brasil (1812-1869). Rio de Janeiro: Instituto Nacional do Livro/ Imprensa Nacional, 1945, p.140.

${ }^{682}$ Utilizamos aqui a definição de cultura política desenvolvida por Keith Michael Baker para o panorama político da Europa e América pós-Revolução Francesa. Para esse autor, a cultura política constituiu um arcabouço teórico e prático que regula a percepção e a práxis política de um dado grupo social, moldando sua identidade e suas inter-relações com os demais grupos com os quais ele trava contado. Cf. BAKER, Keith Michael. "Introduction" In: BAKER, Keith Michael (org.). The French Revolution and The Creation of ModernPolitical Culture. Oxford: Pergamon Press, 1987. v. 1, pp. XII-XIII. Para as relações entre cultura política e imprensa periódica, ver também CHARTIER, Roger (org.). Práticas da leitura. Trad.: Cristiane Nascimento. São Paulo: Estação Liberdade, 1996; MOREL, 2005, op. cit; NEVES, op. cit.
} 
Tais características fizeram a imprensa interagir constantemente na atuação dos Conselhos Provinciais. Membros destes órgãos, personagens como José da Costa Carvalho e Antonio Mariano de Azevedo Marques também desempenharam a função de redatores de O Farol Paulistano e, portanto, valeram-se da imprensa para endossar resoluções tomadas por eles próprios e pelos demais conselheiros. Não se tratava, porém, de legitimar apenas essa atuação política. Por trás do apoio dispensado aos Conselhos subsistia a intenção de divulgar e justificar determinadas práticas de poder, bem como de arrogar à província uma pretensa univocidade, auxiliando a escamotear divergências de interesses. Mas a confrontação de O Farol com o Observador Constitucional e outros periódicos possibilitou questionar tais pressupostos e apontar para o fato de que, na realidade, entre os paulistas não havia um entendimento sobre o perfil dos espaços de poder em nível provincial, de modo que o assunto se tornou um dos mais discutidos no tratamento da reforma constitucional pela imprensa. Nesse sentido, é possível assinalar que os periódicos desempenharam importante papel na veiculação de diferentes concepções sobre a organização dos poderes provinciais dentro de um governo constitucional, contribuindo assim para o debate referente à remodelação dos Conselhos e da criação das Assembléias Provinciais.

Ao cabo dos processos estudados seria reducionista falarmos em uma "vitória” dos “moderados” no cenário político paulista e até mesmo imperial do período, embora seja certo que o resultado da reforma constitucional deixou de contemplar reivindicações importantes da “exaltação”, dentre elas as supressões do Senado vitalício e do Poder Moderador e a implantação do sistema federativo. Elemento fundamental para parte dos “exaltados” paulistas, a transformação dos Conselhos Gerais em Assembléias Provinciais foi concretizada pelo Ato Adicional, o que pode considerar-se uma grande conquista. Além 
disso, o desaparecimento da imprensa “exaltada” e da Sociedade Federal em São Paulo, no ano de 1833, não deve ser visto como simples derrota de seus correligionários, mas como índice de uma reordenação das forças políticas provinciais, o que acompanhou o desenrolar dos acontecimentos na Corte. Mesmo porque, em meio à reforma constitucional, novas preocupações foram surgindo nos círculos políticos da época, como a implantação do Novo Código do Processo Criminal e as atribuições das Assembléias Provinciais, sem contar que antigos “exaltados” passaram a integrar o grupo dos "moderados”, tal como Francisco Bernardino Ribeiro, ex-redator de a Voz Paulistana que se tornou redator de O Novo Paulistano a partir de 1833. A própria “moderação” dava maiores evidências de sua heterogeneidade política, o que ficou explícito nos debates parlamentares e na imprensa em torno da reforma constitucional. Além de por em confronto “exaltados” e “moderados”, as discussões sobre as alterações na Carta de 1824 evidenciaram diferentes concepções de organização do Estado entre os próprios “moderados”, os quais nunca chegaram a compor uma plataforma política homogênea.

Finalmente, cabe destacar que este trabalho representa uma primeira aproximação em relação a campo político complexo e que a compreensão dos nexos e contradições entre “moderados” e “exaltados” em São Paulo, assim como em outras regiões do Império, demanda não só o alargamento da análise da documentação disponível como a problematização de sólida memória que marcou o modo como aprendemos a conhecer e reconhecer o período do Primeiro Reinado e das Regências. 


\section{Fontes e Bibliografia:}

\section{Fontes Manuscritas:}

Documentação Textual do Arquivo Público do Estado de São Paulo:

Atas e Pareceres do Conselho Geral (1824-1834). Latas CO 55649; CO 5650; CO 5682; CO 5651

Documentação Textual do Acervo Histórico da Assembléia Legislativa do Estado de São Paulo:

Fundo Conselho Geral da Província de São Paulo. Caixas 01, 02, 07, 08, 09, 10, 11, 12, $14,16,23,24,30$ e 31.

\section{Fontes impressas:}

Anais do Parlamento Brasileiro. Câmara dos Deputados (1826-1834). Rio de Janeiro: Tipografia de Hipólito José Pinho e Cia., 1874-1879. Disponível no site www.camara.gov.br

Anais do Senado do Império do Brasil. Rio de Janeiro/Brasília, 1826-1889. Disponível no site www.senado.gov.br

Atas do Conselho de Estado (1823-1834). In: RODRIGUES, José Honório (dir.). Atas do Conselho de Estado: obra comemorativa do sesquicentenário da instituição parlamentar. Brasília: Centro Gráfico do Senado Federal, 1973-1978, 13 volms.

Atas do Conselho da Presidência da Província de São Paulo (1824-1834). In: Documentos Interessantes para a história e costumes de São Paulo. São Paulo: Departamento do Arquivo do Estado, 1961, v.86. (Atas referentes ao período 18241829); Boletim. São Paulo: Arquivo do Estado de São Paulo, 1961, v.15 (Atas referentes ao período 1829-1832); Boletim. São Paulo: Arquivo do Estado de São Paulo, 1962, v.16 (Atas referentes ao período 1832-1834).

BONAVIDES, Paulo \& AMARAL, Roberto (orgs.). Textos políticos da História do Brasil. Brasília: Senado Federal, 2002, v.1 (Formação/Império). Disponível no site www.cebela.org.br.

CANECA, Frei. “Crítica à Constituição outorgada”, in Ensaios Políticos. Rio de Janeiro: PUC, 1976.

CHICHORRO, Manoel da Cunha Azeredo Coutinho Soares. "Memória em que se mostra o estado econômico, militar e político da Capitania Geral de São Paulo”, in $\underline{\text { Revista do }}$ 
Instituto Histórico e Geográfico Brasileiro. Rio de Janeiro, XXXVI, $2^{\circ}$ trimestre de 1873.

Coleção das decisões do Governo do Império do Brasil de 1831. Rio de Janeiro: Tipografia Nacional, 1875-1876.

Coleção das leis do Império do Brasil. Rio de Janeiro: Tipografia Nacional, 12 v.

Constituição do Império do Brasil (1824), acompanhada pelo Ato Adicional de 1834 e pela Lei de Interpretação de 1840. Brasília: Ministério do Interior/ Fundação Projeto RONDÓS, 1986.

Diário da Assembléia Geral Constituinte e Legislativa do Império do Brasil: 1823. Brasília: Centro do Senado Federal, 1973, 3 volms.

FEIJÓ, Diogo Antônio. Diogo Antônio Feijó . Organização e prefácio de Jorge Caldeira. São Paulo: Editora 34, 1999. (Coleção Formadores do Brasil).

- Guia das câmaras municipais do Brasil no desempenho de seus deveres por um deputado amigo da instituição. Rio de Janeiro: Typografia D’Astréa, 1830.

Registro Geral da Câmara Municipal de São Paulo, 1826-1828. São Paulo: Publicação Oficial do Arquivo Municipal de São Paulo, 1922.

\section{2) Periódicos impressos:}

Documentação pertencente à Biblioteca do Museu Paulista da USP (MP/USP):

- O Farol Paulistano, São Paulo, 1827 (nº 1-75, impresso original)

Documentação pertencente ao Arquivo do Estado de São Paulo:

- O Farol Paulistano, São Paulo, 1827-1831 (nº 1-504). Todos em microfilme.

Documentação referente ao acervo de microfilmes do Arquivo Edgard Leuenroth (AEL/UNICAMP):

- A Matutina Meiapontense, Meiaponte (Goiás), 1830-1834.

- A Nova Luz Brasileira, Rio de Janeiro, 1829-1831.

- Aurora Fluminense, Rio de Janeiro, 1827-1839.

- O Astro de Minas, São João Del Rei, 1827-1839. 
- O Diário Fluminense, Rio de Janeiro, 1825-1831.

- O Federalista, São Paulo, 1832.

- O Independente, Rio de Janeiro, 1831-1833.

- O Justiceiro, São Paulo, 1834-1835.

- O Mentor das Brasileiras, São João Del Rei, 1829-1832.

- O Novo Farol Paulistano, São Paulo, 1831-1835.

- O Observador Constitucional, São Paulo, 1829 (nºs 2, 9-18);1830 ( $\mathrm{n}^{\mathrm{o}} \mathrm{s} 21-24,26-31,33-$ 46, 63-72, 86, 97-106, 108-113); 1831 (114-175, 179, 184-191); 1832 (257).

- O Paulista, São Paulo, 1831-1832.

\section{4) Obras de referência:}

AMARAL, Antonio Barreto do. Dicionário de História de São Paulo. [Coleção Paulística]. São Paulo: Governo do Estado, 1980.

BARATA, Carlos Almeida; BUENO, Antônio Henrique Cunha. Dicionário das famílias brasileiras. São Paulo: Webmaster, 1999, 2v.

BOBBIO, Norberto; MATTEUCCI, Nicola; PASQUINO, Gianfranco. Dicionário de Política. Brasília: UnB, 1983.

MARQUES, Manuel Eufrásio de Azevedo. Apontamentos Históricos, Geográficos, Biográficos, Estatísticos e Noticiosos da Província de São Paulo. São Paulo: Comissão do IV Centenário da cidade de São Paulo, 1954, 2 tomos.

SISSON, S.A. Galeria dos brasileiros ilustres. Brasília: Senado Federal, 1999, 2 v. $1^{\text {a }}$ edição:1948.

TAUNAY, Afonso de Escragnolle. A Câmara dos deputados sob o Império. São Paulo: Imprensa Oficial do Estado de São Paulo, 1950.

VAINFAS, Ronaldo (org.). Dicionário do Brasil imperial, 1822-1889. Rio de Janeiro: Objetiva, 2002.

\section{5) Bibliografia:}

Anais da Biblioteca Nacional. Rio de Janeiro, 1965, v.85. 
ARAÚJO, Maria Lucília Viveiros. Os caminhos da riqueza dos paulistanos na primeira metade do oitocentos. São Paulo: Hucitec, 2006.

BAKER, Keith Michael. "Introduction” In: BAKER, Keith Michael (org.). The French Revolution and The Creation of ModernPolitical Culture. Oxford: Pergamon Press, 1987. v. 1, pp. XII-XIII.

BANDECHHI, Pedro Brasil. “O município no Brasil e sua função política”. Revista de História. São Paulo, n.90, arb./jun.,1972, pp. 495-530.

BASILE, Marcello Otávio Néri de Campos. Ezequiel Corrêa dos Santos: um jacobino na corte imperial. Rio de Janeiro: Editora FGV, 2001.

- O Império em construção: projetos de Brasil e ação política na Corte regencial. Tese de doutorado apresentada ao PPGHIS da Universidade Federal do Rio de Janeiro, 2004.

BERBEL, Márcia Regina. A nação como artefato. Deputados do Brasil nas Cortes portuguesas (1821-1822). São Paulo Hucitec/Fapesp, 1999.

BLAJ, Ilana. A trama das tensões. O processo de mercantilização de São Paulo colonial (1681/1721). São Paulo: Humanitas, 2002

BLOCH, Marc. Apologia da história ou o ofício do historiador. Rio de Janeiro: Jorge Zahar, 2002.

BORGES, Vavy Pacheco. História Política: Totalidade e Imaginário. Estudos Históricos .Associação de Pesquisa e Documentação Histórica, vol.9: "Historiografia", n¹7, 1996, Rio de Janeiro, Editora FGV, pp.151-165.

BRUNO, Ernani da Silva. História e Tradições da cidade de São Paulo. Rio de Janeiro: José Olympio, 1953, 3 vol.

CANABRAVA, Alice. "Uma economia de decadência: os níveis de riqueza na Capitania de São Paulo, 1765/1767”, in Revista Brasileira de Economia. Rio de Janeiro: 26(4): 95-123, out./dez., 1972.

CALÓGERAS, Pandiá. A política monetária do Brasil. São Paulo: Companhia Editora Nacional, 1960. s/d.

. O Marquês de Barbacena. Brasília: Editora Universidade de Brasília,

CAPELATO, Maria Helena Rolim. “História Política”.Estudos Históricos .Associação de Pesquisa e Documentação Histórica, vol.9: Historiografia.n¹7, 1996, Rio de Janeiro, Editora FGV, pp.161-175. 
CARREIRA, Liberato de Castro. História Financeira e orçamentária do Império do Brasil desde sua fundação. Rio de Janeiro: Imprensa Nacional, 1889.

CARVALHO, José Murilo de. Teatro de sombras: a política imperial. São Paulo: Edições Vértice, 1988.

CARVALHO, Marcio Eulério Rio de. Afirmação de uma esfera pública de poder em Minas Gerais (1821-1851). Tese de doutorado apresentada ao Departamento de História da Faculdade de Filosofia e Ciências Humanas da Universidade Federal de Minas Gerais. Belo Horizonte, 2003.

CASTRO, Jeanne Berrance de. A milícia cidadã: a Guarda Nacional de 1831 a 1850. São Paulo: Editora Nacional, 1979.

CASTRO, Paulo Pereira de. “A 'experiência republicana', 1831-1840”, in HOLANDA, Sérgio Buarque de (org.). História Geral da civilização brasileira, tomo II, "O Brasil Monárquico”, vol.2, São Paulo, Difusão Européia do Livro, 1978, pp.315-352.

CASTRO, Renato Berbert de. História do Conselho Geral da Província da Bahia, 18241834. Salvador: Assembléia Legislativa do Estado da Bahia, 1984.

CATELLI JR, Roberto. Poder local: consolidação e revolta. Sorocaba 1823-1842. Dissertação de mestrado apresentada ao Departamento de História da Faculdade de Filosofia, Letras e Ciências Humanas da Universidade de São Paulo. São Paulo, 1993.

CAVALCANTI, Amaro. Elementos de Finanças. Rio de Janeiro: Imprensa Nacional, 1896.

CHARTIER, Roger. A História Cultural: entre práticas e representações. Trad.: Maria Manuela Galhardo. Lisboa: Difel, 1990.

CONTIER, Arnaldo. Imprensa e ideologia em São Paulo, 1822-1842: matizes do vocabulário político e social. Petrópolis: Vozes, 1979.

COSTA, Wilma Peres. "Do domínio à nação: os impasses da fiscalidade no processo de Independência”, in JANCSÓ, István (org.). Brasil: formação do Estado e da Nação. São Paulo: HUCITEC/FAPESP, 2003.

. "A economia mercantil escravista nacional e o processo de construção do Estado no Brasil”, in SZMRECSÁNYI, Tamás e LAPA, José Roberto do Amaral (orgs.). História Econômica da Independência e do Império. São Paulo, Hucitec/Fapesp, 1996. pp. 147-159.

CUNHA, Pedro Octávio Carneiro da. "A fundação de um império liberal”, in HOLANDA, Sérgio Buarque de. (org.). História Geral da civilização brasileira, tomo II, "O Brasil Monárquico”. São Paulo: Difusão Européia do Livro, 1965, vol.1, pp.379-404. 
DEBES, Célio. “Estrutura política e legal dos governos paulistas de 1821 a 1834”, in Revista do Instituto Histórico e Geográfico de São Paulo, v.65, 1968.

DELATORRE, Aparecida Vanessa. São Paulo à época da independência: contribuição para o estudo do chamado movimento "bernardista", 1821/1822. Dissertação de mestrado apresentada ao Departamento de História da Faculdade de Filosofia, Letras e Ciências Humanas da Universidade de São Paulo. São Paulo, 2003.

DINIZ, Adalton Francisco. Centralização política e apropriação de riqueza: análise das finanças do Império brasileiro (1821-1889). Tese de doutorado apresentada ao Departamento de História da Faculdade de Filosofia, Letras e Ciências Humanas da Universidade de São Paulo. São Paulo, 2002.

DOIN, José Evaldo de Mello. Dívida externa do Império. Organização e consolidação do Estado e início do processo de modernização dos instrumentos de exploração, 18241864. Tese de doutorado apresentada ao Departamento de História da Faculdade de Filosofia, Letras e Ciências Humanas da Universidade de São Paulo. São Paulo, 1986, $2 \mathrm{v}$.

DOLHNIKOFF, Miriam. Caminhos da conciliação: o poder provincial em São Paulo, 1835-1840. Dissertação de mestrado apresentada ao Departamento de História da Faculdade de Filosofia, Letras e Ciências Humanas da Universidade de São Paulo. São Paulo, 1993.

Construindo o Brasil: unidade nacional e pacto federativo nos projetos das elites (1820-1842). Tese de doutorado apresentada ao Departamento de História da Faculdade de Filosofia, Letras e Ciências Humanas da Universidade de São Paulo. São Paulo, 2000.

. O Pacto Imperial: origens do federalismo no Brasil. São Paulo: Globo, 2005.

EGAS, Eugênio. Galeria dos presidentes de São Paulo. São Paulo: Seção de obras do "O estado de S. Paulo", 1926, v.1 (Período Monárquico).

FEBVRE, Lucien. Combates pela História. Lisboa: Editorial Presença, 1977.

FERNANDES, Heloisa Rodrigues. Política e segurança. Força Pública do Estado de São Paulo: fundamentos histórico-sociais. São Paulo: Alfa-Ômega, 1974.

FERREIRA, Tania Maria Bessonde da C.; MOREL, Marco; NEVES, Lucia Maria Bastos Pereira. (orgs.). História e Imprensa: representações culturais e práticas de poder. Rio de Janeiro: DP\&A/ Faperj, 2006.

FLORENZANO, Modesto. "República (na segunda metade do século XVIII - História) e Republicanismo (na segunda metade do século XX - historiografia)”, in Clio, v. 1415, 2006, pp. 33-52. 
FLORY, Thomas. El juez de paz y el jurado em el Brasil imperial. México: Fondo de Cultura Econômica, 1986.

FREITAS, Afonso A. de. “A imprensa periódica de São Paulo”, in Revista do Instituto Histórico e Geográfico de São Paulo, v.19, 1915, pp.322-1133.

"O primeiro centenário da fundação da imprensa paulista”, in Revista do Instituto Histórico e Geográfico de São Paulo, v.25, 1928, pp.06-42.

GOMES, Alfredo. "Primeiros governos provinciais", in Revista do Instituto Histórico e Geográfico de São Paulo, v.65, 1968.

GONÇALVES, Andréa Lisly. Estratificação social e mobilizações políticas no processo de formação do estado nacional brasileiro: Minas Gerais, 1831-1835. São Paulo: Hucitec, 2008.

GOUVÊA, Maria de Fátima Silva. O Império das Províncias. Rio de Janeiro, 1822-1889. Rio de Janeiro: Civilização Brasileira/Faperj, 2008.

"Política Provincial na Formação da Monarquia Constitucional Brasileira. Rio de Janeiro, 1820-1850, in Almanack Brasiliense (online), $\mathrm{n}^{\circ}$ 07, maio/2008, pp.119-137.

HOLANDA, Sérgio Buarque de. "A herança colonial - sua desagregação", in HOLANDA, Sérgio Buarque de. (org.). História Geral da civilização brasileira, tomo II, “O Brasil Monárquico”. São Paulo: Difusão Européia do Livro, 1965, vol.1, pp.0939.

. "São Paulo", in HOLANDA, Sérgio Buarque de. (org.). História Geral da civilização brasileira, tomo II, "O Brasil Monárquico". São Paulo: Difusão Européia do Livro, 1964, vol.2, pp.415-472.

HÖRNER, Erik. Guerra entre pares: a "revolução liberal” em São Paulo, 1838-1844. Dissertação de mestrado apresentada ao Departamento de História da Faculdade de Filosofia, Letras e Ciências Humanas da Universidade de São Paulo. São Paulo, 2005.

IPANEMA, Marcello; IPANEMA, Cybelle. "Imprensa na Regência: observações estatísticas e de opinião pública”. Revista do Instituto Histórico e Geográfico

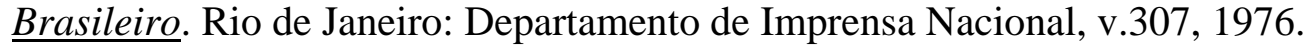

, Marcello. Legislação de imprensa - Leis de Portugal e leis de D. João (primeiro volume) e Leis do Brasil (segundo volume). Rio de Janeiro: Gráfica Editora Aurora, 1949, 2v.

JACQUES, Paulino. O governo parlamentar e a crise brasileira. [Coleção Temas Brasileiros]. Brasília: Editora Universidade de Brasileira, 1982. 
JANCSÓ, István (org). Brasil: Formação do Estado e da Nação. São Paulo: Hucitec/ Unijui/ FAPESP, 2003.

István (org.). Independência: história e historiografia. São Paulo: Hucitec/FAPESP, 2005.

István. "A construção dos Estados Nacionais na América Latina Apontamentos para o Estudo do Império como projeto”, in SZMRECSÁNYI, Tamás e LAPA, José Roberto do Amaral (orgs.). História Econômica da Independência e do Império. São Paulo, Hucitec/Fapesp, 1996. pp. 03-26.

JANOTTI, Maria de Lourdes. $\underline{\text { A balaiada }}$. [Coleção tudo é história]. São Paulo: Editora Brasiliense, 1987.

JULLIARD, Jacques. "A Política”, in LE GOFF, Jacques (org.). História: Novas Abordagens. Rio de Janeiro, Francisco Alves, 1976, pp. 153-180.

KOSELLECK, Reinhart. Futuro passado: contribuição à semântica dos tempos históricos. Trad. de Wilma Patrícia Maas e Carlos Almeida Pereira. Rio de Janeiro: Contraponto/Puc-Rio, 2006.

LEFORT, Claude. "Guizot: o liberalismo polêmico", in LEFORT, Claude. Desafios da escrita política. São Paulo: Discurso editorial, 1999, pp.113-140.

LE GOFF, Jacques. História e memória. São Paulo: Editora da Unicamp, 2003, tradução port. $1^{a}$ edição:1977, pp.477-541.

LEME, Marisa Saenz. "São Paulo no I Império: poderes locais e governo central", in OLIVEIRA, Cecilia Helena de Salles; PRADO, Maria Ligia Coelho; JANOTTI, Maria de Lourdes Monaco (org.). A história na política, a política na história. São Paulo: Alameda, 2006, pp. 59-80.

.Dinâmicas centrípetas e centrífugas na formação do Estado monárquico no Brasil: o papel do Conselho Geral da Província de São Paulo”. Rev. Bras. Hist., Jan./Jun., 2008, vol.28, n.55, pp.197-215. ISSN 0102-0188.

LENHARO, Alcir. As tropas da moderação: o abastecimento da Corte na formação política do Brasil:1808-1842. Rio de Janeiro: Biblioteca Carioca, 1993. 1ª edição: 1979.

LUNA, Francisco Vidal; KLEIN, Herbert S.. Evolução da Sociedade e Economia Escravista de São Paulo, de 1750 a 1850. São Paulo: EDUSP, 2006.

LYRA, Maria de Lourdes V. "A unidade brasileira: uma questão preliminar no processo de independência”. Revista do IEB, 1992, n ³4, pp.121-138”. 
. O Império em construção: Primeiro Reinado e Regências. São Paulo: Atual, 2000.

- A utopia do poderoso império: Portugal e Brasil: bastidores da política, 1798-1822. Rio de Janeiro: Sette Letras, 1994.

MARCÍLIO, Maria Luiza. Crescimento demográfico e evolução agrária paulista. 17001836. São Paulo: Hucitec/Edusp, 2000.

MARSON, Izabel Andrade. Movimento Praieiro, 1842-1849: imprensa, ideologia e poder político. São Paulo: Editora Moderna, 1980.

.O Império do progresso: A revolução Praieira em Pernambuco. São Paulo: Editora Brasiliense, 1987.

MARTINS, Ana Luiza; LUCA, Tania Regina de (orgs.). História da Imprensa no Brasil. São Paulo: Editora Contexto, 2008.

MARTINS, Antonio Egydio. “Jornaes e Jornalistas”, in Revista do Instituto Histórico e Geográfico de São Paulo, v.17/18, 1913, pp.114-138.

MATTOS, Ilmar Rohllof de. O tempo saquarema. A formação do Estado imperial. São Paulo: Hucitec, 2004

MEDICCI, Ana Paula. Entre a 'decadência' e o 'florescimento': capitania de São Paulo na interpretação de memorialistas e autoridades públicas (1782/1822). Dissertação de mestrado apresentada ao Departamento de História da Faculdade de Filosofia, Letras e Ciências Humanas da Universidade de São Paulo. São Paulo, 2005.

MONTEIRO, Tobias. História do Império: o Primeiro Reinado. São Paulo: Itatiana/UDUSP, 1982, 2 vol.

MOREIRA, Luciano da Silva. Imprensa e política: espaço público e cultura política na província de Minas Gerais, 1828-1842.. Dissertação de mestrado apresentada ao Departamento de História da Faculdade de Filosofia e Ciências Humanas da Universidade Federal de Minas Gerais. Belo Horizonte, 2006.

MOREL, Marco; BARROS, Mariana Monteiro de. Palavra, imagem e poder: $o$ surgimento da imprensa no Brasil do século XIX. Rio de Janeiro: DP \& A, 2003.

O período das Regências (1831-1840). Rio de Janeiro: Jorge Zahar Editora, 2003.

- As transformações dos espaços públicos: imprensa, atores políticos e sociabilidade na cidade imperial (1820-1840). São Paulo: Hucitec, 2005. 
MORSE, Richard M. Formação histórica de São Paulo. São Paulo: Difusão Européia do Livro, 1970.

MOTA, Carlos Guilherme (org.). 1822: Dimensões. São Paulo: Perspectiva, 1972.

MOURA, Denise A. Soares de. Sociedade Movediça. Economia, Cultura e Relações Sociais em São Paulo - 1808-1850. São Paulo: UNESP, 2006.

NEVES, Lucia Maria Bastos Pereira das. Corcundas, constitucionais e pés-de-chumbo: a cultura política da independência, 1820-1822. Tese de doutorado apresentada ao Departamento de História da Faculdade de Filosofia, Letras e Ciências Humanas da Universidade de São Paulo. São Paulo, 1992.

OBERACKER JR., Carlos Henrique. O movimento autonomista no Brasil: a província de São Paulo de 1819 a 1823. Lisboa: Cosmos, 1977.

OLIVEIRA, Albino José Barbosa de. Memórias de um Magistrado do Império. São Paulo: Companhia editora nacional. Série Pedagógica Brasileira: Brasiliana, v.231, 1943.

OLIVEIRA, Carlos Eduardo França de. Discutindo a memória de protagonistas do Império. Estudo do Fundo Marquês de Valença pertencente ao acervo do Museu Paulista. Relatório de pesquisa em Iniciação Científica, Museu Paulista, julho 2005.

OLIVEIRA, Cecilia Helena L. de Salles. A astúcia liberal. Relações de Mercado e Projetos Políticos no Rio de Janeiro (1820-1824). São Paulo, Editora Ícone e Edusf, 1999. . A independência e a construção do Império. São Paulo: Atual, 1995.

PALLARES-BURKE, Maria Lucia Garcia. The Spectator, o teatro das luzes - diálogo e imprensa no século XVIII. São Paulo: Hucitec, 1995.

PEIXOTO, Antonio Carlos; GUIMARÃES, Lucia Maria Paschoal; PRADO, Maria Emilia (orgs.). O liberalismo no Brasil Imperial: origens, conceitos e prática. Rio de Janeiro: Editora Revan, 2001.

PERALTA, Ines Garbuio. O Caminho do Mar: subsídios para a História de Cubatão. Cubatão: Prefeitura Municipal de Cubatão, 1973.

PETRONE, Maria Thereza Schorer. A Lavoura Canavieira em São Paulo. Expansão e Declino 91765-1851). São Paulo, Difusão Européia do Livro, 1968.

- O Barão de Iguape. Um empresário da época da Independência. São Paulo, Cia. Editora Nacional, 1976.

PRADO JR., Caio Prado. Formação do Brasil Contemporâneo. São Paulo: Brasiliense, 1999. 1'edição: 1942. 
PUNTSCHART, Willian. Negócios e negociantes paulistas. Tese de doutorado apresentada ao Departamento de História da Faculdade de Filosofia, Letras e Ciências Humanas da Universidade de São Paulo. São Paulo, 1998.

QUEIRÓZ, Suely Robles Reis de. São Paulo. Madrid: MAPFRE, 1992.

RAIOL, Domingos Antonio. Motins Políticos (ou história dos principais acontecimentos políticos da Província do Pará desde o ano de 1821 até 1835). Belém: Universidade Federal do Pará, 1970.

RIBEIRO, Gladys; $A$ liberdade em construção: identidade nacional e conflitos antilusitanos no Primeiro Reinado. Rio de Janeiro: Relume Dumará, 2002.

RIZZINI, Carlos. O livro, o jornal e a tipografia no Brasil 1500-1822. São Paulo: Imprensa Oficial do Estado/ Imesp, 1988.

ROSANVALLON, Pierre. "Por uma história conceitual do político", in Revista Brasileira de História. São Paulo: APUHH/ Ed. Contexto, nº30, 1995. Trad. port. de Paulo Henrique Martinez.

SILVA, Nicolau Duarte. "Libero Badaró (contribuição para a sua biografia)", in Revista do Instituto Histórico e Geográfico de São Paulo, v.28, 1932, pp.462-577.

SLEMIAN, Andréa. Sob o império das leis: Constituição e unidade nacional na formação do Brasil (1822-1834). Tese de doutorado apresentada ao Departamento de História da Faculdade de Filosofia, Letras e Ciências Humanas da Universidade de São Paulo. São Paulo, 2006.

SODRÉ, Nelson Werneck. A história da imprensa no Brasil. Rio de Janeiro: Imprensa Brasileira, 1966.

SOUSA, Otávio Tarquínio de. A vida de D. Pedro I. Rio de Janeiro: José Olympio Editora, 1957. 3 volumes.

- História dos fundadores do Império do Brasil. Rio de Janeiro: José Olympio Editora, 1960, v.5, "Bernardo Pereira de Vasconcelos".

TAPAJÓS, Vicente. Organização política e administrativa do império. [Coleção História administrativa do Brasil, v.9]. Brasília: FUNCEF, 1984.

TAUNAY, Afonso de Escragnolle. História da cidade de São Paulo sob o Império: 18221831. São Paulo: Divisão do Arquivo Histórico, vol.4, 1956.

. História da cidade de São Paulo sob o Império: 1831-1842. São Paulo: Divisão do Arquivo Histórico, vol.5, 1961. 
TOLEDO, Lafayette de. "Imprensa Paulista", in Revista do Instituto Histórico e Geográfico de São Paulo. São Paulo: Typografia do Diário Oficial, v.03, 1898, pp.303-521.

VENTURI, Franco. Utopia e Reforma no Iluminismo. Bauru: Edusc, 2003.

VIANNA, Helio. Contribuição à história da Imprensa no Brasil (1812-1869). Rio de Janeiro: Instituto Nacional do Livro/ Imprensa Nacional, 1945.

WERNET, Augustin. Sociedades políticas (1831-32). São Paulo: Cultrix, 1978.

. O período regencial: 1831-1840. São Paulo: Global, 1982. 


\section{Anexos}

\section{Anexo 1: Excertos traduzidos e publicados por $O$ Farol Paulistano de autores estrangeiros:}

\begin{tabular}{|c|c|}
\hline \multirow{2}{*}{ Autor } & 1827 \\
\hline & Obra/no do periódico \\
\hline $\begin{array}{l}\text { Anne Robert Jacque } \\
\text { Turgot }\end{array}$ & $\mathrm{s} / \mathrm{n}, \mathrm{n}^{0} 2$. \\
\hline Benjamin Constant & “Dos defeitos da arbitrariedade nas diversas partes da existência humana”, nº. \\
\hline Benjamin Franklin & Excerto sobre o trabalho, $\mathrm{n}^{\circ} 6$. \\
\hline Beranger & $\mathrm{s} / \mathrm{n}, \mathrm{n}^{0} 3$. \\
\hline Conde Lanjunais & $\mathrm{s} / \mathrm{n}, \mathrm{n}^{\circ} 4$ \\
\hline Gordon & $\begin{array}{l}\text { Ver títulos, n58, n60; “O governo regulado por leis invioláveis é o mais conforme a } \\
\text { prudência e segurança do Príncipe e do Povo”, n68. }\end{array}$ \\
\hline J.J. Rousseau & $\mathrm{s} / \mathrm{n}, \mathrm{n}^{\circ} 36$. \\
\hline Jeremy Bentham & “Inconvenientes da divisão do poder entre muitos, de Traités de Legislation, n¹4. \\
\hline Le Sage & $\mathrm{s} / \mathrm{n}, \mathrm{n}^{\mathrm{o}} 5$. \\
\hline Sully & $\mathrm{s} / \mathrm{n}, \mathrm{n}^{0} 2$ \\
\hline $\mathrm{s} / \mathrm{a}$ & $\begin{array}{l}\text { “A reunião da soberania e da autoridade executiva é um sistema absurdo”, de Theoria } \\
\text { das leis sociais, n }{ }^{074} \text {. }\end{array}$ \\
\hline $\begin{array}{l}\text { Visconde de } \\
\text { Chateubriand }\end{array}$ & “Discurso sobre a liberdade de imprensa”, n³4. \\
\hline
\end{tabular}

\begin{tabular}{|c|c|}
\hline \multirow{2}{*}{ Autor } & 1828 \\
\hline & Obra/nº do periódico \\
\hline Benjamin Constant & Excerto sobre a condição de ser eleitor, nº161. \\
\hline Bolingbrocke & Excerto sobre os reis de espírito fraco, n96. \\
\hline Bossuet & Excerto sobre igualdade, edição especial de 07/09/1828. \\
\hline Conde Lanjunais & Excerto sobre a tolerância religiosa na Constituição francesa, nº108. \\
\hline Ethan A. Brown & $\begin{array}{l}\text { “Não pode haver felicidade, nem virtude sem liberdade: e a escravidão é o maior de } \\
\text { todos os males”, nº111. }\end{array}$ \\
\hline Jeremy Bentham & $\begin{array}{c}\text { "Sobre os meios de publicidade judiciária”, de Organização Judiciária, nº145; excerto } \\
\text { sobre os homens de leis, n¹48. }\end{array}$ \\
\hline John Adams & Excerto sobre a definição da glória das armas, nº80. \\
\hline Madame de Staël & Excerto sobre a Liberdade, s/n, edição especial de 07/09/1828. \\
\hline Montaigne & Excerto sobre a Liberdade, nº131. \\
\hline Mr. Mercier & Excerto da obra Bonnet de Nuit, nº3. \\
\hline
\end{tabular}




\begin{tabular}{|c|r|}
\hline $\begin{array}{c}\text { Visconde de } \\
\text { Chateubriand }\end{array}$ & Excerto sobre a conceituação de Monarquia, n¹39. \\
\hline s/a & "Os actos abitrarios”; "Principal causa de corrupção dos príncipes”; n¹49; “A reunião \\
de todos os poderes nas mãos do monarca é um sistema absurdo”
\end{tabular}

\begin{tabular}{|c|c|}
\hline \multirow{2}{*}{ Autor } & 1829 \\
\cline { 2 - 3 } & Obra/n $\mathbf{n}^{\mathbf{0}}$ do periódico \\
\hline Beranger & Excerto sobre Justiça Criminal, $\mathrm{n}^{\circ}$ 259. \\
\hline Thomas Jefferson & Discurso proferido na ocasião em que esse tomou posse, em 1801, da presidência dos \\
& Estados Unidos, $\mathrm{n}^{\circ} 222$. \\
\hline
\end{tabular}

\begin{tabular}{|c|c|}
\hline \multirow{2}{*}{ Autor } & 1830 \\
\hline & Obra/nº do periódico \\
\hline $\begin{array}{l}\text { Barão Carlos } \\
\text { Dudin }\end{array}$ & Excerto de Viagens a Grã-Bretanha, n³79. \\
\hline Charles Cont. & Excerto sobre abuso de poder, da obra Tratado de Legislação, n³55. \\
\hline Cusco & Excerto do Ensaio Histórico sobre a Revolução de Nápoles, n³37 \\
\hline Destull de Tracy & Excerto sobre a economia inglesa, $\mathrm{n}^{\circ} 360$. \\
\hline Dunoyer & $\begin{array}{c}\text { Excerto sobre a doutrina cega da obediência, } n^{0} 324 ; \text { sobre a Liberdade, 325; sobre a } \\
\text { Liberdade, } n^{\circ} 327 .\end{array}$ \\
\hline Jean-Baptiste Say & $\begin{array}{c}\text { Excerto sobre as luzes e a ignorância, } n^{0} 355 \text {, sobre os governos autoritários, 357; sobre } \\
\text { a virtude da economia, } 412 .\end{array}$ \\
\hline Jean Sismondi & $\begin{array}{c}\text { Artigo intitulado "Revista dos esforços e dos progressos dos povos nestes } 23 \text { annos } \\
\text { últimos", } \mathrm{n}^{\circ} 331-335 .\end{array}$ \\
\hline J. Droz & Excerto sobre moderação política, nº 381. \\
\hline Livingston & Excerto sobre os meios de publicidade, $\mathrm{n}^{\circ} 320$. \\
\hline Mr. Spurzken & Excerto sobre a natureza moral e intelectual do homem, nº420 . \\
\hline Sully & Excerto sobre a importância da voz do popular, n³55. \\
\hline
\end{tabular}

\begin{tabular}{|c|c|}
\hline \multirow{2}{*}{ Autor } & 1831 \\
\cline { 2 - 3 } & Obra/n $^{\mathbf{0}}$ do periódico \\
\hline Benjamin Constant & Excerto sobre a tirania, $\mathrm{n}^{\mathrm{o}}$ 482. \\
\hline $\begin{array}{c}\text { François-Auguste } \\
\text { Mignet }\end{array}$ & Excerto da obra História da Revolução Francesa, n ${ }^{\circ}$ s 491, 492 e 497. \\
\hline François Guizot & Artigo sobre o conceito de Federação, $\mathrm{n}^{\circ}$ 454. \\
\hline Mr. Spurzken & Excerto sobre o preceito da indulgência mutua, $\mathrm{n}^{\circ}$ 485. \\
\hline
\end{tabular}




\section{Anexo 2: Obras vendidas na Tipografia do Farol Paulistano entre fevereiro de 1827 e junho de 1831:}

\begin{tabular}{|c|c|}
\hline \multirow{2}{*}{ AUTOR } & 1827 \\
\cline { 2 - 3 } & Obra/preço/no do periódico \\
\hline \multirow{2}{*}{ s/a } & $\begin{array}{c}\text { Compendio Scientifico para a Mocidade Brazileira destinado ao uso dos dois sexos, } \\
\text { ordenado de 9 estampas accomodadas às artes e sciencias de que nelle se tracta, } \\
\text { tiradas por litographia. 2:000rs, } \mathrm{n}^{\circ} \text { 75. }\end{array}$ \\
\hline & $\begin{array}{c}\text { Dialogo constitucional Braziliense: contêm todas as leis e disposições regulamentares } \\
\text { da Constituição política do Império, e das eleições: os regimentos do Conselho } \\
\text { d'Estado e um mui bem ornado mappa de todas as garantias, que a mesma constituição } \\
\text { offerece effectivas aos cidadãos brazileiros pela divizão e harmonia dos poderes } \\
\text { políticos, pela responsabilidade dos ministros d'Estado e mui empregados públicos, } \\
\text { pela liberdade da imprensa, pelo juízo por jurados, comprehendendo-se no mesmo as } \\
\text { respectivas limitações. } 720 \mathrm{rs}, \mathrm{n}^{\circ} \text { 75. }\end{array}$ \\
\hline
\end{tabular}

\begin{tabular}{|c|c|}
\hline \multirow{2}{*}{ AUTOR } & 1828 \\
\hline & Obra/preço/no do periódico \\
\hline $\begin{array}{l}\text { Dr. Vicente José } \\
\text { Cardos da Costa }\end{array}$ & O que é Código Civil?, I v., 2:880rs, nº 142 e 143 \\
\hline $\mathrm{s} / \mathrm{a}$ & $\begin{array}{c}\text { Dialogo constitucional Braziliense: contêm todas as leis e disposições regulamentares } \\
\text { da Constituição política do Império, e das eleições: os regimentos do Conselho } \\
\text { d'Estado e um mui bem ornado mappa de todas as garantias, que a mesma constituição } \\
\text { offerece effectivas aos cidadãos brazileiros pela divizão e harmonia dos poderes } \\
\text { políticos, pela responsabilidade dos ministros d'Estado e mui empregados públicos, } \\
\text { pela liberdade da imprensa, pelo juízo por jurados, comprehendendo-se no mesmo as } \\
\text { respectivas limitações, } \mathrm{n}^{\circ} 131\end{array}$ \\
\hline $\begin{array}{l}\text { Padre Diogo } \\
\text { Antonio Feijó }\end{array}$ & $\begin{array}{c}\text { Resposta as parvoíces, absurdos, impiedades e contradições ao P. Luiz Gonçalves dos } \\
\text { Santos, na sua intitulada defesa do Celibato Clerical contra o voto separado do P. } \\
\text { Diogo Antonio Feijó, Membro da Comissão Eclesiástica da Câmara dos Deputados. } \\
\text { 200rs, } \mathrm{n}^{\circ} \text { 136. }\end{array}$ \\
\hline s/a & Regimento dos Conselhos Gerais da Província. 100rs, nº 168 \\
\hline s/a & $\begin{array}{l}\text { Projeto de Lei sobre abuso de liberdade de imprensa, mandado observar por Decreto de } \\
28 \text { de novembro de 1823. } 100 \mathrm{rs}, \mathrm{n}^{\circ} 169 .\end{array}$ \\
\hline
\end{tabular}

\section{Anexo 3: Excertos publicados por $O$ Observador Constitucional extraídos de outros periódicos:}

\begin{tabular}{|c|c|}
\hline \multirow{2}{*}{ Periódico } & 1829 \\
\cline { 2 - 2 } & Número de excertos/ porcentagem \\
\hline A Astréa & $4(20 \%)$ \\
\hline Jornal do & $3(16 \%$ cada $)$ \\
\hline
\end{tabular}




\begin{tabular}{|c|c|}
\hline $\begin{array}{c}\text { Comércio } \\
\text { Courrier du Brésil }\end{array}$ & \\
\hline $\begin{array}{c}\text { A Voz Fluminense } \\
\text { Diário Fluminense } \\
\text { A Aurora } \\
\text { Fluminense }\end{array}$ & 2 (11\% cada) \\
\hline $\begin{array}{c}\text { A Luz Brasileira } \\
\text { O Bahiano } \\
\text { O Universal }\end{array}$ & 1 (5\% cada) \\
\hline
\end{tabular}

\begin{tabular}{|c|c|}
\hline \multirow{2}{*}{ Periódico } & 1830 \\
\hline & Número de excertos/ porcentagem \\
\hline A Aurora Fluminense & $10(33 \%)$ \\
\hline Diário Mercantil & $4(14 \%)$ \\
\hline A Astréa & $3(11 \%)$ \\
\hline $\begin{array}{c}\text { O Astro de Minas } \\
\text { O Bahiano } \\
\text { O Diário Fluminense } \\
\text { O Patriota Brasileiro } \\
\end{array}$ & 2 (6\% cada) \\
\hline $\begin{array}{c}\text { Escudo da } \\
\text { Constituição } \\
\text { Brasileira } \\
\text { Jornal do Comércio } \\
\text { A Estrela Marianense } \\
\text { O Republico } \\
\text { A Voz Fluminense } \\
\text { Revista Política da } \\
\text { Europa } \\
\end{array}$ & 1 (3\% cada) \\
\hline
\end{tabular}

\begin{tabular}{|c|c|}
\hline \multirow{2}{*}{ Periódico } & 1831 \\
\cline { 2 - 3 } & Número de excertos/ porcentagem \\
\hline A Aurora Fluminense & $19(47 \%)$ \\
\hline A Astréa & $4(9 \%)$ \\
\hline $\begin{array}{c}\text { O Tribuno do Povo } \\
\text { O Universal }\end{array}$ & 3 (7\% cada) \\
\hline $\begin{array}{c}\text { O Escudo da } \\
\text { Constituição } \\
\text { Brasileira } \\
\text { Revista Enciclopédica }\end{array}$ & $2(5 \%$ cada) \\
\hline $\begin{array}{c}\text { Constitucional Rio } \\
\text { Grandense } \\
\text { O Republico } \\
\text { A Matutina }\end{array}$ & 1 (3\% cada) \\
\hline
\end{tabular}




\begin{tabular}{|c|c|}
\hline Meiapontense & \\
O Bahiano & \\
Sentinela do Rio & \\
Grande de São Pedro & \\
Diário Mercantil & \\
Diário do Rio de & \\
Janeiro & \\
A Nova Luz Brasileira & \\
O Independente & \\
Jornal do Comércio & \\
\hline
\end{tabular}

\section{Anexo 4: Excertos traduzidos e publicados por $O$ Observador Constitucional de autores estrangeiros:}

\begin{tabular}{|c|c|}
\hline \multirow{2}{*}{ Autor } & 1829 \\
\hline & Obra/no do periódico \\
\hline Daunon Garant & "Regras para manter o despotismo", no 10 ; excerto sobre segurança pública, s/n, nº24. \\
\hline A. F. de Castilho & “Descrição dos maus reis no Inferno”, extraído de uma ode do autor, não 10. \\
\hline Benjamin Constant & $\begin{array}{l}\text { Pensamento sobre constituições e tirania, s/n, } \mathrm{n}^{\circ} 12 \text {; excerto sobre a felicidade nas } \\
\text { sociedades, } \mathrm{s} / \mathrm{n}, \mathrm{n}^{\circ} 28 \text {; excerto sobre o exercício da arbitrariedade, } \mathrm{s} / \mathrm{n}, \mathrm{n}^{\circ} 34 \text {. }\end{array}$ \\
\hline Paul Louis Courrier & s/n, n $n^{\circ} 24$ \\
\hline s/a & $\begin{array}{c}\text { "A educação considerado como o meio de aliviar as necessidades do povo pobre a } \\
\text { laborioso", Ócios Hespanholes, VII, n }{ }^{\circ} 34 .\end{array}$ \\
\hline
\end{tabular}

\begin{tabular}{|c|c|}
\hline \multirow{2}{*}{ Autor } & $\mathbf{1 8 3 0}$ \\
\cline { 2 - 2 } & Obra/n $\mathbf{n}^{\mathbf{0}}$ do periódico \\
\hline s/a & "Das Prisões”, Dicionário de Ciências Médicas, $\mathrm{n}^{\circ} 45$. \\
\hline Destull de Tracy & Excerto sobre economia, s/n, $\mathrm{n}^{\circ} 65$. \\
\hline J. Droz & Excerto sobre revoluções, s/n, $\mathrm{n}^{\circ} 66$. \\
\hline Fritot & $\begin{array}{c}\text { Excerto sobre a relação entre leis e governo, } \mathrm{s} / \mathrm{n}, \mathrm{n}^{\circ} 71 ; \text { excerto sobre o abuso de poder, } \\
\mathrm{s} / \mathrm{n}, \mathrm{n}^{\circ} 72 .\end{array}$ \\
\hline Jean-Baptiste Say & Excerto sobre as ações humanas, s/n, $\mathrm{n}^{\circ} 86$. \\
\hline
\end{tabular}

\begin{tabular}{|c|c|}
\hline \multirow{2}{*}{ Autor } & 1831 \\
\cline { 2 - 3 } & Obra/n $\mathbf{n}^{\mathbf{0}}$ do periódico \\
\hline J. Droz & $\begin{array}{c}\text { Excerto sobre alterações no sistema de governo, s/n, } \mathrm{n}^{\circ} \text { 117; “Algumas observações } \\
\text { sobre a maneira de julgar os homens”, s/n, } \mathrm{n}^{\circ} 122 ; \text { sobre o desenvolvimento do bem nas } \\
\text { sociedades, s/n, } \mathrm{n}^{\circ} 131 .\end{array}$ \\
\hline Voltaire & $\begin{array}{c}\text { Excerto sobre o despotismo, s/n, } \mathrm{n}^{\circ} 118 ; \mathrm{sobre} \text { a relação entre governantes e governados, } \\
\mathrm{s} / \mathrm{n}, \mathrm{n}^{\circ} 119 .\end{array}$ \\
\hline Mr. Rollin & "Caracteres de Temístocles, Aristides, de Cimão e de Péricles”, s/n, $\mathrm{n}^{\circ} 118$. \\
\hline
\end{tabular}




\begin{tabular}{|c|c|}
\hline Suzanne & Excerto sobre as utilidades das leis, s/n, $\mathrm{n}^{\circ} 119$. \\
\hline Junius & Excerto sobre o não cumprimento da constituição, s/n, nº 119. \\
\hline Bodin & Excerto sobre o que é nação, s/n, nº 127. \\
\hline Benjamin Constant & $\begin{array}{l}\text { Excerto sobre a durabilidade das instituições populares, s/n, n }{ }^{0} 129 ; \text { Excerto sobre a } \\
\text { liberdade individual, s/n, } n^{\circ} 136 .\end{array}$ \\
\hline Dunoyer & Excerto sobre o conceito de civilização, s/n, nº 134. \\
\hline Hartinghton & Excerto sobre as oposições à verdadeira liberdade, s/n, n 157. \\
\hline Jouy & Excerto sobre os governos republicanos, s/n, nº 180 . \\
\hline
\end{tabular}

\section{Anexo 5: Deputados paulistas eleitos para as três primeiras Legislaturas do Império: ${ }^{683}$}

\begin{tabular}{|c|c|}
\hline \multirow{2}{*}{ Nome } & $1^{a}$ Legislatura (1826-1829) \\
\hline & Observações \\
\hline $\begin{array}{c}\text { Nicolau Pereira de Campos } \\
\text { Vergueiro (1778-1859), Bacharel }\end{array}$ & --- \\
\hline $\begin{array}{l}\text { José Ricardo da Costa Aguiar de } \\
\text { Andrada (1787-1846), Magistrado }\end{array}$ & ---- \\
\hline $\begin{array}{l}\text { Manoel Joaquim de Ornellas, } \\
\text { Bacharel }\end{array}$ & $\begin{array}{l}\text { Ocupou a vice-presidência da Província de São Paulo de } 5 \text { de } \\
\text { outubro de } 1828 \text { a } 13 \text { de janeiro de } 1829 \text {. }\end{array}$ \\
\hline $\begin{array}{l}\text { José Corrêa Pacheco e Silva } \\
\text { (1778-1836), Bacharel }\end{array}$ & ---- \\
\hline $\begin{array}{l}\text { José Arouche de Toledo Rendon } \\
\text { (1756-1834), Marechal de campo }\end{array}$ & ---- \\
\hline $\begin{array}{l}\text { Francisco de Paula Souza e Mello } \\
\text { (1791-1851) }\end{array}$ & ---- \\
\hline $\begin{array}{l}\text { Francisco das Chagas Santos (?-?), } \\
\text { Marechal de campo }\end{array}$ & ---- \\
\hline $\begin{array}{l}\text { Diogo Antonio Feijó (1784-1843), } \\
\text { Padre }\end{array}$ & $\begin{array}{l}\text { Tomou assento como Suplente do Visconde de São Leopoldo, } \\
\text { que fora nomeado Senador em abril de } 1826 .\end{array}$ \\
\hline $\begin{array}{l}\text { João Chrysostomo de Oliveira, } \\
\text { Padre }\end{array}$ & $\begin{array}{l}\text { Suplente de José da Costa Carvalho, que optou pela deputação } \\
\text { da Bahia. }\end{array}$ \\
\hline
\end{tabular}

${ }^{683}$ Dados extraídos de TAUNAY, 1950, op. cit; MARQUES, op. cit; SISSON, op. cit.; BARATA, Carlos Almeida; BUENO, Antônio Henrique Cunha. Dicionário das famílias brasileiras. São Paulo: Webmaster, 1999, 2v. Os dados biográficos faltantes serão concluídos no segundo ano da pesquisa. 


\begin{tabular}{|c|c|}
\hline \multirow{2}{*}{ Nome } & $2^{\text {a }}$ Legislatura (1830-1833) \\
\hline & Observações \\
\hline Francisco de Paula Souza e Mello & ---- \\
\hline Diogo Antonio Feijó & ---- \\
\hline Manoel Joaquim de Ornellas & $\begin{array}{l}\text { Após seu falecimento, foi substituído em } 1832 \text { e } 1833 \text { pelo } \\
\text { Padre Francisco de Paula Simões. }\end{array}$ \\
\hline $\begin{array}{l}\text { Rafael Tobias de Aguiar (1794- } \\
\text { 1857), Tenente-Coronel, depois } \\
\text { Brigadeiro }\end{array}$ & $\begin{array}{l}\text { Em } 1832 \text { e } 1833 \text { substituiu-o o Padre Valério de Alvarenga } \\
\text { Ferreira. }\end{array}$ \\
\hline $\begin{array}{l}\text { José Corrêa Pacheco e Silva } \\
\text { (1778-1836), Bacharel }\end{array}$ & ---- \\
\hline $\begin{array}{l}\text { Antonio Paes de Barros (1791- } \\
\text { 1876), futuro Barão de Piracicaba }\end{array}$ & ---- \\
\hline $\begin{array}{l}\text { Lourenço Pinto de Sá Ribas, } \\
\text { Capitão }\end{array}$ & $\begin{array}{l}\text { Foi Suplente do Conselho do Governo da Presidência de São } \\
\text { Paulo em } 1828 \text { e } 1829 .\end{array}$ \\
\hline $\begin{array}{l}\text { Rodrigo Antonio Monteiro de } \\
\text { Barros (?-1844), Magistrado }\end{array}$ & ---- \\
\hline $\begin{array}{l}\text { Joaquim Floriano de Toledo } \\
\text { (1794-1875), Coronel }\end{array}$ & $\begin{array}{l}\text { Tomou assento como Suplente de José da Costa Carvalho, que } \\
\text { optou pela deputação da Bahia. }\end{array}$ \\
\hline
\end{tabular}

\begin{tabular}{|c|l|}
\hline \multirow{2}{*}{ Nome } & \multicolumn{1}{|c|}{ 3 $^{\text {a Legislatura (1834-1837) }}$} \\
\cline { 2 - 3 } Observações \\
\hline Rafael Tobias de Aguiar & $\begin{array}{l}\text { Foi substituído em 1836-37 por Rodrigo Antonio Monteiro de } \\
\text { Barros. }\end{array}$ \\
\hline José Correa Pacheco e Silva & $\begin{array}{l}\text { Após seu falecimento, em 1836, foi substituído por Martim } \\
\text { Francisco Ribeiro de Andrada. }\end{array}$ \\
\hline Lourenço Pinto de Sá Ribas & $\begin{array}{l}\text { Após seu falecimento, em 1835, foi substituído por Manuel } \\
\text { Joaquim do Amaral Gurgel. }\end{array}$ \\
\hline $\begin{array}{c}\text { Manoel Dias de Toledo (1802-1874), } \\
\text { lente de Direito }\end{array}$ & \multicolumn{1}{|c|}{----} \\
\hline $\begin{array}{c}\text { Francisco Álvares Machado de } \\
\text { Vasconcellos (1776-1846), médico }\end{array}$ & \multicolumn{1}{|c|}{---- } \\
\hline Valério de Alvarenga Ferreira, padre & \multicolumn{1}{|c|}{} \\
\hline Lourenço Marcondes de Sá, padre & $\begin{array}{l}\text { Suplente de Francisco de Paula Sousa e Mello, nomeado } \\
\text { senador. }\end{array}$ \\
\hline $\begin{array}{c}\text { D. José Antonio dos Reis (1798-?), } \\
\text { bispo de Cuiabá }\end{array}$ &
\end{tabular}




\section{Anexo 6: Conselheiros/ suplentes eleitos para as três Reuniões do Conselho da Presidência da Província de São Paulo: ${ }^{684}$}

\begin{tabular}{|c|c|}
\hline \multirow{2}{*}{ Nome/Cargo } & $1^{a}$ Reunião (1824- 1829) $)^{685}$ \\
\hline & Período de participação/ Observações \\
\hline \multicolumn{2}{|l|}{ CONSELHEIROS } \\
\hline $\begin{array}{l}\text { Luiz Antonio Neves de Carvalho } \\
\text { (1767-1831), Coronel. }\end{array}$ & $\begin{array}{l}\text { No Conselho da Presidência de São Paulo, ocupou assiduamente } \\
\text { o cargo de Conselheiro entre sua implementação, em 20/10/1824, } \\
\text { e 1827. De } 1824 \text { até o final de 1826, sua participação foi assídua. }\end{array}$ \\
\hline $\begin{array}{l}\text { Candido Xavier de Almeida e Souza } \\
\text { (1748-1831), Tenente-General }\end{array}$ & $\begin{array}{l}\text { Sua participação no Conselho da Presidência foi breve, ocupando } \\
\text { o cargo de Conselheiro entre sua implementação, em 20/10/1824, } \\
\text { até } 02 / 12 / 1824 \text {, na } 7^{\mathrm{a}} \text { sessão. Foi substituído pelo Suplente } \\
\text { Francisco Inácio de Sousa Queiroz em } 07 / 02 / 1825 \text {, na } 11^{\mathrm{a}} \text { sessão. }\end{array}$ \\
\hline Manoel Joaquim de Ornellas. & $\begin{array}{l}\text { Compôs assiduamente o Conselho desde sua implementação, em } \\
\text { 20/10/1824, até e } 1827 \text {. A partir de 1828, ausentou-se por alguns } \\
\text { períodos, principalmente durante as sessões extraordinárias, mas } \\
\text { ainda assim sua participação no Conselho foi constante até o } \\
\text { término da } 1^{\text {a Reunião. }}\end{array}$ \\
\hline $\begin{array}{l}\text { Manoel Joaquim Gonçalves de } \\
\text { Andrade (17??-1847), Vigário } \\
\text { Capitular e depois Bispo. }\end{array}$ & $\begin{array}{l}\text { Na } 1^{\text {a }} \text { Reunião do Conselho, ocupou a cadeira de Conselheiro } \\
\text { desde sua implementação, em 20/10/1824 até o término da } 2^{a} \\
\text { Reunião, em 01/05/1830. Sua freqüência foi assídua, contando } \\
\text { apenas com um período de ausência entre outubro de } 1829 \text { e } \\
\text { fevereiro de } 1830 \text {. Manoel Joaquim Gonçalves de Andrade } \\
\text { ocupou a vice-presidência da Província em três ocasiões: entre } 18 \\
\text { de abril de } 1828 \text { e outubro do mesmo ano; entre } 10 \text { de março e } 9 \\
\text { de outubro de } 1829 \text {; e entre } 15 \text { de abril de } 1830 \text { até } 4 \text { de janeiro } \\
\text { de } 1831 \text {. }\end{array}$ \\
\hline $\begin{array}{l}\text { Manoel Rodrigues Jordão, Brigadeiro } \\
\text { (?-1828) }\end{array}$ & $\begin{array}{l}\text { Compôs assiduamente o Conselho desde sua implementação, em } \\
\text { 20/10/1824, até e } 1827 \text {. }\end{array}$ \\
\hline Rafael Tobias de Aguiar & $\begin{array}{l}\text { Compôs assiduamente o Conselho desde sua implementação, em } \\
\text { 20/10/1824, até dezembro de } 1829 \text {, seis meses antes do término } \\
\text { da } 1^{\text {a }} \text { Reunião. Suas ausências foram poucas, de modo que as } \\
\text { mais significativas se deram entre julho e outubro de } 1829 \text {, e } \\
\text { entre fevereiro e junho de } 1830 \text {. Em ambos os períodos, em que } \\
\text { ocorreram sessões extraordinárias do Conselho. }\end{array}$ \\
\hline SUPLENTES & \\
\hline
\end{tabular}

\footnotetext{
${ }^{684}$ Para dados biográficos dos membros do Conselho, ver MARQUES, op. cit; SISSON, op. cit.; BARATA, Carlos Almeida; BUENO, Antônio Henrique Cunha, op. cit. Para dados referentes à participação dos membros no Conselho, consultar Atas do Conselho da Presidência da Província de São Paulo (1824-1834), op. cit. Os dados faltantes serão concluídos no segundo ano da pesquisa.

${ }^{685}$ Em virtude do Conselho da Presidência da Província de São Paulo ter sido instalado em 1824 - dois anos antes da abertura da Assembléia Geral -, e de sua duração estar atrelada ao funcionamento do Parlamento, o término da $1^{\text {a }}$ Reunião do órgão paulista se deu em 1829. Na realidade, a convocação dos Conselheiros referentes à $2^{a}$ Reunião deu-se apenas em 30/06/1830, na 1ª sessão extraordinária.
} 


\begin{tabular}{|c|c|}
\hline $\begin{array}{l}\text { Francisco Inácio de Souza Queiroz. } \\
\text { Conselheiro Suplente }\end{array}$ & $\begin{array}{l}\text { Passou a compor o Conselho a partir de } 13 / 10 / 1825 \text {, na } 19^{\mathrm{a}} \\
\text { Sessão Ordinária, embora já houvesse sido convocado como } \\
\text { Suplente em sessões extraordinárias desde } 07 / 02 / 1825 \text {, na } 11^{\mathrm{a}} \\
\text { sessão extraordinária. Deixa de compô-lo, provavelmente, entre } \\
1827 \text { e } 1828 \text {. }\end{array}$ \\
\hline Antônio José Vaz & $\begin{array}{l}\text { Provavelmente passou a compor o Conselho em } 1827 \text { ou } 1828 . \\
\text { Sua última aparição no Conselho se deu em } 16 / 10 / 1828 \text {, na } 83^{a} \\
\text { sessão ordinária. Faleceu no mesmo mês, sendo substituído por } \\
\text { Antonio Bernardo Bueno da Veiga. }\end{array}$ \\
\hline Antonio Bernardo Bueno da Veiga & $\begin{array}{l}\text { A partir de 1828, passou a fazer parte do Conselho } \\
\text { esporadicamente, nas sessões extraordinárias. Passou a compor o } \\
\text { Conselho regularmente a partir de a tomar assento regularmente } \\
\text { em } 29 / 10 / 1828\left(87^{\mathrm{a}} \text { sessão), após a morte de Antonio José Vaz. }\right. \\
\text { Sua freqüência ao Conselho foi assídua até o encerramento da } 1^{\mathrm{a}} \\
\text { Reunião. }\end{array}$ \\
\hline $\begin{array}{l}\text { Nicolau Pereira de Campos } \\
\text { Vergueiro. }\end{array}$ & $\begin{array}{l}\text { Provavelmente passou a compor o Conselho em } 1827 \text { ou } 1828 . \\
\text { Sua última aparição no Conselho se deu em 22/10/1828, na } 85^{a} \\
\text { sessão ordinária. Sua saída foi decorrente, certamente, da } \\
\text { nomeação que recebeu para senador, em } 1828 \text {. }\end{array}$ \\
\hline $\begin{array}{l}\text { Bernardo José Pinto Gavião } \\
\text { Peixoto }\end{array}$ & $\begin{array}{l}\text { Provavelmente passou a compor o Conselho em } 1827 \text { ou } 1828 \text {. A } \\
\text { partir de } 1828 \text {, sua freqüência ao Conselho foi assídua até o } \\
\text { encerramento da } 1^{\text {a }} \text { Reunião. }\end{array}$ \\
\hline José Arouche de Toledo Rendon & $\begin{array}{l}\text { Provavelmente passou a compor o Conselho em } 1827 \text { ou } 1828 \text {. A } \\
\text { partir de } 1828 \text {, sua freqüência ao Conselho foi assídua até o } \\
\text { encerramento da } 1^{\text {a }} \text { Reunião. }\end{array}$ \\
\hline Lourenço Pinto de Sá Ribas & $\begin{array}{l}\text { Passou a compor o Conselho a partir de } 22 / 08 / 1828 \text {, na } 85^{a} \\
\text { sessão ordinária. Com freqüência assídua, sua última aparição no } \\
\text { Conselho se deu em } 24 / 01 / 1828 \text {, na } 97^{a} \text { sessão ordinária. }\end{array}$ \\
\hline Diogo Antônio Feijó & $\begin{array}{l}\text { Passou a compor o Conselho em } 24 / 01 / 1829 \text {, na } 97^{a} \text { sessão } \\
\text { extraordinária. Participou pouco das sessões extraordinárias, } \\
\text { tornando-se mais efetivo nas ordinárias, a partir de outubro. Sua } \\
\text { ausência nas sessões extraordinárias se deu, provavelmente, por } \\
\text { conta dos trabalhos no Parlamento, no qual era deputado por São } \\
\text { Paulo. }\end{array}$ \\
\hline $\begin{array}{l}\text { Manoel da Cunha de Azevedo C. } \\
\text { S. Chicorro }\end{array}$ & $\begin{array}{l}\text { Compôs o Conselho apenas em } 09 / 03 / 1829 \text {, na } 101^{\text {a }} \text { sessão } \\
\text { extraordinária. }\end{array}$ \\
\hline $\begin{array}{l}\text { Joaquim Mariano Galvão de } \\
\text { Moura Lacerda }\end{array}$ & $\begin{array}{l}\text { Passou a compor o Conselho em } 17 / 06 / 1829 \text {, na } 102^{\text {a }} \text { sessão } \\
\text { extraordinária. Sua freqüência ao Conselho foi assídua até o } \\
\text { encerramento da } 1^{\text {a }} \text { Reunião. }\end{array}$ \\
\hline $\begin{array}{l}\text { José Joaquim Cezar de Serqueira } \\
\text { Leme }\end{array}$ & $\begin{array}{l}\text { Passou a compor o Conselho em } 17 / 06 / 1829 \text {, na } 102^{\text {a }} \text { sessão } \\
\text { extraordinária. Sua freqüência ao Conselho foi assídua até o } \\
\text { encerramento da } 1^{\text {a }} \text { Reunião. }\end{array}$ \\
\hline $\begin{array}{l}\text { José Pedro Galvão de Moura e } \\
\text { Lacerda }\end{array}$ & $\begin{array}{l}\text { Passou a compor o Conselho em } 17 / 08 / 1829 \text {, na } 106^{a} \text { sessão } \\
\text { extraordinária. Sua freqüência ao Conselho foi assídua até o } \\
\text { retorno de Diogo Feijó, em } 21 / 10 / 1829 \text {, na } 114^{\text {a }} \text { sessão ordinária. }\end{array}$ \\
\hline
\end{tabular}




\begin{tabular}{|c|c|}
\hline & Período de participação/ Observações \\
\hline \multicolumn{2}{|l|}{ CONSELHEIROS } \\
\hline Manuel Joaquim de Ornelas & Foi substituído em 1832, após seus falecimento \\
\hline Diogo Antonio Feijó & 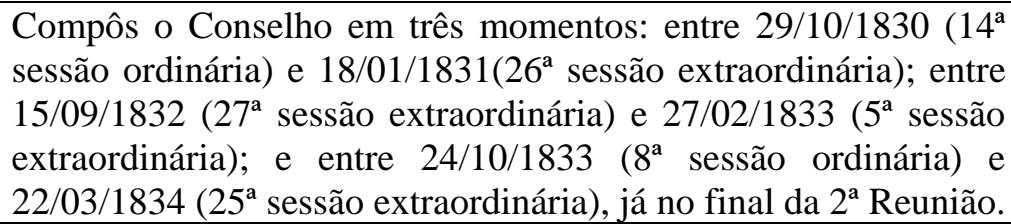 \\
\hline $\begin{array}{c}\text { José da Costa Carvalho (1796-1860), } \\
\text { Bacharel, futuro Marquês de Monte } \\
\text { Alegre. }\end{array}$ & 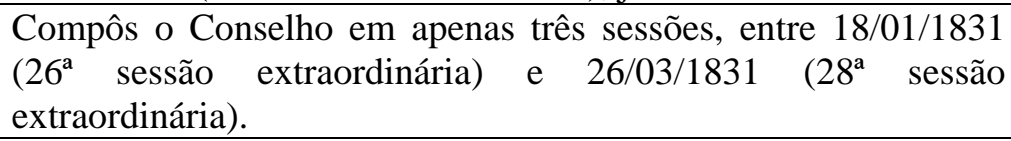 \\
\hline $\begin{array}{l}\text { Manoel Joaquim Gonçalves de } \\
\text { Andrade, Vigário Capitular e bispo. }\end{array}$ & $\begin{array}{l}\text { Compôs assiduamente o cargo de Conselheiro desde a } \\
\text { implementação da } 2^{\mathrm{a}} \text { Reunião, 30/06/1830, até 20/10/1831, } \\
\text { quando optou por ocupar a cadeira de Conselheiro no Conselho } \\
\text { Geral. }\end{array}$ \\
\hline Rafael Tobias de Aguiar & $\begin{array}{l}\text { Não compôs o Conselho como Conselheiro. Passa a ocupá-lo } \\
\text { assiduamente após se tornar presidente da Província de São } \\
\text { Paulo, em } 17 \text { de novembro de } 1831 \text {, até o final da } 2^{\text {a Reunião. }}\end{array}$ \\
\hline Nicolau Pereira de Campos Vergueiro & Não compôs o Conselho. \\
\hline \multicolumn{2}{|l|}{ SUPLENTES } \\
\hline Bernardo Jose Pinto Gavião Peixoto & $\begin{array}{l}\text { Passou a compor o Conselho em } 30 / 06 / 1830 \text {, na } 1^{\text {a }} \text { sessão } \\
\text { extraordinária, em justificativa de que os Conselheiros oficiais } \\
\text { encontravam-se na Câmara dos Deputados como membros. Sua } \\
\text { freqüência ao Conselho foi assídua até seu afastamento, em } \\
\text { 20/10/1831, na } 7^{\text {a }} \text { sessão extraordinária, por ter escolhido tomar } \\
\text { assento no Conselho Geral da Província de São Paulo. }\end{array}$ \\
\hline Antonio Bernardo Bueno da Veiga & $\begin{array}{l}\text { Passou a compor o Conselho em } 30 / 06 / 1830 \text {, na } 1^{\text {a }} \text { sessão } \\
\text { extraordinária, em justificativa de que os Conselheiros oficiais } \\
\text { encontravam-se na Câmara dos Deputados como membros. Sua } \\
\text { freqüência ao Conselho foi assídua até seu afastamento, em } \\
\text { 20/10/1831, na } 7^{\text {a }} \text { sessão extraordinária, por ter escolhido tomar } \\
\text { assento no Conselho Geral da Província de São Paulo. }\end{array}$ \\
\hline Manoel Joaquim do Amaral Gurgel & $\begin{array}{l}\text { Passou a compor o Conselho em } 30 / 06 / 1830 \text {, na } 1^{\text {a }} \text { sessão } \\
\text { extraordinária, em justificativa de que os Conselheiros oficiais } \\
\text { encontravam-se na Câmara dos Deputados como membros. Sua } \\
\text { freqüência ao Conselho foi assídua até seu afastamento, em } \\
\text { 20/10/1831, na } 7^{\text {a }} \text { sessão extraordinária, por ter escolhido tomar } \\
\text { assento no Conselho Geral da Província de São Paulo. }\end{array}$ \\
\hline $\begin{array}{l}\text { Antonio Mariano de Azevedo } \\
\text { Marques }\end{array}$ & $\begin{array}{l}\text { Passou a compor o Conselho em } 30 / 06 / 1830 \text {, na } 1^{\text {a }} \text { sessão } \\
\text { extraordinária, em justificativa de que os Conselheiros oficiais } \\
\text { encontravam-se na Câmara dos Deputados como membros. Sua } \\
\text { freqüência ao Conselho foi assídua até seu afastamento, em } \\
\text { 20/10/1831, na } 7^{\text {a }} \text { sessão extraordinária, por ter escolhido tomar } \\
\text { assento no Conselho Geral da Província de São Paulo. }\end{array}$ \\
\hline
\end{tabular}




\begin{tabular}{|c|c|}
\hline José Arouche de Toledo Rendon & $\begin{array}{l}\text { Passou a compor o Conselho em } 30 / 06 / 1830 \text {, na } 1^{\text {a }} \text { sessão } \\
\text { extraordinária, em justificativa de que os Conselheiros oficiais } \\
\text { encontravam-se na Câmara dos Deputados como membros. Sua } \\
\text { freqüência ao Conselho foi assídua até seu afastamento, em } \\
\text { 03/09/1830, na } 4^{\text {a }} \text { sessão extraordinária, justificando idade } \\
\text { avançada. }\end{array}$ \\
\hline José Manoel de França & 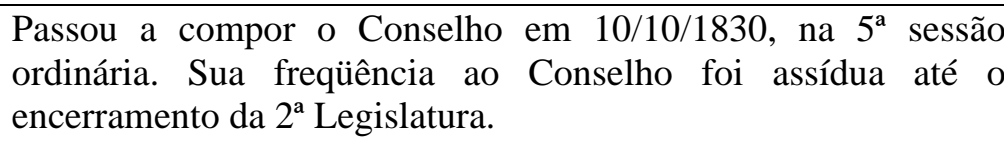 \\
\hline Joaquim José Moraes e Abreu & $\begin{array}{l}\text { Passou a compor o Conselho em } 08 / 10 / 1830 \text {, na } 8^{\text {a }} \text { sessão } \\
\text { ordinária. Sua freqüência ao Conselho foi assídua até julho de } \\
1831 \text {. }\end{array}$ \\
\hline Francisco Alves Ferreira do Amaral & $\begin{array}{l}\text { Passou a compor o Conselho em } 12 / 12 / 1831 \text {, na } 8^{\text {a }} \text { sessão } \\
\text { ordinária, em substituição aos suplentes que optaram em tomar } \\
\text { assento pelo Conselho Geral. Sua freqüência ao Conselho foi } \\
\text { assídua até o encerramento da } 2^{\text {a }} \text { Legislatura. }\end{array}$ \\
\hline $\begin{array}{l}\text { Jose Pedro Galvão de Moura e } \\
\text { Lacerda }\end{array}$ & $\begin{array}{l}\text { Passou a compor o Conselho em } 12 / 12 / 1831 \text {, na } 8^{\text {a }} \text { sessão } \\
\text { ordinária, em substituição aos suplentes que optaram em tomar } \\
\text { assento pelo Conselho Geral. Sua freqüência ao Conselho foi } \\
\text { assídua até } 18 / 10 / 1832 \text {, na } 7^{\mathrm{a}} \text { sessão ordinária, quando deixou de } \\
\text { compô-lo. }\end{array}$ \\
\hline Jose Matias Ferreira de Abreu & $\begin{array}{l}\text { Passou a compor o Conselho em } 12 / 12 / 1831 \text {, na } 8^{\mathrm{a}} \text { sessão } \\
\text { ordinária, em substituição aos suplentes que optaram em tomar } \\
\text { assento pelo Conselho Geral. Sua freqüência ao Conselho foi } \\
\text { assídua até abril de } 1832 \text {, quando deixou de integrá-lo. Voltou a } \\
\text { compô-lo em 07/10/1833, na } 3^{\mathrm{a}} \text { sessão ordinária, tendo } \\
\text { freqüência assídua até o encerramento da } 2^{\mathrm{a}} \text { Legislatura. }\end{array}$ \\
\hline José de Almeida Leme & $\begin{array}{l}\text { Passou a compor o Conselho em } 22 / 12 / 1831 \text {, na } 11^{\text {a }} \text { sessão } \\
\text { ordinária, em substituição aos suplentes que optaram em tomar } \\
\text { assento pelo Conselho Geral }\end{array}$ \\
\hline Lourenço Justiniano Ferreira, Cônego & $\begin{array}{l}\text { Passou a compor o Conselho em } 08 / 05 / 1832 \text {, na } 22^{\text {a }} \text { sessão } \\
\text { extraordinária. Participa de apenas algumas sessões. }\end{array}$ \\
\hline Jose Gomes de Almeida, Cônego & $\begin{array}{l}\text { Passou a compor o Conselho em } 08 / 05 / 1832 \text {, na } 22^{\text {a }} \text { sessão } \\
\text { extraordinária. Sua freqüência ao Conselho foi assídua até o } \\
\text { encerramento da } 2^{\mathrm{a}} \text { Legislatura. }\end{array}$ \\
\hline Manoel Inocêncio de Vasconcelos & $\begin{array}{l}\text { Passou a compor o Conselho em } 18 / 08 / 1832 \text {, na } 26^{\text {a }} \text { sessão } \\
\text { extraordinária. Sua freqüência ao Conselho foi assídua até o } \\
\text { encerramento da } 2^{\mathrm{a}} \text { Legislatura. }\end{array}$ \\
\hline
\end{tabular}




\begin{tabular}{|c|c|}
\hline \multirow{2}{*}{ Nome/Cargo } & $3^{\mathrm{a}}$ Reunião (1834) ${ }^{686}$ \\
\hline & Período de participação/ Observações \\
\hline \multicolumn{2}{|l|}{ CONSELHEIROS } \\
\hline Vicente Pires da Mota, Bacharel & $\begin{array}{l}\text { Compôs o Conselho a partir da implementação da } 3^{\text {a }} \text { Reunião, } \\
\text { em 14/05/1834 ( } 28^{\mathrm{a}} \text { sessão extraordinária), até 28/08/1834 (33 } \\
\text { sessão extraordinária). }\end{array}$ \\
\hline Rafael Tobias de Aguiar & $\begin{array}{l}\text { Não compôs o Conselho como Conselheiro. Ocupou-o } \\
\text { assiduamente durante o período em que foi presidente da } \\
\text { Província de São Paulo: entre } 17 \text { de novembro de } 1831 \text { e } 27 \text { de } \\
\text { maio de } 1834 \text {; de } 14 \text { de setembro de } 1834 \text { até o final da } 3^{\text {a }} \\
\text { Reunião, em novembro de } 1834 \text {. }\end{array}$ \\
\hline José Manoel de França & 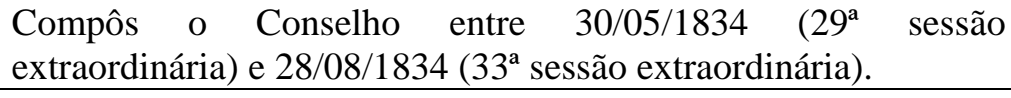 \\
\hline Diogo Antonio Feijó & Não compôs o Conselho. \\
\hline $\begin{array}{l}\text { Joaquim José dos Santos Silva, } \\
\text { Capitão }\end{array}$ & $\begin{array}{l}\text { Compôs assiduamente o Conselho desde a implementação da } 3^{\mathrm{a}} \\
\text { Reunião, em } 14 / 05 / 1834 \text { ( } 28^{\mathrm{a}} \text { sessão extraordinária), até sua } \\
\text { conclusão, em novembro de } 1834 \text {. }\end{array}$ \\
\hline José Manoel da Silva & $\begin{array}{lccccc}\text { Compôs o } & \text { Conselho entre } & 30 / 05 / 1834 & \text { (29a } & \text { sessão } \\
\text { extraordinária) e } 31 / 07 / 1834 \text { ( } 32^{\text {a }} \text { sessão extraordinária). } & \end{array}$ \\
\hline \multicolumn{2}{|l|}{ SUPLENTES } \\
\hline $\begin{array}{l}\text { Antonio Mariano de Azevedo } \\
\text { Marques }\end{array}$ & 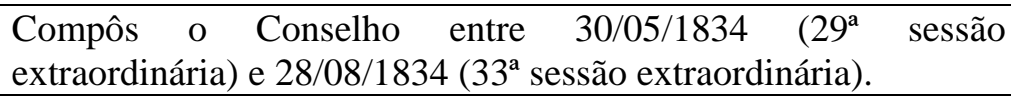 \\
\hline Manuel Joaquim de Amaral Gurgel & 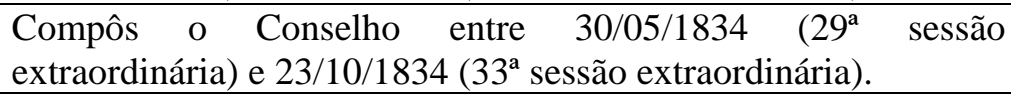 \\
\hline Bernardo José Pinto Gavião Peixoto & $\begin{array}{l}\text { Compôs o Conselho entre 03/10/1834 ( } 1^{\mathrm{a}} \text { sessão ordinária) e o } \\
\text { final da } 3^{\mathrm{a}} \text { Reunião, em novembro de } 1834 \text {. }\end{array}$ \\
\hline Joaquim Jose Morais e Abreu & $\begin{array}{l}\text { Compôs o Conselho entre 03/10/1834 ( } 1^{\mathrm{a}} \text { sessão ordinária) e o } \\
\text { final da } 3^{\mathrm{a}} \text { Reunião, em novembro de } 1834 \text {. }\end{array}$ \\
\hline Jose Manuel da Luz & $\begin{array}{l}\text { Compôs o Conselho entre 03/10/1834 ( } 1^{\mathrm{a}} \text { sessão ordinária) e o } \\
\text { final da } 3^{\mathrm{a}} \text { Reunião, em novembro de } 1834 \text {. }\end{array}$ \\
\hline
\end{tabular}

${ }^{686}$ Para dados biográficos dos membros do Conselho da Presidência, ver MARQUES, op. cit; SISSON, op. cit.; BARATA, Carlos Almeida; BUENO, Antônio Henrique Cunha, op. cit. Para dados referentes à participação dos membros no Conselho, consultar Atas do Conselho da Presidência da Província de São Paulo (1824-1834), op. cit. 